的

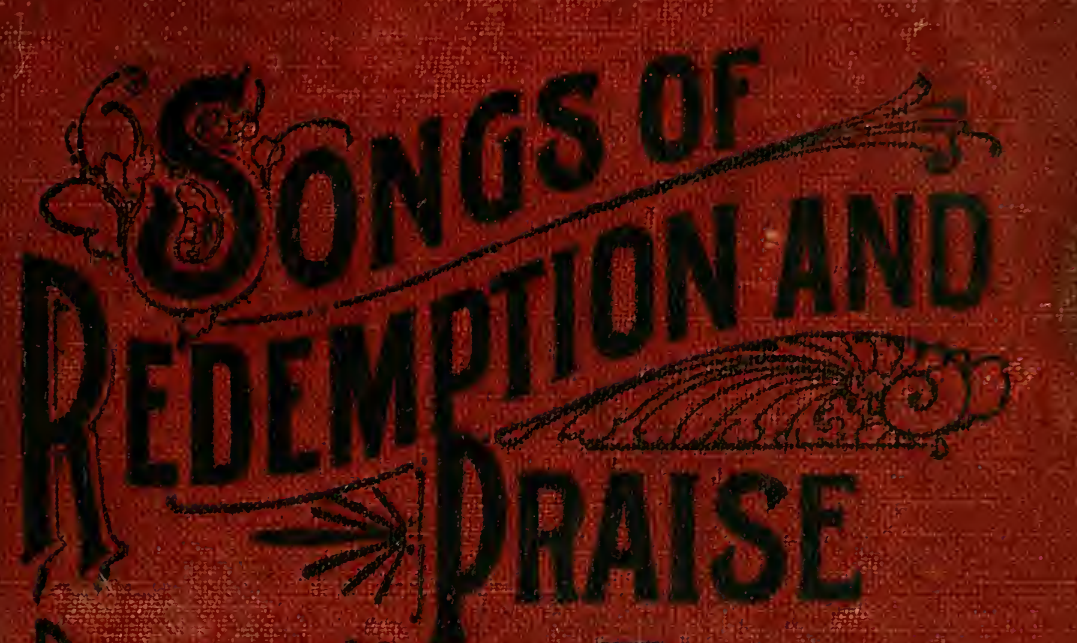

Dractical Helps for workers rinted / inits Jor inqurers. compled by : :

JOHN A. DAVIS (⿻一𠃋)

JNO. R, CLEMENTS 
If this is borrowed by a friend, Right welcome shall he be

To read, to study, not to lend, But to return to me.

Not that imparted knowledge doth

Diminish learning's store, But books, I find, if often lent, Return to me no more.

H. F. WORLEY 
$0 \mathrm{~m}$ t

50 



\title{
...SONGS OF...
}

\section{REDEMPTION AND PRAISE}

REVISED

\section{COMPILED AND EDITED}

\author{
BY \\ JOHN A. DAVIS
}

AND

\section{JNO. R. CLEMENTS}

\section{PRICES :}

Lees Manila reinforced back $\quad\left\{\begin{array}{l}\text { Per copy, 20c. } \\ \text { Per hundred, } \$ 15.00 .\end{array}\right.$

Red Vellum Delux cloth sewed back $\left\{\begin{array}{l}\text { Per copy, 30c. } \\ \text { Per hundred, } \$ 25.00 .\end{array}\right.$

Express not prepait.

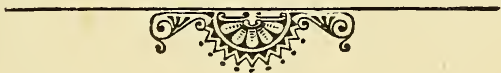

\section{PUBLISHED BY \\ BILHORN BROTHERS \\ 152 E. Lake Street \\ CHICAGO, ILL.}




\section{Preface}

The hearty, and in many ways unlooked for reception which has been accorded SONGS OF REDEMPTION AND

PRAISE leads to an earlier revision of the book than had been at the first intended by its editors.

The original features of the old book have been retained in this, and all the favorite songs have been carried overinto the revision.

The book has been strengthened by the addition of many of the most used gospel hymns of today-productions of the foremost writers and workers in soul-winning effort.

The Practical Bible Helps for Christian Workers will be found in more accessible form in this edition.

We commend SONGS OF REDEMPTION AND PRAISE

REVISED to all who are looking for a book of usable, singable Gospel hymns, suitable for evangelistic, devotional and open air sirvices; as well as the less formal home gatnerings.

J. A. D.

J. R. C. 


\section{...SONGS OF...}

\section{Redemption and Praise} th

\section{Give To Jesus Glory.}

"We behold His glory, the glory as of the only begotten of the Father."-Jno. 1: 14.

W. S. M.

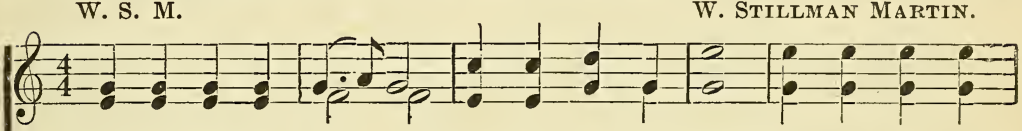

1. Give to Je-sus glo - ry, Praise His ho-ly name;From the Fa-ther's

2. Give to Je-sus glo - ry, Sing His tri-umph hour; When from death and

3. Give to Je-sus glo - ry, As He sits a - bove, Mak-ing in - ter-

4. Give to Je-sus glo - ry, Sing the glad re - frain, Soon in clouds of

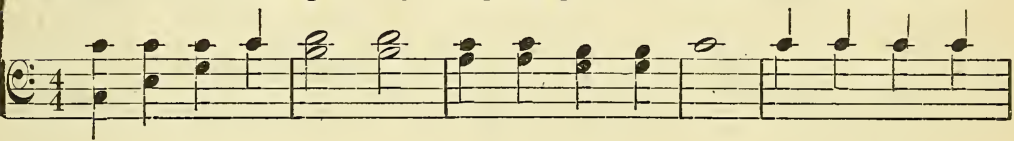

Chorts.

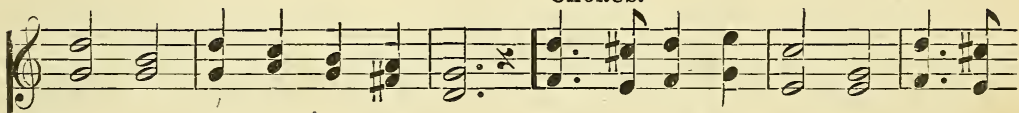

bo - som To the cross He came.

dark-ness He came forth in pow'r. Je - sus, blessed Sav-ior, Proph-et, ces-sion For His own, in love.

heav-en He will come a-gain.
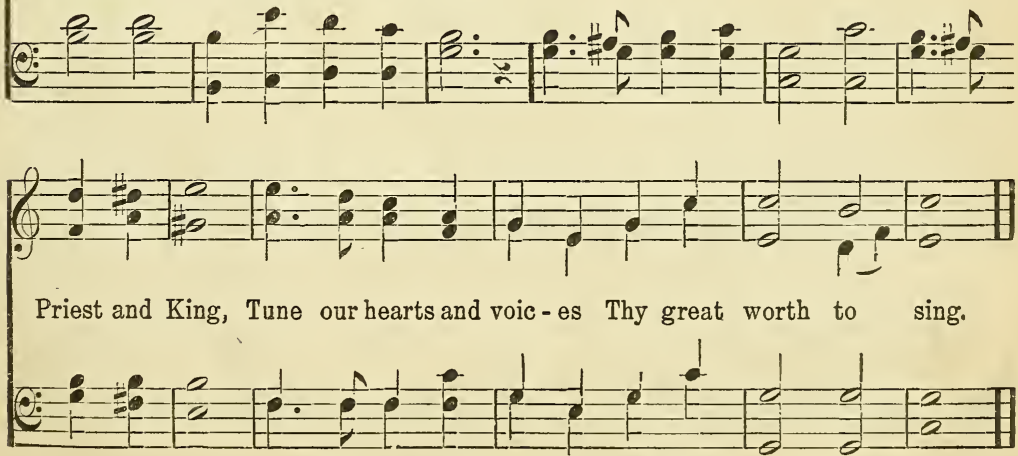

Copyright, 1905 , by John A. Davis. 


\section{o Tell Me More of Christ.}

E. E. HEWITI.

\section{Words and Music}

1. O tell me more of Christ, my Sav-ior; On this glad theme

2. O tell me more of love's sweetsto-ry, If you would cheer

3. O tell me more! How wares of sor-row Shall hear His voice

4. O tell me more! And I re-peat-ing The hap-py news,

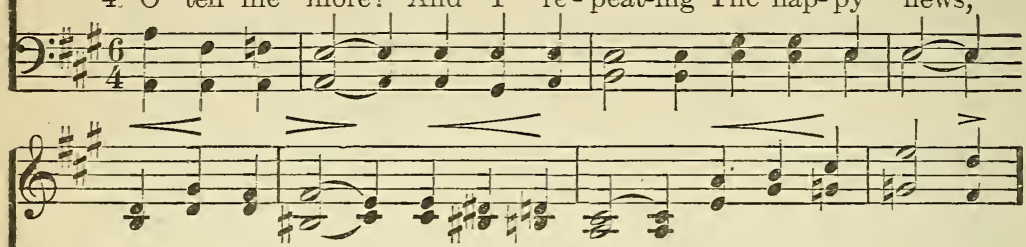

dwello'er and o'er; His boundless grace, His sav-ing fa-vor,

and com-fort me; How Je-sus wept, the King of glo- ry,

say, "Peace, be still;" How af - ter night, bright dawns the mor-row,

shall spread the joy; Come, bless-ed Lord, Thy work com-plet-ing,

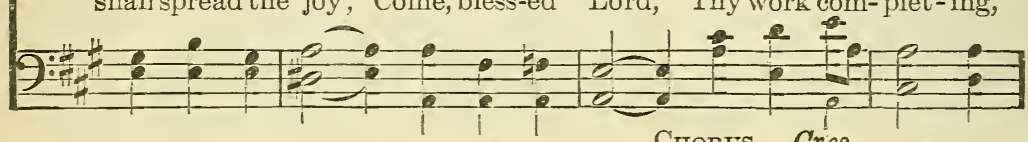

His precious name, O tell me more!
To thosewho trust His bless-ed will.
Till songs of praise our lips em-ploy.

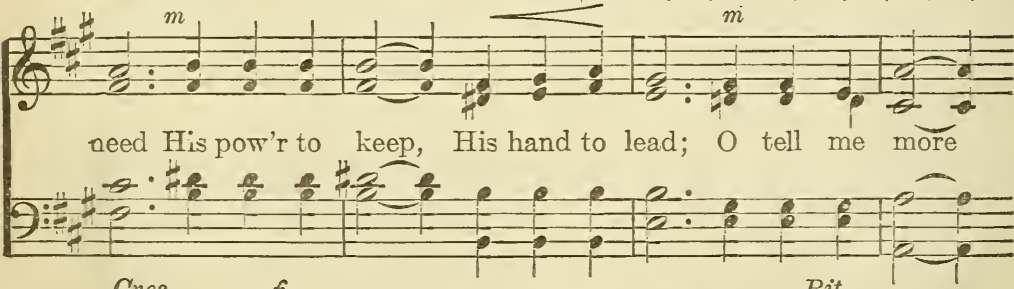

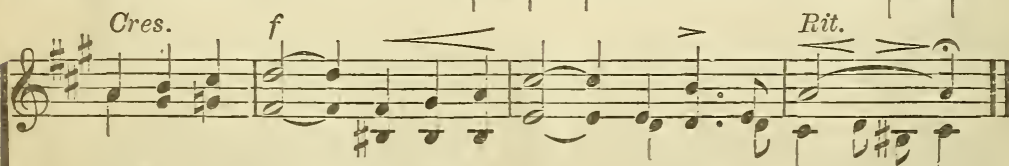

of Him I love, Un-til I see His face a-bove(facea-bove).

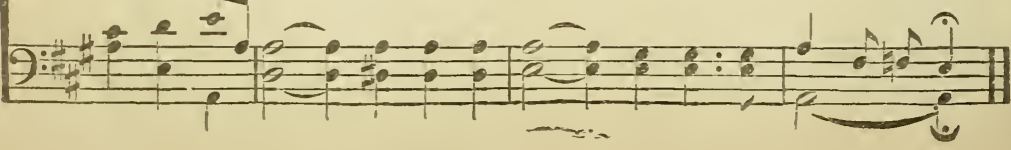




\section{God Will Take Care of You.}

Dedicated to my wife, Mrs. John A. Lavis.

C. D. $M: R T I N$.

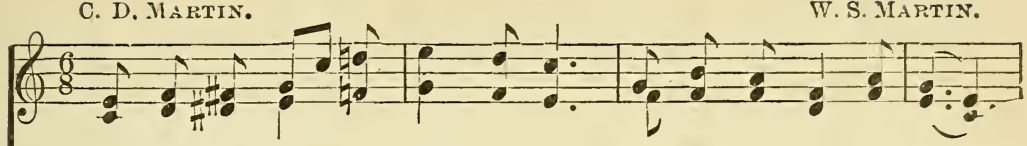

1. Be not dis-mayed what-e'er be-tide, God will take care of you;

2. Thro' days of toil when heart doth fail, God will take care of you;

3. All you may need He will pro-vide, God will take care of you;

4. No mat-ter what may be the test, God will take care of you;
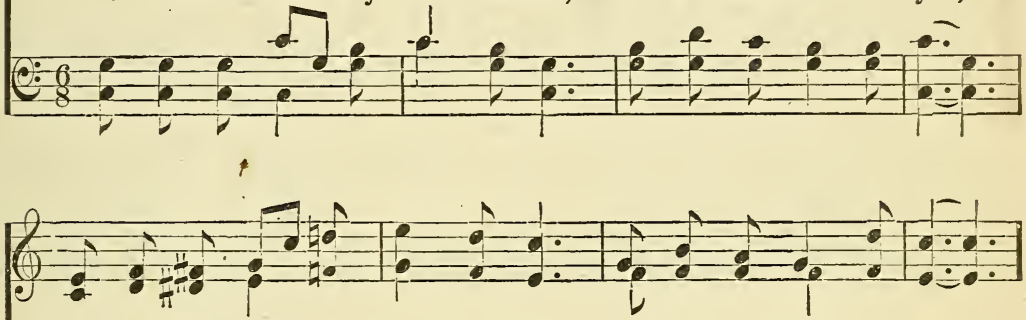

$\mathrm{Be}$-neath His wings of lov a-bide, God will take care of you.

Whendan-gers fierce your path as-sail, God will take care of you.

Noth-ing you ask will be de-nied, God will take care of you.

Lean, wea-ry one, up - on His breast, God will take care of you.

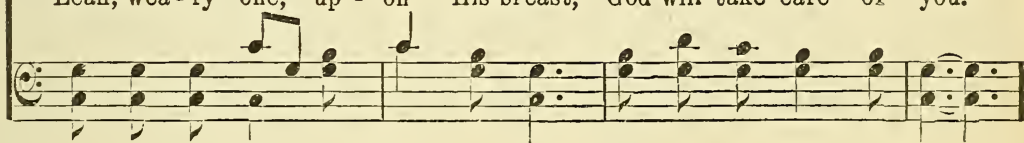

CHORUS.

(1)

God will take care of you, Thro' ev - 'ry day, O'er all the way,
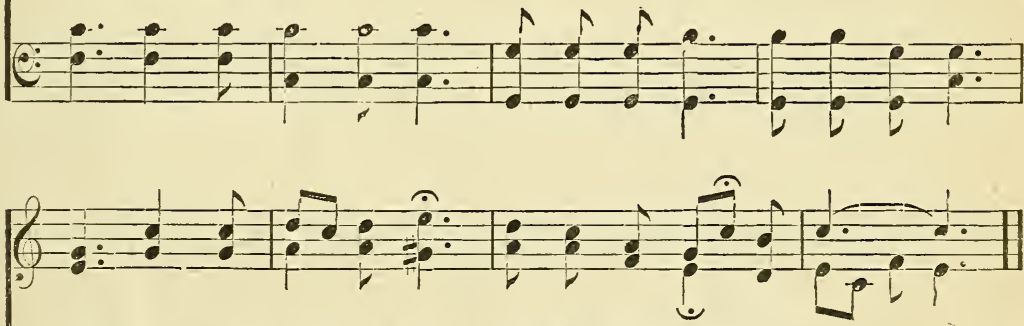

He will take care of you, God will take care of you.

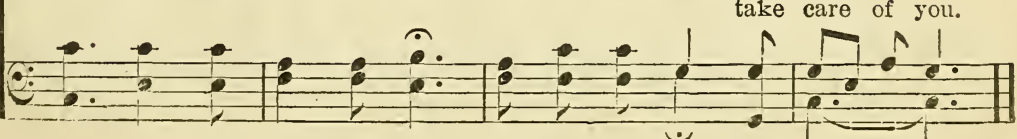

Copyright, 1906, by John A Davis. 
Anon.

M. I. Stocks.

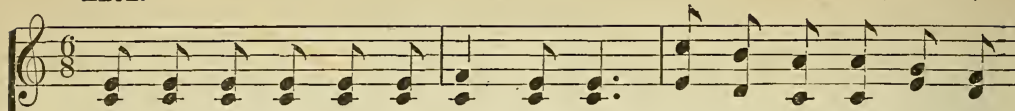

1. Jə - sus is stand-ing in Pi - late's Hall, Friend-less, for - sak - en, be-

2. Je - sus is stand-ing on tri - al still, You can be false to Him

3. Will you e - vade Him as $\mathrm{Pi}$ - late tried, Or will you choose Him what-

4. Will you like $\mathrm{Pe}$ - ter your Lord de - ny? Or will you scorn from His

5. "Je-sus, I give Thee my heart to-day; Je-sus, I'll fol-low Thee
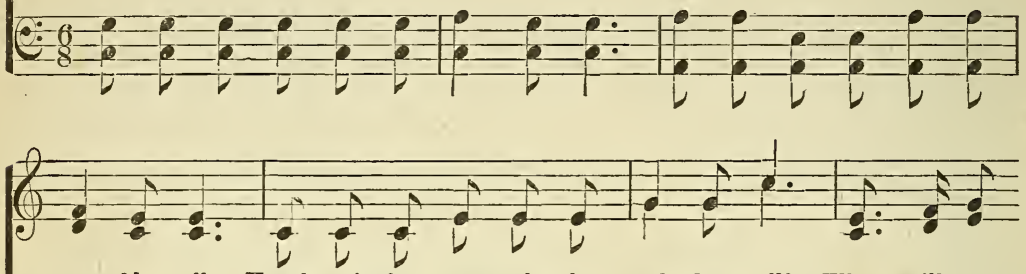

trayed by all; Heark-en! what mean-eth the sud-den call? What will you if you will, You can be faith-ful thro' good or ill,-What will you e'er be-tide? Vain-ly you strug-gle from Him to hide,-What will you foes to fly, Dar - ing for Je - sus to live or die? What will you all the way, Glad - ly o - bey - ing Thee;" will you say: "This will I

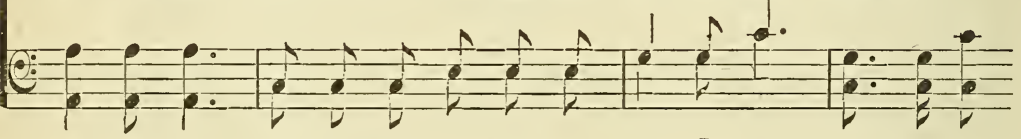

ChORUs.

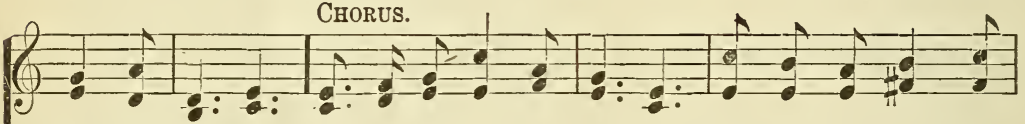

do with Je - sus?

do with Je - sus?

do with Je-sus? What will you do with Je-sus? Neu - tral you can - not

do with Je - sus?

do with Je - sus?"
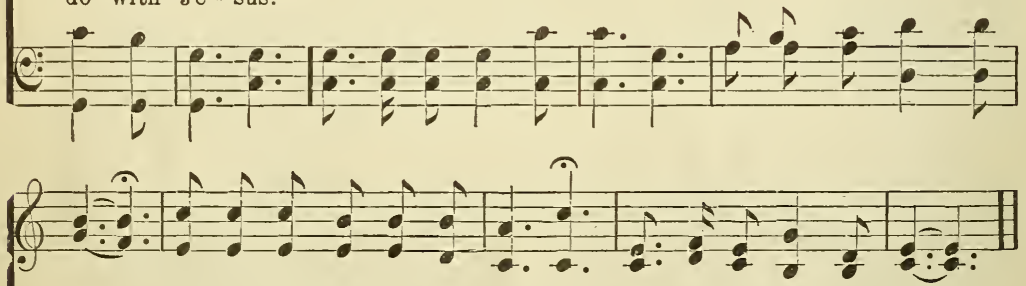

be; Some day your heart will be ask - ing, What will He do with me?

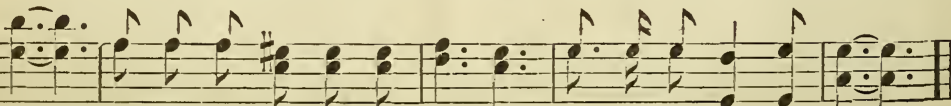
Copyright, 1905, by Chas. M. Alexander. English copyright. Used by per. 


\section{My Lord and I.}

MrS. L. SHOREY.

JOSEPH D. LITTLF.

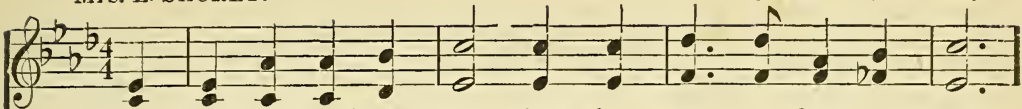

1. I have a Friend so pre - cious, So ve - ry dear to me,

2. Sometimes I'm faint and wea - ry, $\mathrm{He}$ knows that I am weak;

3. He knows how much I love Him, He knows I love Him well;

4. I tell Him all my sor - rows, I tell Him all my joys,

5. He knows how I am long - ing Some wea - ry soul to win,
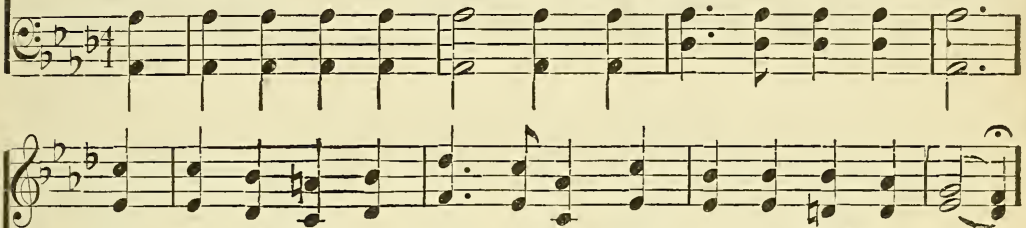

He loves me with a ten - der love, He loves me faith-ful - ly,

And as $\mathrm{He}$ bids me lean on Him, His help I'll glad-ly seek;

But with what love He lov - eth me, My tongue can nev-er tell;

I tell Him all that pleas - es me, I tell Him what an-noys;

And so $\mathrm{He}$ bids me go and speak A lov-ing word for Him;
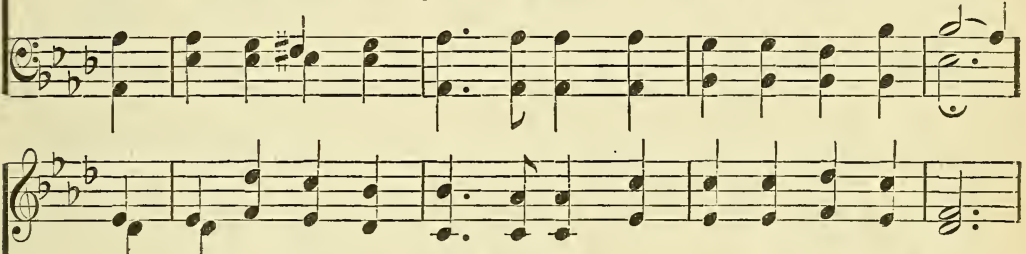

I could not live a - part from Him, I love to feel Him nigh,

He leads $m e$ in the path of light, Be - neath a sun - ny sky;

It is an ev - er - last - ing love In ev - 'ry rich sup - ply;

$\mathrm{He}$ tells me what I ought to do, $\mathrm{He}$ tells me what to try;

$\mathrm{He}$ bids me tell His won-drous love, And why He came to die;

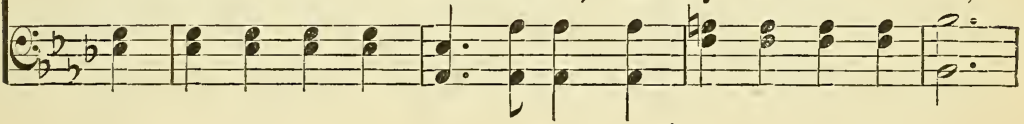

rit.

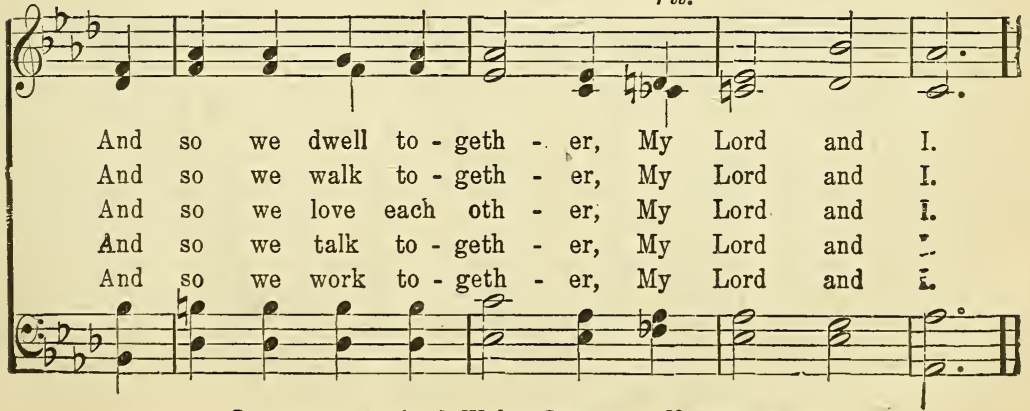

Copyright. 1902, by J, Wilbur Chapman, Used by per, 
W. S. M.

W. StillmaN Martin.

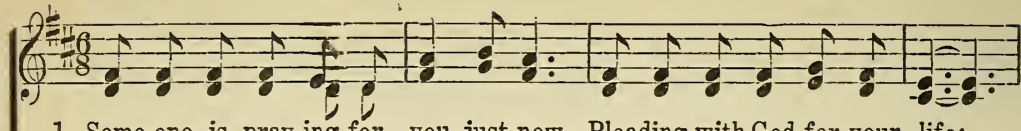

1. Some-one is pray-ing for you just now, Pleading with God for your life;

2. Some-one has pray'd ma-ny years for you, Called up - on God night and day;

3. Some-bod-y pray'd when your heart was gay, Knowing no sor-row or care,

4. Days have gone on, and the months and years, Soon you must face the white throne,

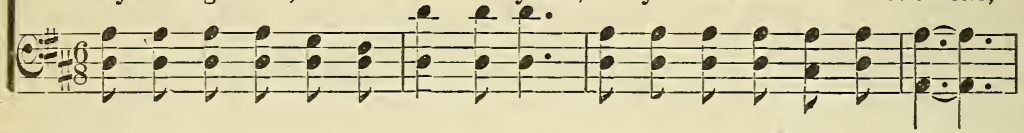

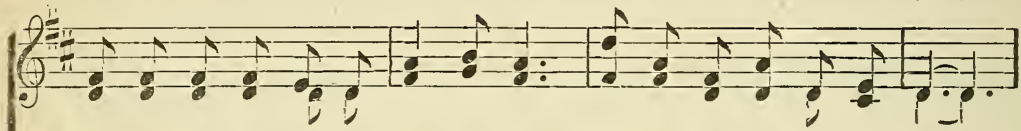

Turn to the Sav-ior, be - fore Him bow, End this re-bel-lion and strife.

Cheeks have been wet as with eve-ning dew, While you have wandered a - way.

Pray'd that their loved one might learn the way, Life ev-er-last-ing to share.

How you will long for those pray'rs and tears, Standing in judgment a - lone.

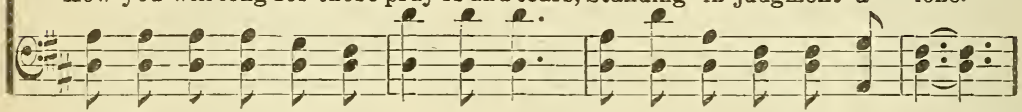

CHORUS.

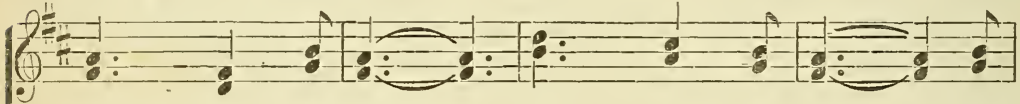

Pray - ing for you, . - pray - ing for you, . . Some

Someone is pray-ing for you just now, Some one is pray-ing for you just now,

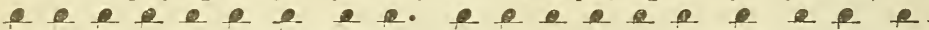

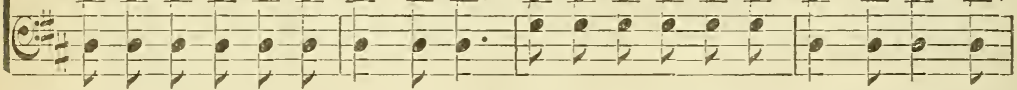

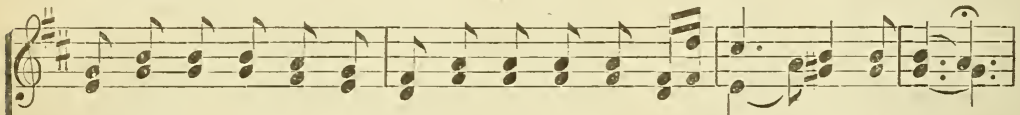

fa-ther or moth-er, Some sis - ter or broth-er is pray - ing for you;
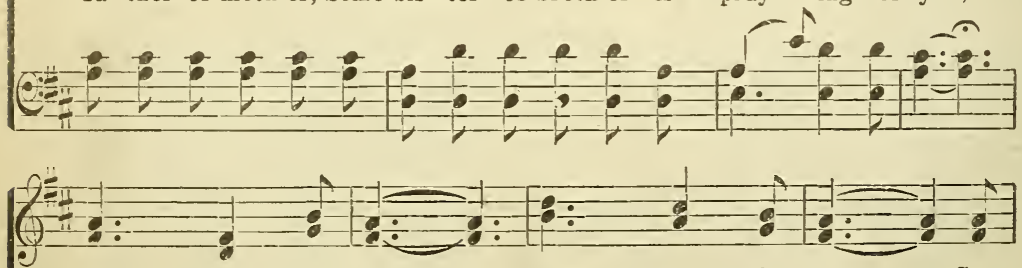

Pray - ing for you, . . pray - ing for you, . . Some

Some one is pray-ing for you just now, Some one is pray-ing for you just now,

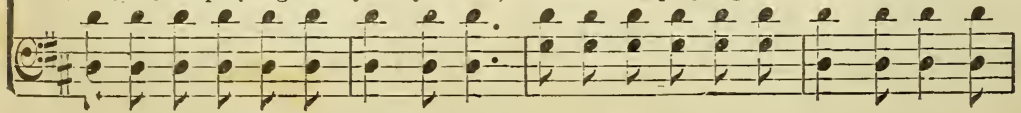

Copyright, 1905 , by John A. Davis. 


\section{Some One is Praying for You.}

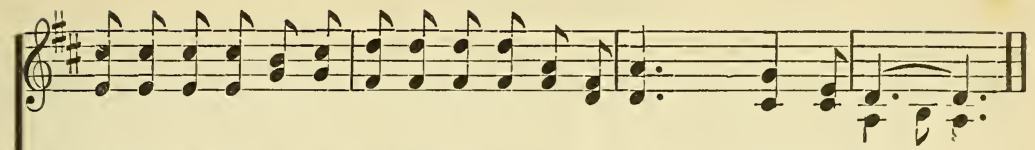

fa-ther or mother, Somesis-ter or brother is pray - ing for you. . pray-ing for you just now, just now,

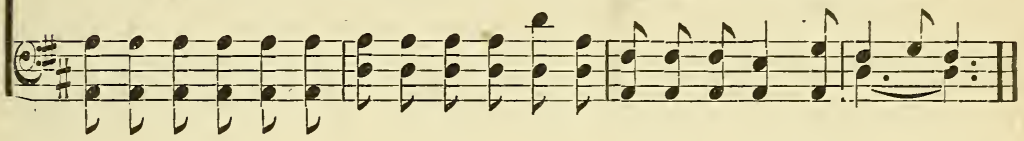

\section{All Hail the Power.}

E. Perronet.

OLIVER HOLDEN.

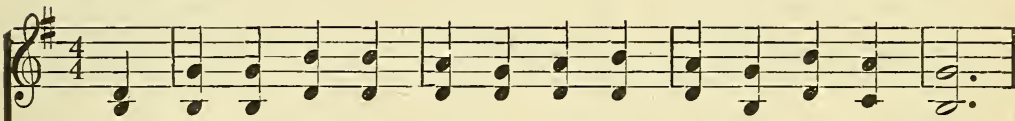

1. All hail the pow'r of Je-sus' name! Let an-gels pros-trate fall;

2. Let ev-'ry kin-dred, ev - 'ry tribe, On this ter - res-trial ball,

3. Oh, that with yon-der sa-credthrong $\mathrm{We}$ at His feet may fall;
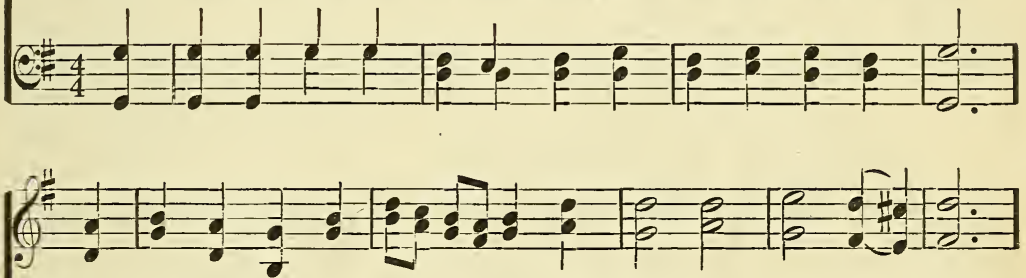

Bring forth the roy - al di - a - dem, And crown Him Lord of all;

To Him all maj-es - ty as-cribe,And crown Him Lord of all;

We'll join the ev - er - last-ing song, And crown Him Lord of all;
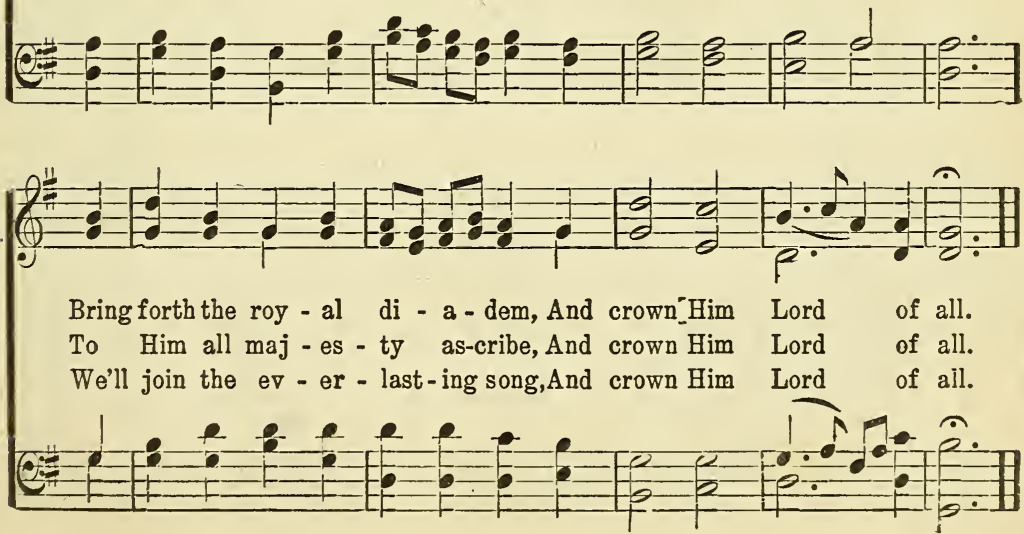
INA DULET OQDON.

Words and Music

Copyright, 1901, by P. P. Bilhorn.

P. P. BILHORN.

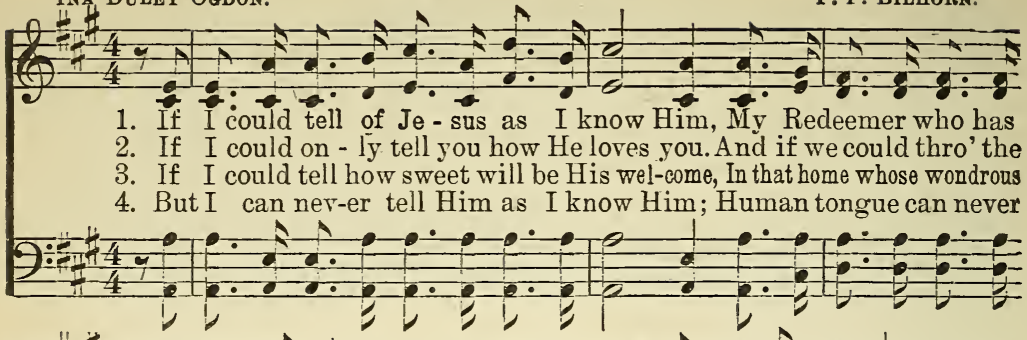

(2)

brightened all my way; If I could tell how precious is His pres-ence,

lone-ly gar-den go, If I could teli His dying pain and par - don.

beauty ne'er was told; And tell you how He waits and longs to save you,

tell of love di-vine; I on - ly can entreat you to ac-cept Him;

$\mathrm{Z}$

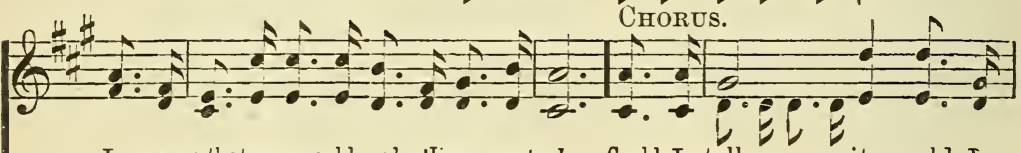

I am sure that you would make Him yours to-day. Could I tell it, could I

You would worship at His wounded feet I know.

You would seek Him, and a-bide within His fold.

Come and know the joy and peace for-ev - er mine. Could I tell it, Jes, I would, could I

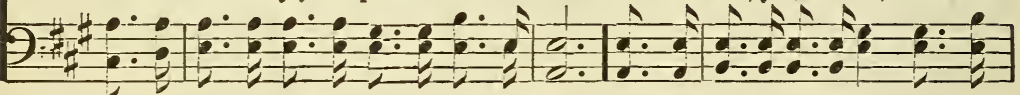
(4)

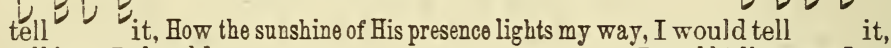
tell it as I should,

I would tell you, jes, I would,
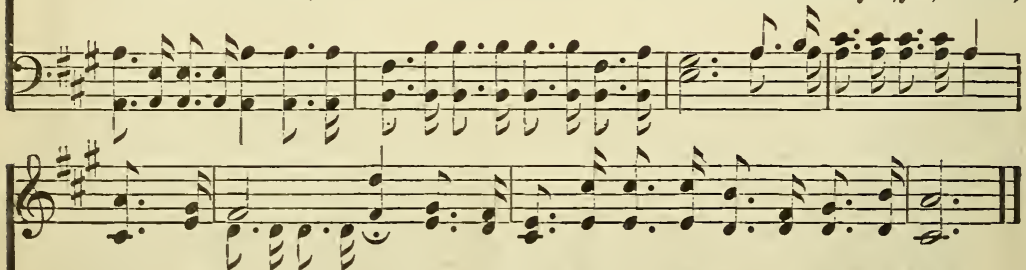

I would tell

it. And I'm sure that you would make Him yours to-day.

I would tell you if I could,

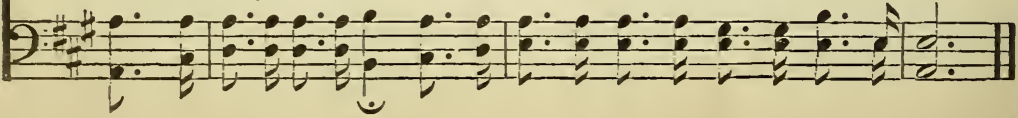


JOHN R. CIEMENTS.

Max Whittle Moody.

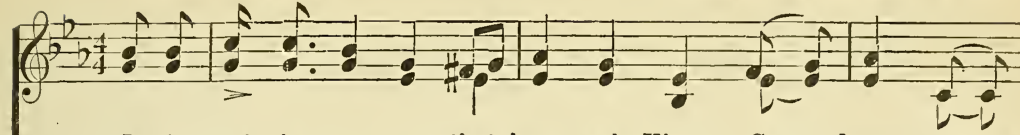

1. Is it noth-ing to you that heav-en's King Came down to this

2. Is it noth-ing to you that by and by You must trav-el

3. Is it noth-ing to you that some sweet day In the heav-en-ly
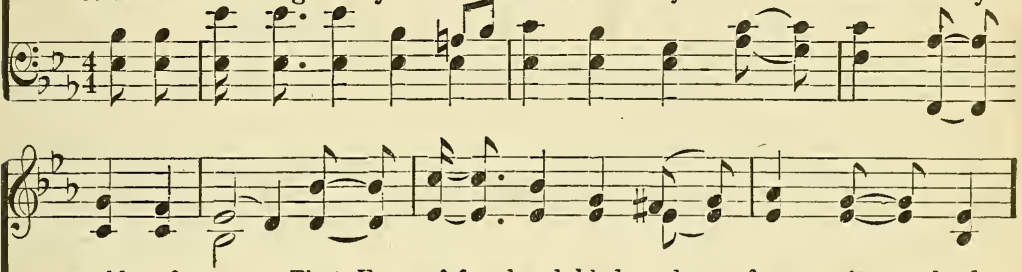

world of woe, That He suf-fered and bled, and rose from the dead, death's dark vale, Where Jor - dan's waves the path - way laves, land so fair You may join the song that the ran - somed throng

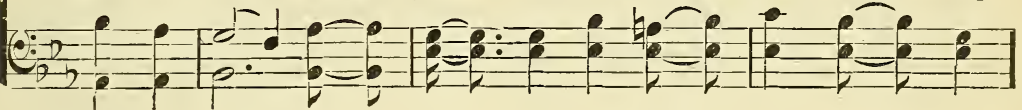

REFRAIN.

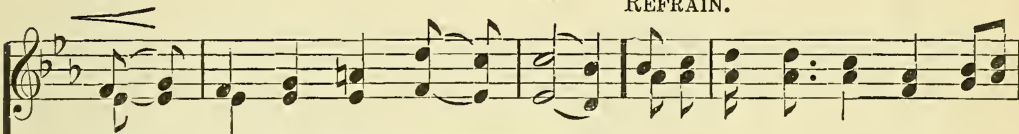

That e - ter-nal life you might know?

And all but Christ doth fail? Is it noth-ing to you that Are for - ev - er sing - ing there?

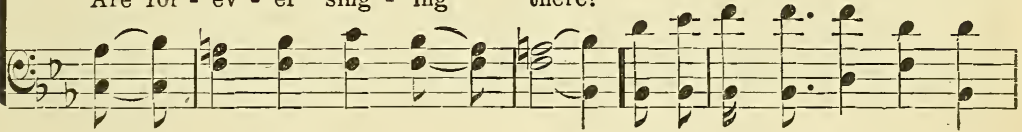

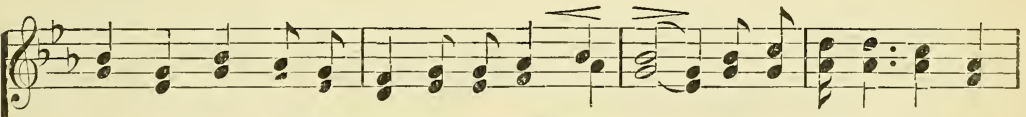

grace is free, And that God in His love doth call? Is it noth-ing to you?
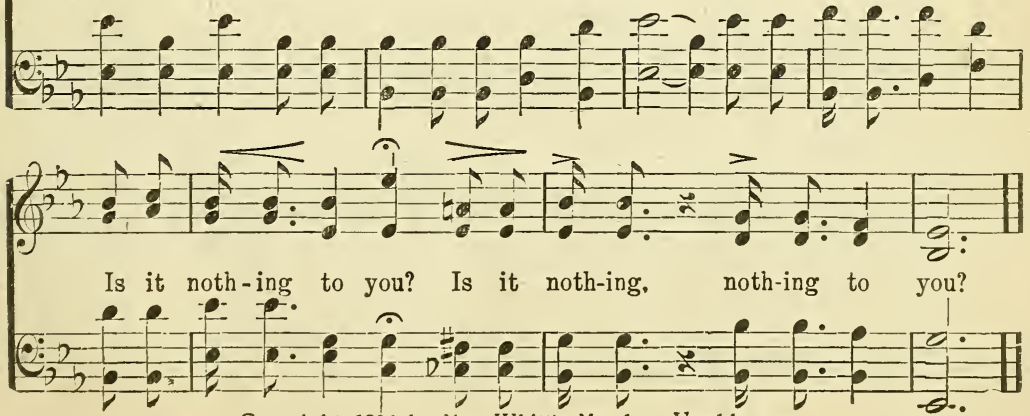

Copyright, 1896, by May Whittle Moody. Used by per. 
J. W. B.

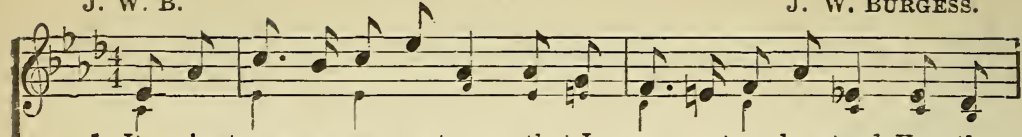

1. It is strange, so ver-ystrange, that I can - not un-der-stand How the

2. It is strange, so $\mathrm{ver}-\mathrm{y}$ strange, how His wondrous love for man, Made Him

3. Is there one poor sin-ner here, who is long-ing to be free? Come to
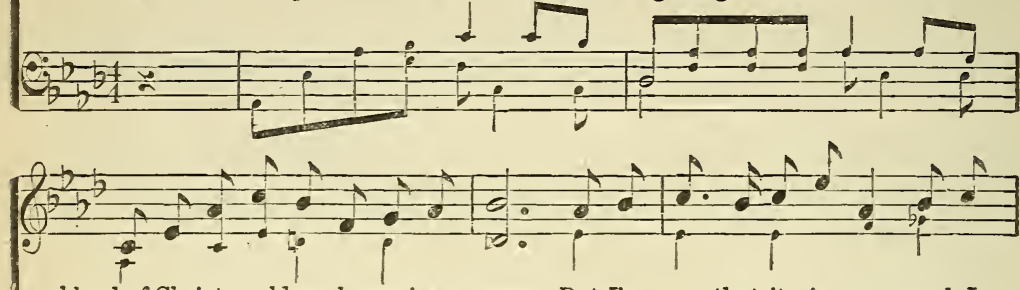

blood of Christ could wash my sins a - way; But I'm sure that it is so, and I leave His throne and radiant home on high; And be in a manger laid, as a

Christ and now His gen-tle call o - bey; He will all your sins forgive-sin-ner
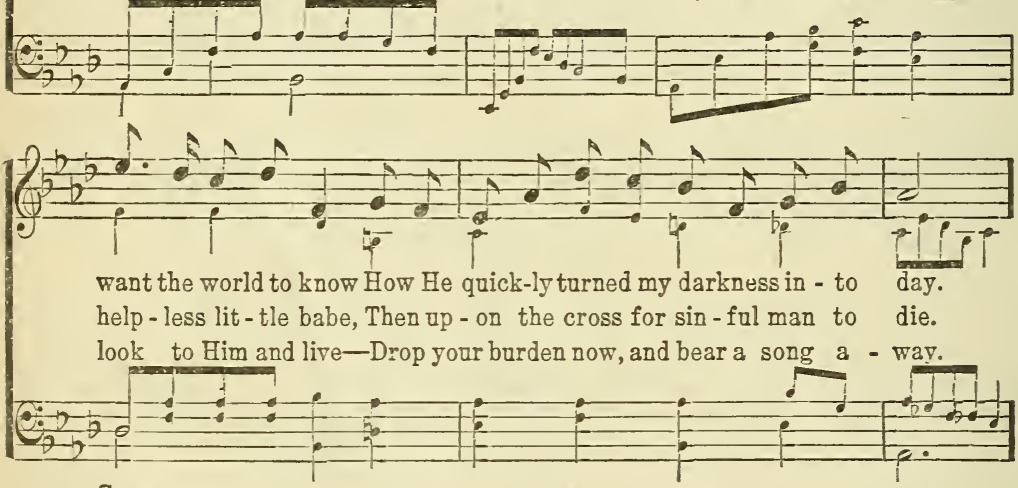

Chorts.

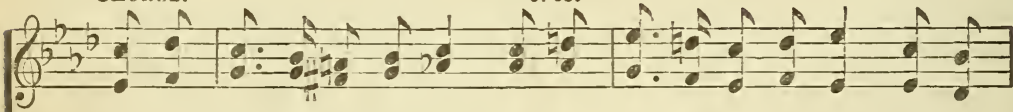

0 the precious blood of Christ, that was shed on Cal - va - ry, How it

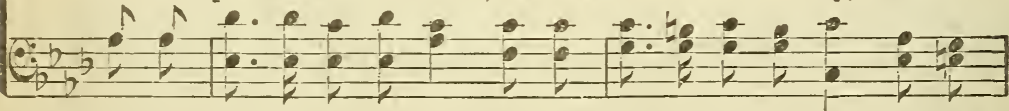

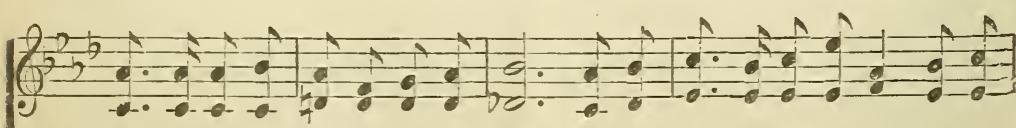

heals the bro-ken heart and makes it whole; How His sweet and gentle voice bids the

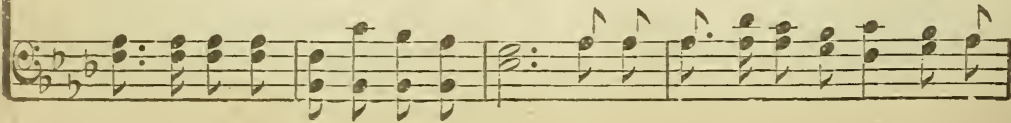




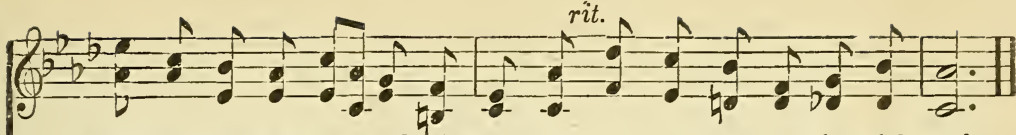

sad-dened ones re-joice, And brings peace to ev - 'ry wea - ry sin - sick soul.

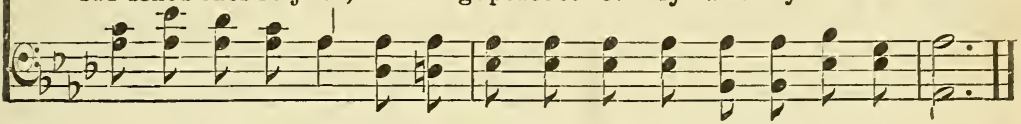

\section{When My Savior I Shall See.}

Arr. P. P. B.

Words and Music Copyright, 1897, by P. P. Bilhorn.

P. P. BILHORN.

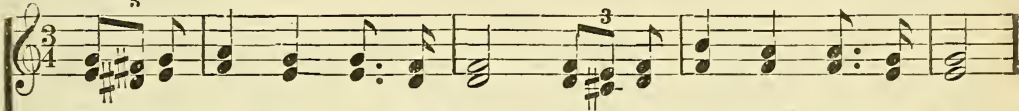

1. When my Sav - ior I shall see, In His glo-rious like-ness be,

2. When I'm whol - ly freed from sin, Spot-less, clean and pure with-in,

3. When my feet shall press the shore, Trod by an - gels feet be - fore; 4. $\mathrm{Oh}$, till then be this my care, More His im - age blest to bear;

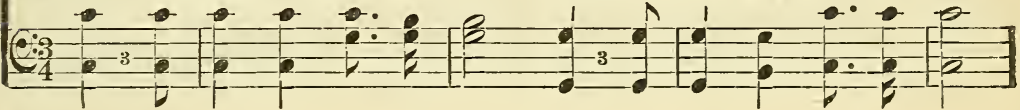
(Q) Clad in robes by love sup-plied, Then shall I be sat-is - fied. Meet to stand by Je - sus' side, Then shall I be sat - is - fied. Near to liv - ing streams that glide, Then shall I be sat - is - fied. More to con - quer self and pride, So shall $I$ be sat-is - fied.

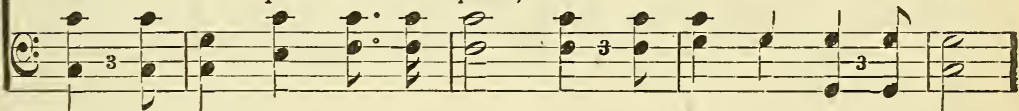
ChoRUS.

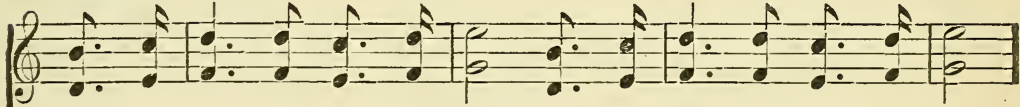

Sat - is - fied with love di - vine, Sat - is - fied, since Christ is mine;

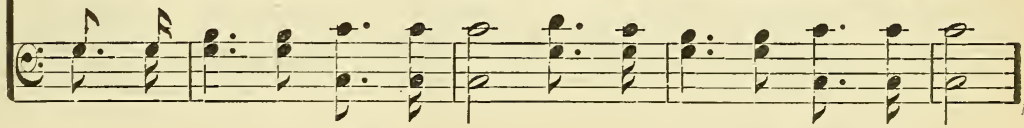

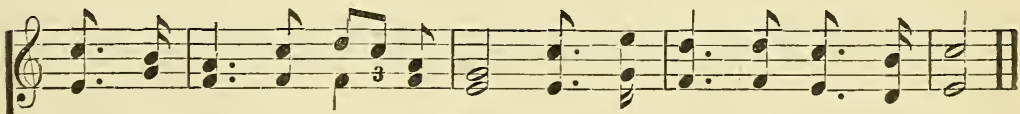

Ev - 'ry need in Him sup - plied, Then shall I be sat - is - fied.

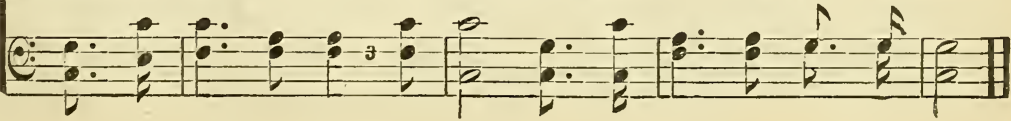


By per, of W. L. Thompson \& Oo., East Lirerpool, O., snd Ohioago, IIl.

W. L. T.

Solo or DuET, ad lib.

W. L. Thoseron.

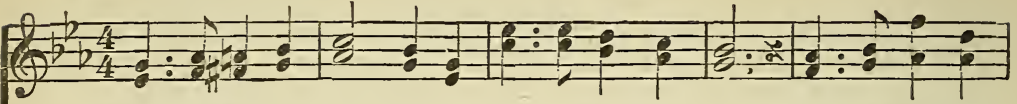

1. Lead me gently home,Father,Lead me gently home, When life's toils are

2. Lead me gently home, Father,Lead me gently home, In life's darkest

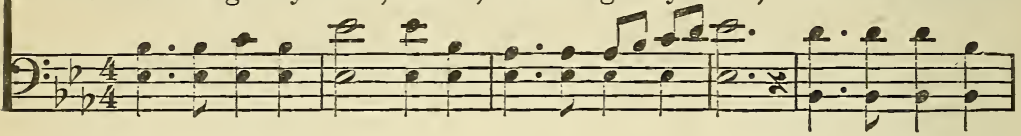

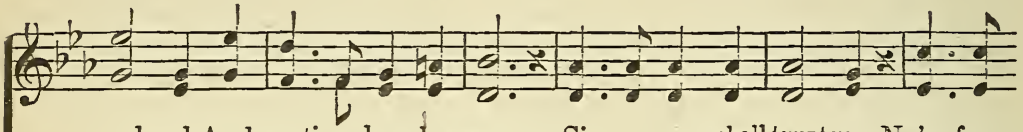

end - ed,And parting days have come. Sin no more shall tempt me, Ne'er from

hours, Father, When life's troubles come,Keep my feet from wand'ring,Lest from

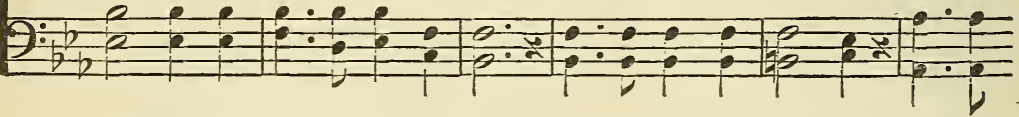

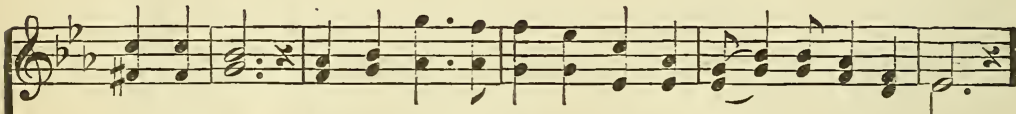

Thee I'll roam, If Thou'lt on-ly lead me,Father, Lead me gently home.

Thee I'll roam, Lest I fall up-on the wayside, Lead me gently home.

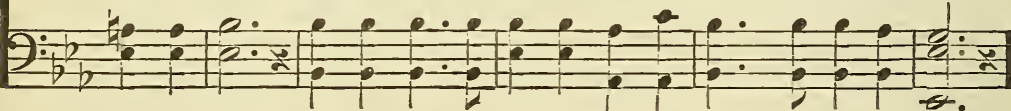

REFRAIN.

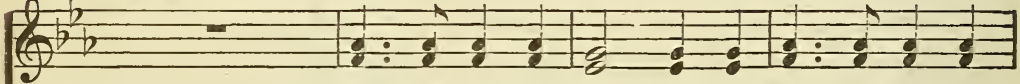

Lead me gen-tly home, Fa-ther, Lead me gen-tly

Lead me gen-tly home, Fa-ther,Leadmegently homc, Fa-ther,
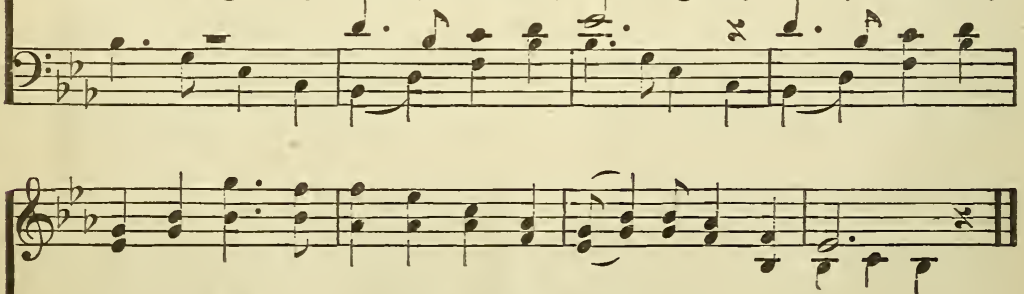

Lest I fall up-on the way-side, Lead me gen-tly home.

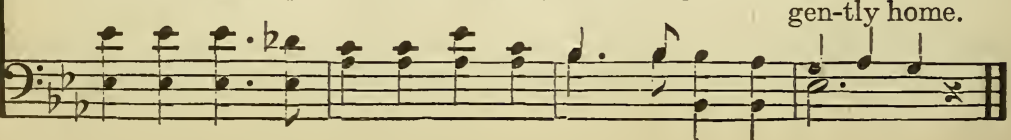




\section{Have Nothing to Do with Tomorrow. I5}

Major D. W. WHITTLE.

MAY WhitTLE MOODY.

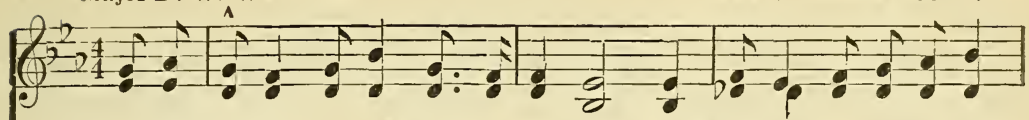

1. I have nothing to do with to-mor-row, Its sun-light I nev-er may

2. Oth-er workers may gath - er the har-vest, And reap from the fields I have

3. So I've nothing to do with to-mor-row, Its bur-dens then why should'I

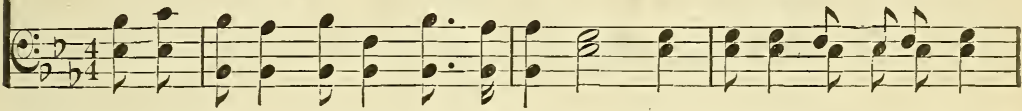

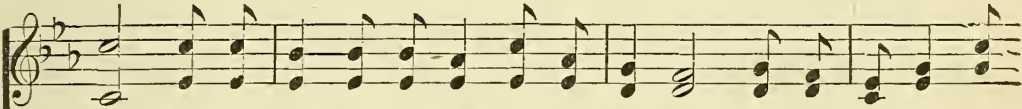

see; So to-day with the plow in the fur-row, In the vine-yard I

sown, But if still I am faith-ful in sow-ing, I shall hear from my

bear? Should He fill it with joy or with sor-row, He will lielp me, with

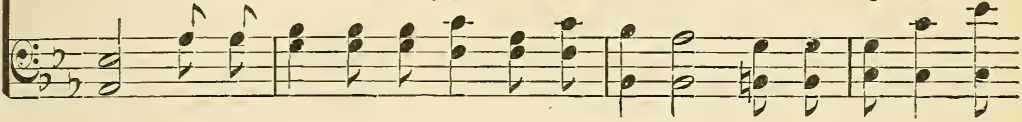

REFRAIN.

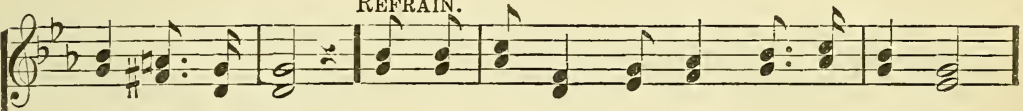

faith-ful would be.

Mas-ter, "Well done." I have noth-ing to do with to-mor-row,

Him, all to share.

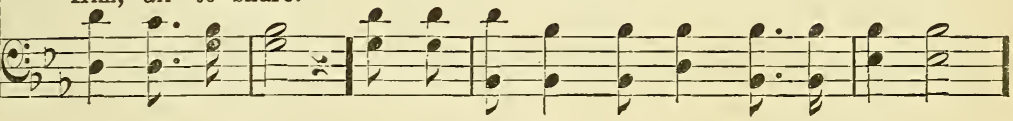

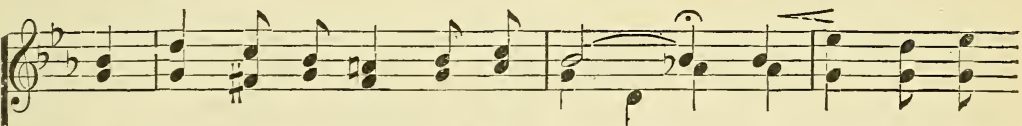

My Sav-jour will make that His care, (His care.) Its grace and its

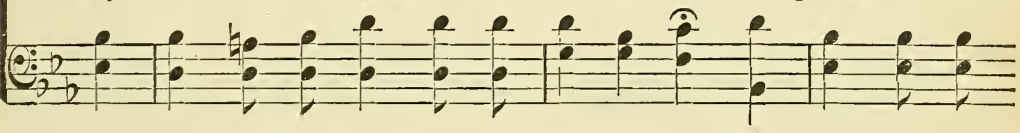

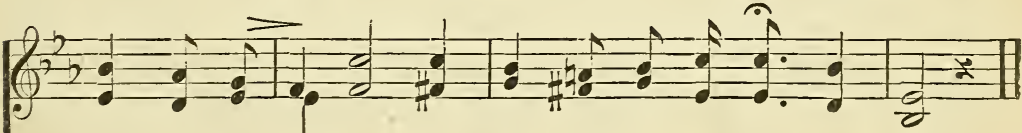

strength I can't bor-row, So why should I bor-row its care?

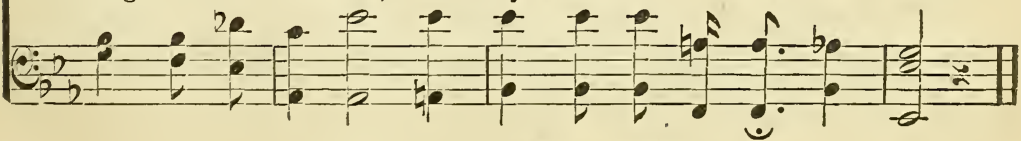

Copyright. 1906, by May Whittle Moody. 
JонN.

Ep. 12. 13.

J. G. FoOTE.

(0)

1. Christ our Re-deem-er died on the cross, Died for the sin-ner,

2. Chief-est of sin-ners, Je - sus can save, As $\mathrm{He}$ has promised,

3. Judg-ment is com-ing, all will be there, Who have re-ject-ed,

4, O, what com-pas - sion, oh, bound-less love! Je - sus hath pow - er,

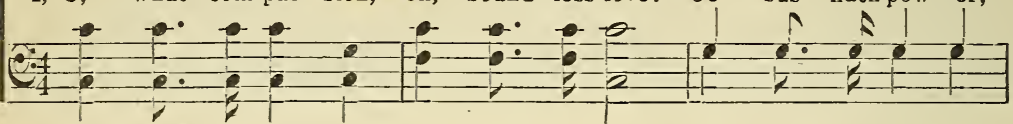

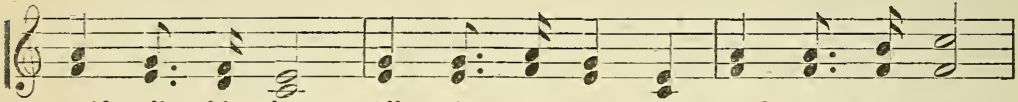

paid all his dae; All who re-ceive Him need nev - er fear, so will He do; $\mathrm{Ob}$, sin - ner, hear Him, trust in His word, who have re-fused? $\mathrm{Ob}$, sin - ner, hast - en, let Je - sus in, Je - sus is true; All who be-lieve are safe from the storm,

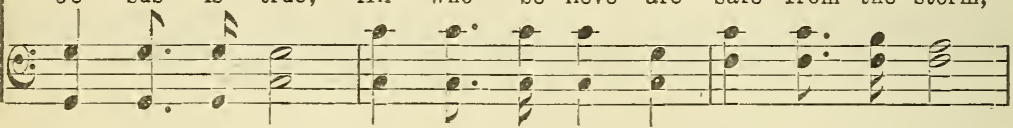

CHORUS.

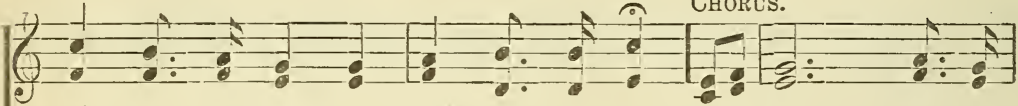
Yes, He will pass, will pass 0 - ver you.

Then $\mathrm{He}$ will pass, will pass o - ver you. When I see the

Then God will pass, will pass 0 - ver you.

$\mathrm{Oh}$, He will pass, will pass 0 - ver you. When I

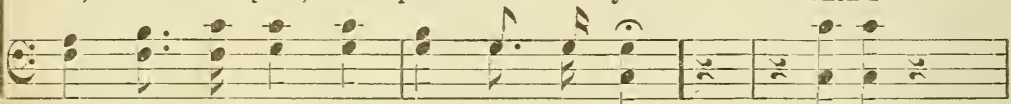

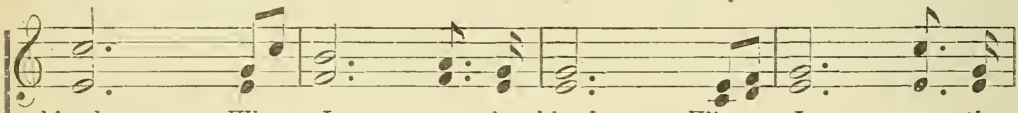
blood, When I see the blood, When I $I_{\text {When I }}$ see the see the blood, When I

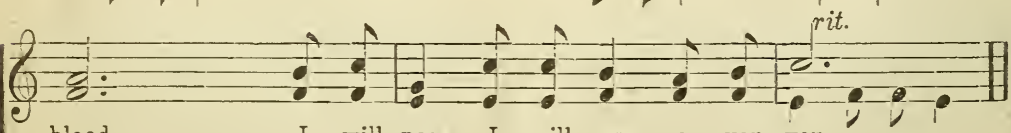
blood, I will pass, I will pass 0 - ver you.

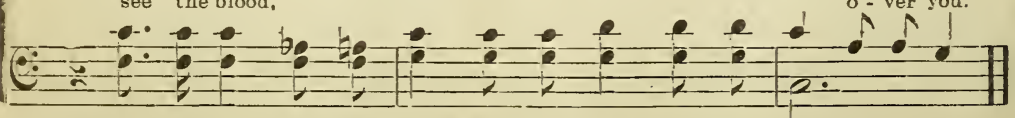

Bᄀ Poote Bros., not copyrighted. Let no one do so. Way this song ever be free to be puoblished for the glory of God. 

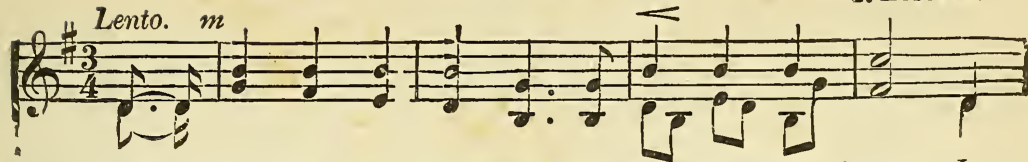

1. The Lord is my Shep-herd, no want shall I know, I

2. 'Thro' the val - ley and shad-ow of death tho' I stray, Since

3. In the midst of af - flic - tion my ta - ble is spread; With

4. Let good-ness and mer-cy, my boun-ti - ful God, Still
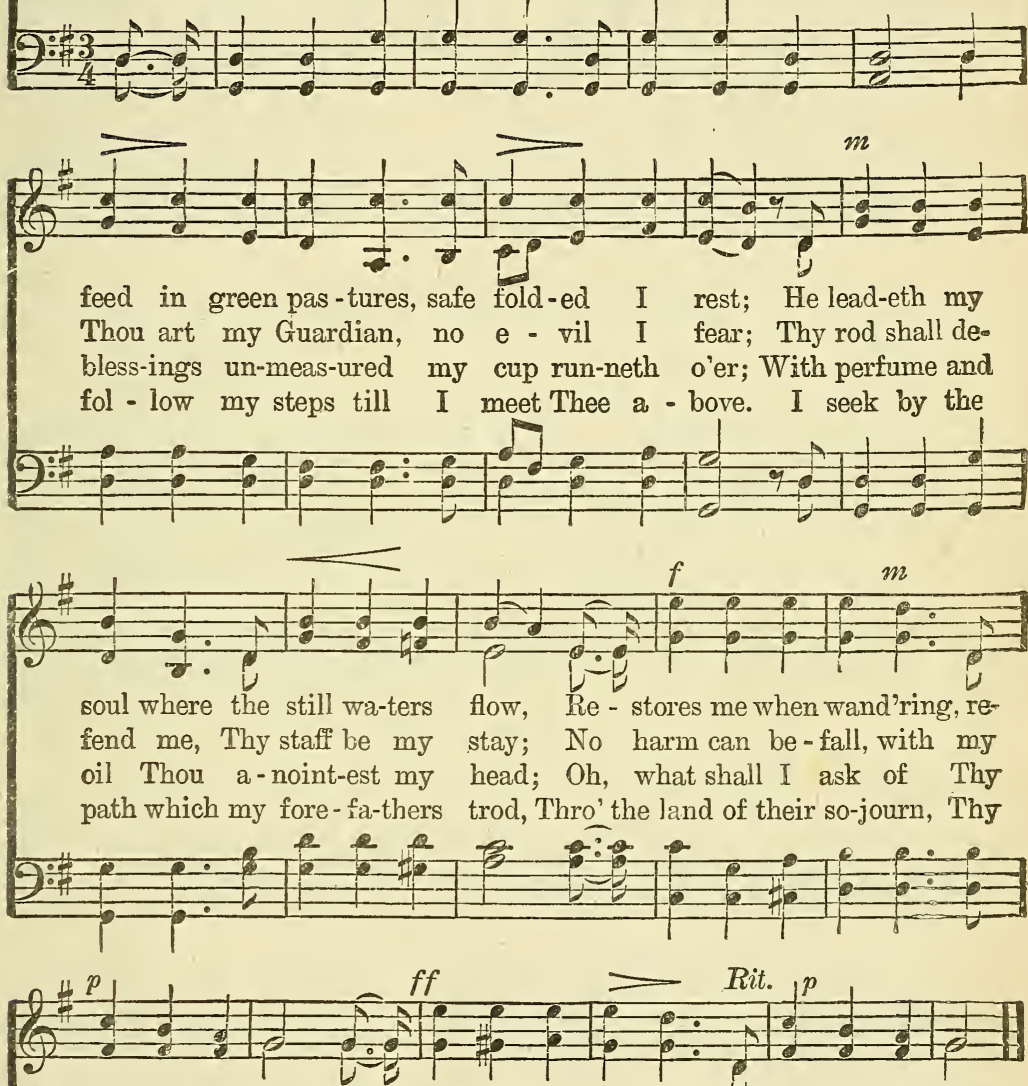

deems when oppressed, Re-stores me when wand'ring, redeems when oppressed.

Com-fort - er near, No harm can be-fall, with my Com-fort-er near. prov-i-dence more? Oh, what shall I ask of Thy prov-i-dence more. king-dom of love, Thro' the land of their so-journ, Thy kingdom of love.

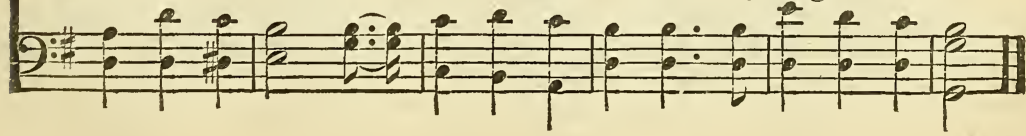


Rev. Walter C. Surith.

FRED H. BYSHE.

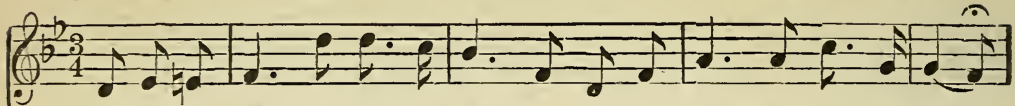
1. One thing I of the Lord de - sire, For all my path hath mir - y been,

2. If clear-er vis - ion Thou im - part, Grate-ful and glad my soul shall be;

3. Yea, on - ly as this heart is clean Maylarg - er vis - ion yet be mine,

4. I watch to shun the mir - $y$ way, And stanch the springs of guilt-y tho't,
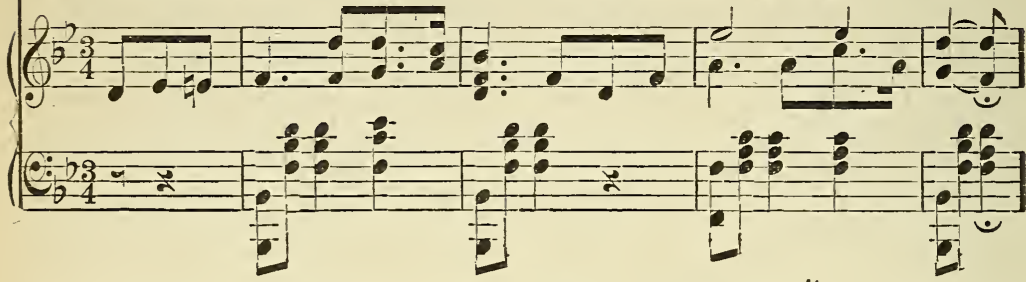

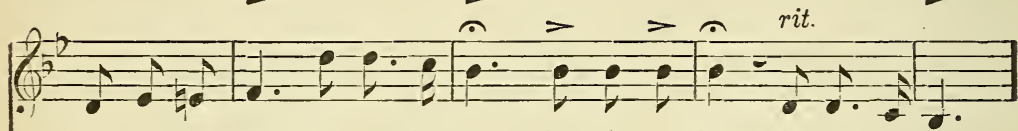

$\mathrm{Be}$ it by wa - ter or by fire, 0 make me clean, 0 make me clean.

But yet to have a pur-erheart Is more to me, Is more to me.

For mir-rored in its depths are seen The things di - vine,The things di - vine.

But, watch and strug-gle as I may, Pure I am not, Pure I am not.

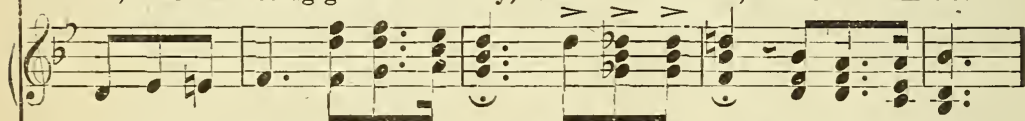

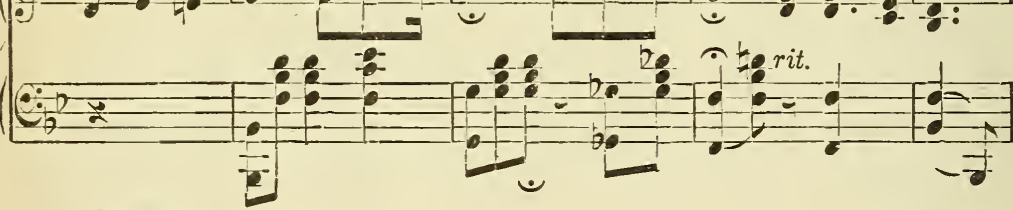

REFRAIN.

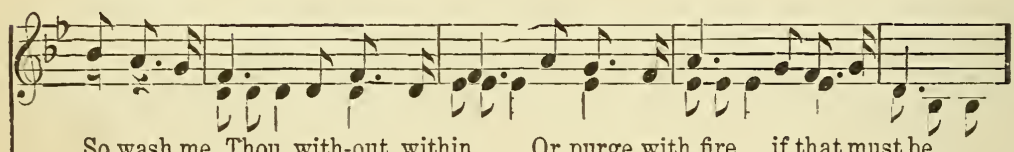

So wash me, Thou, with-out, within, Or purge with fire, if that must be,

Wash me, Thon, with - ont, within, Or pargewith fire, if that must be,
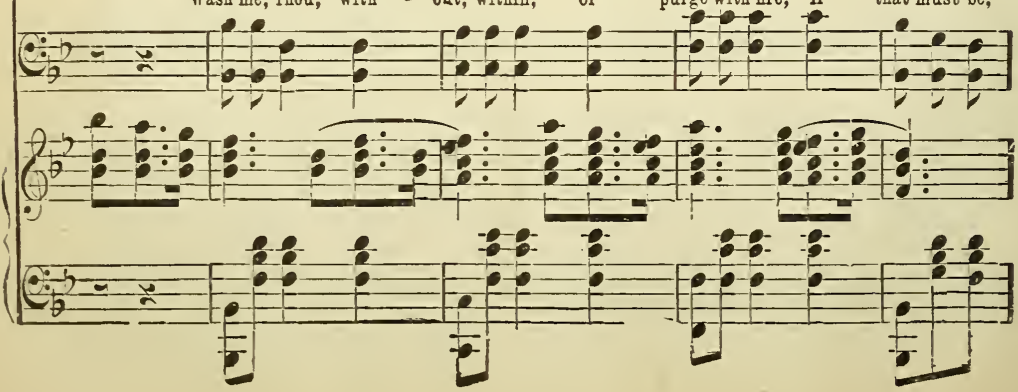


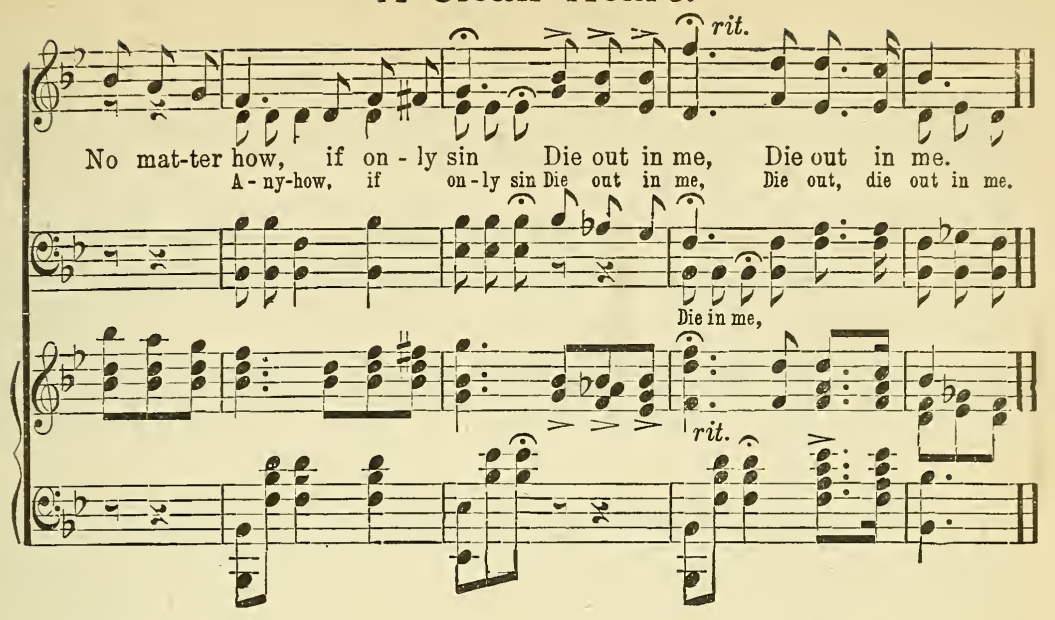

\section{Stand Up for Jesus.}

G. DufField.

G. J. WEBB.

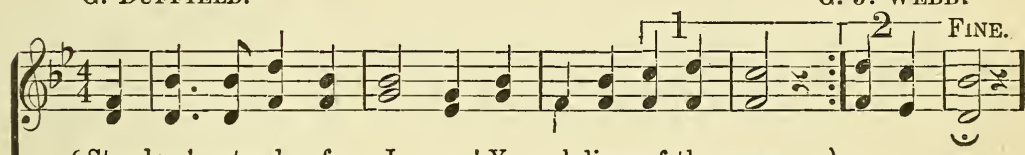

1. $\left\{\begin{array}{l}\text { Stand up!-stand up for Je-sus! Ye sol-diers of the cross; } \\ \text { Lift high the roy-al ban-ner, It must not (Omit) }\end{array}\right\}$ suf-fer loss;

D. S.-Till ev - 'ry foe is vanquished, And Christ is (Omit) Lord in-deed.
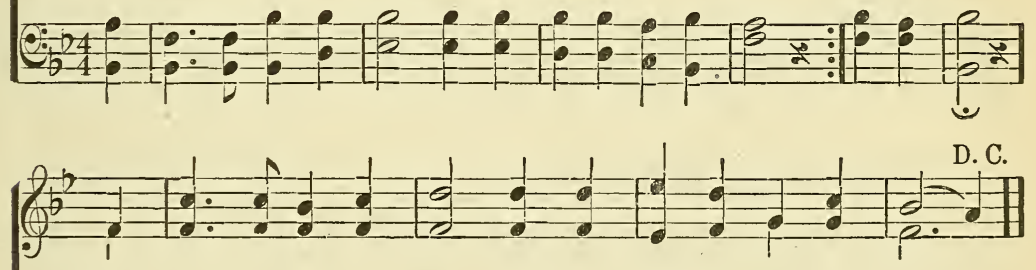

From vic - t'ry un - to vic - t'ry His arm - y shall $\mathrm{He}$ lead,

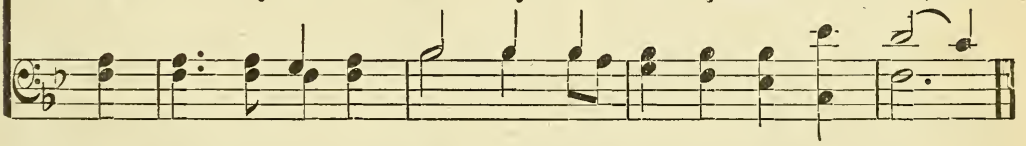

2 Stand up!-stand up for Jesus! Stand in His strength alone,

The arm of flesh will fail youYe dare not trust your own:

Put on the gospel armor, And, watching unto prayer,

Where duty calls or danger, $\mathrm{Be}$ sever wanting there.
3 Stand up!-stand up for Jesus! The strife will not be long; This day the noise of battle, The next, the victor's song:

To him that overcometh, A crown of life shall be

$\mathrm{He}$ with the King of glory Shall reign eternally! 
W, H. PIKE.

"I delight to do Thy will."-Ps. 40: 8 .

Mrs. W. H. PIKE.

Duet.-Tenor and Soprano.

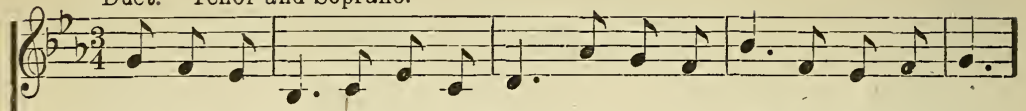

1. 0 gracious God, on Thee I wait, With Thine own self my be-ing fill;

2. In tri-als oft I find my-self With soul oppressed and bod-y ill;

3. And when the glimpse of glory comes, That gives my soul a hap-py thrill,
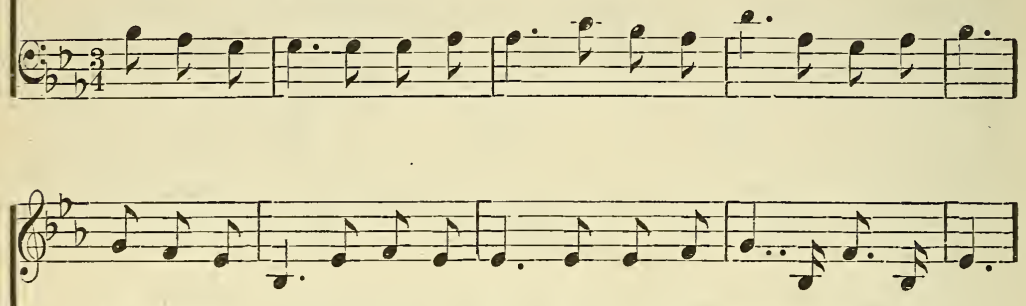

As day by day my life I live, To do Thy will, Thy bless-ed will.

There is a place where peace is found, 'Tis in Thy will, Thy ho-ly will.

My soul shall an-swer with de-light, "I love, dear Lord, to do Thy will"

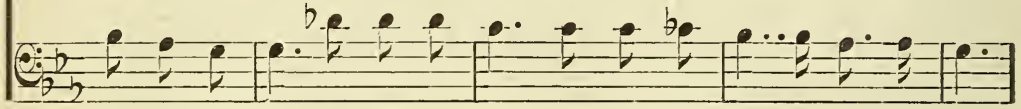

CHORus.

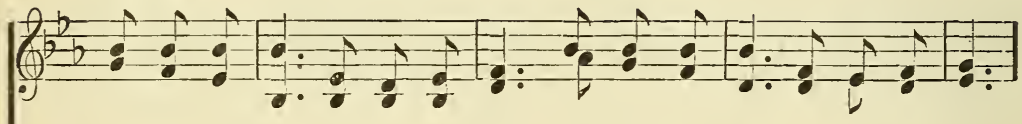

To do Thy will, yes, that is all; To do Thy will, o-bey Thy call;
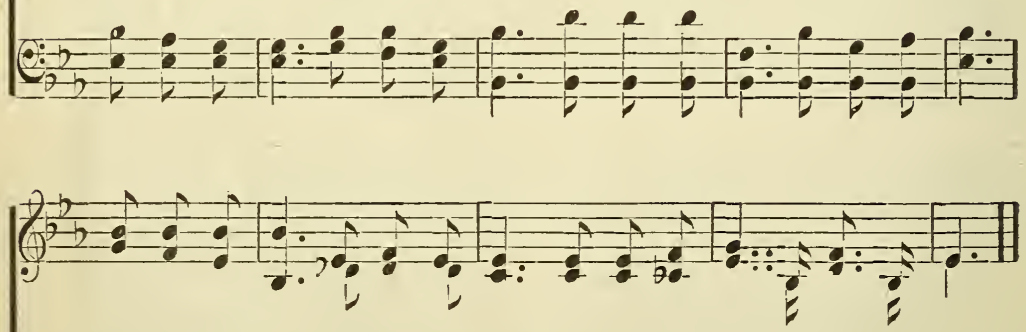

To follow, Lord, where Thou dost lead, To do Thy will is all I need.

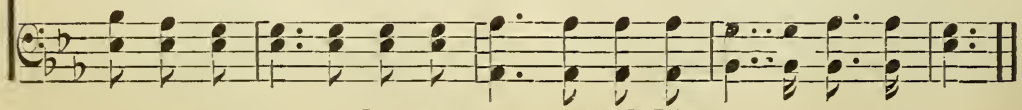

Copyright, 1905, by Davis \& Pike. 
JohN R. Clements.

JNO. R. SWENEY.

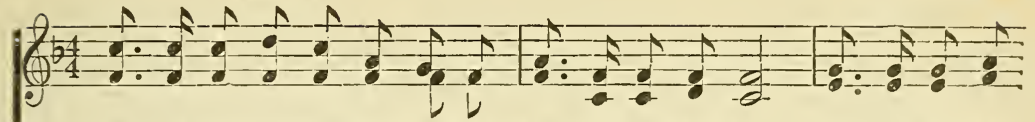

1. Sing a cheerful marching song, And sing it loud and free; Let the mu-sic

2. Sing our glorious Captain's praise, The man of Gal - i - lee; Sing of Him thrc'

3. Christ our "roy-al ban-ner" dyed With Calv'ry's crim-son flow; We've no en-sign

4. Sing we all for "Christ and Church," And know no creed be-side; Loy - al first un-
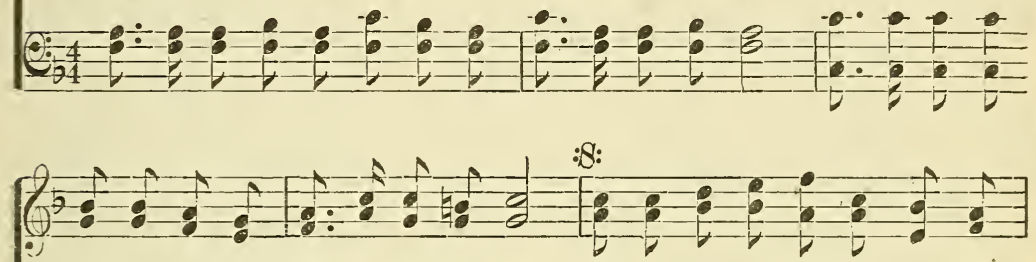

float a-long From east to west-ern sea; Ev-'ry heart may catch the strain, And all our days, In notes of ju - bi-lee; Fight-ing in His name and might, 'Till this be-side, It lead's where e'er we go; Marching 'neath it sure are we, Deto our King, And then un - to His bride: $\mathrm{Ma}$ - ny names, yet still in Him As
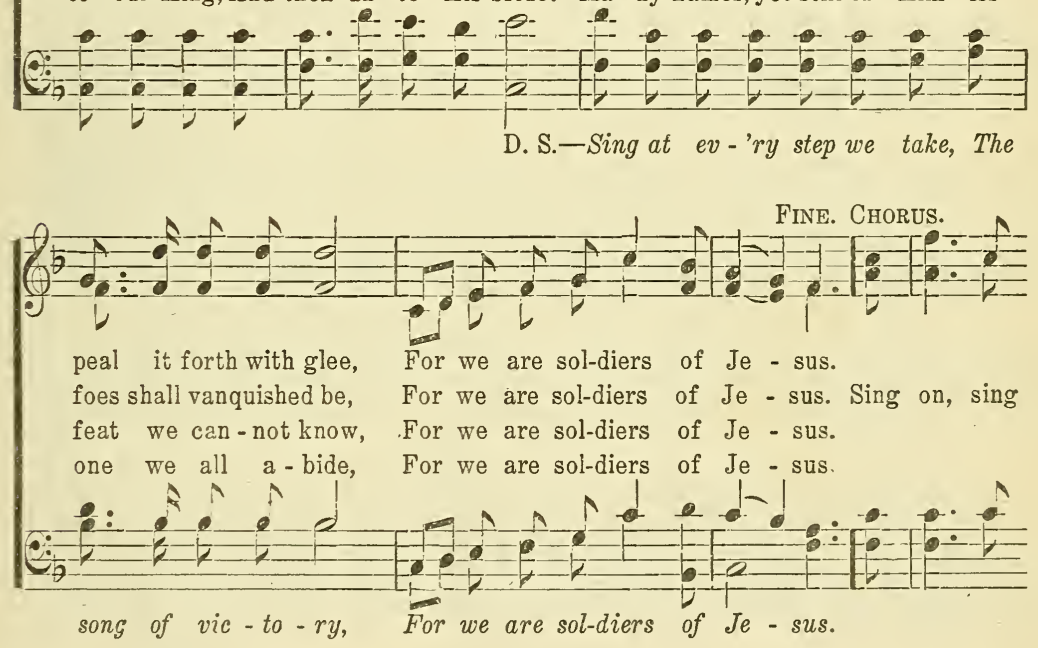

ลD. S.

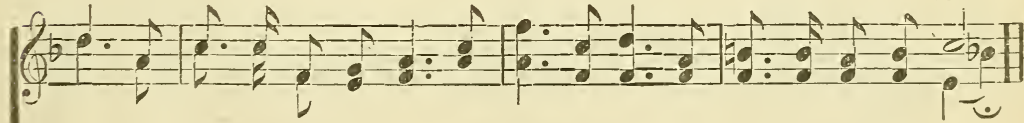

on, in sweetest mel-o - dy; Sing on, sing on, of Him who sets us free;

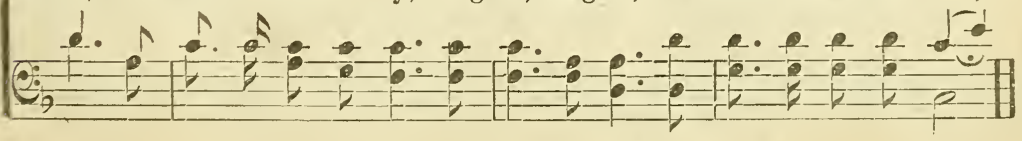

Copyright, 1895, by Jno. R. Sweney. Used by permission. 
"Lord is it I?"-Matt. 26: 22. "There is an accursed thing in the midst "KESWICK." of you."-Josh. 7:13. W. STILLMAN MARTiN.

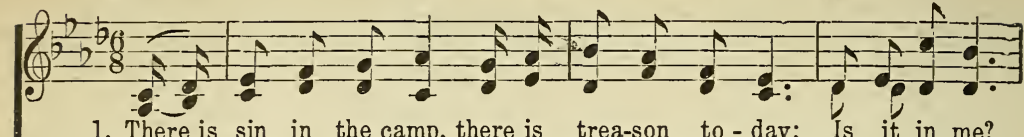

1. There is $\sin$ in the camp, there is trea-son to-day; Is it in me?

2. I come in my need to the life-giv-ing Word; Is it for me?

3. There is peace in be - liev - ing what-ev-er be-tide; Is it for me?
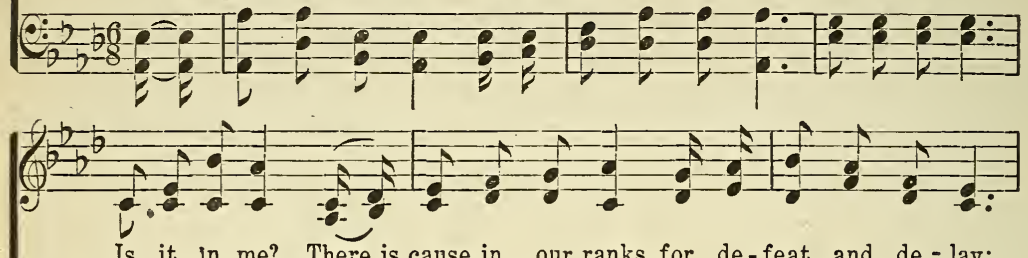

Is it in me? There is cause in our ranks, for de-feat and de-lay;

Is it for me? By faith in its pow'r let my soul be re-stored;

Is it for me? There is rest to the soul that in Je - sus a-bides;
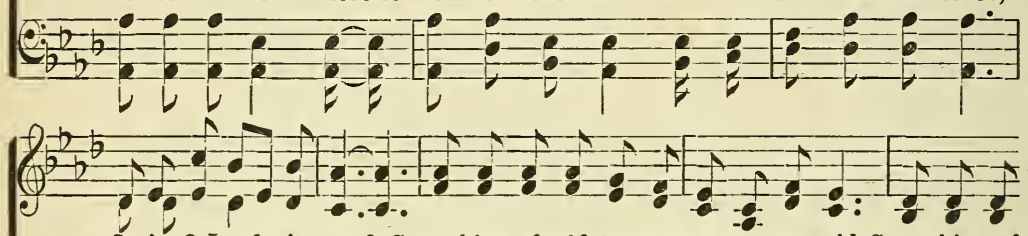
Is it, O Lord, in me? Something of selfishness,garments or gold, Something of Is it, 0 Lord, for me? Par-don and pur - i - ty Je-sus will give, Life ev-erIs it, O Lord, for me? Sure-ly the work of redemption is done, Sure-ly the
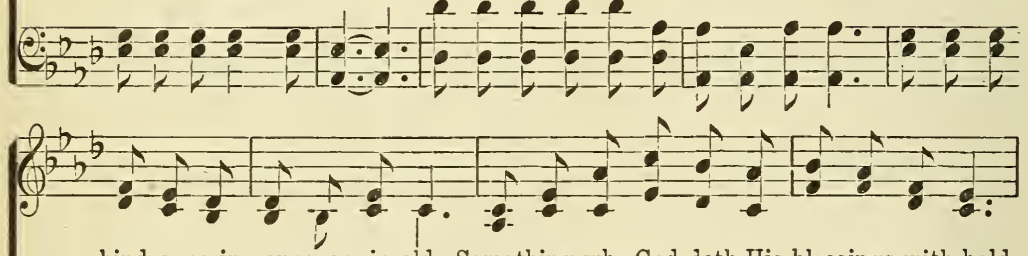

hindrance in young or in old, Something why God doth His blessings with-hold, last - ing to all who be-lieve, Oh, that His pow'r I might ful-ly re-ceive, $\mathrm{Fa}$ - ther is pleased with the Son, Sure - ly the saved and the Sav-ior are one;

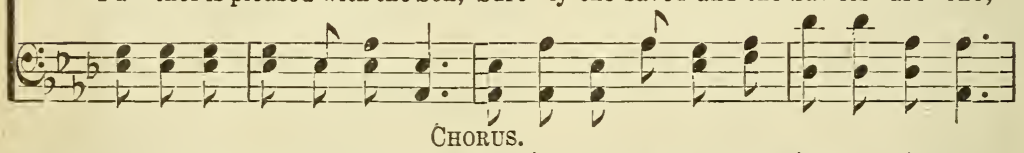

Is it, 0 Lord, in me? Is it in me? Is it in me? Is it, 0 is it in
Is it, 0 Lord, for me? Is it for me? Is itfor me? Is it, 0 is it for
Is 0 Lord, for me? Is it for me? etc. Copvright, 1905 , by John A. Davis. 


\section{Is It for Me?}

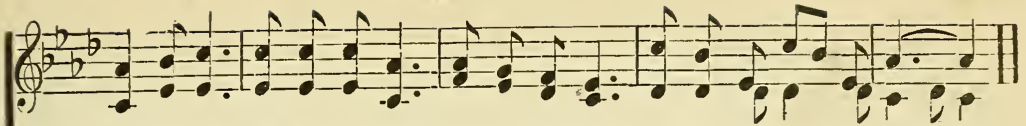

me, in me? Is it in me? Is it in me? Is it, 0 Lord, in me, in me?

me, forme? Is it for me? Is it for me? Is it, 0 Lord, for me,for me?

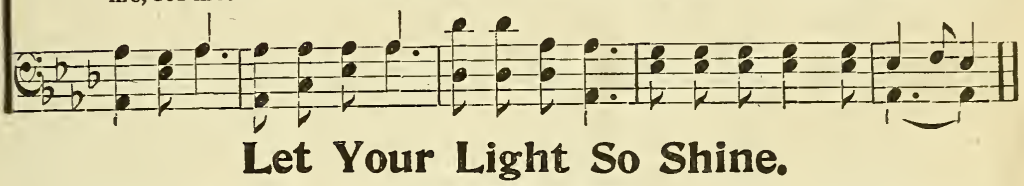

Words arr.by P. P. B. Rit.

Arr. of Words and Music

1. Say, is your lamp burning, my brother? I pray you look quickly and see,

2. Re-mem-ber how many a-round rou Will fol-low wher-ev-er you go;

3. There's many a lamp that is lighted. We see them from near and from far,

4. But if they were trimmed night and morning.They'd never burn down, nor go out,

5. If once all the lamps that are lighted Should steadily blaze in a line,

6. How all the dark places would brighten! 'The mists would roll up and away!
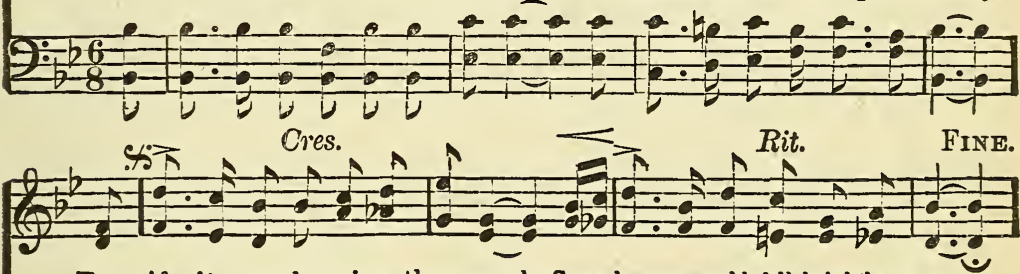

For if it were burning, then surely Some beams would fall brightly on me.

The tho't that they walked in your shadow Would make your lamp brighter, I know.

But few in their lustre and beau-ty Shine stead-i-ly on like a star.

Tho' from the four quarters of heaven The winds were all blowing a-bout.

Wide o-ver the land and the o-cean A gir - dle of glo-ry would shine.

The oarth would langh out in her gladness To hail the mil-len-ni-al day!

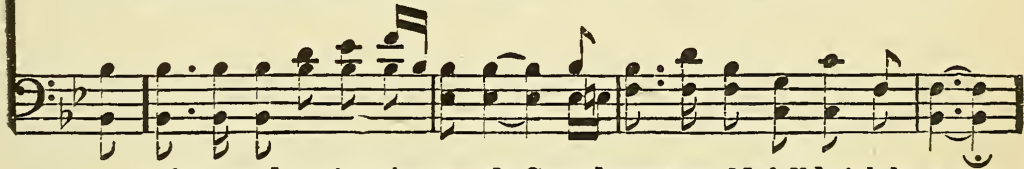

D. S. - if it were burning, then surely Some beams would fall brightly on me.

Chorus.

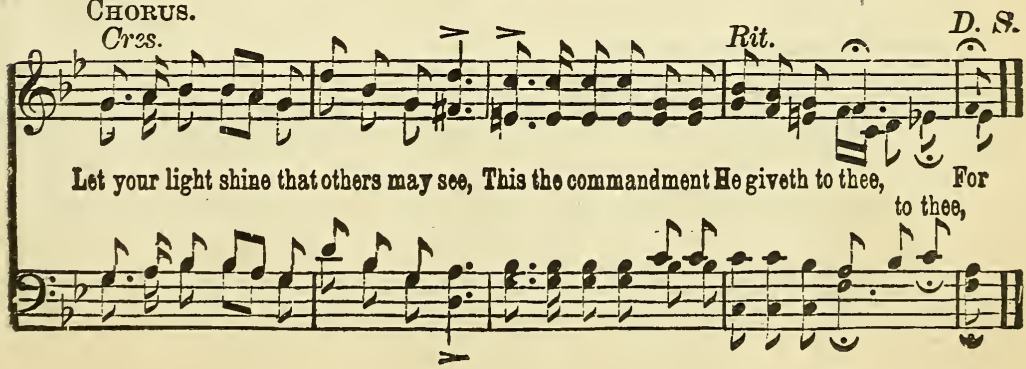




\section{Suggested in a sermon by Rev. J. WiLbUB Cha PMax, D. D.}

JNO, R. CleMENTS.

Slowly, with expression.

W. S. WEEDEN.
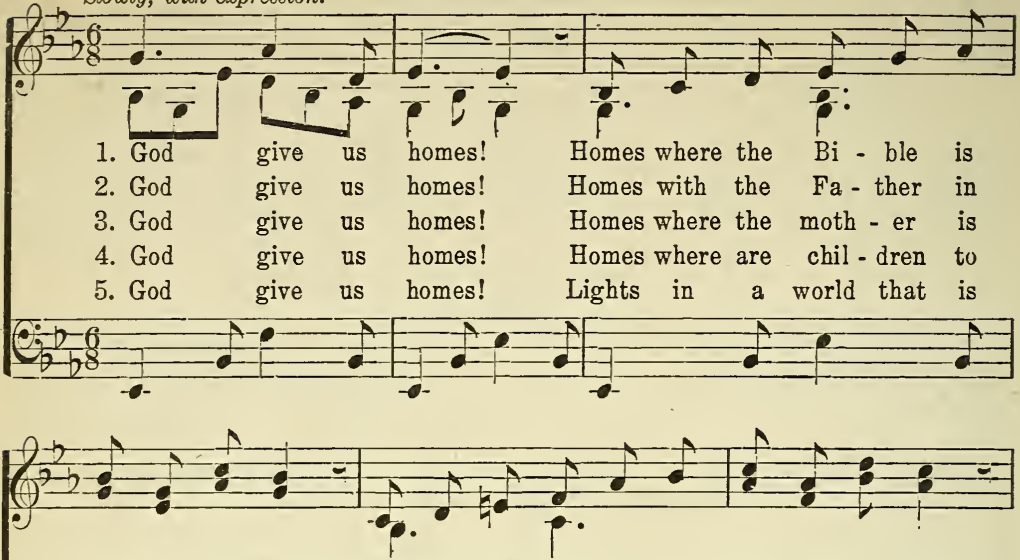

hon-ored and taught; Homes with the Spir - it of Christ in their thought; priest-like em-ploy; Homes that are brightwith a far-reach-ing joy; queen-like in love; Ruled in the fear of the Sav-iour a-bove; bright-en the hours; Bud-ding and bloom-ing like beau - ti-ful flow'rs; flood-ed with night; Day-beams to ban - ish sin's chill and its blight;
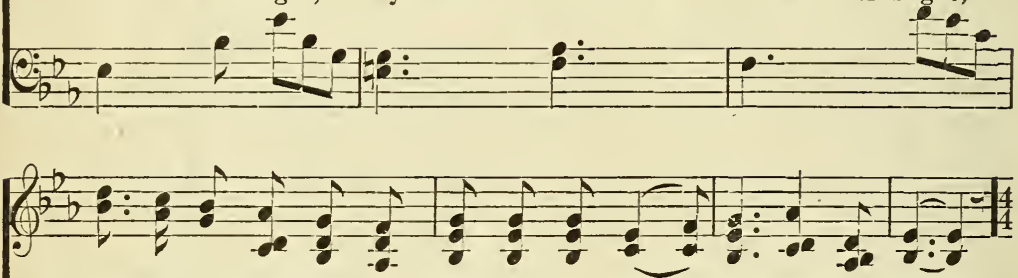

Homes that a like-ness to heav-en have caught. God give us homes!

Homes where no world-stain shall come to an - noy. God give us homes!

Homes that to youth most in - spir - ing shall prove. God give us homes!

Plac - es of sun-shine, sweet, sanc-ti - fied bow'rs. God give us homes!

Pledge of a morn-ing when wrong turns to right. God give us homes!

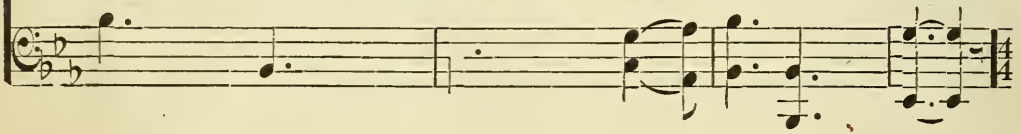

CHorus. After last verse only,

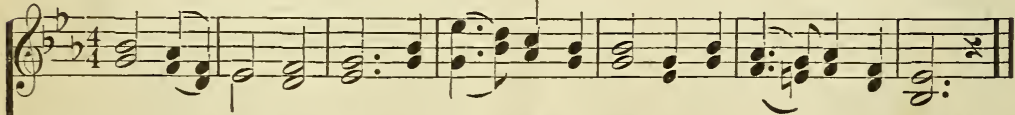

Home,home,sweet,sweet home,A like-ness to heav-en, God give us such homes!

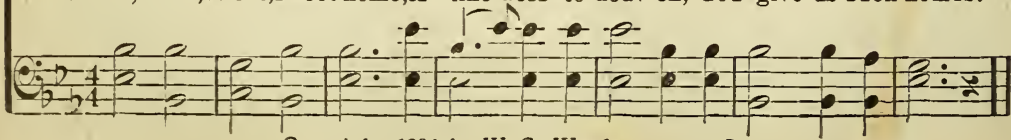

Copyright, 1906, by W. S. Weeden. F. P. Bilhorn. nwner 
"He givet aore grace."-James 4: 8.

Anon. (Abridged).

LOUISE SH HPARD PRIDGEON.

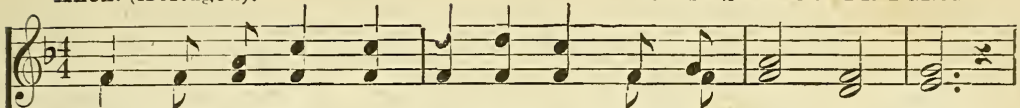

1. Grace, when the sun is shm-ing, Lord, When the sky is black;

2. Grace, when my du - ties all go wrong, When they seem all right;

3. Grace, when the saved ones don't "act saved," And lay blame on me;
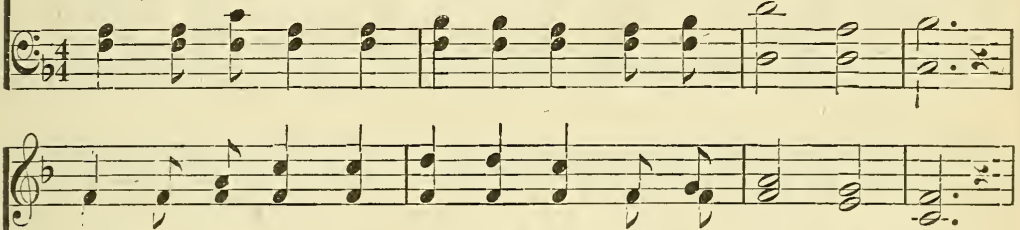

Grace, when I hear the un-kind word, Or am off the track;

Grace, when 'tis glad - ness, praise, and song, When I have to fight;

Grace, when the grace I've asked and craved Seems de - nied by Thee;

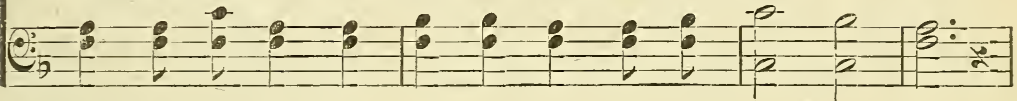

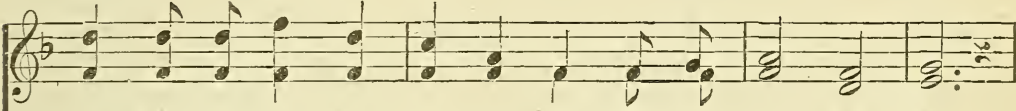

Grace, when I'm el - bowed in a nook Till I can - not turn;

Grace, when my clothes are fresh and new, When they're worn and old;

Grace, when the mid - night hours I tell, When the morn is nigh;

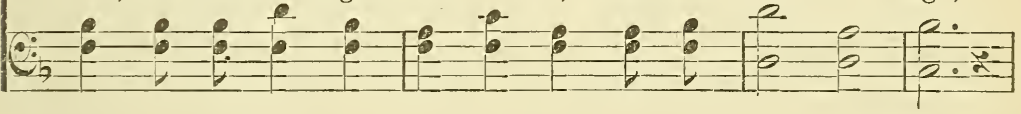

CHORUS. Slower
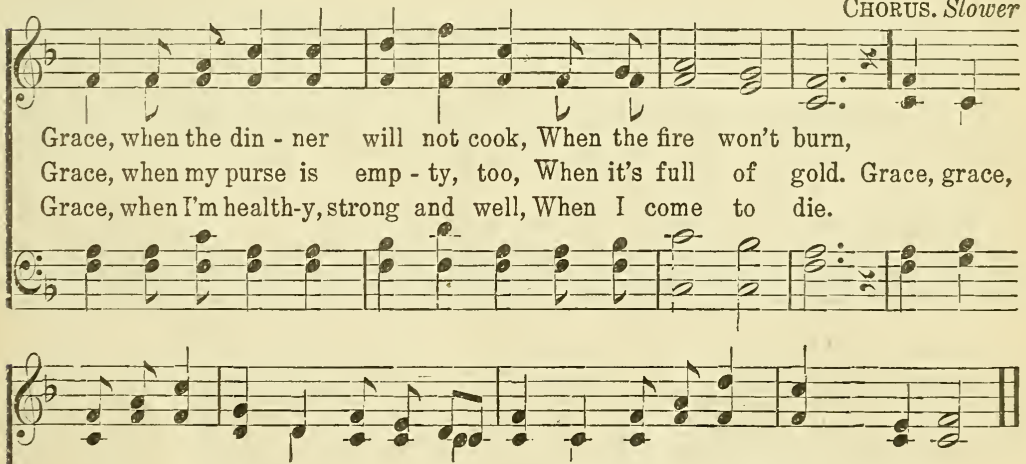

all the way, Grace, grace, ev'ry day, Grace, more grace from Thee, Lord, for me.

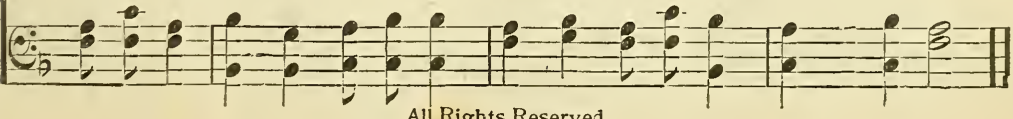

All Rights Reserved. 
H. G.S.

H. G. Sмiтh.

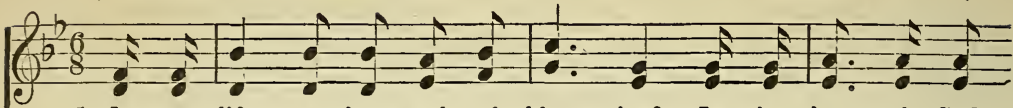

1. Is your life a chan - nel of bless - ing? Is the love of God

2. Is your life a chan-nel of bless - ing? Are you bur-dened for

3. Is your life a chan-nel of bless - ing? Is it dai - ly

4. We can not be chan-nels of bless - ing If our lives are not

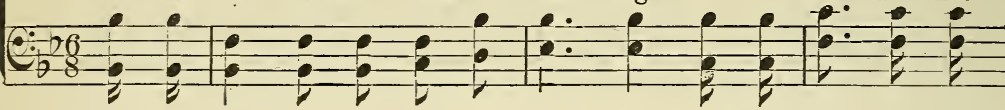

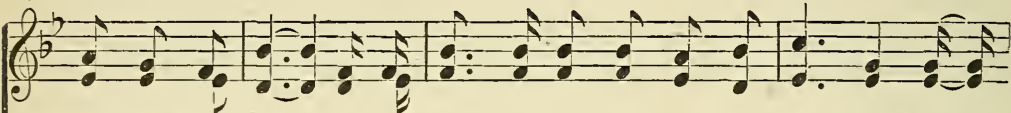

flow - ing thro' you? Are you tell - ing the lost of the Sav - ior? Are you those that are lost? Have you urged up - on those who are stray-ing, The tell - ing for Him? Have you spok - en the word of sal - va - tion To

free from all sin; We will bar - ri-ers be and a hin-drance To

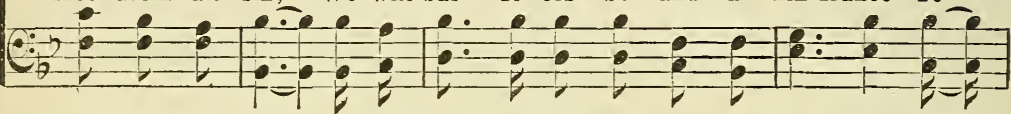

CHORUS.

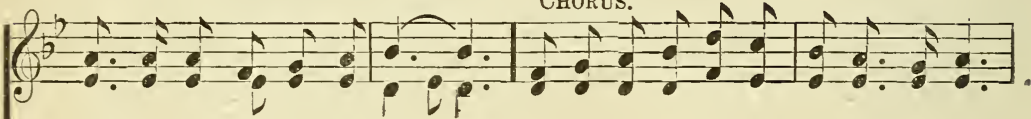
read-y His ser-vice to do.

Sav - ior who died on the cross? Make me a chan-nel of bless-ing to-day, those who are dy - ing in sin?

those we are try-ing to win.

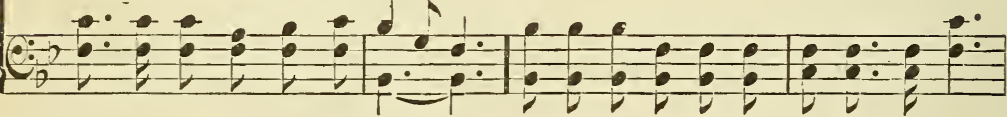

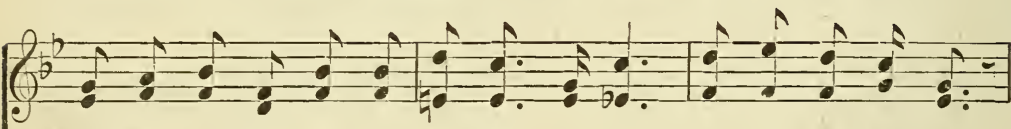

Make me a chan-nel of bless-ing, I pray; My life pos-sess-ing,

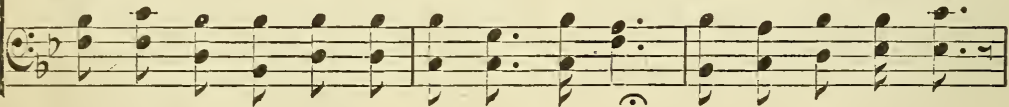

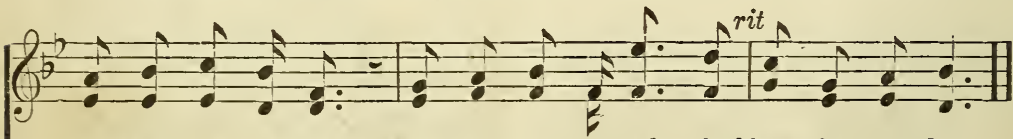

my serv-ice bless-ing, Make me a chan-nel of bless - ing to-day.

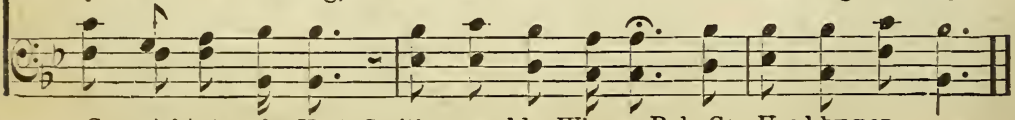

Copyright, 1903, by H. G. Smith, owned by Wínona Pub, Co, Used by per. 


\section{Shall Not Pass Again This Way.}

Arr. by JOHN R. Craments.

W. S. WEEDEN.

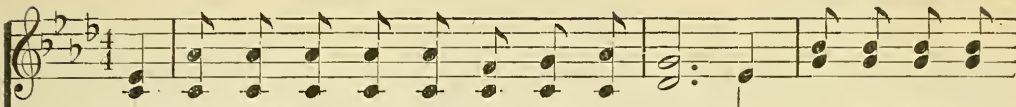

1. The bread that bringeth strength I want to give; The wa-ter pure that

2. I want to give the oil of joy for tears, The faith to con-quer

3. I want to give good meas-ure run-ning o'er, And in - to an-gry

4. I want to give to oth-ers hupe and faith; I want to do what-

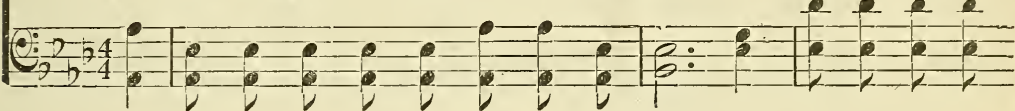

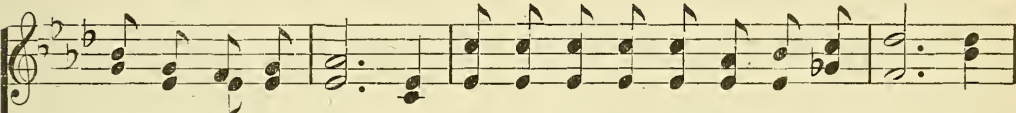

bids the thirst-y live; I want to help the faint-ing day by day; I'm crowding doubts and fears; I want for ash - es beau-ty to dis-play; I'm hearts I want to pour The an-swer soft that can-cels wrath for aye; I'm e'er the Mas-ter saith; I want to live a-right, let come what may; I'm

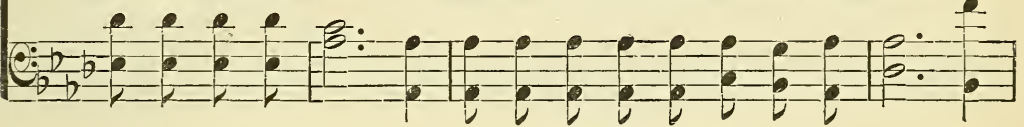
Chorus.

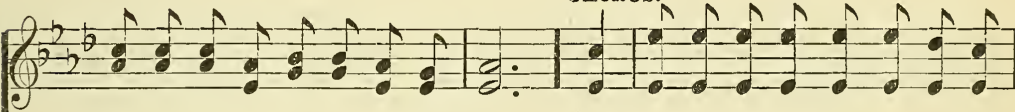

sure I shall not pass a-gain this way. I'm sure I shall not pass a-gain this

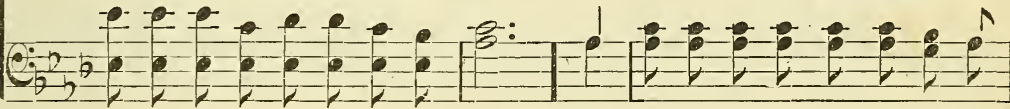

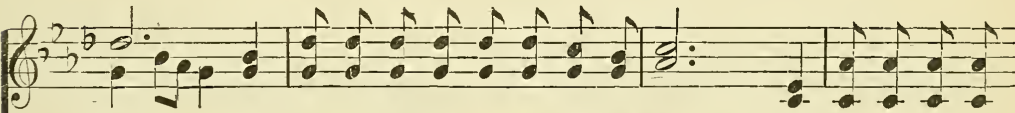

way (this way),I'm sure I shall not pass a-gain this way(this way); So help me live for
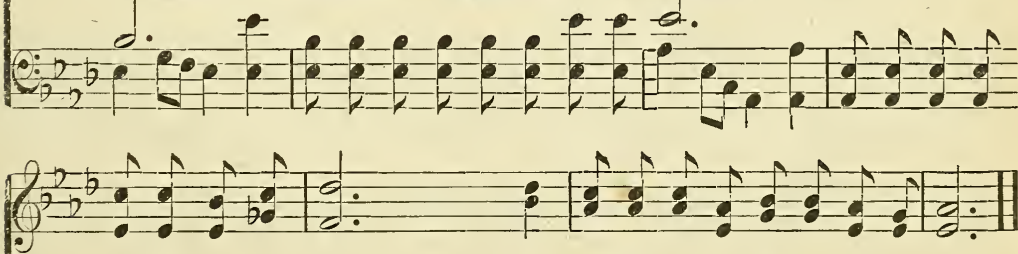

oth-ers day by day (day by day) I'm sure I shall not pass again this way.

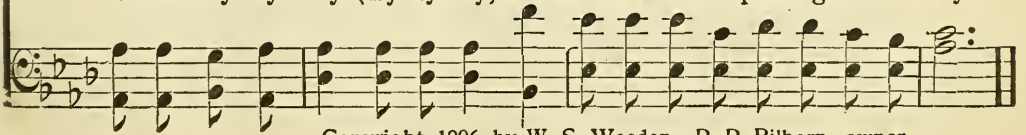

Copyright, 1906, by W. S. Weeden. P. P. Bilhorn, owner 
JNo. R. Clements.

Copgright, 1901, by P. P. Bilhorn.

Arr. by P.P.B.

P. P. BILHORN.

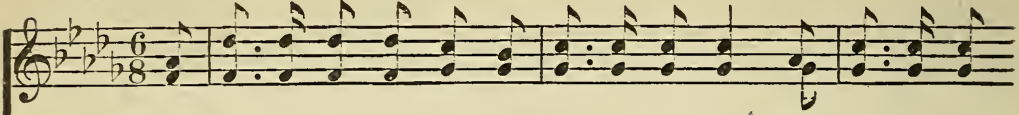

1. Life's pathway grows brighter, as onward I go, Since Je - sus spoke

2. New songs I am singing from morning till night, Since Je-sus spoke

3. My heart doth re-joice in the full-ness of love, Since Je-sus spoke

4. A - bid-ing in Him I am hap - py and blest, Since Je - sus spoke

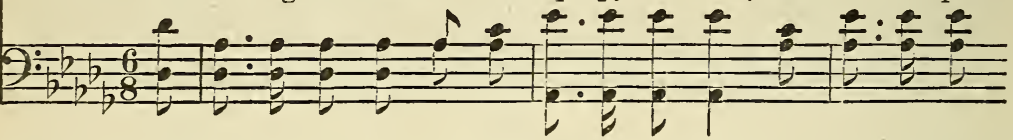

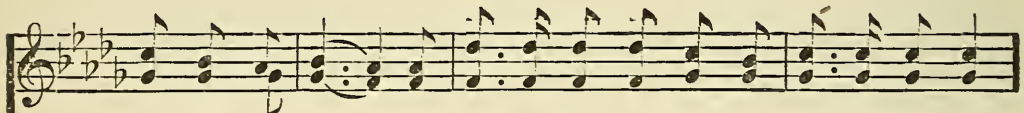

peace to my soul; Rich grac-es are flow-ing, new pleasures I know,

peace to my soul; He lead-eth me on with a heav-en - ly light,

peace to my soul; My spir-it communes with the Heav-en - ly Dove,

peace to my soul; I know with as-sur-ance in Him I can rest,

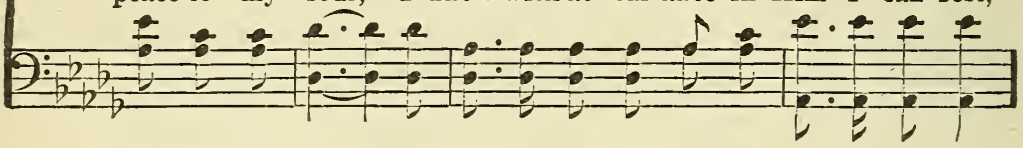

Chorus. $\rightleftharpoons$

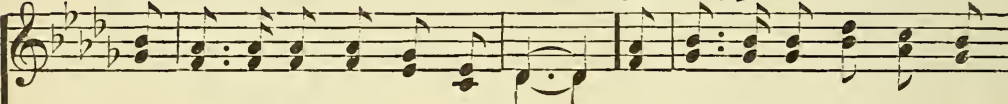

Since Je-sus spoke peace to my soul. Since Je-sus spoke peace to my

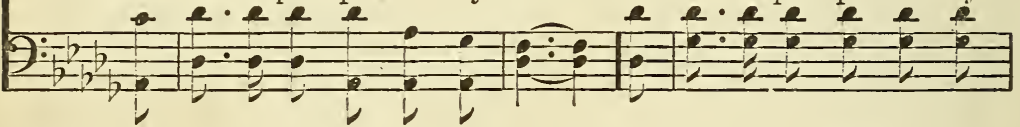

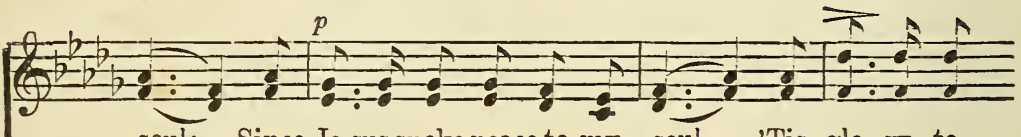

soul; Since Je-sus spoke peace to my soul; 'Tis glo-ry to

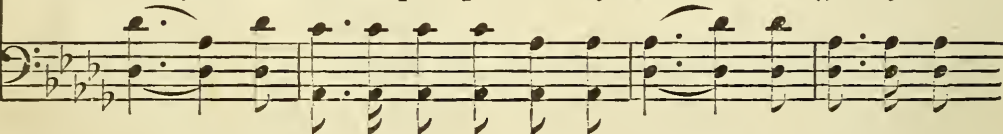

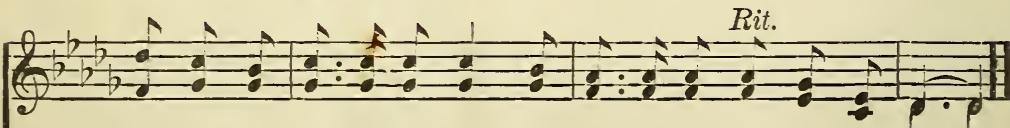

God, I am sing-ing to-day, Since Je-sus spoke peace to my soul.

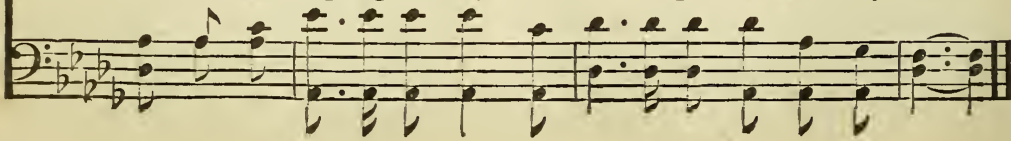


FLORA KIRKLAND.

1. Have you heard the voice of Je - sus Whis-per, "I have chos - en you?"

2. As the first dis-ci-ples fol-lowed, As they went wher-e'er He sent;

3. Or, if He shall choose to send us On some er-rand in His name,

4. Mas - ter, at Thy foot-stool kneel-ing, We, Thy chil-dren, hum-bly wait;
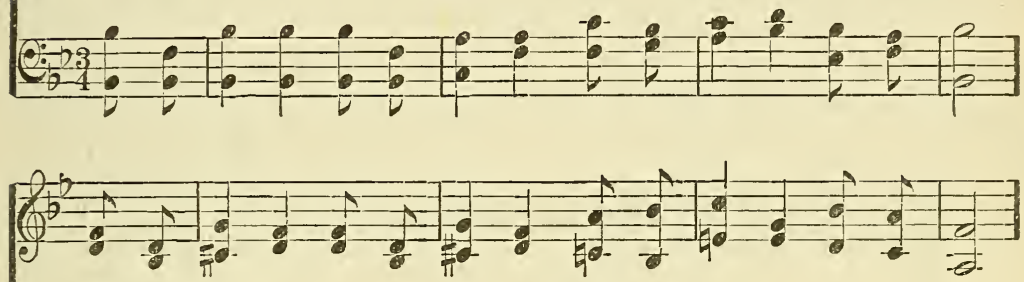

Does He tell you in com-mun-ion What He wish-es you to do? So to - day, we, too, may fol - low, On His lead-ing still in - tent. We can serve Him as dis - ci - ples, For our place is just the same. Løad us, send us, bless us, use us, Till we en - ter heav-en's gate.
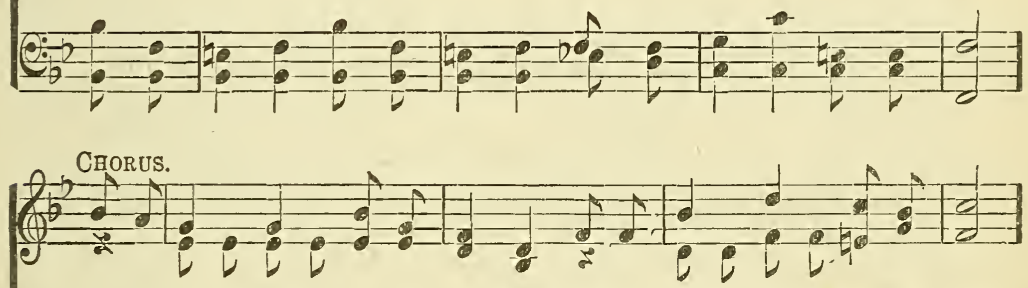

Are you in the in-ner cir-cle? Have you heard the Mas-ter's call? Are you in the in-ner cir - cle? Have you heard the Master's call?
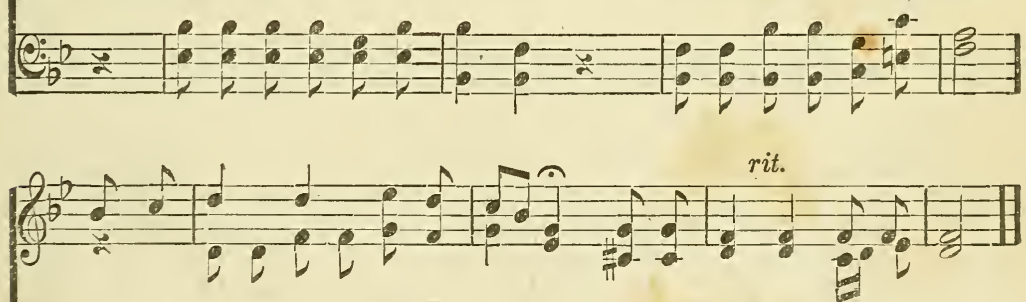

Have you giv'n your life to Je-sus? Is He now your all in all? Have you giv'n your

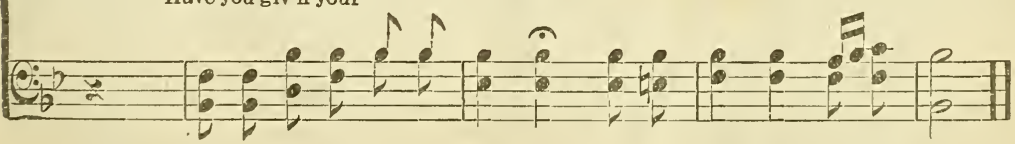

Dedicated to Rev. J. Wilbur Chapman, D. D., and first sung in the Union Meetings at Mount Vernon, in November, 1898. 


\section{Onward, Christian Soldiers!}

GoULD.

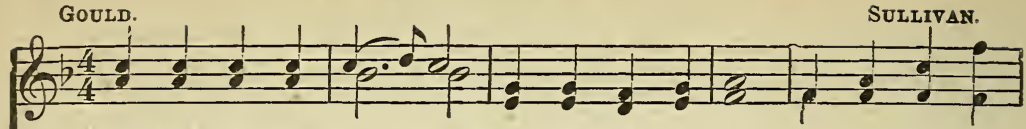

1. On - ward, Christian Sol - diers! Marching as to war, With the cross of

2. Like a might-y ar - my Moves the Church of God; Broth-ers, we are

3. Crowns and thrones may perish, Kingdoms rise and wane, But the Church of

4. On-ward, then, ye peo-ple! Join our hap-py throng; Blend with ours your
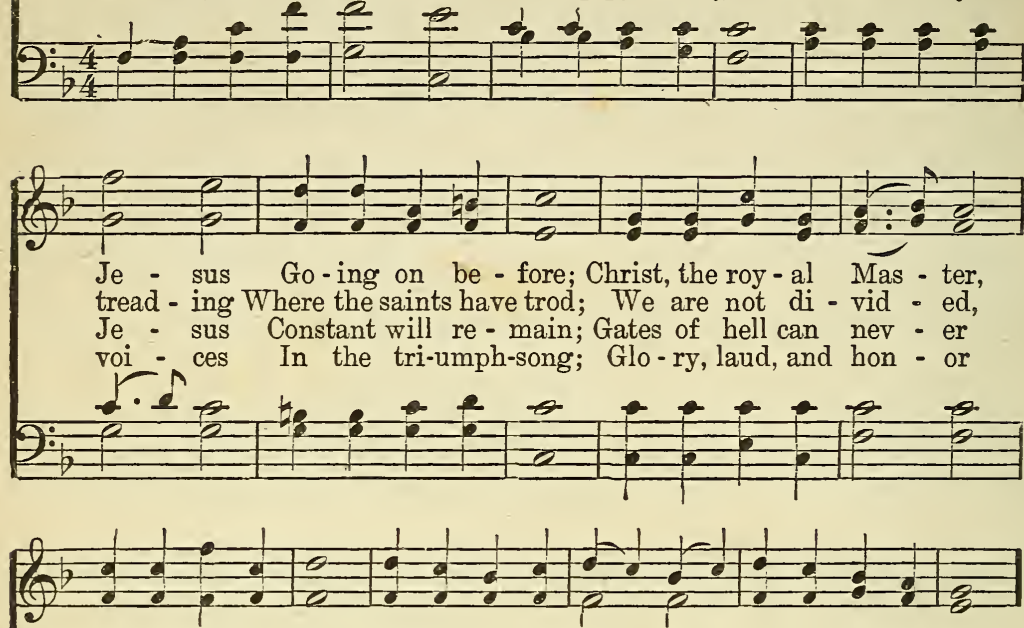

Leads against the foe; Forward in - to bat - tle, See, His banners go!

All one bod-y we, One in hope and doc - trine, One in char - i - ty.

'Gainst that Church prevail; We have Christ's own promise, And that cannot fail.

Un - to Christ, the King; This thro' countless a - ges Men and an-gels sing.

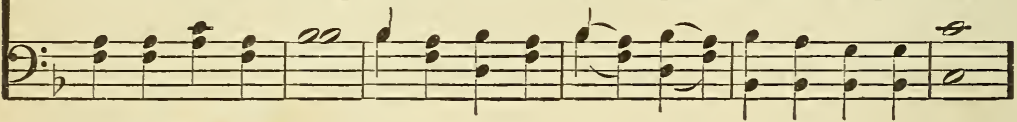

CHORus.

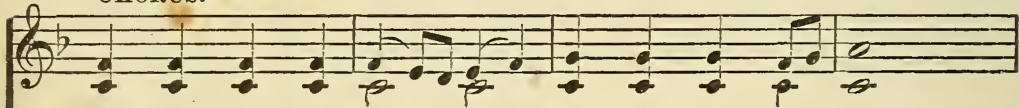

On-ward, Chris-tian sol - diers! Marching as to war,
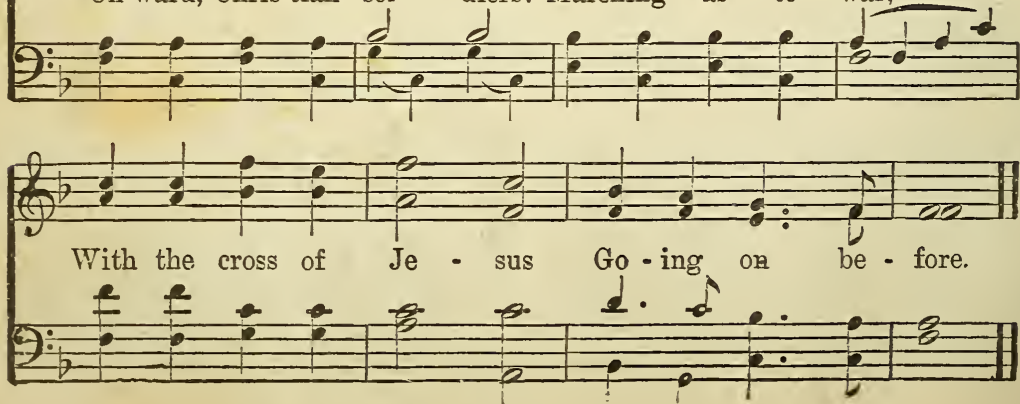


\section{List to the Christ.}

JNo. $\boldsymbol{R}$. Clements.

"Jesus stood and cried." Jno. $7: 37$.

1. List to the Christ in sweet tones of lore, Call - ing from
2. Out on the bleak, lone-ly wastes of sin, Wan-d'ring in
3. Hark to His voice where-so-e'er thou art, Sweet-er and
0.

$\begin{array}{lll}\text { sin and from sor - row; } & \text { Bid - ding thee ev - ry sweet } \\ \text { path-ways of } \text { dan - ger; } & \text { List - en, as gen - tly He } \\ \text { sweet-er 'tis ring - ing; } & \text { Give to Him an - swer and }\end{array}$

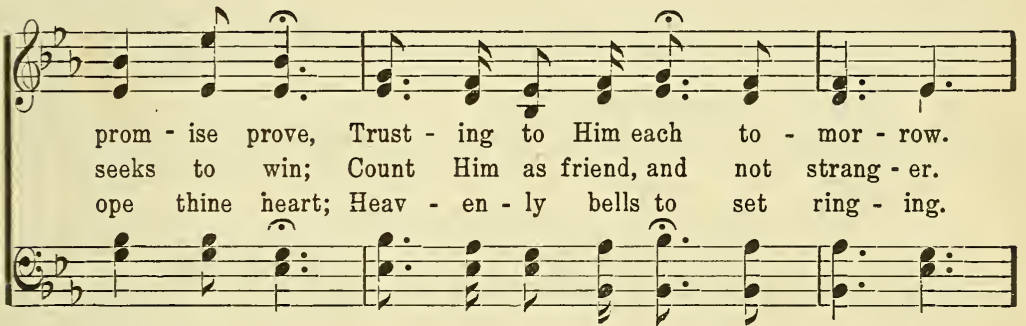

CHORUS.

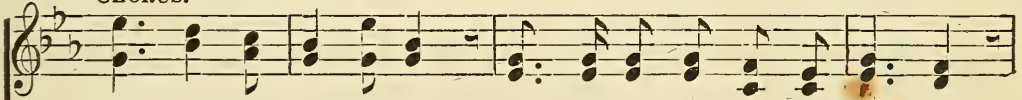

Call - ing, yes, call-ing sweet, Call - ing in tones that are ten - der;

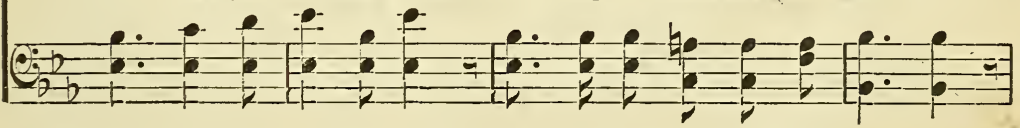

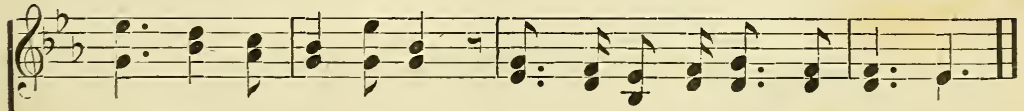

Hear Him thy name re-peat, Come in a glad-some sur-ren-der.

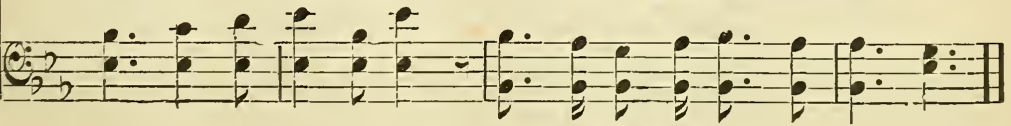

Copyright, 1905, by Jno. R. Clements. 
Rev, F. H. ROWLEY.

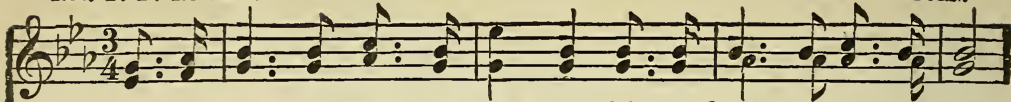

1. I will sing the wondroussto - ry, Of the Christ who died for me,

2. I was lost, but Je-sus found me, Found the sheep that went astray,

3. I was bruised but Je-sus healed me, Faint was I from many a fall,

4. Days of dark-ness still come o'er me, Sorrow's paths I oft - en tread,

5. He will keep me till, the riv-er Rolls its wa-ters at my feet;
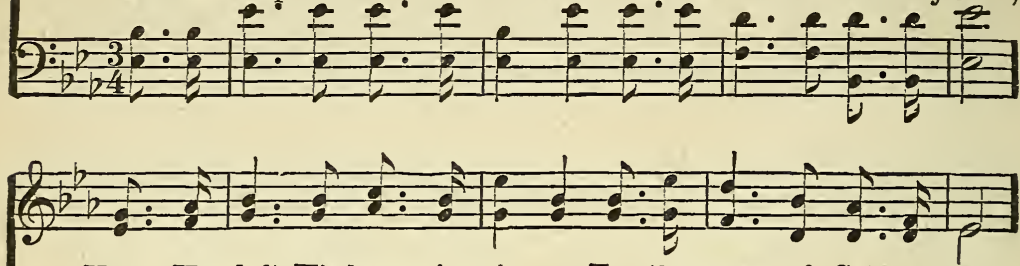

How He left His home in glo-ry, For the cross of Cal-va-ry.

Threw His lov-ing arms a-round me, Drew me back in - to the way.

Sight was gone, and fears possessed me,But He freed me from them all.

But the Sav-ior still is with me, By His hand I'm safe-ly led.

Then He'll bear me safe - ly 0 -ver, Where theloved ones I shall meet.

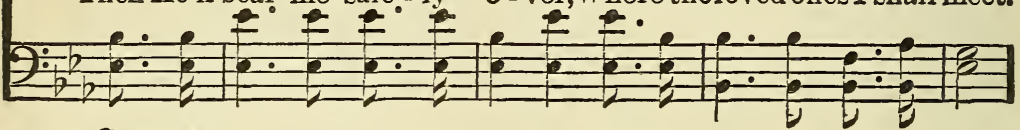

\section{CHOrUs.}
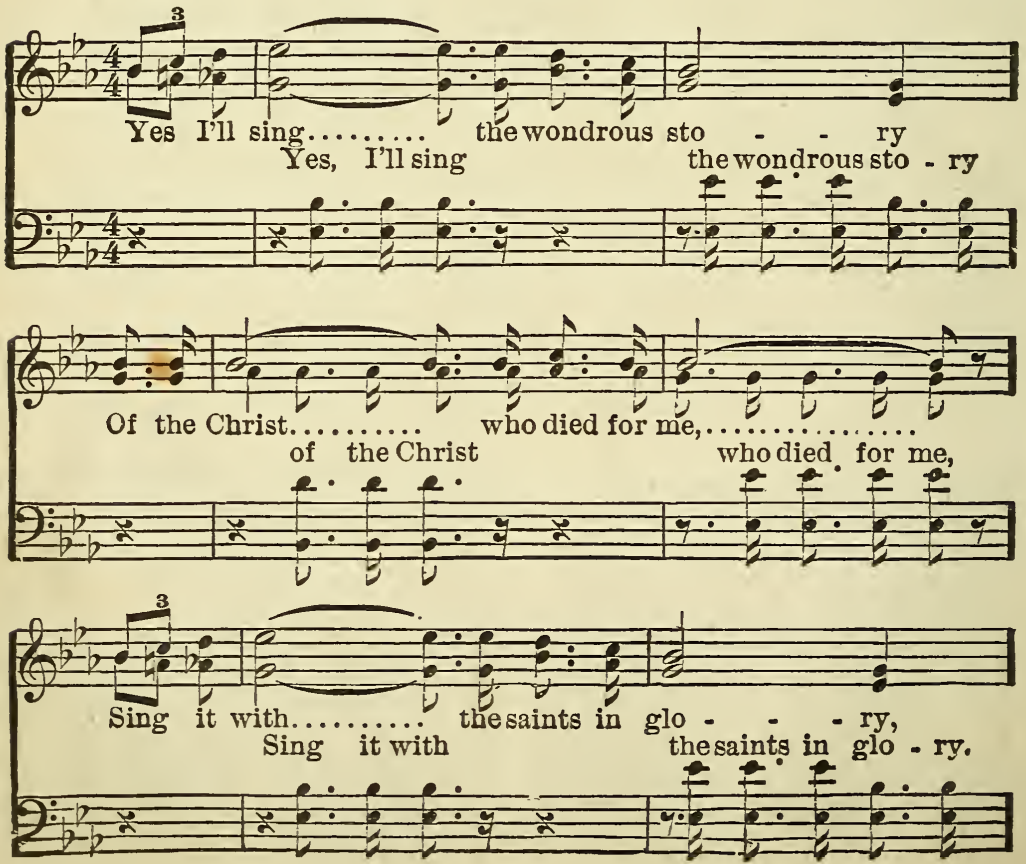


\section{Will Sing the Wondrous Story.}

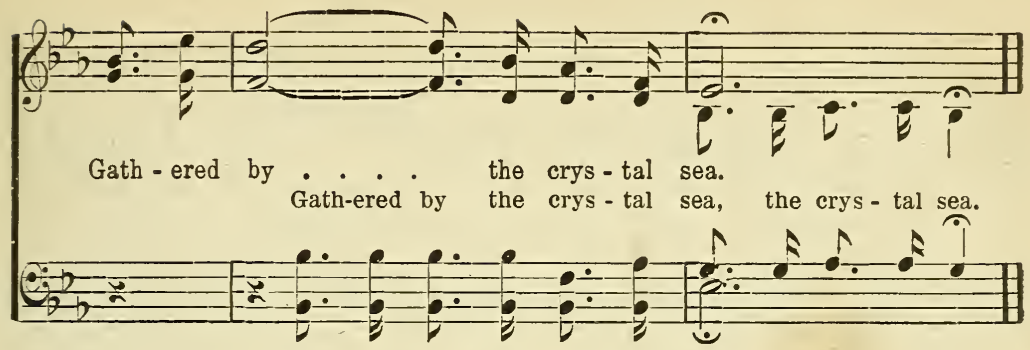

\section{Now I Feel the Sacred Fire.}

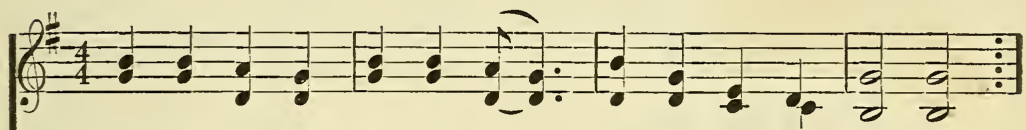

1. $\{$ Now I feel the sa-cred fire, Kind-ling,flam-ing, glow-ing, $\}$

1. $\{$ High-er still and ris-ing higher, All my soul o'er - flow-ing, $\}$

2. $\left\{\begin{array}{l}\text { Now I am from bond-age freed, Ev-'ry bond is riv - en; } \\ \text { Je-sus makes me free in - deed, Just as free as heav - en; }\end{array}\right\}$

3. $\left\{\begin{array}{llll}\text { Glo - ry be to God on high, Glo - ry be to Je - sus! } \\ \text { He hath bro't sal - va - tion nigh, } & \text { From all sin he frees us; }\end{array}\right\}$
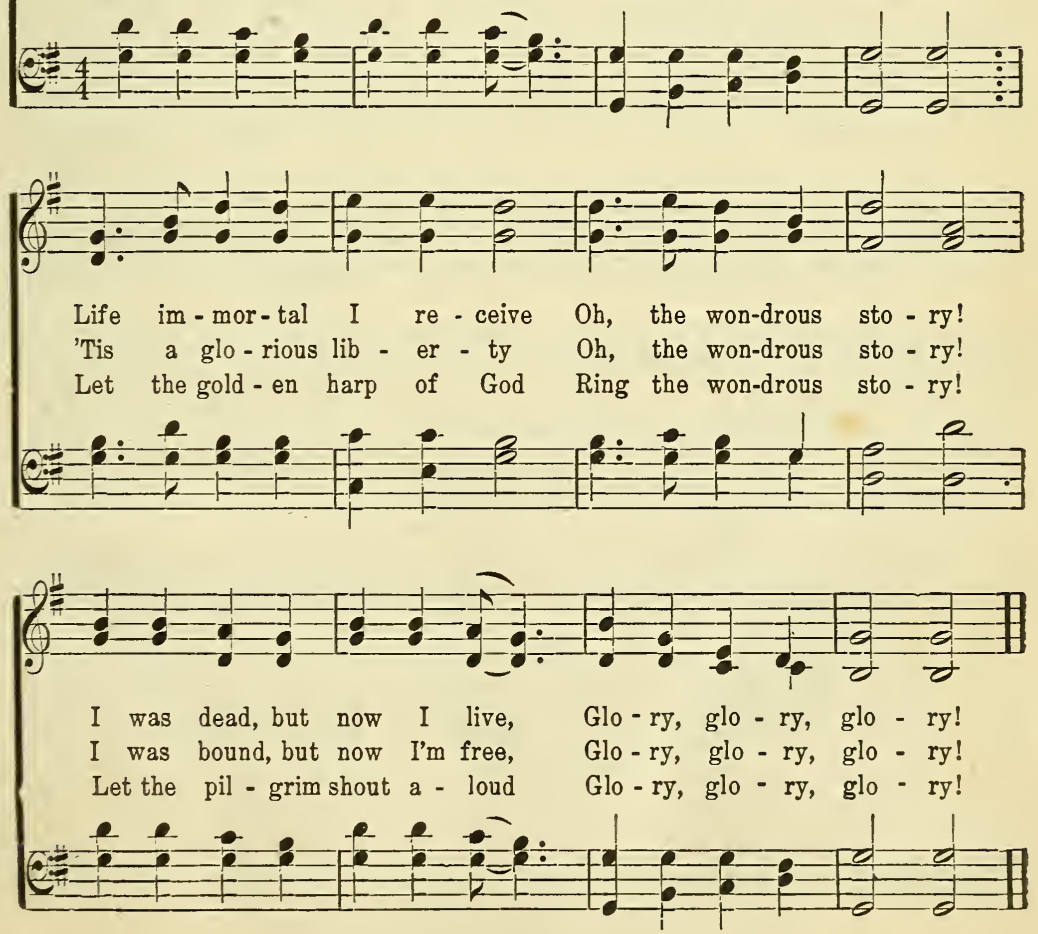
"Ablde in me and I in you." Jno. 15: 4.

W. S. M.

W. STILlmaN MaRTiY.

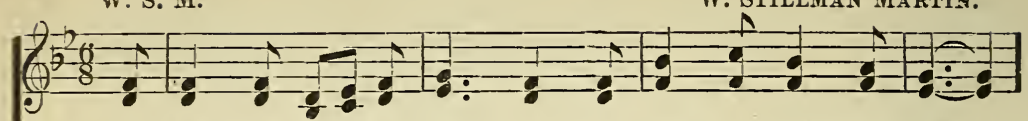

1. I'm trust - ing Je - sus on - ly, for life and rest and power,

2. I'm trust - ing Je - sus on - ly, I take Him at His word,

3. I'm trust - ing Je - sus on - ly, be - neath His wings I hide,

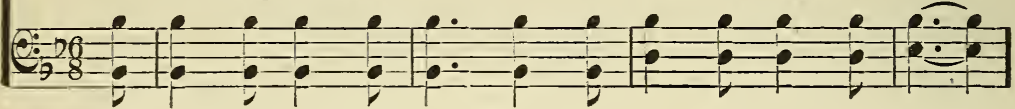

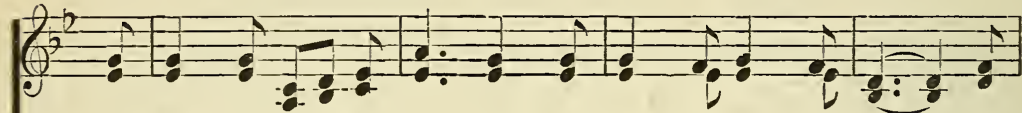

I find Him all suf - fi - cient to save me ev - 'ry hour; He

My life is filled with glad - ness, the deep sweet joy of God; To

A sure safe place of ref - uge what-ev - er will be - tide; His

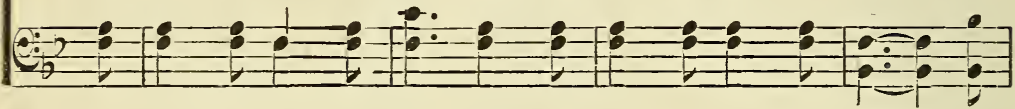

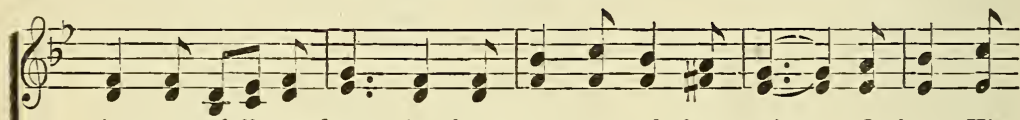

is my full re-demp-tion from sor-row and from sin, I have His

grow more like Him dai - ly, the Spir-it's fruit to bear, This is my

pres-ence all the way makes our life with bliss re - plete, A - bid - ing

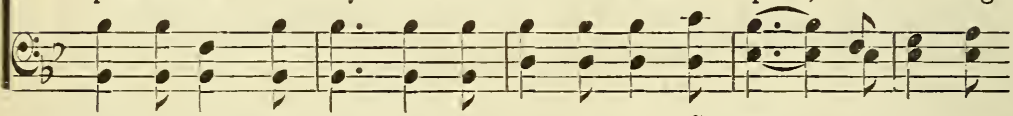

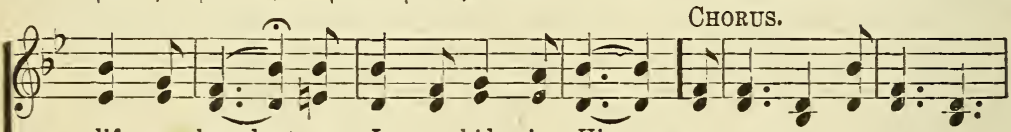

life $\mathbf{a}$-bun-dant as I a-bide in Him.

one de - sire, this is my dai-ly care. A-bid-ing, a-bid-ing

in Him - self I need not fear de-feat.

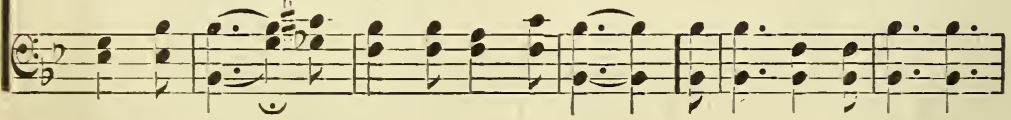

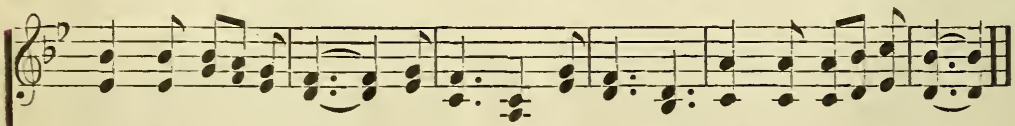

in the liv-ing vine; A-bid-ing, a-bid-ing, His rich life is mine.

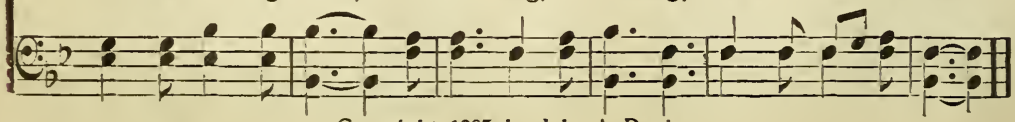

Copyright, 1905, by John A. Davis, 
"Yea, I have loved thee with an everlasting love."-Jer. 31: 3. "For I am the Lord, I

F. A. G.

change not,"-Mal. 3: 6 .

Tenor and Alto Duet.

F, A. GRAVES.
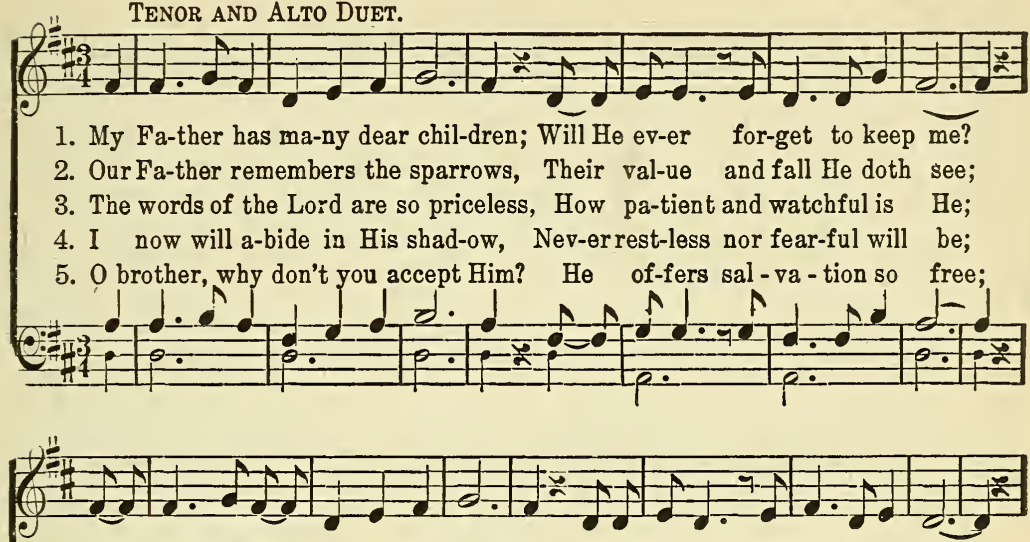

$\mathrm{He}$ gave His own Son to re-deem them,And He cannot for-get to keep me.

But dear - er to Him are His children, And He'll never for-get to keep me.

Tho' moth-er for-get her own offspring, Yet He'll never for-get to keep me.

In the secret of His presence He'll hide me,And He'llnever for-get to keep me.

Re - pent and be - lieve and o - bey Him, And He'll never for-get to keep thee.

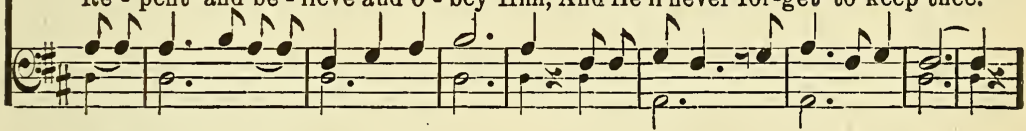

REFRAIN.

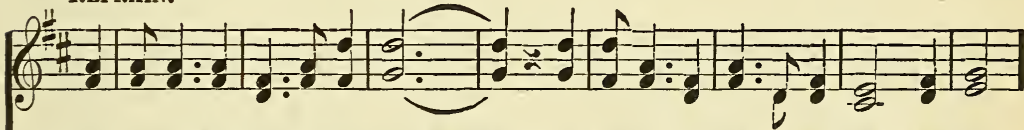

He'll never forget to keep me (keepme), He'll never forget to keep me (keep me); 5 th $\nabla$. He'll never forget to keep thee(keep thee),He'll never forget to keep thee(keep theo);
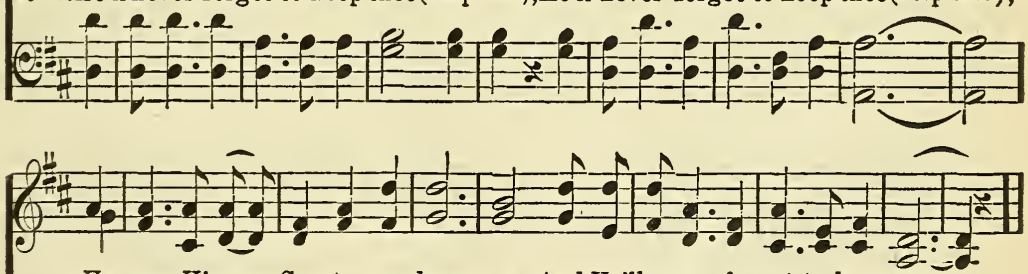

He gave His own Son to re-deem me, And He'll never forget to keep me.

But dearer to Him are His chil-dren, And He'll never forget to keep me.

Tho' mother for - get her own offspring, Yet He'll never forget to keep me.

In the secret of His presence He'll hide me,And He'll never forget to keep me.

Repent and be-lieve and o - bey Him, And He'll never forget to keep thee.

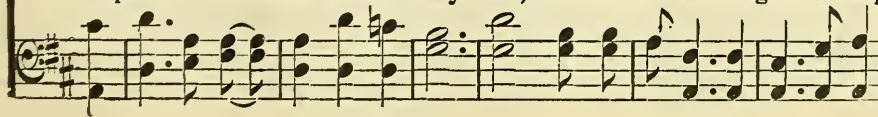

Copyright, 1899, by F. A. Graves. Used by per. 
MeLVin Trotter.

HARRY MONROE. $\Delta r$, by P. P. B,

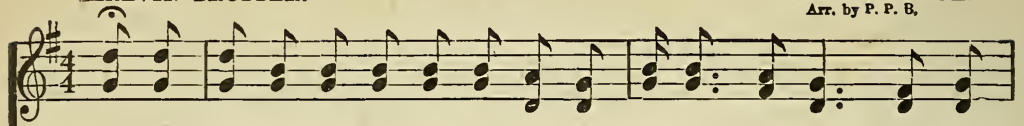

1. If you'll give your heart to Je-sus, You will out-shine the sun, You will

2. If you'll do as Je-sus bids you, You will out-shine the sun, You will

3. If you'll win a soul for Je-sus, You will out-shine the sun, You will
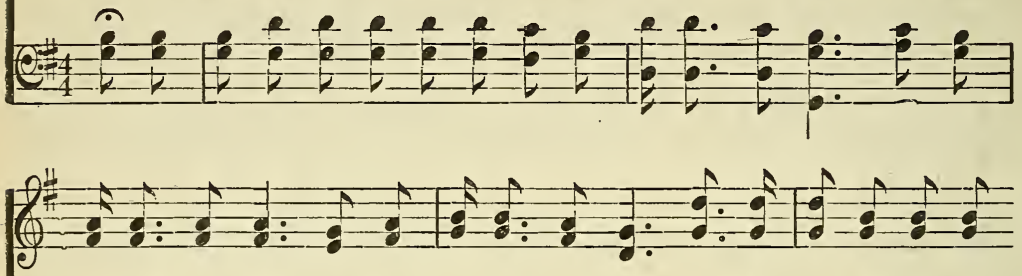

out-shine the sun, You will out-shine the sun; out-shine the sun, You will out-shine the sun;

If you'll give your heart to out-shine the sun, You will out-shine the sun;

If you'll do as $\mathrm{Je}$ - sus If you'll win a soul for
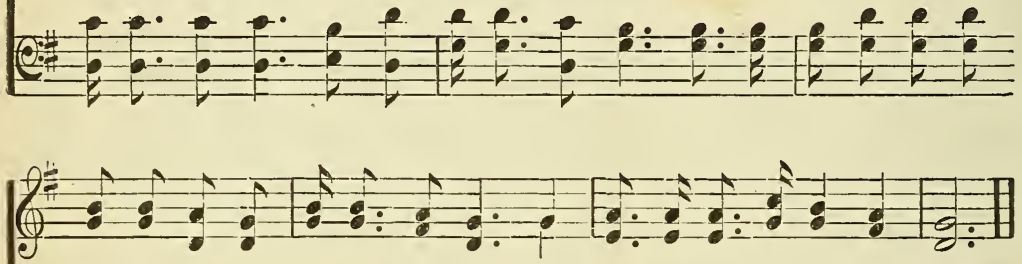

Je - sus, You will out-shine the sun, And walk the gold-en stre ts on high. bids you, You will out-shine the sun, And walk the gold-en streets on high. Je-sus, You will out-shine the sun, And walk the gold-en streets on high.

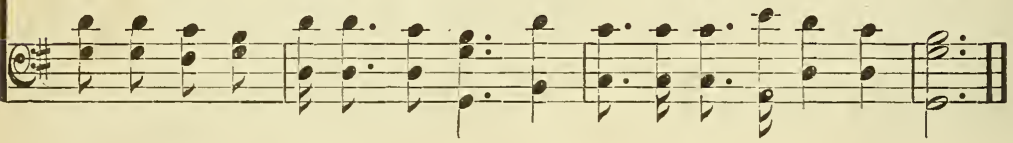

4 If the spirit dwells within you, You will outshine the sun,

You will outshine the sun,

You will outshine the sun;

If the spirit dwells within you,

You will outshine the sun,

And walk the golden streets on high.

5 If you'll only stop your growling,

You will outshine the sun, \&c.

6 If you'll only stop your scowling, You will outshine the sun, \&c.
7 If you'll follow in His footsteps, You will outshine the sun, \&c.

8 If you'll freely give to Jesus, You will outshine the sun, \&c.

9 I will meet you in the morning When we'll outshine the sun, When we'll outshine the sun, When we'll outshine the sun, I will meet you in the morning When we'll outshine the sun, And walk the golden streets on bigh. 


\section{Practical Points On How To Do Personal Work.}

-I. Its Importance.

1. Commanded by God. Matt. $28: 19,20$.

2. It is work in which God works with us. I Cor. $3: 9$

3. It was Christ's work. Luke $19: 10$.

4. We can be used by the Holy Spirit. I Cor. 12.

(Nоте) Many things for the time are important, but this is work for eternity.

Let him know that he which converteth the sinner from the error of his way, shall save a soul from death, and shall hide a multitude of sins.-James $5: 20$.

II. The Responsibility.

(Note) How much depends on the faithfulness of a physician, life saving crew, freman, or those having lives in their care. But this is work for souls. Read Ezek. 33 .

\section{Wisdom Needed.}

Study the fisherman, doctor, hunter, and the wisdom they need. Prov. $11: 30$.

And he that winneth souls is wise; (R. $V$. And he that is wise winneth souls) and it takes wisdom to win souls. Jas. $1: 5$. IV. Advantages, or Value of Personal Work.

1. We can all do it.

2. Can be done anywhere.

3. Can reach all classes which cannot be reached in other ways.

4. Personal efforts appeal to personal needs and reach where sermons often fail.

5. In aiding others to Christ you will deepen your own spiritual life and gain in power.

6. The effect of your influence demands it.

7. Because the salvation of your loved ones may depend on your efforts. John $1: 42$. And he brought him to Jesus.

T. The Rewards and Blessings.

Ps. $126: 6$. There is a blessing in store for those leading souls to Christ. And rewards,

And they that be wise shall shine as the brightness of the firmament; and they that turn many to righteousness as the stars for ever and ever. Dan. $12: 3$. 


\section{Some Things Necessary In Order to be Effective.}

1. Must be thoroughly converted ourselves.

Should know the Lord Jesus before we can introduce Him to others, or point them to Christ as Savior.

2. Should live clean lives.

Remember the power of influence. We desire clean vessels to use. So God wants clean lives to carry the water of life. Are you right with God? winners.

3. We should realize that God expects us to be soul

We expect service from our children, a servant, etc. We are bought with a price. Remember we are saved to serve.

4. Should surrender our lives, obey, and walk up to the light God has given us.

This is very imporiant if we wish freedom, power and victory.

5. Christ's love for souls.

Means not only our loved ones, but the heathen. It takes in the whole world. How to have it? Bible Study. prayer, working for souls, and obedience.

6. Perseverance.

Keep at it, don't get discouraged, be faithful and expectant. (See the fisherman and others.)

7. Must have deep sense that men out of Christ are lost and the gospel can save to the uttermost. Read Heb. $7: 25$

8. Filling of the Holy Spirit for service.

(See page on filling of the Spirit.)

9. Prayer.

1 st. To show you the right person to approach.

2 d. When and where to speak

3 d. For right message.

4 th. Power to carry the message to the heart. (Study page on prayer.)

10. Working knowledge of the Word of God.

1 st. To show to the sinner his true condition.

2 d. To show him how to accept Christ as the true remedy

$3 \mathrm{~d}$. To remove any difficulties that stand in the way.

Some Helpful Points.

"Study to shew thyself approved unto God, a workman that needeth not to be ashamed, rightly dividing the word of truth." 11 Tim 2:15. That you

1 st. May feed your own soul.

2 d. To aid and edify Christians.

3 d. To lead unsaved to Christ.

4 th. To be able to lead meetings and give gospel talks.

Have a Bible of your own. Mark and underline the verses. Have a system and use it. Memorize. Study every spare minute daily. Be teachable, and get all the help you can from others. Look for Christ everywhere, and study it as the word of God, much on your knees, with a surrendered will and obedient heart. 


\section{Endeavoring te Win Souls to Christ.}

Begin. Do your best. Don't be afraid of mistakes, as the greatest is to keep still. Get others to work. Write letters. Call on people and talk about meetings. Be happy and show it out where ever you go. $\mathrm{Be}$ as loyal to Christ in one place as another. Go with the expectation of having a great meeting. Be punctual and ready to do anything that will aid. Grasp every opportunity. Pray, speak or sing. $\mathrm{Be}$ on the look out to speak to souls. If possible talk to them alone. Don't interrupt others. Depend on the Holy Spirit, and hold them to the one point to believe on Christ and accept Him as Saviour. Urge them to surrender their wills on their knees. Use your bible, telling them to read the verse you use. Keep praying while working. Do not argue. Be in earnest, courteous, and adapt yourself, putting yourself in the place of the one you are dealing with and work accordingly Urge them to confess Christ at once, and give instructions how to become a strong Christian

(See page "What it is to believe in Christ and how to be strong.

\section{Choice Thoughts on the Bible.}

This book contains the word of God, the state of man, the way of salvation the doom of sinners, the happiness of believers.

Its doctrines are holy, its precepts are binding, its histories are immutable. Read it to be wise, believe it to be safe, and practice it to be holy, live it to be happy.

It contains light to direct you food to support you and comfort to cheer you.

It is the traveler's map, the pilgrim's staff, the pilot's compass, the soldier's sword and the christian's charter.

Here paradise is restored, heaven opened and the gates of hell disclosed,

CHRIST IS ITS GRAND SUBJECT; our good its design, the clory of God its end.

It should fill the memory, rule the heart and guide the feet.

Read it slowly, frequently, prayerfully.

It is a mine of wealth, an ocean of purity a pradise of glory a river of pleasures.

It is given you in life, will be opened at the judgment and be remem. bered forever.

It involves the highest responsibitily will reward the greatest labor, and condemn all who trifle with its sacred contents.

1. REPENTANCE.-A change of mind. A new mind about God.

2. CONVERSION.-A change of life. A new life for God.

3. REGENERATION.-A change of Nature. A new heart from God.

4. JUSTIFICATION.-A change of State. A new standing with God.

5. ADOPTION.-A change of family. A new relationship toward God.

6. SANCTIFICATION.-A change of service. A separation unto God.

7. GLORIFICATION.-A change of place. A new condition with God. 
W. L. T.

WiLl. L. THomrson.

Slow.

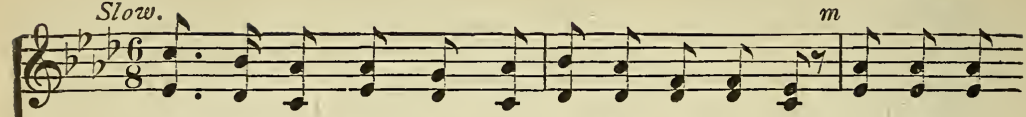

1. Soft - ly and ten - der - ly Je-sus is call-ing, Call-ing for

2. Why should we tar - ry when Je-sus is pleading, Pleading for

3. Time is now fleet - ing, the moments are passing, Pass-ing from

4. Oh, for the won-der-ful love He has promis'd, Promis'd for
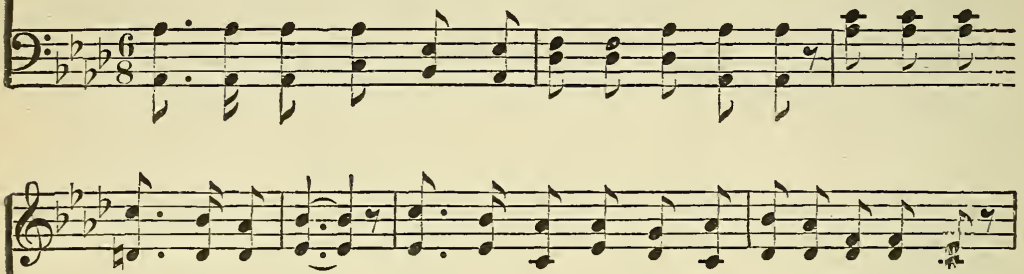

you and for me; See on the por-tals He's waiting and watching, you and for me? Why should we lin-ger and heed not His mercies, you and from me; Shad-ows are gath- er-ing, death - beds are coming, you and for me; 'Tho' we have sinn'd He has mercy and pardon,

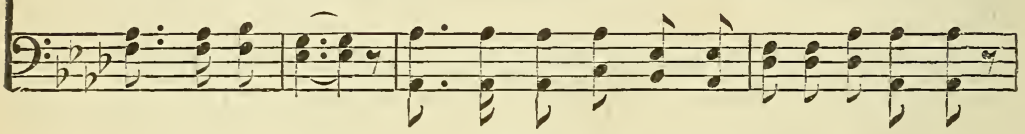

CHORts. $m$ Cres.

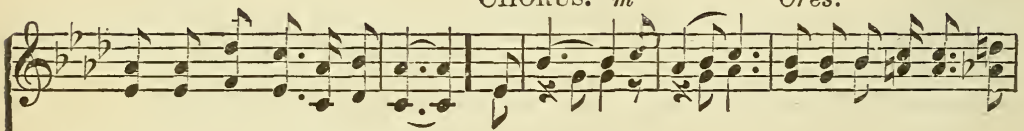

Watehing for you and for me.

Mer-cies for you and for me? Com-ing for you and for me. Come home, Come home, Yewhoare weary, come

Pardon for you and for me.

Come home, Come home,
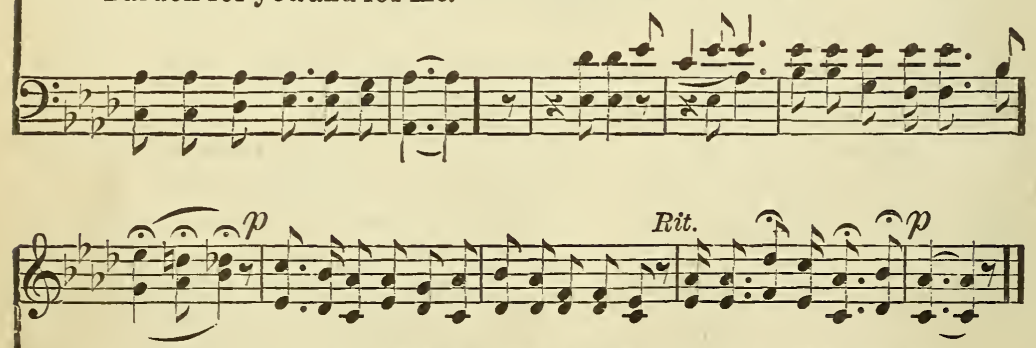

home; ... Earnestly, teader-ly, Jesus is call-ing, Calling, $\mathrm{O}$ sin-ner, come home!

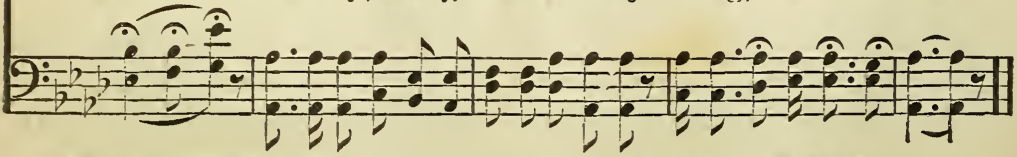

By per. Wul. L. Thompson \& Co., E. Liverpoel, O., and The Thompson Music Co., Chicage, In 


\section{Points On How To Become a Christian,}

ARR. BY JOHN A, DAVIs.

\section{Iou Have Sinned and Are Lost.}

He that believeth on Him (Jesus) is not condemned; but he that be lieveth not is CONDEMNED already. John $3: 18$.

He that believeth on the Son hath everlasting life; and he that believeth not the Son shall not see life, but the wrath of God abideth on him. John $3: 36$.

NOTE - Is CONDEMNED ALREADY, not that he may be some time, i. e. when he comes to die, (most unsayed people never expect to be lost, they hope to repent and be saved before they die) failing to see that they are LOST ALREADY.

The unsaved person in God's sight is not only a sinner, but a LOST, CONDEMNED sinner. He has been tried, found guilty and is already bound over to judgment; simply waiting the moment of execution, and be needs to see that it is only by the mercy of God that he escapes the torments of hell for a single second.

You are either SAVED or LOST NOW. You are either a SAINT (separate one) or a SINNER NOW. You are either a Child of God or a Child of Satan NOW, and you occupy either one or the other of these positions of your Own FREE CHOICE.

Do you say, "I don't know that I am vory bad." "I am better than great many." Do not compare yourself with some one else, but hear what God says ahout you.

"There is none righteous, no not one." Rom. $3: 10$.

The heart is deceitful ahove all things, and desperately wicked; who can know it ? Jer, $17: 9$

If you think you are not a sinner, God says you are deceived.

If we say we have no sin, we deceive ourselves, and the truth is not in us, 1 John $1: 8$,

There is no difference for all have sinned. Rom. $3: 22,23$.

They are all gone aside, they are all together become filthy; there is none that doeth good, no, not one. Ps. 14:3.

There is not a just man upon earth that doeth good and sinneth not。 Ec. $7: 20$.

For as many as are of the works of the law are under the curse, for it is written, cursed is every one that continueth not in all things which are written in the book of the law to do them. Gal. $3: 10$.

Let me ask you, have you kept all of God's law? You say, no, of course not; no one has." "Very good; your admitting that you have failed convicts you, for we read: "Whosoever shall keep the whole law, and yet offend in one point, he is guilty of all. James $2: 10$.

Jesus said unto him, Thou shalt love the Lord thy God with all thy heart, and with all thy soul, and with all thy mind. Matt. 22: 37.

This is the first and great commandment. Matt. $22: 38$.

To break it must be one of the greatest sins before God. Have you kept it? How wretched you must be. For Isa. $53: 6$ says, "All we like sheep have gone astray; we have turned every one to his own way" 
42 II. But You Can be Saved.

And the Lurd hath laid on him (Jesus) the iniquity of us all, Isa. $53: 6$. What good news.

Behold, I bring you good things of great joy, which shall be to all people. Luke 2 : 10 .

This "all" includes you, and the message of "good tidings" is, that you can be saved. Just read, "This is a faithful saying, and worthy of all acceptation, that Christ Jesus came into the world to save sin. ners." 1 Tim. 1 : 15.

For the Son of man is come to seek and to save that which was lost." Luke 19 : 10.

God wills that all men should be saved. 1 Tim. $2: 4$.

God is not willing that any should perish but that all should come to REPENTANCE. 2 Peter $3: 9$.

\section{For Christ Hath Redeemed Iou.}

Do you know that Christ has redeemed you? Do you say, "no?" Will you read carefully what God says and see that he did?

I haye blotted out, as a thick cloud thy transgressions, and as a cloud thy sins; return unto $\mathrm{Me}$, for I have redeemed thee. Isa. $44: 22$.

Notice God says, "I have blotted out," not "I will blot out;" and it is thy sins he says-not the sins of some one else.

But he was wounded for our transgressions, He was bruised for our iniquities, and with His stripes we are healed. Isa. $53: 5$.

Read this verse, "He was wounded for my transgressions, etc." make it personal. In this we see Jesus Christ as our substitute-dying in our stead.

Christ hath redeemed us from the curse of the law, being made a curse for us. Gal. 3 : 13.

You read in Gal. $3: 10$ that whosoever fails to keep all of the law is "cursed." Now, we read that Christ was made a curse for us.

Who his own self bare our sins in His own body on the tree, that we, being dead to sins, should live unto righteousness; by whose stripes ye were healed. 1 Peter $2: 24$.

For He hath made Him to be sin for us, who knew no sin that we might be made the righteousness of God in him. 2 Cor. $5: 21$.

Notice, we are not to be made righteous before God by our moral life or even by our good works, but "in Him." To this perfect offering of Christ nothing can be added.

For Christ also hath ONCE SUFFERED FOR SINS, the just for the unjust, that he might bring us to God. 1 Peter $3: 18$.

"How can I be pardoned?" asks the sinner. "How can I not pardon?" says God. The sinner looks at his sins, but God looks at his Son's atoning blood Sinner, do thou likewise. The work of Christ satisfied God the Father; and it ought to satisfy you.

Read page on "What must I do to be saved." 
it because of Difficulties?

What is your excuse? Is it I am-

\section{Too Great a Sinner.}

Thank God if you know you are lost.

For the Son of man is come to seek and to save that which was LOST. Luke 19 : 10.

This is a faithful saying, and worthy of ALL ACCEPTATION, that Christ Jesus came into the world to SAVE SINNERS; of whom I am chief. 1 Tim. $1: 15$.

The fact that you are a sinner, assures you that you may be saved.

You are as sure of salvation, upon the confession and forsaking of sin, as you are that you this moment have an existence.

"He that covereth his sins shall not prosper; but whoso confesseth and forsaketh them shall have mercy." Prov. $28: 13$.

And you may be sure $\mathrm{He}$ will accept you, for He hath promised.

"Him that cometh to Me I will in no wise cast out." John. 6 : 37 .

No one can say, "I am too great a sinner, Christ cannot save me."

"Though your sins be as scarlet, they shall be as white as snowi though they be red like crimson, they shall be as wool." Isa. $1: 18$.

"Wherefore $\mathrm{He}$ is able also to save them to the uttermost that come unto God by him." Heb. $7: 25$.

Paul was a murderer,-but the grace of God saved him. If he could be saved, surely you can.

Some people say that when grace and good nature meet, we have a great Christian; but Bunyan says, "When grace and a great sinner meet, we have a great Christian." 17.

"Whosoever will, let him take the Water of Life freely." Rev.22 :

This salvation is for you my reader if you "will" to have it, God wants you to have it. Will you take it?

2. Trusting in your own self righteousness or doing best you can.

If you were doing the best you could you would accept Christ as your Savior instead of trusting in yourself.

For they being ignorant of God's righteousness, and going about to establish their own righteousness, have not submitted themselves unto the righteousness of God. Rom. $10: 3$.

But we are all as an unclean thing, and all OUR RIGHTEOUSNESS are as FILTHY RAGS. Isa. $64: 6$.

Jesus said to Nicodemus, Except a man be born again, he cannot see kingdom of God.

Marvel not that I said unto thee, Ye must be born again.

For by grace are ye saved through faith; and that not of yourselves it is the gift of God.

NOT BY WORKS OF RIGHTEOUSNESS which we have done, but according to his mercy he saved us. Tit. $3: 5$. 
God does not ask for feelings but a turning to him from Satan and sin.

Turn ye, turn ye from your evil ways; for why will ye die. Ezekiel $33: 11$.

And then seek ye the Lord WHILE he may be found, call upon him while he is near. Isa $55: 6$.

The word feeling does not occur once in the whole Bible in connection with salvation; but FAITH IN CHRIST is mentioned about three hundred times as that which saves.

That if thou shalt confess with thy mouth the Lord Jesus, and shalt believe in thine heart that God hath raised him from the dead, thou shalt be saved. Rom. $10: 9$.

For with the heart man believeth unto righteousness; and with the mouth confession is made unto salvation. Rom. $10: 10$.

Which would you rather trust? God's UNCHANGING word, or your EVER=CHANGING feelings?

Christ says: Whosoever therefore shall confess me before men, him will I also confess before my Father which is in Heaven. Matt. $10: 32$.

But with this promise there is also a warning which you will do well to heed.

Whosoever shall deny (that is not confess) me before men, him will I also deny before my Father which is in Heaven." Matt. $10: 33$.

Do not be guided by the experience of some Christian friend, but BY GOD'S WORD.

The devil's order is: 1st, Feeling; 2d, Faith; 3d, Fact; but God's order is 1st, Fact; 2d, Faith; then feeling.

The FACT you're a sinner, you cannot but see.

That FAITH in Christ saves you, is ever our plea.

The FEELING will follow in service and love.

Then TAKE from Christ Jesus his GIFT from above.

4. Can't Hold Out.

Of course you cannot in your own strength. But he is mighty to save. Put your trust for pardon in the finished work of Christ and let him come into your life.

Being confident of this very thing, that he which hath begun a good work in you, will PERFORM IT until the day of Jesus Christ. Phil. $1: 6$.

I know whom I have believed, and am persuaded that HE IS ABLE TO KEEP that which I have committed unto him against that day. 2 Tim. $1: 12$.

He cannot keep what you do not commit unto him.

Now unto him that is ABLE TO KEEP YOU from falling, and to present you faultless before the presence of his glory with exceeding joy. Jude 24.

KEPT by the power of God through faith unto salvation ready to be revealed in the last time. 1 Peter $1: 15$. 
There hath no temptation taken you but such as is common to man; but God is faithful, who will not suffer you to be tempted ABOVE THAT YE ARE ABLE; but will with the temptation also make a way of escape, that we may be ABLE TO BEAR IT. 1 Cor. $10: 13$.

Don't be afraid of persecution or temptation. It is a blessing.

Blessed are ye, when men shall revile you, and persecute you, and shall say all manner of evil against you falsely, for my sake. Matt. 5: 11 .

Rejoice, and be exceeding glad; for great is your reward in heaven . Matt. $5: 12$.

Blessed is the man that ENDURETH temptation; for when he is tried, he shall receive the crown of life, which the Lord hath promised to them that love him. Jas. $1: 12$.

\title{
5. Can not Give up the World or my Present Business
}

Is it on account of your business? the desire to make money?

\begin{abstract}
"What shall it profit a man if he shall gain the whole world and lose his own soul." Mark $8: 36$.
\end{abstract}

"Seek ye first the kingdom of God and His righteousness, and all these things shall be added unto you." Matt. $6: 33$.

Attend first to your soul's salvation. It is more important than making money, enjoying the world, or "having fun." Are you waiting for the feeling that some say they have? If so, you are likely to continue to wait, and of you were to live on for all eternity as you are now living, you would never have it, because it is a feeling that comes into one's soul only upon the acceptance of Christ. It is not so much your feeling you are a sinner, as the fact you are one that should lead you to accept Christ now.

And the world PASSETH AWAY, and the lust thereof; but he that doeth the will of God abideth forever. I Jno. $2: 15$ to 17.

Be not deceived: God is not mocked: for whatsoever a man soweth, THAT shall he also reap. For he that soweth to his flesh shall of the flesh REAP CORRUPTION; but he that soweth to the Spirit shall of the Spirit reap life everlasting. Gal. $6: 7,8$.

You are "dead in trespasses and sins." Eph. 2:1. You know this because God's word says so, although you cannot tell it. Knowing this to be a fact, act wisely and accept the remedy, which is Christ Jesus. Show the same common sense in caring for your soul, that you would in caring for your body. The spiritual physician, knowing your need says:

"Choose you this day whom ye will serve." Joshua 24 : 15.

"Seek ye the Lord while He may be found, call ye upon Him while He is near." Isa. $55: 6$.

\section{But The Christian Life is too Hard.}

Christ says: "My yoke is easy and my burden is light;"'but the "way of transgressors is hard." Prov. $13: 15$.

The Christian life is pleasant, with peace, joy and hope of eternal life

For I reckon that the sufferings of this present time are not WORTHY TO BE COMPARED with the glory which shall be revealed in us. Rom. $8: 18$ 
But the path of the just is as the SHINING LIGHT that shinetb more and more unto the perfect day. Prov. $4: 18$.

Sin is expensive. It may be pleasant at first; but then that which is worse and ends in destruction. "For the wages of Sin is Death." Rom. $6: 23$. Are you ready to take your wages now? In Rev. 20 we get a glimpse of what the second death is.

And death and hell were cast into the lake of fire. This is the second death.

And whosoever was not found written in the book of life was cast into the lake of fire.

And these shall go away into EVERLASTING PUNISHMENT, prepared for the devil and his angels. Matt. $25: 41$.

And in hell he lifted up his eyes, BEING IN TORMENTS. Luke $16: 23$

\section{Not Now. Time Enough.}

If you want to be saved, now is the time, because it is God's time. $\mathrm{He}$ would not have you delay one moment, because He knows your peril. Hear His voice.

Behold, now is the accepted time; behold now is the day of salyation. 2 Cor. 6 : 2.

Today if ye will hear his voice, harden not your hearts. Heb. 3 : 15.

What are you waiting for? To better yourself? This will be a waste of time, as we have learned that your trying and doing and working, will not even help to save you, but hinder you. Do you say, 'there is time enough?' How do you know it? God says:

Boast not thy self of tomorrow, for thou knowest not what a day may bring forth. Proverbs $27: 1$.

And Jesus said: Therefore, be ye also ready; for in such an hour as ye think not the Son of man cometh. Matt. $24: 44$.

He that being often reproved and hardeneth his neck, shall suddenly be destroyed, and that without remedy. Prov. 29:1.

There is no time to be lost, for God said in Gen. 6 : 3. My Spirit shall not always strive with man.

Prepare to meet thy God. Amos 4 : 12. 31.

It is a fearful thing to fall into the hands of the living God. Heb. 10:

Seek the Lord whil e He may be found. Isa $55: 6$

\section{There are too Many Hypocrites.}

Yes that is true, but it will not save you looking at them. The more you look the more you are apt to be like them and if they are lost and you are not saved, it looks as if you were both going to the same place.

For there is no difference, all have sinned and come short of the glory of God. But God looks at the heart. 
Judge not, that ye be not judged. For with what judgment ye judge, ye shall be judged: and with what measure ye mete, it shall be measured to you again. And why beholdest thou the mote that is in thy brother's eye, but considerest not the beam that is in thine own eye? Matt, $7: 1$ to 4 .

\section{Read Rom. $2: 1$ Rom. $14: 4,10$ to 13 .}

It is better to be saved and then try and help others if we know how they ought to live There are hypocrites in business and in almost everything else. But we do not give up business, etc. There are counterfeit dollars but it only proves that there are genuine. But suppose they are all hypocrites.

Jesus said: What is that to thee? Follow thou me. John $21: 22$.

\section{To the Backslider.}

Some who are called backsliders, are not. Because they never slid ahead.

Let me ask you. Did you see Christ as your personal Saviour and accept him. If so and you have become cold aud indifferent or fallen into sin, you will never be truly happy or have peace until you confess your sins and return to God.

For the backslider in heart shall be filled with his own ways. Prov. 14 : 14 .

If we CONFESS our sins, he is faithful and just to FORGIVE us our sins and to cleanse us from all unrighteousness. 1 Jno. $1: 9$.

He that covereth his sins shall not prosper; but whoso CONFESSETH and FORSAKETH them shall have mercy. Prov. $28: 13$.

Only acknowledge thine iniquity, that thou hast transgressed against the Lord thy God.

Thine own wickedness shall correct thee.

For my people have committed two evils; they have forsaken me the fountain of living waters, and hewed them out cisterns, broken cisterns, that can hold no water. Jer. $2: 13$.

My little children, these things write I unto you, that ye sin not. And if any man sin, we have an advocate with the Father, Jesus Christ the righteous, and he is the Propitiation for our sins; and not or ours only, but also for the sins of the whole world. 1 Jno. $2: 1,2$ Read Luke 15th. chap.

\section{For The Infidel and Skeptic.}

For the fool hath said in his heart there is no God.-Ps. $14: 1$.

But if you are an honest doubter, let me ask you to pray, "O God, if " there be a God show me the truth and I will follow it." Read the book of John and walk in the light as fast as he reveals it to you, and if you do not understand everything at once, remember you do not understand many other things you use and believe, read Deut. 29:29 I Cor. $2: 14$ I Cor. $1: 18$ II Cor. 4:34; John $7: 17$. You may know God and the truth. 


\section{First-BECAUSE GOD SAYS SO.}

As many as received him (Jesus) to them gave He power to become the sons of God. John $1: 12$.

John $5: 24$ 'He that heareth My word and believeth on Him that sent me hath everlasting life, and shall not come into condemnation (or Judgment) but is passed from death unto life."

A great many people think it is presumption for them to say they know they are saved-that they can only "hope for the best, and will have to wait until the judgment before they know." Paul did not say to the jailer. "Believe on the Lord Jesus Christ and perhaps you will be saved, or you will have a good chance of being saved, or you may hope to be saved." No, but "thou shalt be saved." Acts. 17:31.

"He that believeth on the Son hath (not perhaps will have) everlasting life." John $3: 36$.

"He that hath the Son hath life." 1 John $5: 12$.

But read the following verse, which tells us why these things are written.

"These things have I written unto you that bel leve on the name of the Son of God, that ye may know (not hope, or guess) that ye have (not are going to have) eternal life." 1 John $5: 13$.

Note-If you have received God's gift (Jesus) you have God's word for it, that you have life. The life is in his son, The life is His Son. Believe this and you will know it. Confess Jesus as your Saviour and you will have the witness of the Spirit.

"Put that in black and white," says the merchant when a good offer is made to him. God has put his offer in black and white-"These things are written."

Do you say, I don't feel it? Feeling is not the evidence, or prcof for you to trust. Your feelings may change, like the wind, but God's word never changes. He says, "Heaven and earth shall pass away, but My words shall not pass away." Mark 13 : 31 . Which would you rather trust, God's unchanging Word, or your everchanging feelings? When God says a thing, it is so.

Do you want the Spirit of God to bear witness with your Spirit? We are told that this is one of the evidences:

The Spirit himself beareth witness with our spirit that we are the children of God Rom, $8: 16$.

If you want this evidence you must believe God's word. If you do not, you are making God a liar, and this will prevent the Spirit from working in you.

He that believeth not God hath made Him a liar, because he believeth not the record that God gave of His Son. 1 John $5: 10$.

Notice, if you believe not the record that God has given, you make Him a liar. What is this record that you don't believe? Read the next verse and learn.

And this is the record that God hath given (not will give) unto us eternal life, and this life is in His Son. 1 John $5: 11$.

The record is that we are saved if we trust in Christ, and we may know it. Is it presumption to believe God's word? No! But it is presumption to doubt it.

Jesus said in John $10: 28$. I give unto them eternal life; and they shall never perish, neither shall any man pluck them out of my hand. 


\section{Blessed Assurance.}

F. J. CROSBY.

Copyright, 1873, by Jos. F. Knapp. By par.

Mrs. Jos. I'. ZNAPP.

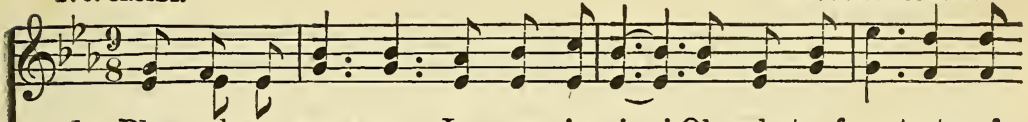

1. Bless-ed as - sur-ance, Te - sus is mine! $\mathrm{Oh}$, what a fore-taste of

2. Per-fect sub-mis-sion, per - fect de- light, Vis-ions of rap-ture now

3. Per-fectsub-mis-sion, all is at rest, I in my Sav-ior am
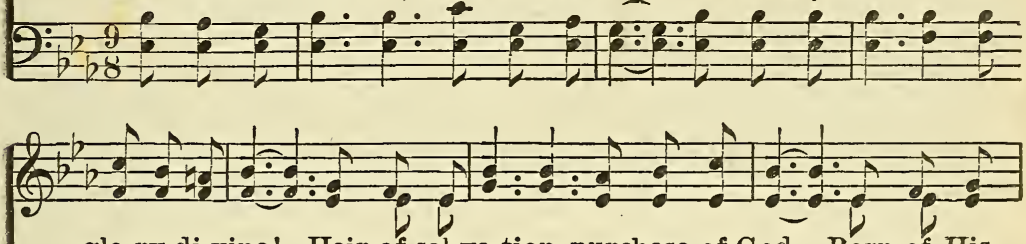

glo-ry di-vine! Heir of sal-va-tion, purchase of God, Born of His

burst on my sight, An-gels de-scending, bring from a-bove Ech - oes of

hap-py and blest, Watching and wait-ing, look-ing a-bove,Filled with His

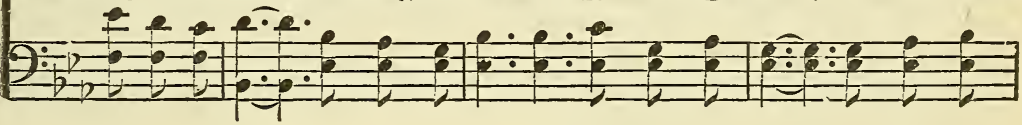

\section{Chorus.}

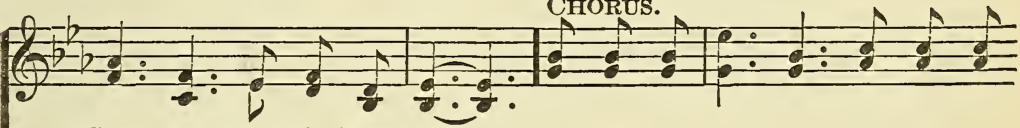

Spir - it,washed in His blood.

mer - cy, whis-pers of love.

This is my sto-ry, this is my

good-ness, iost in his love.

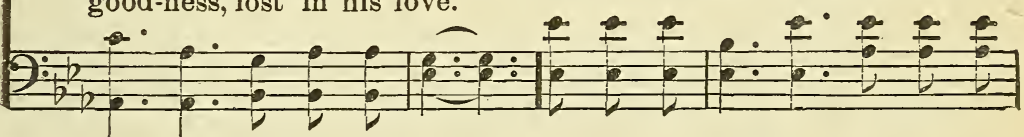
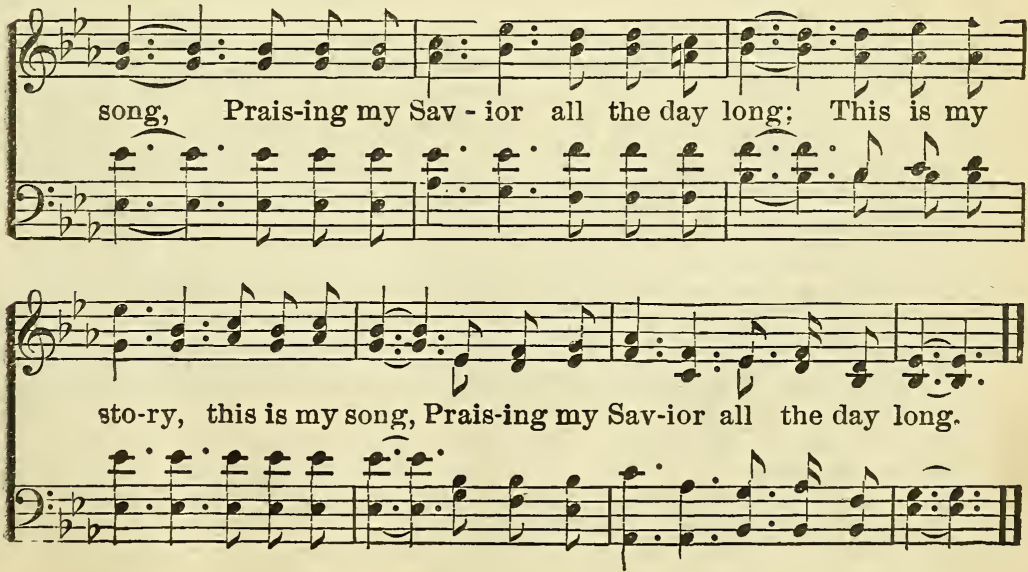


\section{DEAR READER:-}

saved?

Did you eyer ask the question, What must I do to be

I take it you are earnest and sincere or you would not be reading this now. May the Holy Spirit make these few words so plain that you will be able to say, "I see it and will now believe."

What is it to believe on Christ? That is a question that hundreds have asked. No doubt you have sometimes felt alarmed in regard to your sins and have said like the jailer (in Acts 16):

What must I do to be saved ?

When you read Jno. $3: 36$., did you stop and wonder what it meant? "He that believeth on the Son hath everlasting life; and he that believeth not the Son shall not see life; but the wrath of God abideth on him." And still you hesitate.

Why should you ? You are dealing with your eternal welfare. But you say, Mr. Davis, I am in earnest and wish to be saved, but don't see the way clearly. Let us go over it together thoughtfully.

1st. You must realize you are lost aud see your need of Christ as your Saviour.

Until you do I fear you will not trust him wholly. You do not send for a physician until you realize you are ill. You may not understand the disease, but you feel your need of a physician. It was not until Peter found he was sinking that he cried "Lord save me." So the sinner never goes to Christ as a Saviour in the right way until he realizes his lost and wretched condition.

Do you sav, you do not feel it? Oh, then how lost, how wretched you must be ! Lost soul this very thought ought to fill you with shame and fear. As it is written in Romans 3: "There is none righteous, no, not one." "For there is no difference." "For all have sinned and come short of the glory of God." "They are all gone out of the way, they are together become unprofitable. There is none that doeth good, no, not one."

We have all gone astray and turned our own way and broken the great commandment, "Thou shalt love the Lord thy God with all thy heart and with all thy soul and with all thy mind." Have you kept it? If not you have committed one of the greatest sins. Gal. $3: 10$ says, "Cursed is every one that continueth not in all things which are written in the book of the law to do them." And in James it says, "For whosoever shall keep the whole law and yet offend in one point, he is guilty of all." Jas r: 10

Oh, sinner you have broken the first commandment. What must be your terrible condition before God? Whose fault is it that you do not realize your condition? You are alarmed when some fatal disease holds you in its grasp. You are filled with sorrow when a friend is dying in agony before your eyes. Can you have no sorrow when you think of a suffering Saviour whose love you have abused-no alarm when you call to mind that fearful judgment to which you are hasten. ing? Will you dare tell your Judze at the great day that you did not see your need of a Saviour? But you say I do see at least to some degree that I am a poor, lost, undone sinner, but this will not save me. No it will not. Thousands have realized their lost condition and have perished, and you will unless you

2d. Believe that Christ shed His blood, dying in your place, and that He is able and now willing to save you. $\mathrm{Yes}, \mathrm{He}$ is able for He is Almighty, and $\mathrm{He}_{\mathrm{e}}$ is willing now to save you. You are a great sinner, but Christ is a wonderful Saviour.

Satan, your enemy, has been trying to persuade you that Christ is not able to save such a great sinner as you are.

Don't believe Satan, but take God at His word. His word is true. Men are Jnat by believing Satan and saved by believing God. He savs 


\section{Let Jesus Come Into Your Heart.}

C. H. M.

Copyright, 1898, by H. L. Gilmour. Used by per.

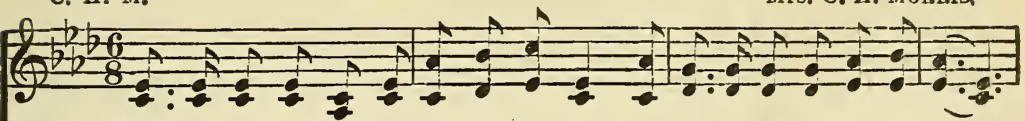

Mrs. C. H. MORrIQ,

1. If you are tired of the load of your sin, Let Jesus come into your heart;

2. If 'tis for pu - ri-ty now that you sigh,Let Jesus come into your heart;

3. If there's a tempest.your voice cannot still, Let Jesus come into your heart;

4. If friends, once trusted, have proven untrue, Let Jesus come into your heart;

5. If you would join the glad songs of the blest, Let Jesus come into your heart;
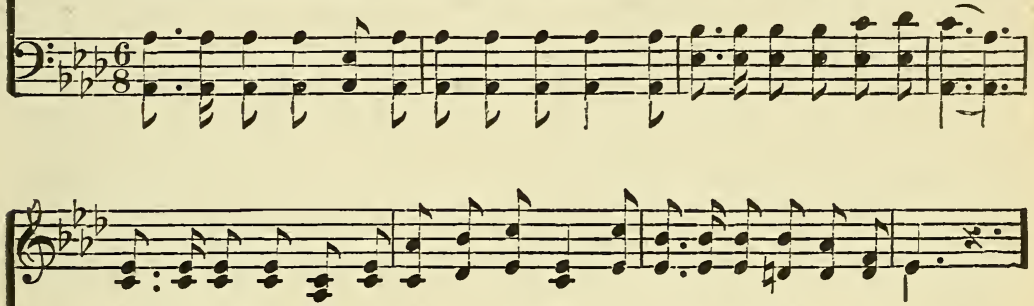

If you de-sire a new life to be-gin, Let Jesus come into your hearto Fountains for cleansing are flowing near by, Let Jesus come into your heart.

If there's a void this world never can fill, Let Jesus come into your heart.

Find what a Friend He will be unto you, Let Jesus come into your heart.

If you would enter the mansions of rest, Let Jesus come into your heart.

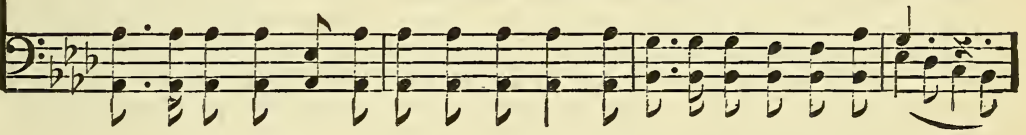

Chorus.

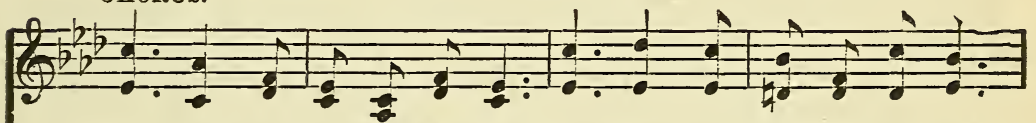

Just now, your doubtings give o'er; Just now, re - ject Him no more;

Just now, my doubtings are o'er; Just now, re - ject - ing no more;
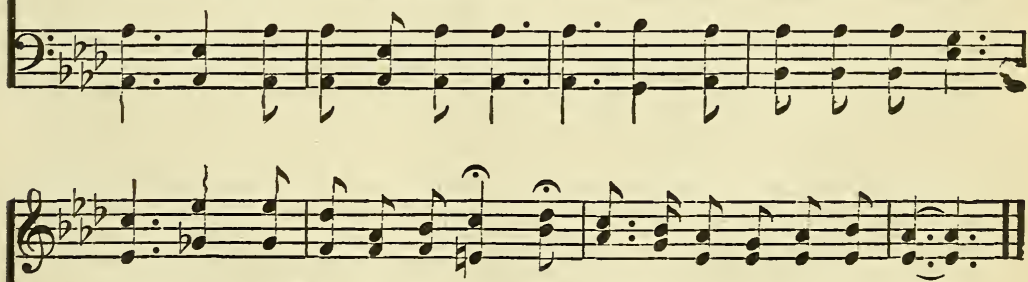

Just now, throw o-pen the door; Let Je-sus come in- to your heart.

Just now, I 0 -pen the door, And Je-sus comes in-to my heart.

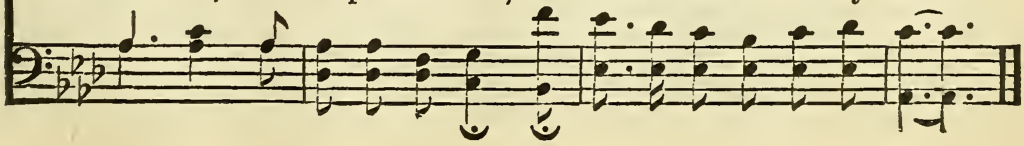


wise cast out." What a welcome to you, sinner. Remember "He came. to seek and to save that which is lost."

$\mathrm{He}$ is willing to save you the moment you fully trust $\mathrm{Him}$, for $\mathrm{He}$ is able to save to the uttermost all that come to Him.

Did you read John 1:12? "But as many as received Him to them gave He power (the right) to become the Sons of God, even to them. "hat believe on his name."

Do you receive him now? For now is the accepted time. Perhaps you have thought He would be willing after a few more days or weeks. spent in prayer, weeping and growing better. Satan desires nothing better than that you should continue to think so. You are growing no better. You are doing nothing to gain Christ's favor while you refuse to yield to His loving invitation and are treading under your feet His blood. What he wants is for you to believe or receive. That is to accept and trust Him now.

The great enemy of your soul does not care if you set a time far distant when you will go to Christ. If you will continue to put it off until next year or even next week, a day or an hour, his object is gained and your poor soul is lost. But you say; Oh, I don't feel-feel what? Well I am waiting for feeling. What kind? I said to a man once (looking for $a$ pin) I can make you feel. He saidI don't want that kind. What kind do you wish, an electric shock or some peculiar feeling to run down your back? He said no; well, I said, in order to get results if you are sick you must take the medicine. Facts first and then results. $\mathrm{He}$ did accept Christ and when I said how about feeling now? Oh, he said, with his face all aglow, I have the Saviour, I am saved, I have feelings now, I am the child of a King. To know you are saved with eternal life is enough to make any one happy and praise God continually.

Yes, you say, "but I am not fit or worthy." Yes, "But the Son of Man came to seek and save that which was lost." But does not a sinner at the moment of actual submission to the Saviour feel more fit to be pardoned, and is not Christ more willing to pardon him than before? No, dear friend, no, no. He is less fit to be pardoned for his sins have been increasing every hour as he puts off this great salvation. Don't go on sinning and rejecting Christ, but just now.

3d. Cast yourself unreservedly upon His mercy and grace and trust Him alone for salvation.

"For by grace [uumerited favor of God as revealed in Jesas Christ] are you saved through faith, and that not of yourselves; it is the gift of God. Not of works." This means that you renounce all expectations of sav. ing yourself, or of being saved any other way than through the righteousness and glorious redemption of Jesus Christ. Do you feel you have done all you could? Are you thinking of something more to do in order to obtain forgiveness? You have done too much in this way already. Just stop doing and begin now to trust Christ to do all.

He satisfied God, pleasing him by His life, dying for your sins, the just for the unjust, a perfect Redeemer. By His stripes we are healed; He is our substitute. If God accepted Christ in our place, are you willing just now to say. I come, I come, it is all I can do. Yes, I do believe and accept Him and trust Him. If so you are saved this moment. What a wonderful Saviour, mighty to save even unto the uttermostSee the man in bathing, he is caught in the current and carried toward the terrible falls. It means death to go over. His friends on the bank give him up for lost. He swims, struggles and calls for help; in another moment a rope is thrown towards the wretched man. Do all the friends call to swim harder in order to reach the shore? Oh, no, stop your struggling. Take hold of the rope.

So the sinner's hope lies not in struggling and trying but in taking Christ and in yielding to Him who will save. But you say why then 
do you urge me to become a Christian? Why not let me wait and sit still until Christ shall save me? If the man in the water should fold his arms and wait for the rope to save he might as well have struggled ou. In both cases he would have gone over the falls: but he must grasp the rope. Not wait until he is in better condition if he wishes to be saved.

If he neglects he is certain of death. So you must lay hold on Christ. Believe His word, trust Him now.

I was preaching in the city of $\mathbf{E}$ - on the plan of salvation; at the ll meetings I announced that I would be glad to shake hands with those that had taken Christ as their Saviour during the meetings and also asked those that had decided that night to come to the front with the rest and tell me when they had decided. Scores came; after some little time I noticed two strong young men on the platform. I went up to one and said, are you a Christian? Yes sir, he answered, with his face shining. Well how lowg? Oh, about fifteen minutes. I said how is that? Why you made the plan of salvation plain and I saw it, sir, and accept= ed it down there in that seat. Then you believe the Bible? Yes sir. And the text $10 \mathrm{John}$. "He that cometh unto me I will in no way cast out?" Yes sir. Have you come? Yes sir. Does he cast you out? No, sir. How do you know? He says he will not and I believe him. I took him over to John $1: 12$, and said, if you have received Him you are God's child and that is worth more than this world to rou. And then we went over to Jno. $3: 36$., "He that hath the Son hath life," and I said, What have you by accepting Christ? He said life. Well is that worth anything to you ? Yes, he answered, with a smile, and I have eternal life. Reader, do you say this moment I see, it is clear. I will take Christ, believe and trust Him for salvation. If you do $\mathrm{He}$ saves you now.

Let us go and prove by our lives and testimony to those around us that we do believe.

If you believe on Christ and will take eternal life as God's gift to you through Christ by faith-

Sign your name here-

NAME.

ADDRESS.

And in order to be a strong healthy Christian-

1. Confess Christ.

In the home, on the street, in public, in every place, by your life and by your mouth. Be among the first to speak in every meeting.

Rom. 10:9-10. "That if thou shalt confess with thy mouth the Lord Jesus, and shait believe in thine heart that God hath raised Him from the dead, thou shalt be saved.

"For with the heart man believeth unto righteousne'ss; and with the mouth confession is made unto salvation."

\section{Prayer and Praise.}

Begin the day with prayer and continue to pray about everything with thanksgiving. Have the blessing at the table and the family altar.

Phil. 4:6. "But in everything by pruyer and supplication with thanks. giving let your requests be made known unto God."

\section{Study your Bible.}

Read it much, but study it prayerfully.

Study I.John, Romans, The Gospels, Eph., Gal., and so on Learn all the scripture possible, at least a verse a day. Be a thorough Bible student. Study and pray it into your soul and then give it out.

II. Tim. 2:15. "Study to show thyself approved unto God, a work:man that needeth not to be ashamed, rightly dividing the Word of truth."

4. Attend every means of Grace possible.

Church service, prayer meetings, etc. You need all the help you can get that you may be strong to help others. The greatest blessing is to be a blessing. Live for others. 
Rom. 12:1. "I beseech you therejure, brethren, oy the mercies of God, that ye present your bodies a living sacrifice, holy, acceptable unto God, which is your reasonable service.

\section{Be a Worker.}

Don't be a jerker, shirker, growler or kicker, but a worker. Faithfuı in all little things wherever you are. Be a soul-winner.

Do all the good you can, in all the ways you can, to all the people you can, as long as ever you can.

John 4: 35. "Behold, I say unto you, lift up your eyes, and look on the fields, for they are white already to harvest."

\section{Be Baptized and Join Some Church.}

Ask God to guide you. Study and find out what you believe God tells you and follow Him wherever Heleads you. Where you can be a worzer and a blessing, faithful in whatever you find to do for the Master

I. cor. 15 : 58. "Therefore, my beloved brethren, be ye steadfast, unmov. able, always abounding in the work of the Lord, for as much as ye knou that your labor is not in vain in the Lord.

\section{Give, Be Generous.}

Don't rob God, you can not afford not to give, ask God to guide you in all your givings. Remember what it cost Christ to redeem you and this is your opportunity to purchase heavenly property. Laying up treasure in Heaven.

Don't hold on to money here, for time, and lose the reward in Heaven, for eternity.

II. Cor. 8:12. Prov. 11:2425. II Cor.9:6-9. "For God loveth a cheerful giver."

\section{If You Should Stumble or Fall.}

Don't lay there, but get up at once and go on. I remember of slip. ping on some ice freshly covered over with snow and falling. But I did not lay there, I got up at once, looked around to see if any one saw me, brushed off my clothes and went nn, more careful as to where I was going. If the devil should fix up some slippery place and you fall get up at once and go on.

9. Live a Clean Life.

Don't follow questionable practices. Cut loose from every known sin or weight, abstain from all appearance of evil. Be separate from the world and worldly things. It pays to live right.

Heb. 12:1-3. "Wherefore, seeing we also are compassed about with so great a cloud of witnesses, let us lay aside every weight, and the sin which doth so easily beset us, and let us run with patience the race that is set before us, looking unto Jesus."

10. Go on to Victory.

Go on, go on, go on to Victory, make the most of your life by the Gruce of God.

II. Peter 3 : 18. "But grow in grace, and in the knowledge of our Lora and Saviour, Jesus Christ."

\section{How Spurgeon Found Christ, Written by himself}

Born twice. First at Kelvedon, Essex, Eng., June 19 1834; the second time at Colchester in 1849.

Died once. Fell asleep in Jesus at Mentone, France, Jan. 31, 1892. His body laid to rest at London, Feb 11, 1892.

I had been about five years in the most fearful distress of mind, as a lad. If any human being felt more of the terror of God's law I can indeed pity and sympathize with him. Bunyan's "Grace Abounding" contains, in the main, my history. Some abysses he went into I never trod; but some into which I plunged he seems te have never known.

I thought the sun was blotted out of my sky-that I had sinned so against God that there was no hope for me. I prayed- the Lord knoweth how I prayed; but I never had a glimpse of an answer that I knew of. I searched the word of God: the promises were more alarming than ube threatenings. I read the privileges of the people of 
God, but with the fullest persuasion that they were not for me. The secret of my distress was this; I did not know the gospel. I was in a Christian land, I had Christian parents, but I did not fully understand the freeness and simplicity of the gospel.

I attended all the places of worship in thetown where I lived, but I honestly believe that I did not hear the gospel fully preached. I do not blame the man, however. One man preached the divine sovereignty. I could hear him with pleasure; but what was that to a poor sinner who wishej to know what he should do to be saved? There was another admirable man who always preached about the law; but what was the use of plowing up ground that needed to be sown?

Another was a great practical preacher. I heard him, but it was very much like a commanding officer teaching the manoeuvres of war to a set of men without feet. What could I do? All his exhor. tations were lost on me. I knew it was said, "Believe on the Lord. Jesus Christ and thou shalt be saved," but I did not know what it was to believe in Ohrist.

I sometimes think I might have been in darknes $\mathrm{s}$ and despair now, had it not been for the goodness of God in sending a snowstorm one Sunday morning, when I was going to a place of worship. When I could go no further, I turned down a court and came to a little Primitive Methodist chapel. In that chapel there might be a dozen or fifteen people. The minister did not come that morning; snowed up, I suppose. A poor man, a shoemaker, or something of that sort, went up into the pulpit to preach.

Now, it is well that ministers should be instructed, but this man was really stupid, as you would say. He was obliged to stick to his text for the simple reason that he had nothing else to say. The text was. "Look unto $\mathrm{Me}$, and be ye saved, all the ends of the earth." $\mathrm{He}$ did not even pronounce the words rightly but that did not matter.

There was, I thought, a gleam of hope for me in the text. $\mathrm{He}$ began thus: "My dear friends, this is a very simple text indeed. It says, "Look." Now that does not take a deal of effort. It ain't lifting your foot or your finger it is just 'look'. Well a man nee己 not go to college to learn to look. You may be the biggest fool and yet you can look. A man need not be worth a thousand a year to look. Anyone can look; a child can look. But this is what the text says. Then it says 'Look unto M⿶.' "Ay' said he in broad Essex, "many on ye are looking to yourselves. No use looking there. You'll never find comfort in yourselves. Some look to God the Father. No, look to Him by-and-by. Jesus Christ says 'Look unto Me.' Some of you say 'I must wait the Spirtt's working.' You have no business with that just now. Look to CHRIST. It runs: 'Look anto Me.',

Then the good man followed ap his text in this way: "Look unto Me; I am sweating great drops of blood. Look unto Me; I am hanging on the cross. Look! I am dead and buried. Look unto $\mathrm{Me}$; I rise again. Look unto $\mathrm{M} \theta$; I ascend; I am sitting at the Father's right hand. O! look to me! look to me!",

When he had got about that length and managed to spin out ten minutes or so he was at the end of his tether. Then he looked at me under the gallery and I dare say with so few present he knew me to be a stranger. He then said: "Yorng man you Look miserable." Well I did; but I had not been accustomed to hav remarks made on my personal appearance from the pulpit before. However it was a good blow struck. He continued?" And you will always be miserable-miserable in life and miserable in death-if $r o n$ do not obey my text. But if you obey now this moment you will be saved.",

Then he shouted as only a Primitive Methodist nan; "Young man, look to Jesus Christ!" I did "look."

There and then the cloud was gone, the darkness had rolıed away, and that moment I saw the sun: I could have risen that moment ana sung with the most enthusiastic of them of the precious blood of Ohrist and the simple faith which looks alone to $\mathrm{Him}$. Oh, that 
somebody had told me that before: TRUST UHRISI AND YUU SHALL BE SAVED.

"E'er since by faith I saw the stream, Thy wounds supplied for me. Redeeming love has been my theme, And shall forever be.'

\section{Facts or Feelings,}

Facts and feelings are widely different, but are often sadly confounded in our thoughts about spiritual things in general, and about the way of salvation in particular. They are as different as rock and sand, and yet they are frequently mistaken for each other, and seeking souls are constantly putting "the cart before the horse," and reasoning within themselves thus:- "If I could only feel forgiven, I could believe;" "If I could only feel better I should have some hope;" "If I could only feel saved, I should be happy."

I am only aware of one person in the Scriptures who is said to have "felt" anything in regard to salvation, and in that case her feelings were based upon facts. (Mark 5 . 25-29.) Observe the order here-tacts, faith and foelings. First the facts: her need of healing: and His power to heal. Next the action of faith: "She touched His garment" "Then the feeling: "Straightway she felt she was healed of that plague.",

I trust the following correct account of an incident which occurred recently may serve to make the distinction between facts and feelings still more clear:

A Christian minister visited a sick man who had been for many /years a member of a noted infidel club in London. He was received. with words to this effect, "Oh you have come to ask if I 'feel saved,' I suppose? Well you need not trouble; my wife is always talking about 'feeling saved' but I do not believe in any such thing. I gave up all that sort of rubbish twenty years ago when I burnt my Bible."

"No; I have not the slightest wish to hear that you feel saved for if you did you might soon feel lost again. But whether you accept it or not, there is one great FACT, that the Son of God came and died to save your soul 1800 years ago, and if you do not choose to believe God's Word, you will certainly be lost for ever, not because you have been a sinner, but because you are so utterly mad as to reject the fact which God sets before you. And yet it will remain a fact forever, that the Son of God died for you, and you might have been saved by that fact."

On calling again the servant of God found that the two-enged sword had pierced through the hard thick rust formd by a life of infidelity and sin.

The sick man said: "I wish you would tell me more about that fact you mentioned the last time you were here."

The truth was again simply set before him,and illustrated by the following thought:

"Suppose you are in prison owing $\$ 5000$, and unable to pay it. A decree has just gone forth that on the morrow, that prison with all its inmates is to be utterly destroyd by fire. I, hearing of your awful plight pay the money for you and send you the receipt. Let us imagine, if possible that you are insane enough to tear up the receipt, refuse your liberty and perish in the fire that destroys the prison. Your death does not ALTER THE FACT THAT YOUR DEBT WAS PAID and that you might have escaped had you been willing to accept your deliverance and believe the blesse news."

Shortly afterwards he died. Just before he passed away his weeping wife said to him: "John, dear, do tell me you FEEL SAVED before you go.",

With the little strength he had left, he raised his head and said:

"FEELINGS CANNOT SAVE ME BUT FACTS CAN. IT IS A FACT I'HAT THE SON OF GOD DIED FOR ME AND I DIE ON THAT FACT."

Let me again remind you of the divine order. You are a sinner. Christ is the only Savior. These are facts. "BELIEVE on the Lord Jesus Christ and thou shalt be saved." (Acts xvi_31.) This is faith. 
P. H. DINGMAN.

JNO. R. SWHNRY.

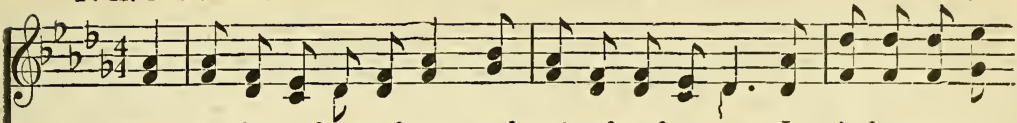

1. You ask what makes me happy,my heart so free from care, It is besause my

2. I was a friendless wand'rer till Je-sus took me in, My life was full of

3. I wish that ev-'ry sin-ner before His throne would bow; He waits to bid them

4. I mean to live for Jesus while here on earth I stay,And when His voice shall
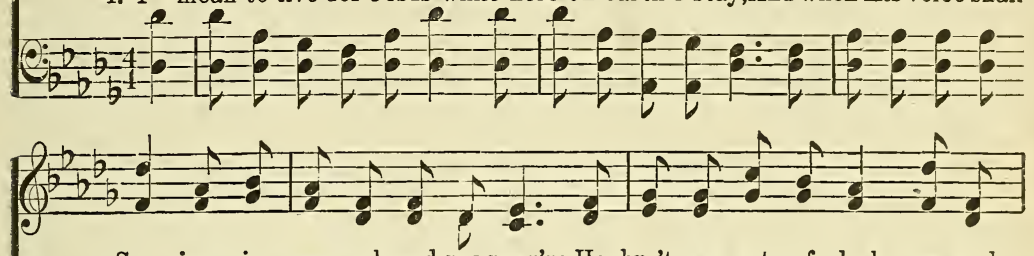

Sav-iour in mer-cy heard my pray'r; He bro't me out of dark-ness and sor - row, my heart was full of sin; But when the blood so pre-cious spoke wel-come, He longs to bless them now; If they but knew the rapt-ure that

call me to realms of end-less day; As one by one we gath - er, re-

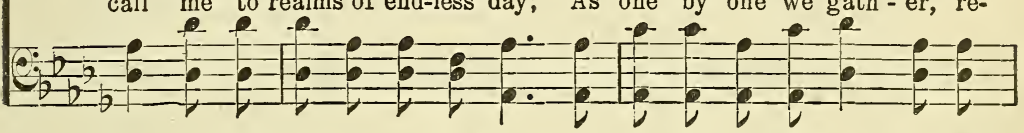

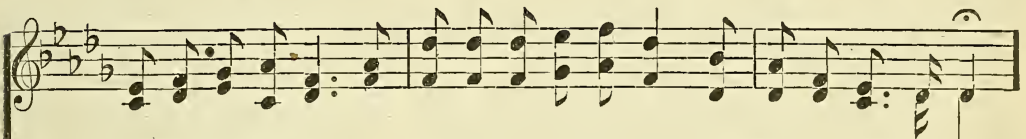

now the light I see; 0 bless-ed, lov-ing Saviour! to Him the praise shall be.

par - don to my soul; 0 bliss-ful,bliss-ful moment!'twas joy be-yond con-trol.

in His love I see, They'd come and shout salvation,and sing His praise with me.

joic-ing on the shore, We'll shout His praise in glory and sing for ev - er-more.

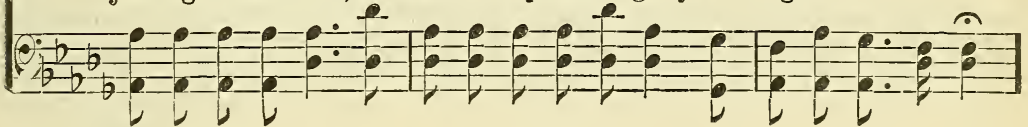

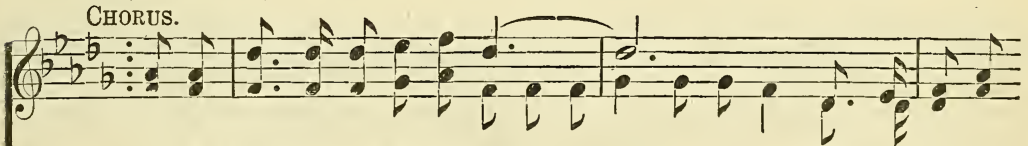

I will shout His praise in glory so will $\mathrm{I}$, so will I,

And we'll all sing

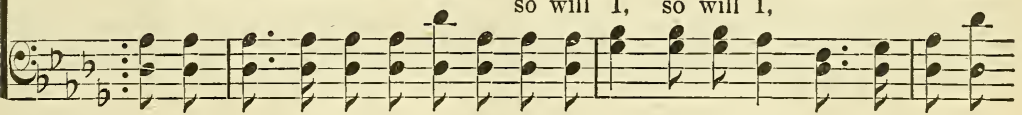

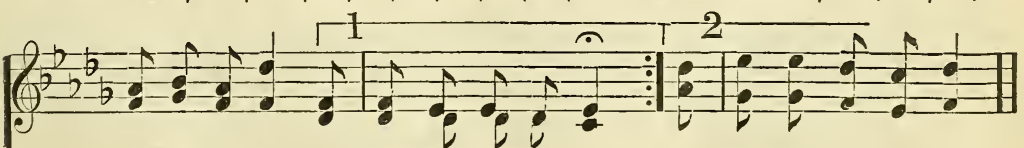

hal-le-lu-jah in heav-en by and by; in heav-en by and by.

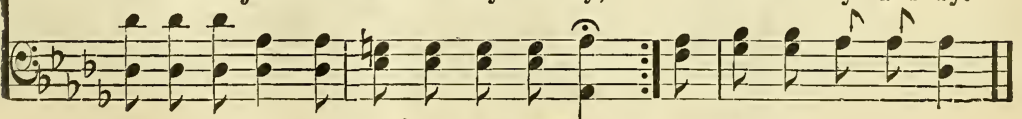

Copyright, 1889, by Jno. R. Sweney. Used by permission. 


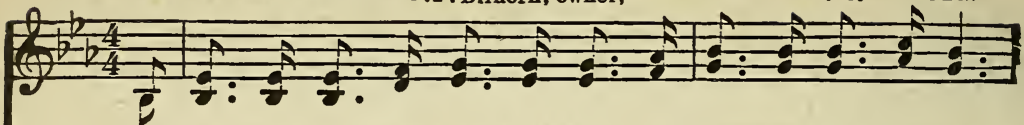

1. I wan-dered in the shades of night, Till Je - sus came to mt,

2. Tho' clouds may gather in the sky, And bil-lows round me roll,

8. While walking in the light of God, I sweet com-mun-ion find;

4. I cross the wide-ex-tend - ed fields, I jour - ney o'er the plain,

5. Soon I shall see $\mathrm{Him}$ as $\mathrm{He}$ is, The light that came to me,
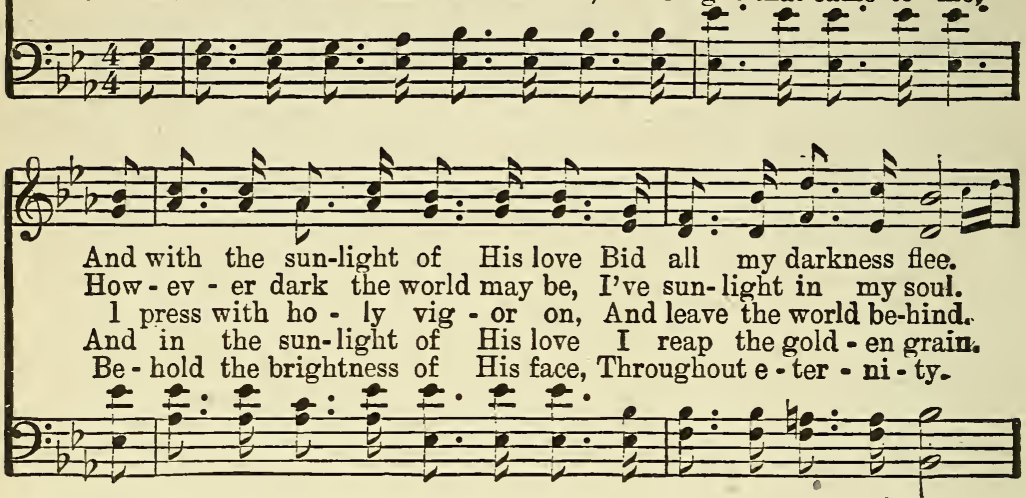

Chorus.
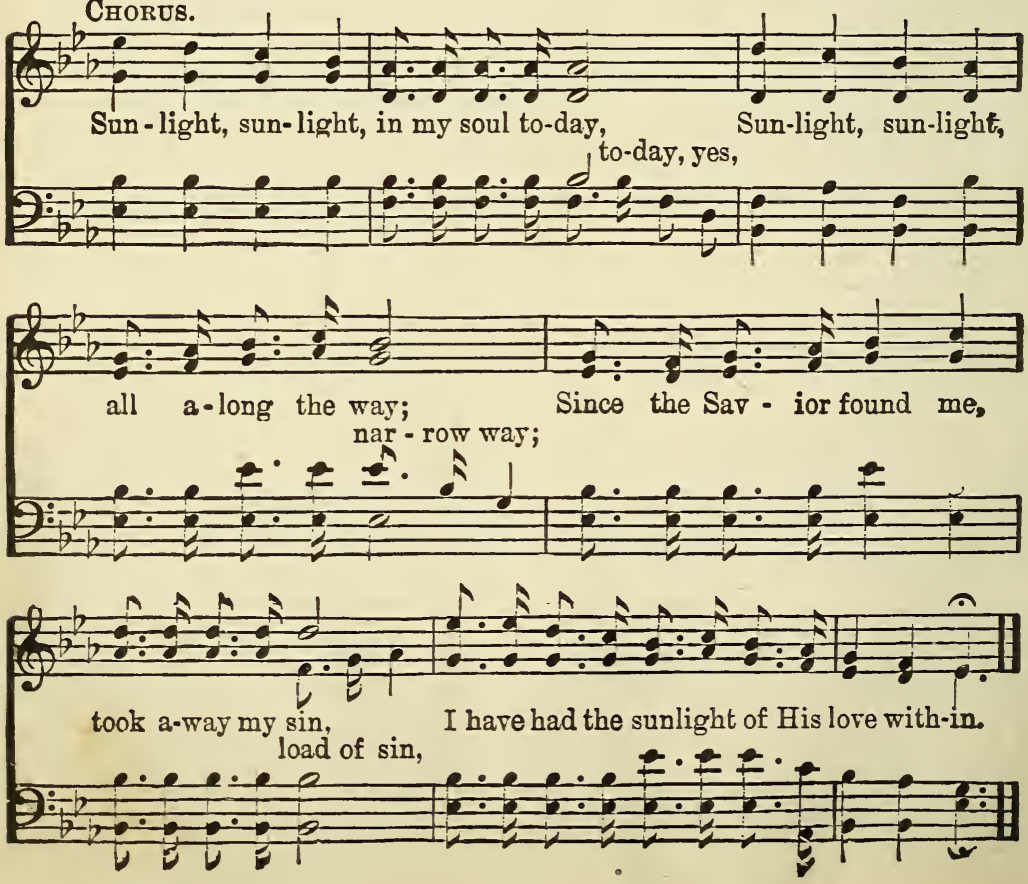
W. S. M.

W. STILLMAN Martin.

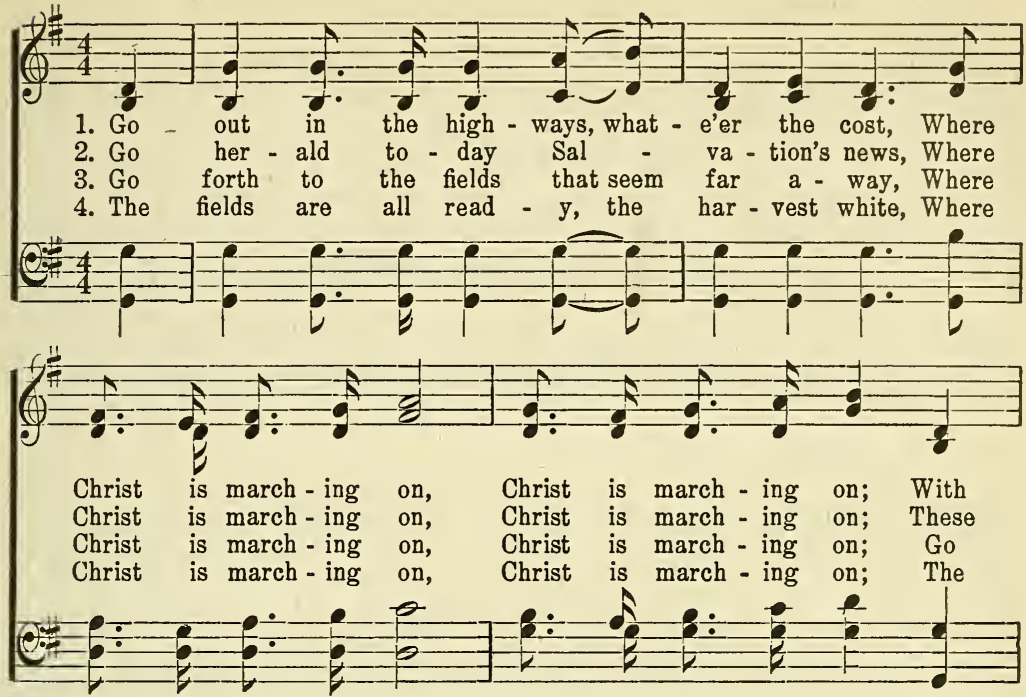

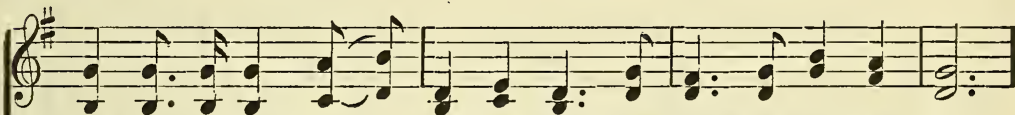

hearts full of love for sin-ner lost, Where Christ is march-ing on.

won - der - ful chanc-es why now re-fuse, Where Christ is march-ing on.

preach men the word in this gos-pel day, While Christ is march-ing on.

day is far spent soon, will come the night, Where Christ is march-ing on.

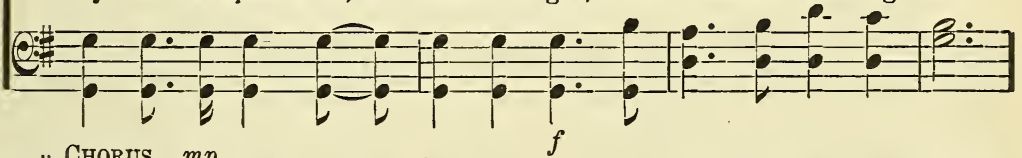

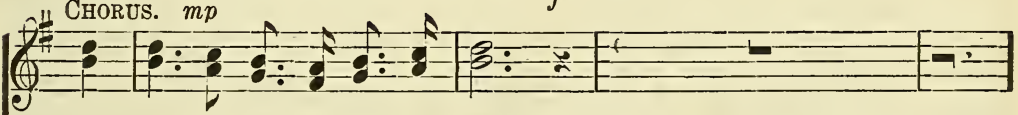

He came the lost to seek and save, For this His pre-cious life $\mathrm{He}$ gave;

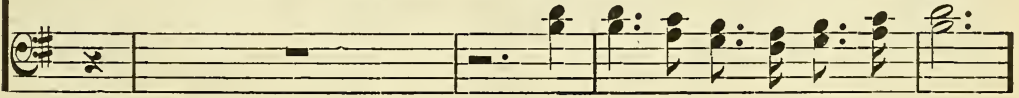

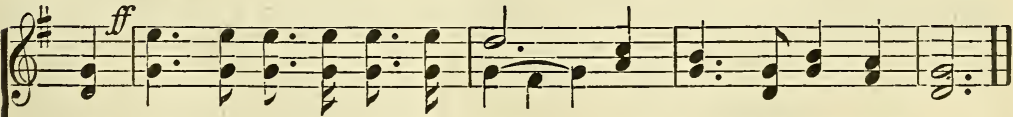

$\mathrm{He}$ rose tri-umph-ant from the grave, And now He's march-ing on.

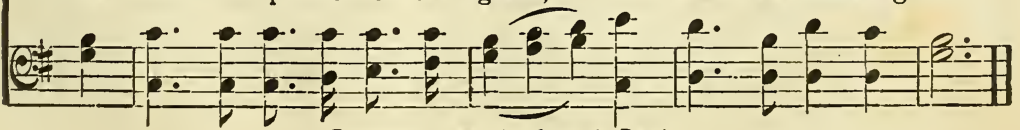

Copyright, 1905, by John A. Davis. 
1. W. VAN DEVENTER.

W. S. WEEDEN.

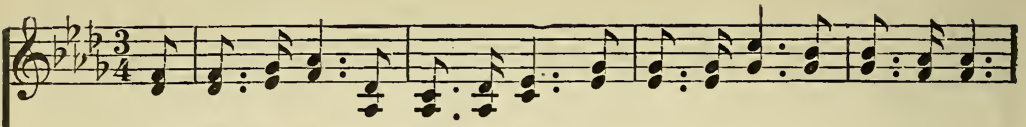

1. I nev-er can for-get the day I heard my mother kindly say:

2. I nev-er can for - get the voice That always mademy heart rejoice;

3. Tho' years have gone, I can' $t$ for-get Those words of love-I hear them yet;

4. I nev-er can for - get the hour I felt the Savior's cleansing pow'r;
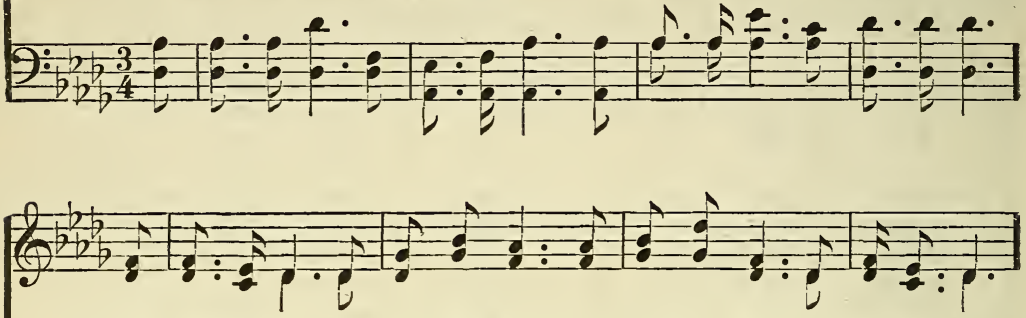

"You're leaving now my ten-der care; Remember, child, your mother's pray'r."

Tho' I have wandered God knows where, Still I remember mother's pray'r.

I see her by the old arm chair, My mother dear, in humble pray'r.

My sin and guilt He canceled there; 'Twas there He answered mother's pray'r.

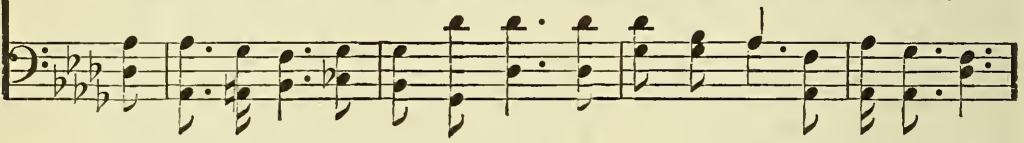

CHORUS.

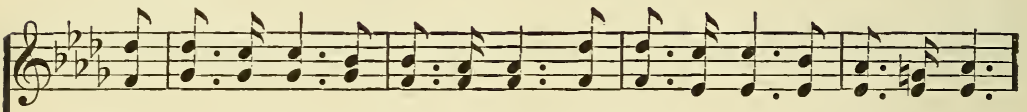

Whene'er I think of her so dear, I feel her an-gel spir-itnear; Last $\nabla$. Oh, praise the Lord for saving grace; We'll meet up yon-der face to face;
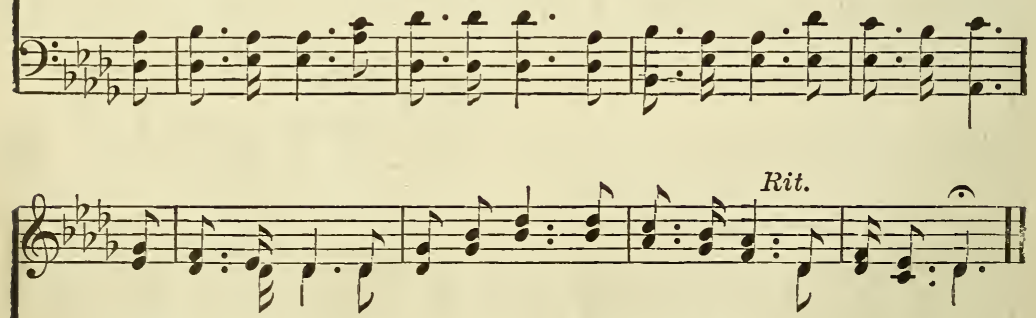

A voice comes floating on the air, Reminding me of mother's pray'r.

The home a-bove to-geth-er share, In answer to my mother's pray'r.

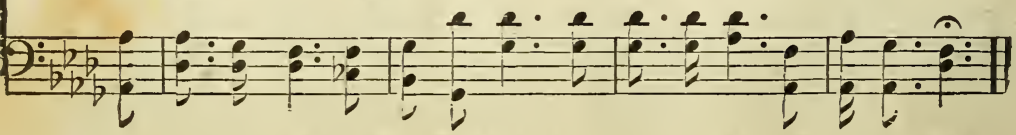

Copyrignt. 1895, by W. 3. Weeden and J. W. Van DeVenter. P. P. Bilhorn. ownez 


\section{The Best Friend is Jesus.}

P. P. B.

Copyright, 1891, by P. P. Bllhorn.

DUET.

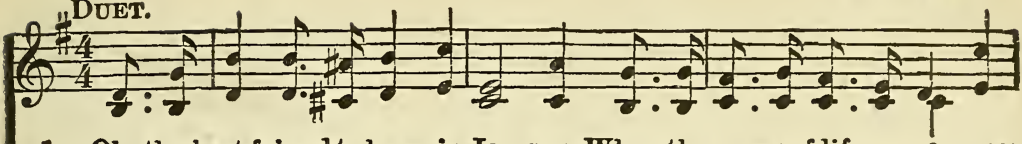

1. Oh, the best friend to have is Je - sus, When the cares of life up-on you

2. What a friend Ihave fond in Je-sus! Peace and comfort to my soul He

3. 'Tho' I pass thro' the night of sorrow, And the chilly waves of Jor-dan

4. When at last to our home we gath-er, With the loved ones who have gone beOrgan or Prano.
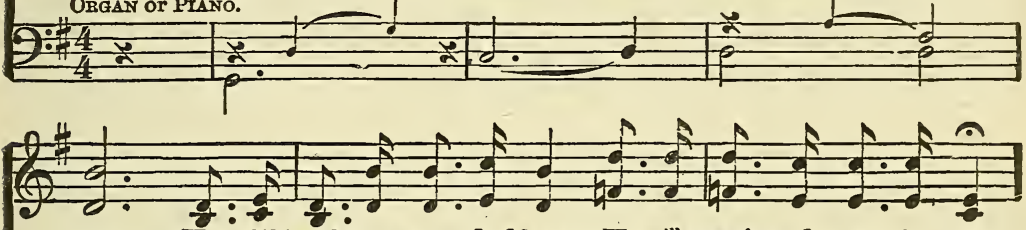

roll; He will heal the wounded heart, He will strongth and grace im-part;

brings; Lean - ing on His might-y arm, I will fear no ill nor harm; roll, Nev - er need I shrink nor fear, For my Sav-ior is so near;

fore, We will sing up-on the shore, Praising Him for-ev - er more;
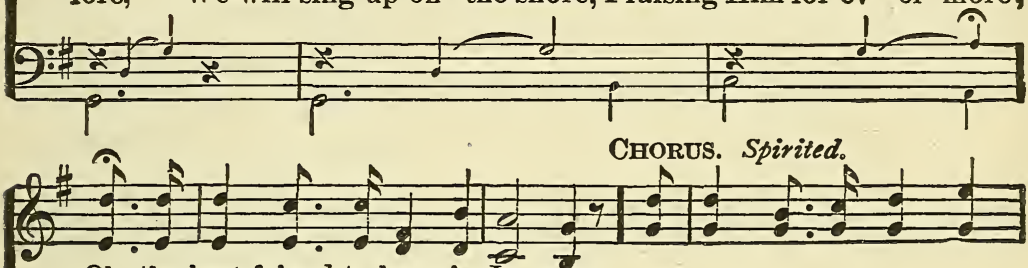

$\mathrm{Oh}$, the best friend to have is Je - surs.

$\mathrm{Oh}$, the best friend to have is Je-sus. The best friend to have is

$\mathrm{Oh}$, the best friend to have is Je-sus.

$\mathrm{Oh}$, the best friend to have is Je-sus.
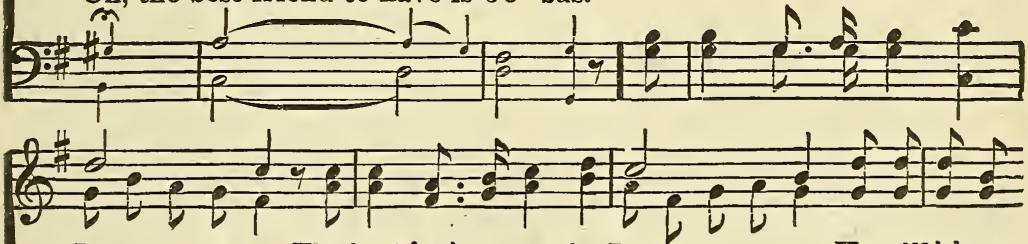

Je - - - sus, The best fruend to have is Je - - - sus, He will help jon

Je-sus ev'ry day,
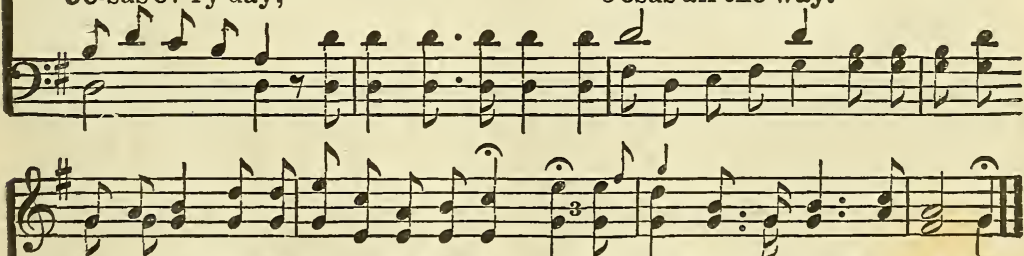

when you fall, He will hear you whon you call; Oh, the best friend to have is Je-sus.

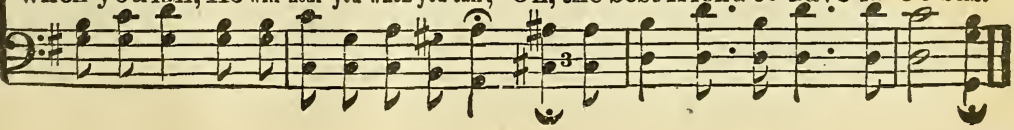


Rev. W. C. Martin.

E. S. I.ORENZ.

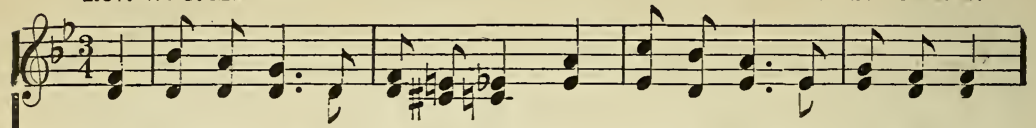

1. The name of Je-sus is so sweet, I love its $\mathrm{mu}$ - sic to re-peat;

2. I love the name of Him whose heart Knows all my griefs and bears a part;

3. That name I fond-ly love to hear; It nev-er fails my heart to cheer;

4. No word of man can ev - er tell How sweet the name I love so well;
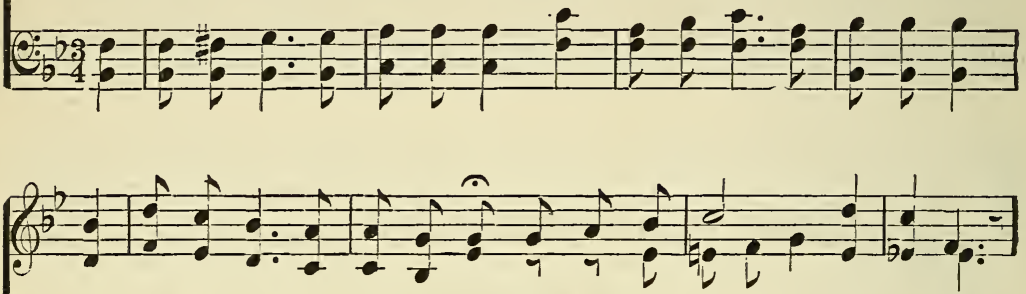

It makes my joys full and complete, The precious name of Je-sus. Who bids all anx-ious fears de-part-I love the name name of Je-sus.

Its mu-sic dries the fall-ing tear; Ex-alt the name name of Je-sus.

0 let its prais - es ev-er swell, 0 praise the name name of Je-sus. $O$ praise the name

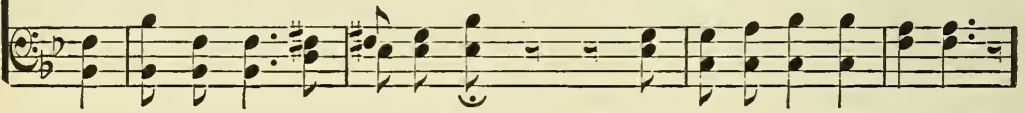

Chorus.

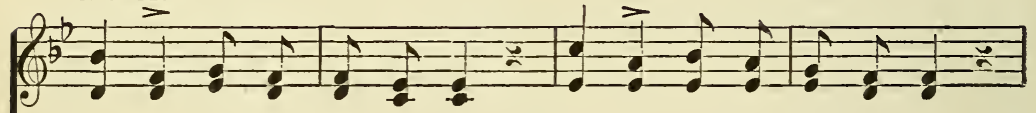

"Je - sus," 0 how sweet the name! "Je - sus," ev - 'ry day the same;
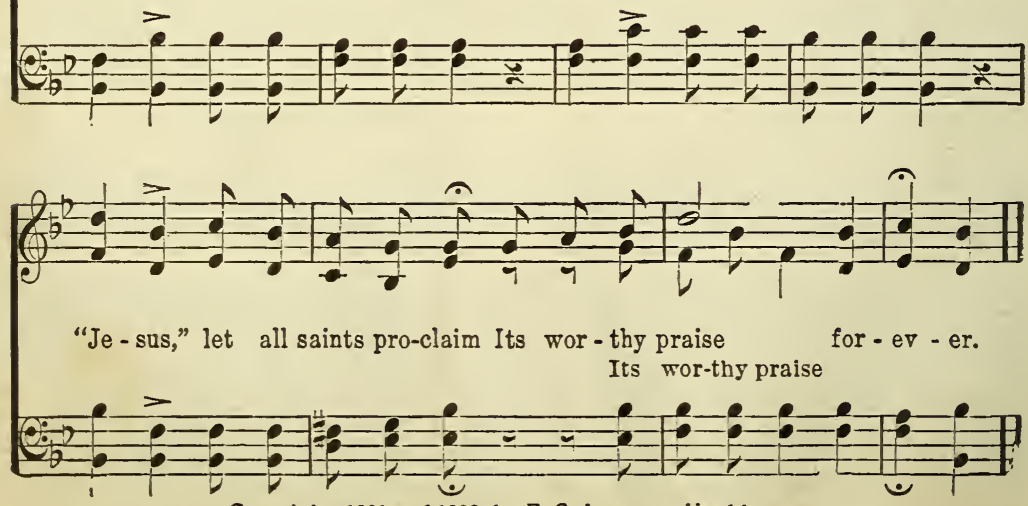

Copyright, 1901 and 1903, by E. S. Lorenz. Used by per. 
E. P. Stites.

JNO. R. SWENEY.

(1)

1. I've reach'd the land of corn and wine, And all its rich-es free-ly mine,

2. The Saviour comes and walks with me, And sweet com-mun-ion here have we;

3. A sweet per-fume up - on the breeze Is borne from ev - er ver - nal trees,

4. The zeph-yrs seem to float to me, Sweet sounds of heaven's mel - o-dv,

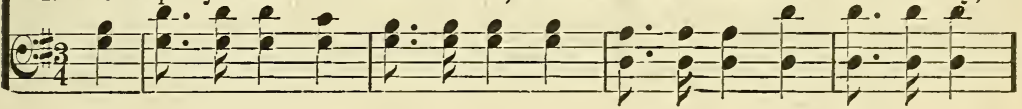

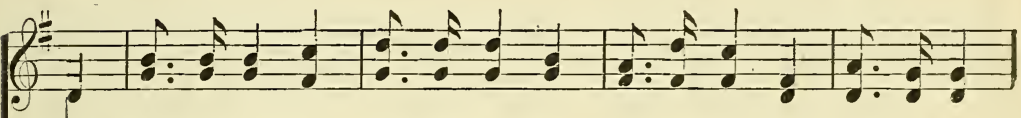

Here shines undimm'd one bliss - ful day, For all my night has pass'd a-way.

$\mathrm{He}$ gen - tly leads me with His hand, For this is heav-en's bor-der-land.

And flow'rs that nev - er fad - ing grow Where streams of life for - ev - er flow.

As an -gels with the white rob'd throng, Join in the sweet re-demp-tion song.

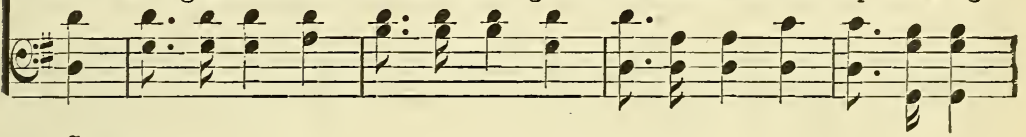

Chorus.

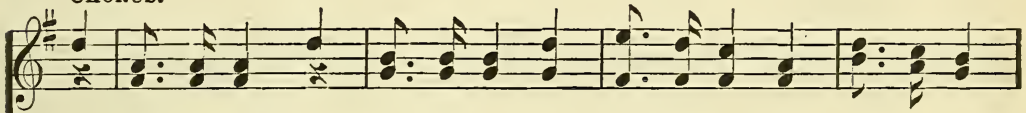

Beu - lah land, sweet Beu-lah land, As on thy high-est mount I stand,

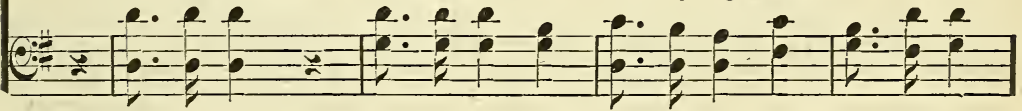

Q

! look a-way a - cross the sea, Where man-sions are pre-pared for me,

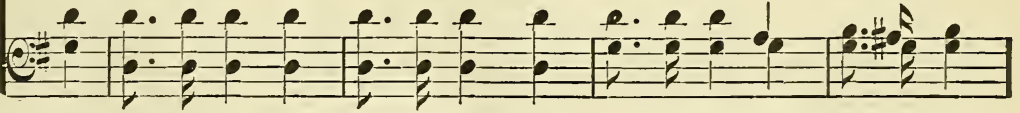

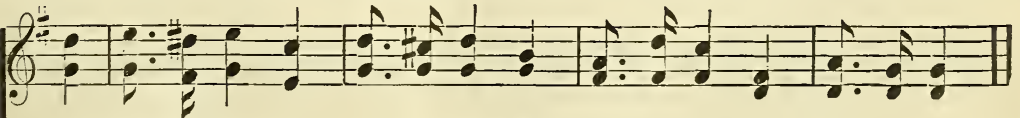

And view the shin - ing glo - ry shore, My heav'n, my home for - ev - er-more.

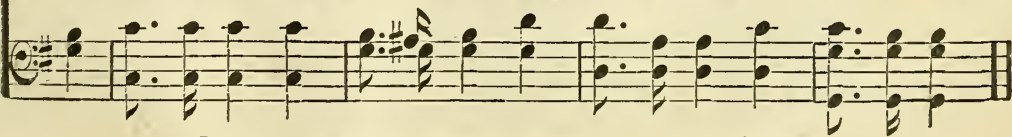

Copyright by John R. Sweney. Used by per of Mrs. Sweney. 
Johy R. Clemexts. $\quad$ Copyright, 1901, by P.P. Bilhorn. $\quad$ P. P. BilmoRN.

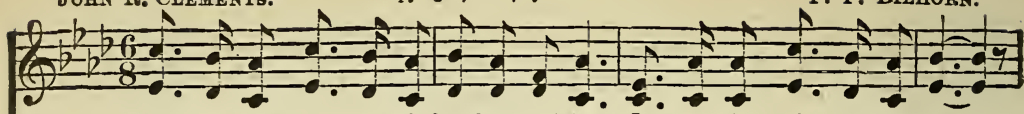

1. Sail-ing life's ocean 'mid breakers and foam, Je - sus is pi - lot-ing me;

2. Fear I notempest, tho' threat'ning and dark, Je - sus is pi - lot-ing me;

3. Pleasant the voy-age when shineth the sun, Je-sus is pi - lot-ing me;

4. Fair is the morning,and bright is the day, Je - sus is pi - lot-ing me;

5. Trust to this Pilot your frail bark,ny friend,Je - sus your pi - lot will be;
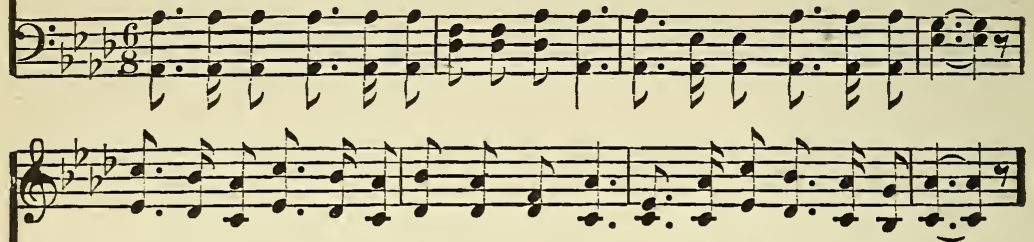

Sailing life's ocean tow'rds heaven and home,Je - sus is pi - lot-ing me.

Safe o'er the trackless deep guides $\mathrm{H}_{\theta} \mathrm{my}$ bark, Je - sus is pi - lot-ing me.

$\mathrm{Oh}$, what a meeting when sailing is done, Je-sus is pi-lot-ing me.

$\mathrm{Nev}$-er an-oth-er that knoweth the way, Je-sus is pi-lot-ing me.

Trust Him to pi - lot you safe to the end, Je - sus your pi - lot will be.

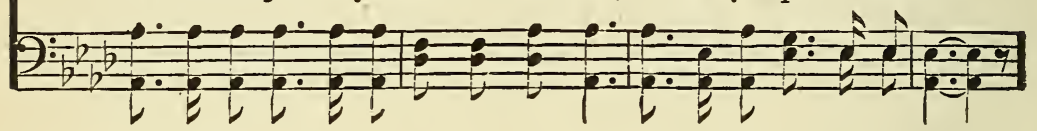

Chorus.

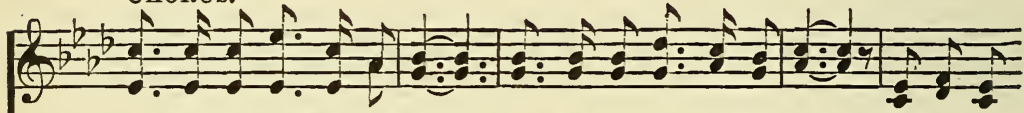
$\mathrm{Je}$ - sus is pi-lot-ing me, Je-sus is pi - lot-ing me; Safe in-to
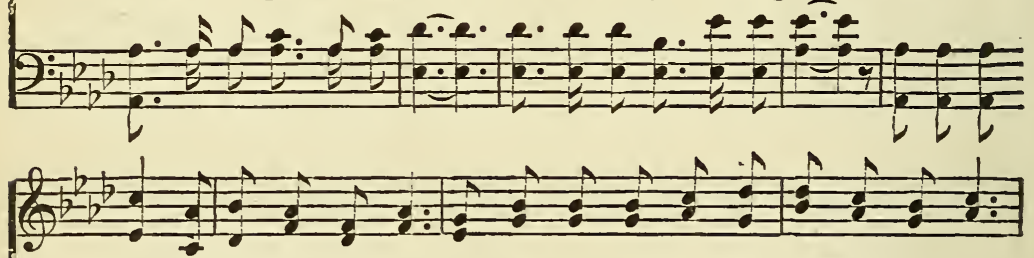

port my bark He will bring; Storm-cloads may hov-er, yet to Him I'll cling;
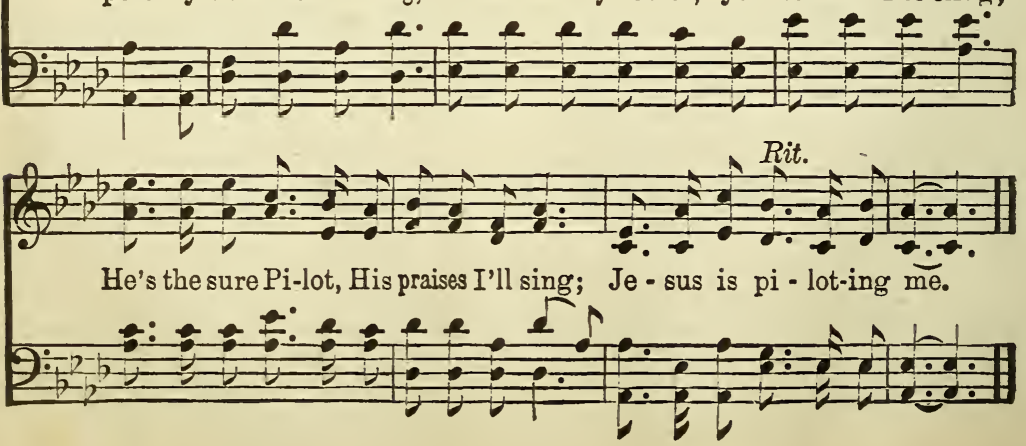
W. S. M

Duet.

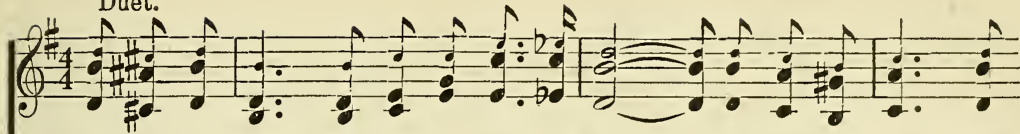

1. One step a-head is all I need to see,

One step a - head - this

2. To walk by faith, how rest-ful such a life,

How free from care, from

3. Onestep a-head, nor anxious would I be,

He goes be - fore

to

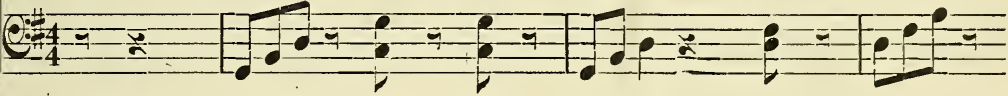

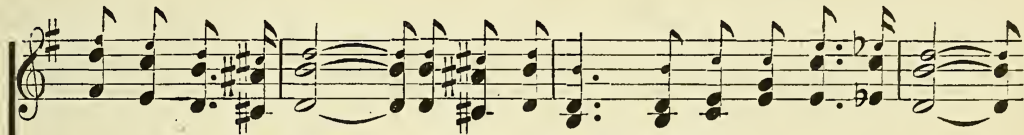

is His will for me; He leads the way, with Him I dare to go;

wor-ry and from strife; To live each day with-in His bless-ed will,

mark the path for me; Just what is best to me my Lord will give;

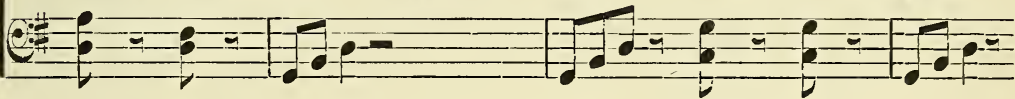

Chorus.

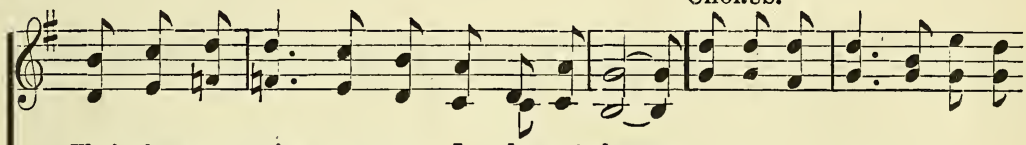

Tho' what a-waits me now I do not know.

How sweet to hear Him say-ing, "Peace, be still." One step a - head is all I

How safe my life as in this realm I live.

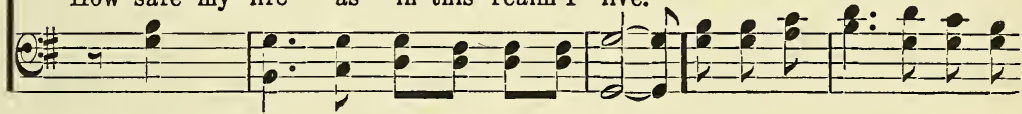

(1)

care to see, One step $\mathbf{a}$-head, this is e-nough for me; He leads the

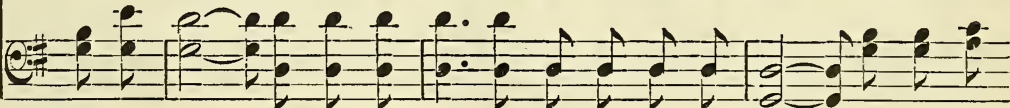

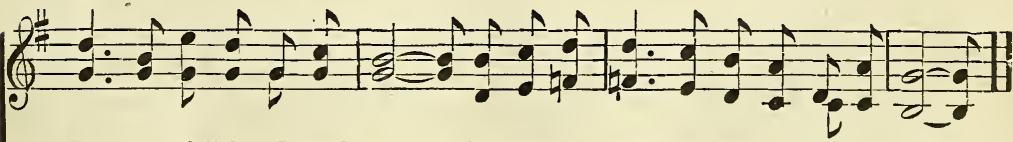

way, and glad-ly I will go, Tho'whata-waits a-head I do not know.

t: $<-\frac{0}{2}$ i 1 er

Copyright. 1905, by John A. Davis. 


\section{Will There be Anyone Waiting for Me?}

W. S. M.

W. Stillman Martin.

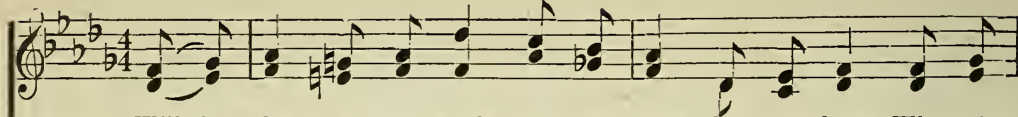

1. Will there be a - ny souls in the king-dom a-bove; Whom the

2. I am saved, praise the Lord! but my neigh-bor is lost, In the

3. "As the stars in the king - dom of God they shall shine, Who shall

4. 0 be not con-tent to reach heav - en a - lone, Make some

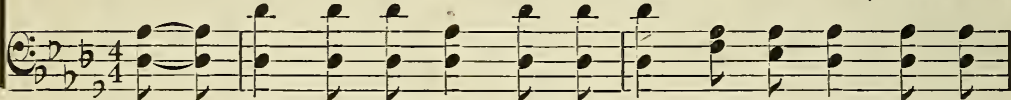

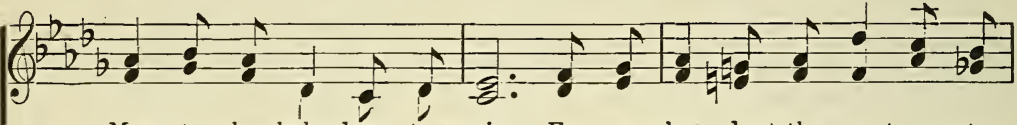

Mas - ter has helpedme to win; For a - bun-dant the en-trance to

far a - way land now is he; And if I am un-faith-ful, how

ma - ny to right-eous-ness turn;" But they suf - fer great loss,-hear the

oth - ers' sal - va - tion thy care; For each tro-phy of grace who for

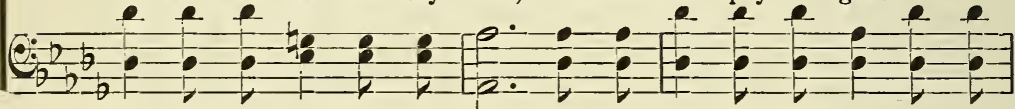

CHORus.

those who in love, Have rescued the lost from their sin.

fear - ful the cost, The blood of a soul rests on me. Will there be a - ny

warn-ing divine, Whose works at the judgment must burn.

$\mathrm{Je}_{-}$- sus is won, Will add to thy pleas-ure up there.

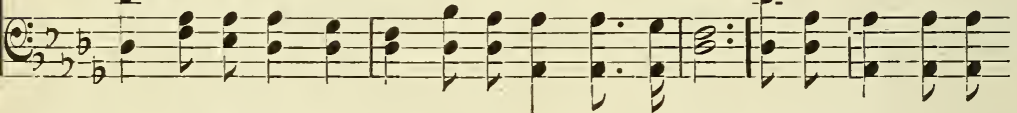

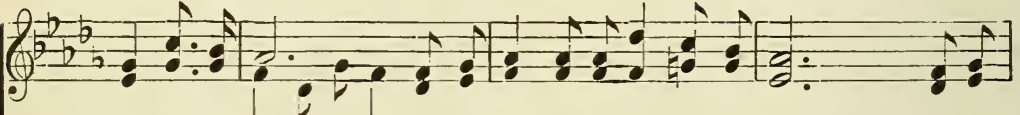

souls 0 - ver there, I have helped to the straight narrow way?

(n)

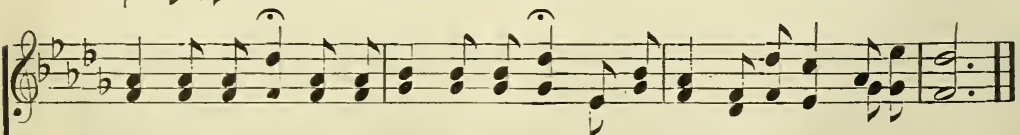

happy the tho't,that with them I shall share In the glo-ry of God's endless day.

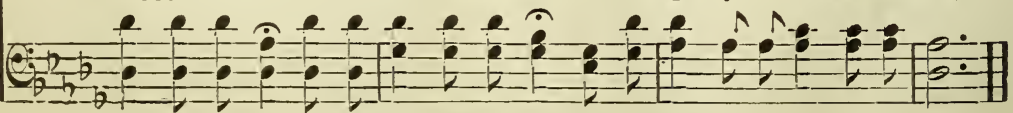

Copyright 1905 , by John A. Davie 


\section{The Man on the Other Side.}

"Into heaven itself, now to appear in the presence of God for us." Heb. 9:24. W. S. M.

W. Stillman Martin.

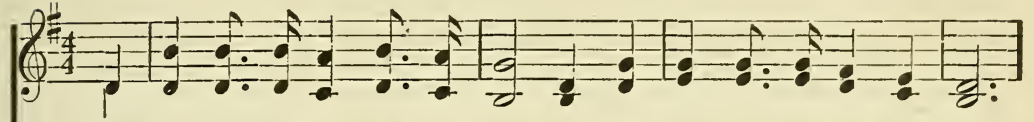

1. How oft-en the heart would he wea - ry, How oft - en your feet would slide;

2. He went to the cross to re-deem us, Be-hold now the crim-son tide,

3. Ex - alt-ed, a Prince and a Sav-ior, A ref-uge where all may hide;

4. He lives in the glo-ry of heav-en, The door $\mathrm{He}$ has o-pened wide;

5. Some day $\mathrm{He}$ will call all His true ones, With Him they shall ever a - bide;
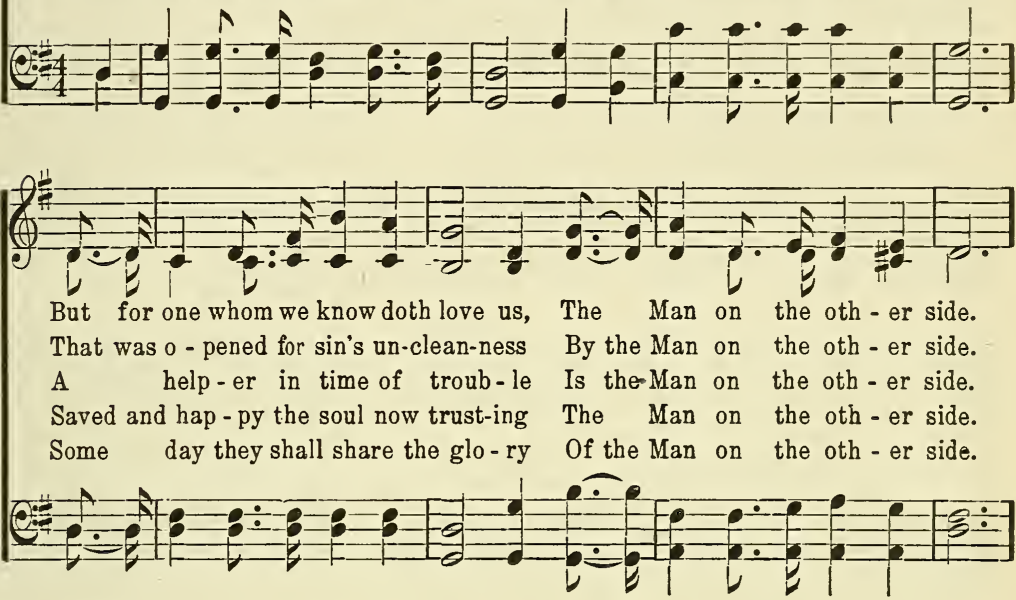

Chorus.

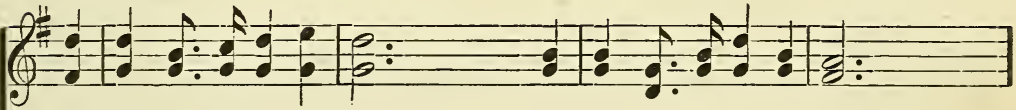

The Man on the oth-er side,

The Man on the oth-er side;

the other side,
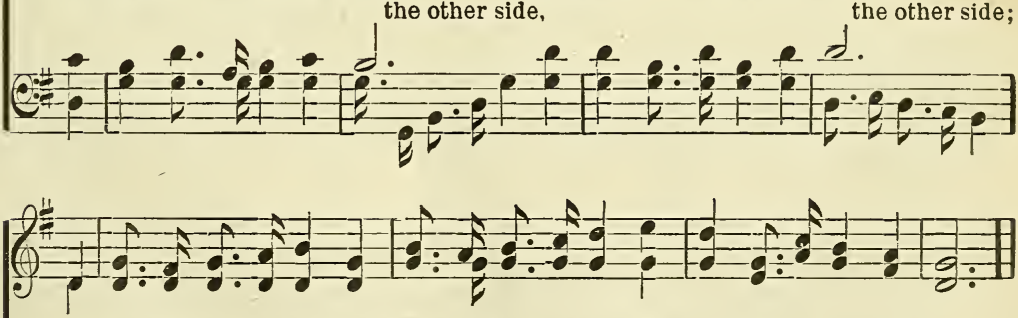

Oh,praise His ho-ly name, He's always just the same, The man on the oth-er side.

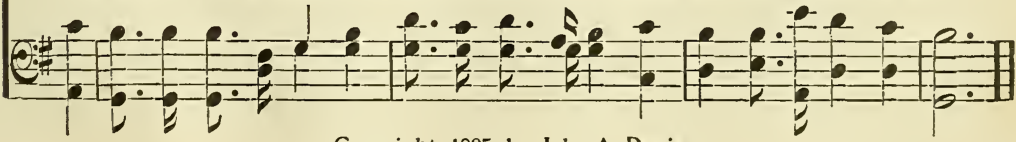

Copyright, 1905, by John A. Davis. 
C. H. G.

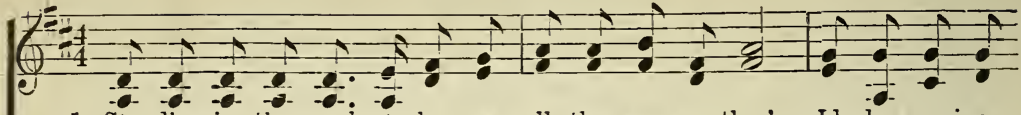

1. Standing in the mark-et plac-es all the sea-son thro', Id - ly say-ing

2. Ev-'ry sheaf you gath-er will be-come a jew - el bright In the crown you

3. Morning hours are passing, and the evening fol-lows fast; Soon the time of

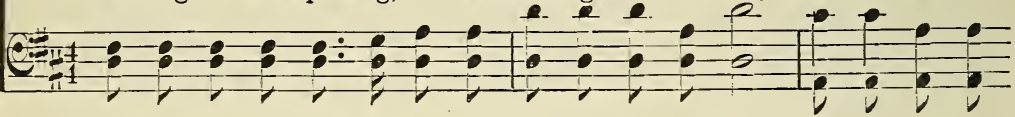

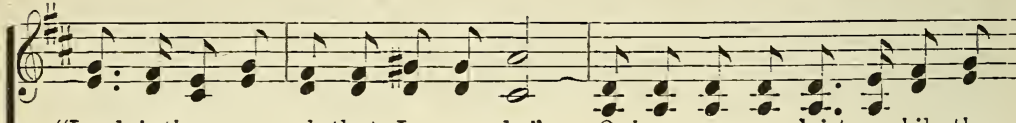

"Lord, is there no work that I can do," 0 how ma-ny loi-ter, while the

hope to wear in yon-der world of light. Seek the gems im-mor-tal that are

reap-ing will for - ev - er -more be past. Emp-ty hand-ed to the Mas-ter

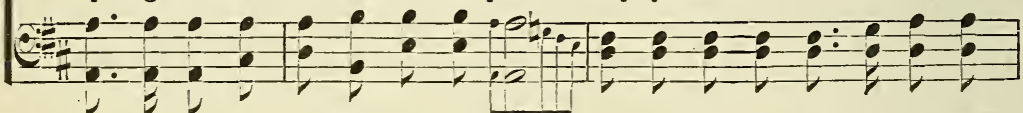

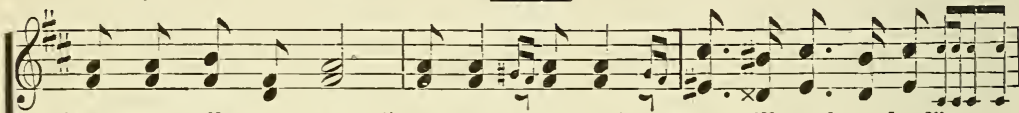

Mas - ter calls a - new-"Reapers! reap - ers! Who will work to-day?"

pre-cious in His sight! "Reapers! reap - ers! Who will work to-day?"

will you go at last? "Reapers! reap - ers! Who will work to-day?"

- 2 ?

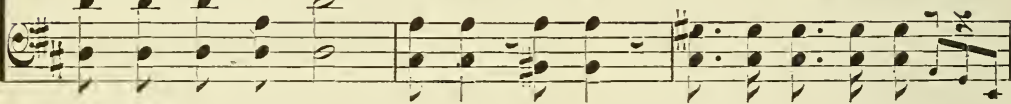

Chorus.

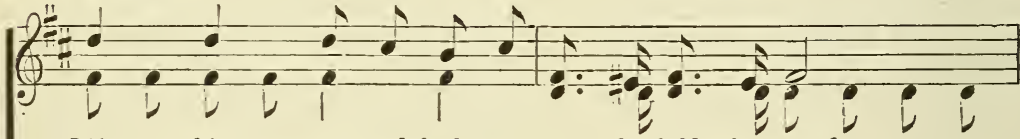

Lift thine eyes and look up - on the fields that stand

Lift thine eyes and look up - on the fields that stand all read $-y_{\text {. }}$

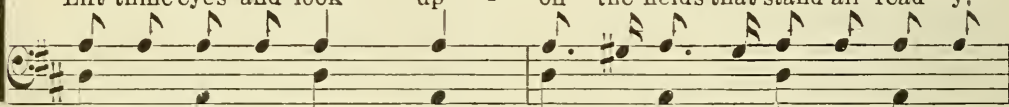

Lift thine eyes th fields that stand all

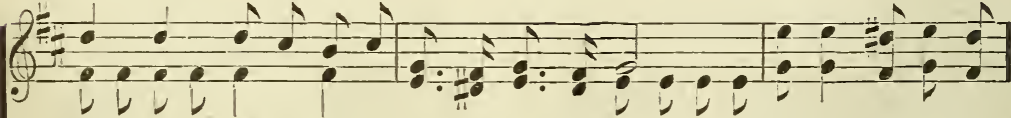

Ripe and read-y for the will-ing gleaner's hand,

Rouse ye, 0 sleepers!

Ripe and ready for the will-ing gleaner's hand, $O$ rouse ye,

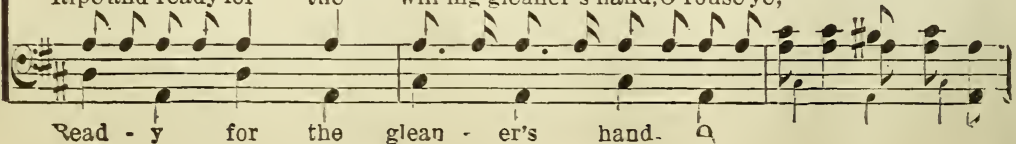




\section{Keapers are Needed.}

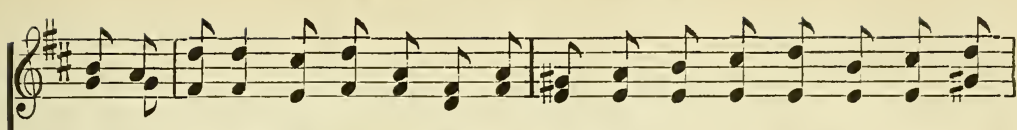

Ye are need-ed as reap-ers! Who will be the first to an-swer, "Master,

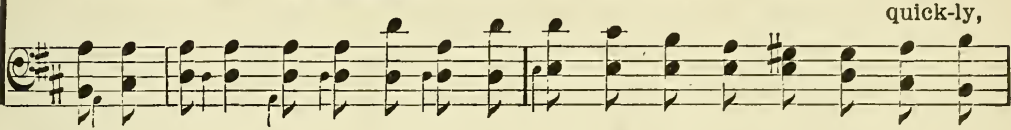
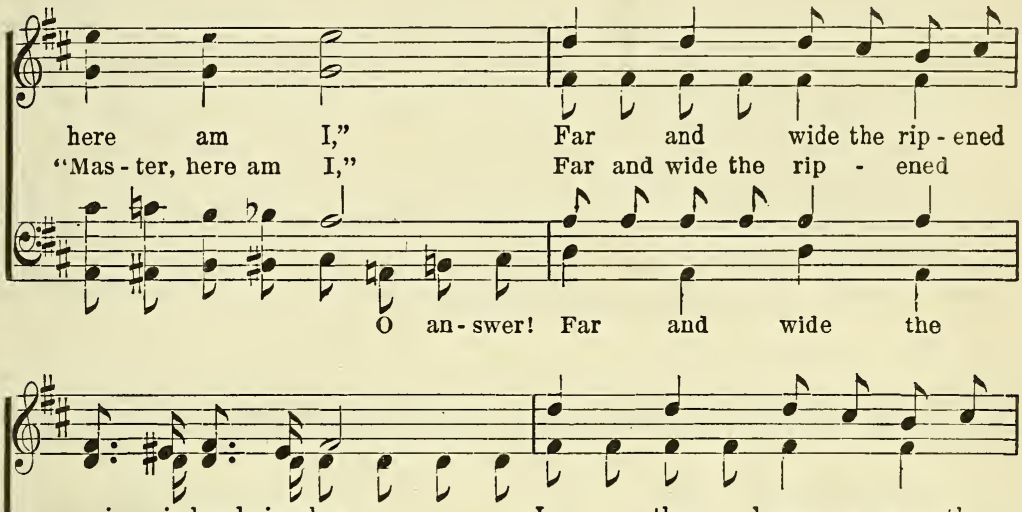

grain is bend -ing low, In the breez-es gen - tly

grain is bend-ing low, In breez-es, in the breez-es gen - tly

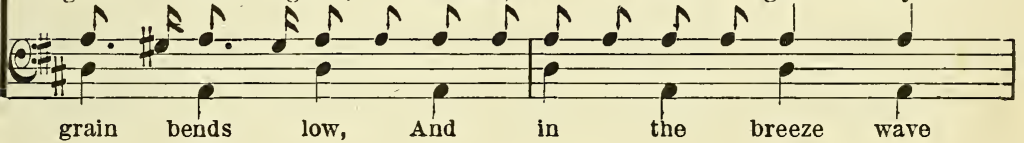

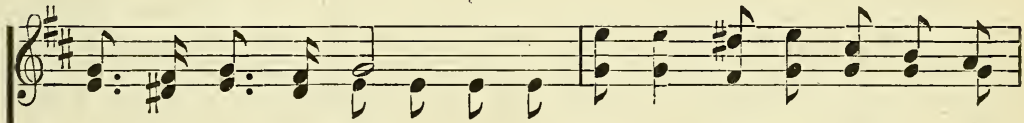

wav - ing to and fro;

wav - ing to and fro; $O$ rouse ye,

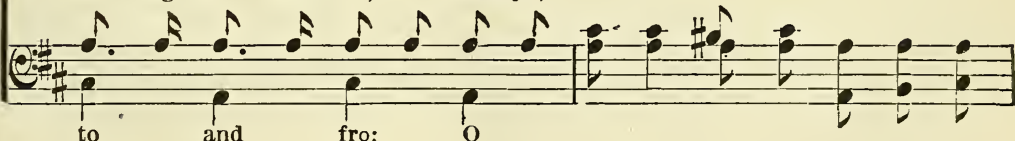

(1)

need-ed as reapers, And the gold - en harvest days are swift-ly pass-ing by.

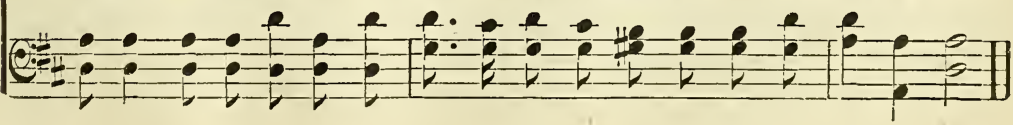


II. A. S.

May Agnew Stephens.

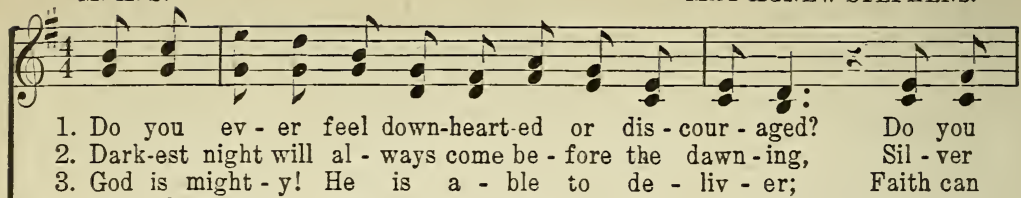

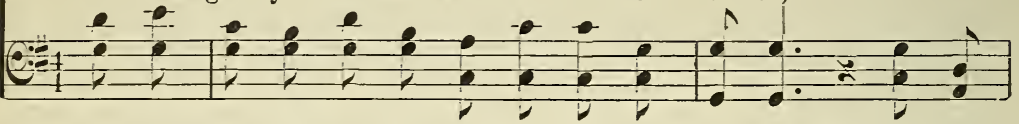

(2)-

ev - er think your work is all in vain? Do the bur-dens thrust up - on you

lin - ings shine on God's side of the cloud; All your jour-ney He has prom-ised

vic - tor be in ev - 'ry try - ing hour; Fear, and care, and sin, and sor - row

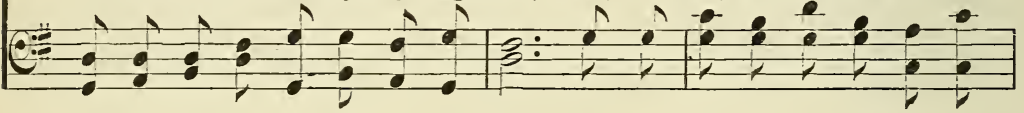

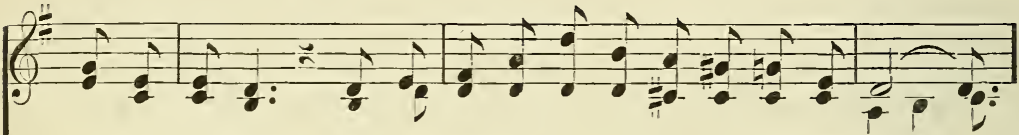

make you trem-ble, And you fear that you shall ne'er the vic - t'ry gain?

to be with you, Naught has come to you but what His love al - lowed.

His lore al-lowed,

be de-feat - ed By our faith in God's al-might-y, con-qu'ring pow'r

conqu'ring pow'r,

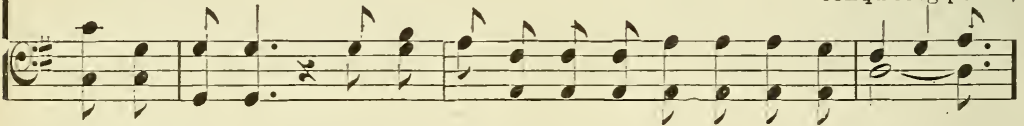

CHORUS.

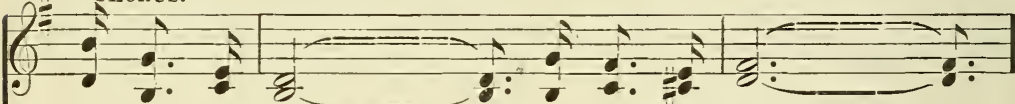

Have faith in God, Hare faith in God, the sun will shine, ${ }^{\circ}$ the sun will shine,
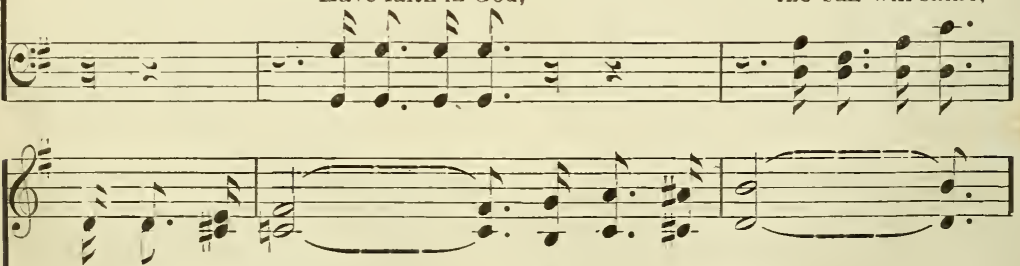

Tho' dark the cloud Tho; dark the cloud may be to - day; may be to-day;

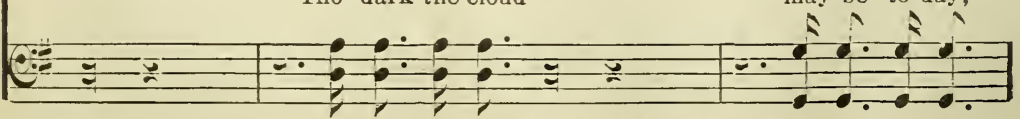

Copyright, 1897, by May Agnew Stephens. Used by per. 


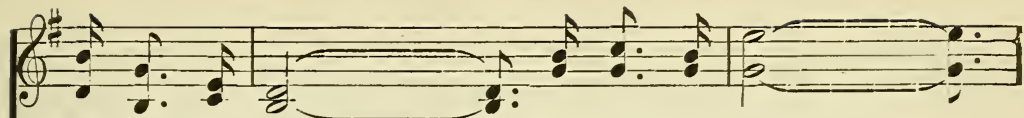

His heart hath planned
His heart hath planned path and mine; your path and mine;
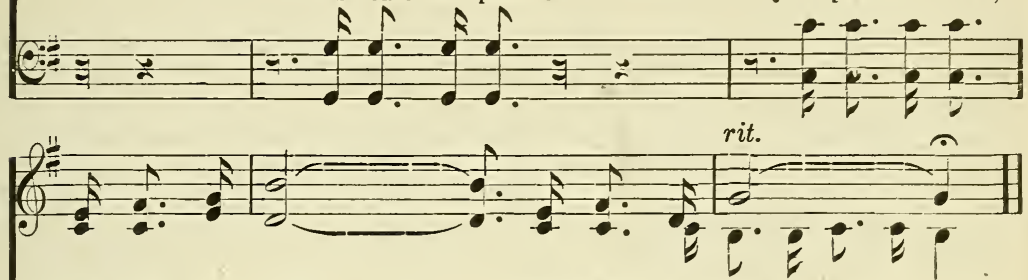

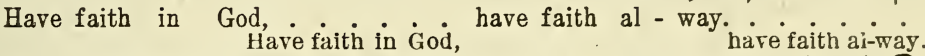

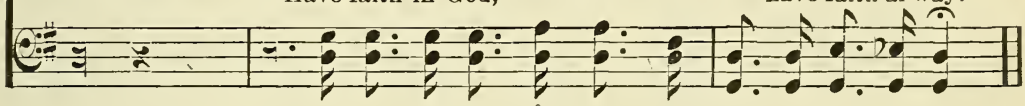

\section{Lord, at Thy Mercy Seat.}

Arr. by Theo. E. Perkixs.

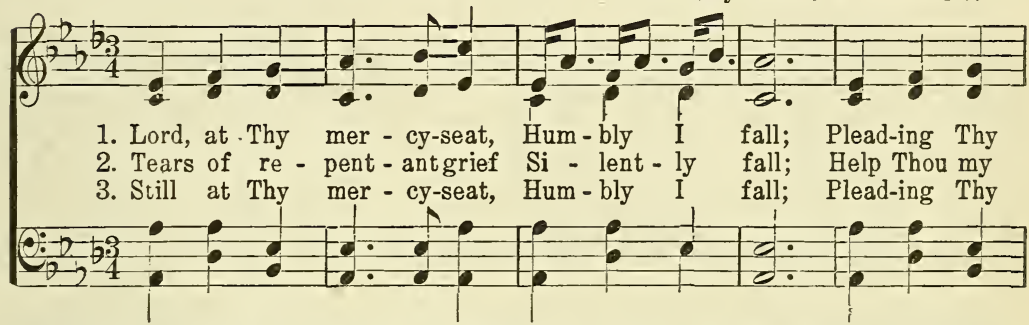

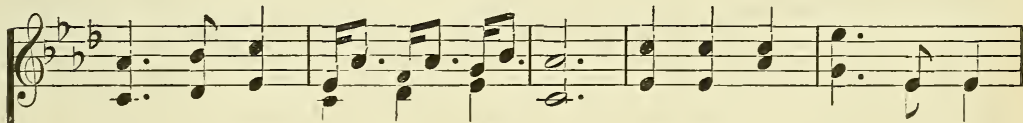

prom - ise sweet, Lord, hear my call; Now let thy work be-gin,

un - be-lief, Hear Thou my call; Oh, how I pine for Thee!

prom - ise sweet, Heard is my call; Faith wings my soul to Thee,

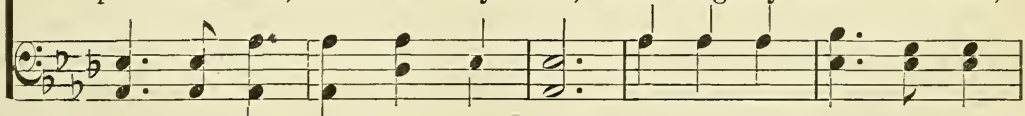

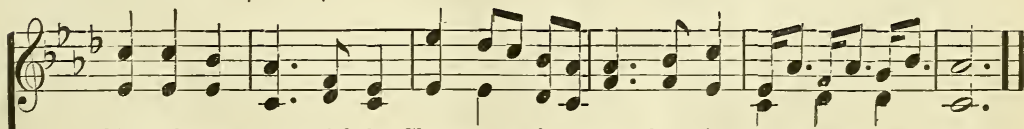

Oh, make me pure with-in, Cleanse me from ev - 'ry sin, Je - sus, my all.

'Tis all my hope. my plea; Je - sus has died for me, Je - sus, my all.

This all my hope shall be, Je - sus has died for me, Je - sus, my all.

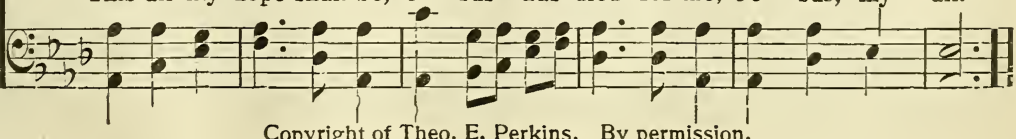

Copyright of Theo. E. Perkins. By permission. 
P. P. B.

Copyright, 1901, by P. P. Bllhorn.

P. P. BILHOR:.

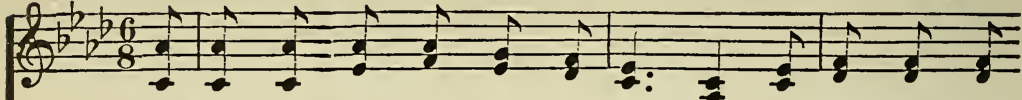

1. I stood all a - lone by the way - side, And gazed at the

2. The stars had more beau - ty and splen-dor Than earth with its

3. Some day, on the wings of the morn - ing, To yon - der bright

4. And when I shall reach that fair coun - try, Where sor-row shall

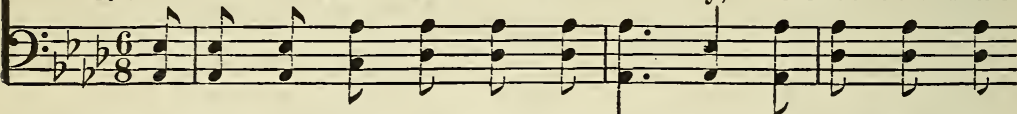

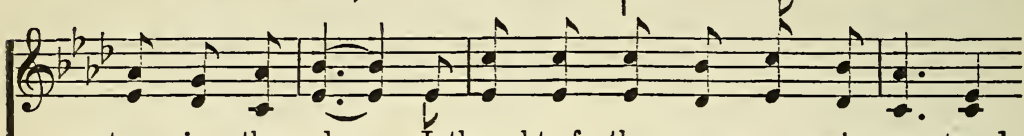

stars in the sky; I thought of the man - y who en-tered

wealth could sup-ply; I longed for a glimpse of the por - tals,

home I will fly; I'll en - ter the gates of that cit - y,

ne'er dim mine eye, I'll sing forth for $-\mathrm{ev}-\mathrm{er}$ and praise it,

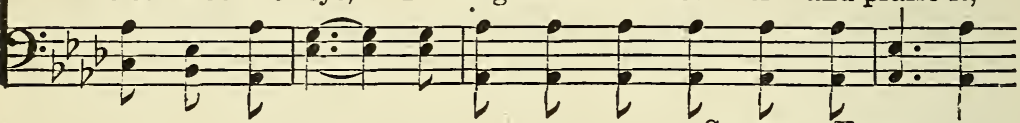

Chorus. Faster.

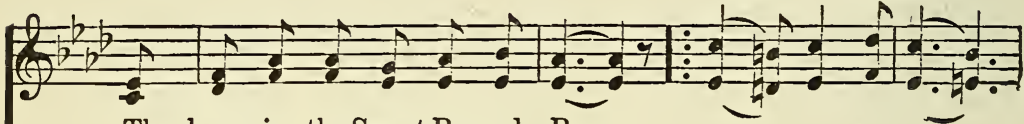

The home in the Sweet By and By.

$A$ home in the Sweet By and By.

And dwell in the Sweet By and By.

Sweet By and By:

The home in the Sweet By and By.

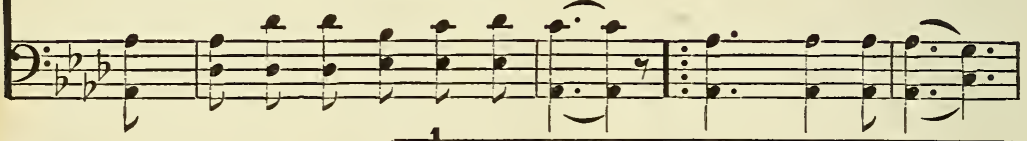

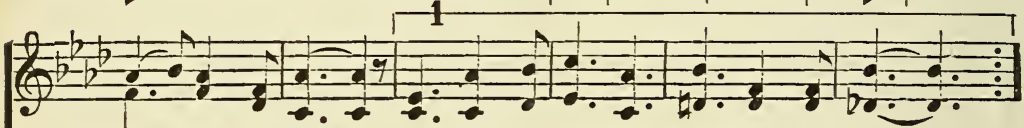

Sweet By and By, 0 land of beau-ty, home in the sky;

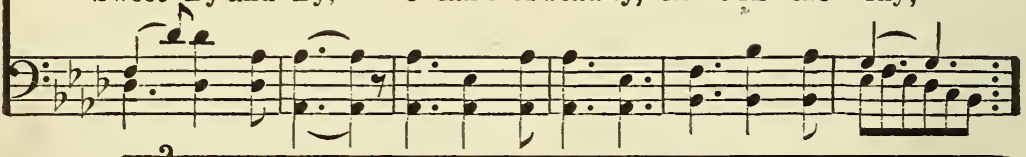

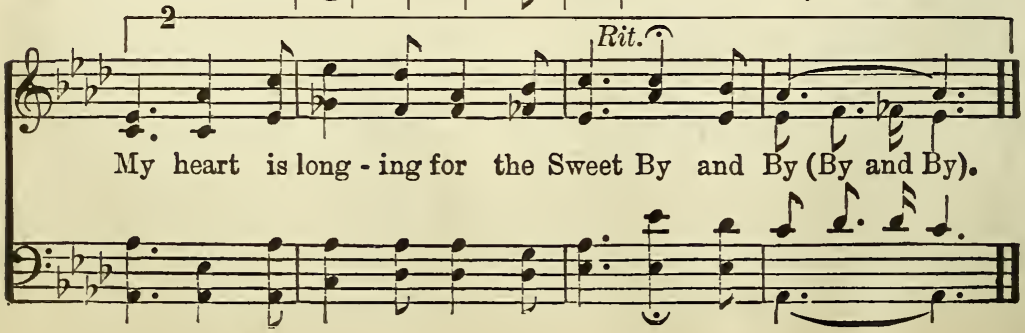




\section{O Come to the Precious Fountain.}

"The blood of Jesus Christ His Son cleanseth from all sin." I. Jno. 1: 7. C. D. M.

C. D. Maktin.

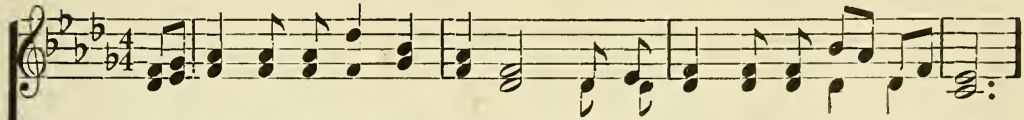

1. 0 come to the preciousfount-ain, Where Cal-va-ry's stream doth flow;

2. 0 come to the precious fount-ain, There is life in the cleansing flood;

3. 0 come to the precious fount-ain, Where the Prince of Glo - ry died;

4. 0 come to the precious fount-ain,And your bur-den will dis - ap - pear;
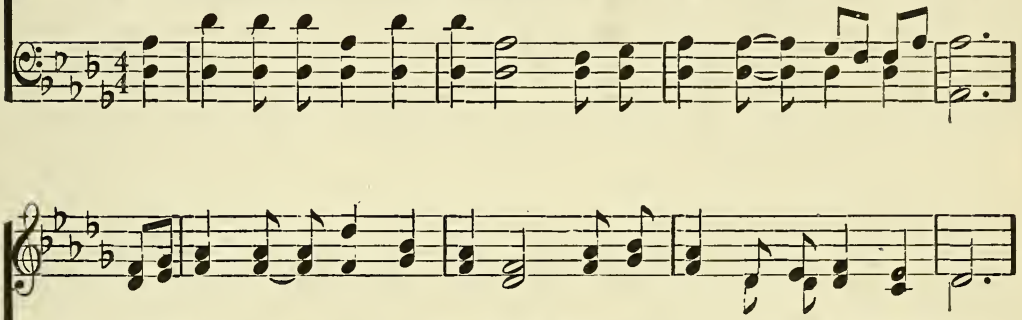

The Sav - ior is there to bless you, Make you whit-er by far than snow.

You are not too vile for Je - sus, To make clean in His pre-cious blood.

Your sin by the blood is cov-ered, 0 come now to the crim-son tide.

When the Sav-ior shall come in glo-ry, Yourglad heart will be free from fear.

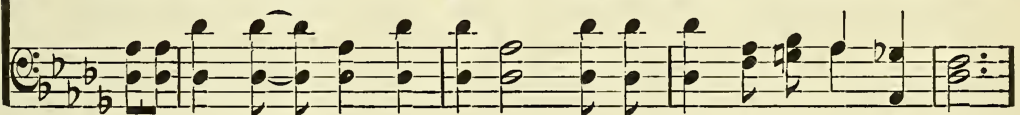

CHORUS.

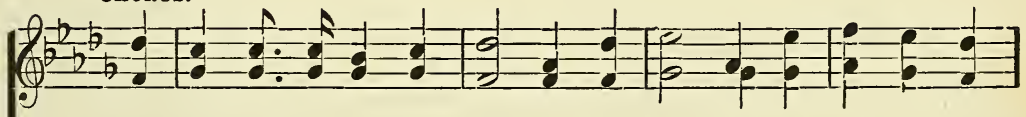

0 come to the pre - cious fount-ain, Find cleansing from ev - 'ry sin;
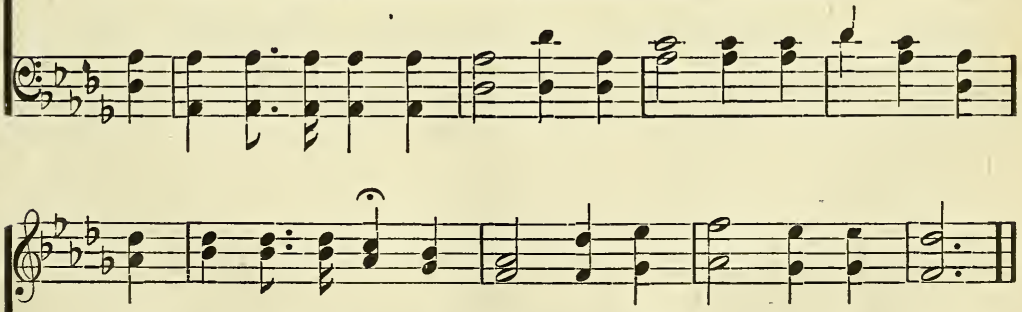

Oh, come to the pre-cious fount-ain!'Twas 0 - pened for you.

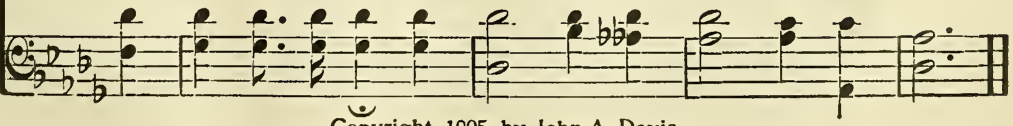

Copyright, 1905, by John A. Davis. 
O. M. RoBns:

P. P. BாRกR:
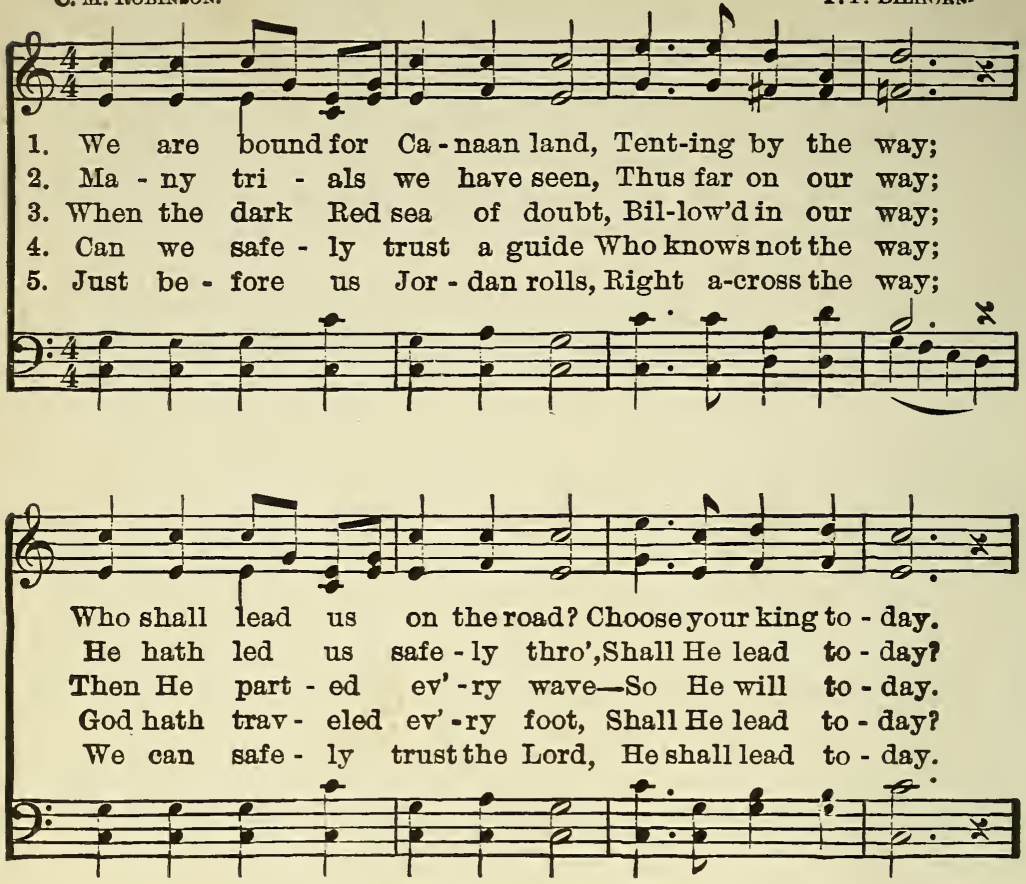

Choros.

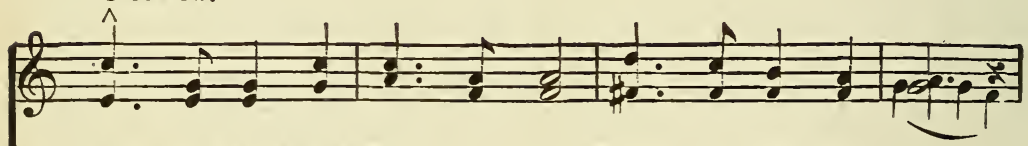

Dare to stand like Josh - u - a, Dare to say the word;
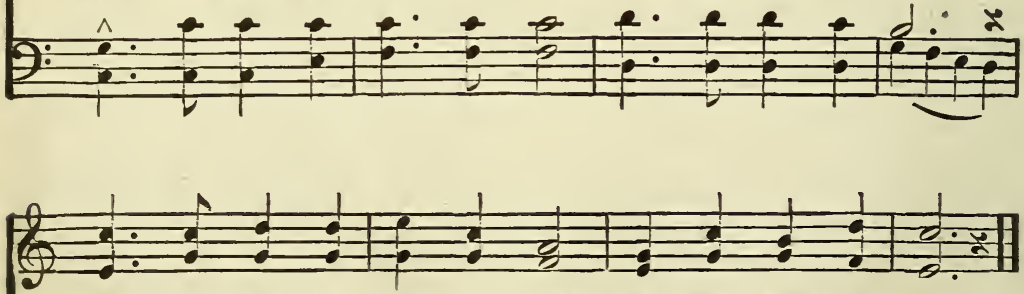

As for me and for my house, We will serve the Lord.

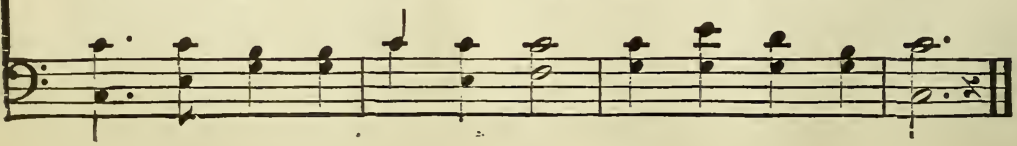


JOHN R. CLEMENTS.

H. P. DANKs.

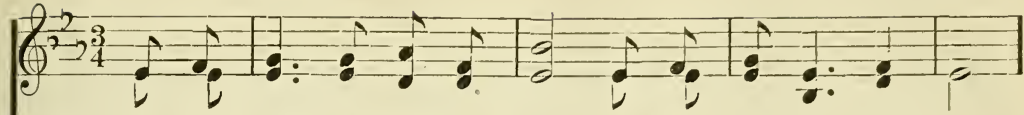

1. In the land of fade-less day Lies "the cit - y four-square,"

2. All the gates of pearl are made In "the cit - y four-square,"

3. And the gates shall nev-er close To "the cit - y four-square,"

4. There they need no sun-shine bright, In "that cit - y four-square,"

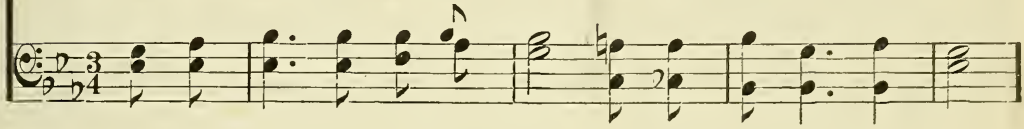

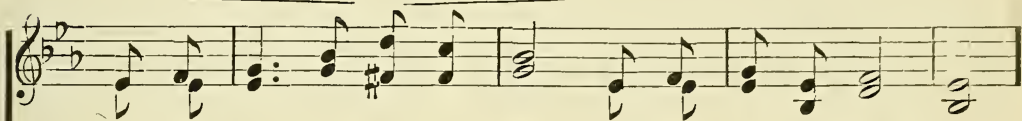

It shall nev - er pass a - way, And there is "no night there."

All the streets with gold are laid, And there is "no night there."

There life's crys - tal riv - er flows, And there is "no night there."

For the Lamb is all the light, And there is "no night there."

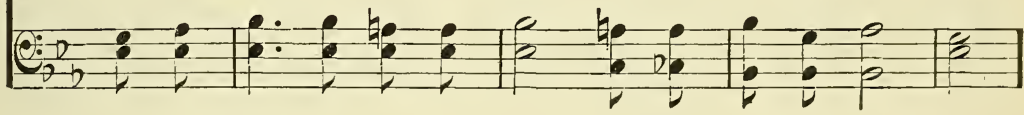

Chorus. $m f$

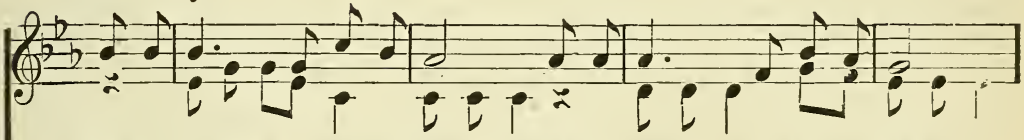

God shall "wipe a - way all tears;" There's no death, no pain, nor fears;

God shall "wipe a - way all tears;" There's no death, no pain, nor fears;
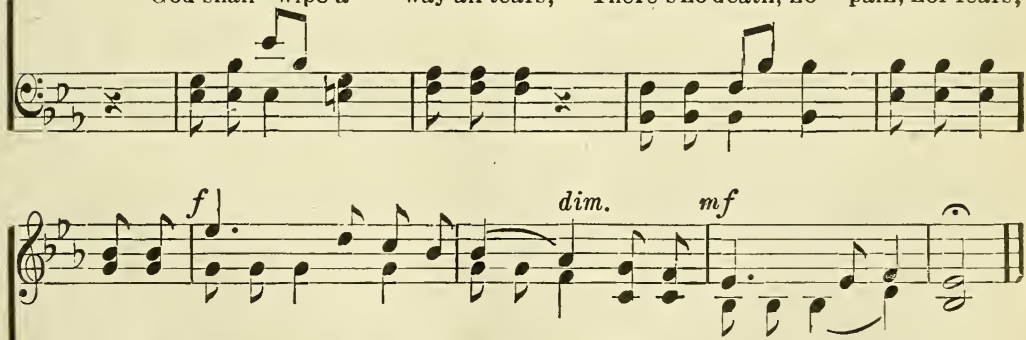

And they count not time by years, For there is no night there." And they count not time by years, by years, For there is "no night ... there."

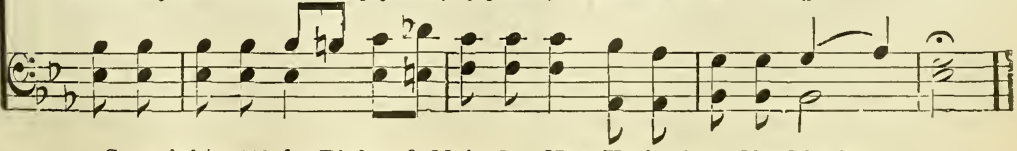

Copyright, 1899, by Biglow \& Main Co, New York City. Used by Per. 
Copjright transferred to P. P. Bilhorn, 1895.

HETEKTAR BUTTERWORTE.

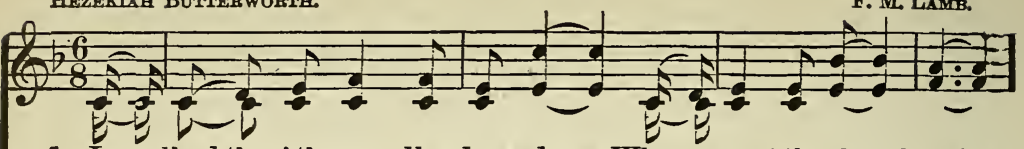

1. I walked thro' the woodland meadows, Where sweet the thrushessing;

2. I found a young life broken

3. But the bird with a bro-ken pin-ion

By sin's se-duc-tive art;

4. But the soul that comes to Je-sus

Kept an-oth-er from the snare;

Is saved from ev-'ry sin,
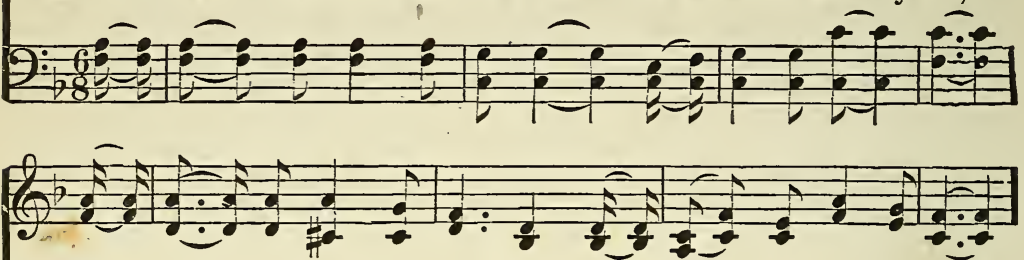

And found on a bed of moss-es, A bird with a bro-ken wing.

And touched with a Christ-like pi-ty $I$ took him to my heart.

And the life that sin hath strick-en Raised an-oth-er from de-spair.

And the heart that ful - ly trusts Him Shall a crown of glo - ry win;
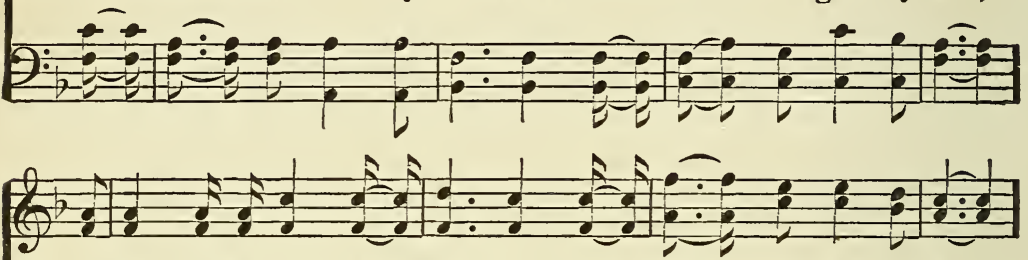

I heal-ed itswouna, and each morning It sang its old sweet strain;

He lived with a no - ble pur-pose, And strug - gled not in vain;

Each loss has its com-pen - sa - tion, There is healing for ev - 'ry pain;

Then come to the dear Re - deem - er, He'll cleanse you from ev-'ry stain.
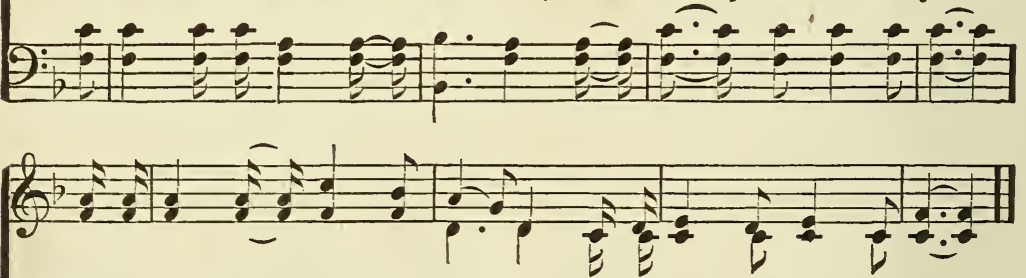

But the bird with a bro-ken pin - ion, Nev-er soared as high a-gain.

But the life that sin hath strick-en, Nev-er soared as high a-gain.

But the bird with a bro-ken pin-ion, Nev-er soars as high a-gain.

By His won-der-ful love and mer - cy. You shall sure-ly rise a - gain.

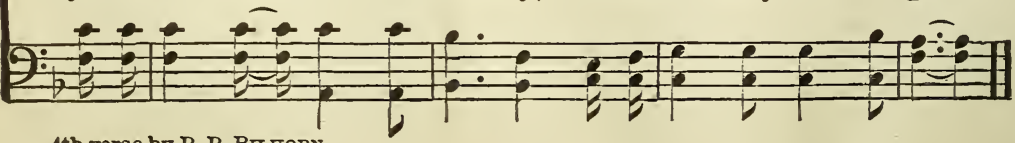

4th verse by P. P. BrHEORN. 
Some years ago, in "The Youths Companion," appeared the first three verses of this song written by Hezekiah Butterworth. They were afterwards found in the vest pocket of a man who died while in prison.

During a meeting held in one of our Western state's prisons, after the sermon, the chaplain, Rev. Gun, D. D., gave an invitation for any who so desired to speak. Several spoke. I sang the three verses this song then contained. For a moment there was death-like silence, when a man wearing prison clothes tremblingly arose, supporting himself on the bench in front of him, and with quivering voice said: "Gentlemen, according to the sentiment of that song, although I serve my time, and resolve to do better, I never can rise to the position I once occupied." He sank back, covered his face with his hands and began to sob. Many were touched by his emotion, and wept with him. I bowed my head in shame as I considered the sad truth of his statement. That night, on bended knees, I said: 'O God! I cannot sing those verses again; they do not contain the grace of Thy love and power to save and lift men up." While thus praying, the fourth verse as it now appears in the song, came to me. I could scarcely wait for the next Sunday, that I might go and sing the additional verse. The hour came, and in a few words I thanked the man who had reproved me, sat down to my little organ, and sang the song again. There seemed to be little interest during the singing of the first three verses, but there was a marked change when the new verse rang out.

The blessing of God and the Holy Ghost fell upon the meeting. The man who uttered the reproof the previous Sunday was the first to bow his head and weep. Many others followed. The chaplain asked those who would accept the mercy and love of God offered in the fourth verse, to lift their right hand. 'Many responded, and, thank God! the hand of my reprover was among them.

A few years after, at the close of a meeting held in the Y. M. C. A. Auditorium, of Chicago, I was about to leave, when a well dressed gentleman stopped me, took hold of my hand and said: "God bless you, Brother Bilhorn. I'd rather see you than the President of the United States." I said, "You have the better of me. Who are you, please?" He seemed greatly surprised that I did not recognize him. He then said, "Don't you remember the fourth verse of "The Bird With a Broken Wing?" Grasping his hand again, I said, "How goes it with you?" "Goes it? Why! hav'nt you heard? I was pardoned a year after you were there. Instead of serving the sentence of eight years, I served a little more than three. I found good employment at once and have since paid my indebtedness with interest and compound interest, niy family are with me again. I am a trustee and deacon in a church and I am as happy as it is possible for me to be."

I could not refrain from shouting "Glory to God!"

In the winter of 1902 , in a western city, at the close of the Sunday eve. ning service where I had related this incident and sung the song, as the people were leaving the church, a fine appearing gentleman approached me, handed me his business card and requested me to call upon him the next day. I complied with his request and found him in one of the finest business places in the city in which he had become a partner.

He told me how in that Sunday prison meeting he had sat beside the man who had reproved me, and on the following Sunday had listened to the fourth verse of the song, been blessed by it and resolved to live a Christian life. By the grace of God he is to-day a respected citizen, prominent in the social and church life of his city and helpful to those about him. 
C. A. M.

C. Austin Miles.

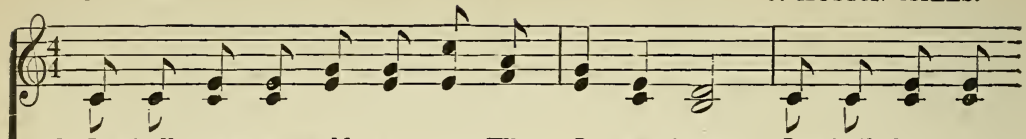

1. I shall wear a gold - en crown, When I get home; I shall lay my

2. All the dark-ness will be past, When I get home; I shall see the

3. I shall see my Saviour's face, When I get home; Sing a-gain of

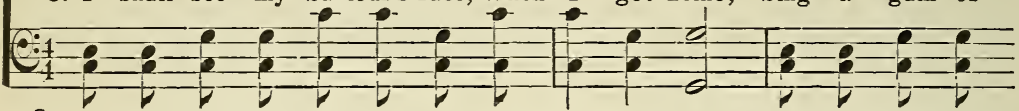

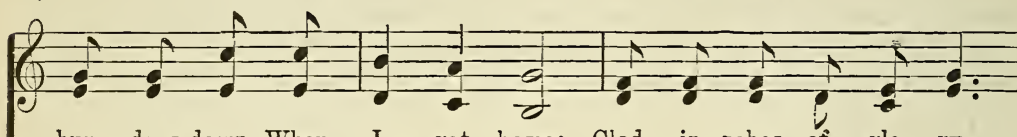

bur - dens down, When I get home; Clad in robes of glo - ry,

light at last, When I get home; Light from heav - en stream-ing,

sar - ing grace, When I get home; I shall stand be - fore Him;

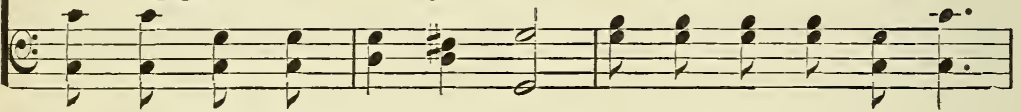

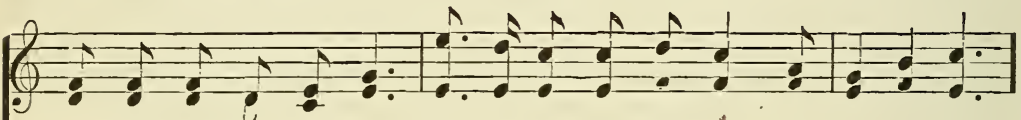

I shall sing the sto - ry of the Lordwhoboughtme, When I get home.

O'er my path-way beam-ing, Ey-erguidesme on-ward Till I get home.

Glad-ly I'll a-dore Him; Ev-er to be with Him, When I get home.
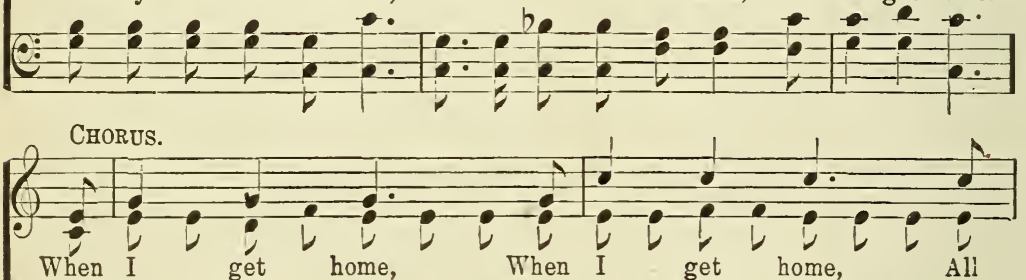

When I get home, when I get home, When I get home, when I get home,
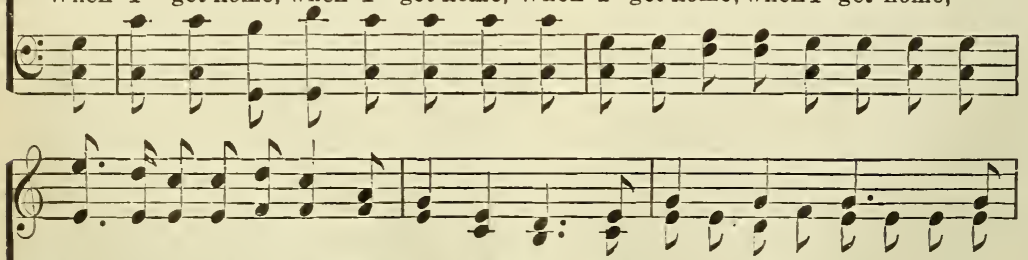

sor-row will be 0 -ver, When I get home; When I get home, When

When I get bome, when I get home, When

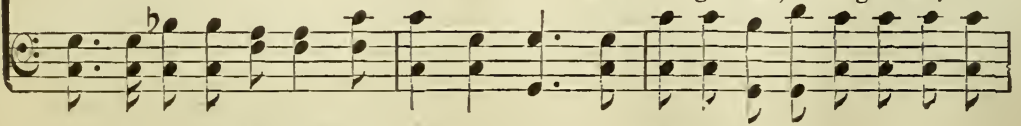

Conyright, 1900 , by Hall-Mack Co. Used by per. 


\section{When I Get Home.}

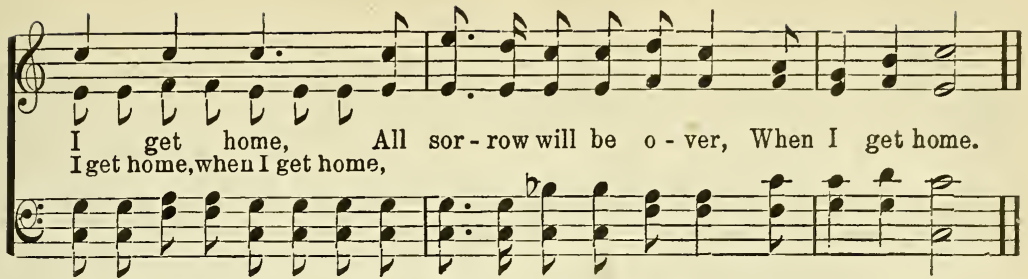

\section{Where Do You Stand Tonight?}

JNo. R. Clements.

Geo. C. Stebbins.

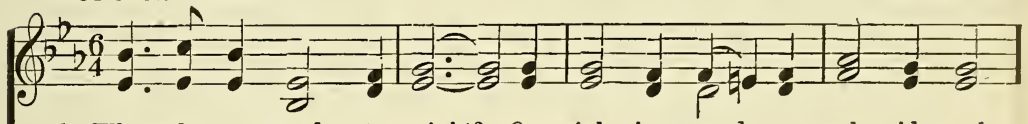

1. Where do you stand to - night? On sink - ing sand, or sol - id rock

2. Have you a hope to - night? Stead-fast and sure with - in the veil,

3. Who is your guide to - night? Christ is the Way, thro' Him a-lone

4. If He should come to - night, Would pearl-y gate, by streets of gold

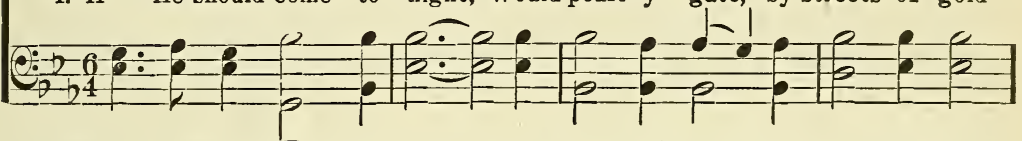

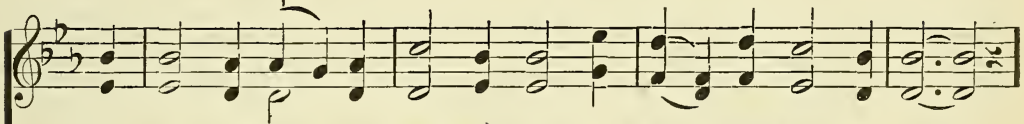

That can with-stand the tem-pest shock? 0 , where do you stand to - night?

To firm en - dure what-e er as - sail? 0 , have you a hope to - night?

Can end - less day and joy beknown, 0 , who is your guide to - night?

Where an - gels wait, for you un - fold? If He should come to - night?

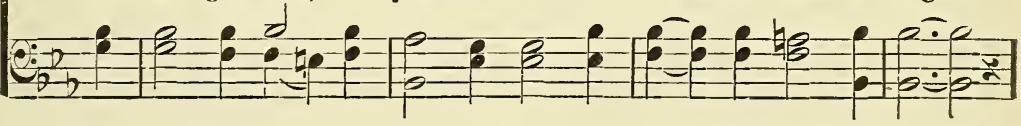

CHORTSS.

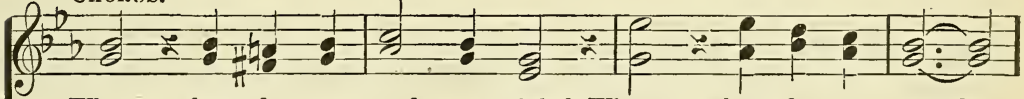

Where, where do you stand to - night? Where, where do you stand?

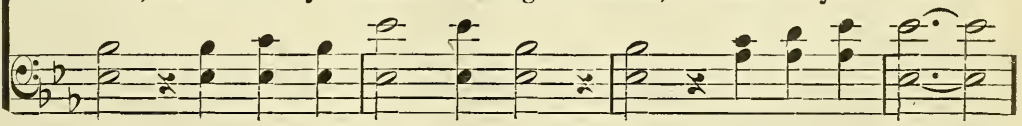

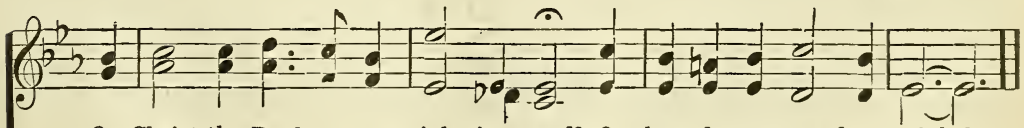

On Christ,the Rock,or on sink - ing sand? 0, where do you stand to - night?

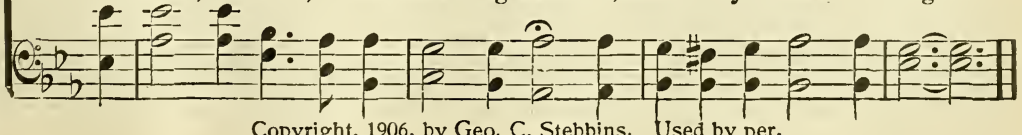

Copyright, 1906, by Geo. C. Stebbins. Used by per. 
Solo or Chorus.

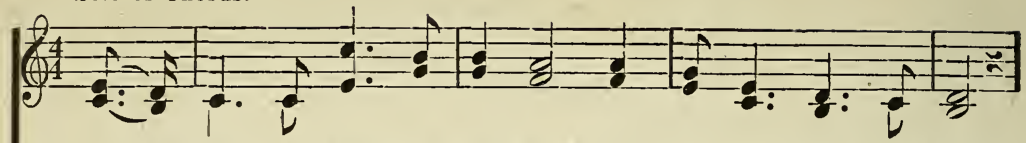

1. I am on a shin - ing path-way, A - down life's short-'ning years,

2. My soul hath had its con-flicts With might-y hosts of sin;

3. I am com - ing near the cit - y My Sav-ior's hands have piled,
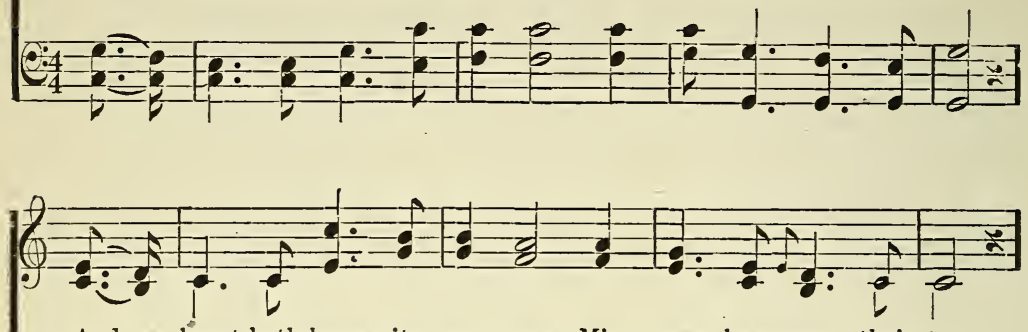

And my heart hath known its sor-rows, Mine eyes have seen their tears;

With dead - ly foes with-out me; And dead - lier foes with-in;

And I know my Fa-ther's wait-ing To wel-come home his child;
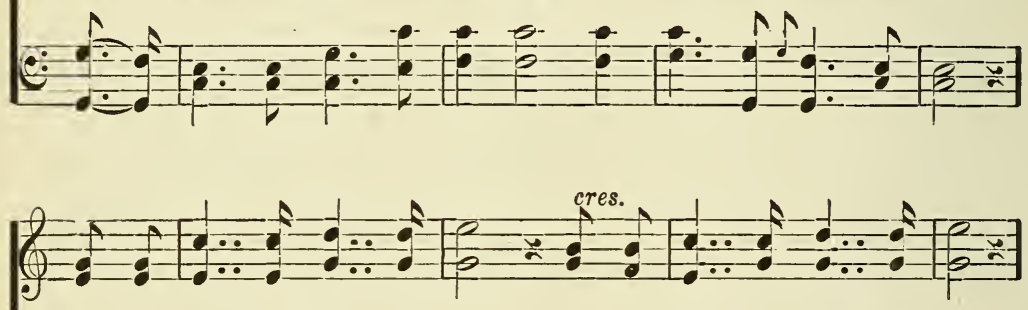

But I saw those shad-ows flee, And the shin - ing light I see, But I saw those le-gions flee, And my soul found vic - to - ry, For un-wor-thy tho' I be, $\mathrm{He}$ will find a place for me,
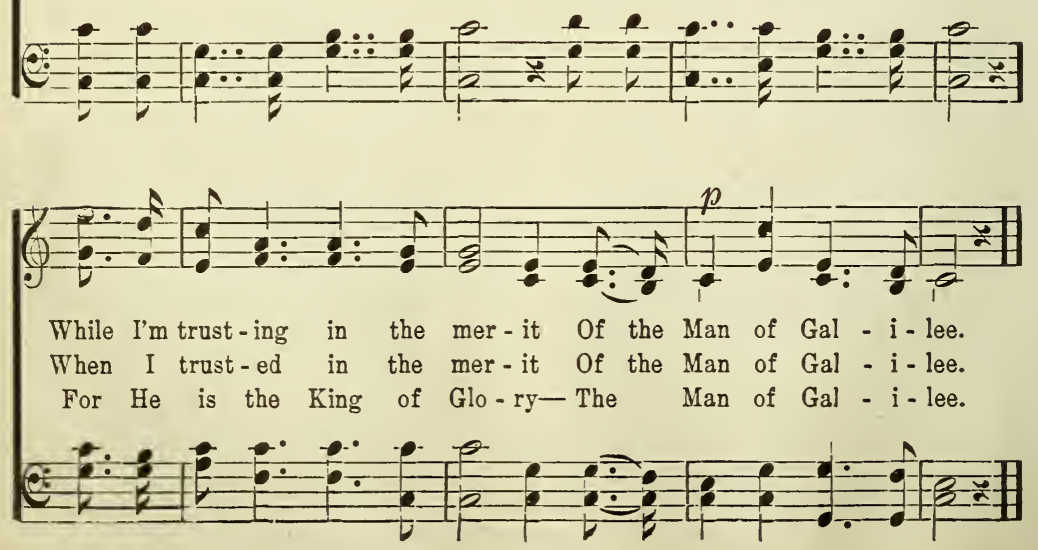


\section{Am On the Right Side.}

INA DULEY Ogdon.

Words and Music

IN

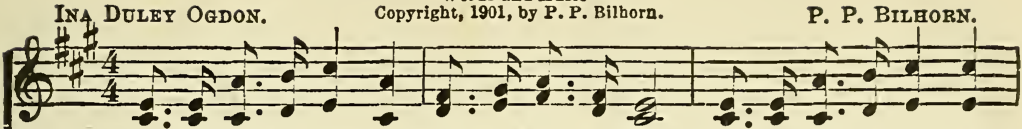

1. In the roy-al ar-my, fighting for the right, Serving for Je-ho-vah,

2. Many foes to conquer, ere the day be done, Ere the cry of tri-umph

3. See the ranks of darkness, backward as they fall,Never more to ral-ly,

4. Hasten onward, brother, triumph o-ver sin, Ev-'ry e-vil van-quish,

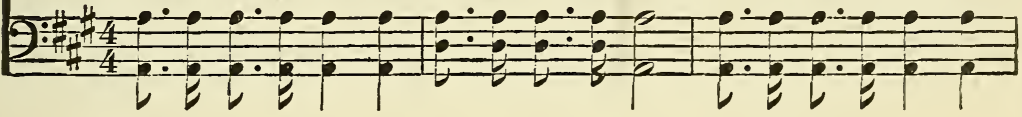

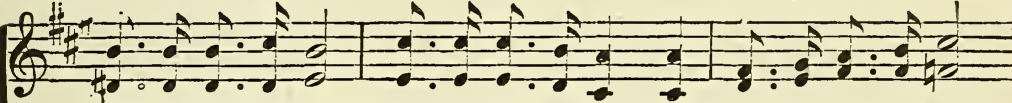
trust-ing in His might,Standing by my Cap-tain, vic - to - ry in view, tells of vic-t'ry won; Clad in gos-pel ar - mor, Satan's hosts pursue; ru - in o-ver all; See Je-ho-vah's ar - my, re-in-forced a-new; ev - 'ry con-flict win; Has - ten on to $\mathrm{Zi}$ - on, for the grand review;
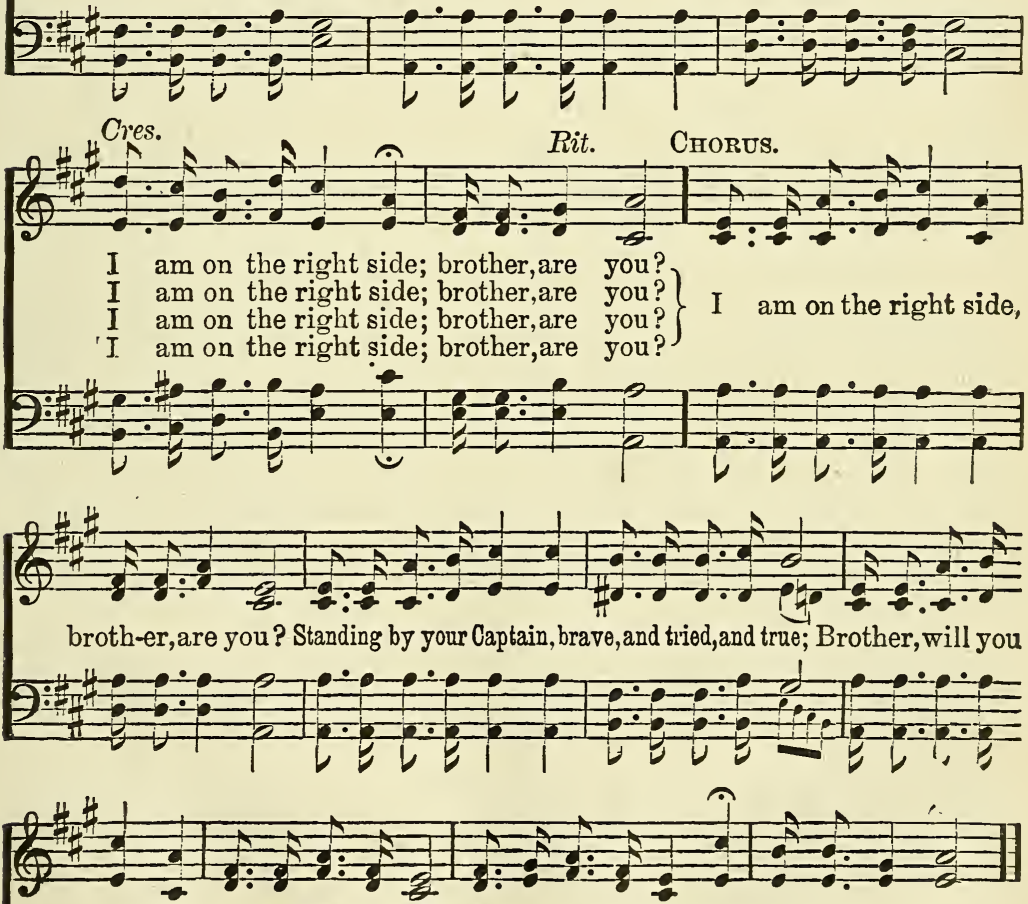

meet me in the grand review, I am on the right side; brother,are you?

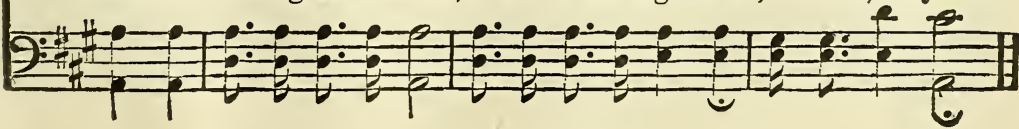


"A man that hath friends must show himself friendly."-Prov. 18:24.

SAM WALTER Foss. Last verse and chorus by $M$.

W. S. Martin.
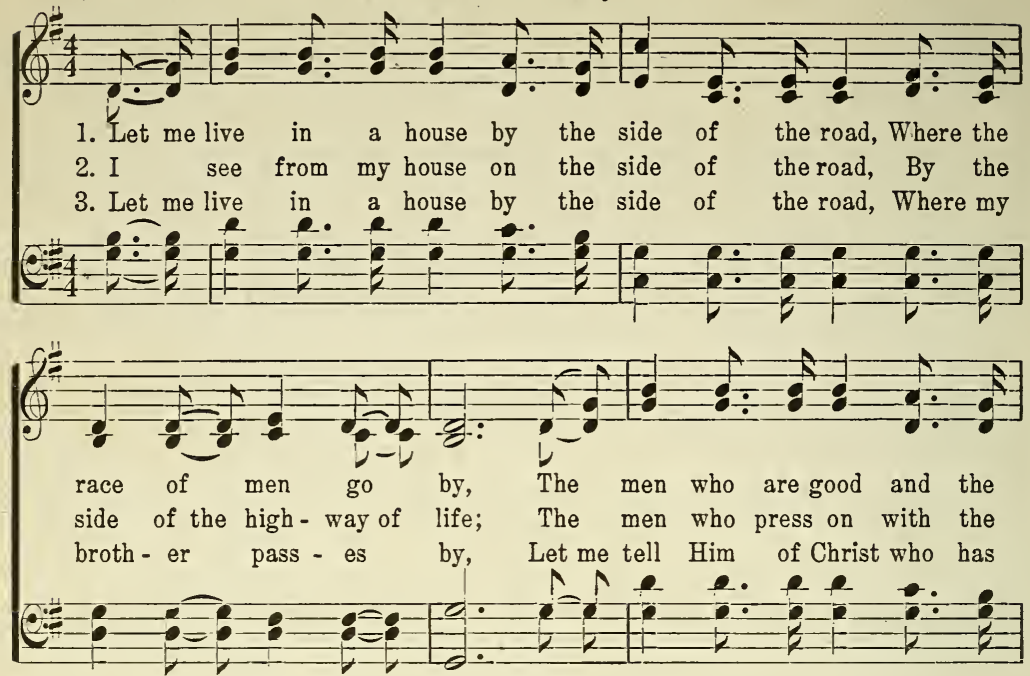

men who are bad, Just as good and as bad as ar - dor of hope, The men who are faint with strife; But I turn not a-

luve of His life, Left His throne on the cross to die; If he feels in his
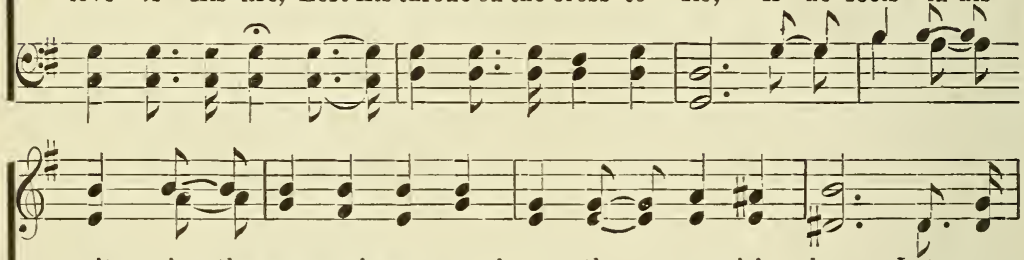

sit in the scorn-er's seat or hurt the cyn-ic's ban; Let me way from theirsmiles nor tears, both parts of an infinite plan; Let me heart he would like to be good, I'll show him how he can; Let me (1):

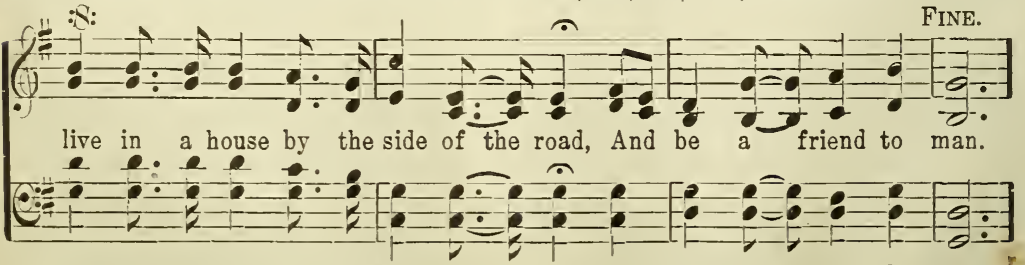
D.s.-great tender heart, and His might-y arm Were read-y to bless the throng. Copyright, 1905, by John A. Davis. 
CHORUS.

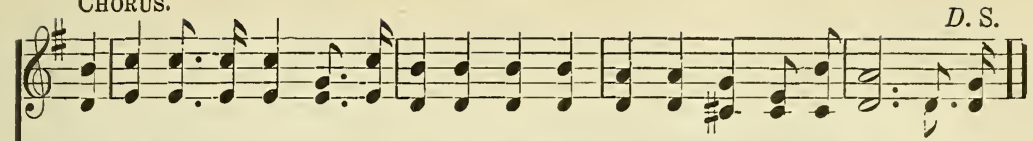

For Je-sus Him-self lived up-on the road Where men were passing a-long; And His

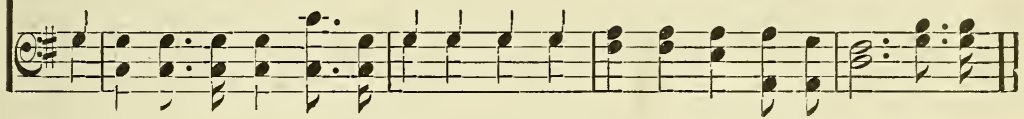

\section{Give Me Jesus.}

"A part from me ye can do nothing."-John 15: 5.

Arr. by M.

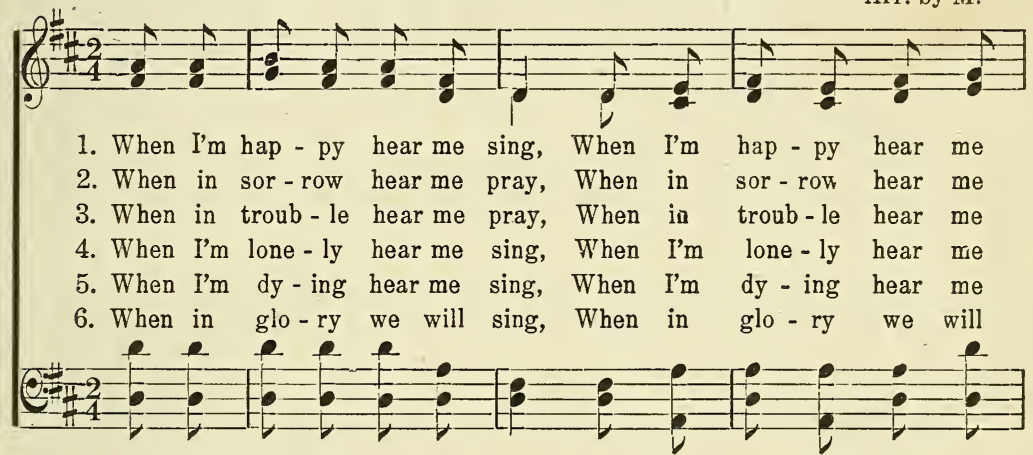

Chorus.

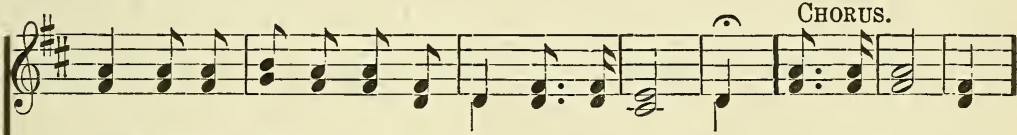

sing, When I'm hap-py hear me sing, Give me Je - sus. Give me Je - sus, pray, When in sor-row hear me pray, Give me Je - sus. Give me Je - sus, pray, When in troub-le hear me pray, Give me Je - sus. Give me Je - sus, sing, When I'm lone-ly hear me sing, Give me Je - sus. Give me Je - sus, sing, When I'm dy - ing hear me sing. Give me Je - sus. Give me Je - sus, sing, When in glo - ry we will sing, Give me Je - sus. Give me Je - sus,

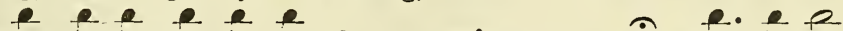

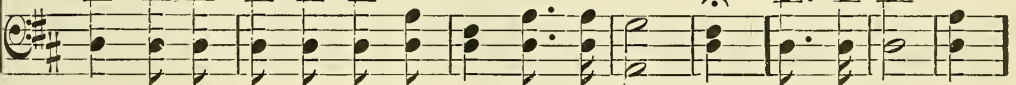

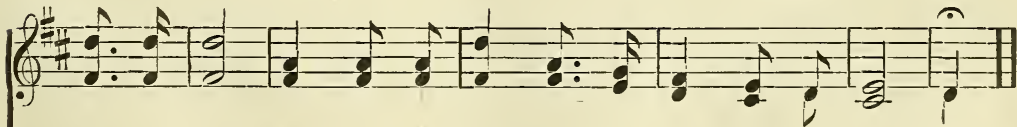

Give me Je - sus, You may have all the world, Give me Je - sus.

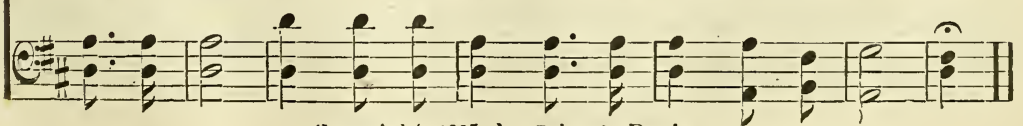

Copyright, 1905, by John A. Davis. 
W. S. M.

W. StillmaN MartiN.

(9)

1. I am walk-ing with my Sav-ior, And His pres-ence is so dear, How His

2. I am walk-ing with my Sav-ior, And our fel-low-ship is sweet, For this

3. I am walk-ing with my Sav-ior, I can nev-er lose my way; $\mathrm{He}$ is

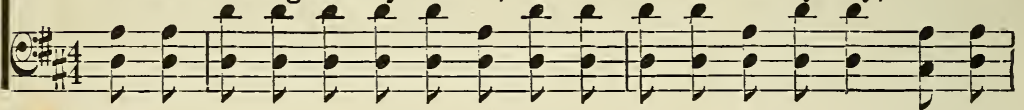

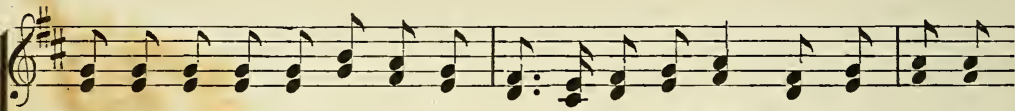

ten-der word doth bless me, scatt'ring ev-'ry doubt and fear; Tho' the path be

bless-ed ho-ly un-ion by His blood I am made meet; Ev - 'ry day the

near me ev-'ry mo-ment thro' the night and thro' the day; Tho' I meet with

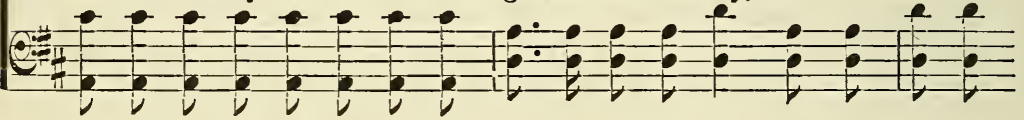

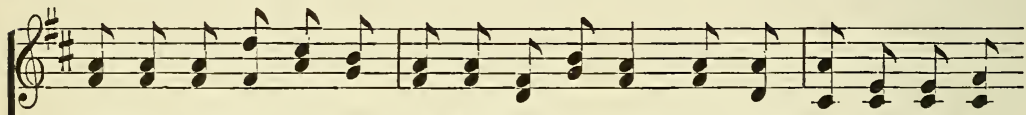

rough and thorny, Tho' the way seem ver-y long, Still my heart is filled with

way grows brighter, As I tri-umph o-ver wrong, And my heart is filled with

fierce tempta-tions, As I min-gle with the throng, Still my heart is filled with

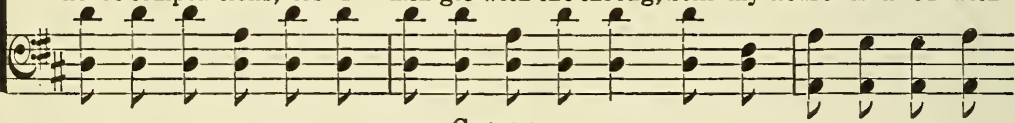

ChORUS.

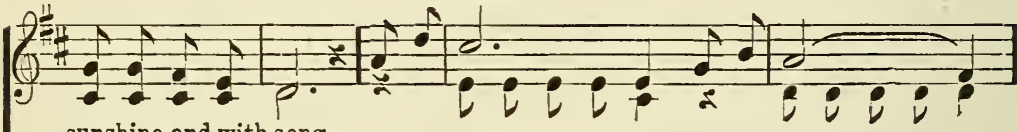

sunshine and with song.

sunshine and with song. I am walk - ing with my Lord, .

sunshine and with song.

Walking with my Lord,

walking with my Lord,
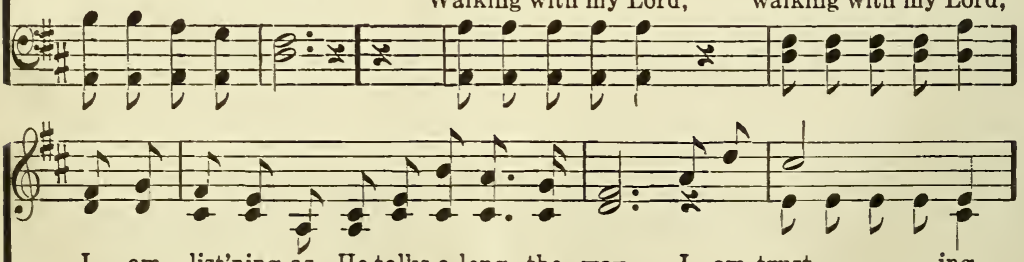

I am list'ning as Hetalks a-long the way, I am trust - ing

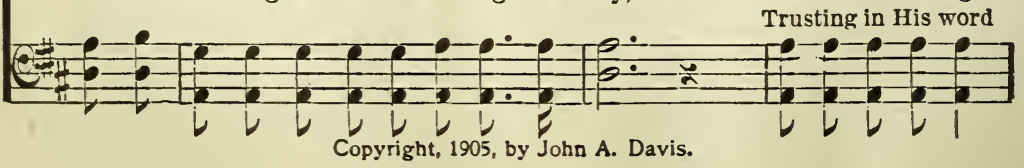




\section{Filled With Sunshine and Song.}

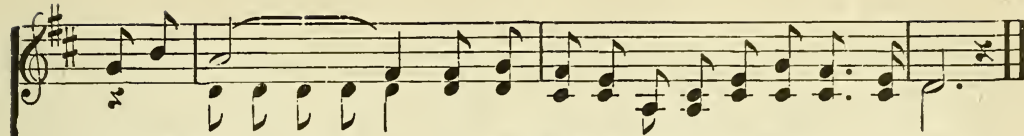

in His word, $I$ am ask-ing Him for power to 0 -bey.

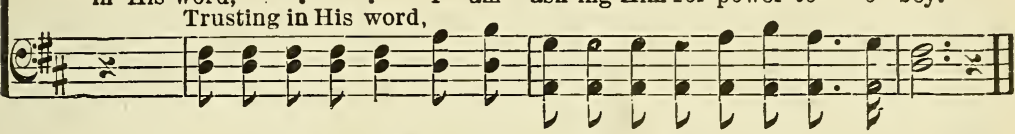

The Promised Land.

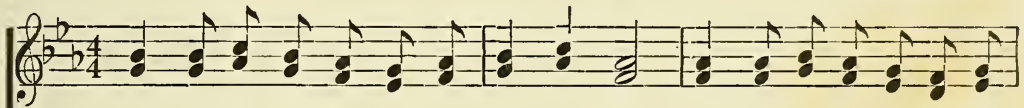

1. I have a Fa-ther in the prom-ised land, I have a Fa-ther in the

2. I have a Saviour, in the prom-ised land, I have a Saviour in the

3. I have a crown in the prom-ised land, I have a crown in the

4. I hope to meet you in the prom-ised land, I hope to meetyou in the

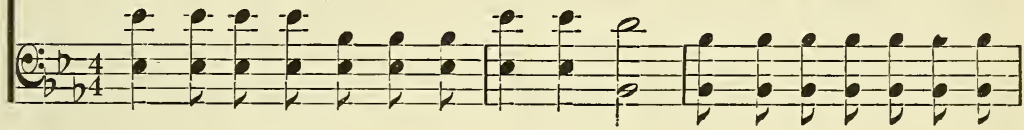

FINE.

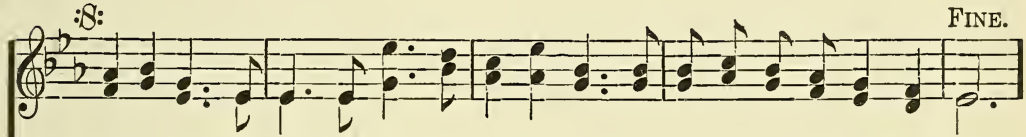

promised land; My Fa-ther calls me I must go To meet Him in the promised land. promised land; My Saviour calls me I must go To meet Him in the promised land. promised land; When Je - sus calls me I must go To wear it in the promised land. promised land; At Je - sus' feet, a joy-ous band,We'll praise Him in the promised land.

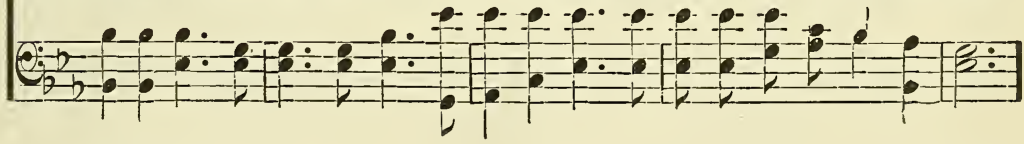

Chorus.

D. $S$.

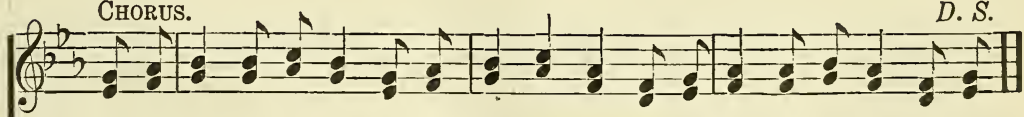

I'll a-way, I'll a-way to the promised land; I'll a-way, I'll a-way to the

I'll a-way, I'll a-way to the promised land; I'll a-way, I'll a-way to the

I'll a-way, I'll a-way to the promised land; I'll a-way, I'll a-way to the

I'll a-way, I'll a-way to the promised land; I'll a-way, I'll a-way to the

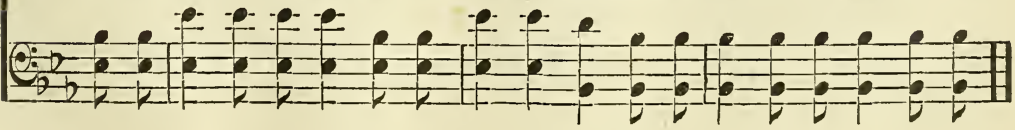


"Pray without ceasing." Thess. 5: 17.

W. Stiliman Martin.

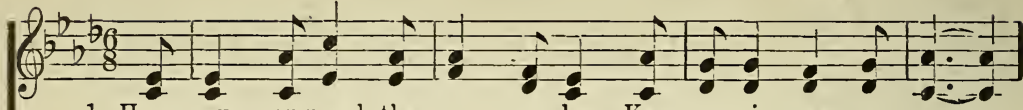

1. How - ev - er rough the way may be, Keep pray-ing as you go;

2. When out in life's great har-vest field, Keep pray-ing as you go;

3. To walk in fel-low-ship with God, Keep pray-ing as you go;
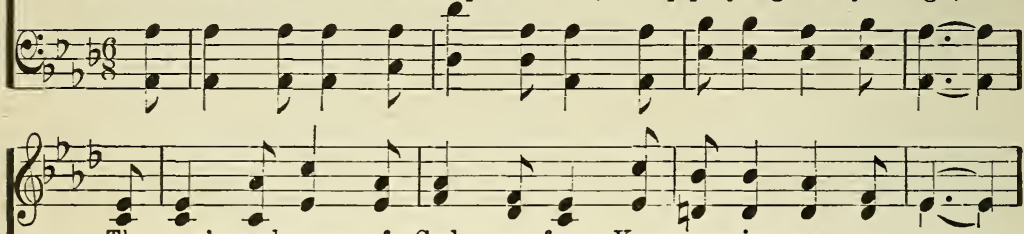

The pow'r and grace of God are free, Keep pray-ing as you go;

By pray'r God's weap-ons you must wield, Keep pray-ing as you go;

To un - der-stand this pre-cious Word, Keep pray-ing as you go;
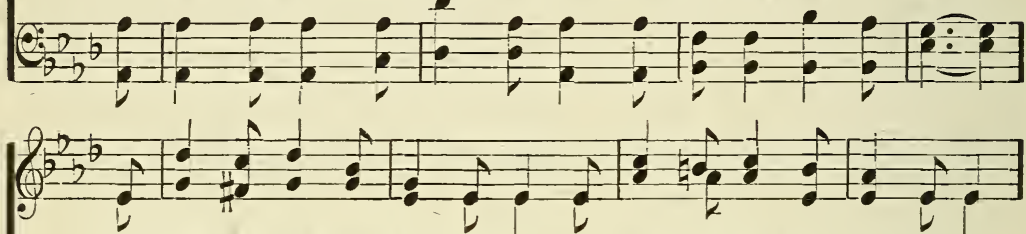

Un - ceas - ing pray'r is what you need, 'Tis pray'r that makes you strong indeed,

Be - fore you none can ev-er stand, The pow'r of God you may commund,

To live a life of cease-less praise, To be made use - ful all your days,
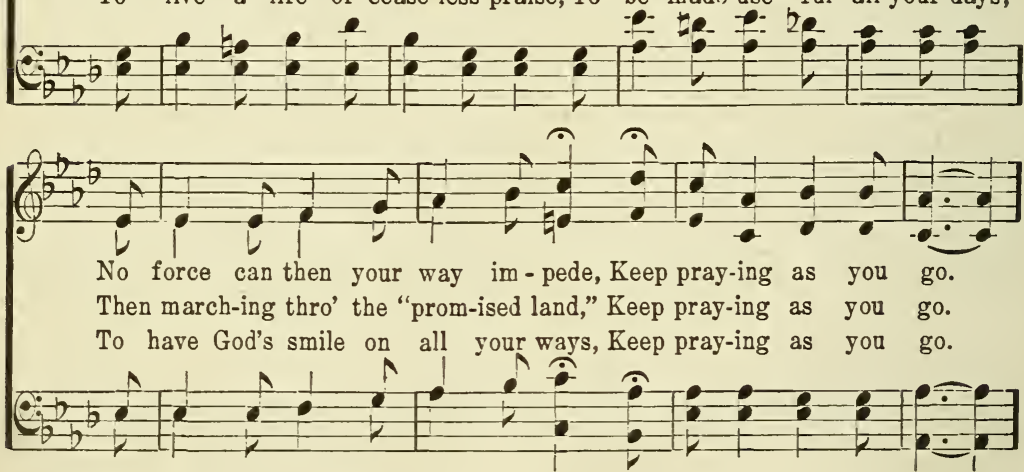

ChORUS.

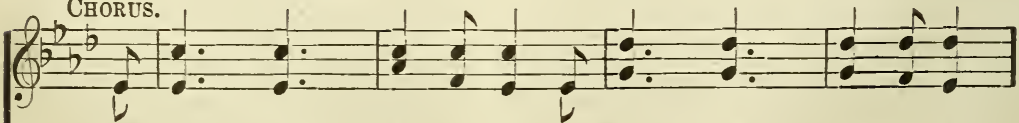

Keep pray - ing

as you go, Keep pray - ing

as you go;

Keep pray-ing as you go, Keep pray-ing as you go:

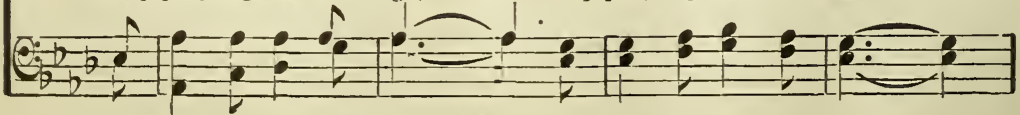

Copyright, 1905, by John A. Davis 


\section{Keep Praying as You Go.}

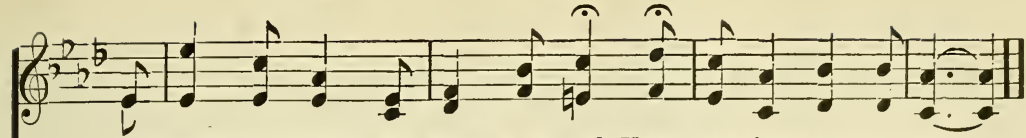

Un-ceas-ing pray'r is what you need, Keep pray-ing as you go.

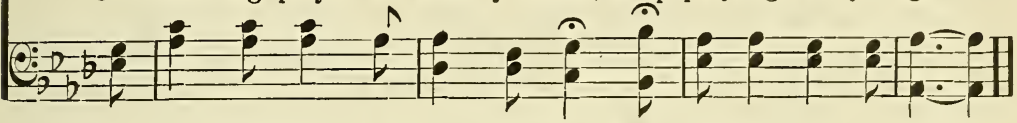

\section{Since I Found My Savior.}

E. E. HEwitT.

May be used as a Solo and Chorus.

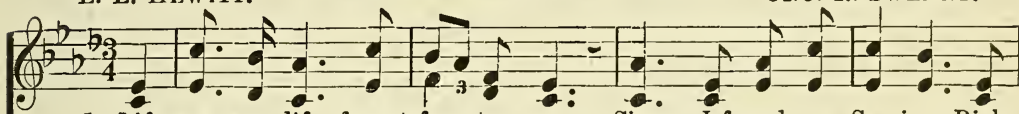

1. Life wears a dif - ferent face to me, Since I found my Sav-ior; Rich

2. He sought me in His won-drous love, So I found my Sav-ior; He

3. The pass-ing clouds may in - ter-vene, Since I found my Sav-ior; But

4. A strong hand kind-ly holds my own, Since I found my Sav-ior; It

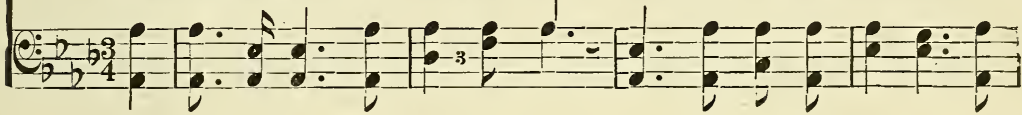

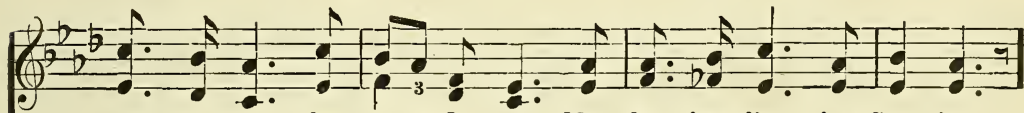

mer - cy at the cross I see, My dy - ing, liv - ing Sav - ior.

broughtsal-va - tion from a - bove, My dear, Al-might - y Sav - ior.

$\mathrm{He}$ is with me, tho' un - seen, My ev - er pres - ent Sav - ior.

leads me on - ward to the throne, 0 there I'll see my Sav-ior.

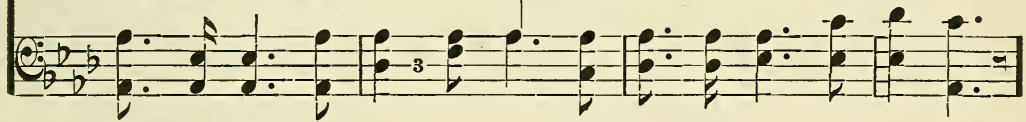

CHoRus.

Gold - en sun-beams 'round me play,

Je - sus turns my nights to day;
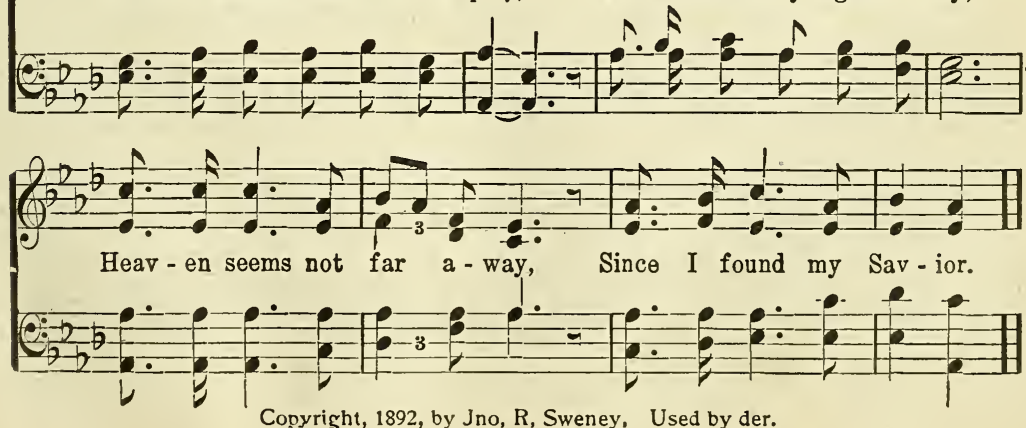

Copyright, 1892, by Jno, R, Sweney, Used by der. 
C. D. MartiN. "Christ is all."-Col. 3:11. W. Stillman Martin.

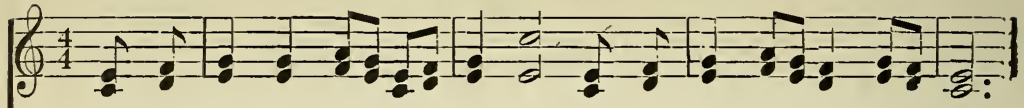

1. Let me work for Je - sus on - ly, As the days are roll - ing on,

2. Let me go to Je - sus on - ly, When my heart is full of care,

3. Let me live for Je - sus on - $1 y$, And from e - vil turn a - way,

4. Let me live with Je - sus on - ly, When my work on earth is done,
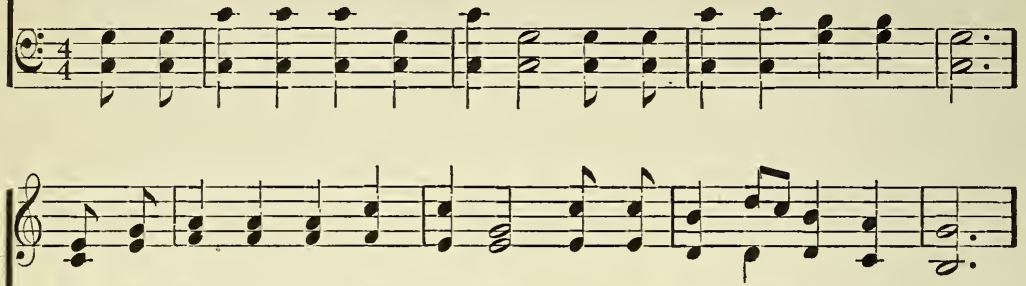

Let me speak for Je-sus on-ly; Let me tell what He has done.

Let me talk to Je-sus on-ly, Let me live the life of pray'r.

Let me point to Je-sus on - ly, All whose feet have gone a - stray.

Let me share His throne an $\mathrm{glo}-\mathrm{ry}$, When all vic-t'rys here are won.

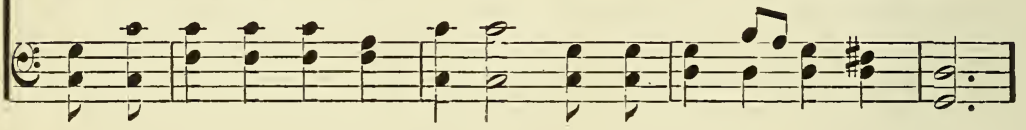

CHORUS.

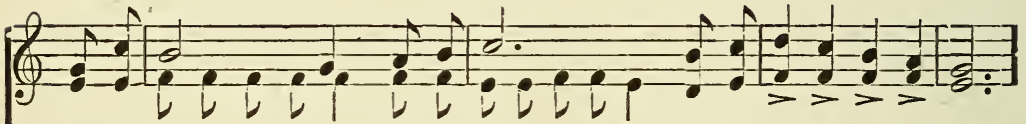

Je-sus on - ly would I know,

$\mathrm{He}$ is "all in all" to me;

$\mathrm{Je} \cdot$ sus on - ly would I know, Jesus fonly would I know,
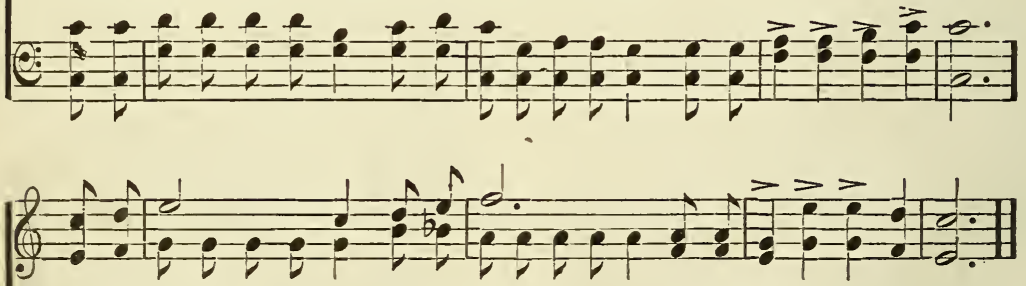

As I jour - ney here be - low,

Je-sus on-ly would I see.

As 1 journey here below, As I journey here below,

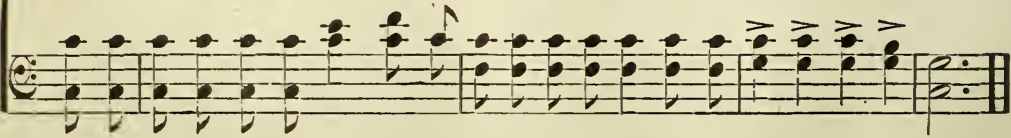

Copyright, 1905, by John A. Davis. 
Sweet Peace, trie Gift of God's Love. $\quad 89$

P. P. B. Copyright, $1887 \mathrm{snd} 1889$, by P. P. Bilhora.

P. P. BILHORN.

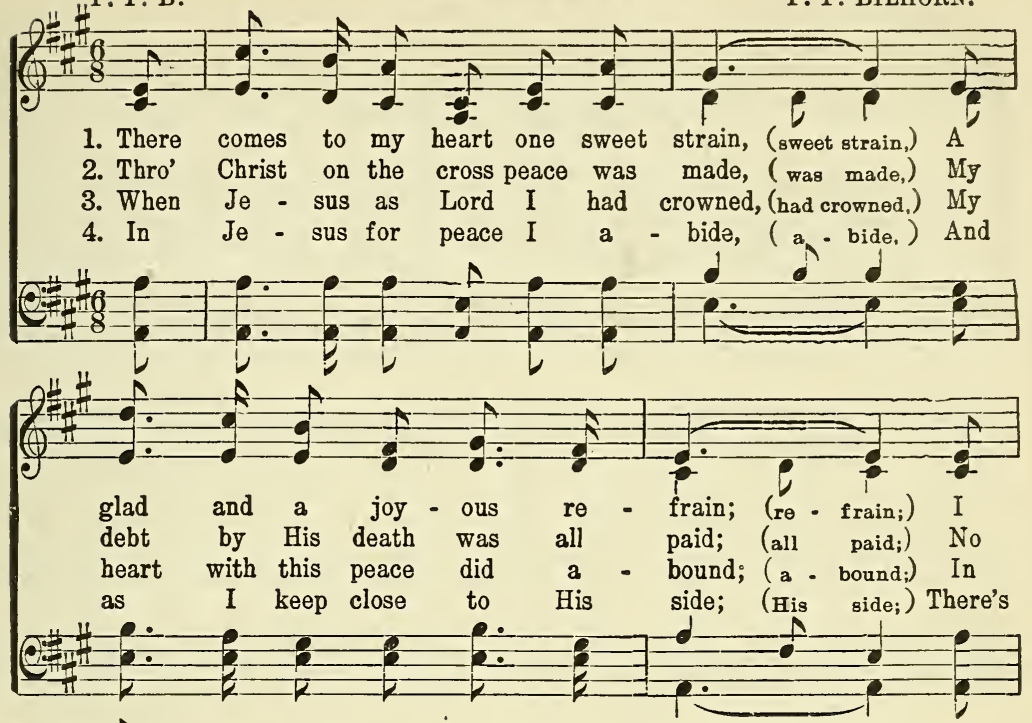

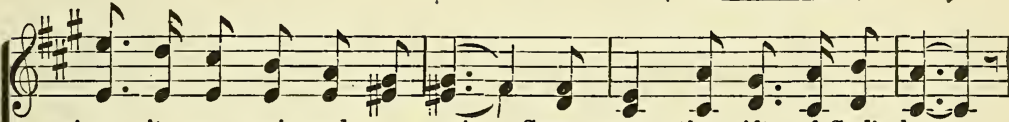

sing it a - gain and a - gain, Sweet peace, the gift of God's love.

oth - er foun-da-tion is laid For peace, the gift of God's love.

Him the rich bless-ing I found, Sweet peace, the gift of God's love.

noth - ing but peace doth be - tide. Sweet peace, the gift of God's love.

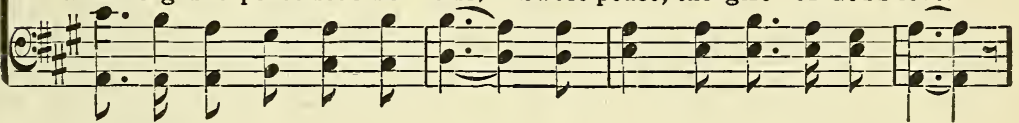

CHoRUS.

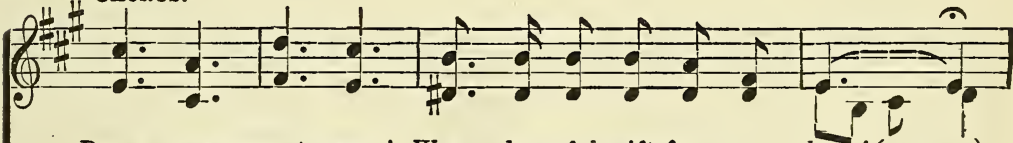

Peace, peace, sweet peace! Won - der - ful gift from a - bove! (a-bove!)

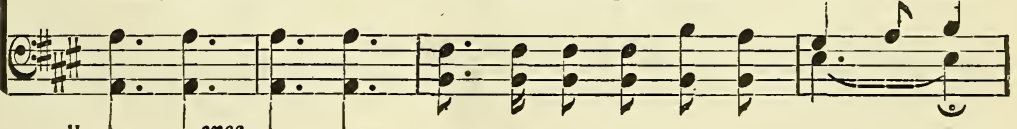

$e_{-1}^{4}$

Oh, won-der-ful, won-der-ful peace! Sweet peace, the gift of God's love!

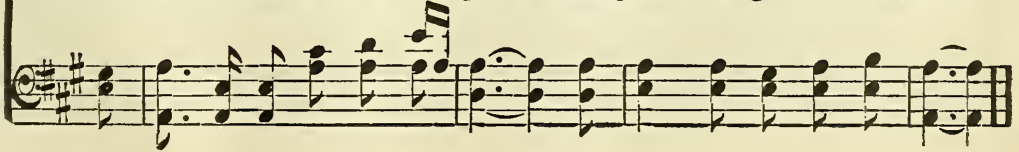


"Come unto me all ye that labor and are heary laden, and I will gire you rest." F. F. LEONARD.

Matt. 11: 28.

W. Stillman Martin.

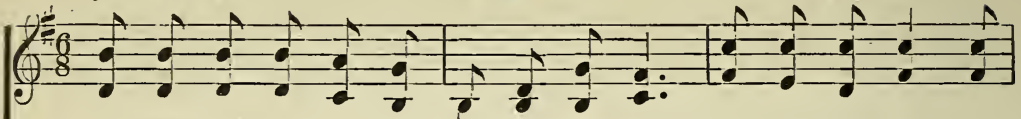

1. Je - sus is plead-ing, oh, list to His voice: Plead-ing with you to

2. Je - sus is wait-ing this mo-mentfor you; $\mathrm{He}$ is a Friend al-

3. Brother, has Je - sus not spo-ken be - fore? Has He not oft - en

4. Now whilewe'repraying, and while all is still, Will you not yield to
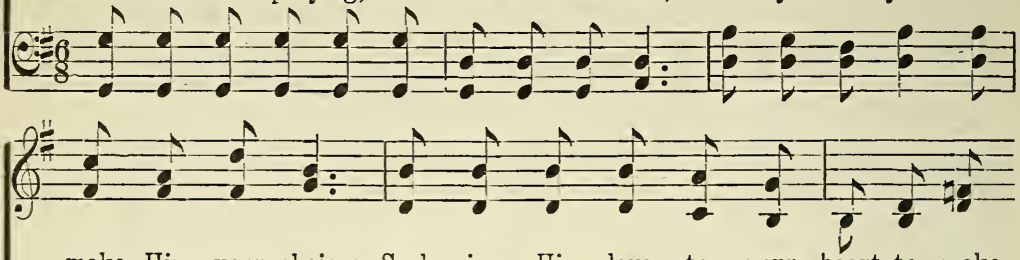

make Him your choice; Seek - ing His love to your heart to make might $-y$ and true; Wait - ing to hear you say, "Mas - ter come knocked at your door? Do not re - fuse Him, but give Him His $\mathrm{Je}$ - sus your will? List, $\mathrm{He}$ is plead-ing, oh, is it in

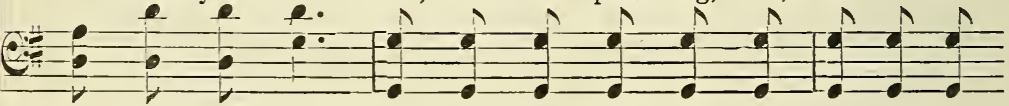

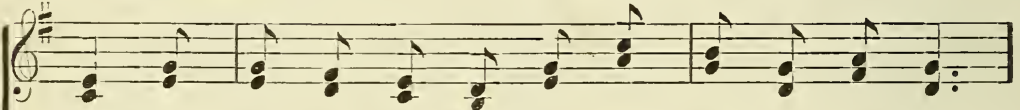
known; Oh, will you ac - cept Him? oh, will you come home? in," He's wait - ing to cleanse you from all of your sin. place, Ac - cept of His love, of His truth and His grace. vain That $\mathrm{He}$ has been call - ing a - gain and a - gain?

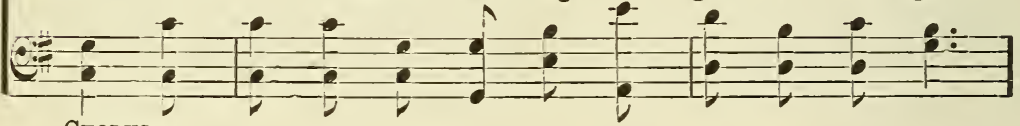

Chorus.

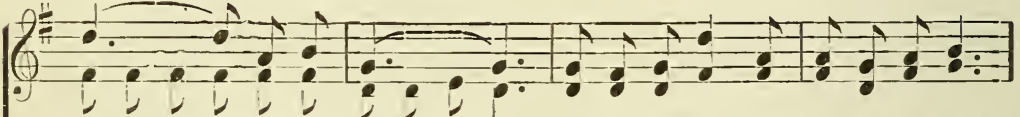

Je - sús says, "Come;". . Give Him your burdens, you shall be free; Je-sus inrites you, says, "Come unto me;

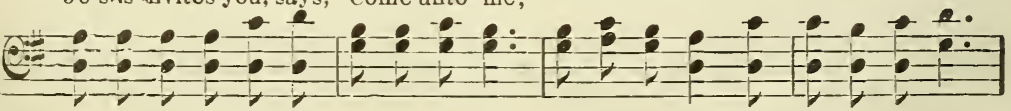

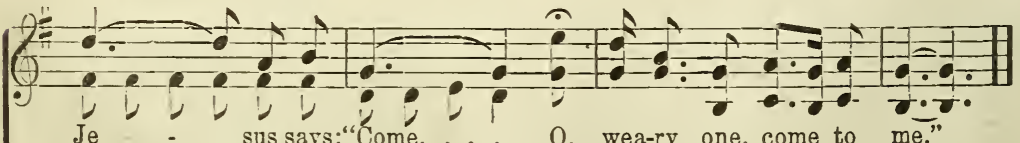
Je - sus says;"Come, . - O, wea-ry one, come to me."

Je - sus invites you, says, "Come unto me;"

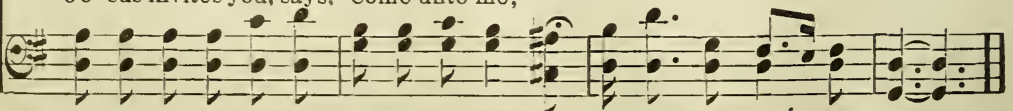

Copyright, 1905, by John A. Davis. 


\section{Blessed Jesus, Keep Me White.}

P. P. B.

Copyright, 1885, by P. P. Buhorn.

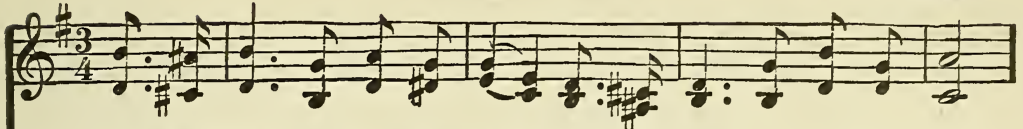

1. Bless-ed Je-sus, Thou art mine, All I have is whol-ly Thine;

2. I am safe with - in the fold, All mycares on Thee are roll'd;

3. Pre - cious Je - sus, day by day, Keep me in the ho-ly way;

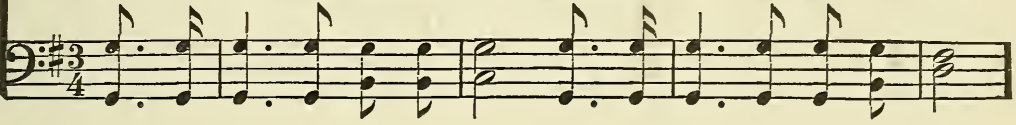

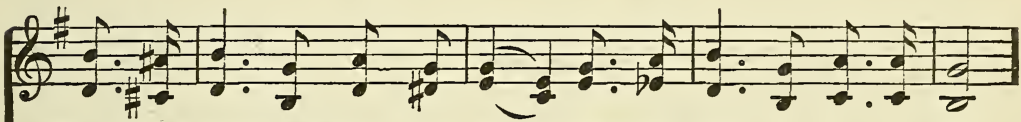

Thou dost dwell with-in my heart, make me clean in ev-'ry part.

I en-joy the sweet-est rest, For I'm lean-ing on Thy breast.

Keep my mind in per - fect peace, $\mathrm{EV}_{\mathrm{V}}$ - 'ry day my faith in-crease.

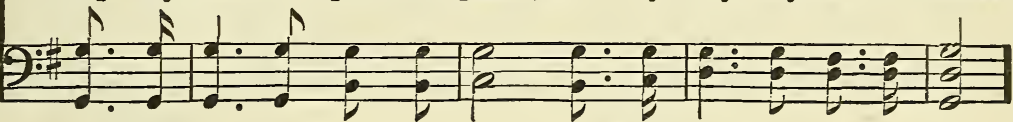

Chords.

white..........

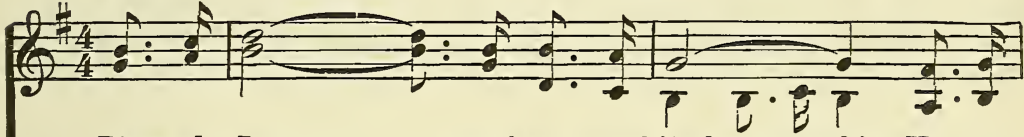

Bless-ed Je - - - sus, keep me white, keep me white, Keep me Bless-ed Je - sus,

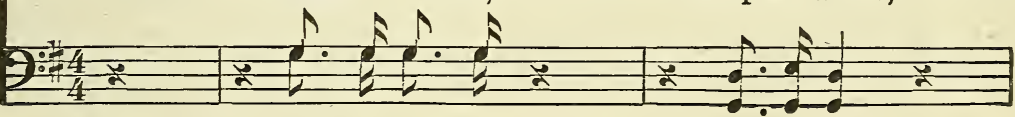

walk - - - ing,

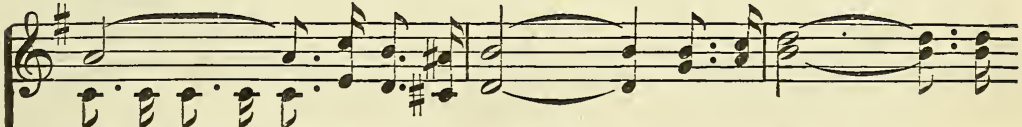

walking, keep me walk-ing in the light,..... All I have......

Keep me ralk-ing in the light, All I have

is
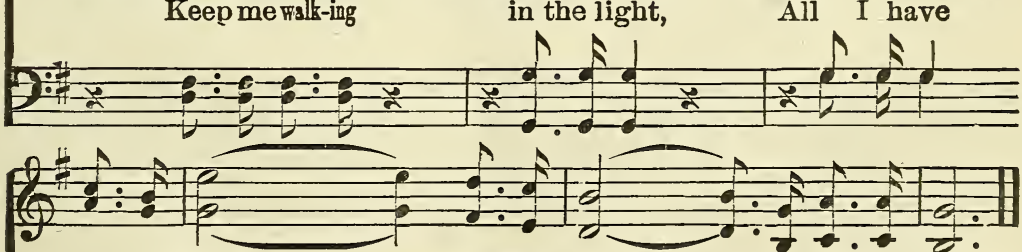

whol-ly Thine,........ Blessed Je - - sus, Thou art mine

is wholly Thine, Bless-ed Je-sus,

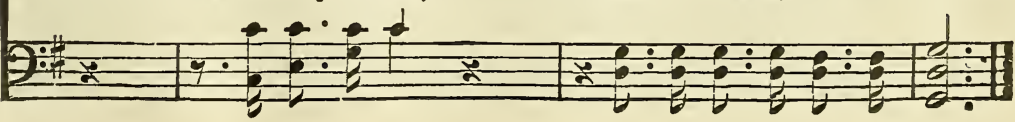


W. S. M.

W. Stillman Martin.

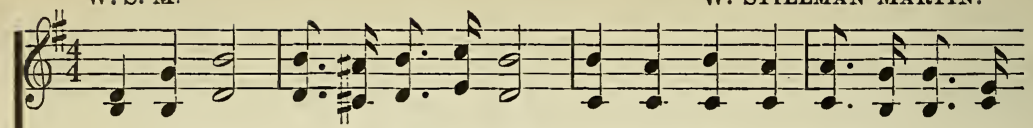

1. On the cross, Je - sus shed His blood,-Rich-est gift that heav-en could af-

2. At the cross, par-don may be found, Precious blood, the sin-ner's on - ly

3. From the cross, ra - di-ant with light, Shines God's love in splen-dor rare and

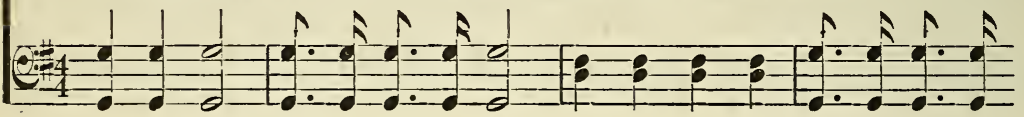

Chorus.

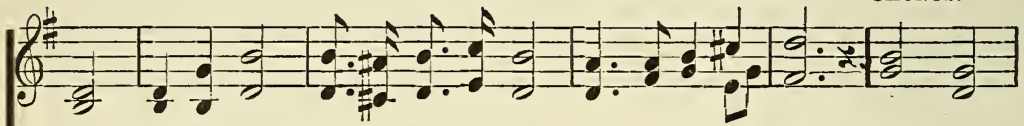

ford, That we might be redeemed to God, Glo - ry to His name. Glo - ry, ground; Here God's grace rich-ly doth a-bound, Glo - ry to His name.

bright; Hosts a-bove won-der at the sight, Glo - ry to His name. Glo-ry, glo-ry

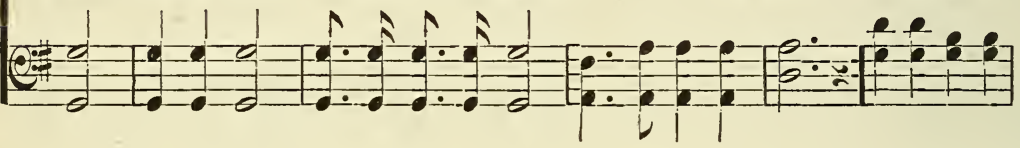

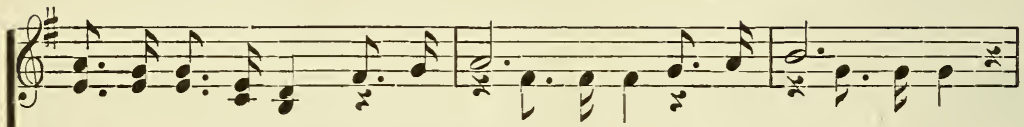

glo - ry to His name, For the cross,

pre-cious cross;

For the cross,

pre-cious cross;

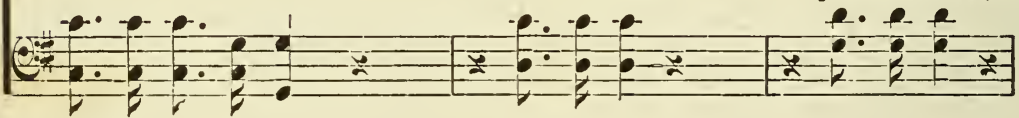

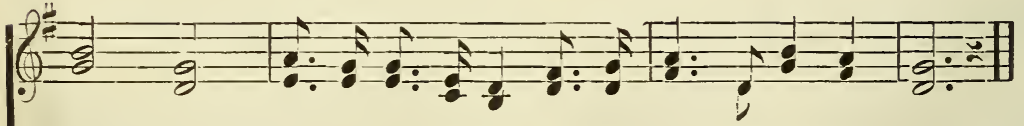

Glo - ry, glo - ry to Elis name, For the pre-cious, pre-cious cross.

Glo - ry, glo-ry,

e 2

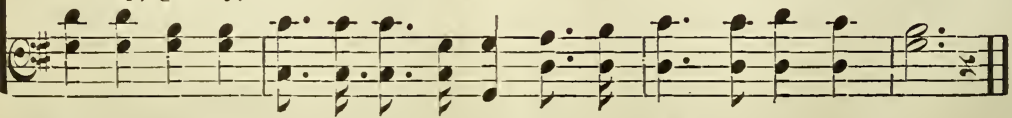

Copyright, 1905, by John A. Davis. 


\section{Jesus is All the World to Me.}

W. L. T.

Copyright, 1904, by Will L, Thompson, East Liverpool, Ohio,

Used by per.

WILL L. THOMPSON.

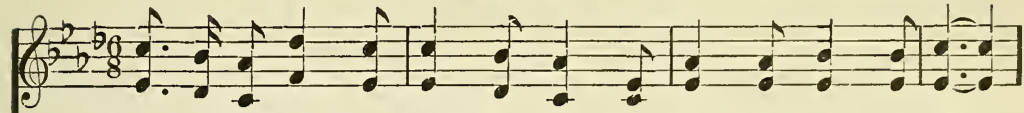

1. Je-sus is all the world to me, My life, my joy, my all;

2. Je-sus is all the world to me, My friend in tri - als sore;

3. Je-sus is all the world to me, And true to Him I'll be;

4. Je - sus is all the world to me, I want no bet - ter friend;
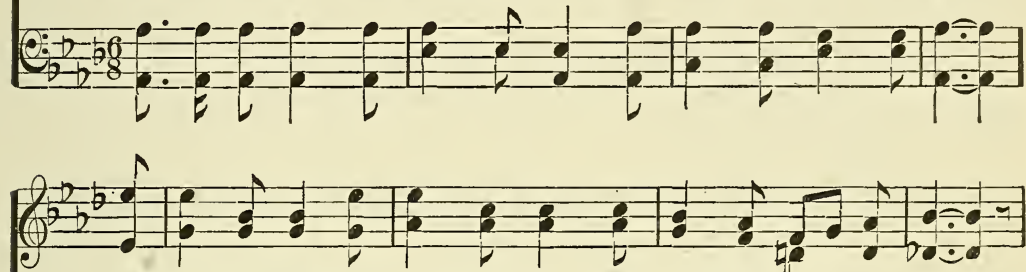

$\mathrm{He}$ is mystrength from day to day, With-out Him I would fall.

I go to Him for bless - ings and He gives them o'er and o'er.

Oh, how could I this friend de - ny, When He's so true to me?

I trust Him now, I'll trust Him when Life's fleet-ing days shall end.
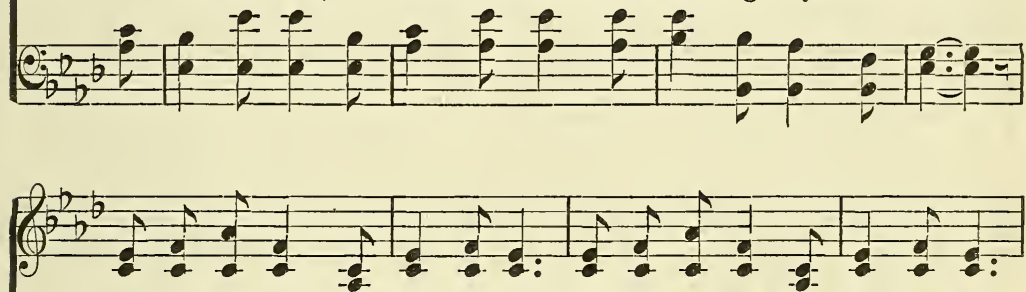

When I am sad, to Him I go, No oth-er one can cheer me so;

He sends the sun - shine and the rain, He sends the harvest's gold - en grain;

Fol - low-ing Him I know I'm right, Keep-ing His cross with -in my sight;

Beau-ti-ful life with such a friend; Beau-ti-ful life that has no end;
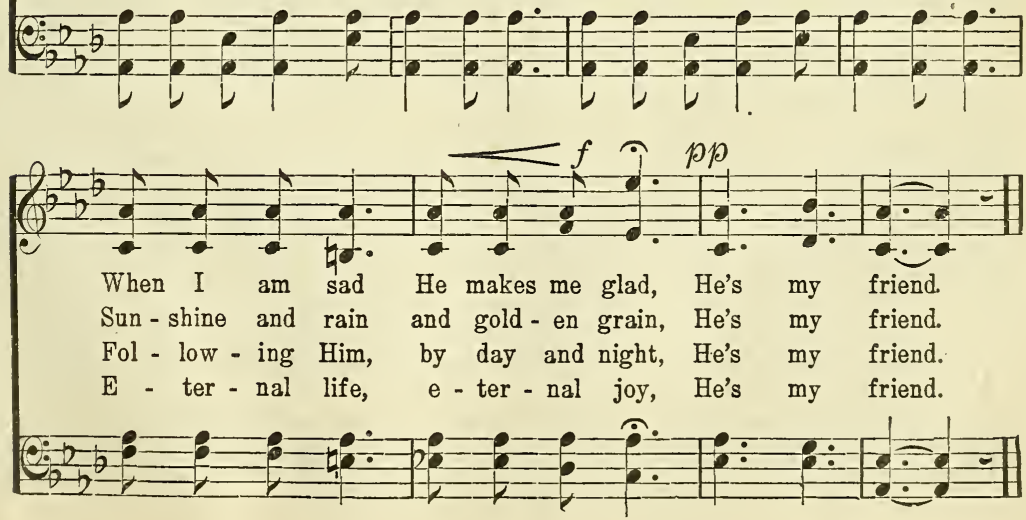
W. S. M.

W. STillman MaRTiN.

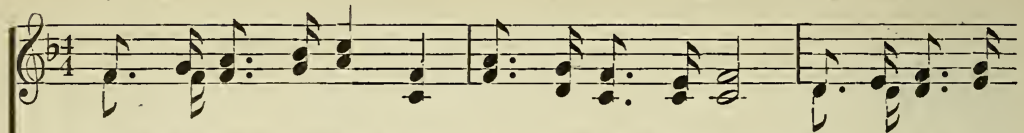

1. Spread a-broad the sun-shine, ev - 'ry-where you go; Help to light the

2. Sun-shine, what a bless-ing! giv - ing warmth and cheer, Love of God so

3. Liv - ing in the sun-shine, walk - ing in the light, Fear - ing neith-er

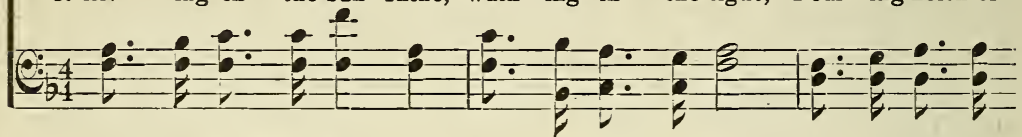

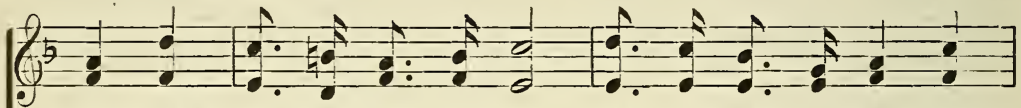

dark-ness of this world be-low; Ma - ny wea - ry wan-d'rers,

bound-less, bring - ing heav - en near; Je - sus, pre - cious Sav - ior,

dark-ness, nor the chill - ing night, 0 how bright the path - way

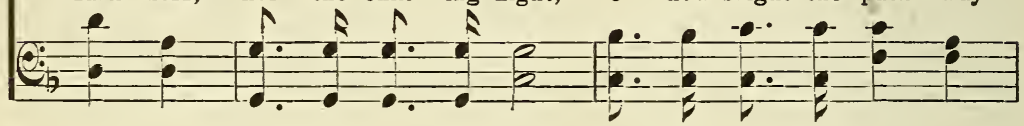

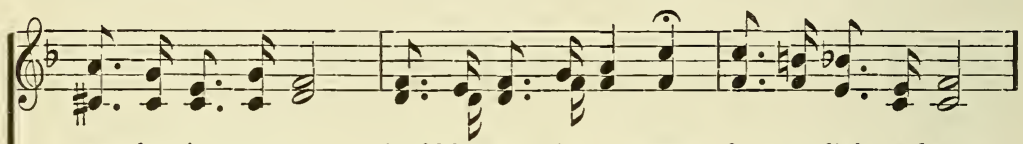

as they jour-ney on, Could be won for Je - sus by your light and song.

is the "Light of Life," In His gracious pres-ence there is bless-ing rife.

as you pass a-long, And this world is bet-ter by your light and song.

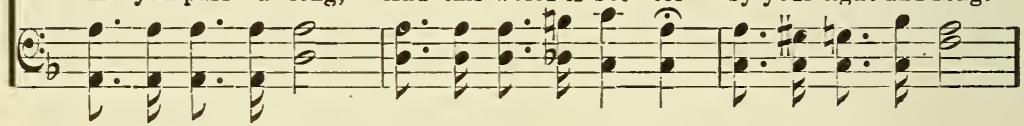

(1)

Spread a - broad the sun - shine, sing some cheer-ful song, Gath-er

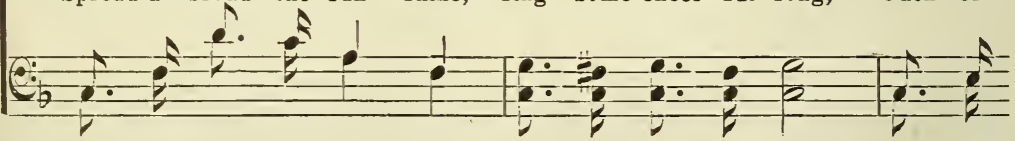

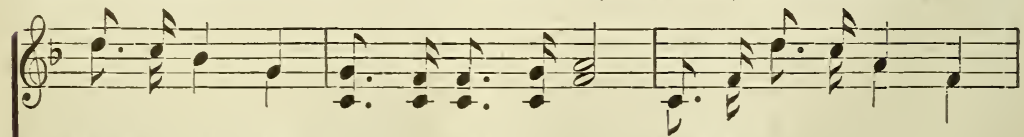

souls for Je - sus from the bus - y throng; Make some-bod-y hap - py,

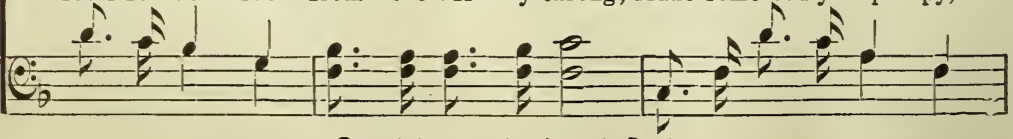

Copyright, 1905, by John A. Davis. 


\section{Spread Abroad the Sunshine.}

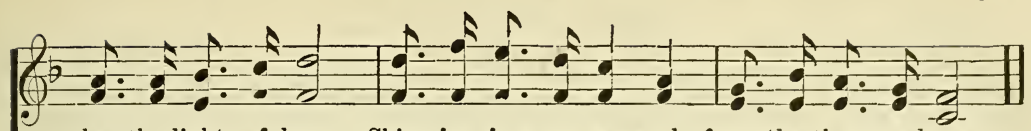

by the light of love Shin-ing in your own soul, from the throne a-bove.

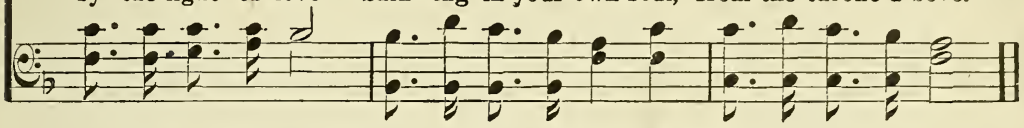

\section{How Firm a Foundation.}

GEO. KEITH.

Portugese.

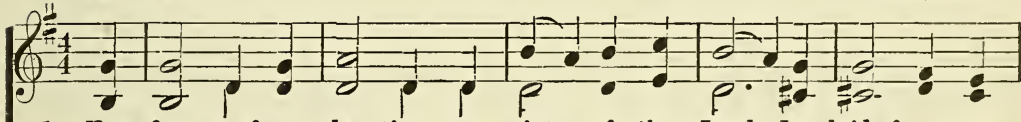

1. How firm a foun-da-tion, ye saints of the Lord, Is laid for your

2. "Fear not, I am with thee, 0 be not dis-mayed, For I am thy

3. "The soul that on Je - sus hath leaned for re - pose, I will not, I

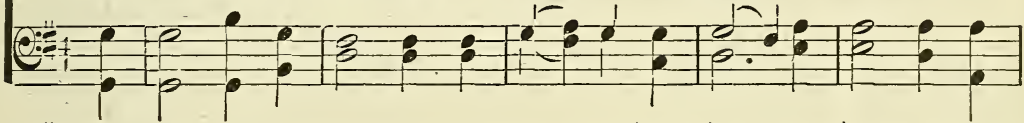

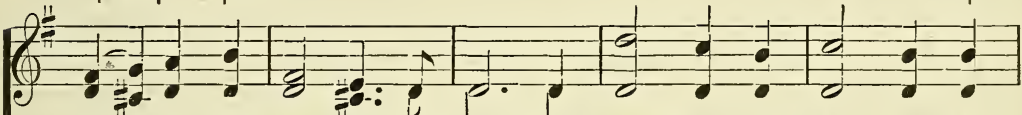

faith in His ex-cel-lent word! What more can $\mathrm{He}$ say, than to God, I will still give thee aid; I'll strength-en thee, help thee, and will not de-sert to his foes; That soul, though all hell should en-

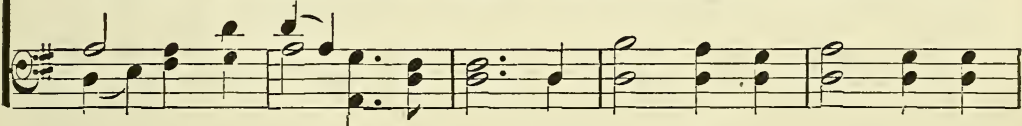

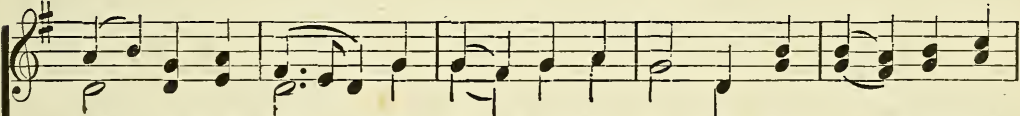

you He hath saith, To you, who for ref - uge to Je - sus have cause thee to stand, Up - held by my gra-cious, om - nip - o - tent deav - or to shake, I'll nev - er, no nev - er, no nev - er for-
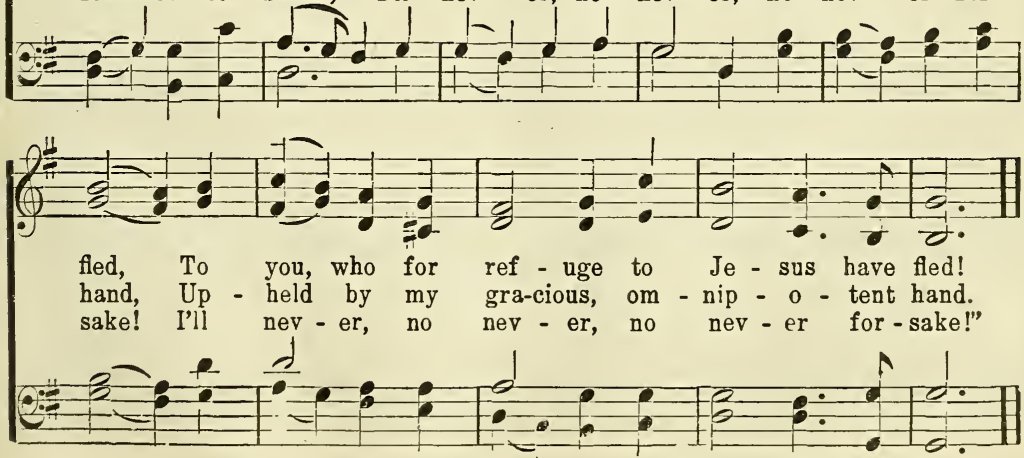


\section{IXA DULEY OGDON. \\ P. P. Brzonx.}

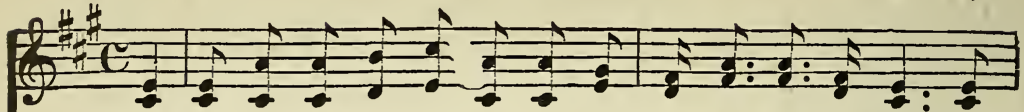

1. I've cast my heav - y bur-dens down on Ca-naan's happy shore,

2. With Is-rael's trusting chil-dren I'm re-joic-ing on my way, $\}$ 'm

3. My hung'ring soul is sat - is - fied with man-na from a-bove,

4. I'm sing-ing "Hal-le-lu-jah," safe-ly an-chored is my soul,
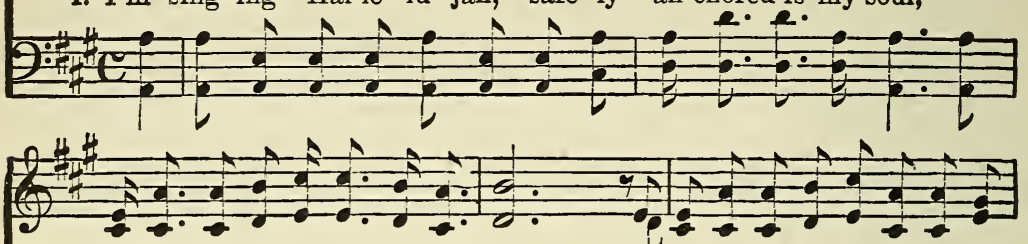

I'll wander in the wilderness of

living where the healing waters flow; $\left\{\begin{array}{l}\text { The cloudy, fier-y pil-lar is my } \\ \text { Nomore I thirst, therock I've found, that }\end{array}\right.$

I'm resting on His promises; the
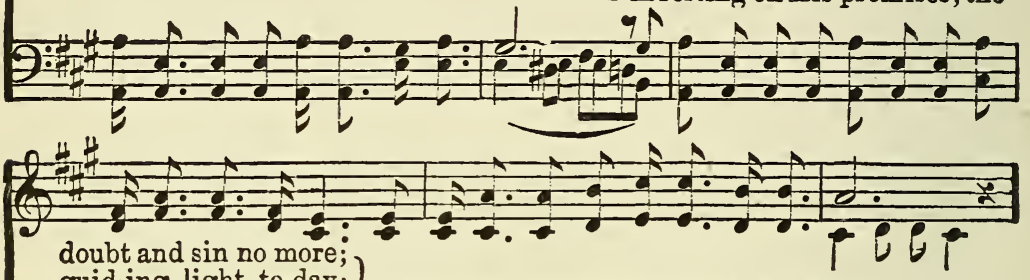

doubt and sin no more;

$\left.\begin{array}{l}\text { guid-ing light to-day; } \\ \text { fount of end-less love; }\end{array}\right\}$ 'm living where the healing waters flow.

blood has made me whole; (waters flow.)
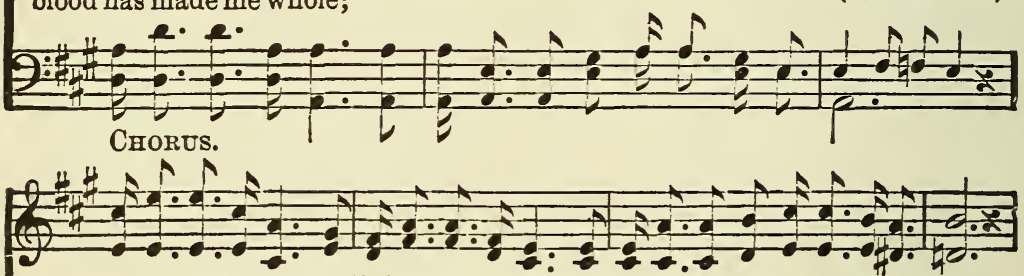

Living on the shore, I'm living on the shore, I'm living where the healing waters flow;
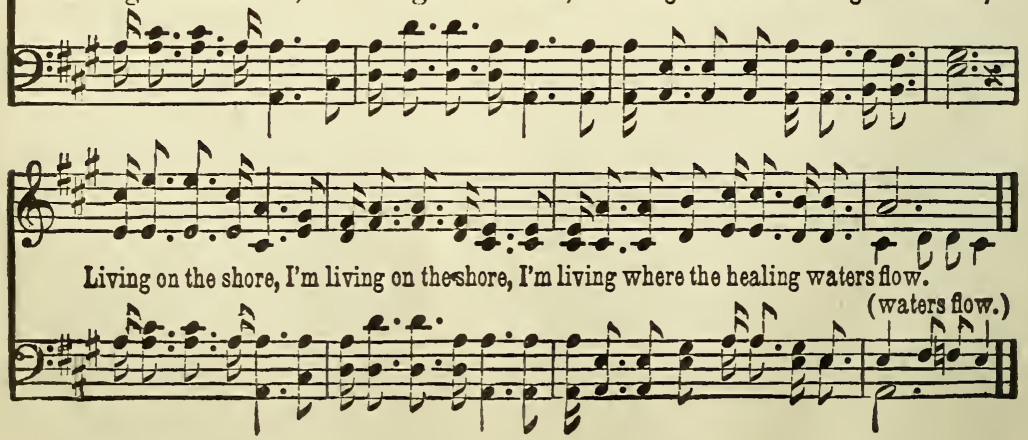


\section{Do You Know Jesus?}

"To know the love of Christ, that ye might be filled with all the fullness of God."

W. S. M.

Eph. 3: 19.

W. Stilluman Martin.

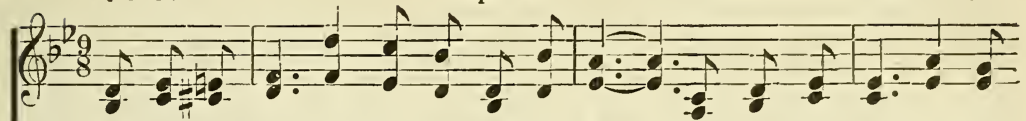

1. Do you know Je - sus, my Sav-ior and Friend? Je - sus on whom all my

2. Do you know Je - sus who rose from the grave? Je - sus who liv - eth for-

3. Do you know Je - sus when troubled, dis-trest? Do you know Je - sus who

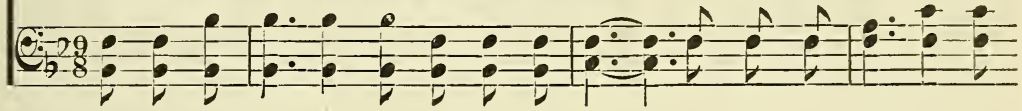

(4)

hopes now de - pend; Je-sus who sought me when wand'ring from God, Je - sus who ev - er to save; Do you know Je - sus ex - alt - ed on high? All who will giv - eth sweet rest; Do you know Je - sus in temp-ta-tion's hour? Read - y to

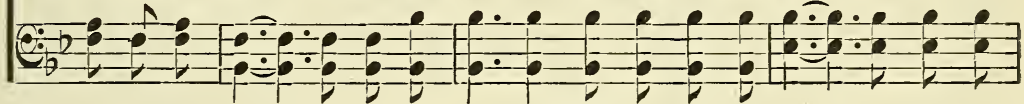
Chorus.

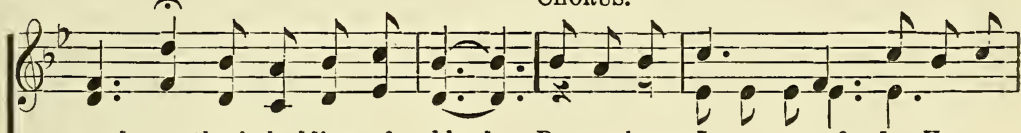
saved me thro' shedding of blood. Do you know Je - sus? Is He your trust Him shall nev - er more die.

help with His grace and His pow'r.

Do you know Je-sus?

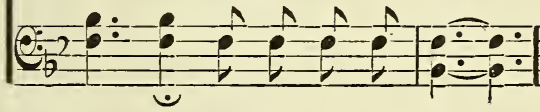

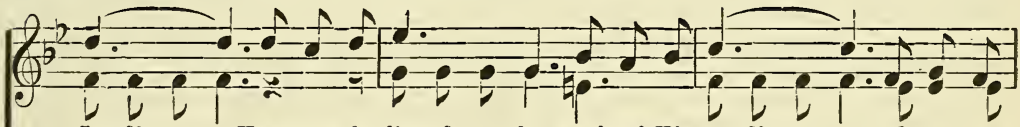
Lord? Have you be-lieved the truth of His word? . . O can you

Is He your Lord? Have you believed the truth of His word?

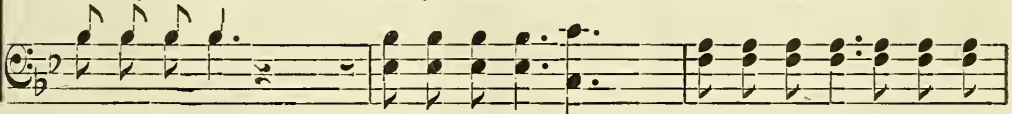

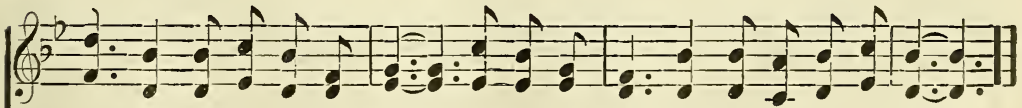

call Him your Sav-ior and Friend? Do you now trust Him your soul to de - fend?

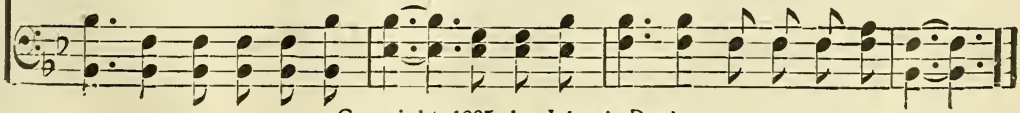

Copyright 1905, by John A. Davis. 
J. W. VaN DE VENTER.

W. S. WEEDEN.

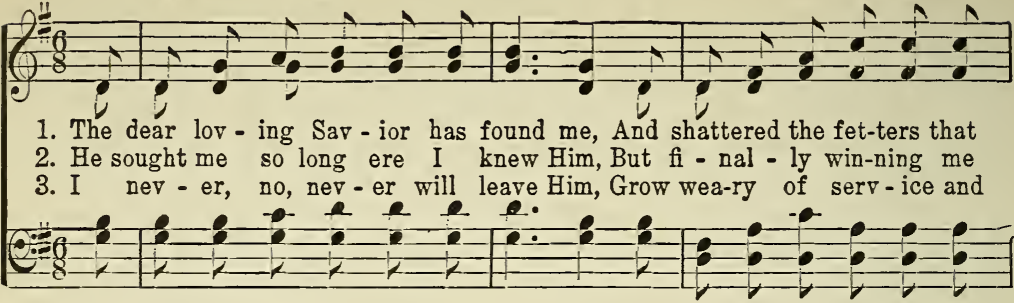

Q

bound me, Tho' all was con-fu-sion a-round me, $\mathrm{He}$ came and spake

to Him, I yield - ed my all to pur-sue Him, And asked to be

grieve Him, I'll con-stant-ly trust and be-lieve Him, Re-main in His

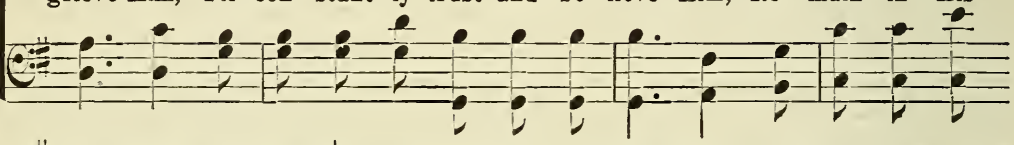

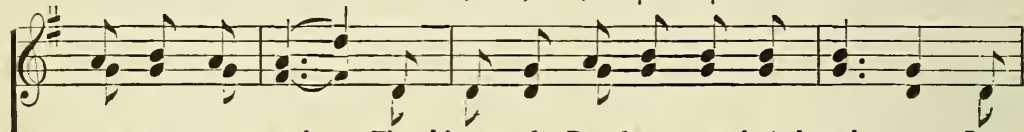

peace to my soul; The bless-ed Re-deem-er that bought me, In

filled with His grace; Al-though a vile sin-ner be - fore Him, Thro'

pres-ence di - vine; A - bid - ing in love ev-er flow - ing, In
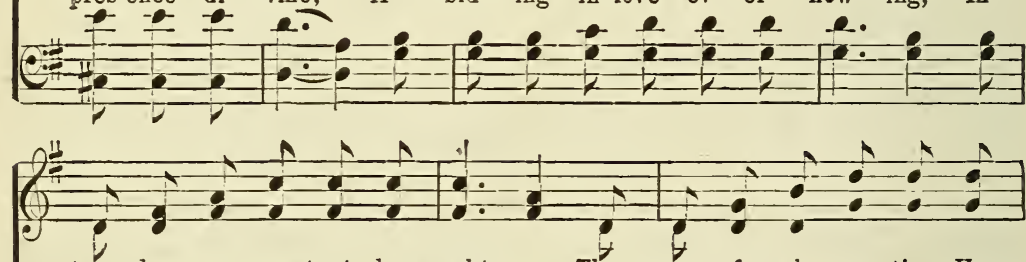

ten - der-ness con-stant-ly sought me, The way of sal-va-tion He

faith I was led to im-plore Him, And now I re-joice and a-

knowledge and grace ev - er grow - ing, Con - fid - ing im - plic - it - ly,

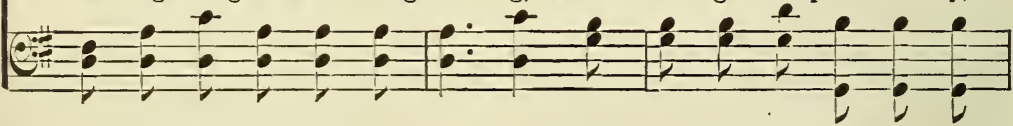

Chorus.

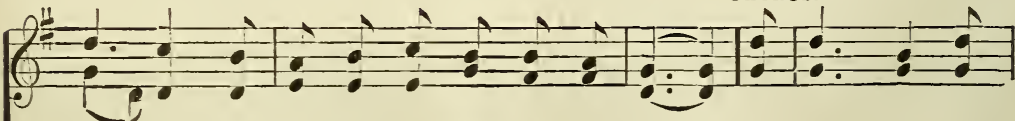

taught me, And made my heart per - fect - ly whole.

dore Him, Re-stored to His lov-ing em-brace. He saves me, He

know-ing That Je-sus the Sar-inr is mine.

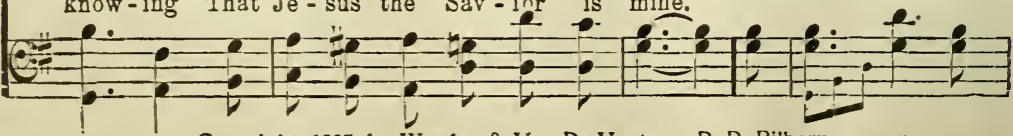

Copyright, 1895, by Weeden \& Van De Venter. P. P. Bilhorn, owner. 


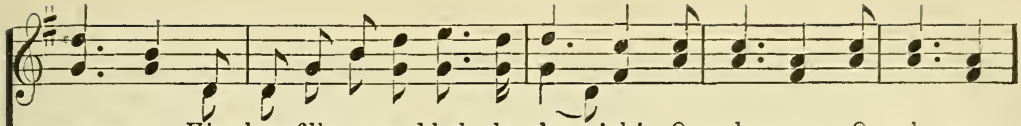
saves me, His love fills my soul,hal - le - lu - jah! 0 glo - ry, 0 glo - ry,

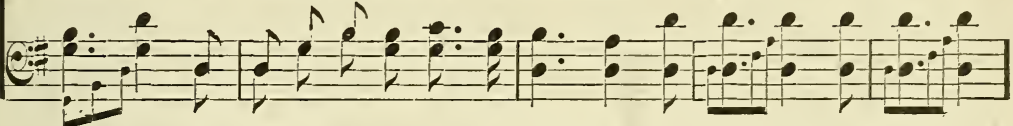
$\theta=\frac{1}{2}+\frac{1}{2}+8=8 \div 8$ -

His spir - it a - bid-eth with - in; His blood cleanseth me from all sin. E-

\section{Oniy Trust Him.}

J. H. S.

J. H. SтосктоN.

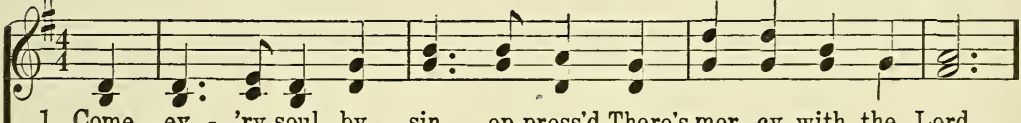

1. Come, er - 'ry soul by sin op-press'd,There'smer-cy with the Lord,

2. For Je - sus shed His pre-cious blood Rich bless-ings to be-stow;

3. Yes, Je - sus is the Truth, the Way, That leads you in - to rest;

4. Come then, and join this ho - ly band, And on to glo-ry go, (5)

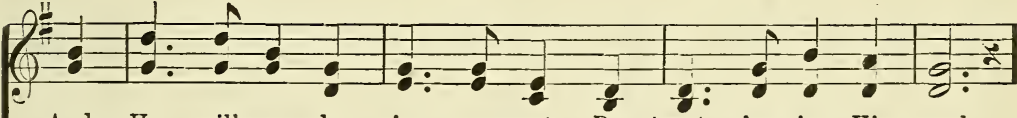

And $\mathrm{He}$ will sure-ly give you rest, By trust - ing in His word.

Plunge now in - to the crim - son flood That wash - es white as snow.

$\mathrm{Be}$ - lieve in Him with - out de - lay, And you are ful - ly blest.

To dwell in that ce -.les - tial land, Where joys im-mor-tal flow.

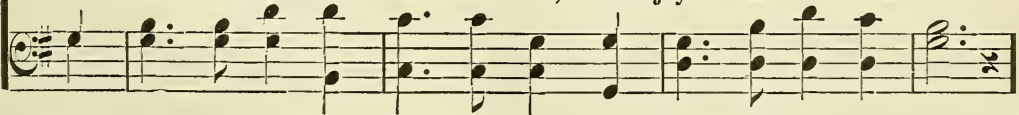

Q

$\{$ On - ly trust Him, on - ly trust Him, On - ly trust Him now;

$\{$ He will save you, He will save you, He will (Omit . . . \} save you now.

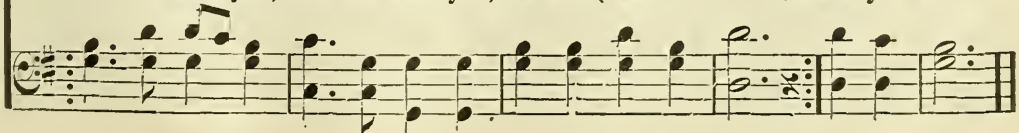


W. L. T.

WILL L. THOMPSON.

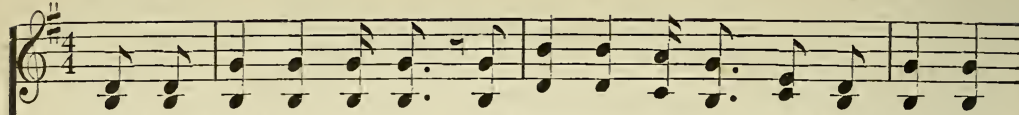

1. There's a great day com-ing, A great day com-ing, There's a great day

2. There's a bright day com-ing,

A bright day com-ing, There's a bright day

3. There's a sad day com-ing,

A sad day com-ing, There's a sad day

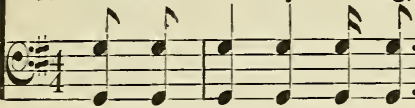

0

com-ing by and by, When the saints and the sin-ners shall be

com-ing by and by, But its bright-ness shall on - ly come to

com-ing by and by, When the sin - ner shall hear his doom "De-

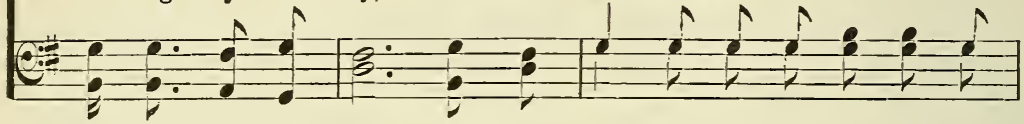

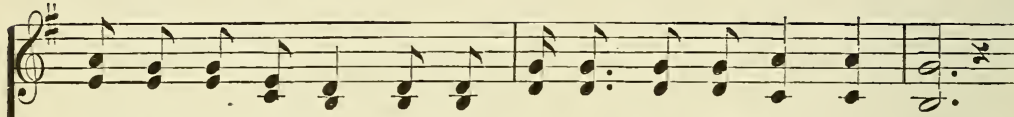

part-ed right and left, Are you read-y for that day to come?

them that love the Lord, Are you read-y for that day to come?

part, I know ye not," Are you read-y for that day to come?

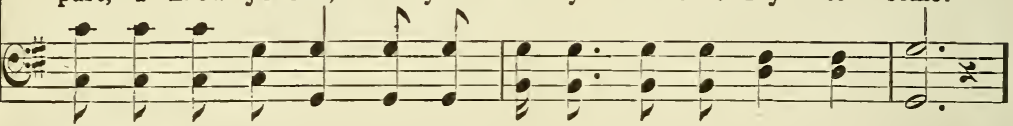

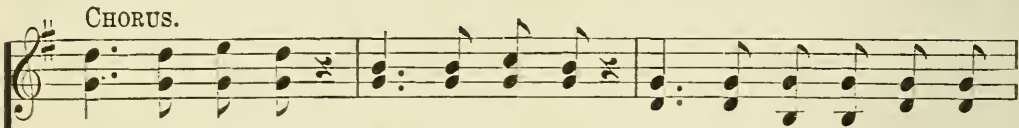

Are you read-y? Are you read $-y$ ? Are you read-y for the

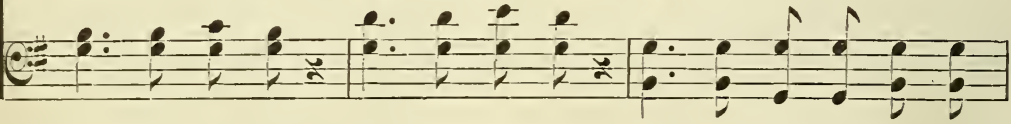

(0)

judg-ment day? Are you read-y? Are you read-y for the judgment day?

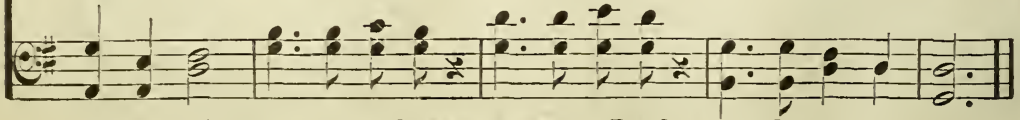

Copyright, by Will L. 


\section{Drifting Away from God.}

Mrs. J. A. GRIFrTtH.

Copyright, 1891, by P. P. Bilhorn.

P. P. BILHORN,

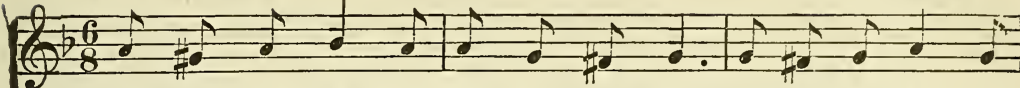

1. Drift - ing a-way from Christ in thy youth, Drifting a-way from

2. Drift - ing a-way from moth - er and home, Drifting a-way in

3. Drift - ing a-way on sin's treach'rous tide, Drifting where death and

4. Drift - ing a-way from hope's bless-ed shore, Drifting a-way where

5. Why will you drift on bil - lows of shame, Spurning His grace a-
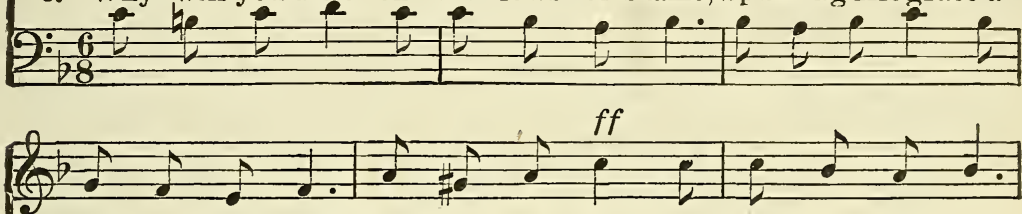

mer - cy and truth, Drift-ing to sin in ten - der - est youth, sor - row to roam, Drift-ing where peace and rest can - not come, dark-ness a-bide, Drift-ing from heav'n a - way in your pride, wild break-ers roar; Drift-ed and strand-ed, wreck'd ev-er - more, gain and a-gain? Soon you'll be lost! in sin to re-main,

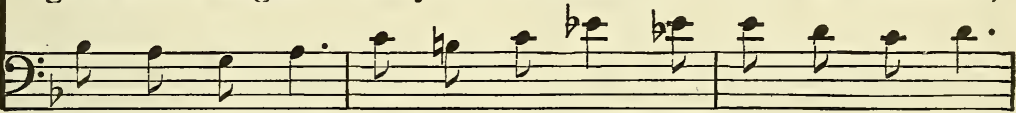

\section{Chorus.}
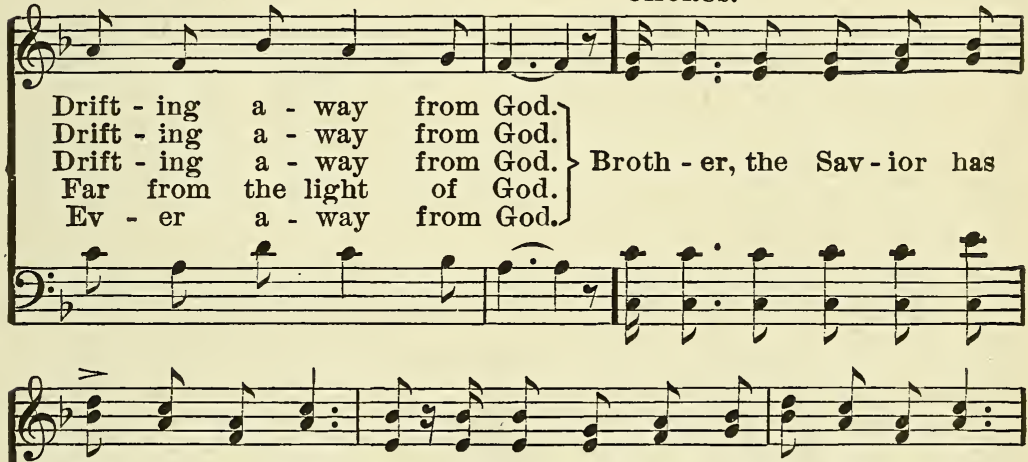

called you be-fore; See! you are near-ing e-ter-ni-ty's shore!
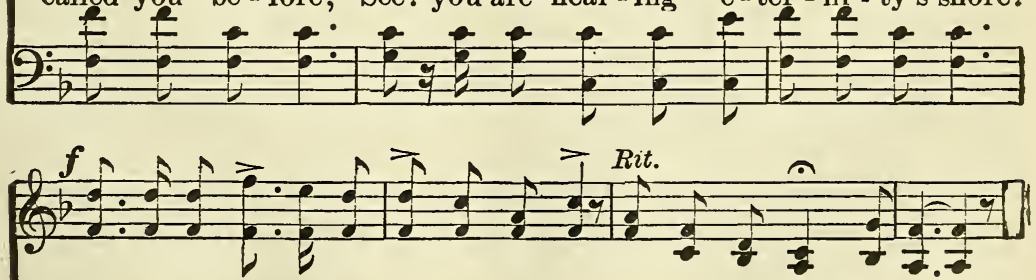

Soon you may perish, be lost ev - er-more, Je-sus now calls for you.

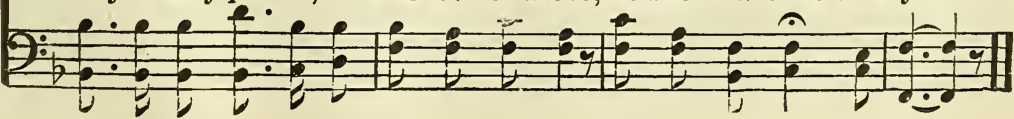




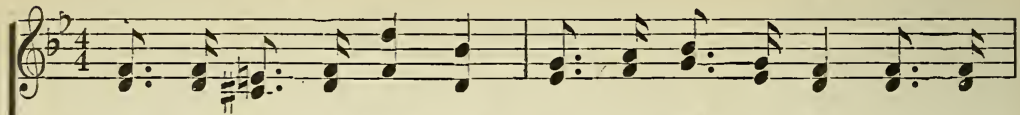

1. See yon soul that's sink - ing

2. 'Mid the break-ers foam, tho'

in the sea of sin, Throw the

3. Tho' the night be dark and

by the wild waves toss'd, Throw the

(6.-b4

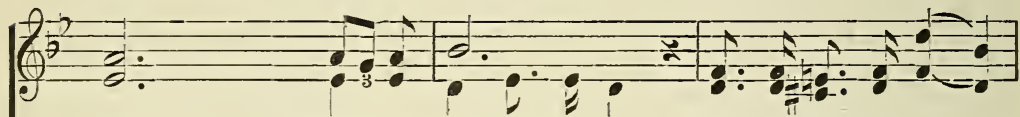

line! Throw the line!

line! Throw the line!

line! Throw the line!

Throw the line!

With a hand of love

Should you fail to act then

Yon-der strug-gling form

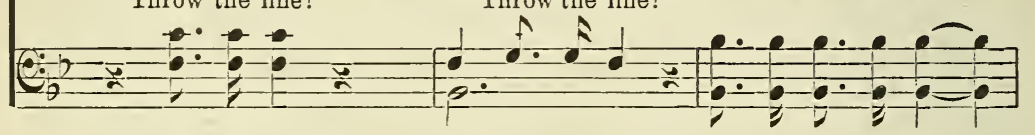

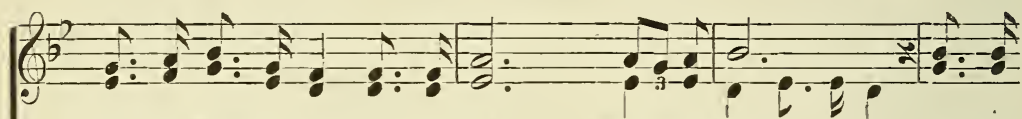

you may draw him in, Throw the line!

someone may be lost, Throw the line!

is your father's child, Throw the line!

Throw the line!

Throw the line!

Throw the line!

In the

Throw the line!

Throw the line!

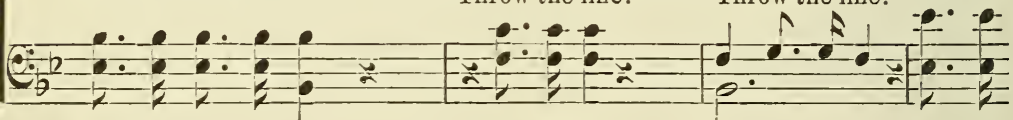

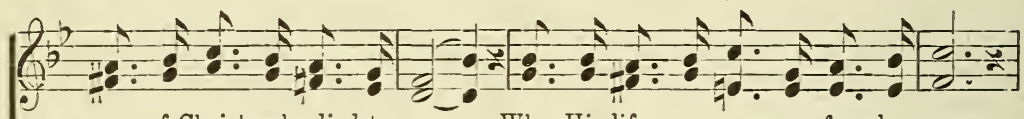

name of Christ; who died to save, Who His life a ran-som free-ly gave,

strength that meets each hour of need, With a love that knows no selfish greed,

death rides proud the midnight gale, With an in-born hope your ef-forts fail,

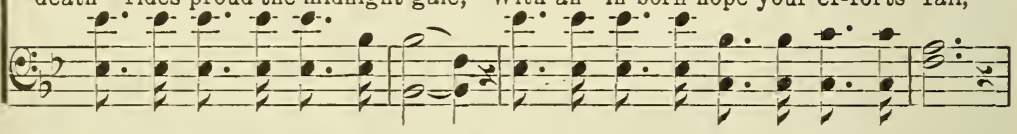

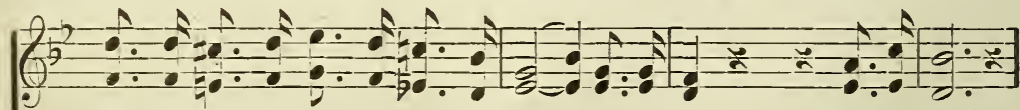

Who a-rose vic - tor-'ous o'er the grave, Throw the line!

You may do a soul a kind - ly deed. Throw the line!

'Tho' your hands grow cold, your cheeks turn pale, Throw the line!

Throw the line!

Throw the line! Throw the line!

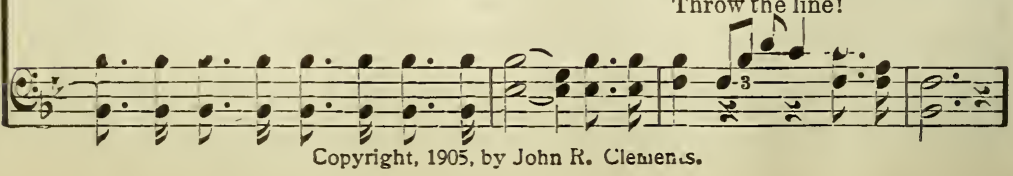


Chorus.

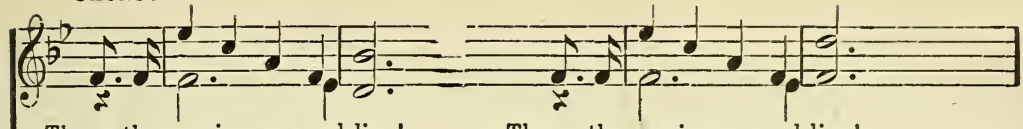

Throw the precious gos-pel line! Throw the line!

Throw the sav-ing gos-pel line! throw the line!

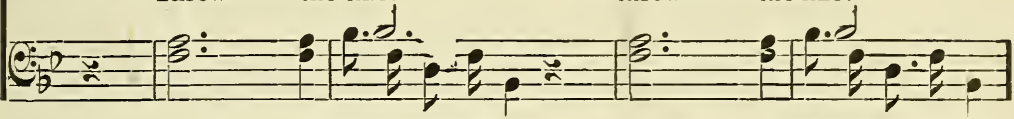

precious gospel line!

precious gospelline!

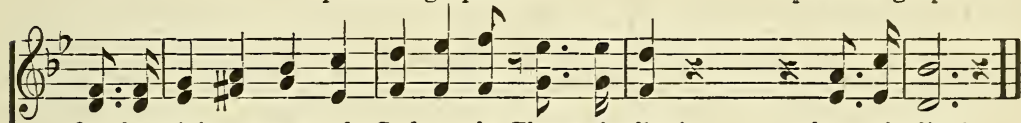

On the might-y arm of God re-ly, Throw the line!

throw the line!

throw the line!

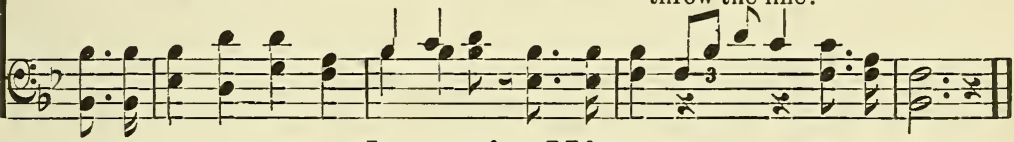

Jesus is Mine.

Mrs, C J. BONAR.

T. E. PERKINS.

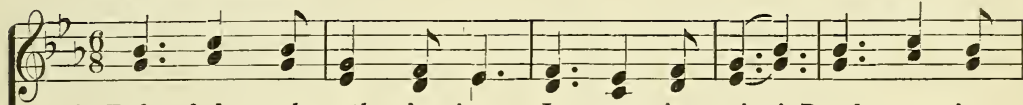

1. Fade, fade each earth - ly joy, Je - sus is mine! Break ev - 'ry

2. Tempt not my soul a - way, Je - sus is mine! Here would I

3. Fare - well, mor - tal - i - ty, Je - sus is mine! Wel-come, e-

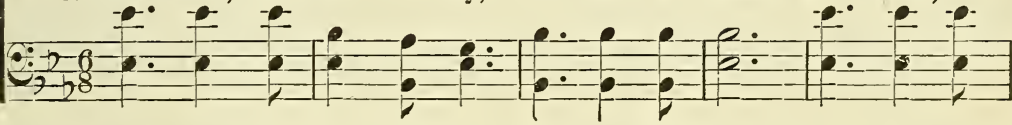

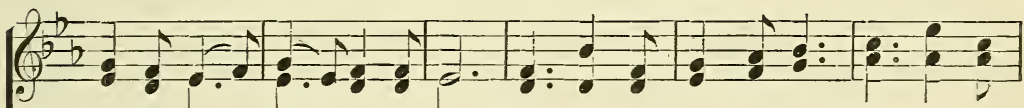

ten-der tie, Je - sus is mine! Dark is the wil-der-ness, Earth hath no

ev - er stay, Je - sus is mine! Per - ish - ing things of clay, Born but for

ter-ni-ty, Je - sus is mine! Wel-come, Oloved and bless'd, Welcome, sweet

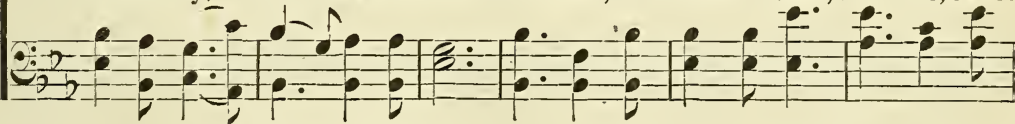

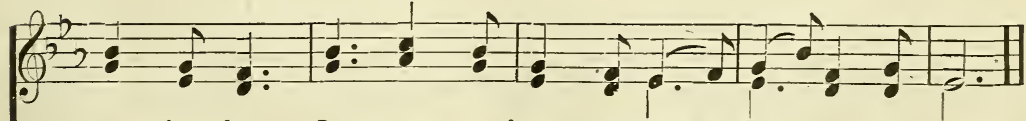

rest - ing place, Je - sus a - lone can bless, Je - sus is mine!

one brief day, Pass from my heart a-way, Je - sus is mine!

scenes of rest, Wel-come, my Sav-iour's breast, Je - sus is mine!

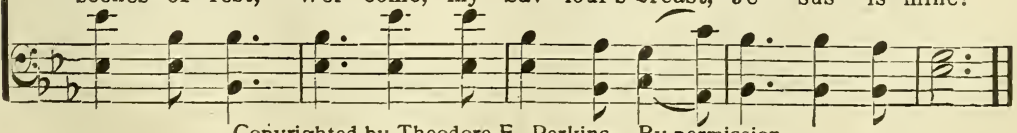

Copyrighted by Theodore $\mathrm{E}$ Perkins. By permission. 
E. A. H.

Elisha A. HofFirax.

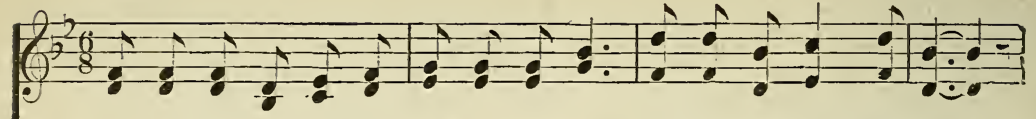

1. Have thy af-fec-tions been nailed to the cross? Is thy heart right with God?

2. Hast thou do-min - ion o'er self and o'er sin? Is thy heart right with God?

3. Is there no more con-dem-na-tion for sin? Is thy heart right with God?

4. Are all your pow'rs un-der Je-sus' con-trol? Is thy heart right with God?

5. Art thou now walk-ing in heav-en's pure light? Is thy heart right with God?

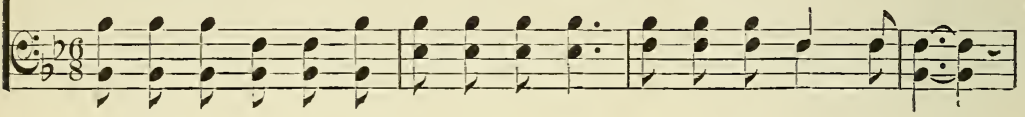

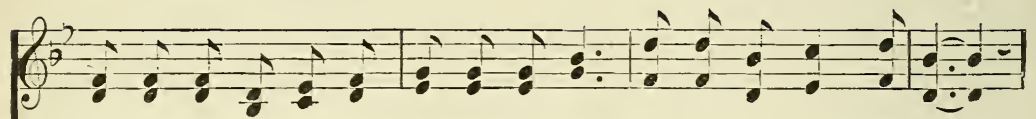

Dost thou count all things for Je - sus but loss? Is thy heart right with God?

0 - ver all e-ril with-out and with-in? Is thy heart right with God?

Does Je-sus rule in the tem - ple with-in? Is thy heart right with God?

Does he each mo-ment a - bide in thy soul? Is thy heart right with God?

Is thy soul wear-ing the gar-ment of white? Is thy heart right with God?

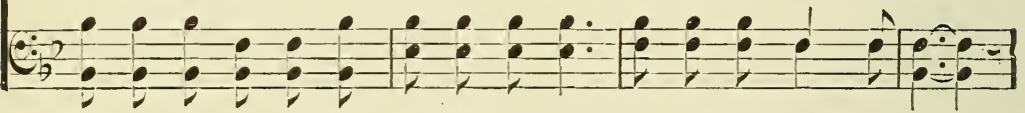

CHORUS.

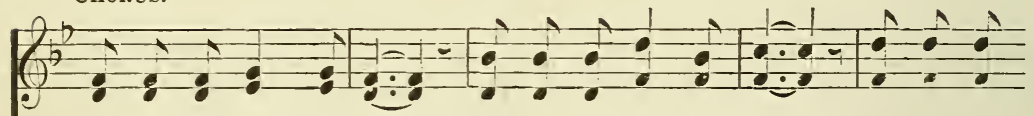

Is thy heart right with God? Wash'd in the crim-son flood, Cleans'd and made
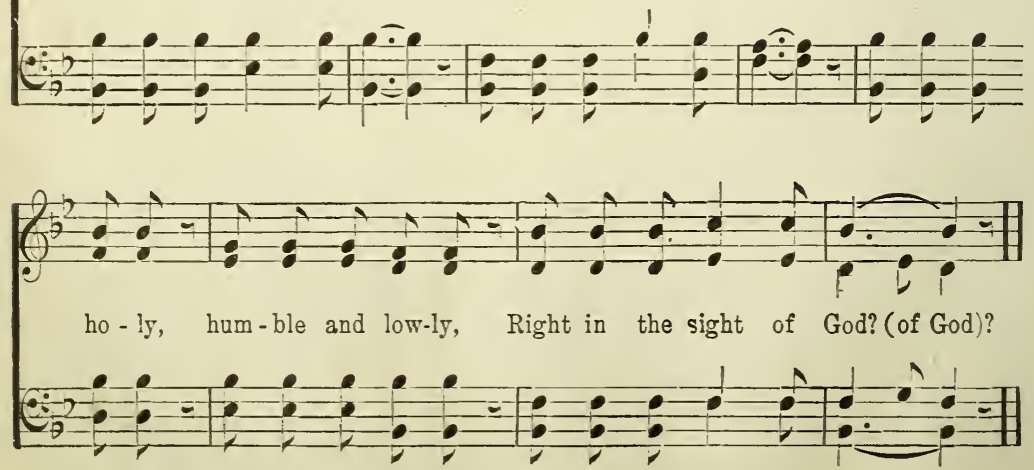

Used by per. of E. A. Hoffman, owner of copyright. 
LOUIS MORFAU GOTTSCHALK.

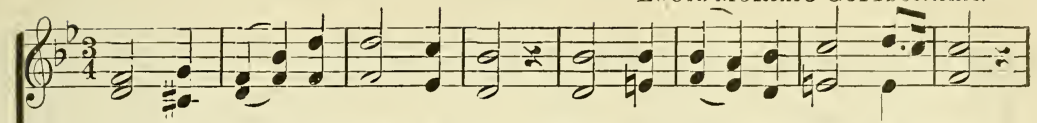

1. Ho - ly Ghost, with light di - vine, Shine up - on this heart of mine;

2. Ho - ly Ghost, with pow'r di - vine, Cleanse this guilt - y heart of mine;

3. Ho - ly Spi - it, all di - vine, Dwell with-in this heart of mine;
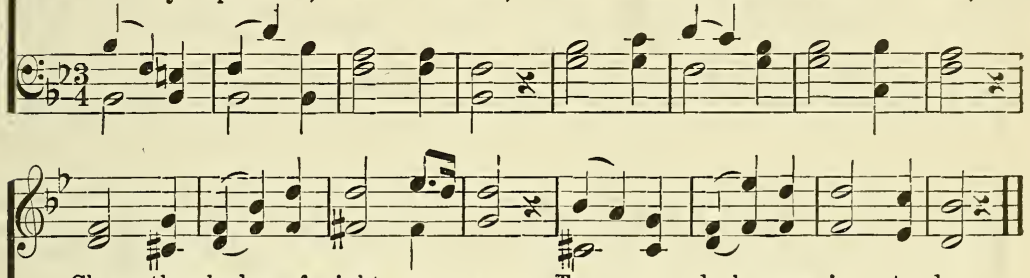

Chase the shades of night a - way, Turn my dark-ness in - to day.

Long hath sin, with-out con-trol, Held do-min - ion o'er my soul.

Cast down ev - 'ry i - dol-throne, Reign su-preme-and reign a-lone.

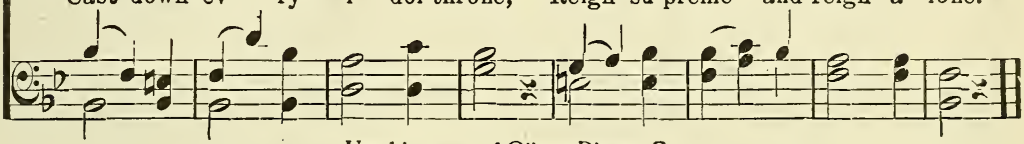

Used by per, of Oliver Ditson Co,

M. M. W.

Holy Spirit, Faithful Guide.

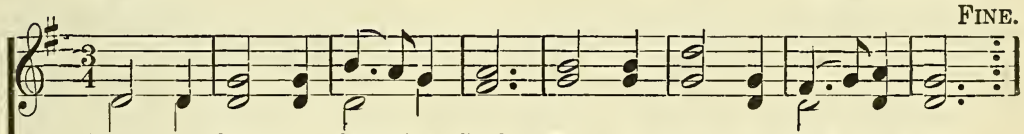

1. $\{$ Ho - ly Spir - it, faith-ful Guide, Ev - er near the Christian's side,

1. $\{$ Gen-tly lead us by the hand, Pil-grims in a des-ert land; $\}$ D. C.-Whisp'ring soft-ly wand'rer come? Fol - low me, I'll guide thee home.
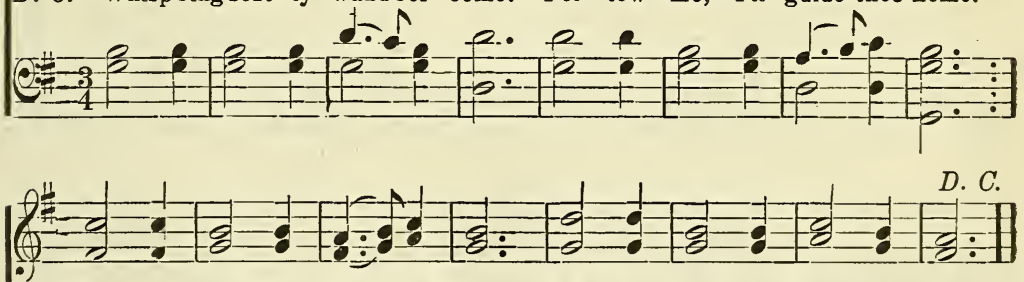

Wea - ry souls for e'er re-joice, While they hear that sweet-est voice,

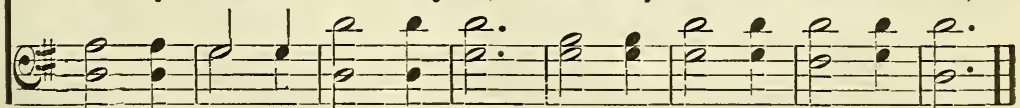

2 Ever present, truest Friend,

Ever near, thine aid to lend,

Leave us not to doubt and fear,

Groping out in darkness drear.

When the storms are raging sore,

Hearts grow faint and hopes give o'er;

Thisper softly, wand'rer, come!

Follow me, I'll guide thee home.
3 When our days of toil shall cease, Waiting still for sweet release, Nothing left but heaven and prayer, Wond'ring if our names are there; Wading deep the dismal flood, Pleading naught but Jesus' blood, Whisper softly, wandrer, come!

Follow me, I'll guide thee home. 


\section{Would You Know Why?}

C. D. MARTiN.

Mark 5:19

W. Stillman Martin.

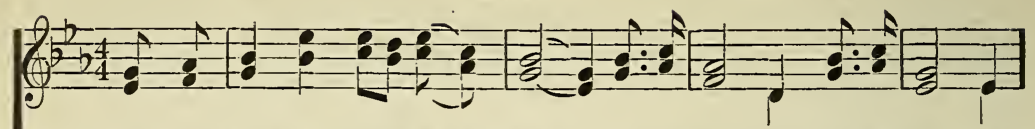

1. Would you know why Christ is my song? He redeemed me, He redeemed me;

2. Would you know why I praise His name? He redeemed me, He redeemed me;

3. Will you take Him as your own? He redeemed you, He redeemed you;

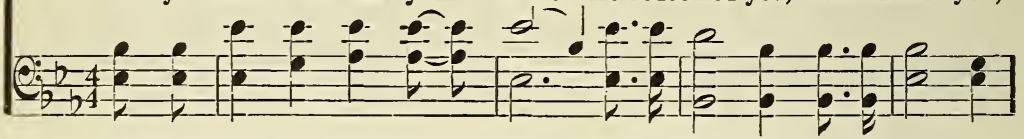

$\left(\begin{array}{ll}\frac{b}{2}-1 & -1\end{array}\right.$

Why $\mathrm{He}$ is my joy all day long? He redeemed me from all sin.

Why I seek to spread His fame? He redeemed me from all sin.

Will you help to make Him known? He redeemed you with His blood.

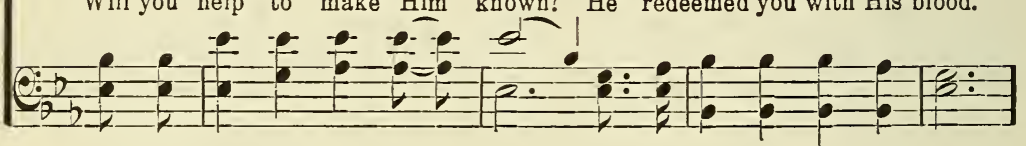

CHORUS.

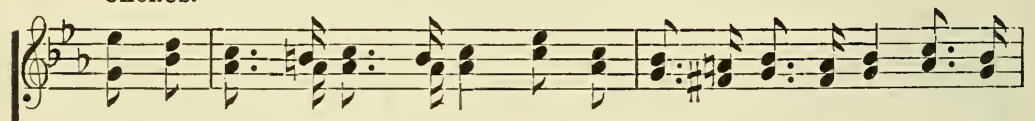

He has made me white as snow, This is why I love Him so, He re-

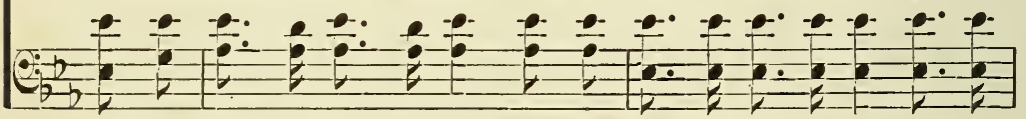

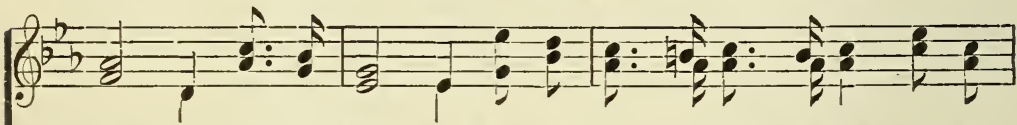

deemed me, He re-deemed me; This is why I sing His praise, This is

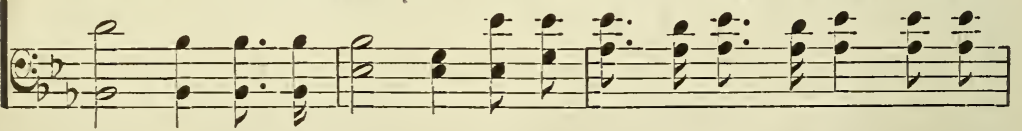

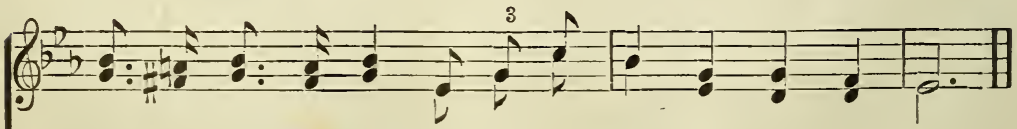

why I tell His grace, $\mathrm{He}$ has re-deemed me from all sin.

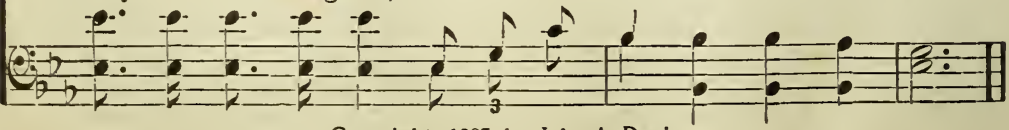

Copyright, 1905 , by John A. Davis. 


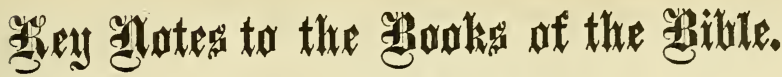

ARr. BY JOHN A. DAVIS.

1. Gen.-Beginnings.

2. Exodus-Covenant.

3. Lev. -A tonement.

4. Num.-Discipline.

5. Deut.-Obedience.

6. Josh. -Possessions.

7. Judges-Failure.

8. Ruth-Kinsman.

9-10 I. II. Sam. -Kingdom.

11-12 I., II. Kings-Royalty.

13-14 I., II. Chron.-The Temple.

15. Ezra.-Restoration (Relig1on)

16. Neh. -Political.

17. Esther.-Providence.

18. Job. - Tested.

19. Psalms.-Praise.

20. Prov.--Wisdom.

21. Eccl. - Vanity.

22. Song of Sol.-Love.

23. Isaiah. - Salvation.

24. Jer. -Warning.

25. Lam.-Chastening.

26 Ezek. - Visions.

27 Dan.-Kingdom.

28. Hosea. - Return.

29. Joel.-Judgment.

30. Amos.-Punishment.

31. Obediah. -Edom.

32. Jonah.-Repentance.

¿3ิ. Micah. -Controver.y.

34. Nahum. -Ninoveh.

35. Habak. -Faith.

36. Zephaniah. - Remnant.

37. Haggai. - Build.

38. Zachariah.-God ways.

39. Mal. - Robbery. New Testament

1. Matt. - Uhrist as King.

2. Mark. - The Mighty Worker.

3. Luke. - The Son of Man.

4. John. - Son of God.

5. Acts. $-W i$ tness.

6. Rom. - Justification.

7. I. Cor. - God's Power.

8. II. Cor.-Our Sufficiency.

9. Gal. -Liberty.

10. Eph. -In Ohrist.

11. Phil._Gain.

12. Col. -Fullness.

13. I. Thess. - Oomfort.

14. II. Thess. - Comfort

15. I. Tim. - Church. Order.

16. II. Tim. -Doctrine.

17. Titus. - Ministry.

18. Philemon.-Brotherhood.

19. Heb.-New Covenant

20. James. - Works.
21. I. Peter.-ChristianHope.

22. II. Peter. - The Last Days.

23. I. John.-Assurance.

24. II. John. - Truth.

25. III. John. - Fellow Helper.

26. Jude. -Kept.

27. Rev. -Overcome.

Key word to Chapters.

Shepherd. Ps. 23. Ezek. 34. John. 10.

Courage. Josh, 1.

Consecration. Rom. 12.

Prayer. John 17.

Holy Spirt, John 16.

Abiding. John 15.

Beginning. John I. Gen. I.

New Birth. John 3.

Water. John 4.

Bread. John 6 .

Lazarus. John 11.

Peace and Promise. John 14.

Crucitixion. John 19.

Ascension. Acts I.

Pentecost. Acts 2.

Deacon. Acts 6., I. Tim. 3.

Victory. Rom. 8.

Salvation. Rom. 10.

Jews and Gentiles. Rom. 11.

Gift. I. Cor. 12.

Love. I. Cor. 13. ,I. John 4.

Resurrection. I. Cor. 15.

Separation. II. Cor. 6.

Duty. Ezek. 33.

Marriage. Eph. 5.

Atonement. Heb. 9.

Faith. Heb 11

Fiery Furnace. Dan. 3

Work. James 2.

Assurance I John 5.

Heaven. Rev. 21.

Millenium. Rev. 20.

Baptism. Matt. 3.

Temptation. Matt.4.

Apostles. Matt. 10.

Revival. Joel. 2.

Hypocrites. Matt. 23.

Serviee. Luke 10.

Soldiers Eph. 6.

Repentance. Luke 13.

Excuses. Luke 14.

Lost and Found. Luke 15.

Zaccheus. Luke 19.

Joyful Ps. 98.

Great Ps. Ps. 119.

Travelers Ps. Ps. 2.

Intemperance. Prov. 23. 
108 Study to Show Thyself Approved.

Dedicated to The Practical Bible Training School, of Lestershire, N. Y. JNo. R. Clements. 2 Timothy 2: 15.

W. S. WEEDEN.

(1)

1. God's Word, as a lamp to the feet, shines bright;'Tis a brilliant light to the way;

2. God's. Word is the food for a hun-gry soul; 'Tis a mor-sel sweet to the taste;

3. God's Word is a song on our pil-grim way; 'Tis an an-them sweet to the ear;

4. God's Word is the key to the pearl-y gate, To the "cit - y fair, o'er the tide,"

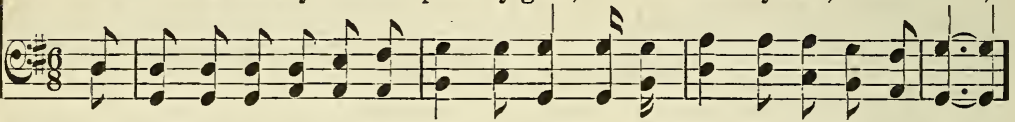
(Q)

It will keep a-right in the dark-est night; Whowalks by it nev-er can stray.

Give the Word control, if thou wouldst be whole, It builds up the drear-i-est waste.

It will cheer each day, let there come what may; It dries up the bit-ter-est tear.

Where our loved a-wait, tho' we tar - ry late; Where sav'd of the a - ges a - bide.
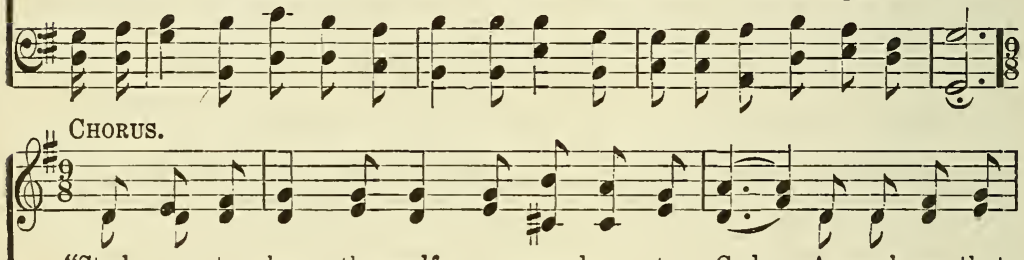

"Stud - y to show thy-self ap-proved un-to God; A workman that
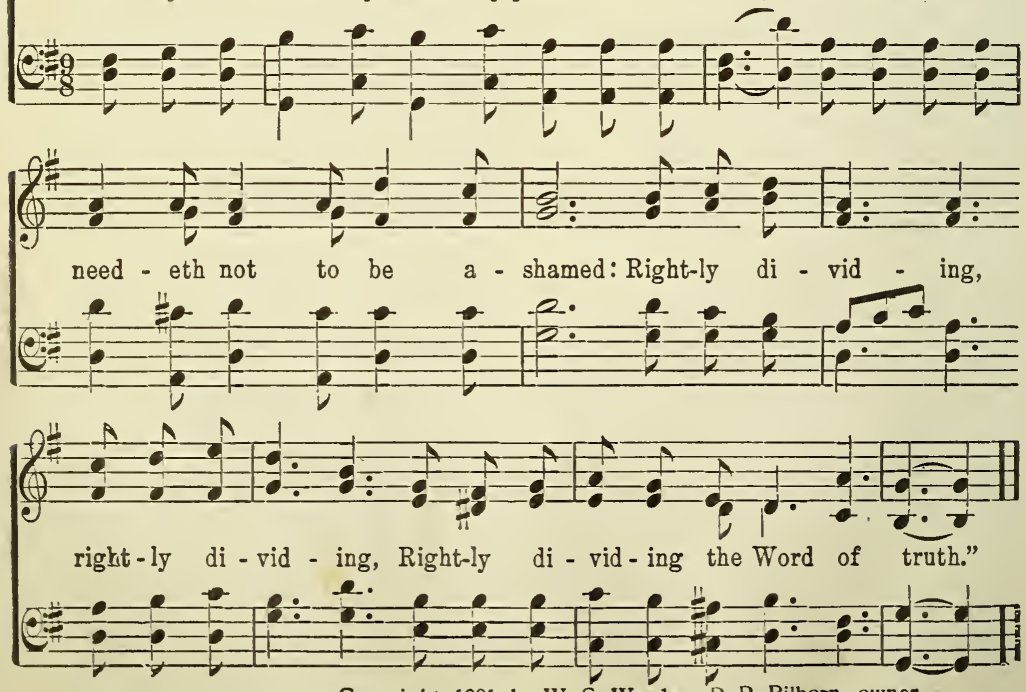

Copyright, 1901, by W. S. Weeden P. P. Bilhorn, owner. 
ARr. BY JOHN A. DAvis.

\section{UUHAT JESUS IS TO US.}

1 Saviour, Matt. 1:21.

And she shall bring forth a son, and thou shalt call his name JESUS: for he shall save his people from their sins.

2 Strength Phil. 4:13.

I can do all things through Christ which strengtheneth me.

3 The Way. John 14:6.

Jesus saith unto him, I am the way, the truth, and the life: no man cometh unto the Father, but by me.

4 The Unsearchable Riches. Eph. 3 :8.

Unto me, who am less than the least of all saints, is this grace given, that I should preach among the Gentiles the unsearchable riches of Christ.

5 Our Hope 1 Tim. 1: 1.

Paul, an apostle of Jesus Christ by the commandment of God our Saviour, and Lord Jesus Christ, which is our hope.

\section{SALVATION.}

For the grace of God that bringeth salvation hath appeared to all men. Titus. $2: 11$.

For by grace are ye saved through faith; and that not of yourselves; it is the gift of God.

1 It is a Present Salvation. II. Cor. $6: 2$.

For he said, I have heard thee in a time accepted, and in the day of salvation have I succoured thee: behold now is the accepted time; be= hold, now is the day of salvation.

2 It is a Free Gift Salvation. Rom. 6 : 23.

For the wages of sin is death; but the gift of God is eternal life through Jesus Christ our Lord.

3 It is a Great Salvation Heb. 2:3.

How shall we escape, if we neglect so great salvation; which at the first began to be spoken by the Lord, and was confirmed unto us by them that heard him.

4 It is a Common Salvation. Jude $1: 3$.

Beloved, when I gave all diligence to write unto you of the common salvation, it was needful for me to write unto you, and exhort you that ye should earnestly contend for the faith which was once delivered unto the saints.

5 It is The Only Salvation. Acts $4: 12$.

Neither is there salvation in any other: for there is none other name under heaven given among men, whereby we must be saved.

6 It is a Finished Salvation. John $19: 30$.

When Jesus therefore had received the vinegar. he said, It is finished, and he bowed his head, and gave up the ghost.

7 It is an Eternal Salvation. Heb. 5 : 9.

And being made perfect, he became the author of eternal salvation unto all them that obey him. 
IIO III. Seven Things the Christian Should Be.

1. Light. Matt. $5: 14$.

Ye are the light of the world. A city that is set on an hill cannot be hid.

2. Salt. Matt. $5: 13$.

Ye are the salt of the earth: But if the salt have lost its savor, wherewith shall it be salted? it is thenceforth good for nothing, but to be cast out and to be trodden under foot of men.

3. Burden Bearers. Gal. 6 : 2.

Bear ye one another's burdens and so fulfill the law of Christ.

4. Servants. John 13:16.

Verily, verily, I say unto you, The servant is not greater than his lord, neither he that is sent greater than he that sent him.

5. Epistles. 2 Cor. 3 : 3 .

For as much as ye are manifestly declared to be the epistle of Christ ministered by us, written not with ink, but with the Spirit of the living God; not in tables of stone, but in fleshy tables of the heart.

6. Disciples. John $15: 8$.

Herein is my father glorified, that ye bear much fruit; so shall ye be my disciples.

7. Witnesses. Acts 1:8.

But ye shall receive power, after that the Holy Ghost is come upon you; and ye shall be witnesses unto me both in Jerusalem, and in all Judæa, aud in Samaria, and unto the uttermost part of the earth.

\section{IY. THINGS WE NEED AND HOW SUPPLIED.}

But my God shall supply all your need according to his riches in glory by Christ Jesus. Phil. 4 : 19 .

\section{MAN NEEOS. JESUS SUPPLIES.}

1 Salvation, John $3: 16$. For God so loved the world, that he gave his only begotten Son, that whosoever believeth in him should not perish, but have everlasting life. 12 Light, John $8: 12$. Then spake Jesus again unto them saying I walk in darkuess, but shall have the light of life.

3 Bread, John $6: 35$. And Jesus said unto them, I am the bread of life: he that cometh to me shall never hunger.

4 Water, John $\%: 3 \%$. Jesus stood and cried, saying, If any man thirst, let him come unto me and drink.

15 Truth, John 14:6. Jesus saith unto him, I am the way, the truth and the life.

6 Joy, John $15: 11$. These things have I spoken unto you, that my joy might remain in you, and that your joy might be full.

7 Peace, John 14:27. Peace I leave with you, my peace I give un= to you: not as the world giveth, give I unto you. Let not your heart be troubled.

8 Friendship, John $15: 14 \cdot$ Ye are my friends, if ye do whatsoever I command you.

9 Knowledge, John $7: 17$. If any man will do his will, he shall know of the doctrine, whether it be of God, or whether I speak of myself.

10 Holy Spirit, John 16:7. Nevertheless I tell you the truth; It is expedient for you that I go away: for if I go not away, the Comforter will not come unto you; but. if I depart, I will send him unto you. 
1 We are to Believe. John $3 ; 16$.

F'or God so loved the world that he gave his only begotten son, that whosoever believeth in him should not perish, but have everlasting life.

2 To Know. 1 John $5 ; 13$.

These things have I written unto you that believe on the name of the Son of God: that ye may know that ye have eternal life, and that ye may believe on the name of the Son of God.

3 To Confess. Matt. 10: 32, 33.

Whosoever therefore shall confess me before men, him will I confess also before before my Father which is in heaven. But whosoever shall deny me before men, him will I also deny before my Father which is in heaven.

4 To Remember. 1 Cor $10: 13$.

There hath no temptation taken you but such as is common to man: but God is faithful, who will not suffer you to be tempted above that ye are able; but will with the temptation also make a way to escape that ye may be able to bear it.

5 To Live. Gal. $2: 20$.

I am crucified with Christ nevertheless I live; yet not I but Christ liveth in me; and the life which I now live in the flesh I live by the faith of the Son of God, wholoved me, and gave himself for me.

6 To Heed. Phit. $4: 8$.

Finally, brethren, whatsoever things are true, whatsoever things are honest, whatsoever things are just, whatsoever things are pure, whatsoever things are lovely, whatsoever things are of good report; if there be any virtue, and if there be any praise, think on these things.

7 To Practice, Rom. 6; 15.

Neither yield ye your members as instruments of unrighteousness unto sin: but yield yourselves unto God, as those that are alive from the dead, and your members as instruments of righteousness unto God.

8 To Pray. Eph. 3 : 17 to 19.

That Christ may dwell in your hearts by faith; that ye, being rooted and grounded in love, may be able to comprehend with all saints what is the breadth, and length, and depth, and height; and to know the love of Christ, which passeth knowledge, that ye might be filled with all the fulness of God.

9 To Preach. Rom. 1; 16.

For I am not ashamed of the gospel of Christ; for it is the power of God unto salvation to every one that believeth; to the Jew first, and also the Greak.

10 To Study. II. Tim. $2 ; 15$.

Study to shew thyself approved unto God, a workman that needeth not to be ashamed, rightly dividing the word of truth. 


\title{
To be used as a Looking Glass Before Prayer.
}

\author{
ARR. BY JOHN. A. DAVIS.
}

Each question to be asked thoughtfully and prayerfully.

1. To Whom am I going?

See Isa. 6,1 to 8 .

2. For what purpose am I going to God?

(Did you ever analyze one of your prayers.) Study John. 17.

3. Have I had power with God in prayer and am I conscious of His presence when I pray? (See Christ)John. $11: 41,42$

4. Have $I$ entered the school of prayer seeking the mind of God as revealed in His word and by His spirit?

IIatt, $26: 39$,

5. Am I makina use of God's promise, (as I ought.)

(See Phil. 4 : 19. Ps. 37.)

6. Do I really expect God to answer my prayer?

Jas. $1: 5$ to 7

7. Do I pray without ceasing, (depending on the Holy Spirit to help me.) Luke $18: 1$.

8. Do I use a prayer list and honor the requests of others? Acts. $12: 5$.

9. Am I living right? Prov, $1: 24$, to29

10. Do I give as much time to prayer as $I$ ought?

Luke $6: 12$.

11. Does my pocketbook hinder my prayer life?

Luke $18: 9$ to 16 .

12. Has prayer been more to me a duty than a privilege? Study John 15.

13. Am I improving the time?

See, Paul says "Brethren, the time is short," -1 . Cor. $7: 29$.

14. Am I teachable? Jer. $33: 3$.

15. 'Am Iwilling to receive answers to my prayers daily in God's way? Jas. $4: 3$.

16. Am I willing to follow Christ's teaching and example in prayer?

Heb. $5: 7$.

17. Has my prayer life been fruitless because of-

1. A neglect of anything? 4. Questionab'e practice?

2. Wrong motives?

3. Disobedience?

5. Besetting sins?

Ps. $66: 1$,

18. Have the following had the proper places in my prayer life?

1. Adoration.

2. Petition.

3. Confession.

4. Thanksgiving.
5. Restitution.

6. Forgiveness.

\%. Submissiveness.

8. Faith.

Are you right with God? LORD TEACH US TO PRAY. 


\section{one with the Best Results,}

A Revival is a time of quickening or impartation of life. God alone can give life, and so a revival is a time when God visits His people and by the power of His Spirit imparts new life to them, and through them im. parts life to sinners dead in trespasses and sin.

\section{New life from God-that is a revival.}

Study the following Scripture. Psa. 85:6-13. Isa. 40:1-5. Mal. 3:10. Hab. 3:2. Hos. 6:1-3. Acts 3:19. Acts 2nd chap. and Book of Acts.

Revivals have marked the history of God's dealings with His people. They have blazed a glorious path through the centuries. Mr. Moody defined a revival as "a bringing forth from obscurity"

The Need is very great. Look at the Church with many of it's pastors preaching because they feel it is a duty, without the deep burning love for souls and the precious Word. See Paul much in prayer with tears following his preaching by beseeching men every where to be reconciled to God. One trouble is, many of the members of the churches do not study the Bible as if they believed it to be the Word of God; and a neglect of the Word of God goes hand in hand with neglect of earnest prevailing prayer.

Very many Christains, so called, spend a great deal more time with Sunday newspapers, wallowing through murder and sensation, and in reading trashy literature, than they do in bathing in the cleansing laver of God's Word. Many church members are just as eager as any in the rush to get rich. They use the methods of the world in the accumulation of wealth and hold just as fast to wealth as any when they have gotten it.

There is a great lack of generosity. The churches are rapidly increasing in wealth but the treasuries of missionary societies are suffering. Christians do not average $\$ 1.00$ a year for foreign missions. It is simply appalling to see the disregard for the Lord's Day; it is fast becoming a day of worldly pleasure instead of a day of holy service to God. Many are mingling with the world in all forms of questionable amusements intead of entering into fellowship with Jesus Christ in His burden for souls.

Look at the awful state of the unsaved world. "If the righteous scarcely be saved where shall the ungodly and the sinner appear", with a lack of conviction of sin and so few conversions compared with the great mass? Unbelief and gross immorality lift their serpent heads every where.

Look at the awful greed for money and the way in which men are selling their souls in the mad rush, living for self and worldly pleasure.

The moral condition of the world in our day is disgusting, sickening appalling. We need a revival as nature needs revival in springtime.

See example of revivals in politics, business and almost everything else. We need a revival for the most important thing in this world-God's work in soul-saving for Eternity.

Concerning Methods I believe in securing the best Evangelist obtainable to work with the pastors. A new voice and way of presenting the truth by a man called to be an evangelist aids in reaching men. I believe in good gospel singing and wise advertising, special committees, after meetings and every other good thing and yet all this will avail little without the right spirit hehind them. with all our methods and plans God must give the increase and our efforts should be the result of much praying, II. Chron. 7:14. "If my people, which are called by my name shall humble themselves and pray and seek my face, and turn from their wicked ways; then will I hear from heaven, and forgive their sin and will heal their land". 
do His will with prayer, humiliation, confessing our sins and making things right, He will send a blessing, with the result that the pastor and people will have a new love for souls which will compel them to work earnestly, and a new love for and faith in God's Word, which will enable them to preach and testify with new power and liberty.

A genuine revival is not only a blessing to the Christian but brings deep conviction of sin, conversion and then regeneration. When God refreshes his people $\mathrm{He}$ converts sinners also. The first result of Pentecost was new life and power to the 120 disciples in the upper room.

Second result was three thousand conversions in a single day. We need a revival, deep, far-reaching and general in the power of the Holy Spirit. That is the only cure for stemming the awful tide of sin.

A new life from God.-Let us pray for it, take up Ezekiel's prayer, "Come from the four winds, O, breath (breath of God), and breathe upon these slain that they may live." Oh! that we may see a living army rising to thus fight for God and righteousness. Let us pray and pray and pray, till the spirit of God moves his people. Take up the Psalmist's prayer, "Revive us again, that thy people may rejoice in thee".

\section{How To Be Filled With The Holy Spirit.}

Have ye received the Holy Ghost since ye believed? was the question Paul asked. See Acts 19:2. Shall we ask it now?. God says in Eph. 5:18, "Be filled with the spirit." Acts, 1:8. "Ye shall receive power after that the Holy Ghost is come upon you". There is a great lack of power in our churches and lives to-day.

The Need.-See that factory with all its splendid machinery but it needs power to run it. The churches are well equipped, but they need the power of the Holy Spirit. Yes, the evangelist, singer, pastor, teacher, and every member of the church, fathers and mothers, all need Him and all may be filled with the Holy Spirit for service.

Who Is The Holy Spirit?-He is a person. See John 16:13.

His Work.-He convicts the world of sin and of righteousness and of judgment, He makes anew or regenerates. John 3:3-5. Every true believer has the Holy Spirit. You cannot be a child of God and in the Kingdom of God unless you are born again. But it is one thing to accept Christ as your Saviour, another thing to yield your life to Him as Lord and Master and recognize the Holy Spirit's right of way in your life, because you are bought with a price, the precious blood of Christ. It is your birthright. Also study I. Cor. 12:4-14. Luke 24:49. Matt. 3:11. Acts. 1:8. Rom. 8 chapter and Acts. 2 .

How To Be Filled.-We must see our need and utter helplessness to do God's work, without this power, and surrender our wills and lives and claim the blessing. See Acts 2:38-39. Luke 11:13. By faith, the faith that counts it as its own (see Mark 11:24.) with the motive to glorify God and then obey what ever the Spirit tells us to do. Three things may help us to know God's will. (1st,) The Word. (2nd) Inward impressions. (3rd) Outward circumstances. All three should agree.

The Results will be manifested in service, the Spirit taking possession of our faculties imparting to us some gifts not otherwise our own. He will help to qualify you for the service to which God has called you. Being occupied with Christ and spiritual things, $\mathrm{He}$ guides into all truth, strengthens for every good work, gives victory over the flesh, world and the Devil, so we may bring forth the fruit of the Spirit, (See Gal. 5:22:23) enabling us to pray, preach and testify with liberty and holy boldness, to aid others and lead souls to Christ.

Be filled with the spirit. 
JOHN R. CLEM ENTS. Words sad Music Copyright, 1904, by P. P. Bllborn.

DuET. For all voices.

P. P. BILHORN.

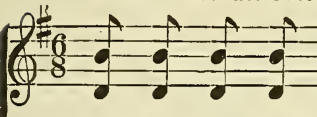

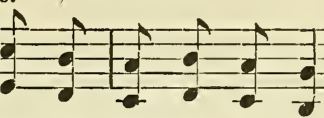

1. Je - sus is wait-ing to give you to-day

$-\frac{1}{2}+\frac{1}{-1}+\cdots$

2. Ma - ny, so ma - ny, have nev - er re-ceived Full-ness of pow'r,

3. Ask for thy la - bors to res - cue the lost, Full-ness of pow'r,

4. Low let us bow as we ask God to give Full-ness of pow'r,

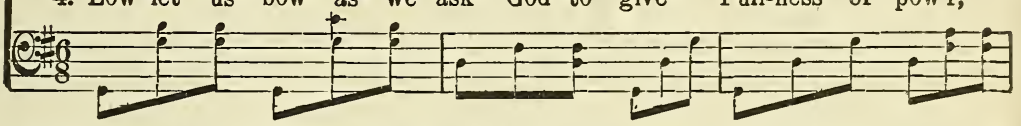

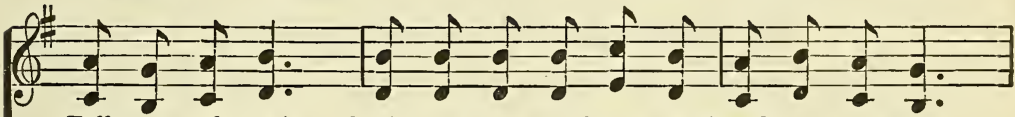

Full-ness of pow'r; Wait - ing to send you equipped on your way,

Full-ness of pow'r; Nev - er have pray'd for it since they be-lieved,

Full-ness of pow'r; Would you suc-ceed? Then you must pay the cost,

Full-ness of pow'r; As its pos - ses-sors for Him let us live,

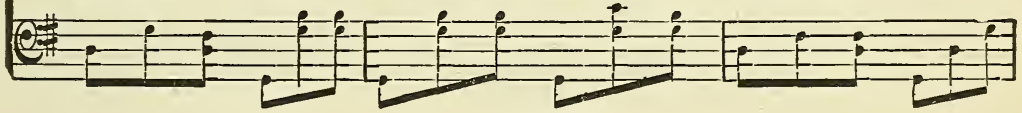

(2)

Wait-ing to fill you this hour.

Tho' 'tis their heav-en-ly dower. Full - ness of Pow - er,

For heav-en's boun-ti-ful shower.

Clothed with the fullness of pow'r. Full -ness of pow'r,

$\frac{2}{2}=\frac{2}{2}=2$

full-ness of pow'r,

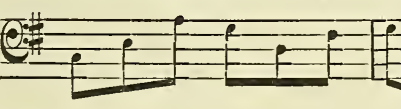

슨

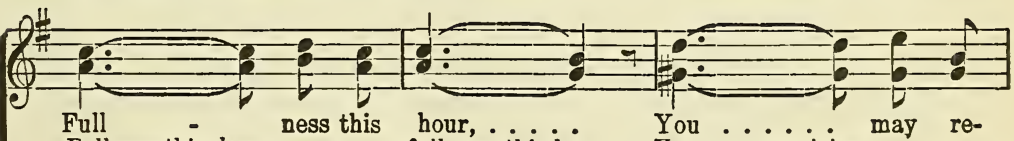

Full-ness this hour, ness this full-ness this hour, You may re-joice,
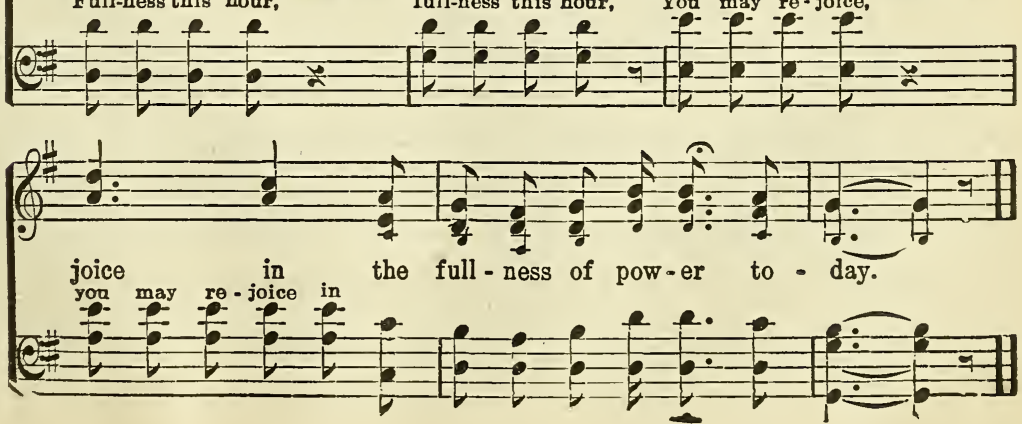
Selected by JoHN A. DAVIS.

Fiery trials make golden Christians.

God looks most where man looks least-at the heart.

The reward for service is more service.

He who seeks trouble will have no trouble in finding it.

Hem your blessings with praise less they unravel.

He who sins for profit will not profit by his sins.

Character is what a man is in the dark. (Morgan).

Your blessing will not be a blessing until you are a blessing

If it is nothing to you say nothing about it.

- If you blow out another man's candle it will not light your own

If you cannot help don't hinder.

If you say nothing no one will repeat it.

It is sure to be dark if you shut your eyes.

If sin were not deceitful it would never be delightful.

Improve time in time while time doth last;

For all time is no time when time is past.

Sin puts hell into the soul and the soul into hell.

Sorrow is inseparable from sin.

A sick man helped by you shall make you strong.

Wish for and work for the best things.

Lift up your heads ye sorrowing ones and be ye glad of heart; for Calvary-Day and Easter-Day-earth's Saddest day and

Gladdest day were just one day apart.

Teach by your lives.

Cursing men are cursed men.

Do good with your money or it will do you no good.

Putting off till to-morrow will lead us to sorrow.

In the Home, ORDER is its BEAUTY. CONTENTMENT is its BLESSING. HOSPITALITY is its GLORY.

GODLINESS is its CROWN.

Life is too short to waste.

Don't be yoked to one who refuses the yoke of Christ.

Don't pray and talk cream and live skim milk.

The doctor does not fight the patient but the disease.

Be not simply good; be good for something.

Dost thou lore life? than do not squander time for that is what life in made of.

Dare to do right and walk in the light.

Evil reaorts find willing ears. 


\section{CHOICE NUGGETS.}

eesees

The Devil is never too busy to rock the cradle of a sleeping Saint. -

Opportunities travel on wings.

Heart wisdom is ahead of book learning.

We interpret things according to the condition of our own heart.

Men are willing to pay a high price for damnation when salvation is free.

Mourning over present troubles makes us forget past blessings.

Some folks get rid of their religion by letting it run out of their = mouths.

Faults are thick where love is thin.

Error always stubs its toes on a fact.

Count yourself richer the day you discover a new fault in yourself.

Loving God is letting God love you.

$\mathrm{He}$ wants all of us that $\mathrm{He}$ can be all to us.

If you would lift me up you must be on higher ground.

Starving the Soul to feed the body makes lean Christians.

If a sermon pricks your conscience it must have good points.

A dog with a gold collar is still a dog.

Resolves are like blossoms, actions like fruit.

Sunstrokes affect the head, sinstrokes the heart.

Sweetness at home gives power abroad.

Beware of any sociey in which you feel compelled to put a bushel over your testimony.

When thou prayest rather let thy heart be without words than thy words without heart.

Eternity is God's life time.

Salvation cannot be analyzed but must be realized.

To bring up a child in the way he should go travel that way yourself.

Better be a poor man and a rich Ohristian than a rich man and a = poor Christian.

Take Christ with you as a friend and when you meet any one introduce him.

A handiul of good life is worth a bushel of learning.

There is a great difference between a man being white washed and being washed white.

This is the hour for doing good. 


\title{
Responsive Readings in Public
}

\section{and Family Altar at Home.}

\author{
Arr, by J.A. DAVIS.
}

Selection 1.

(AN OPENING RESPONSE)

Surely the Lord is in this place.

This is none other than the house of God; and this is the gate of heaven.

Serve the Lord with gladness.

Come before His presence with singing.

Enter into His gates with thanksgiving.

And into His courts with praise.

Give thanks unto Him, and bless His name.

For the Lord is good; His mercy endureth forever.

O sing unto the Lord a new song:

For great is the Lord, and greatly to be praised:

Honor and majesty are before Him.

Strength and beauty are in His sanctuary.

Give unto the Lord the glory due unto His name:

0 worship the Lord in the beauty of holiness.

\section{Selection 2.}

(A GCRIPTURAL CONFESSION)

Behold the Lamb of God which taketh away the sin of the world.

All we like sheep have gone as= tray; we have turned every one to his own way, and the Lord hath laid on Him the iniquity of us all.

Let the wicked forsake his way and the unrighteous man his thoughts, and let him return unto the Lord, and $\mathrm{He}$ will have mercy upon him; and to our God, for He will abundantly pardon.
O God, I acknowledge my trans. gressions, and $\mathrm{my}$ sin is ever before me. Wash me thorough: ly from mine iniquity, and cleanse me from my sin. Cast me not away from Thy presence, and take not Thy Holy Spirit from me. Create in me a clean heart, 0 God, and renew a right spirit within me.

God was in Christ reconciling the world unto Himself, not imputing their trespasses unto them, and hath committed unto us the word of reconciliation.

There is, therefore, now no con= demnation to them which are in Christ Jesus, who walk not after the flesh, but after the spirit.

Let us therefore come boldly unto the throne of grace, that we may obtain mercy, and find grace to help us in time of need.

\section{Selection 3.}

(From Psaturs 122, 125.)

I was glad when they said unto me, Let us go unto the house of the Lord.

Pray for the peace of Jerusalem. They shall prosper that love thee.

Peace be within thy walls, And prosperity within thy palaces.

For my brethren and companion's sakes, I will now say, Peace be within thee.

For the sake of the Lord our God I will seek thy good.

They that trust in the Lord are as Mount Zion, which cannot be moved, but abideth for ever.

As the mountains are round about Jerusalem, so the Lord is round about his people. From this time forth and for evermore. 


\section{Selection 4.}

(Psarias 1)

Blessed is the man that walketh not in the counsel of the ungodly,

Nor standeth in the way of sinners, Nor sitteth in the seat of the scornful.

But his delight is in the law of the Lord.

And in His law doth he meditate day and night.

And he shall be like a tree planted by the rivers of water,

That bringeth forth its fruit in its season,

Whose leaf also does not wither;

And whatsoever he doeth shall prosper.

The wicked are not so; but are like the chaff which the wind driveth away.

Therefore the wicked shall not stand in the judgement, nor sin= ners in the congregation of the righteous.

For the Lord knoweth the way of the righ teous:

But the way of the ungodly shall perish.

\section{Selection 5.}

(Psatir 23)

The Lord is my shepherd; I shall not want.

He maketh me to lie down in green pastures: He leadeth me beside the still waters.

Hé restoreth my soul:

He leadeth me in the paths of righteousness for His name's sake.

Yea, though I walk through the valley of death, I will fear no evil:

For Thou art with me; Thy rod and Thy staff, they comfort me.

Thou preparest a table before me in the presence of mine enemies:

Thou anointest my head with oil; My cup runneth over.
Surely goodness and mercy shan follow me all the days of my life;

And I will dwell in the house of the Lord for ever.

\section{Selection 6 .}

(From Psalms 19)

The heavens declare the glory of God;

And the Firmament showeth his handiwork.

Day unto day uttereth speech, And night unto night showeth knowledge.

There is no speech nor language where their voice is not heard.

Their line is gone out through all the earth, and their words to the end of the world.

The law of the Lord is perfect, re storing the soul:

The testimony of the Lord is sure, making wise the simple.

The precepts of the Lord are right, rejoicing the heart:

The commandment of the Lord is pure, enlightening the eyes.

\section{Selection 7.}

(From Joms 10.)

Then said Jesus unto them:

Verily, verily, I say unto you, I am the door of the sheep.

I am the door; by $\mathrm{Me}$ if any man enter in, he shall be saved.

The thief cometh not, but to steal, and to kill, and to destroy:

I am come that they might have life, and that they might have it more abundantly.

I am the good shepherd: The good shepherd giveth his life for the sheep.

I am the good shepherd, and know my sheep, and am known of Mine

As the Father knoweth $M e$, even so I know the Father:

And I lay down My life for the sheep. 
"Whither thou goest, I will go."-Ruth 1: 16.

W. S. M.

W, Stillman Martin.

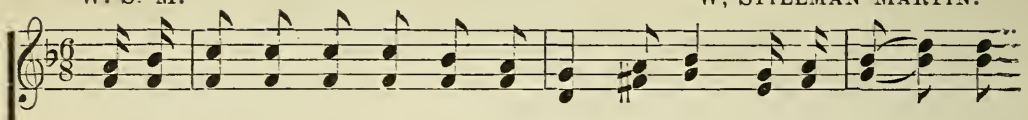

1. There's a beau - ti - ful coun-try just $0^{\prime}$ er the way, Where they rest in the

2. There is free-domfrom sin on that hap - py shore; There all sor-row and

3. There's a moth-er who asked you to meet her there; There's a ba-by, the

4. There is noth-ing un - ho-ly can reach that place, 'Tis the pure in
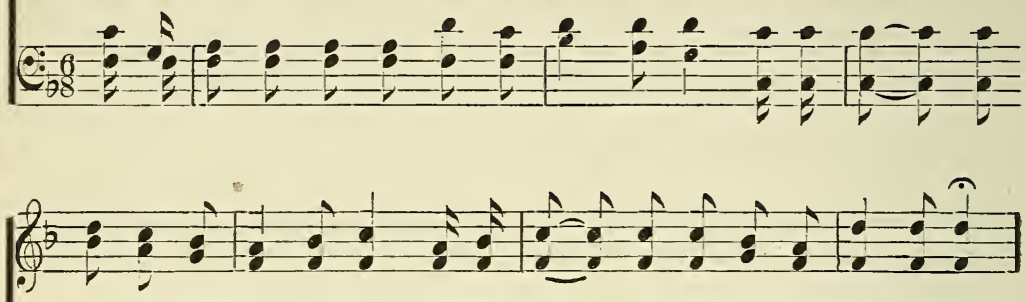

light of e - ter - nal day, And with Je - sus, the King, they shall reign for aye; sigh - ing will be nomore; There you'll meet the dear friends who have gone be-fore; child of your ten-der care, There's a friend in whose hap-pi-ness you may share; heart who shall see His face, And their song of joy is re-deem-ing grace;

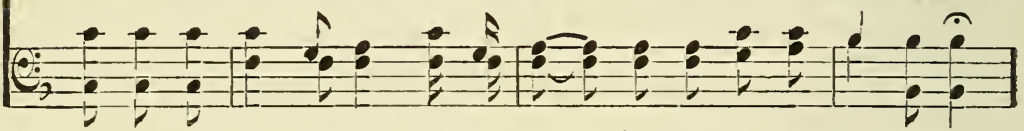

Chorus.

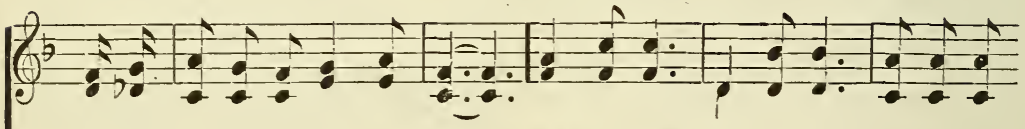

Will you go to that land with me? Will you go? will 5oa go? Go to that
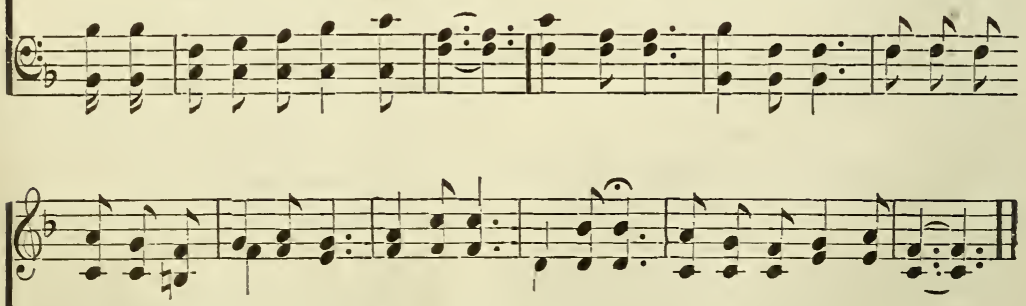

beau-ti - ful land with me? Will you go? will you go? Go to that land with me?

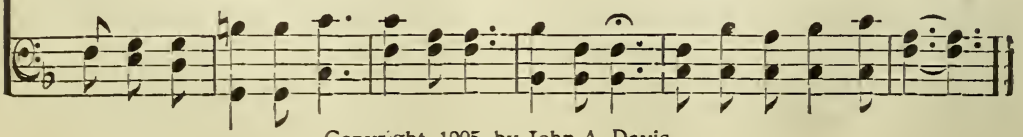

Copyr ght, 1905, by John A. Davis. 
J. KING.

Arr, by W S. M.

1. When His sal - va-tion bringing, $\mathrm{To} \mathrm{Zi}$ - on Je-sus came, The
2. And since the Lord re - tain-eth $\mathrm{His}$ love for chil-dren still, Tho'
3. For should we fail pro-claiming Our great Re-deemer's praise, The

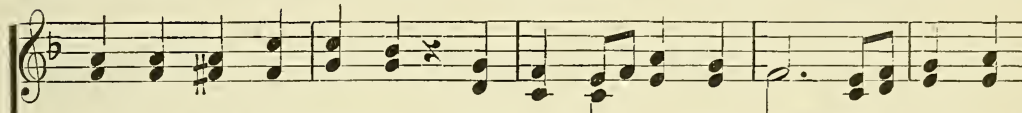

chil-dren all stood sing - ing "Ho-san - na to His name;" Nor did their now a Priest, He liv - eth On Zi - on's ho - ly hill, We flock astones our si-lence sham-ing Would their ho-san-nas raise; But shall we

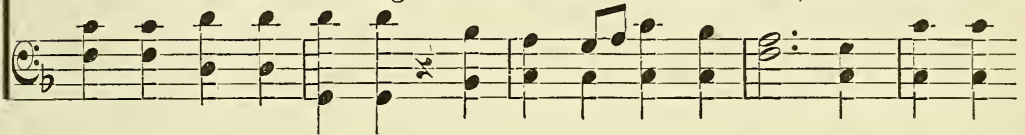

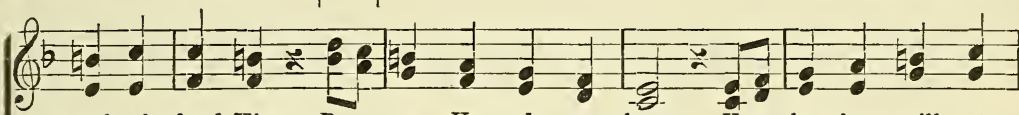
zeal of - fend Him; But as He rode a - long, He let them still atround His ban-ner, We bow be-fore His throne, And cry a-loud "Hoon-ly ren-der The trib-ute of our words? No, while our hearts are

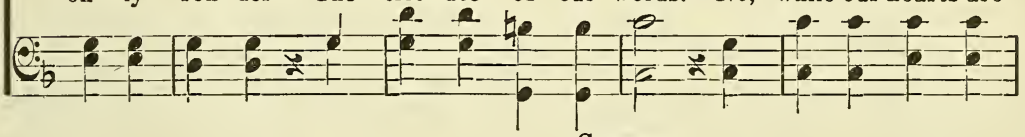

Chorus.

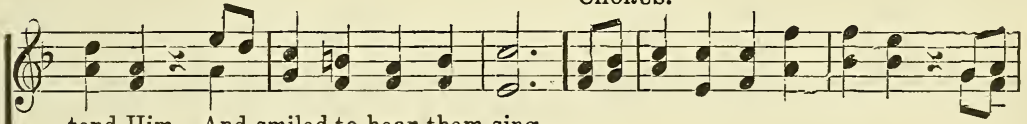

tend Him And smiled to hear them sing.

san-na To Da-vid's roy - al Son." Fling out, fling out the ban-ner of ten-der, They too shall be the Lord's.
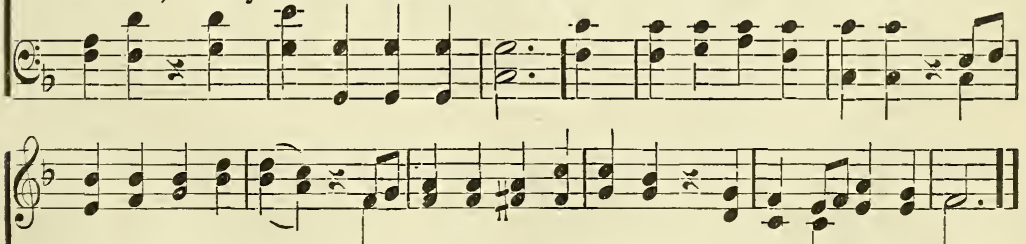

Christ the heav'nly king, Ring out, ring out Ho-san-na And hal-le-lu-jah sing.

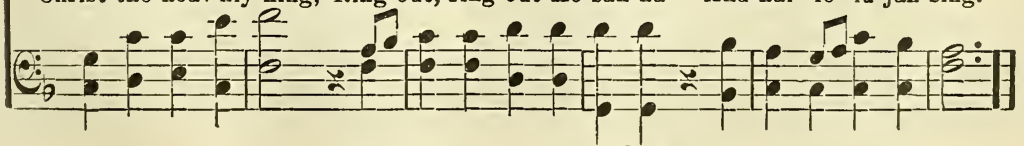

Cooyright, 1905, by John A. Davis. 


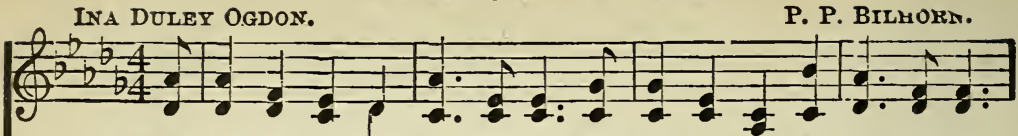

Tords and Murio Copyright, 1904, by P. P. Bulborn.

1. My soul se-cure, no fear I know, With songs of praise I home-ward go;

2. No mat-ter what my grief or strife,No mat - ter what the storms of life,

3. The heal - ing wa - ter cheers my way,The liv - ing man-na greets my day;

4. Would you from sin and darkness flee?Would you from pain and death be free;

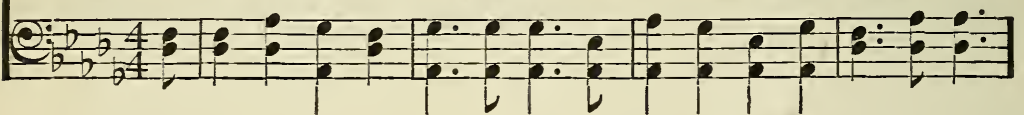

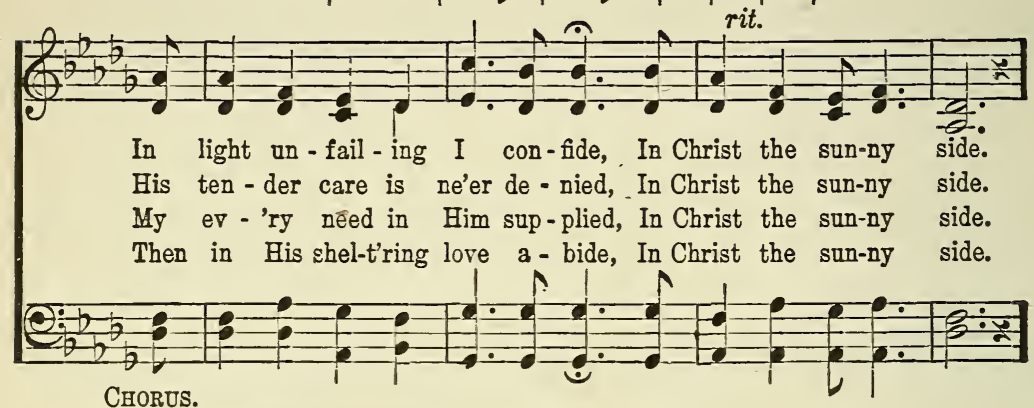

CHORUS.

$\frac{0^{2}-\frac{b}{2}-6}{28} \div$

Christ ........ is the sun - ny, the sun - ny side;

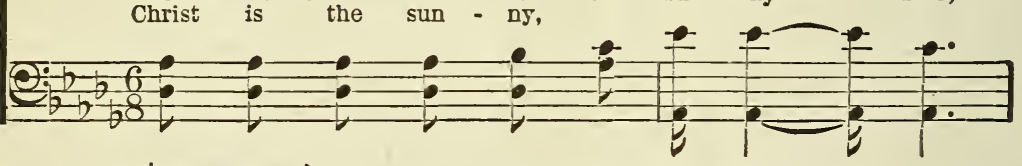

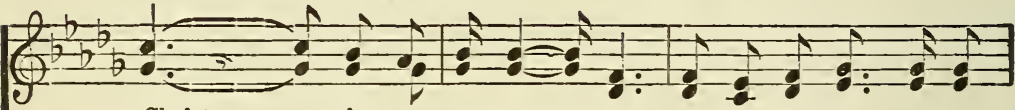

Christ . - is the sun-ny side; Safe-ly He hid - eth me,

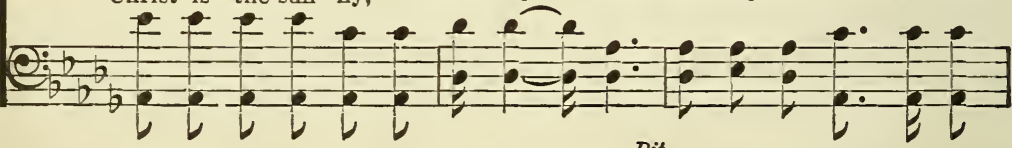

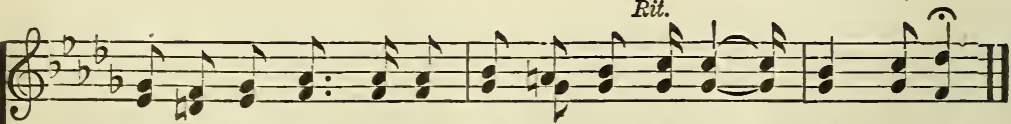

Gen-tly He guid - eth me, Christ is the sun-ny side of life.

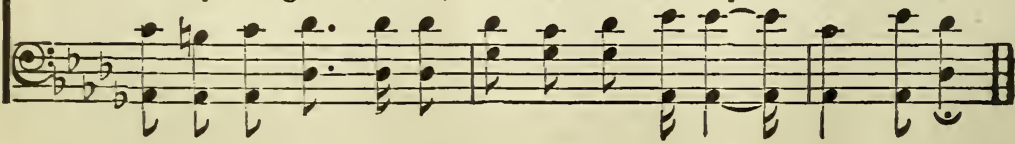




\section{Far Beyond Our Fairest Vision.}

W. S. M.

"Behold the half was not told me."-1 King 10;7.

Theme from G. F. RooT.

W. Stillman MartiN.

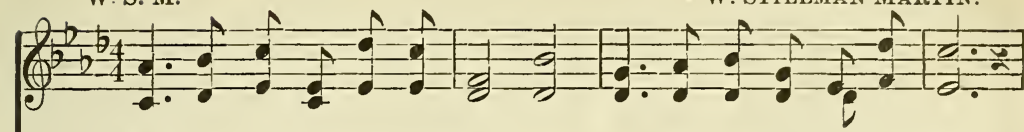

1. Far be-yond our fair-est vis - ion, Is the land of cloud-less day;

2. Streets of gold and walls of Jas - per, Gates of pearl and jew-els rare;

3. Half of all the cit-y's beau-ty, Nev-er yet has been made known;
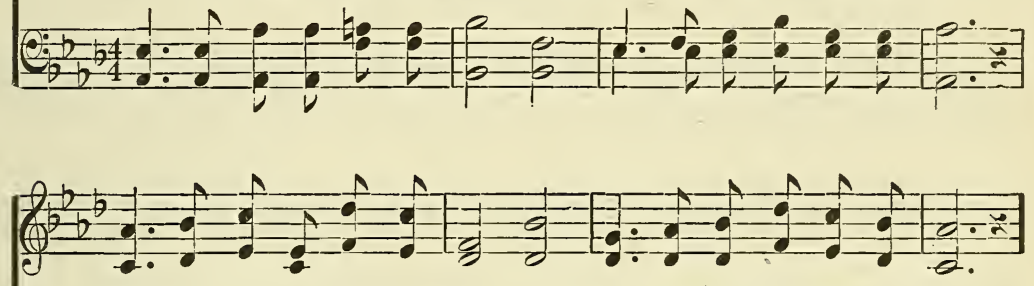

Where is beau-ty bright and ver - nal, Where all tears are wiped a - way.

Seek the man-sions up in heav-en, Best of all the Lord is there.

But the chief a-mong ten thousands, Is the Lamb up-on the throne.

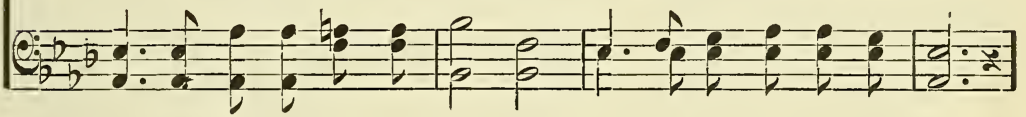

CHORUS.

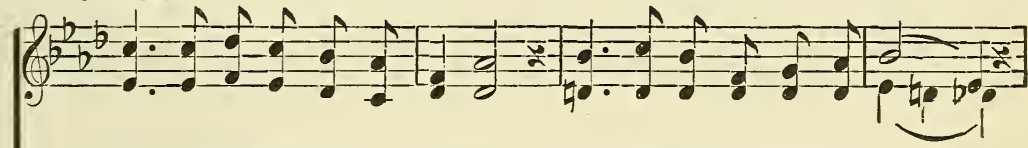

"Where I am," sweet words of Je-sus, "There shall all my servants be;"
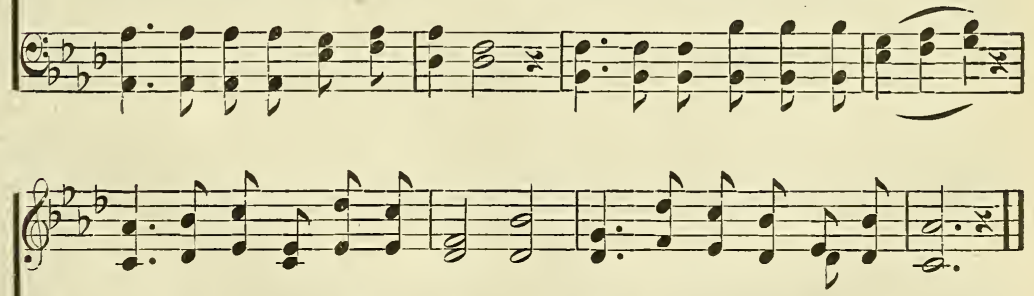

"In the glo - ry grand, e - ter - nal, They shall reign for aye with me."

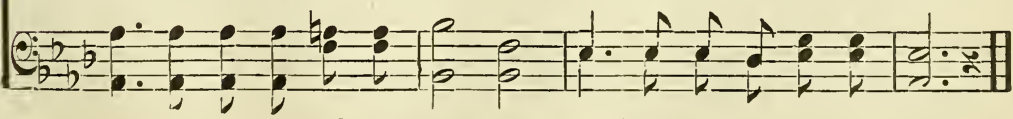

Copyright, 1905, by John A. Davls. 


\section{JNo. R. Clements.

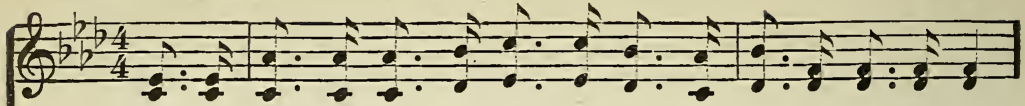

1. Don't you hear the Sav - ior call - ing In those tones so matchless sweet?

2. Don't you hear the Sav - ior call - ing? How He loves each wand'ring child:

3. Don't you hear the Sav-ior call-ing? He may nev-er call a-gain;
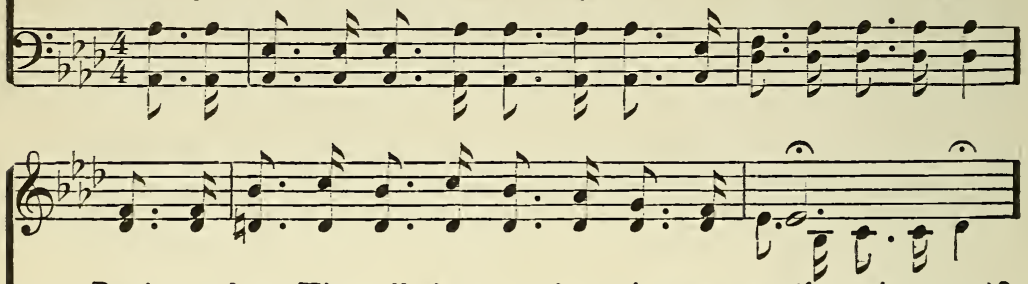

Don't you hear Him call -ing you from sin a-way (from sina-way)?

What re-joic-ing when He sees one com-ing home (one coming home)!

It is now $\mathrm{He}$ bids you turn to Him and live ( $\mathrm{O}$ turn and live);
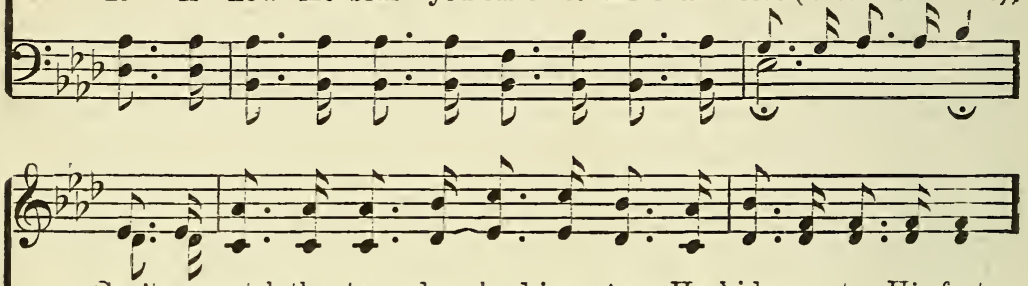

Can't you catch the ten - der plead-ing As He bids you to His feet,

Not a night was e'er so cheer-less, Nor a storm has raged so wild

For His ways are ways of pleas-ant-ness, And all His paths are peace;

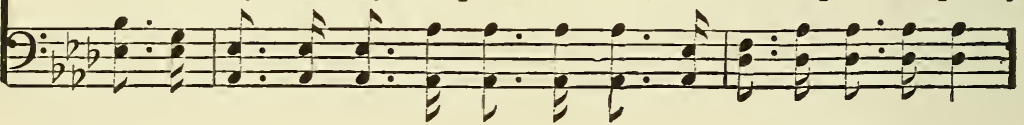

CHORUS.

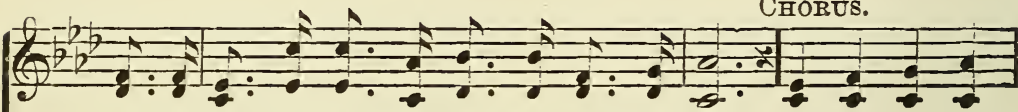

There to learn love's sweetest les - son for each day?

To restrain Him in His search for those who roam. Calling, calling;

"Tis a life of joy and hap-pi-ness He'll give.
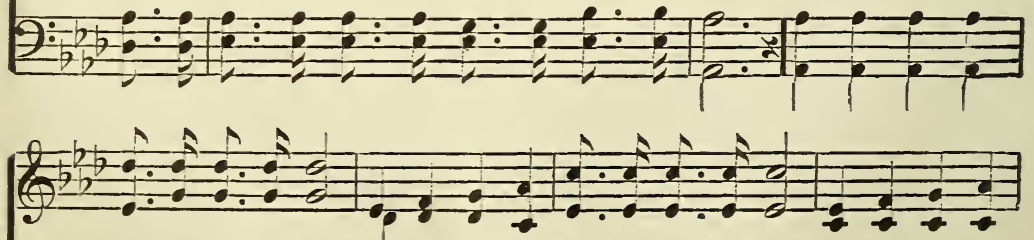

Heed His tender voice; Listen, listen, Make to-day the choice. Calling,calling,

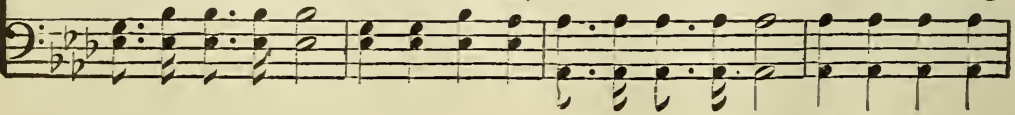




\section{Hear Him Calling.}

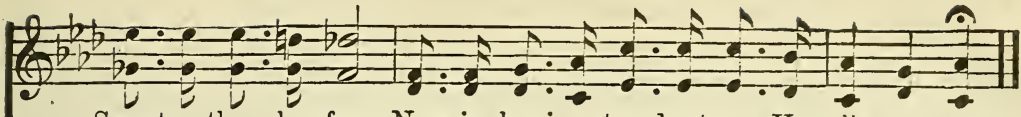

Sweet-er than be - fore; Now in lov-ing, ten-der tones He calls once more.

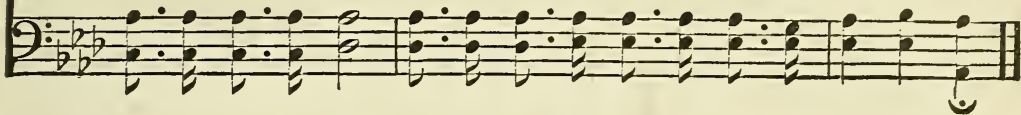

\section{Better Farther On.}

Worda and Music

Copyright, 1901, by P. P. Bilhora.

Art. by P. P. BrLHORF,

From Southern Melody.

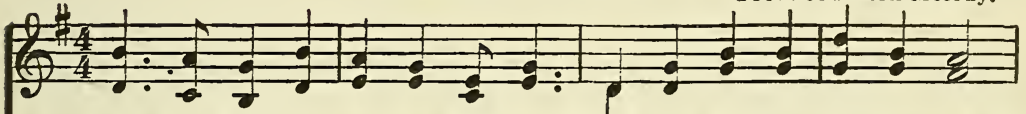

1. Dark and storm-y is the des-ert Thro' which pilgrims make their way;

2. Hark! a voice from heav-en steal-ing Soft-ly, in an un-der-tone;

3. Night and morn it sings the samesong, Sings it while I sleep a-lone;

4. At the grave I'll sing the same song, Tho' my lips to earth are dumb;
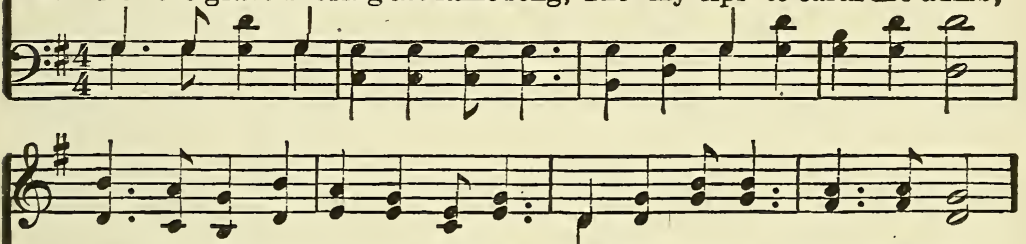

Just be-yond the vale of sor-row Lies the field of

Hark! I hear the gen -tle whis-per, "It is bet-ter

Sings it so my soul can hear it, "It is bet-ter

Sing it till the morning dawneth, "It is bet-ter

end - less day. far - ther on." far - ther on." far - ther on."

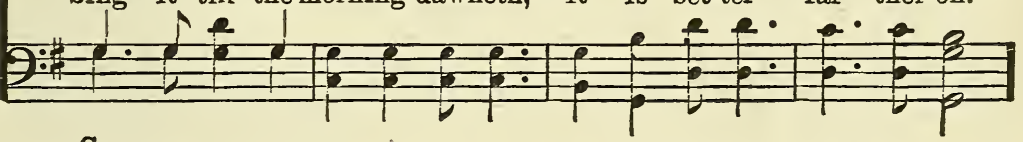

Chorus.

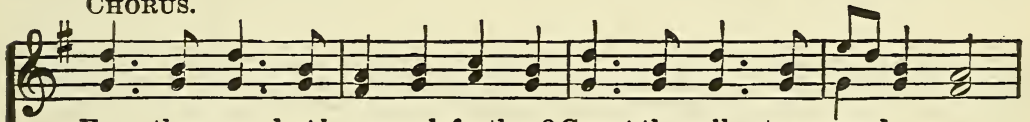

Far - ther on, buthow much farther? Count the mile-stones one by one;
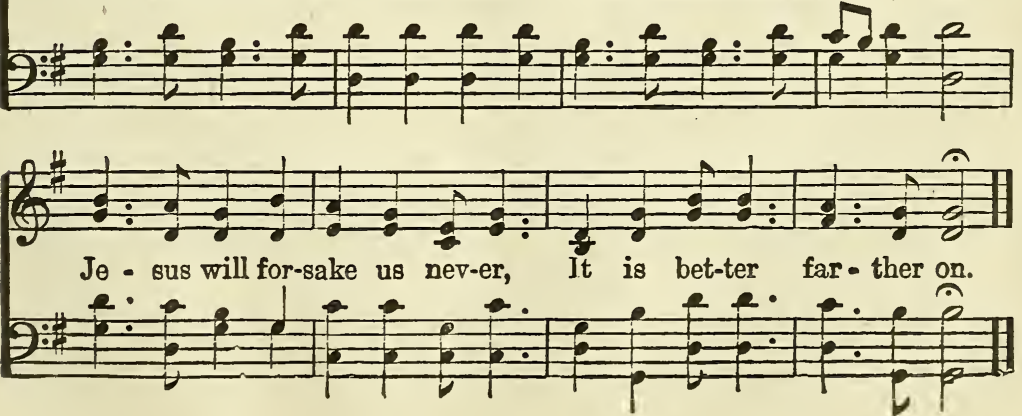
"I am debtor both to the Greeks and barbarians."-Rom. 1: 14.

W. S. M.

W. Stillman MaRtin.

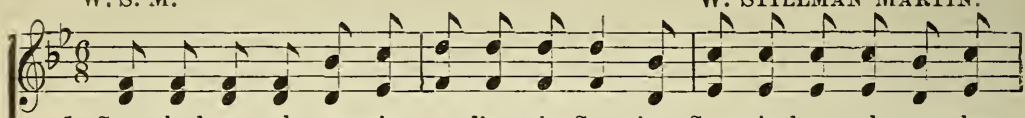

1. Some-bod-y al-ways is needing the Sav-ior, Some-bod-y al-ways has

2. Some-bod-y al-ways is dy-ing of hun-ger, Some-bod-y al-ways is

3. Some-bod-y al-ways is dy-ing for wa-ter, Riv-ers of bless-ings to

4. Some-bod-y al-ways is walking in dark-ness Close to the pit of de-
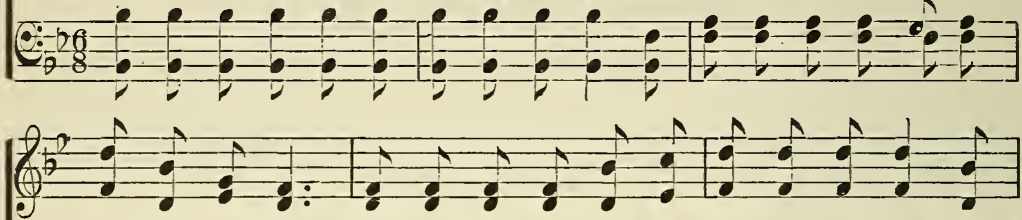

sins to re-move; Some-bod - y al-ways is heart-sick and wea - ry, need-ing God's bread; Some emp - ty heart must be told of His ful-ness, you have been giv'n; Some-bod - y al-ways is home-sick and friend-less, struction and sin; Some-bod - y al-ways is wan-d'ring from Je - sus,

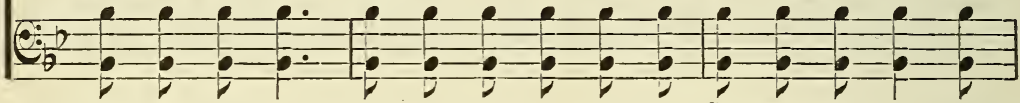
CHORUS.

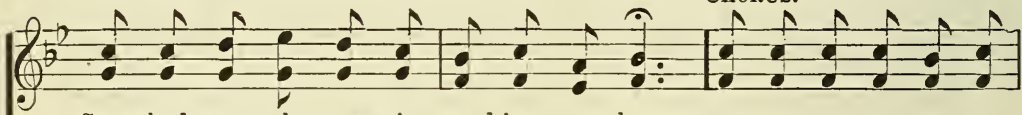

Some-bod-y al-ways is need-ing your love.

Some child of grace with His word must be fed. Are you a chan-nel of Some-bod - $y$ need to be told of God's heav'n.

Wise is the soul who a lost one shall win.

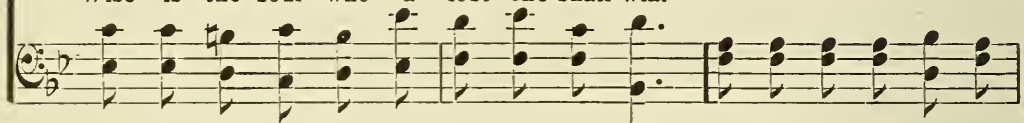

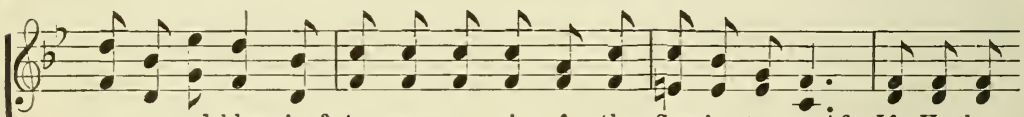
mer-cy and bless-ing? Are you a voice, for the Sav-ior to speak? If He has

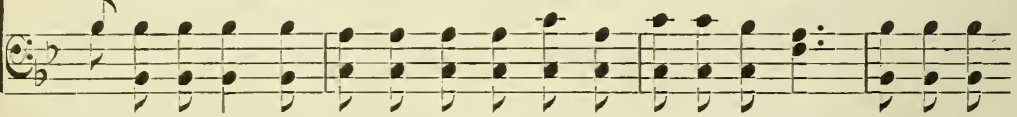

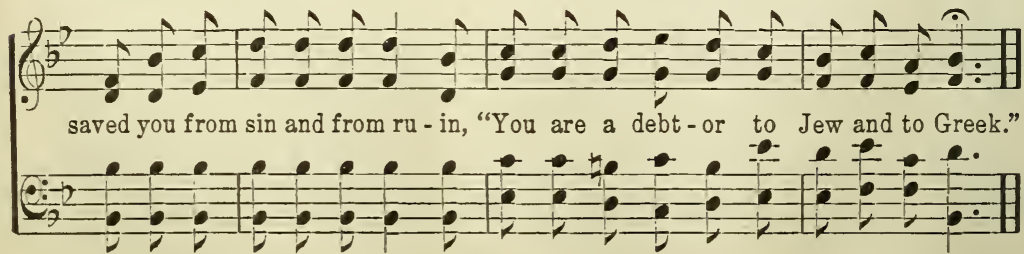
Copyright, 1905, by John A. Davis, 


\section{There is Power in the Blood.}

L. E. J.

Copyright, 1899, by H. L. Gilmour. By per.

2. E. JokEs.

1. Would you be free from your bur - den of sin, There's pow'r in the blood,
2. Would you be free from your passion and pride, There's pow'r in the blood,
3. Would you be whiter, much whiter than snow, There's pow'r in the blood,
4. Would jou do serv - ice for Je-sus your King, There's pow'r in the blood,

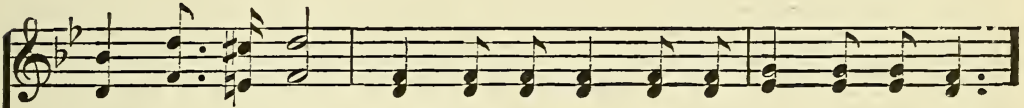

pow'r in the blood; Would you o'er e - vil a vic - to- ry win, pow'r in the blood; Come for a cleans-ing to Cal-va-ry's tide, pow'r in the blood; Sin stains are lost in its life-giv-ing flow, pow'r in the blood; Would you live dai - ly, His prais - es to sing,
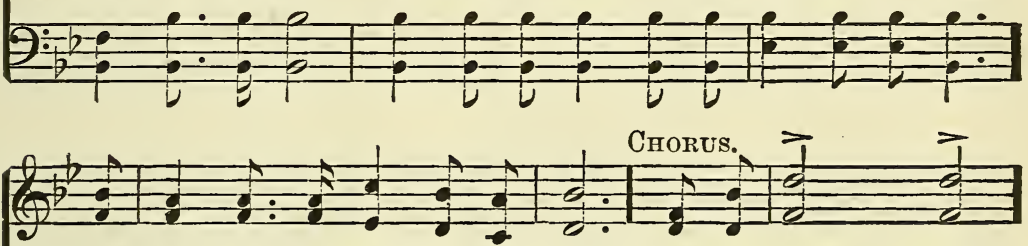

There's won - der - ful pow'r in the blood. There is pow'r, pow'r,
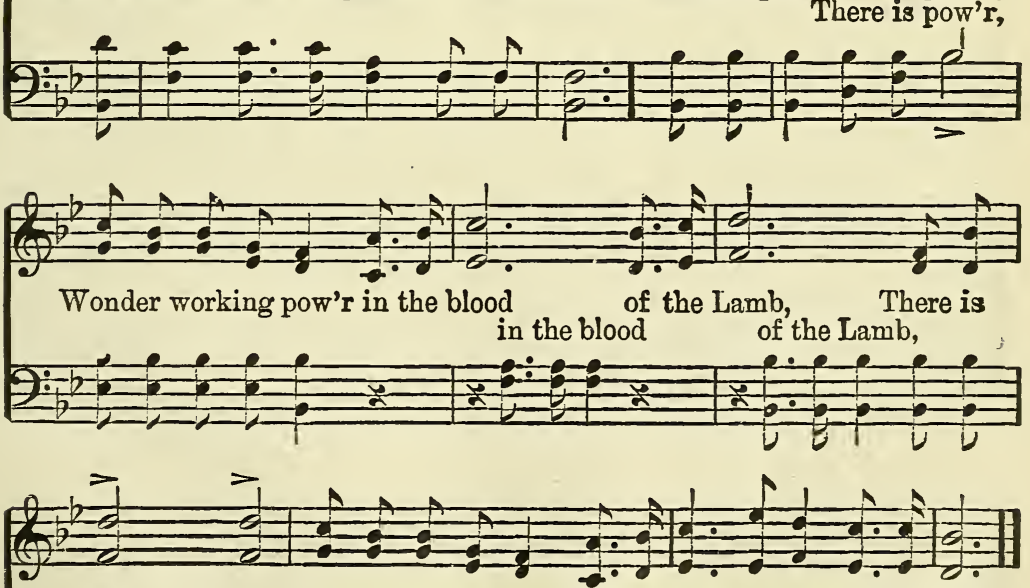

pow'r, pow'r, Wonder working pow'r, In the precious blood of the Lamb. There is pow'r.

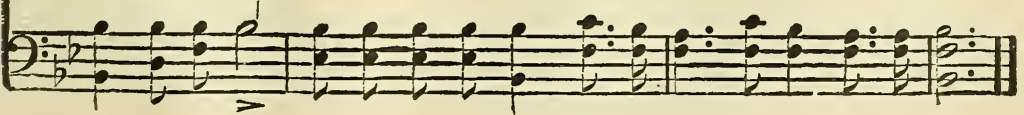




\section{8}

I've Had a Glimpse of Jesus.'

Used by per, of Henry Date, owner of copyright.

JOHN R. CLEMENTS.

Elisha A. HofFMAN.

DUET, SOP. AND TENOR.

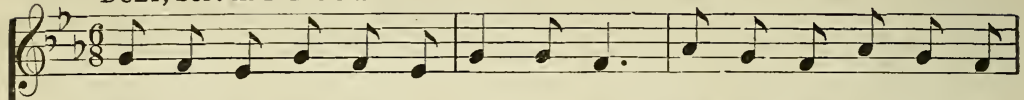

1. Back to the cold world I will not go, Back to the old paths of

2. Back on the night-shroud-ed sea to die? Back, where the break-ers of

3. Back to the boon friends of for-mer days, Still walk-ing on in their
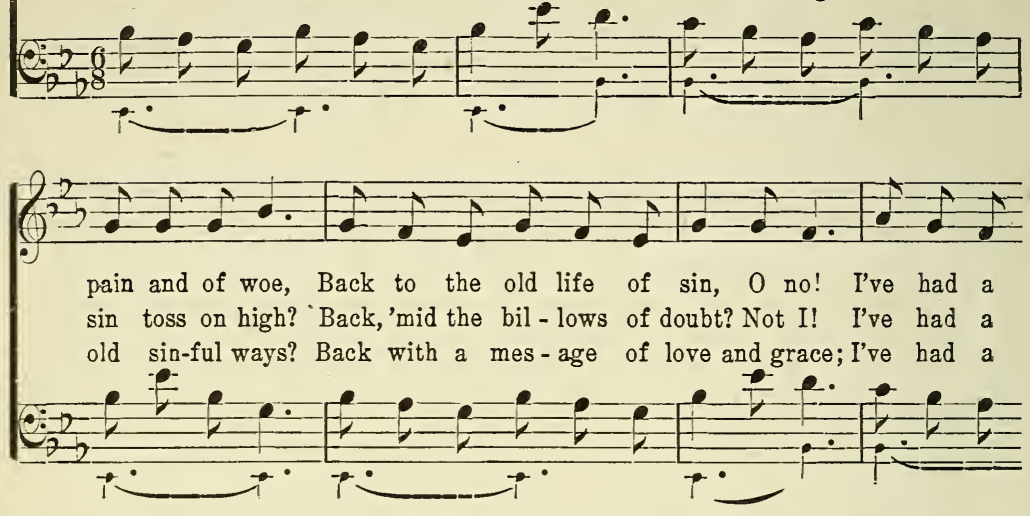

DUET. SOP. AND ALTO.

glimpse of Je - sus. I've found a life that is sweet-er to me,

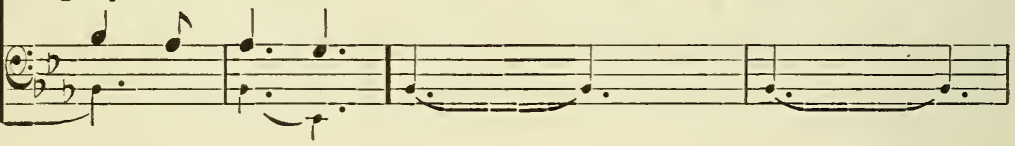

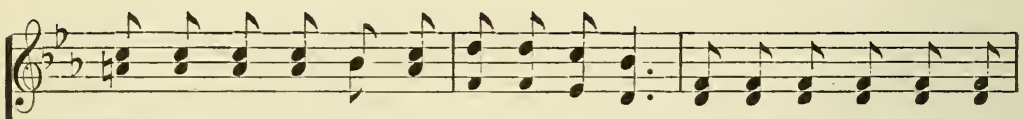

Sweet-er with peace, from un - hap - pi-ness free, Full - er of joy than the

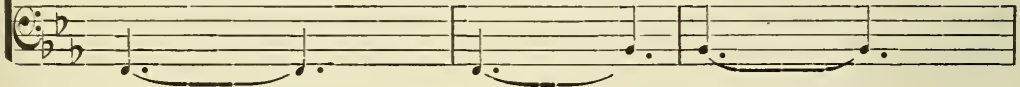

CHORUS.

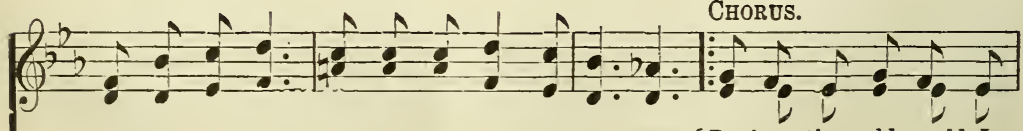

old life could be; I've had a glimpse of Je-sus. \{ Back to the cold world I

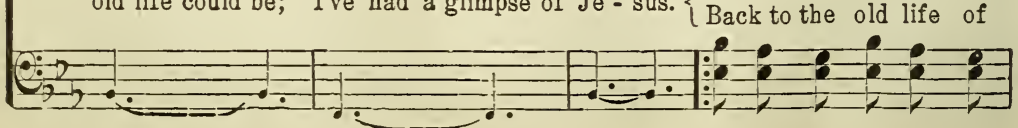


(2)

will not go, Back to the old paths of pain and of woe, ?

sin, 0 no! I've had a Omit . . . . . . J glimpse of Jesus.

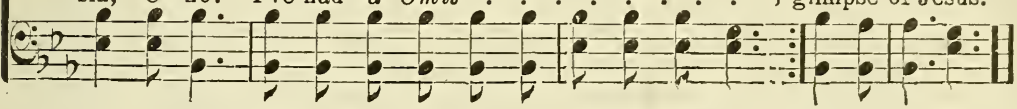

When I Think of My Dear Lord.

Words and Music guggested by

Words and Muaic Copyright, 1904, by P, P. Bilhorn.

HARRY MONROE.

P. P. BILHORN.

$(0)^{2-b^{2}-1}+\frac{1}{2-a}$

1. When I think how they cru-ci-fied my Lord, When I think how they

2. When I think how He wore the crown of thorns, When I think how $\mathrm{He}$

3. When I think how they nailed Him to the tree, When I think how they

4. When I think how they laid Him in the tomb, When I think how they

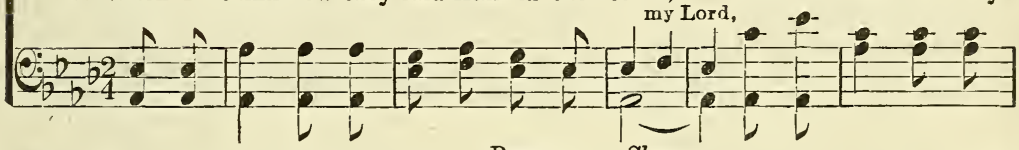

REFraIN. Slower.

cru - ci - fied my Lord;

wore the crown of thorns;

h, it some-times makes me trem-ble,

nailed Him to the tree;

$\mathrm{Oh}$, it some-timesmakes me trem-ble,

laid Him in the tomb;

$\mathrm{Oh}$, it some-tines makes me trem-ble,

- - - -2 - $-e-0$

$\mathrm{Oh}$, it some-times makes me trem-ble,

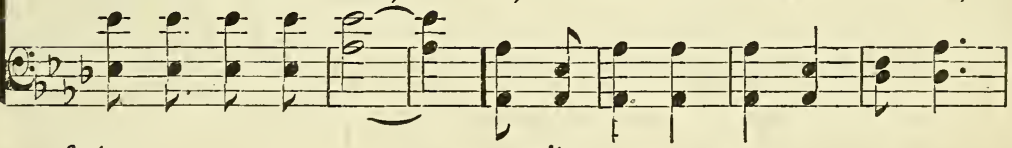

(2) faster.

trem-ble, When I think how they cru - ci-fied my Lord.

trem-ble, When I think how He wore the crown of thorns.

trem-ble, When I think how they nailed Him to the tree.

trem-ble, When I think how they laid Him in the tomb. 'my dear Lord,

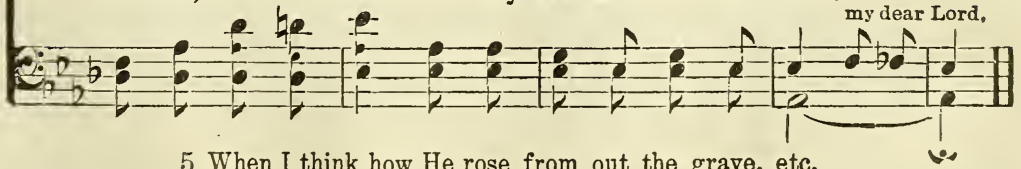

5 When I think how He rose from out the grave, etc.

6 When I think how He did it all for me, etc.

7 When I think how He ascended up on high, etc. 
Arr. bs M. G. P.

Arr. by Rev. M. G. Prescotr.
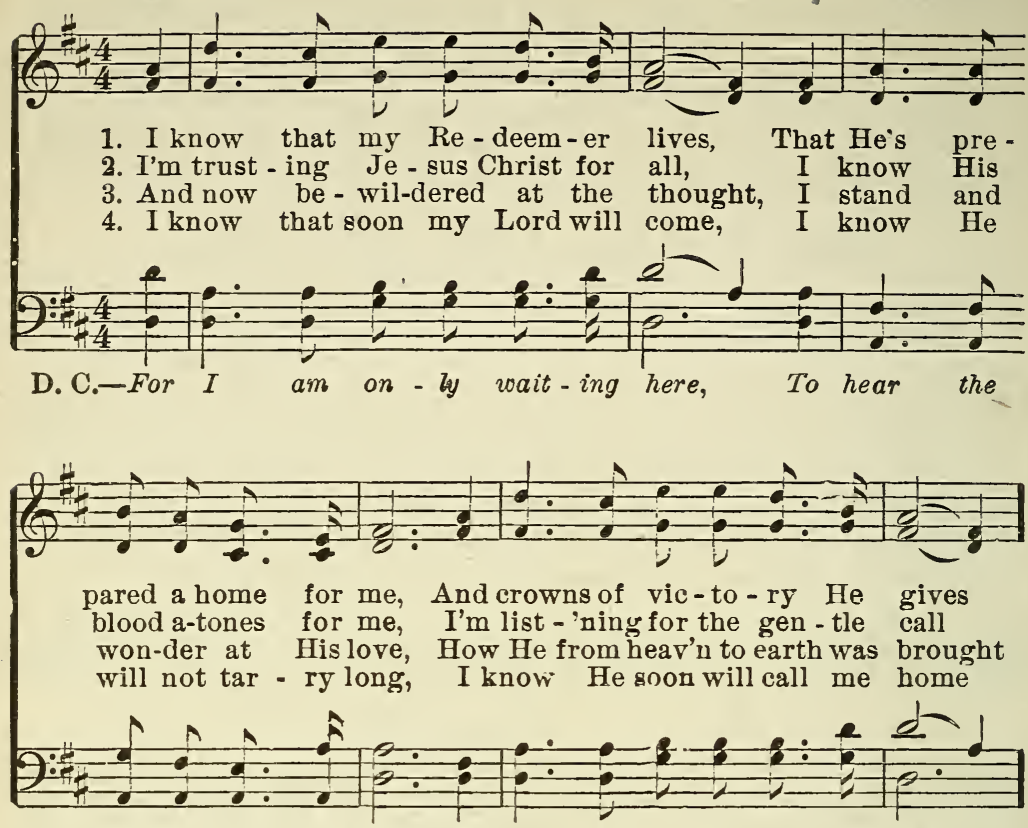

summons,"child, come home," For I am on-ly wait-ing here,

Fixe. ChORUS.

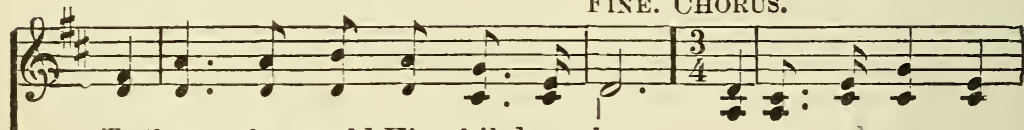

To those who would His chil-dren be.

To say, the Mas - ter wait -eth thee. $\}$ Then ask me not to

To die, that I might live a-bove.
To sing with joy the heav'n-ly song.

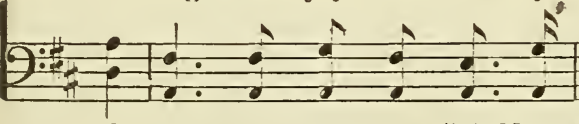

To hear the sum-anons "child come home."

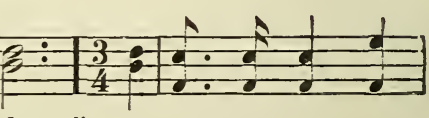

D. C.

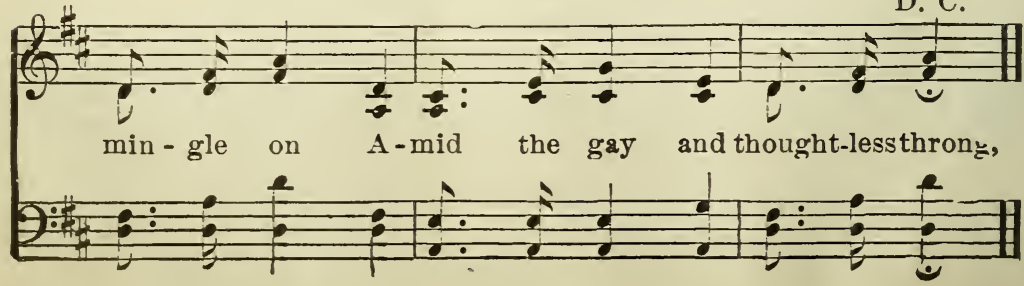




\section{Want Everybody to Know.}

Mrs. Frank A. Breck. Copyright, 1901, by P. P. Bilhorn,

From C. H.

P. P. BILHORR.

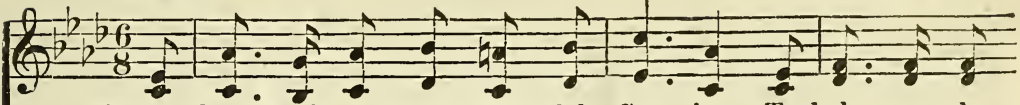

1. I have such a won-der - ful Sav-ior To help me wher-

2. He helps me o'er-come all temp-ta - tion, And makes me with

3. He cheers me if I am in sor-row, Hepress-es me

4. He heark-ens to hum-ble con-fess-ing, And ev - er His

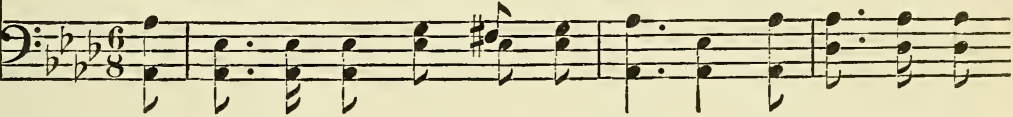

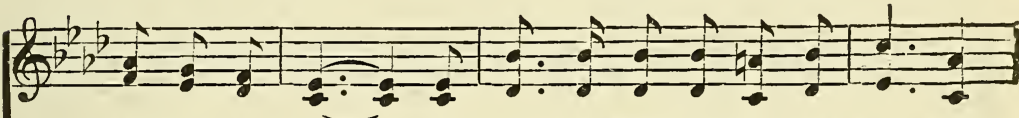

ev-er I go, I have to keeptell-ing His good-ness, glad-ness o'er - flow; He brings me a bless-ed sal - va - tion close to His heart, And telis of that brighter to - mor-row, mer-cy doth show; He crown-eth my life with His bless-ing,

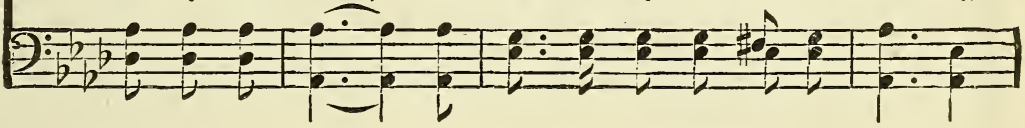

(4)

For I want ev-'ry-bod-y to know.

That I want ev-'ry-bod-y to know.

Where troubles shall never have part.

And I wantev-'ry-bod-y to know.

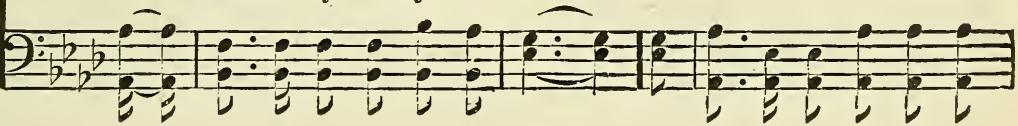
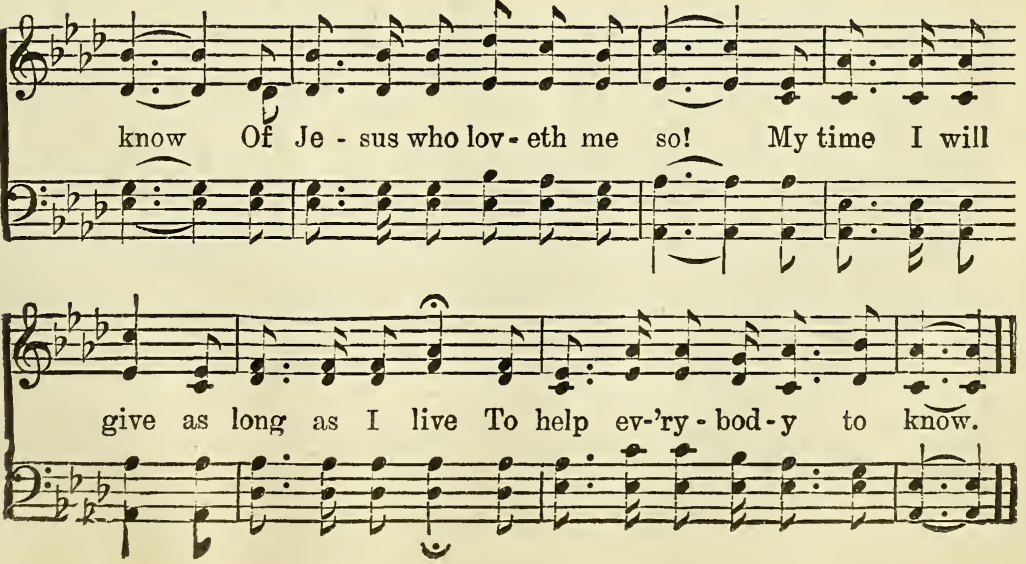
Arr. by M.

Arr. by W. S. MARTIN.

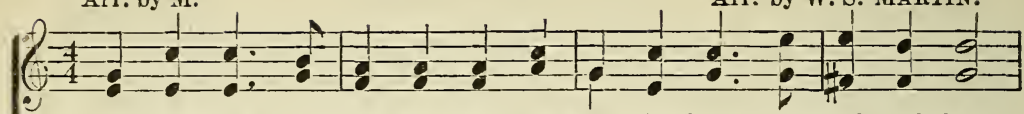

1. Tho the days are dark with troub-le, And the heart is filled with fear;

2. Ma - ny days have dawn'd se-rene - ly, While the birds sang with de - light;

3. Soon will dawn a bright-er morn-ing, On a bless - ed tran-quil shore;

4. Soon will come the Lord of glo-ry, With e - ter - nal joy and bliss;
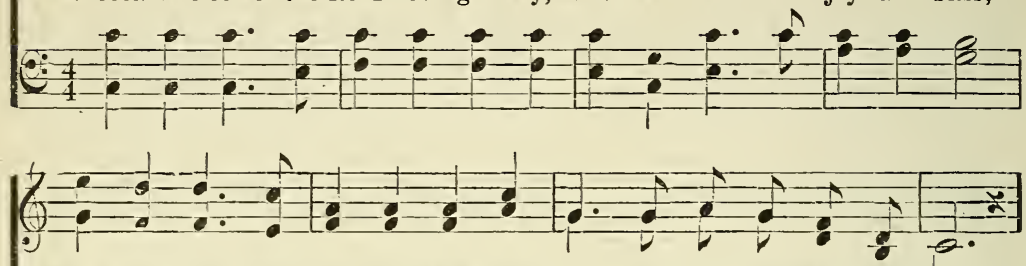

There is one who ev - er sees thee, And will hold thee near and dear.

But the skies were dark and gloom-y, Ere the sun had reach'd its height.

Sighs will then give place to sing-ing, Tears to bliss for-ev-er-more.

Thou shalt share the crown and king-dom, Share the glo - ry that is His.

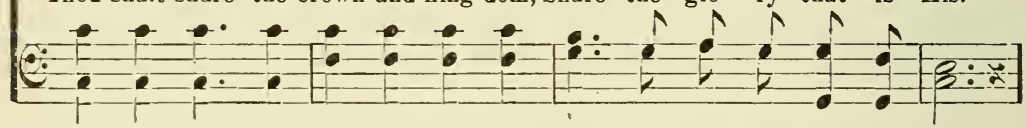

Chorus.

(1)

There's a Friend that's ev - er near; Nev-erfear, He is ev-er near;

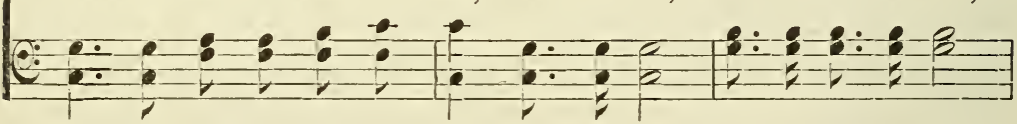

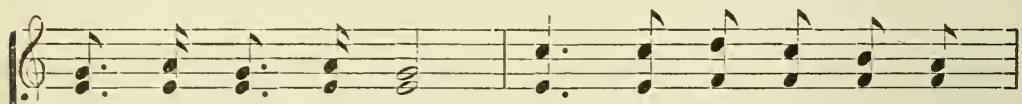

Nev - er, nev - er fear, There's a Friend that's ev - er

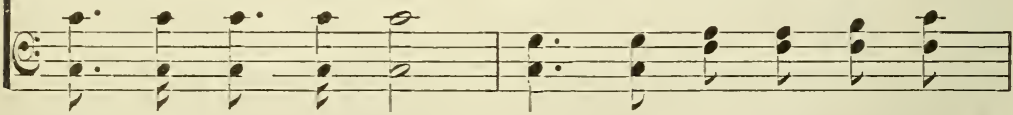

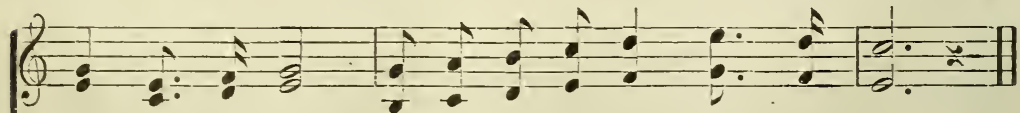
near, Nev-er fear, $\mathrm{He}$ is ev - er near, Nev-er fear.

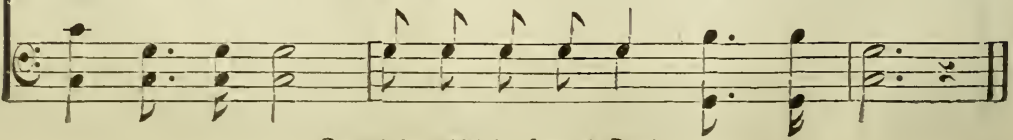

Copyright, 1905, by John A. Davis. 


\section{Sailing U'er Life's Ocean.}

"Some have mede ship-wreck."-Tim. 1: 19.

Rev. JAMES CARTER, $1894 . \quad$ Navigans.

Rev. JAMES CARTER.

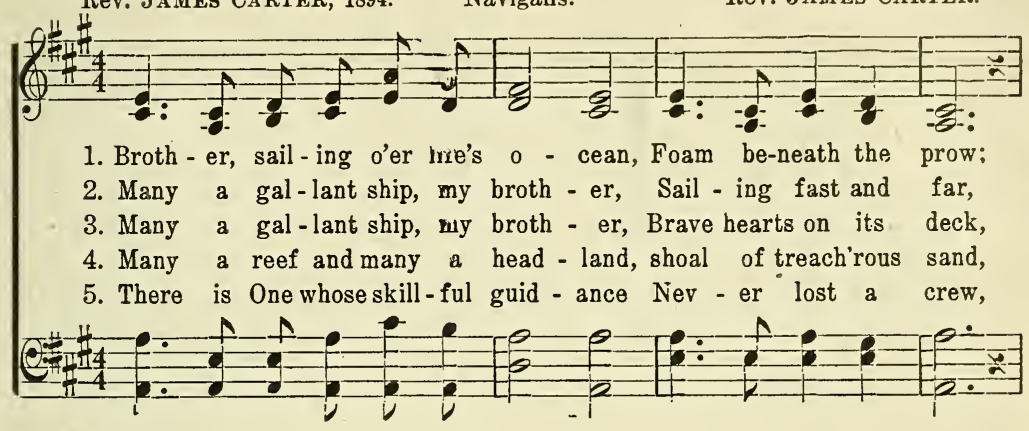

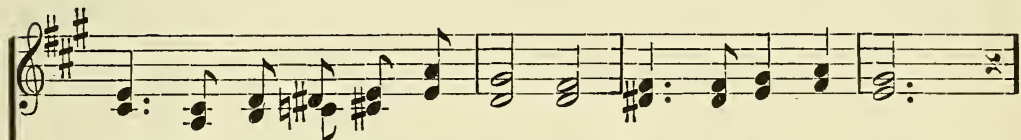

Know you where your proud course tend-eth? Whith - er sail - ing now?

$\mathrm{Nev}$ - er glides with-in the safe-ty of the har-bor bar.

By the waves of pas-sion beat-en, Stag-gers on to wreck.

Lie be - fore yourves-sel's toss-ing Ere you reach the land.

Give your-self in - to His keep-ing; $\mathrm{He}$ will pi lot you.
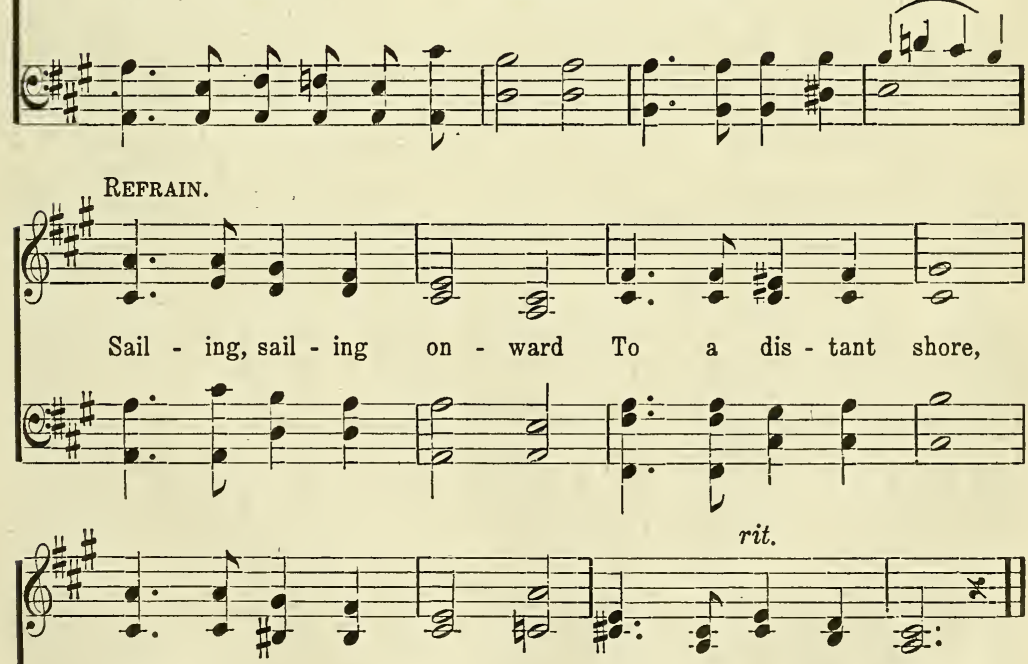

Sail - ing to the har - bor Whence we come no more.

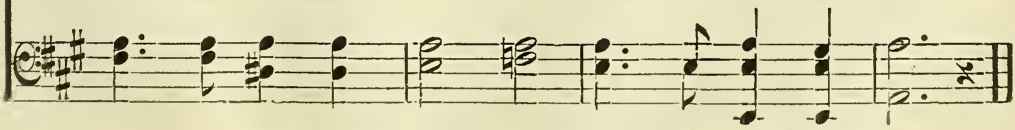

Words ana Music Copyright, 1894, by Rev. James Carter. Used by per. 
The testimony of a good old christian "thirty odd years on the way." JоH天 R. CLEMENTS.

Rer. E. S. UFFORD.

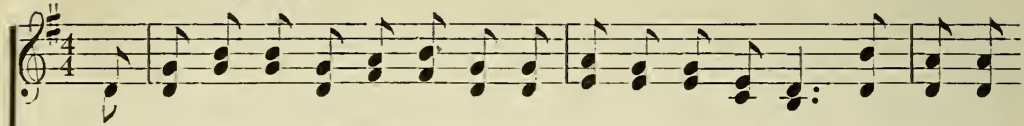

1. I love the road that leads to light, I would not from it stray, I walk it

2. I love it for yon saintlythrong have gonethis ver-y way, They now are

3. I love it when I think of One Who died my debt to pay, And opeid the

4. I love this road,'twill lead me home,to where my lov'd ones stay, They're watching

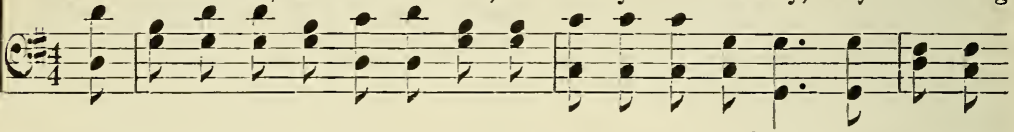

CHORUS.

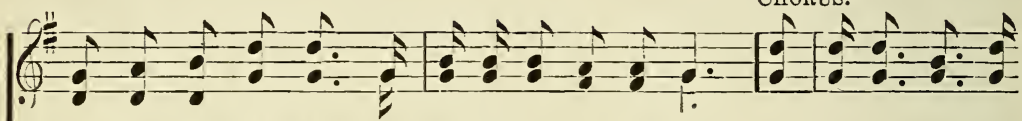
for I know it's right, It's hap-pi-er ev-'ry day,

sing-ing heav-en's song, It's hap-pi-ar ev-'ry day, It's brighter all the road by what He's done, It's hap-pi-er ev-'ry day,

long-ing till I come, It's hap-pi-er ev-'ry day,

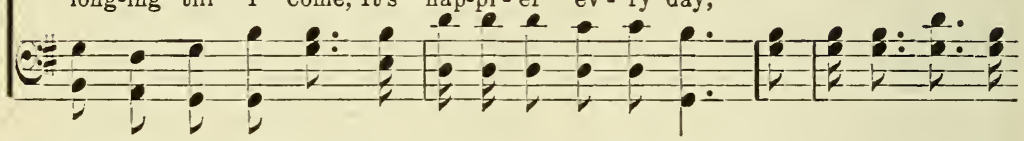

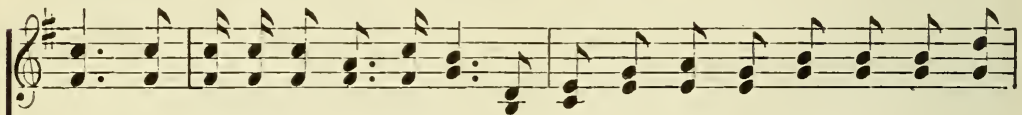

way, It's hap-pi-er ev-'ry day, I love the road that leads to light, I

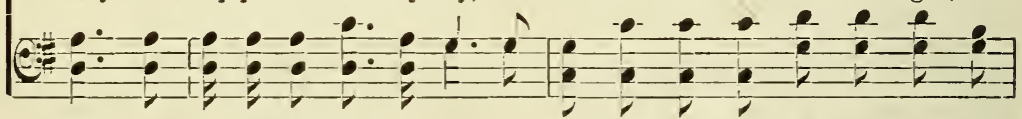

$\operatorname{lic}_{0}^{2}$ would not from it stray; It's brighter all the way, It's hap-pi-er ev-'ry

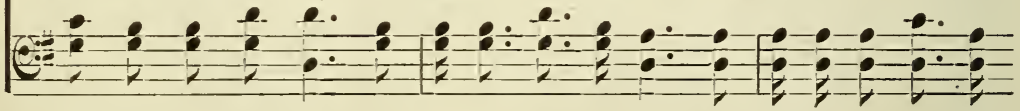

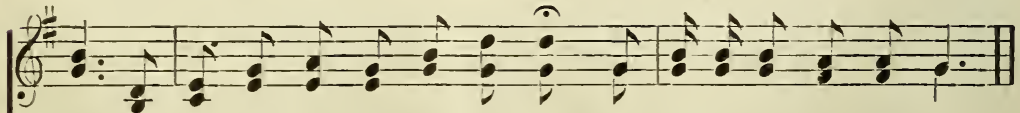

day, I love the road that leads to light, It's hap-pi-er ev-'ry day.

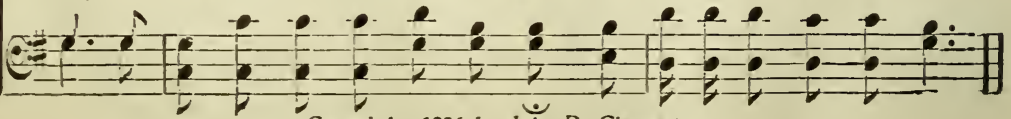

Copyright, 1896, by Johñ R. Clements. 
W. S. M.

By the name or Jesus Cnrist of Nazareth. Act. 4:11.

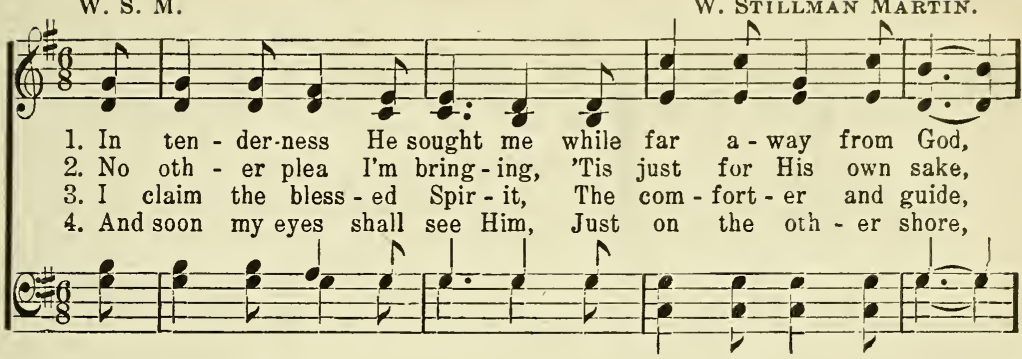

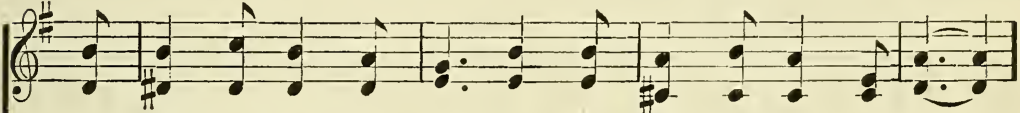

And from my lost con - di - tion, He saved me in His blood;

My soul is filled with sing - ing, As peace from Him I take;

A - lone through Je - sus mer - it, To in my life a - bide;

And with the saints and an - gels, I'll praise Him ev - er-more;
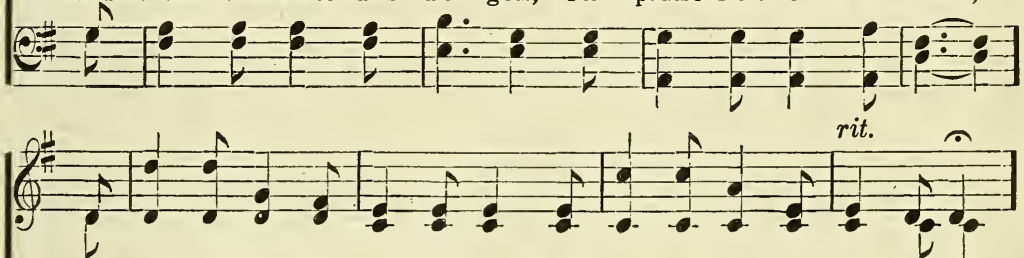

In His rich bless-ings I par-take, My on - ly plea for Je-sus' sake.

The peace He purchased with His blood, The deep, un-chang-ing peace of God.

To sanc-ti - fy my sin-ful heart, The pow'r of God to me im-part.

And when I see Him face to face, My , on - ly plea I'm saved by grace.
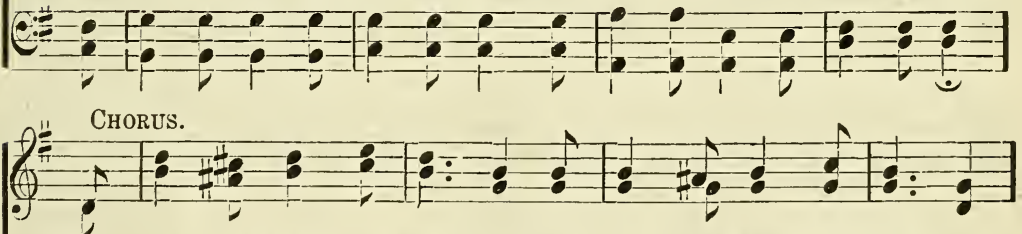

For His own sake He sought me, For His own sake He bought me,
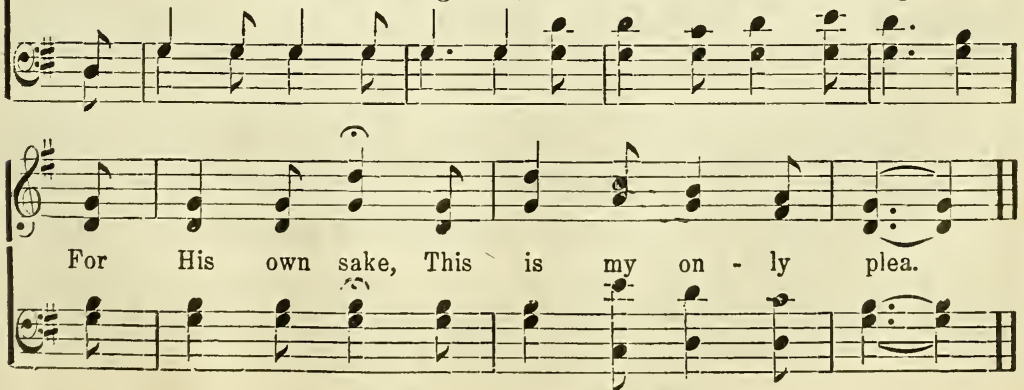

Copyright, 1905, by John A. Davis. 
"I will come again." Jno. 14:3. "This same Jesus shall so come."-Act. 1: 1.. M.

W. S. MARTIN.

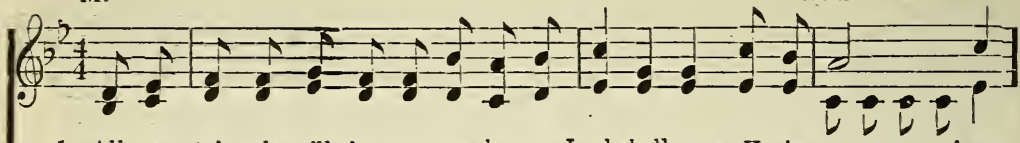

1. All our tri - als will be o-ver when our Lord shall come; He is com - ing

2. How our hearts will be made happy when we see $\mathrm{His}$ face, $\mathrm{He}$ is $\mathrm{com} \quad$ - ing

3. Not as sac-ri-fice for sin-ners will He come a-gain, $\mathrm{He}$ is com - ing

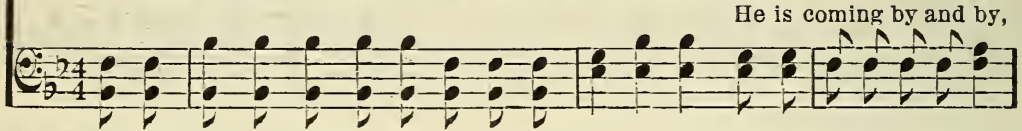

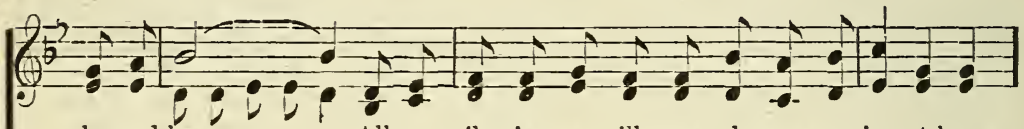
by and by;

by and by;

by and by;

All our pil-grim-age will cease when we ar-rive at home, He is coming by and by

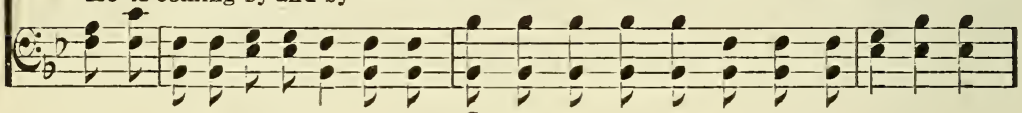

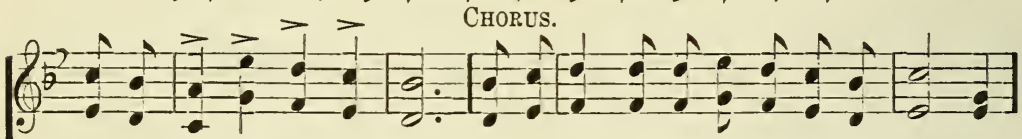

$\mathrm{He}$ is com-ing by and by. He may come at the midnight or the morning,

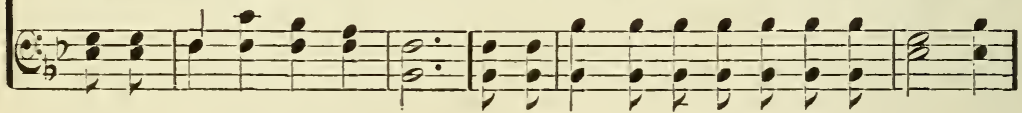

(2-2)

He may come at the brightness of the noon, We will watch, we will pray,

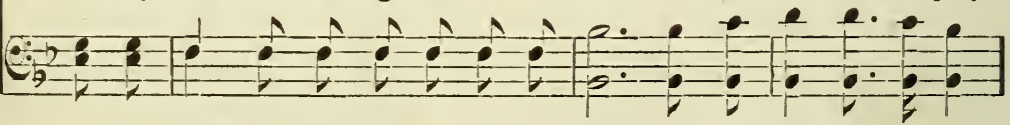

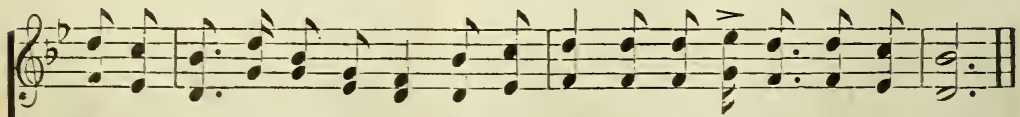

We will la-bor ev-'ry day, For we know He is com-ing ver-y soon.

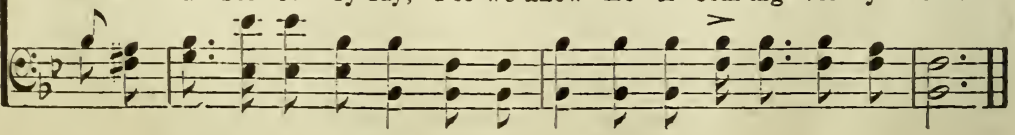

Copyright, 1905. by John A, Davis. 


\section{Since I Began to Walk with Jesus. 137}

JOHN R. Clements.

J. H. RUEBUSH. ;

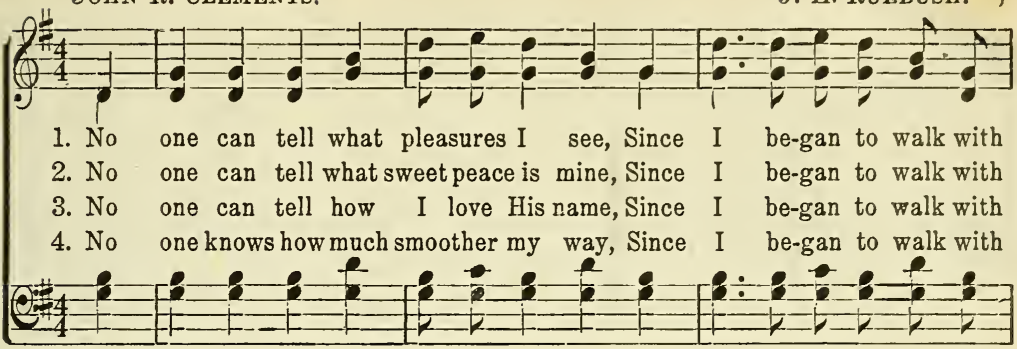

$\begin{aligned} & \mathrm{Je} \text { - sus; } \mathrm{My} \text { heart sings ev-er His love to me, Since I } \text { be- } \\ & \mathrm{Je} \text { - sus; Each load He bids me to Him re-sign, Since I } \text { be- } \\ & \mathrm{Je} \text { - sus; Nor how I love His word to pro-claim, Since I be- } \\ & \mathrm{Je} \text { - sus; Nor how much brighter I find each day, Since I be- }\end{aligned}$

ChORUS.

$\left(2+\frac{1}{2}=1\right.$

gan to walk with Je-sus. Since I be-gan to walk with Je - sus,

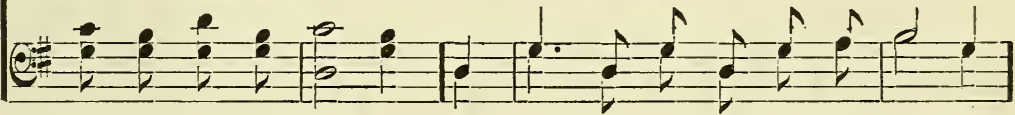

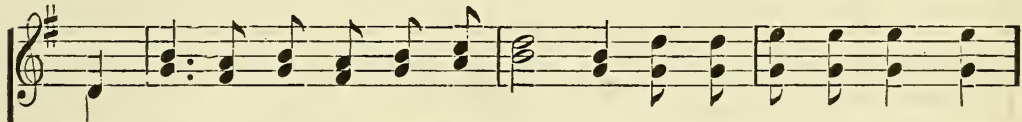

Since I be-gan to walk with Je - sus; All my path-way is bright,

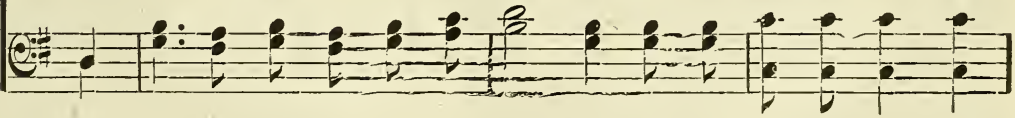

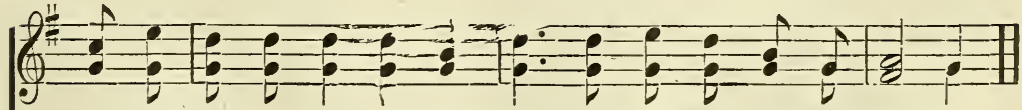

All my bur-dens are light, Since I be-gan to walk with Je-sus.

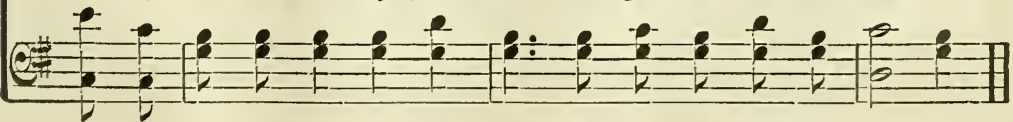

Copyright, 1900, by The Ruebush-Kieffer Co. Used by per. 


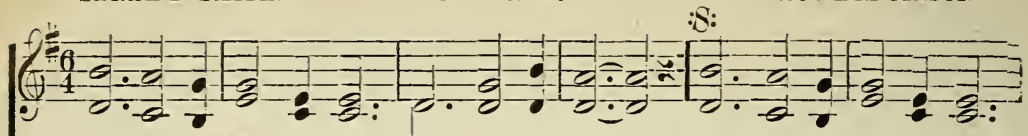

1. Near-er, my God, to Thee, Near - er to Thee! E'en though it be a cross

2. Tho' like a wan-der-er, The sun gone down, Dark-ness be o-ver me,
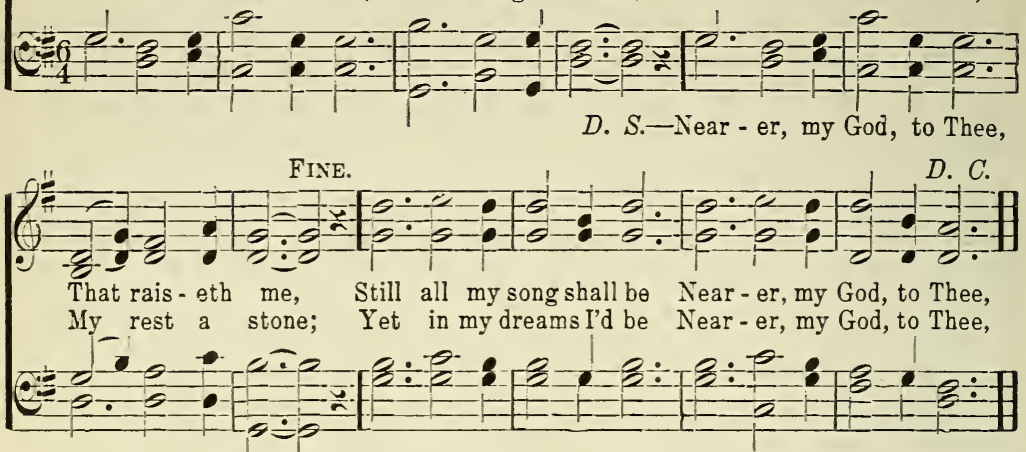

Near - er to Thee!

3 There let the way appear

Steps unto heaven;

All that Thou sendest me,

In mercy given;

Ange!s to beckon me

Nearer, my God, to Thee,

Nearer to Thee!
4 Or if on joyful wing, Cleaving the sky,

Sun, moon, and stars fergut, Upward I fly.

Still all my song shall be, Nearer, my God, to Thee,

Nearer to Thee!

\section{All to Christ I Owe.}

E. M. H A LL.

J. T. GRAPF. By peo.

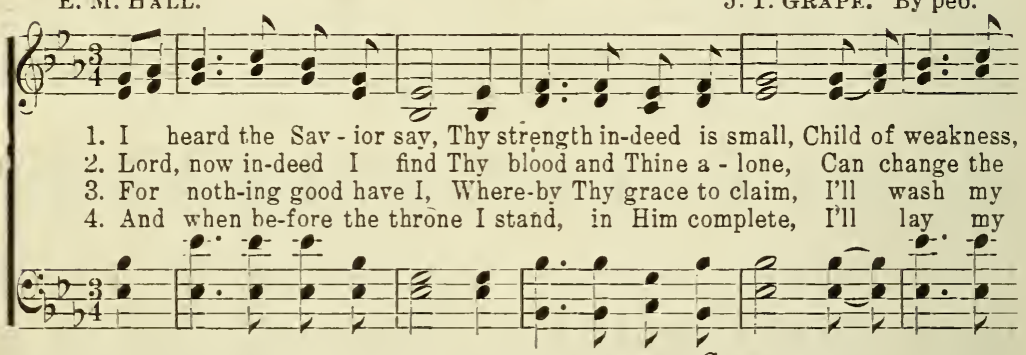

Chorus.

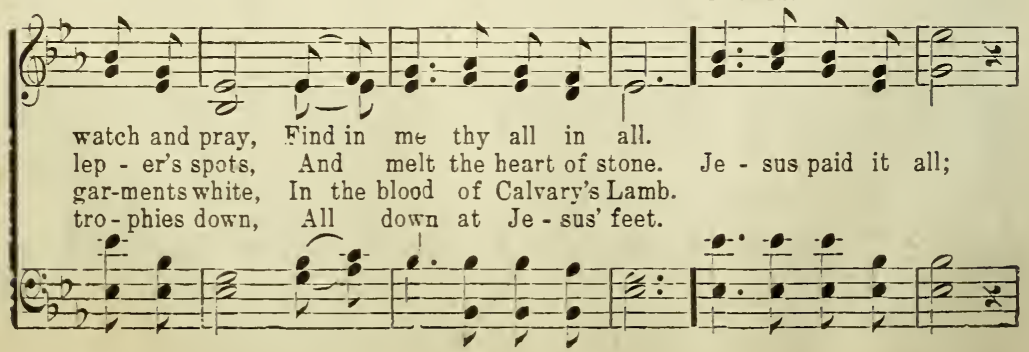




\section{All to Christ I Owe.}

(2)

All to Him I owe; Sin had left a crimson stain, He wash'd it white as snow.

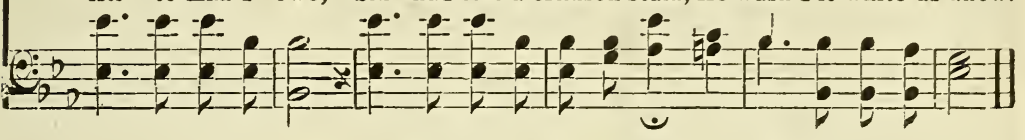

\section{Christ is Best.}

W. H. Pike.

W. StillmaN Martin.

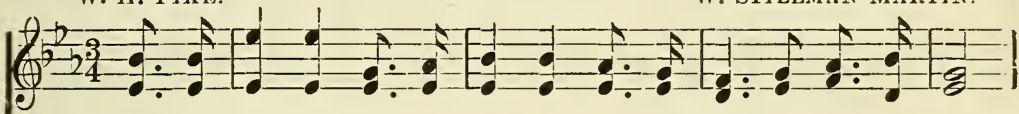

1. This fair earth is lined with treas-ure And its gold ap-pealed to me;

2. There is wealth in pre-cious met-als, There is joy in earti-ly name;

3. Christ is bet-ter than the sil-ver, Bet-ter than the fin-est gold;
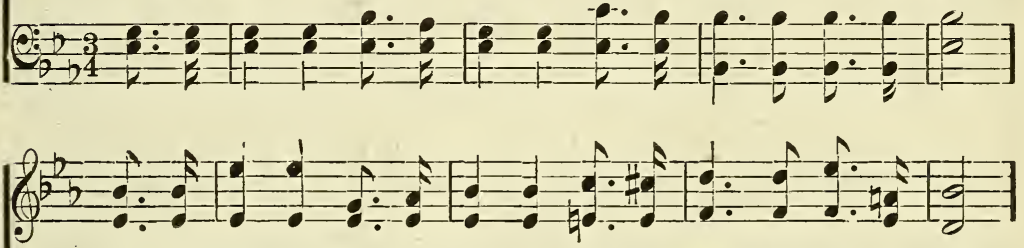

Till I founs the Christ, my Sav-ior, Bet-ter wealth than land or sea. But the wealth and joy of heav-en Is be-yond all earth-ly fame. Christ is bet-ter far than an-gels Or the wealth of worlds un-told.

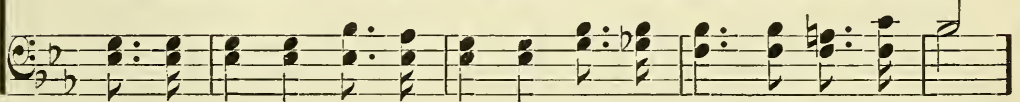

CHORUS.

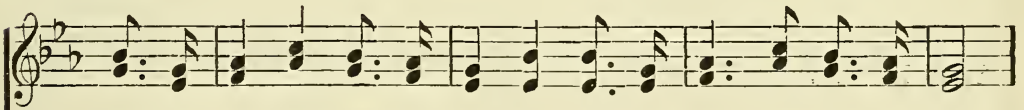

Christ is bet-ter, Christ is bet-ter, Christ is bet - ter than the rest;

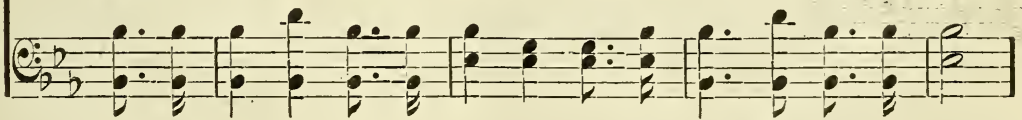

(a)

Christ is bet-ter than the great-est, For He's bet - ter that the $\mathrm{k}$

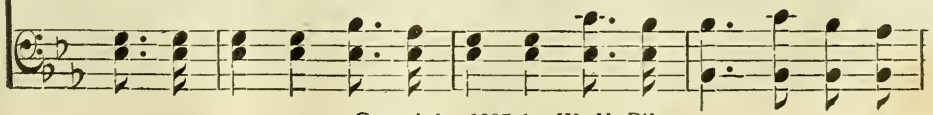

Copyright, 1905, by W. H, Pike. 


\section{Come Speak a Word for Jesus.}

"Tell what great things the Lord hath done for you."-Mar. 5: 16.

C. D. MARTIN.

W. STILLMAN MARTYN:

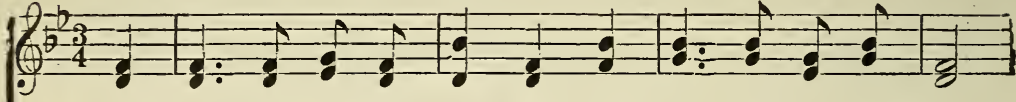

1. Come speak a word for Je - sus, Your love for Him con-fess,

2. Come speak a word for Je - sus, Tell of His pre-cious love,

3. Come speak a word for Je - sus, Say how He made you glad,

4. Come speak a word for Je - sus, Come Chris tians true and brave,
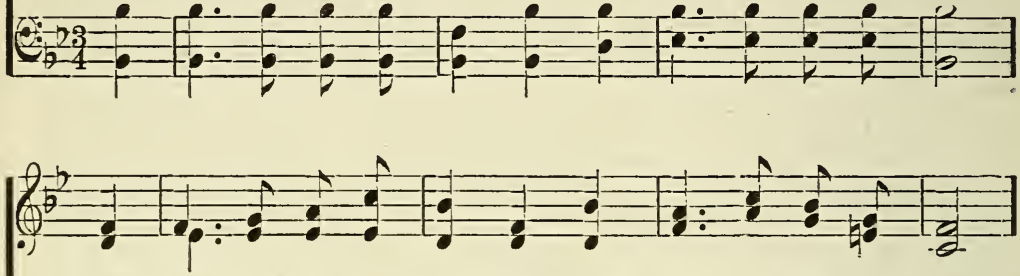

Just bring a sim-ple mes - sage, Some sin - sick soul to bless.

Tell of His cross and tri-umph, The home pre-pared a - bove.

And gave you joy and com - fort, When lone - ly worn and sad.

Per - haps your lov - ing mes - sage, Some oth - er soul may save.

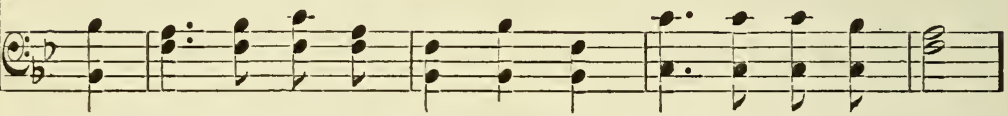

Chorus.

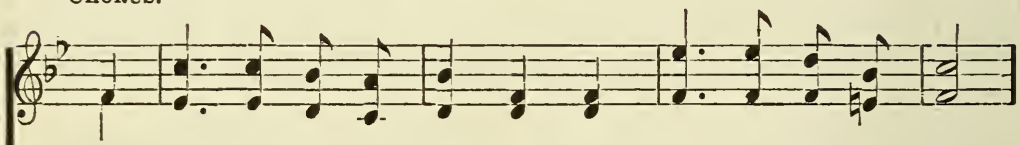

Some lov - ing word for Je - sus, Tell what $\mathrm{He}$ did for you;
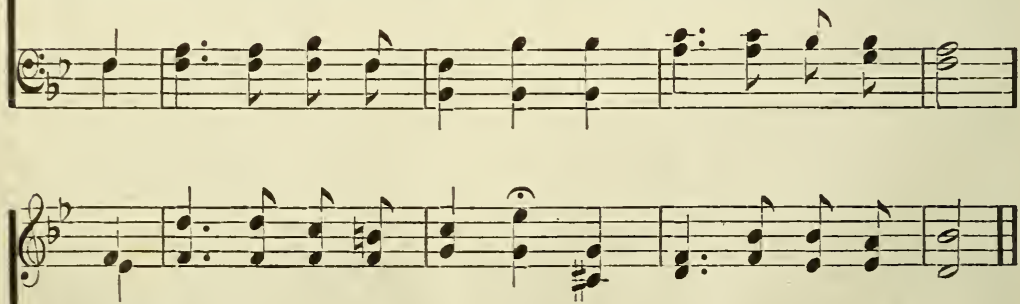

Then some who hear your sto - ry May trust your Sav-ior too.

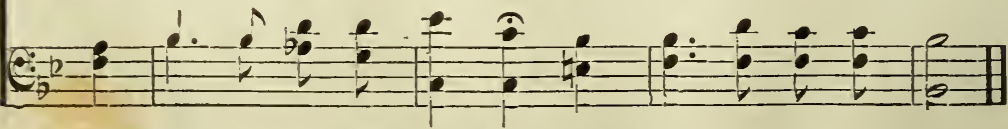

Copyright, 1905, by John A. Davis, 


\section{Ring Bells of Heaven.}

JOHN R. CLEMENTS.

STILLMAN MARTIN.

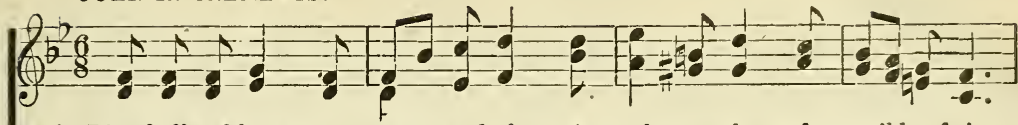

1. Ring bells of heav - en sweet and clear, A soul comes home from wilds of sin,

2. Ring bells of heav - en loud and long, Let joy a-bound on ev - 'ry hand,

3. Ring bells of heav - en chime on chime, Till all yon high-est arch-es swell,

4. Ring bolls of heav - en, ne'er be aumb, But ring your notes un - ceas-ing-ly,

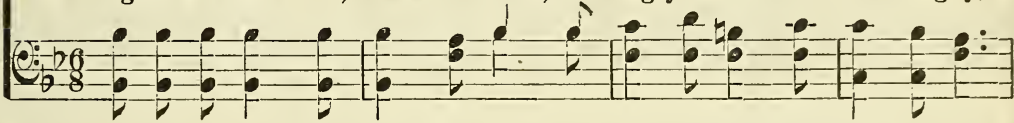

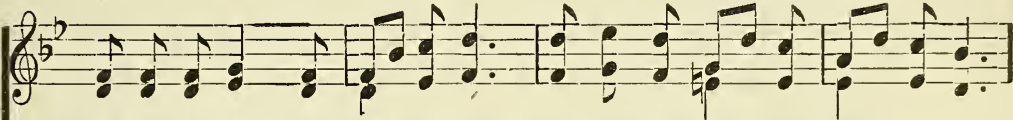

Sound forth the joy notes far and near, Swing wide the por - tal, let Him in.

Each voice break forth in sweetest song, To wel-come one from al - len land.

This is a ho - ly hap-py time, Since safe the wan-d'rer all is well.

Till ev-'ry child shall homeward come, And till the last en-slaved is free.
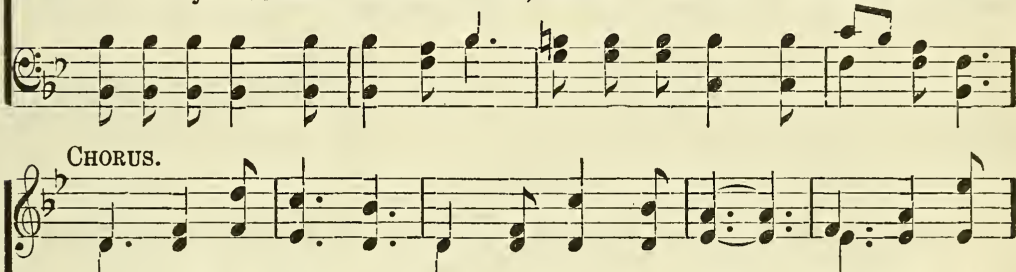

Ring bells of heav - en, ring for - ev - er - more, Ring bells of

Ring, ring, ling, ring,

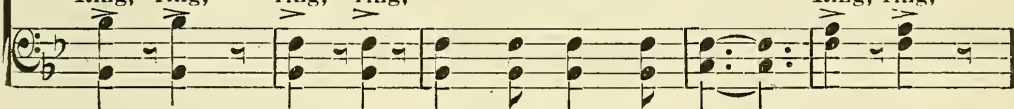

(4)

heav - en, Ring from shore to shore; Ring, a hap - py welcome raise, Ring, a

Ring, ring,

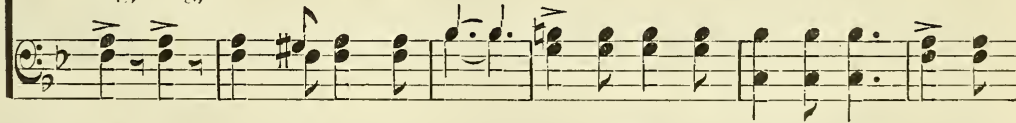

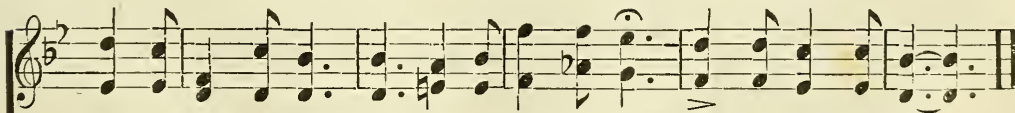

joy-ful peal of praise, Wand'rers are coming home, Ring thro' end-less days.

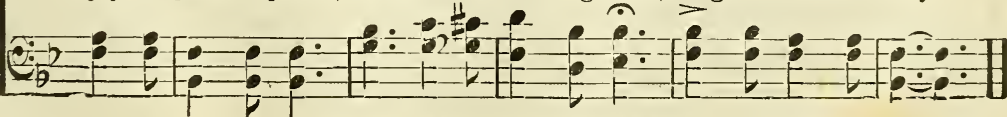

Copyright, 1905, by John R. Clements. 
JohN R. Clements.

Rev, xxii: 5.

JOHN. R. SW ENEY.

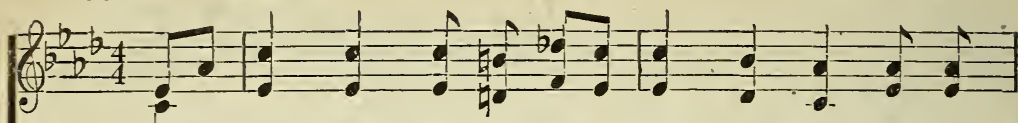

1. Though bur - dens heav-y we here must bear And the

2. With toil - some ef - fort in faith we sow, Tho' no

3. We'll la - bor on with a smile and song, And we'll

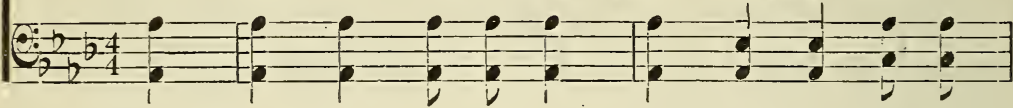

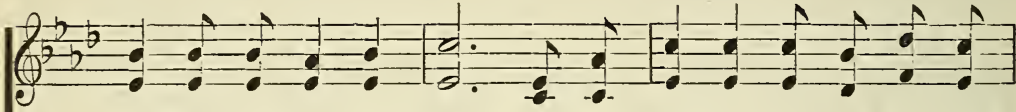
eyes are made dim with tears, There'll be naught of sor - row "0 - ver har-vest our vis-ion cheers; We will not lose heart, 'twill all be give to the winds our fears, For the day of tri - als can't be

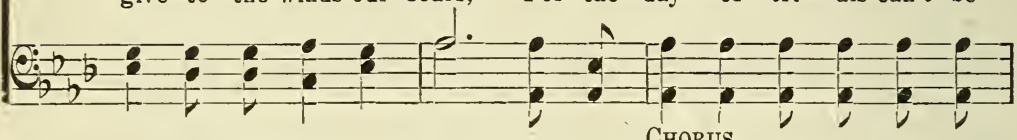

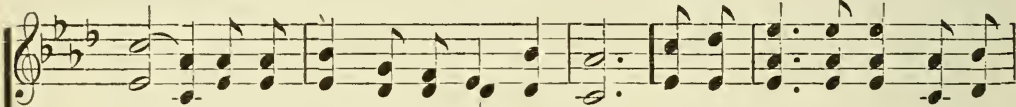
there" In the "home of the end-less years."

plain, In the "home of the end-less years." In that bet-ter land, In that long, Soon the "home of the end-less years.

$\frac{6-2-6}{2-2} \frac{0}{2}=5$

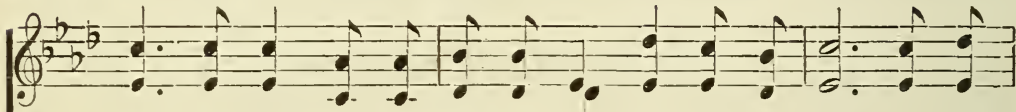
sun - ny land, In that $E$ - den land, safe by and by; In that

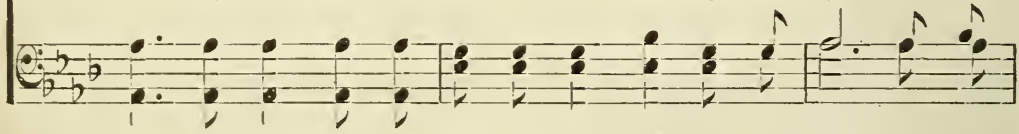

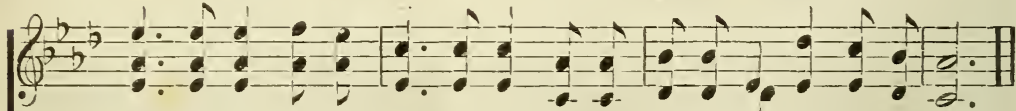
bet-ter land, In that sun - ny land, In that E-den land, safe by and by.

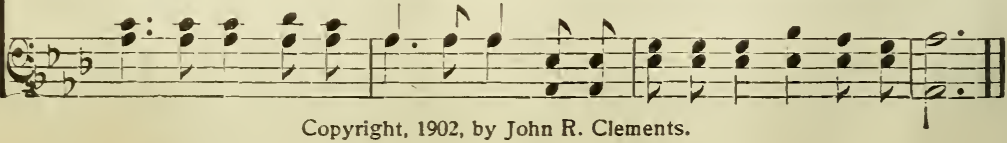

Copyright, 1902, by John R. Clements. 
1. My heart was not right In my dear Savior's sight, I knew not the

2. My soul was dis-trest, With its sor-row oppressed, Till Je-sus my

3. I walk in the light of $H$ is pres-ence so bright, His love makes $m_{7}$

4. And there ev-er-more I'll my Sav-ior a-dore, Give praise to His

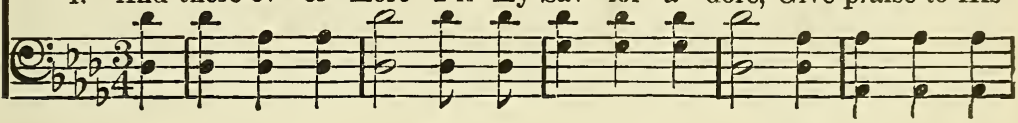

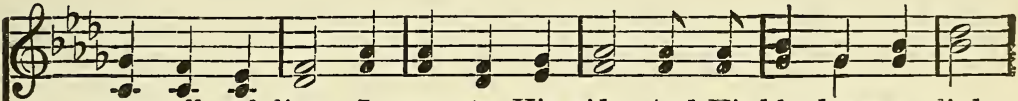

peace all sub-lime; I came to His side, And His blood was applied,

Sav - ior I found, But now He's my theme, While His word keeps me clean,

heav - en be - low, I'll sing of His grace Till I see His dear face,

pow - er di - vine, I'll fall at His feet And the sto - ry re-peat,

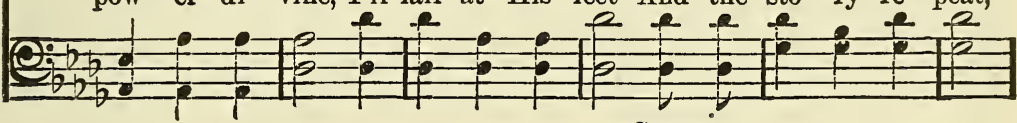

Chorús.

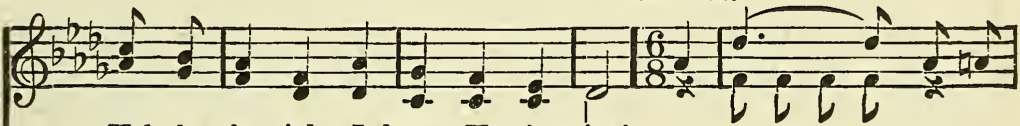

$\mathrm{Hal}-\mathrm{ie}-\mathrm{lu}-\mathrm{jah}, \mathrm{I}$ know $\mathrm{He}$ is mine!

$\mathrm{Hal}-\mathrm{le}-\mathrm{lu}$ - jah, His grace doth abound! I know..... He is

With the dear ones washed whiter than snow. Je-sus is mine,

Hal-le-lu - jah, I know $\mathrm{He}$ is mine!

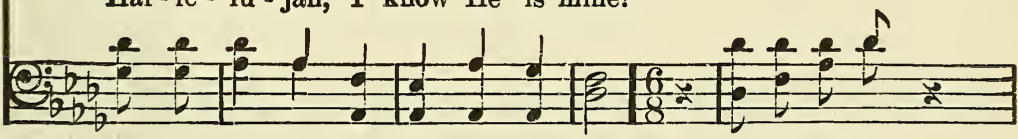

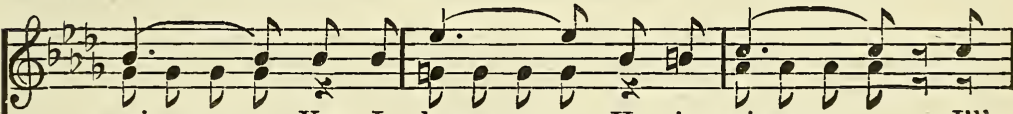

mine,...... Yes, I know..... He is mine...... I'll

yes $\mathrm{He}$ is mine, Je-sus is mine, yes $\mathrm{He}$ is mine,

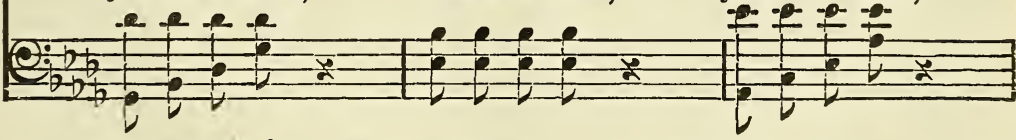

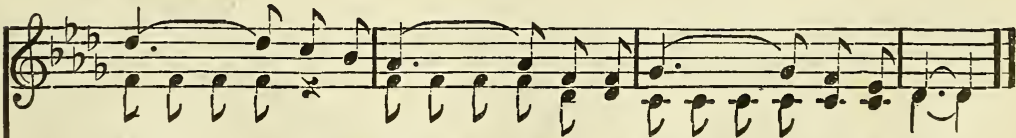

doubt...... Him no lon - - ger, I know..... He is mine.

doubt Him no more, doubt Him no longel; I know the dear Sav-ior is mine.

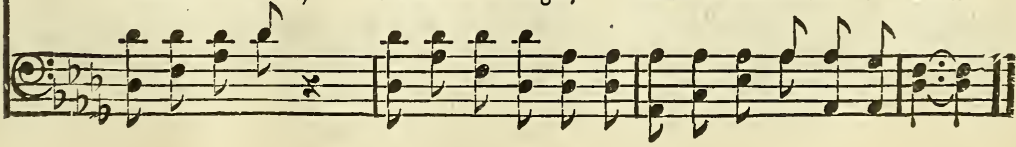




\section{I44 God Does Niot Ask You to Try.}

"To him that worketh not, but beliereth on him that justifieth the ungodly, his faith is counted unto him for righteousness."-Rom. 4:5.

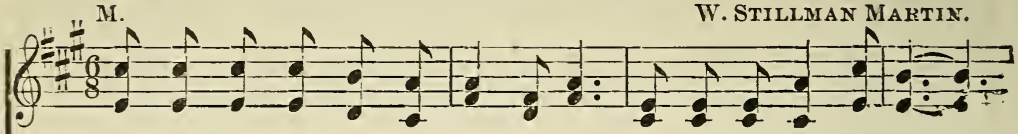

1. God does not ask you to try, brother, Trust-ing a-lone will s .,

2. God does not ask you to work, brother, 'Till you on Christ be-lieve;

3. God does not ask you to wait, brother, You will no bet-ter be;
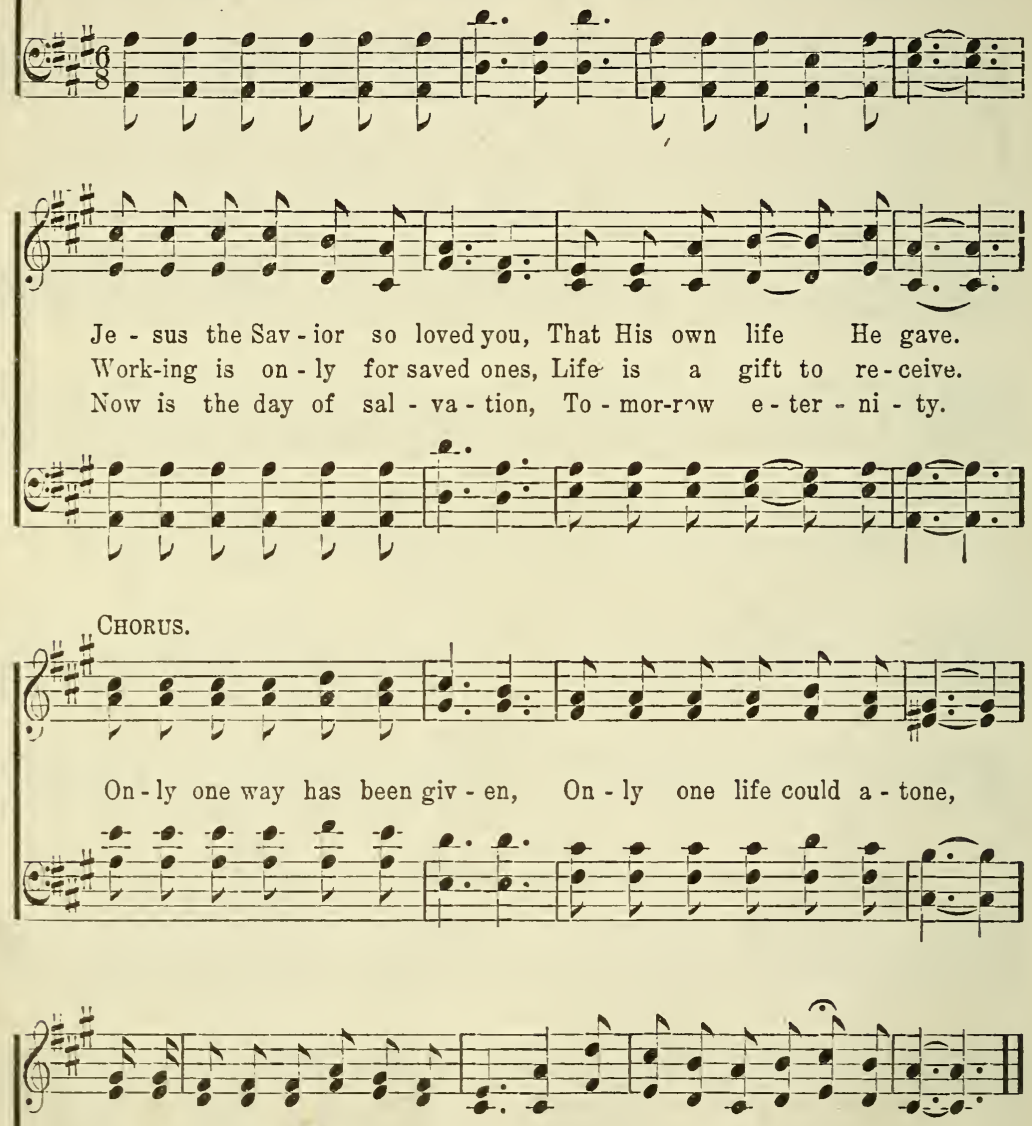

There is on-ly one passport to heav-en, 'Tis Je-sus and Je-sus a - lone.

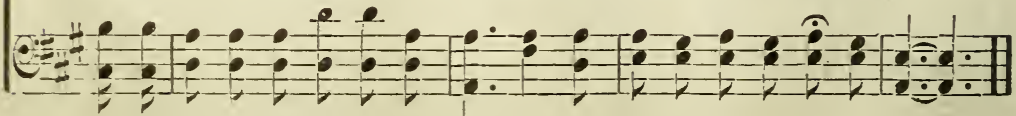

Copyright, 1905, by John A. Davis. 


\section{Beautiful Vision of Jesus.}

JOHN R. ClemeNts.

Welsh Chorale.

Arr. by W. H. JUDE.

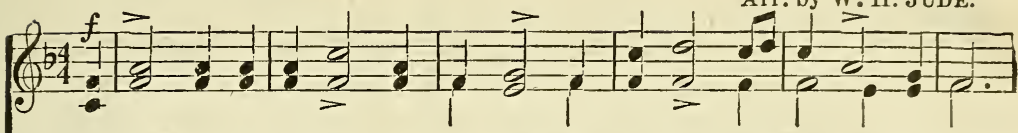

1. 0, beau-ti-ful vi-sion of Je-sus! My Sav-iour, All-glo-rious He stands

2. 0 , beau-ti-fulmis-sion of Je-sus! My sins to for - ev-er re-move,

3. 0 , beau-ti-ful vi-sion of Je-sus! The thorn-crown with jew-els be - set,
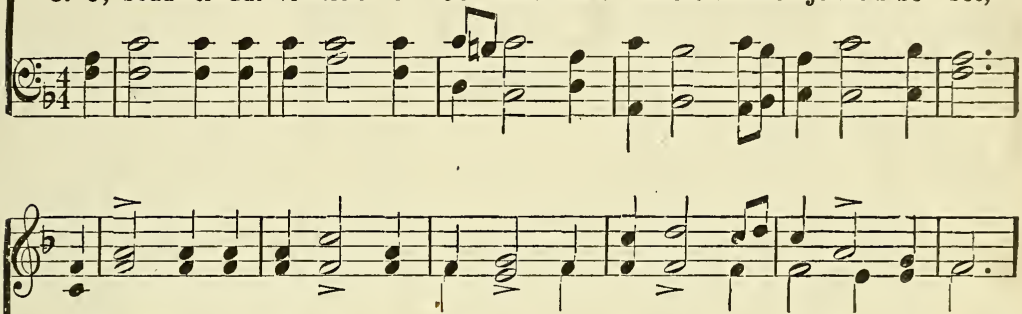

Re-splendent in heav - en - ly gar-ments; But look! yon are nail-pierc-ed hands.

To 0 - pen in heav - en an en-trance, The Fa-thar's own good-ness to prove.

The nail-prints all bril-liant with splendor, The scourge-marks more ra-di-ant yet;
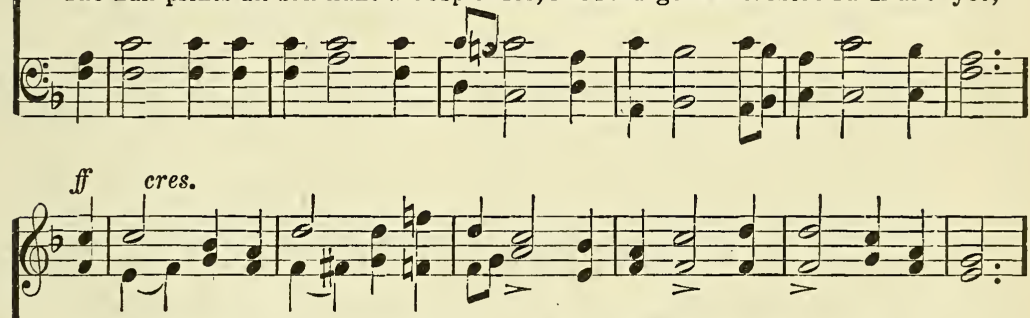

My song shall re - sound thro' the a - ges, His prais-es my voice shall em.ploy,

0 , Je - sus, Re-deem-er, I love Thee! And on thro' the a - ges to be,

That face is smile-light - ed for-ev-er, All-glo-rious in love-beams un-told;
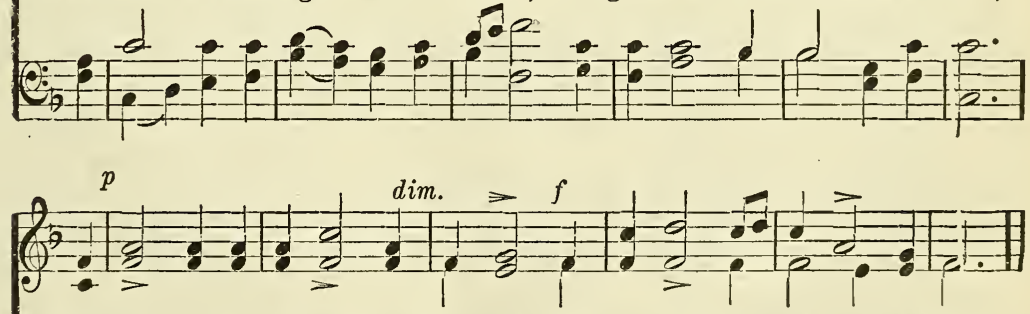

Re-deemed by His in - fin - ite an - guish, His name and His fame be my jo. I'll sing of Thymer-cy and good-ness Un - to a poor sin-ner like me. $u$, beau - ti-ful vis - ion of Je - sus! My Sav-iour, by faith I be-hr" d!

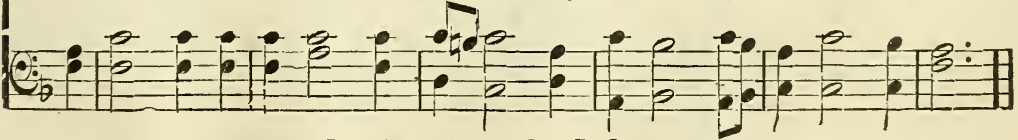

Copyright, 1906, by Jno. R. Clements. 
J. EDW. RUARK.

WM. J. KIRKPATRCK.

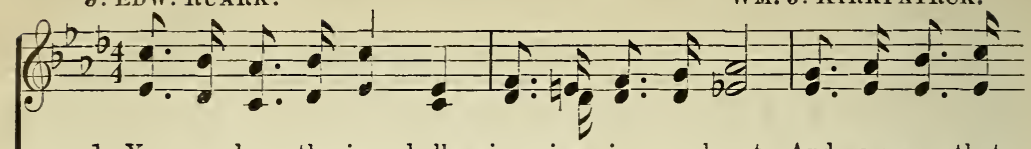

1. You may have the joy - bells ring - ing in your heart, And a peace that

2. Love of Je-sus in its ful-ness you may know, And this love to

3. You will meet with tri - als as you jour - rey home, Grace suf - fi-cient,

4. Let your life speakwell of Je-sus ev - 'ry day, Own His right to

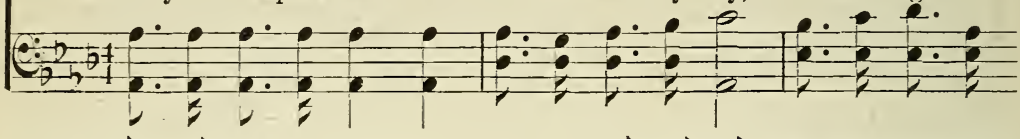

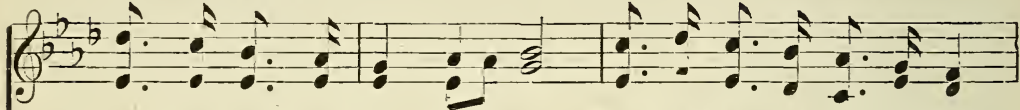

from you nev - er will de-part; Walk the straight and narrow way,

those a-round you sweet-ly show; Words of kind-ness al - way say,

$\mathrm{He}$ will give to 0 - ver-come; Tho' un-seen by mor-tal eye,

ev - ry serv-ice you can pay; Sin - ners you can help to win,

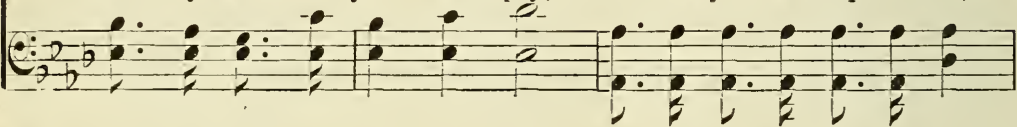

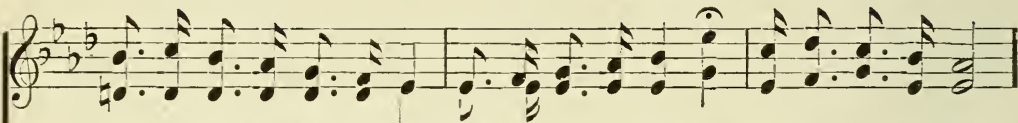

Live for Je - sus ev - 'ry day, He will keep the joybells ringing in your heart.

Deeds of mercy do each day, Then He'll keep the joybells ringing in your heart.

$\mathrm{He}$ is with you, ev-er nigh, And He'll keep the joybel's ringing in your heart.

If your life is pure and clean, And you keep the joybells ringing in your heart.

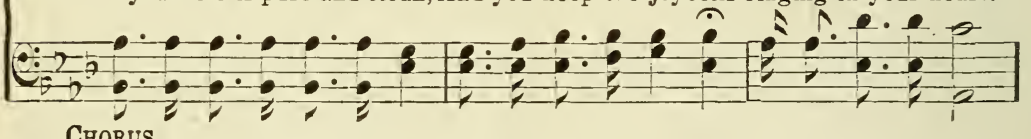

CHORUs.

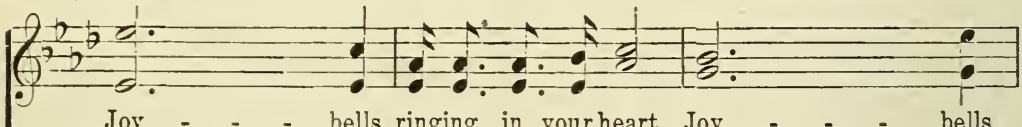

Joy - - - hells ringing in yourheart, Joy - - - bells

Ring-ing in your heart, You may hare the joy-bells

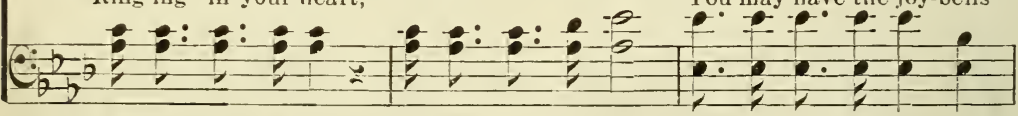

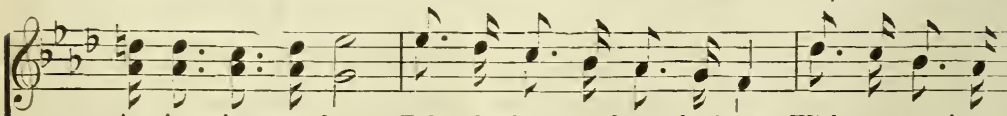

ring-ing in your heart; Take the Sav-iour here be-low, With you ev-'ry-

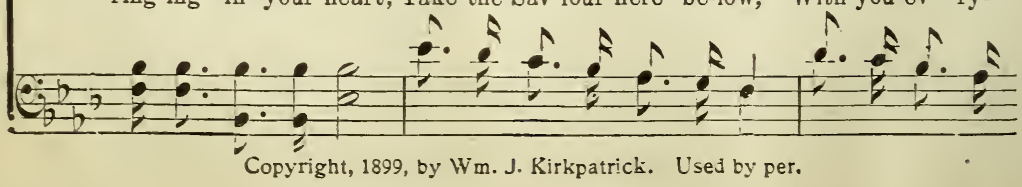




\section{You May Have the Joybells Ringing. 147}

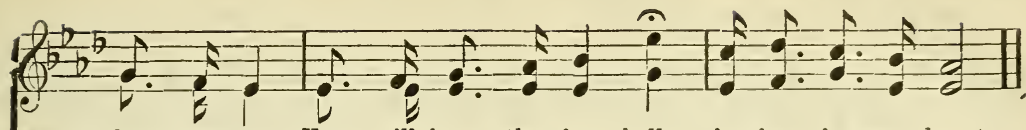

where you go, $\mathrm{He}$ will keep the joy-bells ring-ing in your heart.

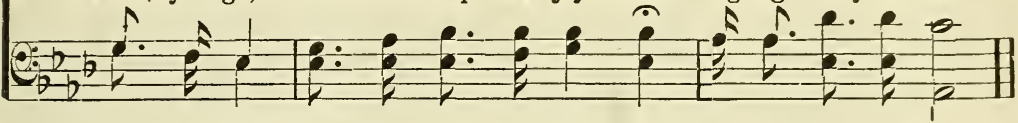

\section{He Came to Save.}

H. E. BLAIR.

WM, J. KIRKPATRICK.

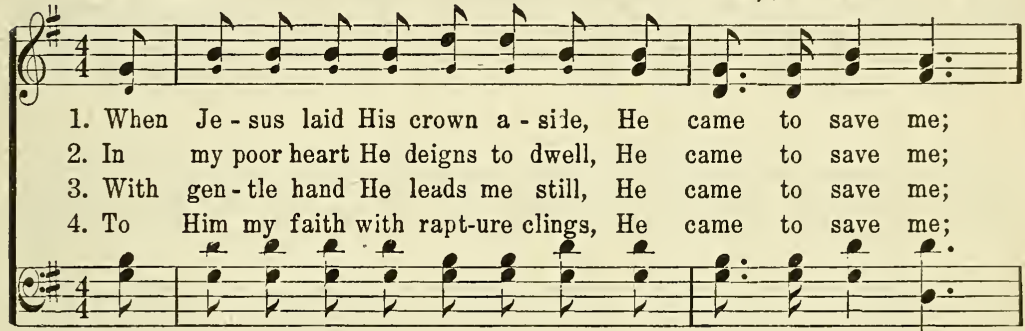

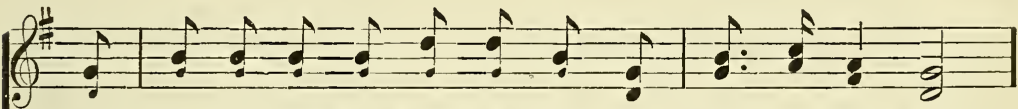

When on the cross $\mathrm{He}$ bled and died, $\mathrm{He}$ came to save me.

Oh, praise His name, I krow it well, He came to save me.

And trust-ing Him I fear no ill, $\mathrm{He}$ came to save me.

To Him my heart looks up and sings, $\mathrm{He}$ came to save me.

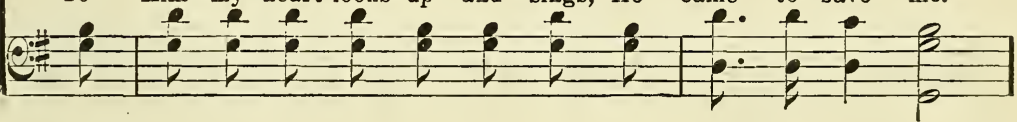

0

I'm so glad, I'm so glad, I'm so glad that Je-sus came, And grace is free,

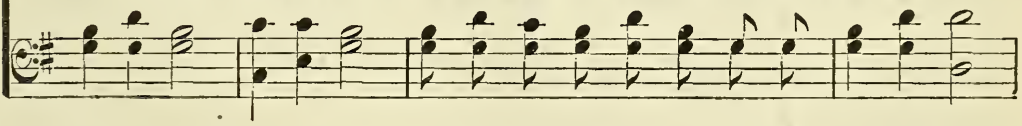

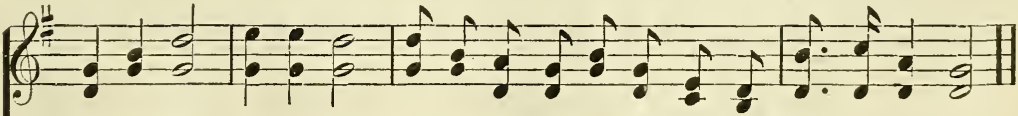

l'm so glad, I'm so glad, I'm so glad that Je-sus came, He came to save me.

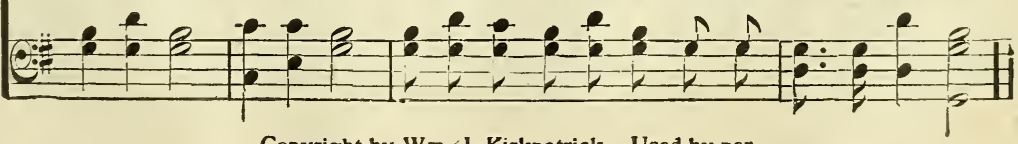

Copyright by Wm.J. Kirkpatrick. Used by per. 
Ret. Johnson OATMan, JR.

Chas. H. Gabriel.

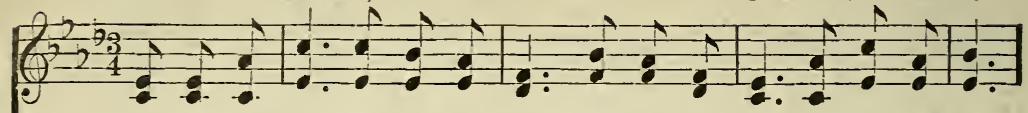

1. I'm press-ing on the up-ward way,New heights I'm gain-ing ev - 'ry day;

2. My heart has no de-sire to stay Where doubts a-rise and fears dis-may;

3. I want to live a-bove the world, Tho' Sa-tan's darts at me are hurled;

4. I want to scale the ut-most height, And catch a gleam of glo-ry bright;
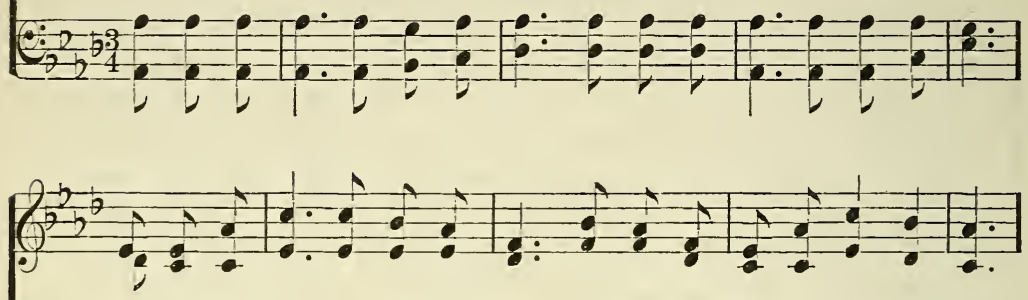

Still pray-ing as I on-ward bound, "Lord,plant my feet on high-er ground." Tho' some may dwell where these abound, My prayer, my aim is higher ground. For faith has caught the joy-ful sound, The song of saints on higher ground. But still I'll pray till heav'n I've found, "Lord, lead me on to higher ground.

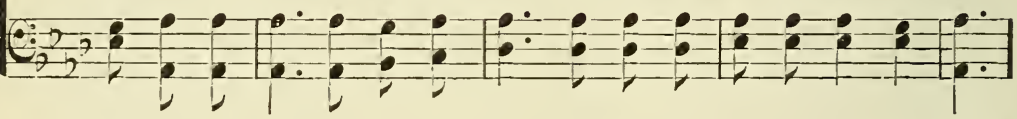

Chorus.

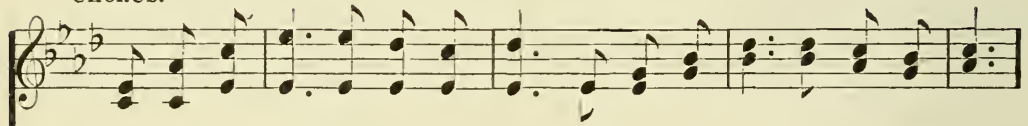

Lord, lift me up and let me stand, By faith, on heav-en's ta-ble-land;
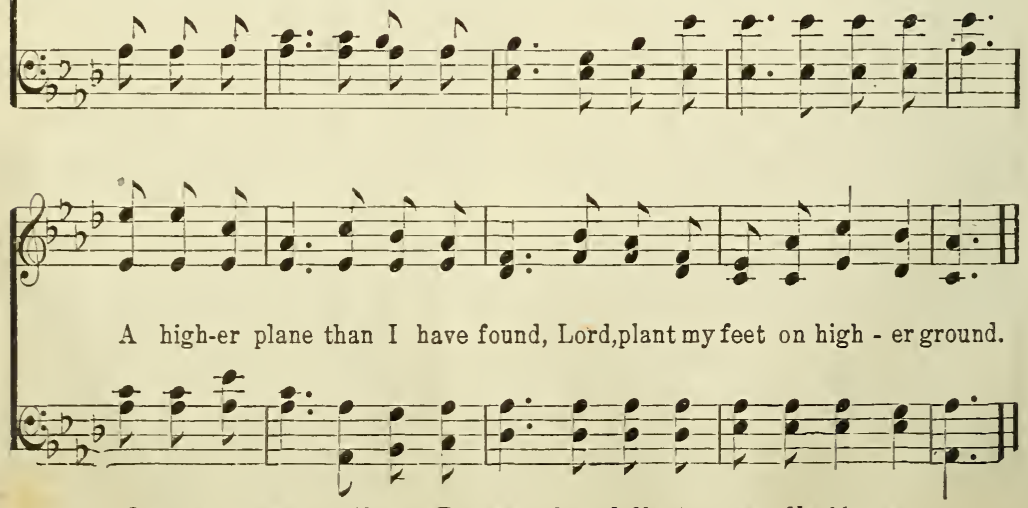

Copyright, 1898, by J. Howard Entwisle. John J. Hood, owner. Used by per. 


\section{Going Home.}

он $\mathbf{N}$ R. Cr.нмeNтs. "That great city."-Rev. 21: 10.

B. Frank BUTT؟.

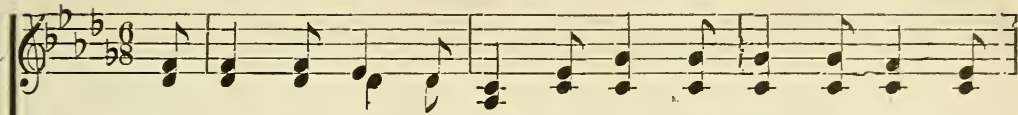

1. The day is done, its tasks are o'er, The eve-ning shades un-

2. The day held cares, its paths were rough, The mo-ments wore on

3. Life's day wears on with rap - id stride,'Mid scenes of earth I'll
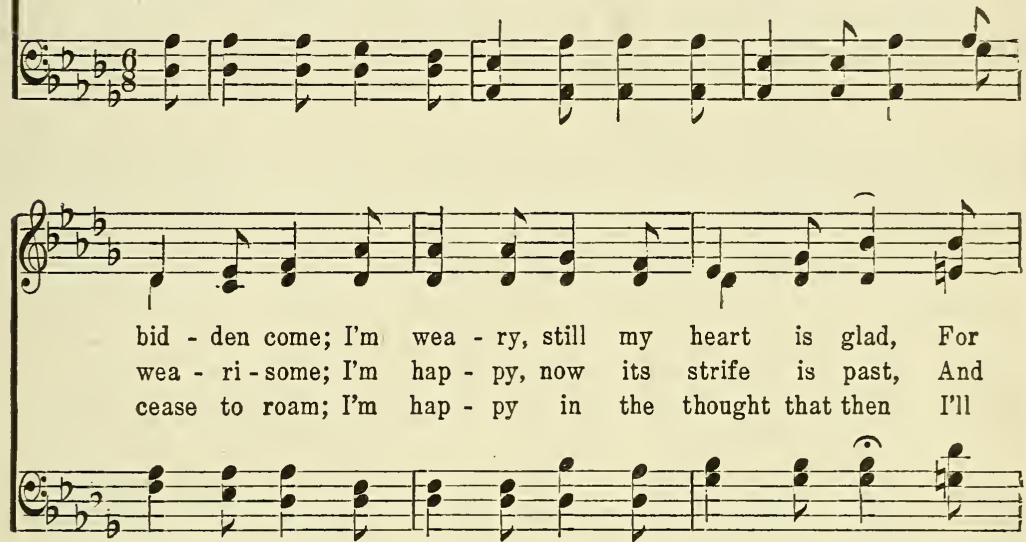

Chorus.

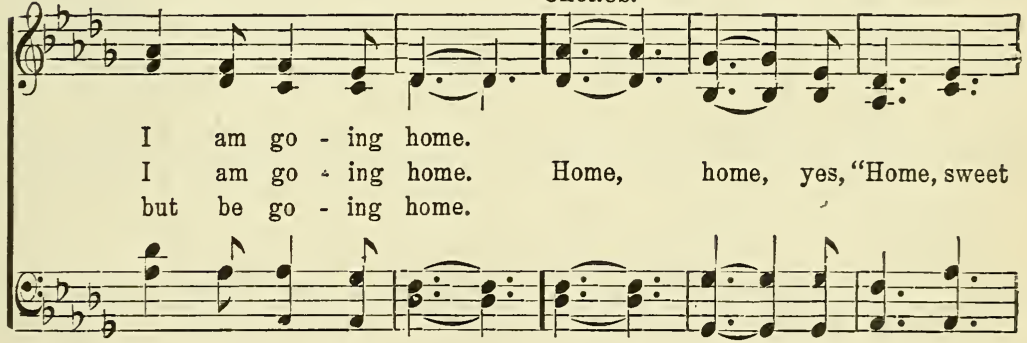

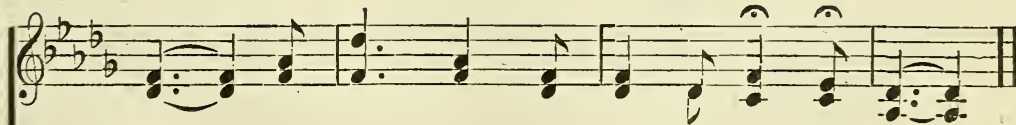
home;" There's no joy like that of go - ing home.

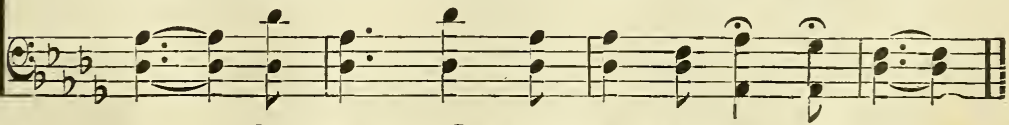

Copyright, 1900 , by B. Frank Butts, Used by per. 


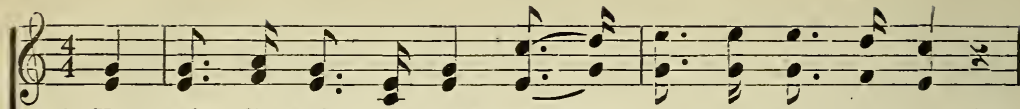

1. Ye sol - diers of the cross, rise and put your ar - mor on;

2. The watch-men they are cry - ing, at-tend the trum-pet's sound;

3. Lay hold up - on the Sav - iour by faith's vic - tor - ious shield,

4. Ne'er think the vic - t'ry won, nor lay your ar - mor down;

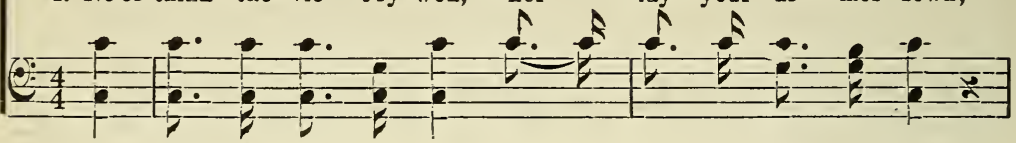

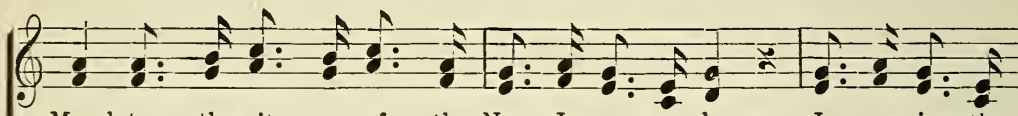

March to the cit - y of the New Je-ru - sa-lem; Je - susgives the

Take the gos-pel banner, and the pow'rs of hell surround; Hearts and arms make

March on in or - der till you win the glo-rious field; Faint not by the

Marchon in du - ty, till you gain the star - ry crown; When the war is

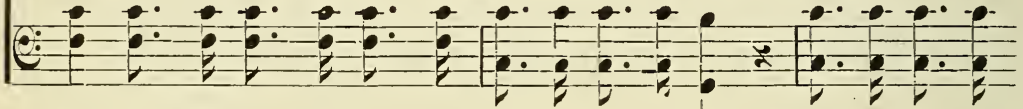

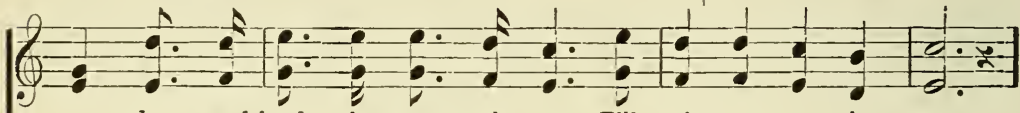

or - der, and leads the peo - ple on Till vic - to - ry is won.

read - $y$, the bat - tle is at hand; Go forth at Christ's com-mand.

way till you've gain'd that peace - ful shore, Where war shall be no more.

o'er, and the bat - tle you have won, Je - sus will say, "Well done."

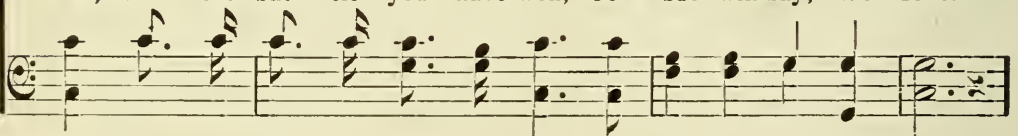

(2horus.

Glo - ry, glo - ry, hal - le - lu - jah! Glo - ry, glo - ry, hal - le - lu - jah!

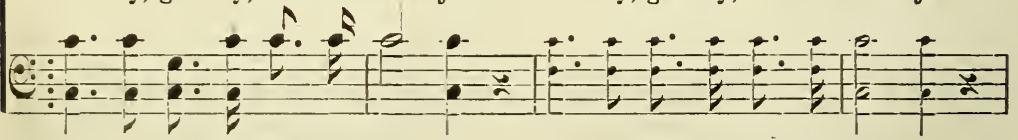

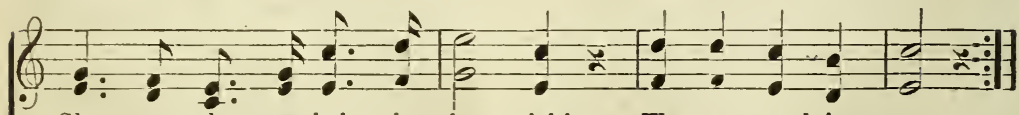

Glo - ry, glo - ry, hal - le - lu - jah! We are march-ing on

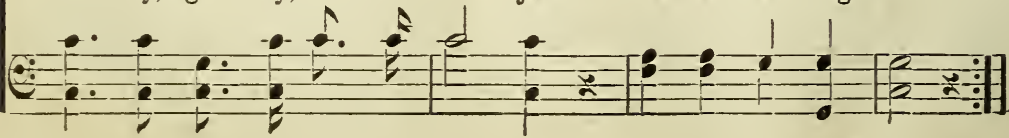


MARY D. JAMES.

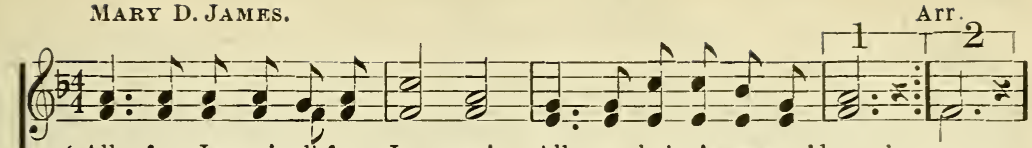

1. All for Je-sus! all for Je - sus! All my being's ransom'd pow'rs;

- All my tho'ts andwords and do-ings, All my days and all my hours.

2. $\{$ Let my hands perform His bid-ding, Let my feet run in His ways-

2. $\{$ Let my eyes see Je-sus on - ly, Let my lips speak forth His praise,

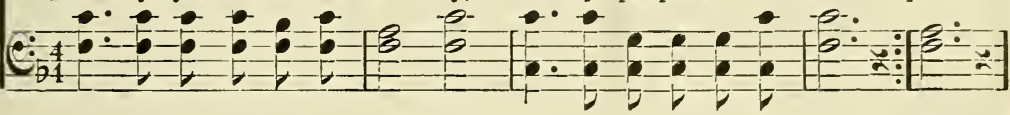

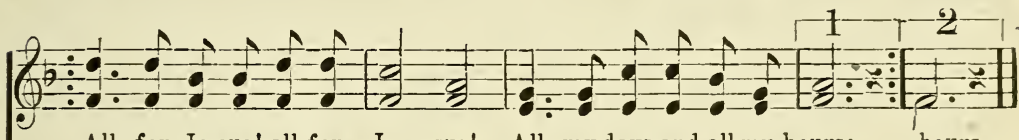

All for Je-sus! all for Je - sus! All my days and all my hours; hours.

All for Je-sus! all for Je - sus! Let my lips speak forth His praise; praise.

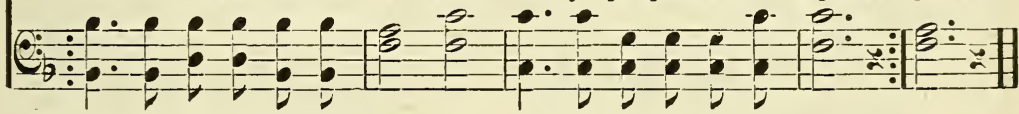

3 Since my eyes were fixed on Jesus,

I've lost sight of all besides;

So enchained my spirit's vision,

Looking at the crucified.

\|: All for Jesus! all for Jesus!

Looking at the Crucified. :॥
$4 \mathrm{Oh}$, what wonder! how amazing! Jesus, glorious King of kings-

Deigns to call me His beloved, Lets me rest beneath His wings. $\|$ : All for Jesus! all for Jesus!

Resting now beneath His wings!:

\section{Just As I Am, Without One Plea.}

Charlotte Elliot.

\section{(Woodworth, L. M )}

WM.B. BRADBURY.
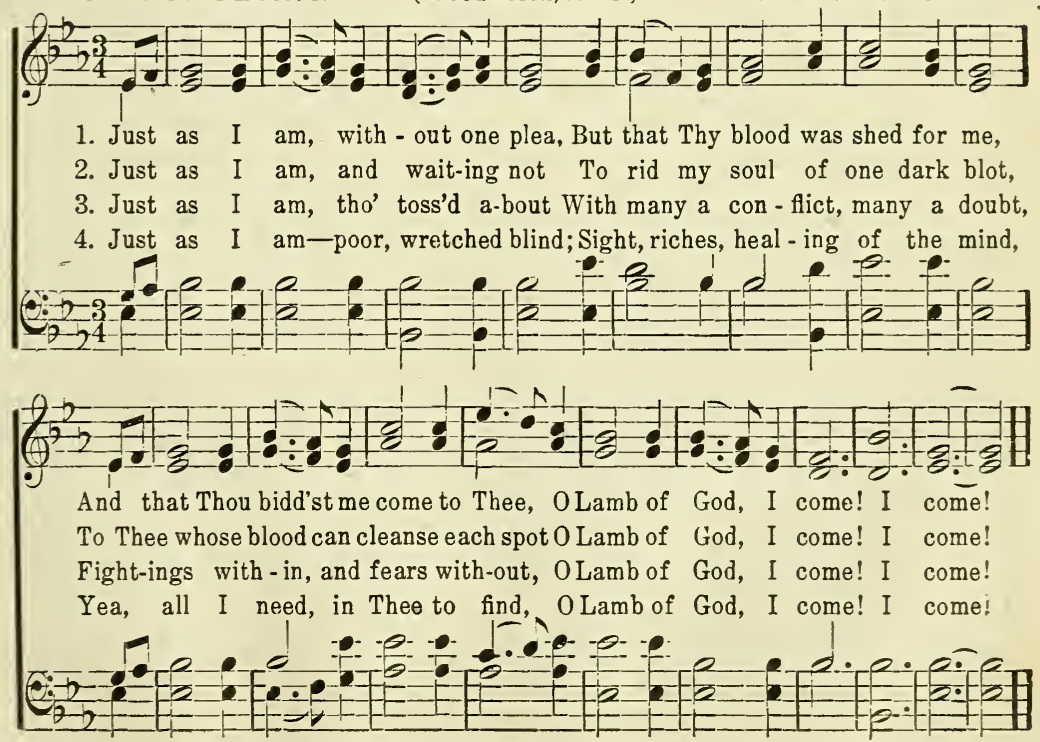


\section{2 Jesus Is the Sinner's Friend.}

"This man receiveth sinners."-Luke 15:2.

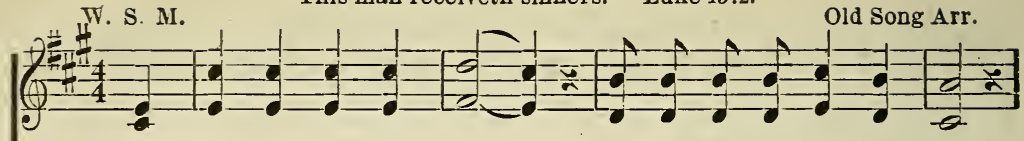

1. Oh, tell to all a - round, Je-sus is the sin-ner's Friend;

2. Oh, hearts so full of strife, Je-sus is the sin-ner's Friend;

3. Then lift your hap-py voice, Je-sus is the sin-ner's Friend;
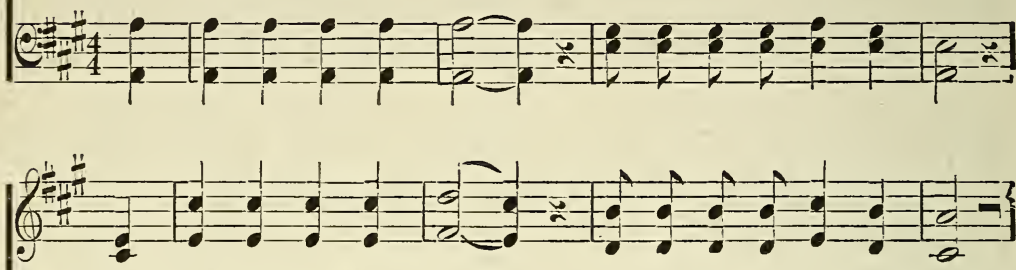

$\mathrm{Oh}$, let the words re - sound, Je - sus is the sin - ner's Friend;

$\mathrm{He}$ of - fers end-less life, Je-sus is the sin-ner's Friend;

And bid the lost re - joice, Je-sus is the sin-ner's Friend;
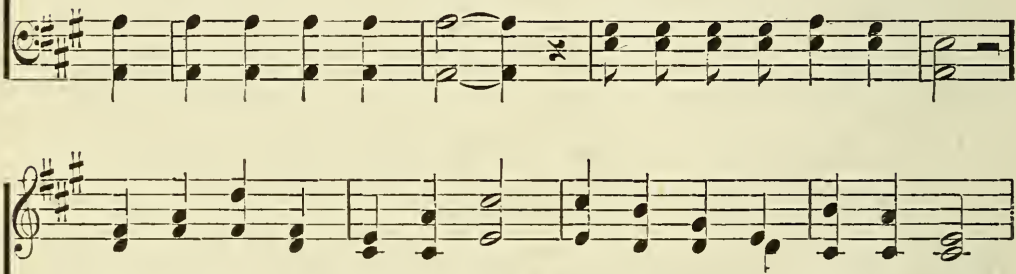

Glo - ry, glo - ry, this we know, When He came to earth be - low,

Tell it forth o'er land and sea, $\mathrm{He}$ has come to make men free-

Bear this truth to ev - 'ry land, "Go," it is your Lord's com-mand,
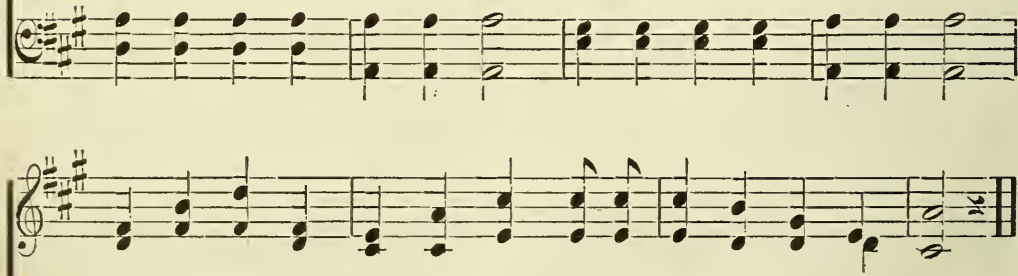

'Twas up - on the cross to go, Je-sus is the sin-ner's Friend.

Earth shall have a Ju - bi - lee, Je - sus is the sin - ner's Friend.

Tell men Christ is just at hand, Je-sus is the sin-ner's Friend.

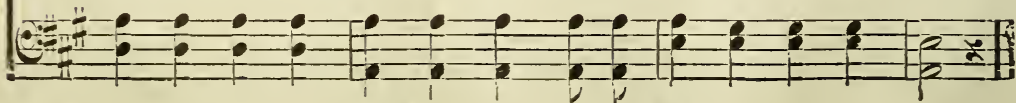

Copyright, 1905, by John A. Davis. 
A. M. TOPLADY.

(Toplady 7s. 6 1.)

Thos. Hastings.

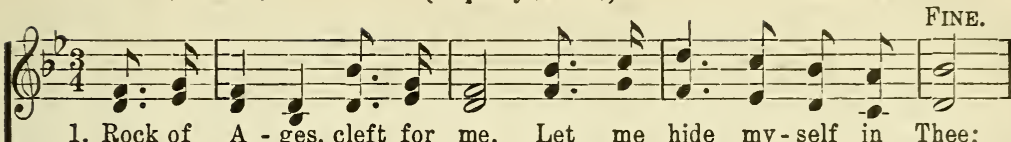

1. Rock of A-ges, cleft for me, Let me hide my-self in Thee; D. C.-Be of sin the dou-ble cure, Save from wrath and make me pure.
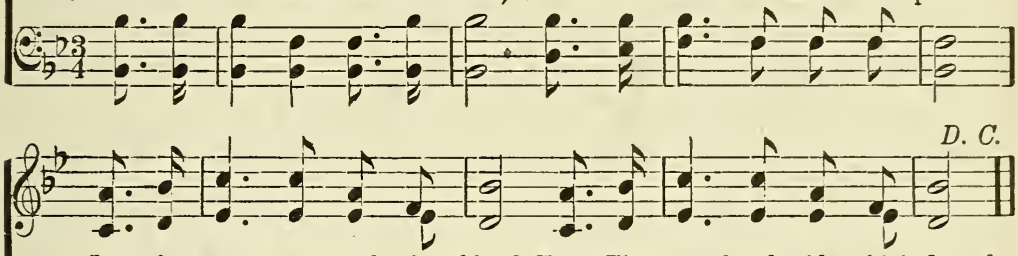

Let the wa - ter and the blood, From Thy wound-ed side which flowed,

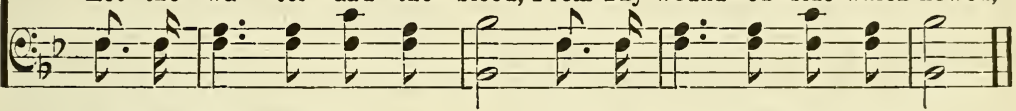

2 Could my tears forever flow, Could my zeal no languor know, These for sin could not atone, Thou must save, and thou alone: In my hand no price I bring, Simply to Thy cross I cling.
3 While I draw this fleeting breath, When my eyes shall close in death, When $I$ rise to worlds unknown, And behold Thee on Thy throne, Rock of Ages, cleft for me, Let me hide myself in Thee.

\section{At the Fountain.}
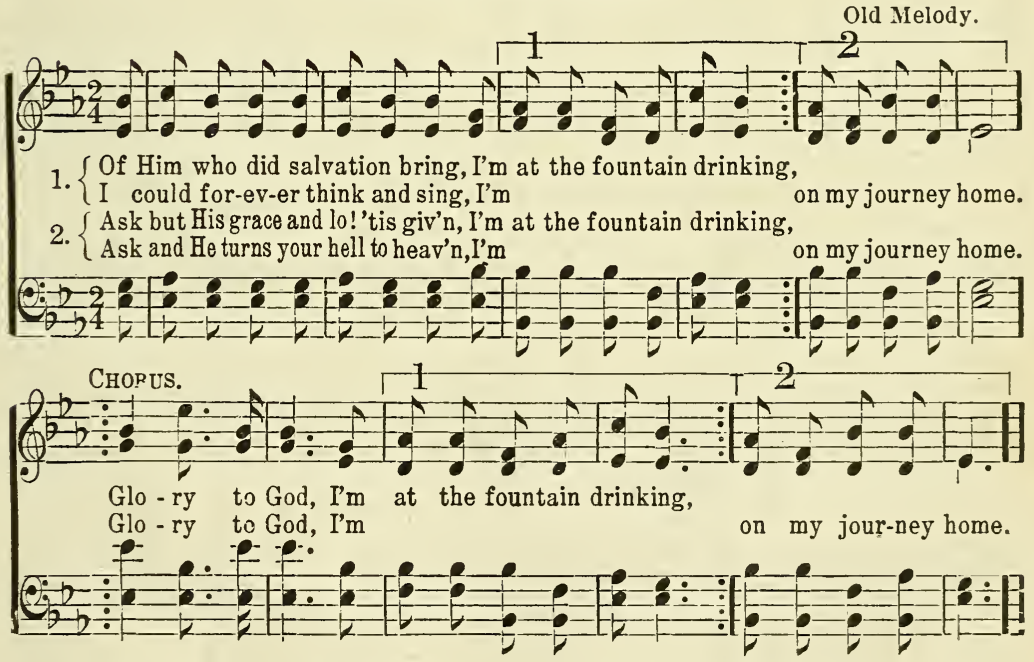

3 Tho' sin and sorrow wound my soul,

I'm at the fountain drinking,

Jesus, Thy balm will make me whole,

I'm on my journey home.

4 Where'er I am, where'er I move,

I'm at the fountain drinking,

I meet the object of my love,

I'm on my journey home.
5 Insatiate to this spring I fly,

I'm at the fountain drinking,

I drink and yet am ever dry,

I'm on my journey home.

Chorus.-Glory to God,

I'm at the fountain drinking,

Glory to God,

My soul is satisfied. 


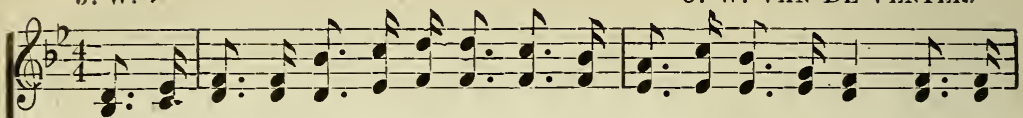

1. When the days are dark and dreary, And my load is hard to bear, When the

2. Oth - er friends may die and leave me, But the Lord is ev - er near, And the

3. It is sweet to tar-ry with Him, And to wor-ship at His feet, Tho' the

4. Could my tongue re-veal the rap-ture And the joy with-in my heart, You would

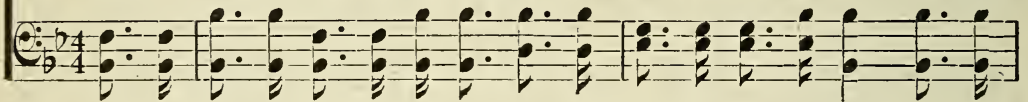

$\left(\begin{array}{l}0-1 \\ \theta-1-1\end{array}\right.$

waves of doubt and trouble o'er me roll,

lit - tle cares and troubles flee a-way;

earth-ly form of clay I can-not see;

nev - er keep Him standing at the door;
Then I car - ry all to Je-sus, In the se - cret of His presence, Yet I know the Light is shin-ing If you knew how ver $-\mathrm{y}$ pre-cious

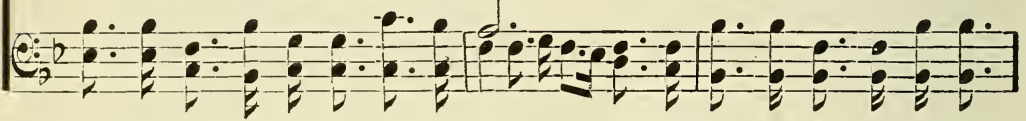

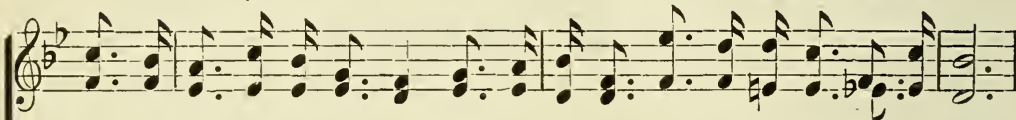

And I find a solace there; "He's the fair-est of ten thousand to my soul."

We commune to-geth-er here; He's my ref-uge, my com-pan-ion, day by day.

Just a-bove the mer-cy-seat, And I praise Him for His ten-der love to me.

You would choose the better part; You would love Him and a-dore Him ev - er-more.

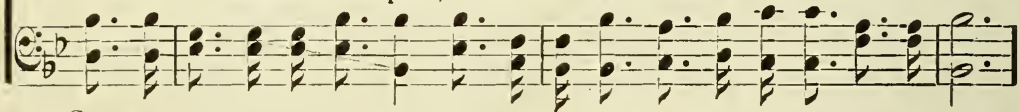

Chorus.

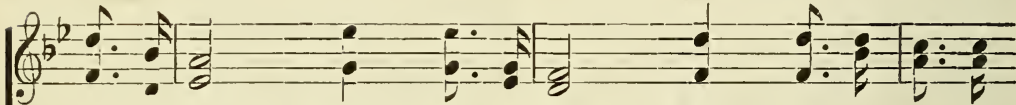

He's the fair - est and the dear - est: How I wish my

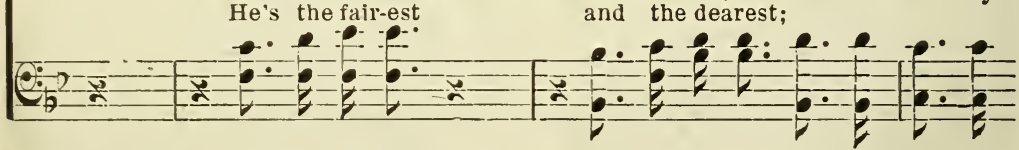

blessied Sav-ior could be thine! Houwould love Him, if you could be thine! You would lore Him.

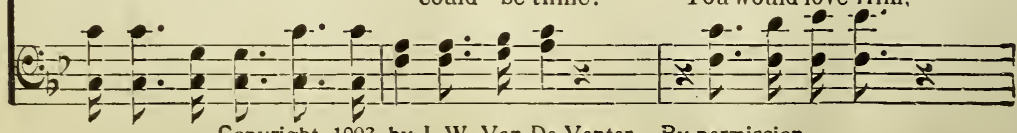

Copyright, 1903, by J. W. Van De Venter. By permission. 


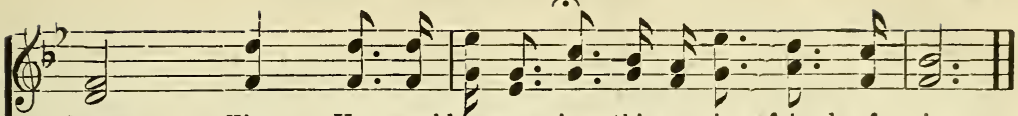

knew Him; You would never grieve this precious friend of mine.

if you knew Him;

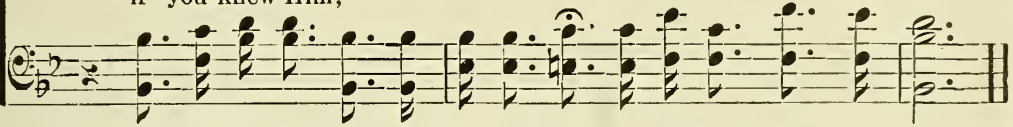

\section{Lord, I'd Follow Thee.}

JоHN R. CLEMENTS. "The Captain of our Salvation."

Scotch Air.

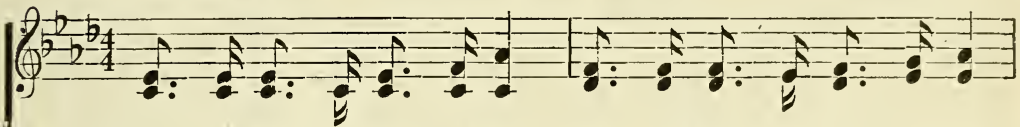

1. On the bat - tle field of life, With its fierce un-ceas - ing strife;

2. Sounds the stir-ring bu - gle call, And its mes - sage is for all;

3. What tho' foes in am-bush stay, They've no pow'r to win to-day;
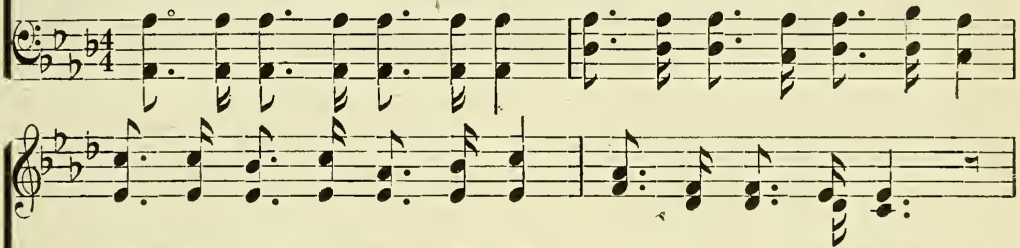

Where the con-flict e'er is rife, Lord, I'd fol - low Thee.

Though my strength may be but small, Lord, I'd fol - low Thee.

Thou canst sweep them from the way, Lord, I'd fol - low Thee.
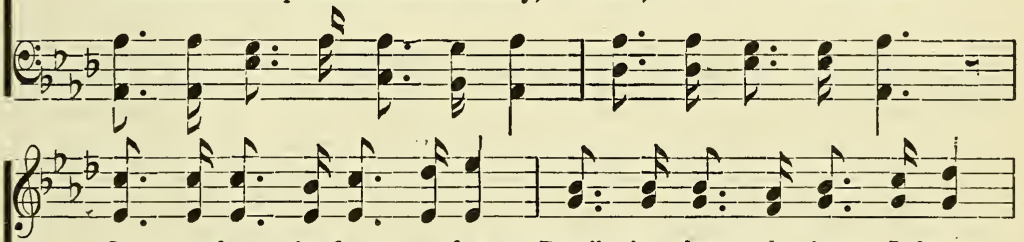

I can face the fierc-est foe, Batt'l - ing brave-ly since I know

'Mid the din of can-non's roar, Where the bat - tle press-es sore,

Press-ing on with cour-age new, Ev - er to my Cap-tain true,
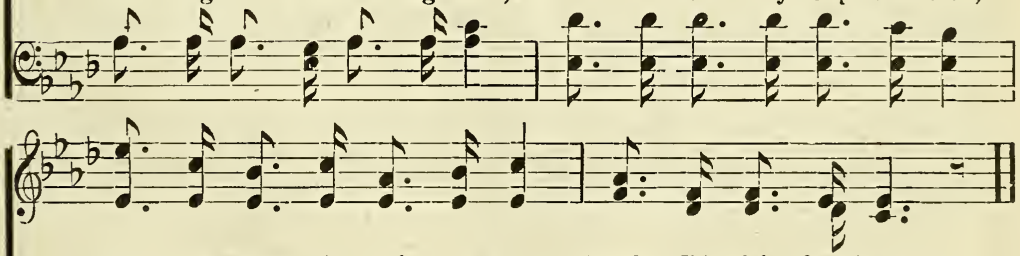

Thou art where Thy col - ors go; Lord, I'd fol - low Thee.

There to fight as ne'er be-fore, Lord, I'd fol - low Thee.

There's a shin - ing goal in view, Lord, I'd fol - low Thee.

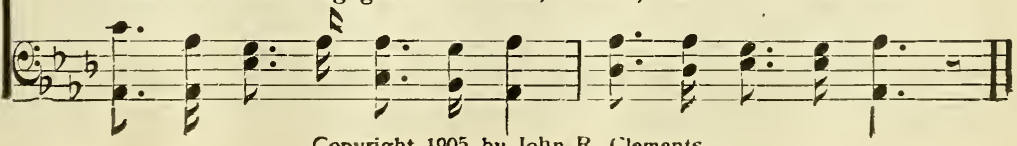

Copyright. 1905, by John R. Clements. 
Rev. EDWARD HOPPER.

J. E. GOULd.

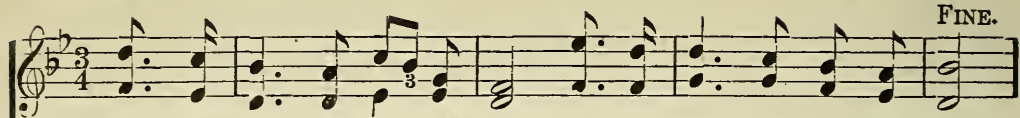

1. Je - sus, Suv - ior, pi - lot me 0 - ver life's tem-pest-uous sea;

D. C.-Chart and com-pass come from Thee; Je - sus, Sav - ior, pi - lot me.
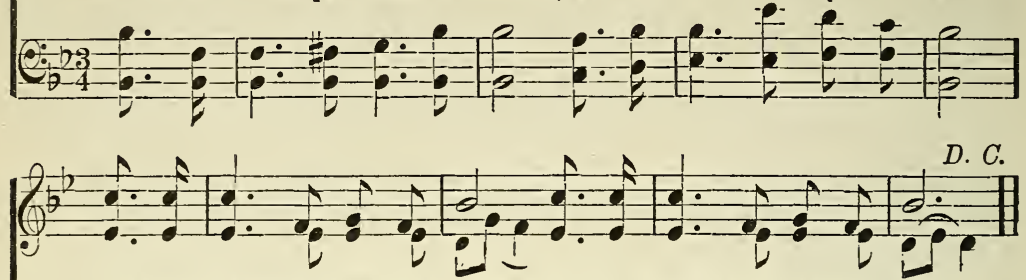

Unknown waves be-fore me roll, Hid-ing rock and treach'rous shoal;

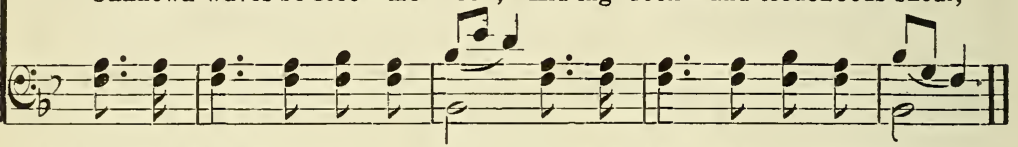

2 As a wother stills her child,

Thou canst hush the ocean wild;

Boist'rous waves obey Thy will,

When Thou say'st to them, "Be still!"

Wondrous Sov'reign of the sea,

Jesus, Savior, pilot me.
3 When at last I reach the shore, And the fearful breakers roar 'Twixt me and the peaceful rest, Then, while leaning on Thy breast, May I hear Thee say to me, "Fear not, I will pilot thee."

\section{There is a Fountain.}

LOWELl Mason.

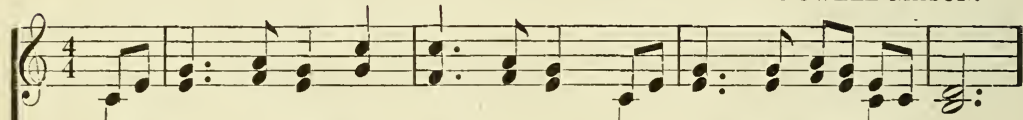

1. There is a fount-ain filled with blood Drawn from Im-man-uel's veins;

2. The dy - ing thief re-joiced to see That fount-ain in His day;

3. Dear dy - ing Lamb Thy pre-cious blood, Shall nev - er lose its pow'r,

4. E'er since by faith I saw the stream Thy flow-ing wounds sup - ply,

5. Then in a no-bler, sweet - er song, I'll sing Thy pow'r to save,
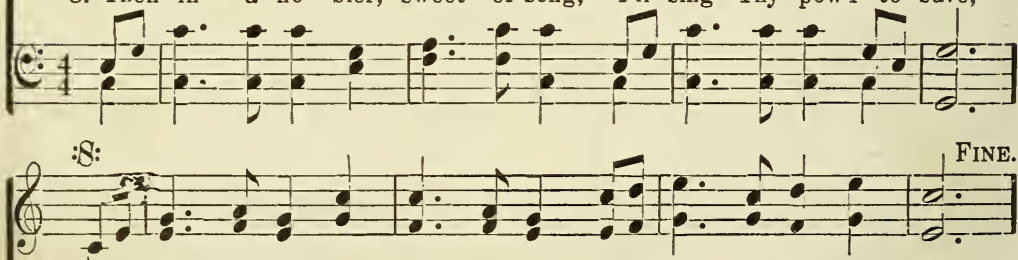

And sin-ners plung'd be - neath that flood, Lose all their guilt-y stains.

And there may I though vile, as he, Wash all my sins a - way.

Till all the ransomed Church of God, Are saved to sin no more.

$\mathrm{Re}$ - deem - ing love has been my theme And shall be till I die.

When this poor lisp-ing stamm'ring tongue, Lies si - lent in the grave.

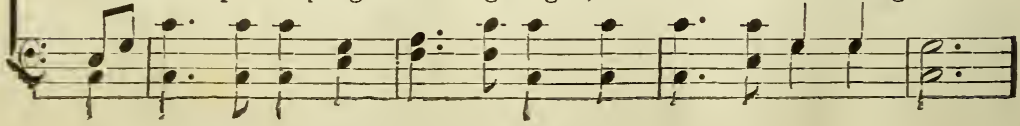




\section{There is a Fountain.}

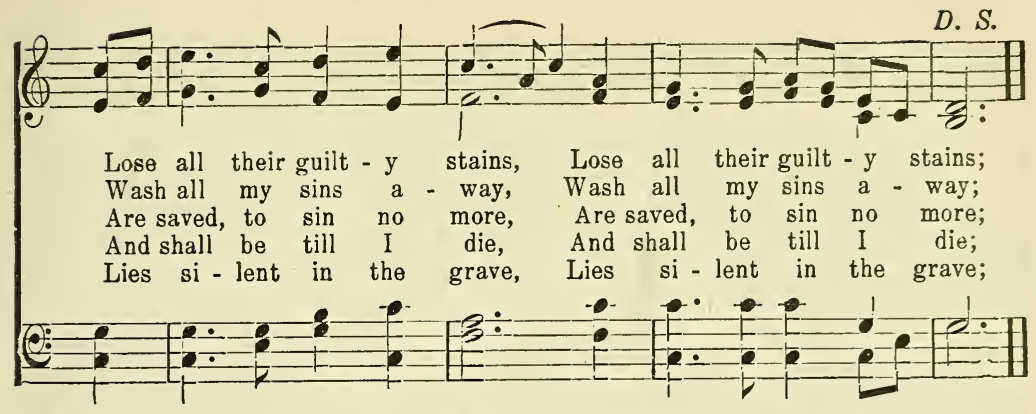

\section{My Jesus, I Love Thee.}

London Hymn Book.

A. J. Gordon. By per.

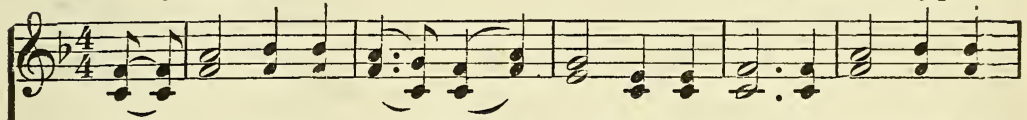

1. My Je-sus, I love Thee,I know Thou artmine,For Thee all the

2. I love Thee, be-cause Thou hastfirstlov-ed me, And purchased my

3. I will love'Thee in life, I will love Thee in death,And praise Theo as

4. In man-sions of glo - ry and end-less de-light, I'll ev - er a =
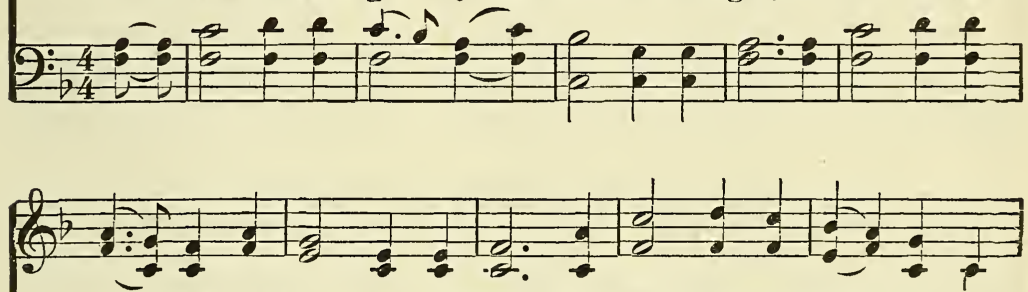

fol-lies of sin I re-sign; My gra-cious Re-deem-er, my

par-don on Cal - va-ry's tree; I love Thee for wear-ing the

long as Thou lend-est me breath;And say when the death-dew lies

dore Thee in heav -en so bright;I'll sing with the glit - ter-ing
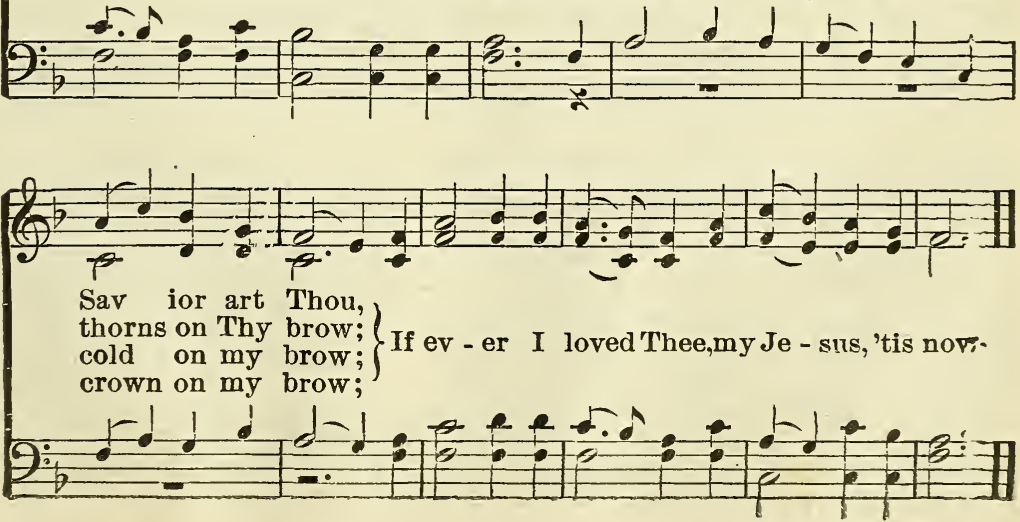


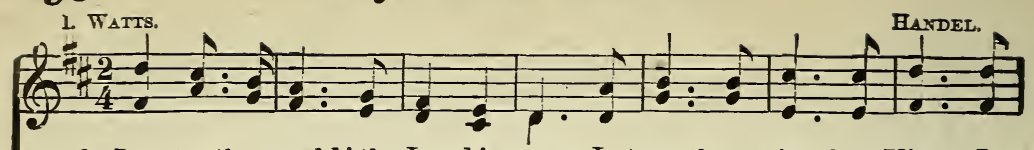

1. Joy to the world! the Lord iscome; Let earth receive her King; Let

2. Joy to the world! the Sav-ior reigas! Let men their songs employ; While

3. He rules the world with trath and graco,And makes the nations prove The
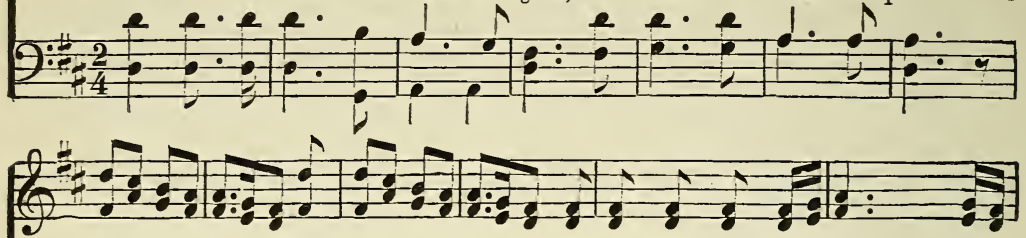

ev - 'ry heart pre-pare Him room,And hear'nand nature sing, And

fields and floods,rocks, hills and plains,Repeat the sounding joy, Re .

glo-ries of His right-eous-ness, Andwonders of His jove, And
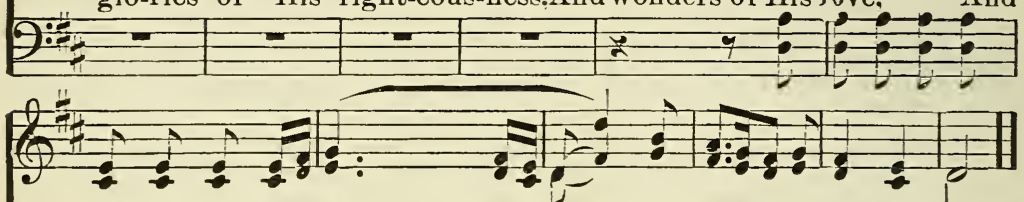

heav'n and na-ture sing,

peat the sounding joy,

won - ders of His love,
And heav'n, And heav'n and na-ture sing. Re - peat, Re - peat the sounding joy, And won. And won-ders of His love.

Charles Weslet.

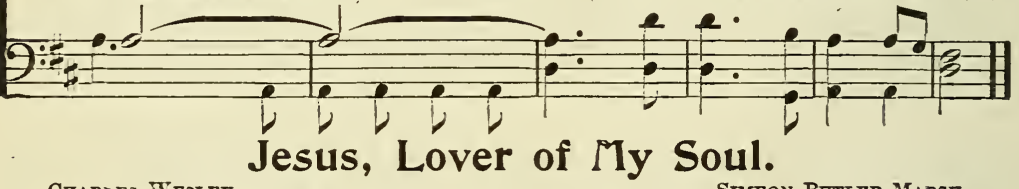

FINE.

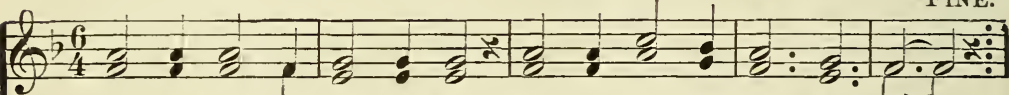

1. $\{\mathrm{Je}$-sus,lov - er of my soul, Let me to Thy bo-som fly.

1. $\{$ While the nearer waters roll, While thetempest still is high. $\}$

D. C. Safein - to the hav-en guide; Oh, re-ceive my soul at last.

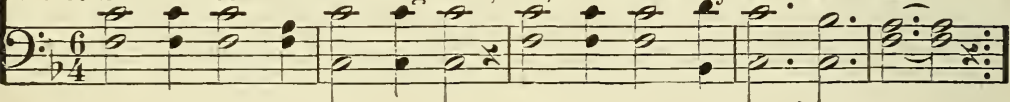

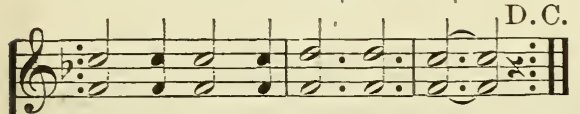

\{ Hide me,Oh my Sar-ior, hide, \} Till the storm of life is past:

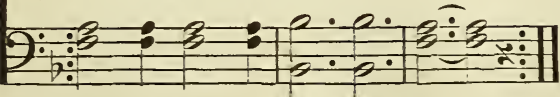

2 Other refuge have I none; Hangs my helpless soul on Thee: Leave, $O$ leave me not alone, Still suppori and comfort me. All my trust on Thee is stayed, All my help from Thee I bring; Cover my defenseless head

With the shadow of Thy wing
3 Plenteous grace with Thee is foundGrace to cover all my sin;

Let the healing streams abound; Make and keep me pure within.
Thou of life the fountain art, Freely let me take of Thee; Spring Thou up within my heert Rise to all eternit. 
Songs of Redemption.-Revised.

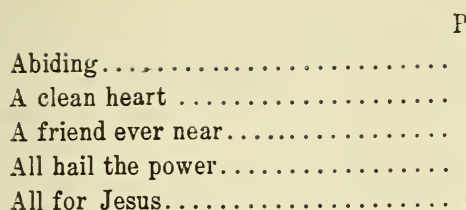

All to Christ I owe...............

At the fountain............. 15

Beautiful vision of Jesus........... 145

Better farther on ............. 125

Beulah Land................ 63

Blessed assurance...............

Blessed Jesus keep me white........

Christ is best.

Christ is the sunny side.......... 122

Come speak a word for Jesus........ 140

Cotid I tell it................ 10

Dare to stand like Joshua ......... 74

Do you know Jesus?............. 97

Drifting away from God.......... 101

Fairest and dearest............ 154

Far beyond our fairest vision....... 123

Filled with sunshine and song........

Fling out the banner............ 121

Fullness of power............. 115

Give me Jesus................. 83

Give to Jesus glory..............

God does not ask you to try........ 144

God give us homes............. 24

God will take care of you..........

Going Home............... 149

Grace ..................... 25

He came to save.............. 147

Have faith in God............. 70

Hear Him calling. . . . . . . . . . . . 124

$\mathrm{He}$ is coming by and by ........... 136

He'll never forget to keep me....... . 35

He Saves Me................ 98

Higher Ground ............... 148

Holy Ghost, with light divine....... 105

Holy Spirit, faithful guide......... 105

How firm a foundation........... 95
Page

I know that my Redeemer lives..... 130

Is it for me?................ 22

Is it nothing to you?........... 11

I shall not pass again this way...... 27

Is thy heart right with God?...... 104

It's happier every day........... 134

It is strange $\ldots \ldots \ldots \ldots \ldots \ldots \ldots$

I want everybody to know........ 131

I will sing the wondrous story...... 32

I will shout His praise in glory...... 57

I've had a glimpse of Jesus......... 128

Jesus lover of my soul.......... 158

Jesus is all the world to me....... . 93

Jesus is mine............... 103

Jesus is piloting me............ 64

Jesus is pleading............ 90

Jesus is the sinners friend........ 152

Jesus only would I know......... 88

Jesus, Savior, pilot me........... 156

Just as I am ................ 151

Joy to the world............. 158

Keep praying as you go........... 86

Lead me gently home Father....... 14

Let Jesus come into your heart..... 51

Let me be a friend to man........ 82

Let your light so shine.......... 23

List to the Christ.............. 31

Living where the healing waters flow. 96

Longing for the sweet by and by.... 72

Lor 3 , at Thy mercy seat......... 71

Lord I'd follow Thee............ 155

Make me a channel of blessing....... 26

My Jesus I love Thee............ 157

My Lord and I.............. 7

My Mother's Prayer............. 60

My only plea............... 135

My Redeemer Lives............ 130

Nearer my God to Thee........... 138

No night there............... 75

5 Now I feel the sacred fire ......... 33 
Songs of Redemption-Revised.

Page

0 come to the precious fountain.... 73 The Lord is my Shepherd........ 17

One step ahead............. 65 The Man of Galilee........... 80

Only trust $\operatorname{Him} . \ldots \ldots \ldots \ldots \ldots \ldots . .99$ The Man on the other side....... 67

Onward Christian soldiers........ 30 The Inner circle............. 29

0 tell me more of Christ......... 4 The Name of Jesus............ 62

Reapers are needed............ 68 The precious cross............ 92

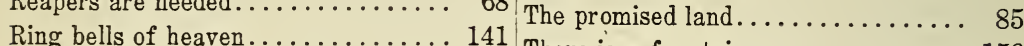

Rock of Ages.............. 153 There is a fountain........... 156

Sailing o'er life's ocean......... 133 There is power in the blood....... 127

Since I began to walk with Jesus. . . . 137 Throw the Gospel line. . . . . . . . . . 102

Since I found my Savior........ 87 To do thy will ............. 20

Since Jesus spoke peace to my soul... 28

Soldiers of the cross............ 150

Somebody is needing Jesus . . . . . . 126

Some One is praying for you........ 8

Softly and Tenderly............ 40

Spread abroad the sunshine........ 94

Stand up for Jesus . . . . . . . . . . . 19

Study to show thyself approved...... 108

Sunlight.................. 58

Sweet peace the gift of God's love... 89

The best friend is Jesus. . . . . . . . 61

We are soldiers of Jesus.......... 21

What will you do with Jesus....... 6

When I get home.............. 78

When I see the blood .......... 16

4 When I think of my dear Lord...... 129

9 When my Savior I shall see........ 13

Where Christ is marching on...... 59

Where do you stand tonight?...... 79

9 Will there be anyone waiting for me?. 66

Will you go?............... 120

The bird with a broken wing...... 76

The bird with a broken wing (Story) . 77 You may have the joybells ....... 146

The home of endless years....... 142 |You will outshine the sun....... 36

\section{Index of Practical Points.}

Bible Readings............ 109-110 What are We to Do?........

But you can be saved..........

Choice Nuggets. .

42 What Must I Do to Be Saved....

Choice Thoughts on the Bible....

116-117 Why are You not Saved? Is it be-

Facts or Feelings...........

How Spurgeon Found Christ ....

39 cause of Difficulties?.......

56 1. Too Great a Sinner........

54-55 2. Trusting in Self-righteousness

How to be Filled with the Spirit..

How You May Know You are Saved

Key Notes...............

Points on How to Become a Christian

Practical Points on Personal Work

Psalms .

3. Have no Feeling.........

4. Can't Hold Out............

5. Cannot give up the world....

6. But the Christian life is too

Hard ................

7. Not now. Time enough.....

113 8. There are too many Hypocrites

9. To the Backslider.........

Some Things Necessary in Order

10. For the Infidel and Skeptic.. 


\section{Special Supplement \\ Of Songs Used by \\ DA VIS and MILIS \\ GEO. H. CARR, Pianist \\ In their Evangelistic Campaigns}

1

Live for Others.

R, MCNadghtaN.

D. B. TOWNER.

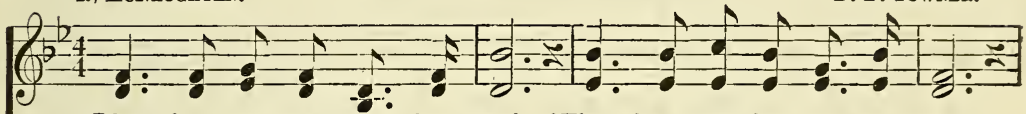

1. Live for oth - ers, day by day! 'Tis the true,the bet - ter way;

2. Live for oth - ers, for that One, Who, though God's be-lov-ed Son,

3. Live for oth - ers! spend, be spent! 'Tis the life the Mas - ter meant,

4. Live for oth - ers! and when death Shall cut short life's lat - est breath,
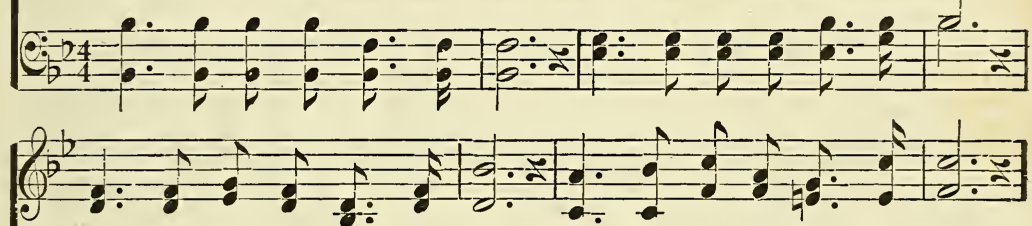

'Tis the way the Son of God, When on earth as Sav - ior trod.

Yet, "for oth - ers" lived and died, And is crowned"the Cru - ci - fied."

Giv - ing with a lav - ish hand, Meet - ing ev - er love's de - mand.

You with joy shall meet the Lord, And re-ceive a full re-ward.

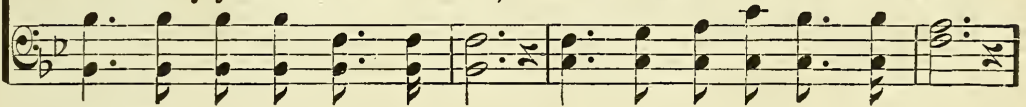

Chorus.

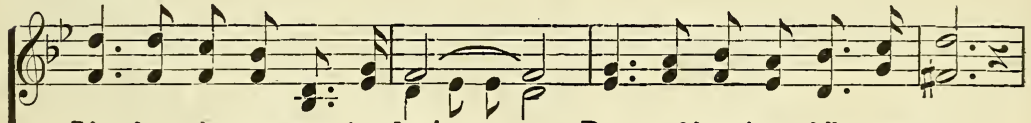

Live for oth - ers, ev - 'ry day!........ Be a bless-ing while you may,

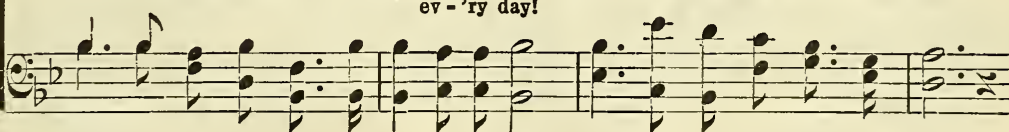

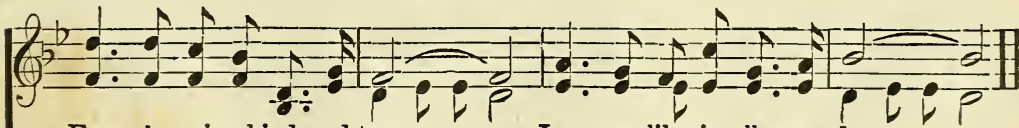

Ev-er lov - ing kind, and true, ..... Je - sus like in all you do......

in

Copyright. 1903, by Daniel B. Towner. 


\section{You Can Win the Victory Thro' Christ.}

G. H. C.

Gro. H. Carh

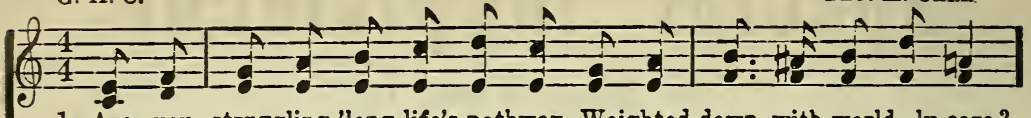

1. Are you struggling 'long life's pathway, Weighted down with world-ly care?

2. Are you los - ing bat-tles dai-ly, As you strive to con-quer sin?

3. Are you tim - id in Christ's ser-vice, Are you hin-dered by your fears?

4. Does life seem to be a fail-ure? Is your lot a joy-less one?

4. Does life seem to be a fail - are? Is your lot

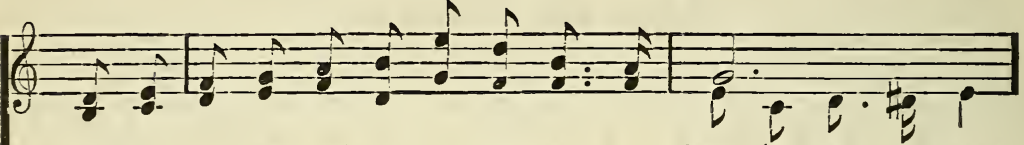

Is your dai-ly toil a bur - den hard to bear? (yes, hard to bear?)

Do temp-ta - tionsfierce-ly seek to en - ter in? (to en - ter in?)

Do your fee - ble ef - forts cause you bit - ter tears? (such bit - ter tears?)

Does the fu-ture hold no hope when life is done? (when life is done?)

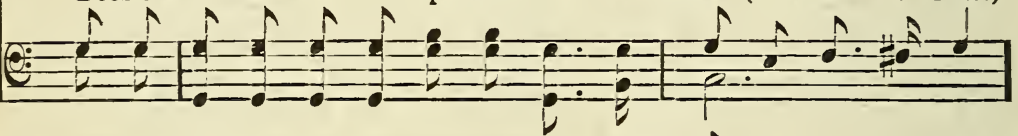

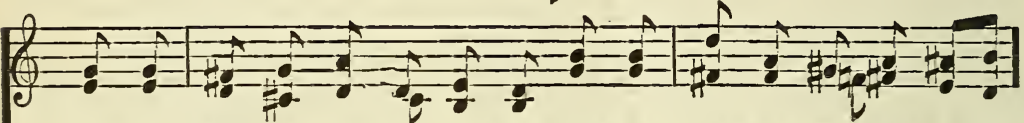

When it seems be-yond en-dur-ance, Trust in God's most firm as-sur-ance,

In the Spir - it there is pow - er, Strength to keep you hour by hour,

Strength and cour-age are God's bless-ing, To the weak, their need con-fess-ing,

$\mathrm{Je}$ - sus Christ shall reign vic-to-rious, With His saints in heav'n all glorious,

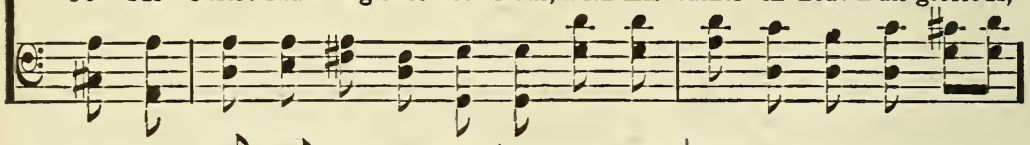

Q

You can win the vic - to - ry, through Christ.....................

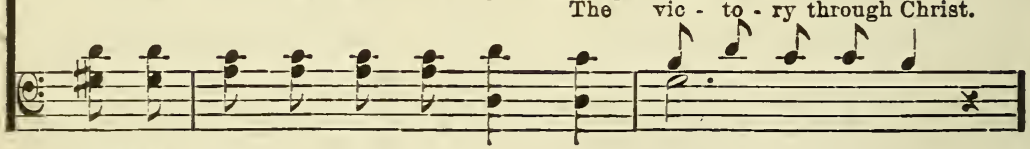

Chовеs.

$\theta=1=1-1=1$

Vic - to - Iy, yes, vic - to - Iy, You can win the vic - to - ry thro'

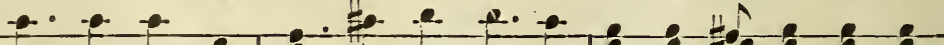

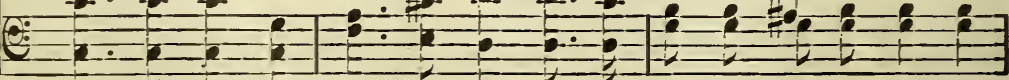

Copyright, 1907, by Erangelist John A. Daris. 


\section{You Can Win the Victory Thro' Christ.}

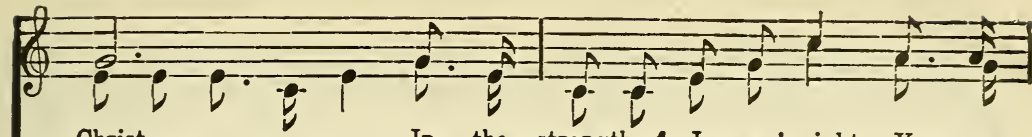

Christ,

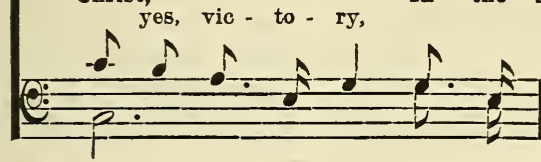

In the strength of Jo-sus' might, You can

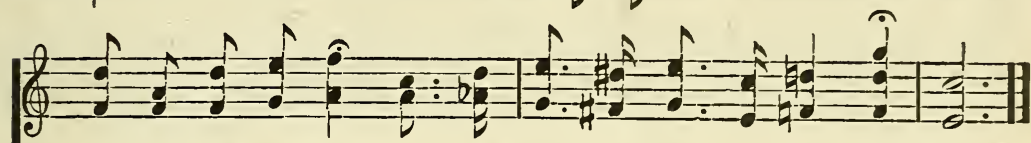

put the foe to flight; You can win the vic - to - ry through Christ.

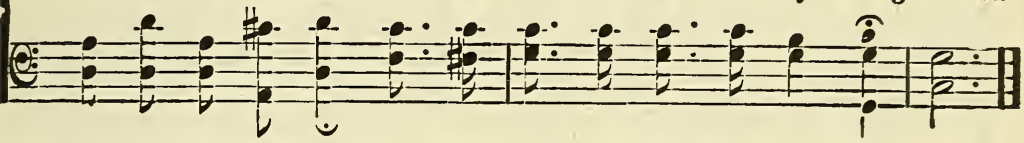

3

Faith of Our Fathers.

FREDERICK W. FABER.

ST. CATHERINE.

Adapted by J. G. WALTON.

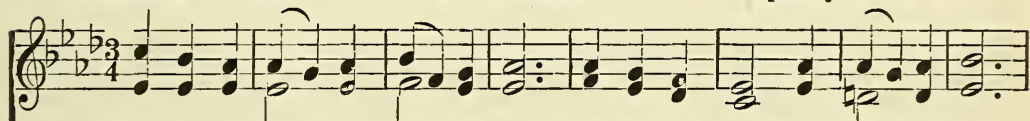

1. Faith of our fa - thers! liv - ing still In spite of dungeon, fire and sword;

2. Our fa - thers, chain'd in pris-ons dark, Were still in heart and conscience free;

3. Faith of our fa - thers! we will love Both friend and foe in all our strife,

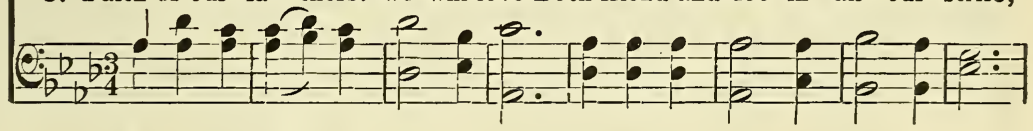

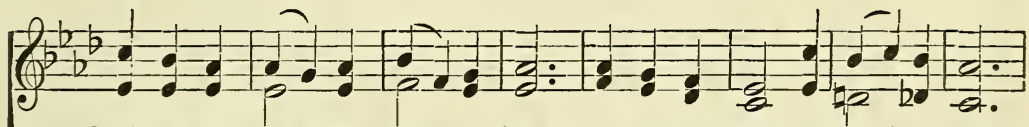

0 how our hearts beat high with joy When-e'er we hear that glorious word:

How sweet would be their children's fate, If they,like them,could die for thee!

And preach thee, too, as love knows how, By kind-ly words and virtuous life:

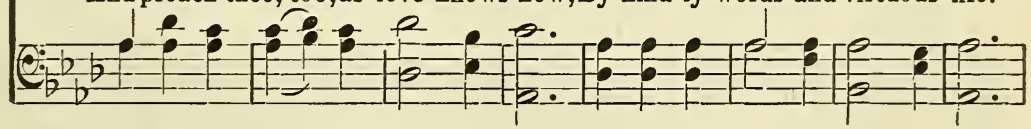

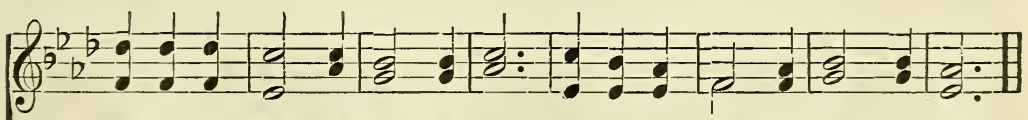

Faith of our fa-thers! ho - y faith! We will be true to thee till death!

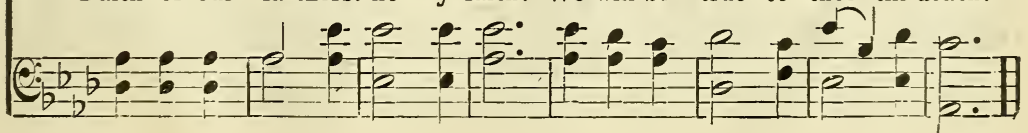


ADA R. HABERSHON.

ROBERT HARKNESS.

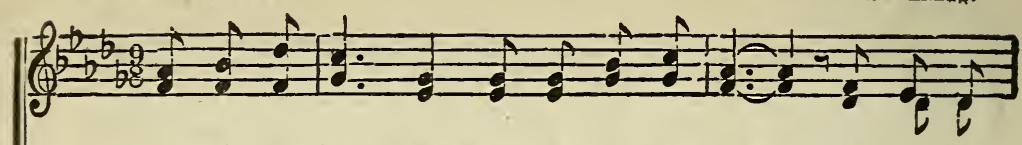

1. Soon will our $\mathrm{Sa}$ - viour from heav-en ap - pear, Sweet is the

2. Lone - li - ness changed to re - $\mathrm{a}$ - nion com-plete, Ab-sence ez-

3. Sun - rise will chase all the dark-ness a - way, Night will bo

4. Weak-ness will change to mag-ni - fi - cent strength, Fail - ure will
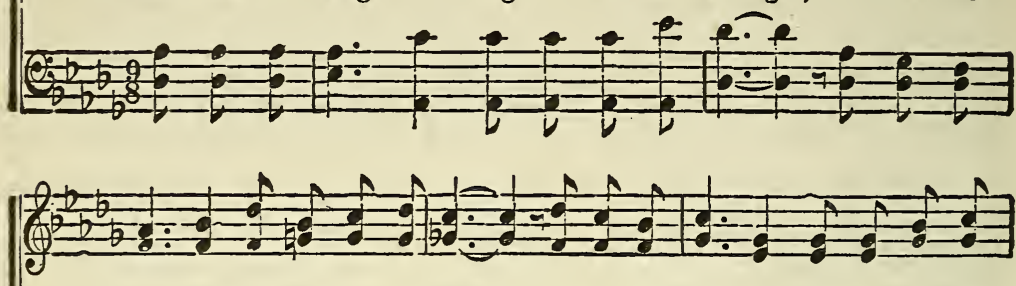

hopo and its pow-er to cheer; All will be changed by aglimpse of His changed for a place at His feet, Sleep-ing ones raised in a mo-ment of changed to the brightness of day, Tempests will chango to in - ef - fa - ble change to fer-fec-tion at length, Sor-row will changeto un-end-ing de-
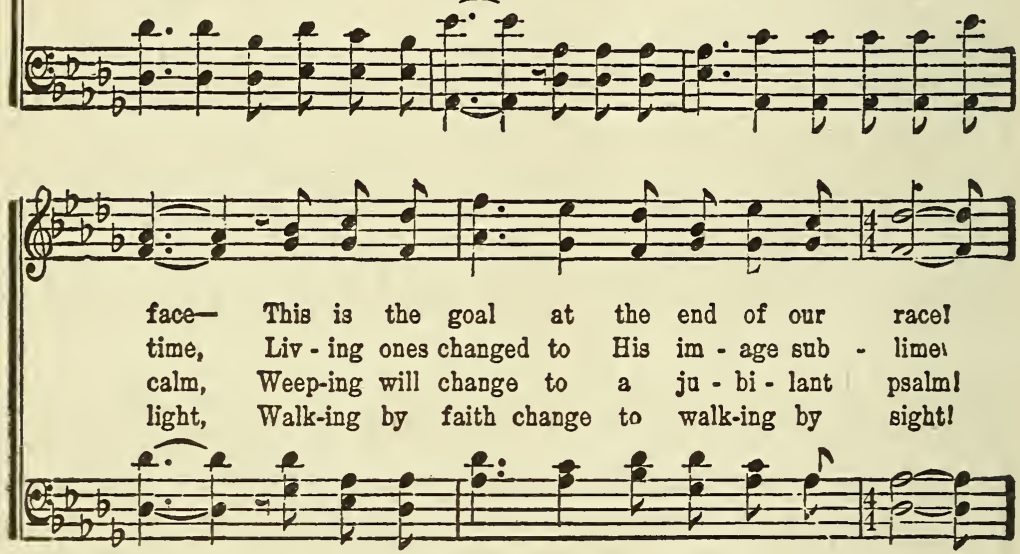

Chorus.

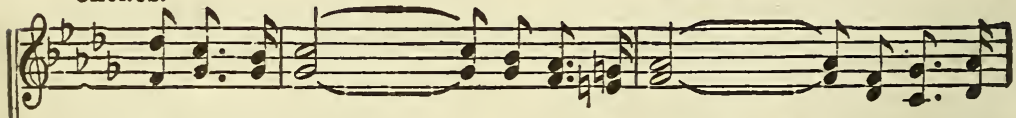

Oh, what a change, .... Oh, what a change,.... When I shall $\mathrm{Oh}$, what a change,

$O h$, what a change,

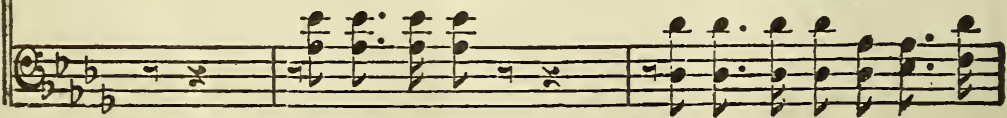

Copyright, 1905, by Chas. M. Alesander, English copyright. Used by per. 


\section{Oh, What a Change.}

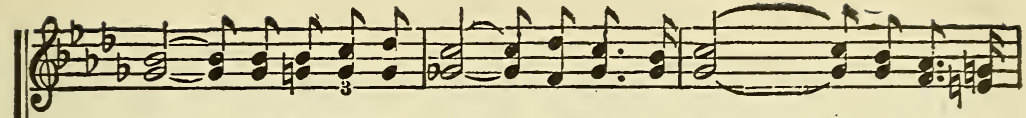

see His wonder-ful face! $\mathrm{Oh}$, what a change,.. O O
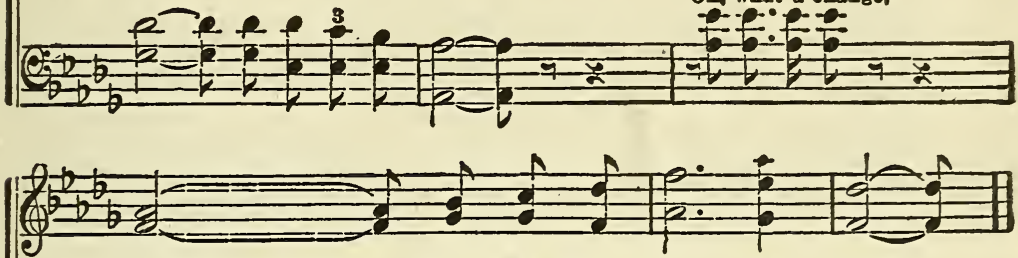

change, ....... When I shall see His face!

Oh, what a change.

(O)

5 Remember Me.

Anon.

MALE VOICES.

JOANNA KINKEL.

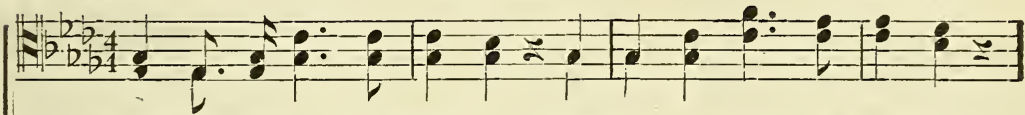

1. When storms around are sweep - ing, When lone my watch I'm keep-ing,

2. When walk - ing on life's o cean, Con - trol its rag - ing mo - tion;

3. When weight of sin op - press - es, When dark de-spair dis - tress - es,

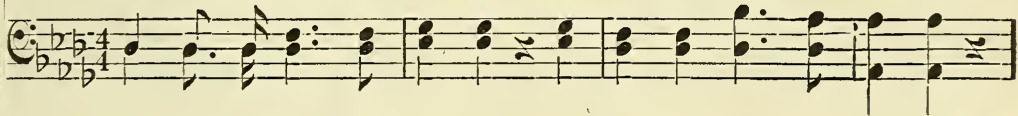

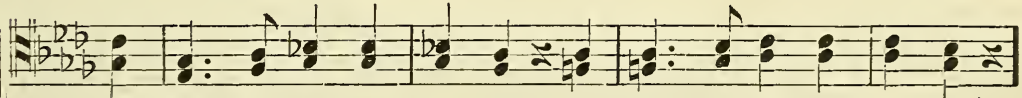

'Mid fires of e - vil fall - ing, 'Mid tempters' voic - es call - ing,

When from its dan - gers shrink-ing, When in its dread deeps sink-ing,

All thro' the life that's mor-tal, And when I pass death's por-tal,

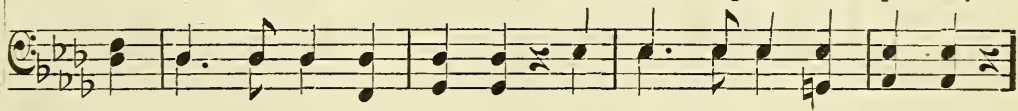

Chorus.

Re-mem-ber me, 0 Might-y One! Re-mem-ber me, 0 Might - y One!

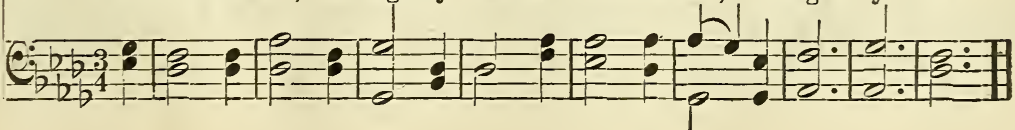


G. H. C.

"They that sow in tears shall reap in joy."-PSALM $126: 5$.

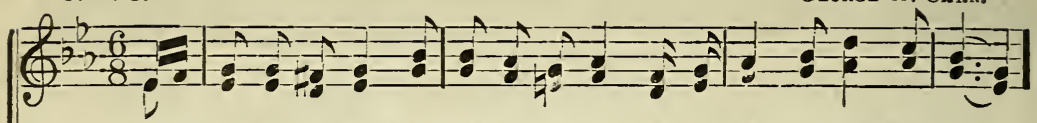

1. We know not how great the harvest will be, From the seed we sow each day;

2. We know not how great the harvest will be, Of the souls we strive to win;

3. We know not how great the harvest will be, Till the reap-ing time shall come;

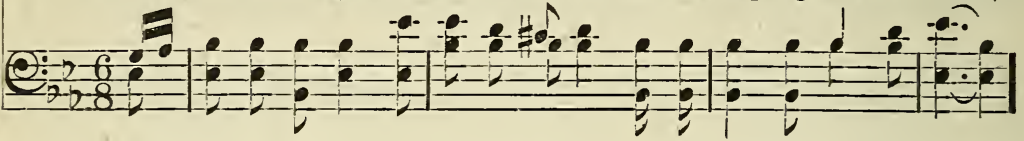

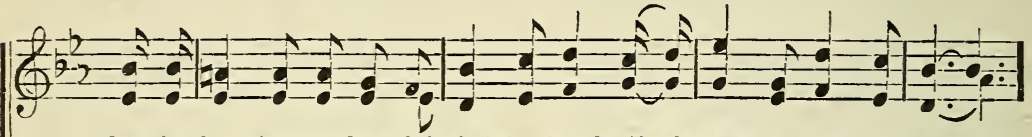

Of the lov - ing words and the helping hands, To theweak a-long our way.

We can on - ly tell them of Je-sus Christ, The Sav-iour from all sin.

And the Lord shall gather the ripened grain, To grace His heav'n-ly home.

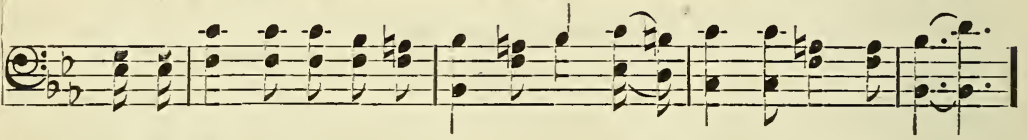

Chorus.

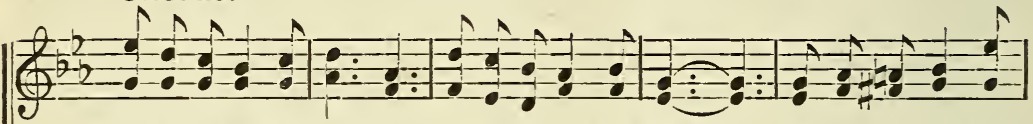

Scatter the seeds of ser-vice, Nothing can e'er be lost; Spending your life for

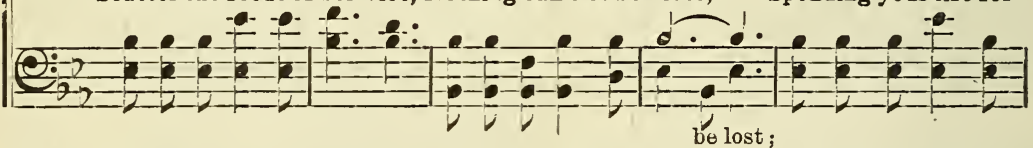

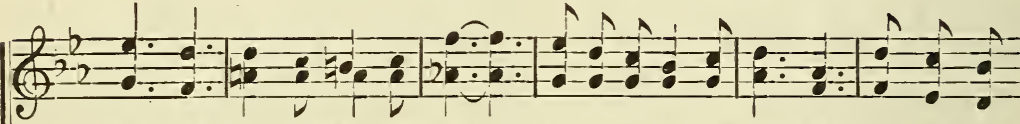

oth-ers, Counting not the cost; Speak oft a word for Je - sus Do-ing your

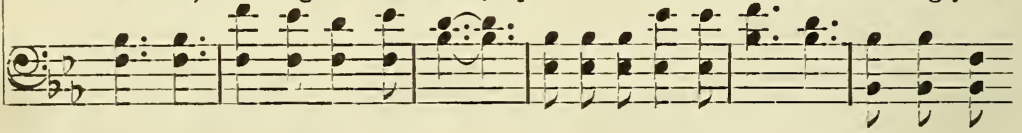

$\left(\frac{2}{2-2}=1\right)$

ver - y best. Leave the results to the Spir - it, He will do the rest.

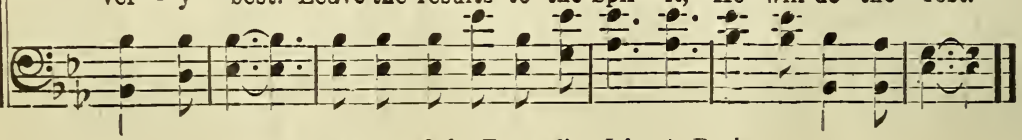

Copvright, Igu8, by Evangelist, John A. Davis. 


\section{Keep Confessing Jesus.}

F. A. M.

F. A. MrLls.

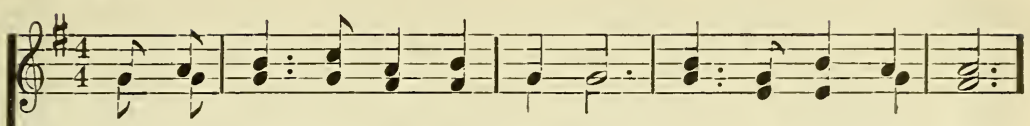

1. You may have God's rich - est bless - ing Ev - en though you fall,

2. Do you ev - er get de - feat - ed, Pierc'd by Sa - tan's dart?

3. When the storms of life have bro't you Sor - row, pain and woe,

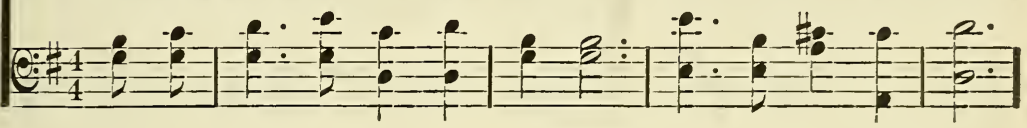

$\theta+\frac{1}{2}=0$

If with faith you keep con - fess - ing, Christas all in all.

Tho' your pas-sions are deep-seat - ed, God will cleanse your heart.

Claim the peace the Word has taught you, God's re-deemed may know.

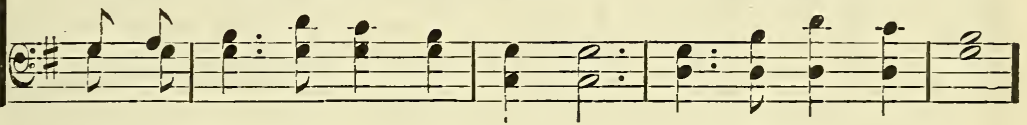

Chorus.

(2)

Keep con-fess-ing Je - sus, It. will make you strong and true;

을

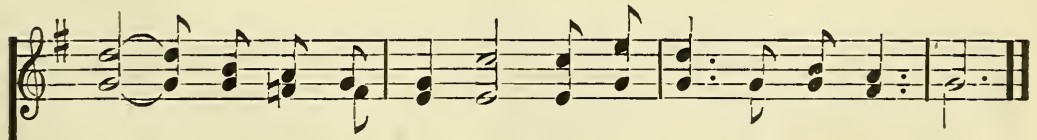

Keep con-fess-ing Je-sus, He in heav'n con-fess-es you.

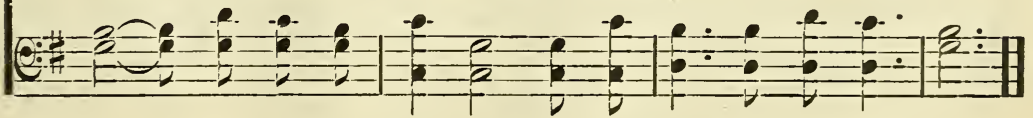

Copyright, 1907, by Evangelists Davis and Mills. 
Mrs. C. H. M.

Mrs. C. H. MORRIS.

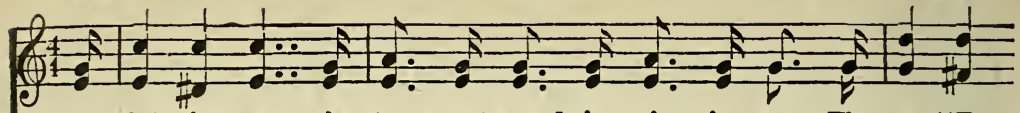
1. The fight is on, the trum-pet sound is ring -ing out, The cry "To 2. The fight is on, A-rouse, ye sol - diers brave and truel Je-ho - vah 3. The Lord is lead - ing on to cer - tain vic - to - ry; The bow of (0.4:

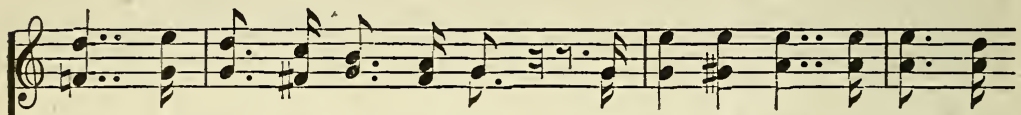
arms!" is heard a - far and near; The Lord of hosts is march-ing leads, and vic - t'ry will as - sure; Go, buck-le on the ar - mor prom - ise spans the east - ern sky; His glo - rious name in ev - 'ry

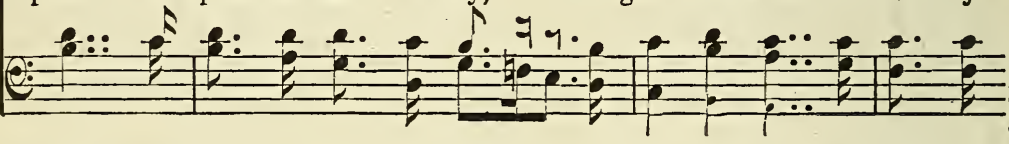

(4) on to vic - to - ry, The tri - umph of the Christ will soon ap-pear. God has giv - en you, And in His strength un - to the end en-dure. land shall hon-ored be; The morn will break, the dawn of peace is nigh. (i,

Chorus. Unison,

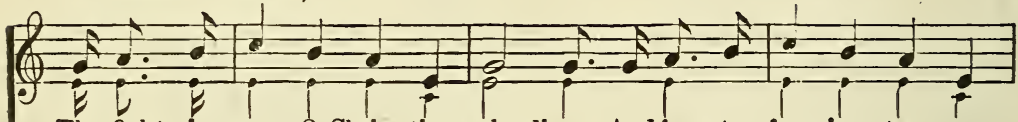

The fight is on, $O$ Chris-tian sol-dier, Andface to face in stern ar-

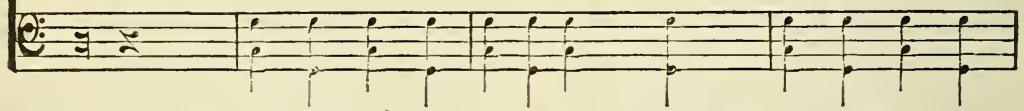

(l) ray,... With ar - mor gleam-ing, and col - ors stream-ing, The right and

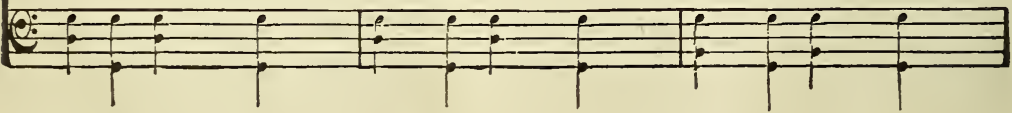




\section{The Fight is On.}

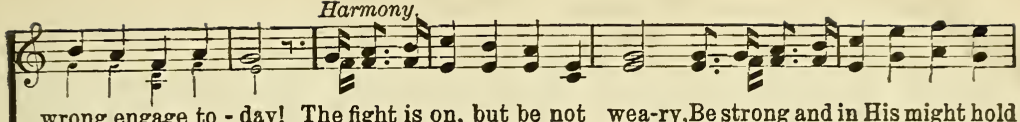

wrong engage to - day! The fight is on, but be not wea-ry,Be strong and in His might hold

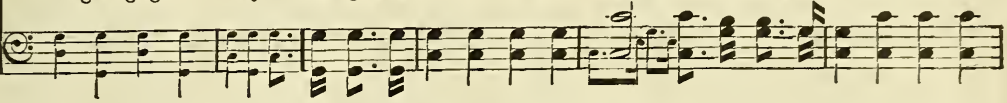

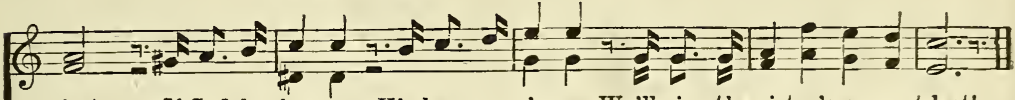

fast; If God be for us, His ban-ner o'er us, We'll sing the victor's song at last!

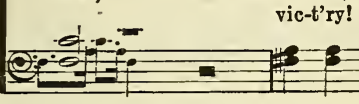
vic-t'ry!

$9 \quad 0$ Love That will not Let Me Go.

Gerorge Matheson.

Dedicated to F. A. Mills.

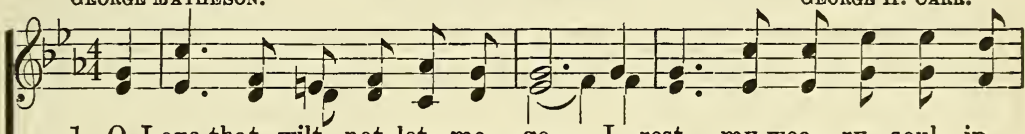

1. 0 Love that wilt not let me go, I rest my wea-ry soul in

2. O Light that followest all the way, I yield my flickering torch to.

3. 0 joy that seek - eth me thro' pain, I can - not close my heart to

4. 0 cross that lift - est up my head, I dare not ask to fly from

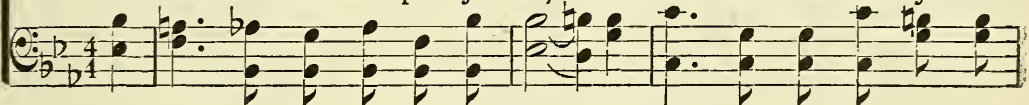

Thee; I give Thee back the life I owe, That in Thine
Thee; Iy heart re - stores its bor - rowed ray, That in Thy
Thee: I trace the rain - bow through the rain, And feel the
Iay in dust life's glo - ry dead, And from the

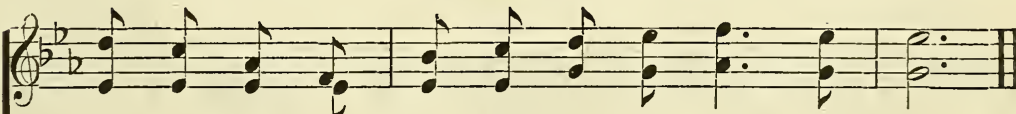

o - cean depths its flow May rich - er, full - er be. sunshine's glow its day May bright-er, fair - er be. prom-ise is in vain That morn shall tear - less be. ground there blossoms red Life that shall end - less be.

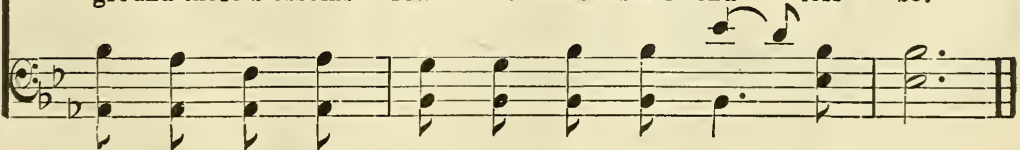

Music Copyright, , 1910, by George H. Carr. 
F. E. B.

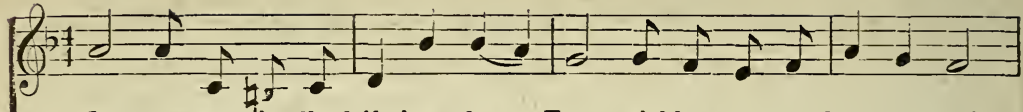

1. O voy - ager $\mathrm{i}$ - dly drift-ing down, Turn, quickly turn your boat around!

2. Not thinking of the gold-en shore, Not car - ing for the works be - fore,

3. Why in - to death and darkness float?God's gos-pel oar is in each boat;

4. More swiftly do the boats glide on, As near-er to the end they come;
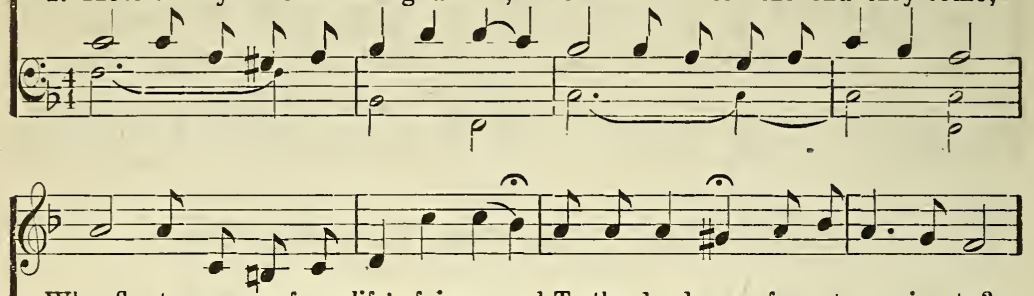

Why float a-way from life's fair ground,To the dead sea of e - ter - ni - ty? Just lay-ing down the gos - pel oar, Reach the dead sea of e - ter - ni - ty. Heed, heed the solemn warn-ing note, Shun the dead sea of e - ter - ni - ty. Soon en - ter - ing the soul's dark home, In the dead sea of e - ter - ni - ty.

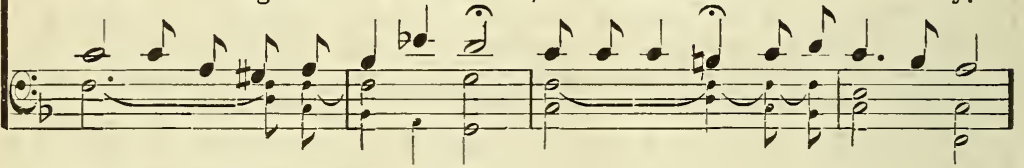

Chorus. Moderato. softly, except last time.

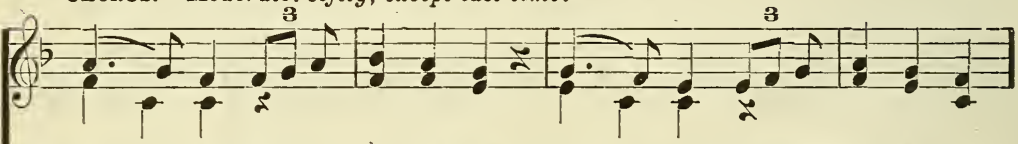

Drift - ing, gen-tly drift - ing down, Drift - ing, by the soft winds blown; Last]Drift - ing, swift-ly drift - ing down, Drift - ing, by the mad winds blown;
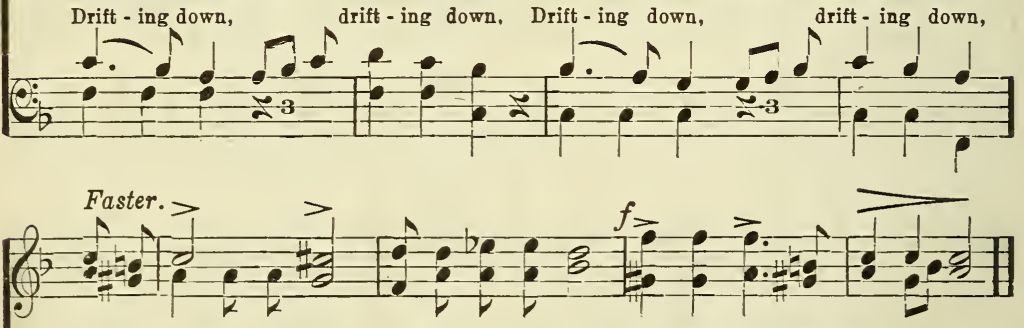

Quickly turn! turn! Pull the gospel oar; Life or death for - ev-er-more!

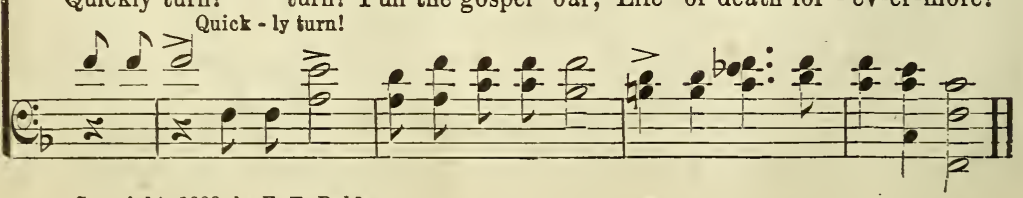

Copyright, 1909, by F. E. Belden. 
"Bear ye one another's burdens and so fulfil the law of Christ."-GaL. $6: 2$.

G. H. C.

Grorge H. Carr.

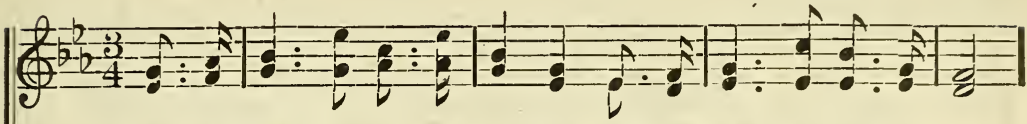

1. Bear ye one an-oth-er's bur-dens, Said the Mas - ter long a - go;

2. Oft the bur - dens may be lift - ed By a gen - tle touch of love;

3. Pass your bless-ings to the need-y Thus your blessings will in-crease;

4. Bear ye one an-oth - er's bur-dens, Je - sus lived to serve man-kind;

5. Bear ye one an-oth-er's bur-dens, Je - sus bore our load of sin;

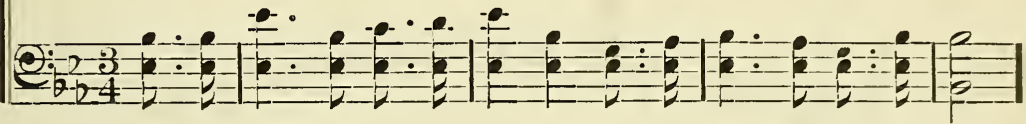

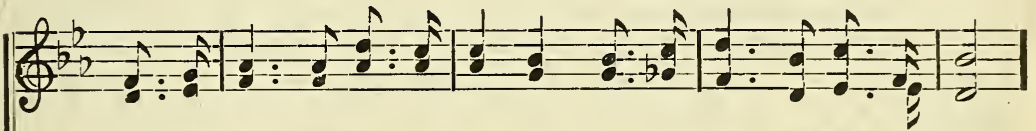

Oh, what chan-ces to be help-ful To each oth - er here be - low.

Leading souls from gloom and darkness To the sun - ny realms a - bove.

Self de-nied for sake of oth-ers, Brings pure joys that never cease.

Heal-ing sick-ness, spreading gladness, Giv-ing eye-sight to the blind.

Died to give the world sal-va-tion, So that all might Heav-en win.

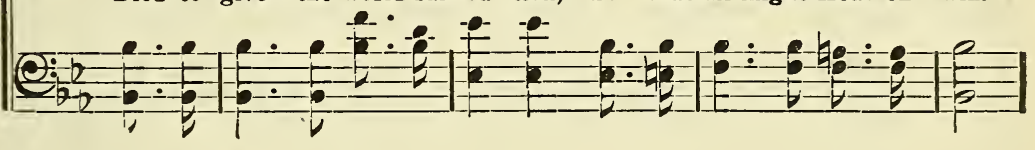

Chorus.

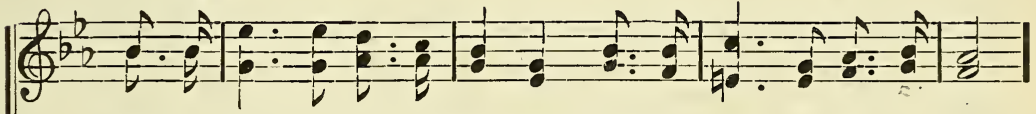

Bear ye one an-oth-er's bur-dens, None can live a life a-lone;

(2):-2,

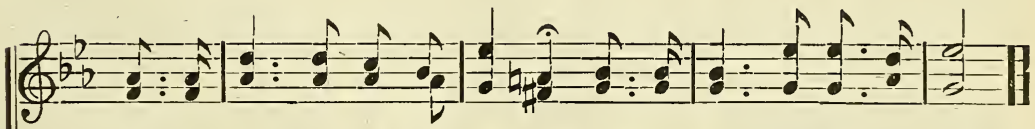

Much we need each oth-er's serv-ice, Free-ly serve, you're not your own.

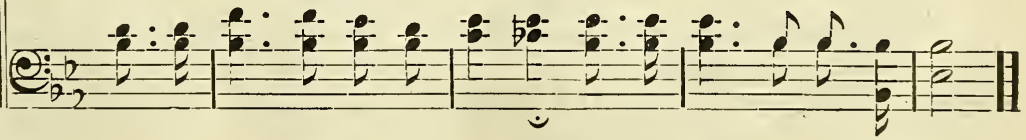

Copyright, Igo:, ly. Evangelist Jonn A. Davis. 
G. H. C.

Copyrighted, 1907, by Evangelist John A. Davis.

(a) ${ }^{2}-4=$

1. With Sa - tan's hosts a - bout us, With sin on ev - 'ry hand, Oh,

2. The bat-tle fierce-ly ra-ges, The foe is press-ing hard, Let

3. We hear the cries of ma-ny, Cut down by cru-el sin, We

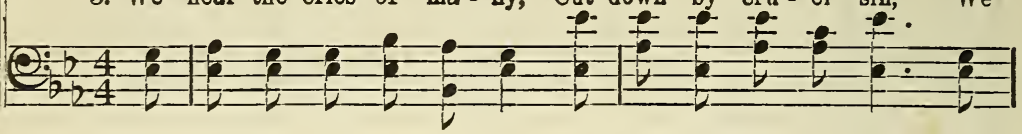

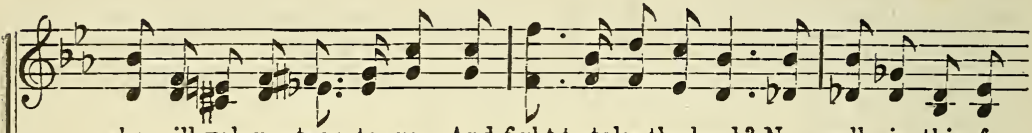

who will vol- un-teer to go And fight to take the land? No call is this for

ev'ry man be brave and true, Let all be on their guard. The en - e - my is

see them carried off the field A - mid the battle's din. But hark! who comes to

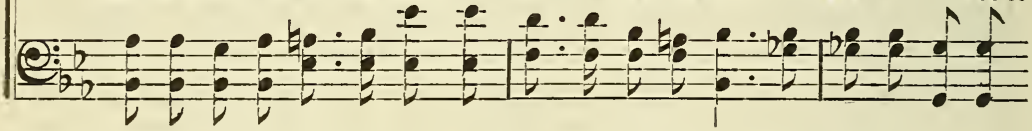

$\mid \begin{array}{ll}\theta^{2}-2 \\ 0\end{array}$

cowards, Nor traitors does He need, But all who love to serve the King, This craft - y, He knows where we are weak, Some way to break the solid ranks We help us? 'Tis Christ, our blessed King, He'll lead us on to vic - to - ry, A

(e)

$\left(\frac{2}{2}+2\right)$

call of His should heed. )

know he'll sure-ly seek. Forward, march! the call comes ringing loud and clear;

song of tri- umph sing.

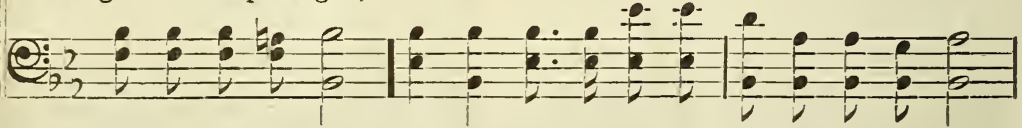

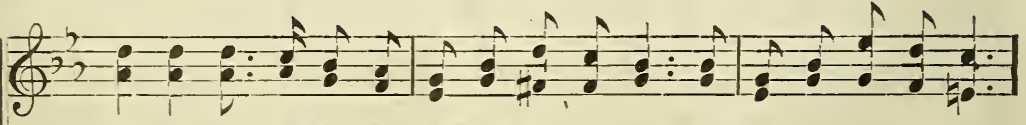

Charge, men,'gainst the foe, The summons now we hear. With weapons gleaming bright,

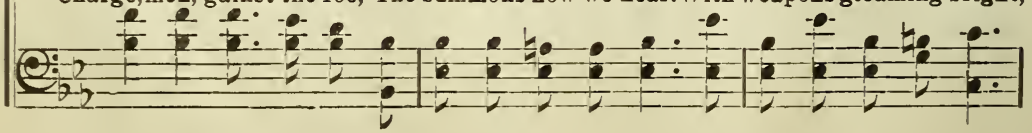


3 :

We'll fight for God and right, We're here to win the vic - to - ry for our King.

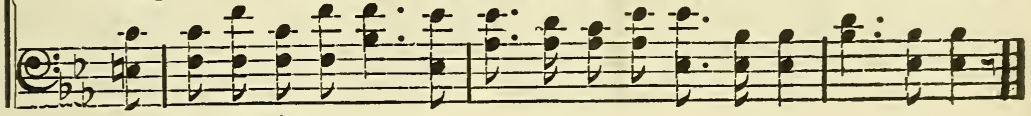

13

Great Is My Need.

Mrs. C. A. M.

Mrs. C. H. Morate.
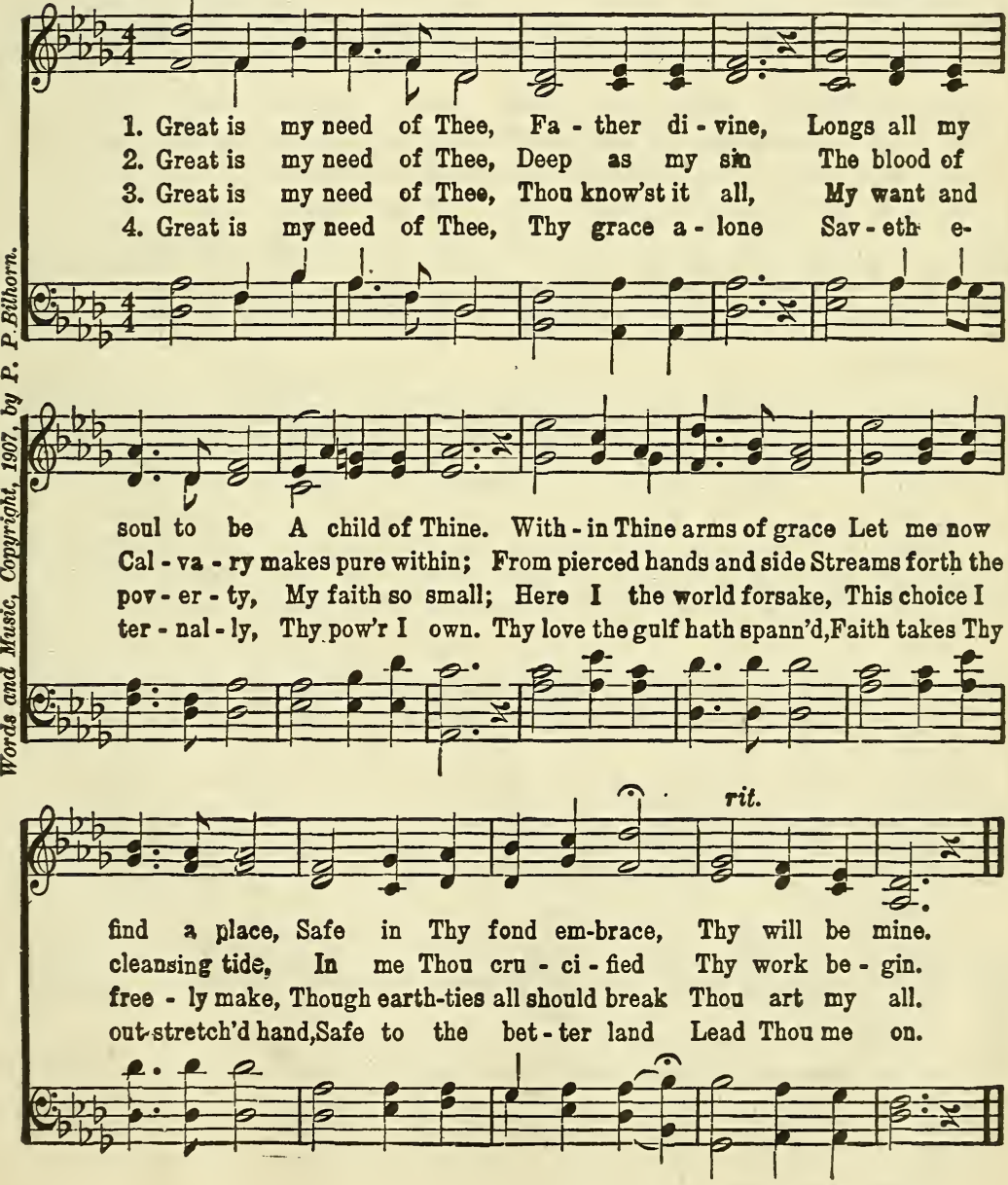
Fnnay J. Crosbi.

I. ALLAN SANEeY.

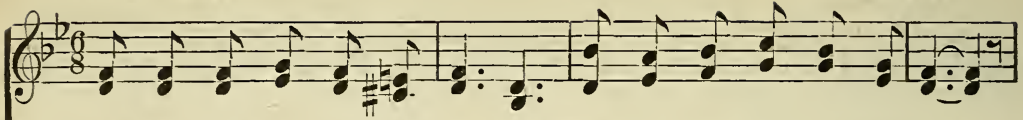

1. Nev-er be sad or de - spond - ing If thou hast faith to be - lieve;

2. What if thy bur-dens op-press thee, What tho' thy life may be drear?

3. Nev - er be sad or de - spond-ing,-There is a mor-row for thee;

4. Nev - er be sad or de - spond-ing,-Lean on the arm of thy Lord;

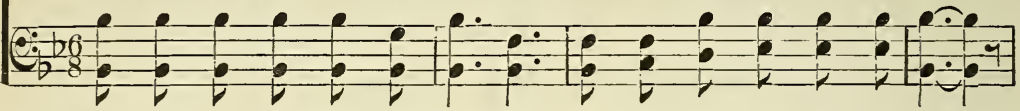

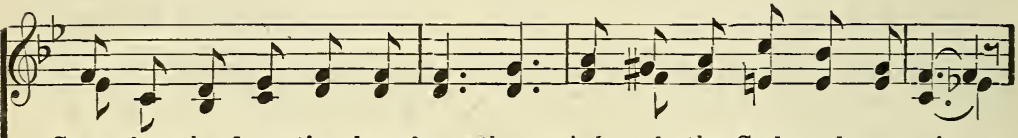

Grace for the du - ties be - fore thee Ask of thy God, and re - ceive.

Look on the side that is bright - est; Pray, and thy path will be clear.

Soon thou shalt dwell in its bright - ness, There with the Lord thou shalt be.

Dwell in the depths of His mer - cy, Thou shalt re-ceive thy re-ward.

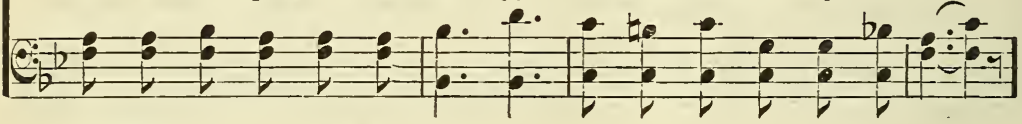

Chorus.

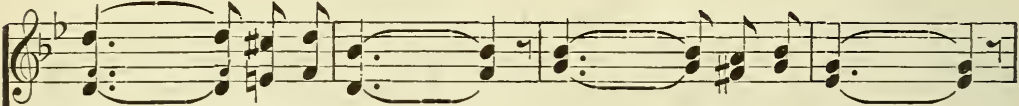

$\mathrm{Nev}$ - er give up,.... Nev - er give up,.......

$\mathrm{Nev}$ - er give up, nev-er give up. Nev-er give up, nep-ergive up,

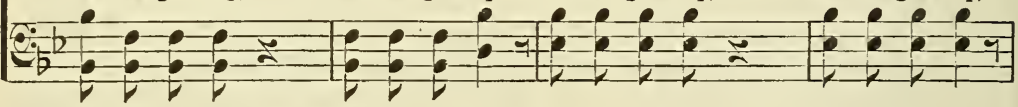

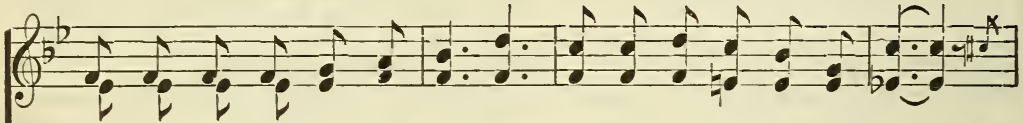

$\mathrm{Nev}$ - er give up to thy sor-rows, Je-sus will bid them de - part;

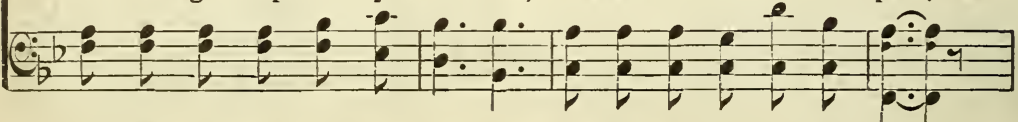

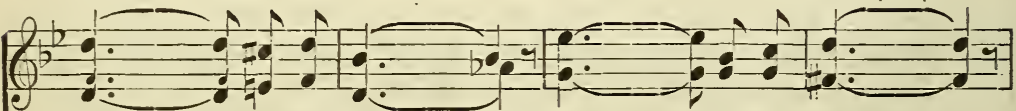

Trust..... in the Lord,.... Trust..... in the Lord,....

Trust in the Lord, trust in the Lord, Trust in the Lord, trust in the Lord,

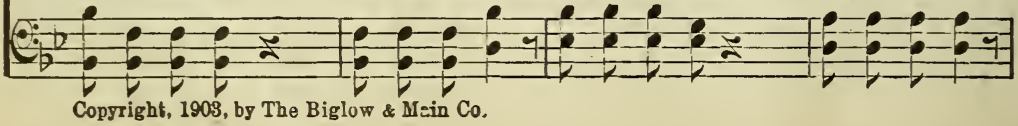




\section{Never Give Up!}

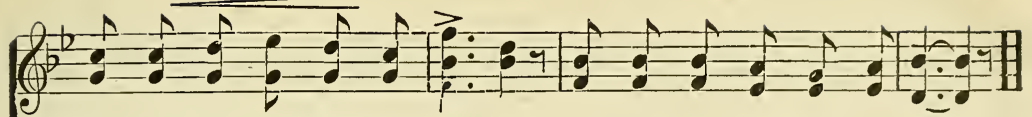

Sing when your tri - als are great - est, Trust in the Lord and take heart!

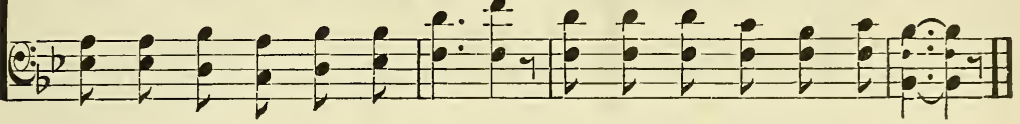

\section{Like a River, Glorious.}

Francre R. Havergal.

REV. J. MOUNTANN.

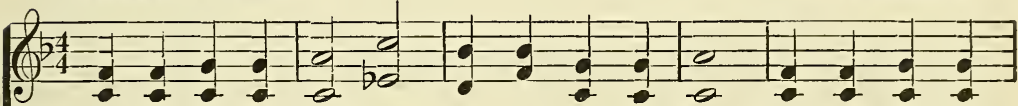

1. Like a riv - er, glo - rious Is God's perfect peace, 0 - ver all vic -

2. Hid - den in the hol-low Of his bless - ed hand, Nev - er foe can

3. Ev - 'ry joy or tri - al Fall - eth from a - bove, Traced up - on our
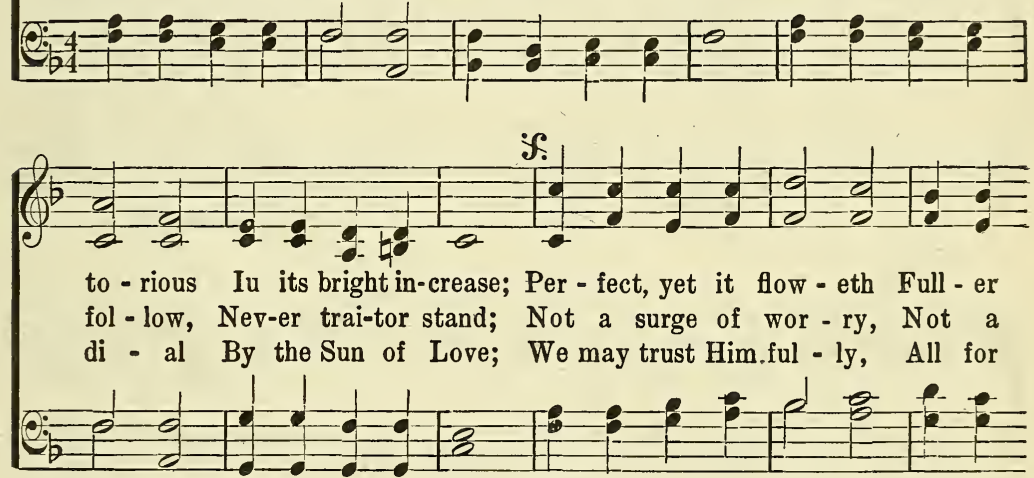

Сно.-Stayed up - on Je - ho - vah, Hearts are

D. S. for Chorus.

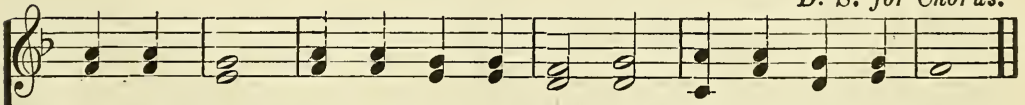

ev - 'ry day-Per - fect, yet it grow - eth Deep - er all the way. shade of care, Not a blast of hur - ry Touch the spir - it there. us to do; They who trust Him whol-ly Find Him whol-ly true.

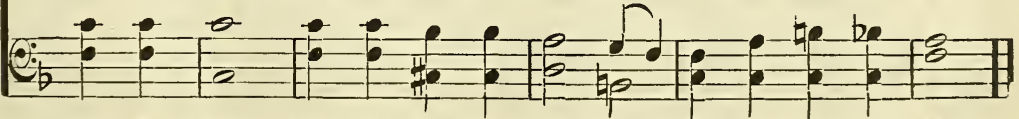

ful - ly blest; Find-ing as He prom-ised, Per-fect peace and rest.

Used by permission. From "Keswick Hymn Book." 
Jokn R. Clements.

W. S. WEEDRN.

(4)

1. I am here to search for jew - els-Pre-cious jew - els for my King;

2. I am here to search for jew-els, In the mud and mire of sin;

3. I am here to search for jew - els, Bright-er than the gems of earth;

4. So I hast - en here and yon - der, Where-so - e'er my Mas-ter leads,
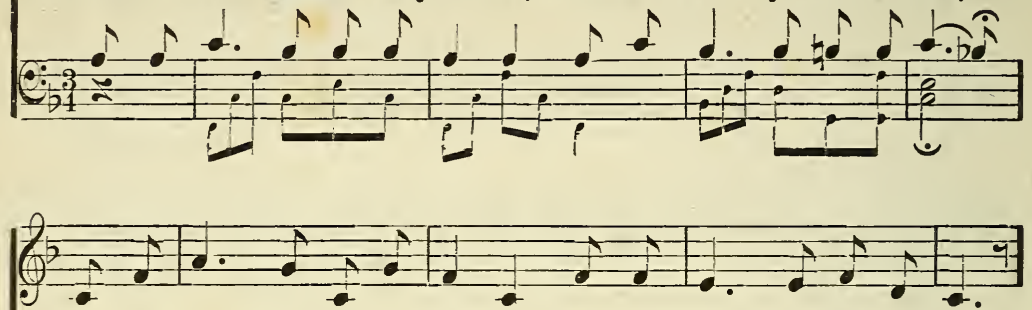

It is wor - thy toil and ef - fort, Gems of worth to Him to bring.

Dig-ging toil - ing, nev - er wea - ry, Tho' but one bright gem I win.

Liv - ing stones for heav'n-ly u - ses, Pre-cious in their price-less worth.

Delving, dig - ging, toil-ing, look-ing, 'Mid the flow'rs or 'mid the weeds.

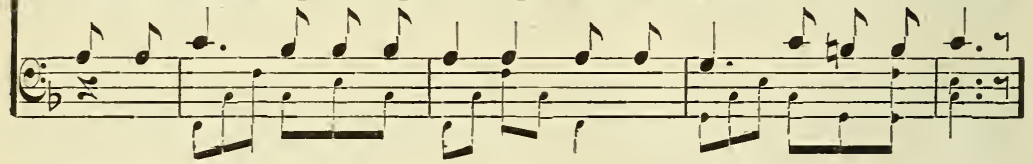

Chorus.

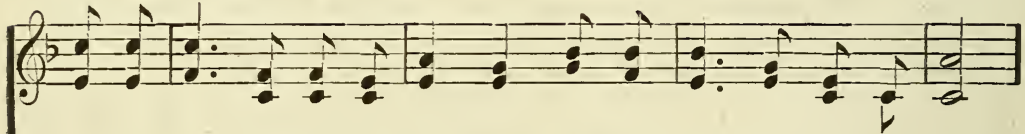

I am here to search for jew - els, That's my business, day by day;
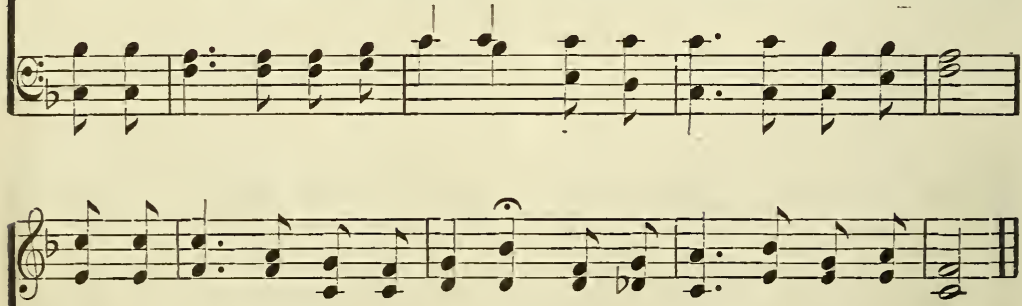

I am here to search for jew - els, Gems at Je - sus' feet to lay.

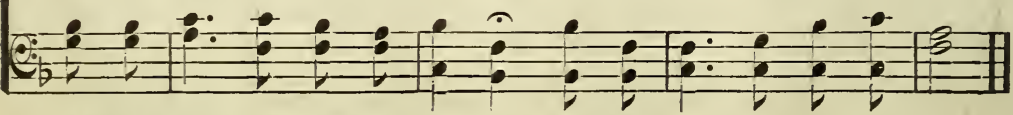

Copsright, 1908, by W. S. Weeden, by per. Jno, R. Clements. 
F. A. M.

"The measure of the gift of Christ."-Eph. $4: 7$.

F. A. Mills.

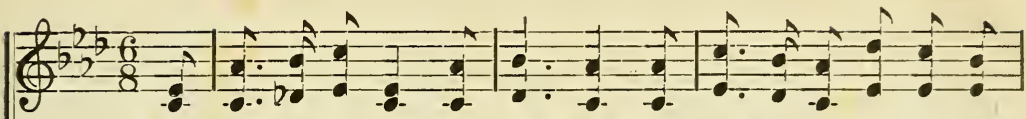

1. A won-der-ful gift is Je - sus, Our ran-som, from heav-en a -

2. A won-der-ful gift is Je - sus, Thro' Him is sal-va-tion at -

3. A won-der-ful gift is Je - sus, My heart o-ver-flows with His

4. A won-der-ful gift is $\mathrm{J}_{\theta}$ - sus, He saves from ca-lam-i-ties

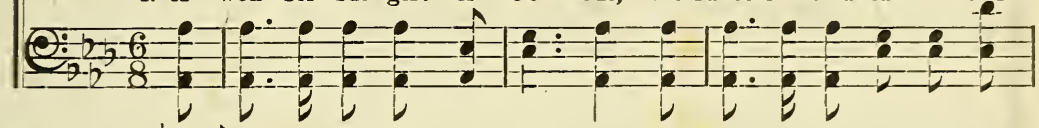

(6) bove; Who came down from our God's cherished pres-ence, A tained; And $\mathrm{He}$ says if we first seek His king - dom, Tru-ly songs, But my voice can sug- gest but a shad - ow Of the grim; And no wor - ry nor heart-ache can move me, I have

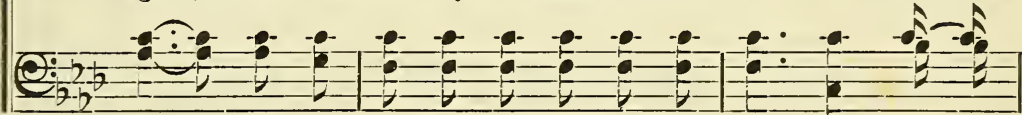
Chorus.

$\frac{\theta^{2}{ }^{2}-1}{2}=0$ to -ken of in - fi - nite love.

all things en - dur - ing are gained.

glo - ry that to Him be - longs.

A won-der-ful gift is

vic - to - ry rest - ing in Him.

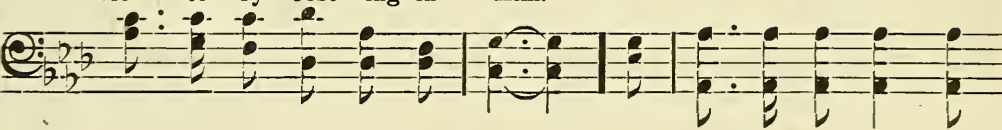

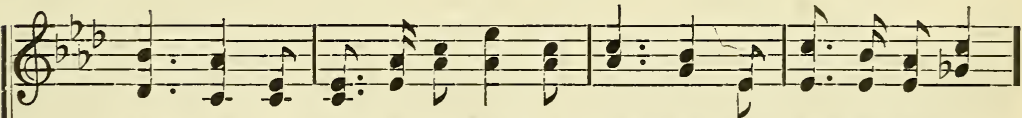

Je - sus, A won - der-ful gift is Je - sus; Earth's values grow dim,

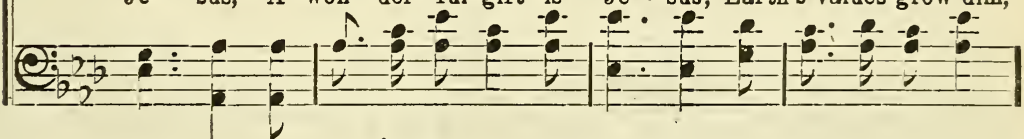

$\left(\frac{1}{2}{ }^{2}=a+a\right)$

They are all lost in Him, A won-der-ful gift is Je - sus.

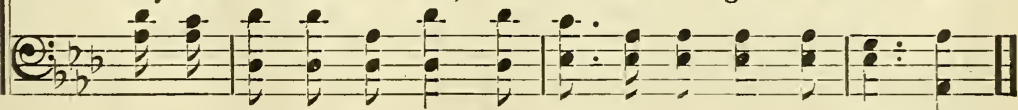

Copyright, rqu8, by Evangelists Davi ; M Mills. 
"I can do all things through Christ which strengtheth me."-PHIL. 4:13.

G. H. C.

Grorgr H. CirR.

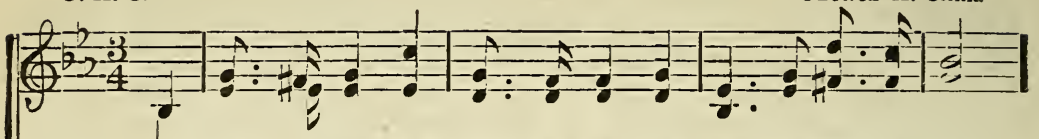

1. I ought to trust God's prom-is - es Be-cause His Word is true,

2. I ought to seek some soul to save, For Je - sus died for all,

3. I ought to send a - broad His truth To lead men to the Light,
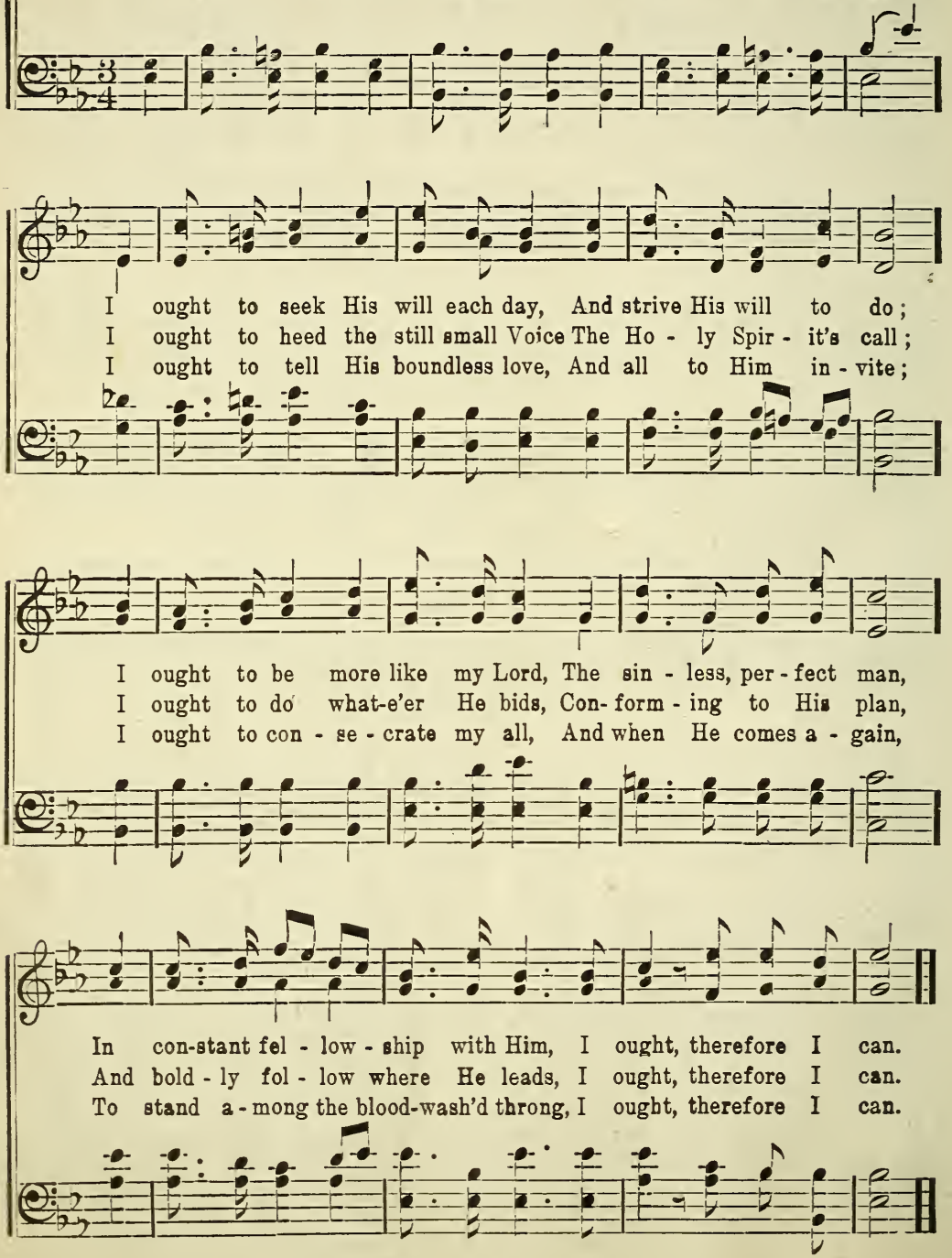

Copyright, ז908, by Evangelist, John A. Davis. 
"Set your mind on the things that are above."-Col. $3: 2$. R. V.

G. H. C.

George H. Carr.

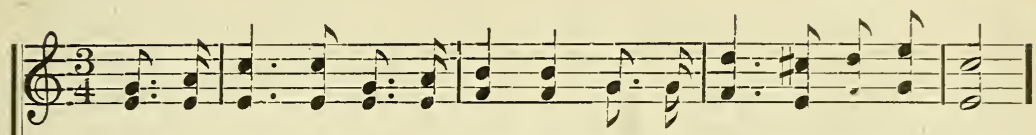

1. With a life to live be-fore me, With a prize to win or lose;

2. Fame and for - tune loud - ly beck-'ning, Prom-ise sat - is - fact-ion sure;

3. With a life to work for some-thing, With a long - ing heart to flll;
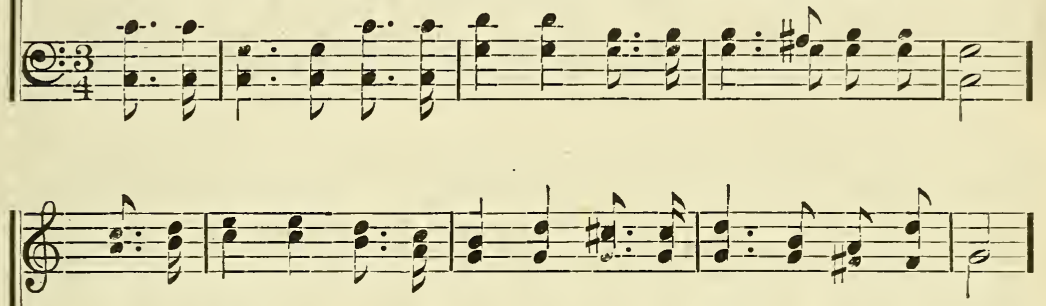

Not the good, nor e'en the bet - ter, But the best, Lord, would I choose.

Earth-ly pleas- ures bright-ly glit-t'ring, Oft the sen - ses do al - lure.

Choose the Christ-life more a - bun-dant, Let your joy be in His will.

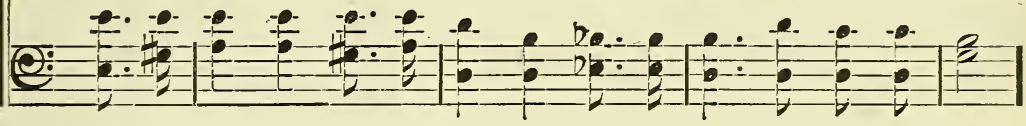

\section{Chorus.}

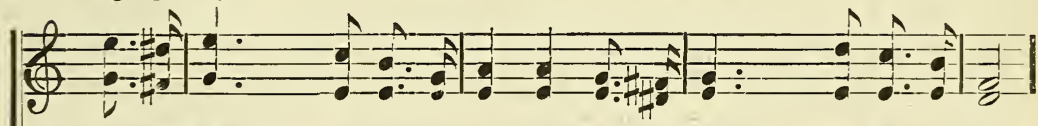

Choose the best, 'tis found in Je-sus, Life on earth will soon be o'er;

Choose the best,'tis found in $\mathrm{J}_{\Theta}$ - sus, Life on earth will soon be o'er;
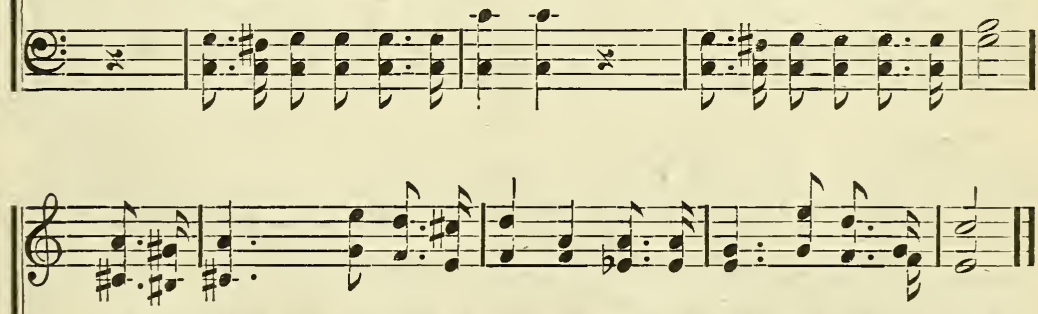

We must leave the dross be-hind us When we reach the heav'nly shore.

We must leave the dross be-hind us,

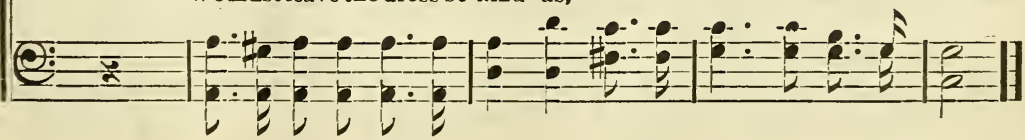

Copyright, 19o8, by Evanrelist Tohn A. Davis. 
F. E. BELDEN.

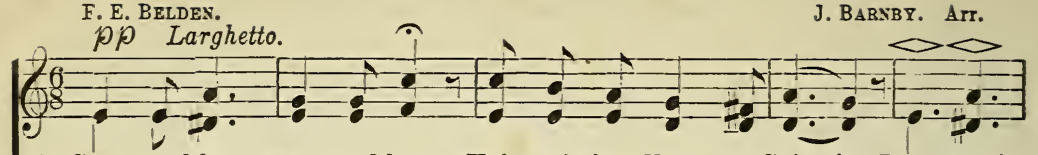

1. Sweet and low, sweet and low, Voice of the Ho - ly Spir-it; Low, low,

2. Come and rest, come and rest, Fa-ther still loves the lost one; Rest, rest,

3. Make thy choice, make thy choice, Not by the roll - ing thunder;"Small voice,"

4. Dark the night, dim the sight, Star-less the sin-ners heav-en; Shine, shine,
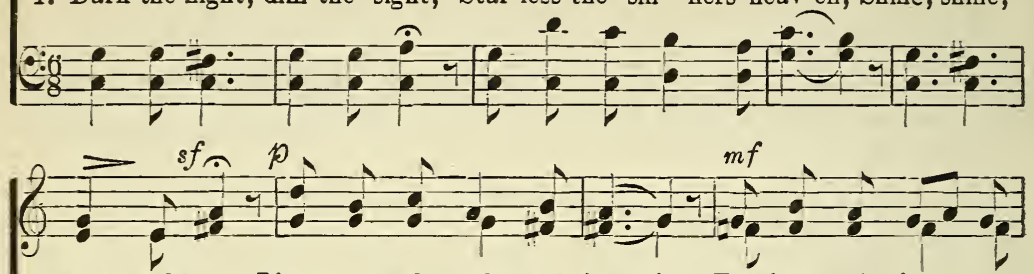

sweet and low; List - en, sad soul, and hear it, Tell-ing of joy you on His breast, Ter - ri - fled tem - pest-tnss'done. Here is a Port se"still small voice," This is the gos - pel won-der. "God's goodness to relight di - vine, Beau - ti - ful word, For - giv - en. Sin can not hide this
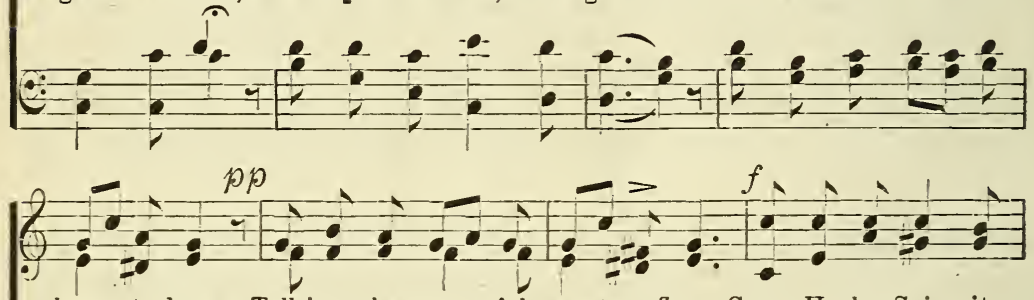

long to know, Tell-ing where peaceful wa - ters flow; Come,Ho-ly Spir - it, cure from woe, Val-ley where love's white lil - ies grow: Come,Ho-ly Spir - it, pentance leads, "Where Calv'ry's Lamb in si-lence bleeds:Come,Ho-ly Spir - it, star of grace,Night can not reil God's lore - ly face: Come,Ho-ly Spir - it,
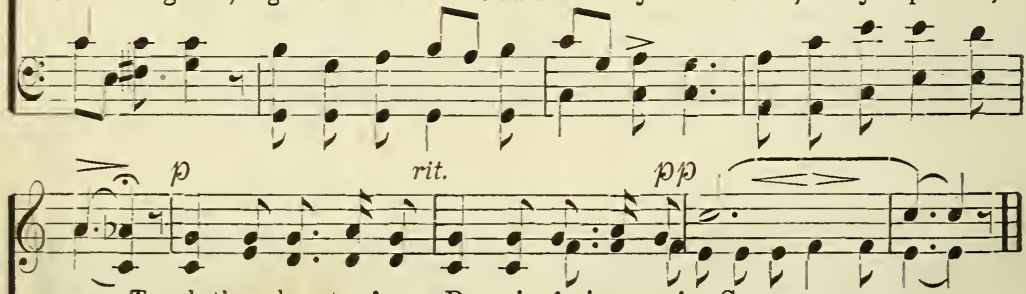

come, Touch these hearts of ours $\mathrm{Pu}$ - ri - fy-ing pow'rs;Come ...........

come, Breathe thy balm-y air, Till we an-chor there; Come...........

come, Whis - per love di - vine, Till the lost is thine; Come...........

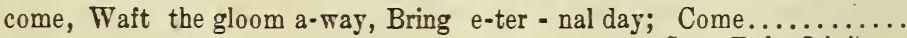

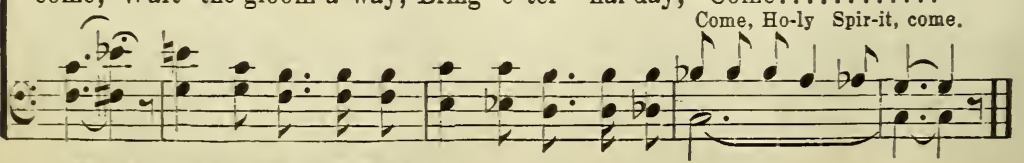

Words Copgright, 1909, by F. E. Belden. 
M. J. C.

Mabel Johnston Camp.

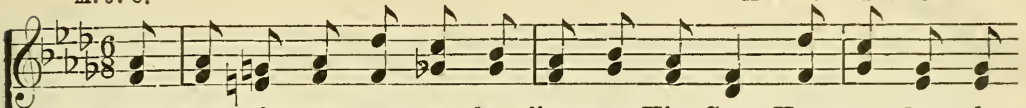

1. God says who-so-ev-er be-lieves on His Son Has par - don ob-

2. $\mathrm{He}$ says He makes righteous and cleans-es from sin The one who the

3. O soul with - out God, with-out hope, with-out peace,Just now come to

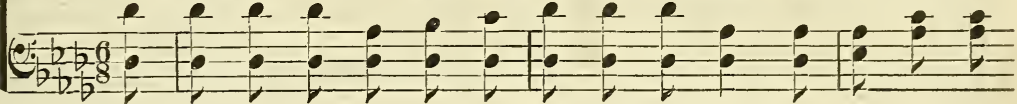

(1)

tained and a new life be-gun; His sins blotted out,-not by aught he has chief-est of sin - ners has been;He sanc - ti - fies whol-ly and jus - ti - fies

Him,let your doubtings all cease; He says He'll receive you,your joys will in-

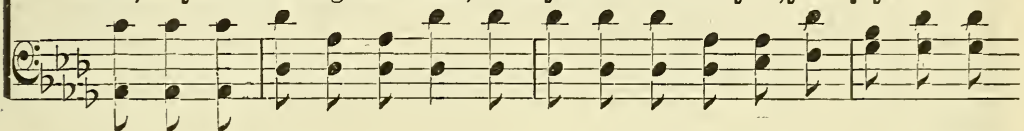

(2)

done, But thro'faith in the word of God!

him Who has faith in the word of God! His word is a strong, e crease, $O$ have faith in the word of God!

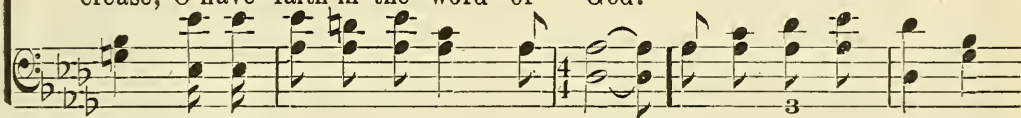

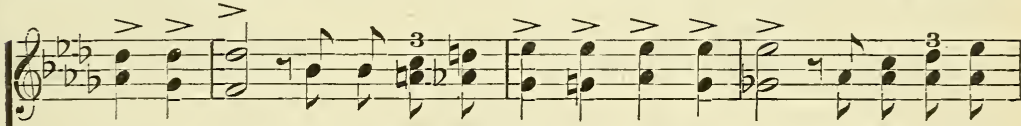

ter - nal rock; Un-sha-ken it stands thro' fiercest shock; Tho' Satan and
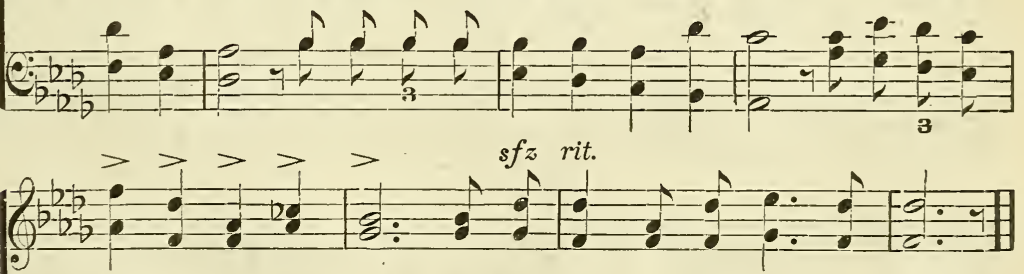

all his hosts may mock, I have faith in the word of God!

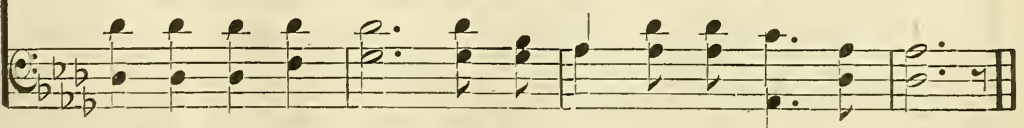

Copyright, 1906, by Norman H. Camp. B. A. Torrey. Owner. 
22 I'm Going All the Way With Jesus.

A. H. ACKLEY.

B. D. ACKLEY.

(1)

1. Bow-ing low be - neath the bur-den of the con-flict, Leav-ing

2. When I trav-el thro' the val-ley deep with shad-ows, There will

3. $\mathrm{Oh}$, the tri-umph of that hour when I be-hold Him $0-$ ver

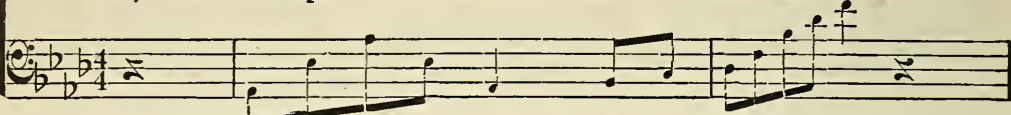

(4) roses where the thorns had pierc'd His hand; O the sweetness of His touch which be a bea-con light as clear as day; It will brighten up my journey yon-der in the glo-ry-land so fair; Thro' the golden streets of heaven

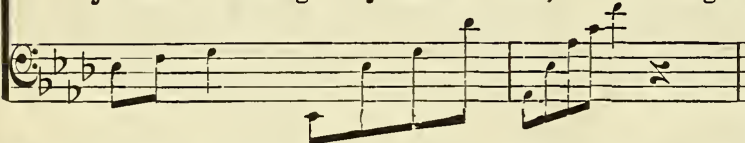
heal'd the helpless, As He passed a-long the road to Glo - ry - land. on to glo-ry, All my bur-dens will in $\mathrm{Je}^{-}$- sus roll a - way. I will praise Him, And for-ev - er I shall reign with $\mathrm{Je-sus}$ there.

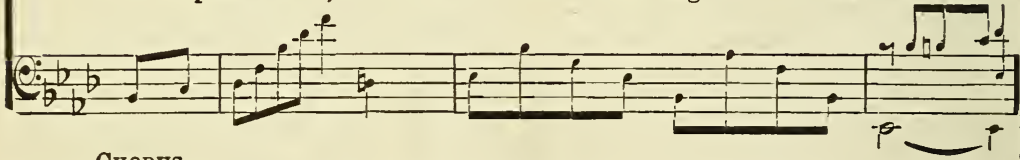

Chorus.

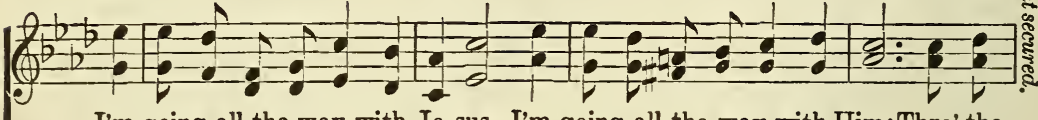

I'm going all the way with Je-sus, I'm going all the way with Him;Thro' the

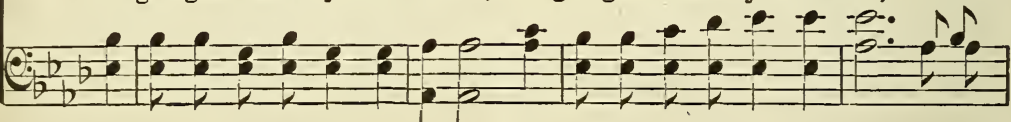

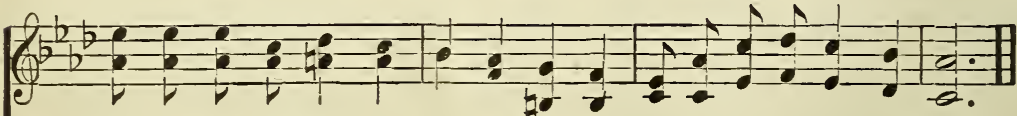

heav'nly gates I'll shout in triumph,For I've traveled all the way with Him.

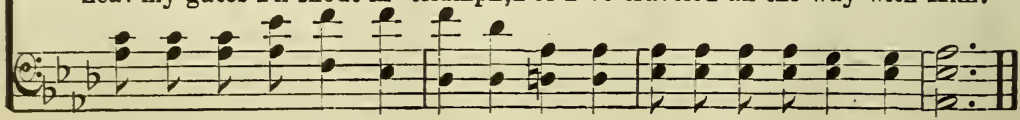


F. A. M.

"Walk in the Spirit." Gal. 5:16.

F. A. Mills.

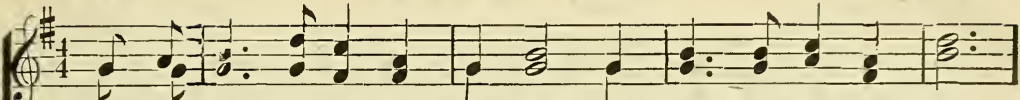

1. As we pass thro' life's broad meadows Our friendships cheer the way,

2. How He talks of peace and glo - ry, Of heav'n and joy we crave,

3. Man-y times He finds us stray-ing, De-ceived by Sa-tan's pow'r,

4. Oh! what joy to be soul - win-ners And turn the chast'ning rod,

(-)

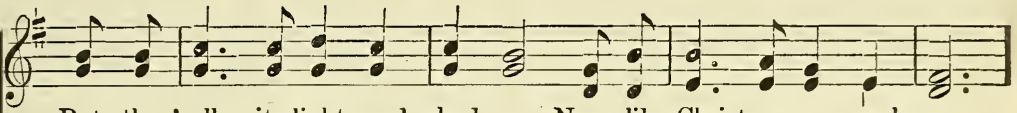

But thro' all its lights and shad-ows None like Christ commune al-way;

Then He tells the pre-cious sto - ry How He conquered sin and grave,

When by His commands o - bey - ing He would keep us hour by hour,

Preachlng Christ to wayward sin - ners That their souls be right with God,

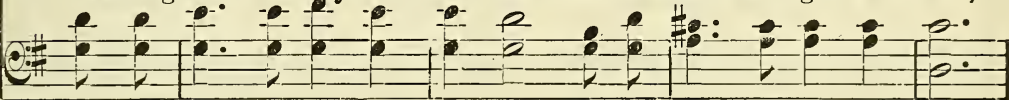

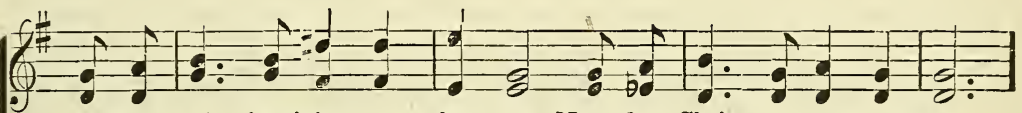

But thro' all its lights and shad-ows None but Christ commune al-way.

Then re-peats the sweet old sto - ry How He died the world to save.

When by Christ's commands 0 - bey - ing He would save us hour by hour.

Preaching Christ to Church and sin-ners, Till their bearts are right with God.

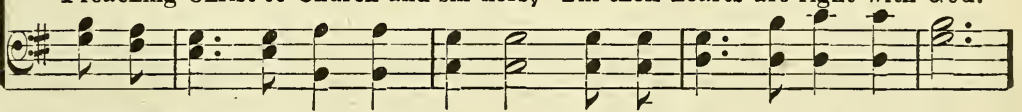

Chorus.

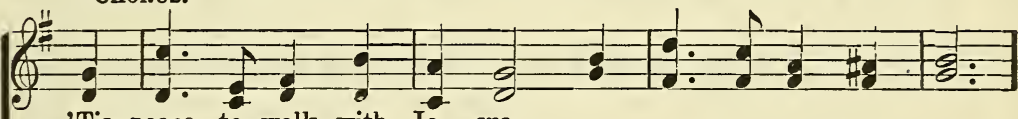

'Tis peace to walk with $\mathrm{Je}$ - sus,

'Tis sweet to talk with $\mathrm{Je}=$ sus,

'Tis sin to stray from $\left.\mathrm{J}_{\theta}-\mathrm{sus},\right\}$ For me I know $\mathrm{He}$ cares,

'Tis joy to work for Je - sus,

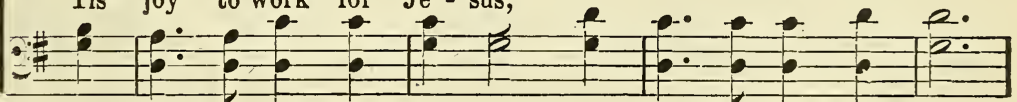

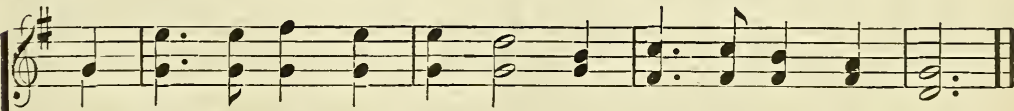

Each day He grows more pre-cious $\mathrm{My}$ griefs and joys $\mathrm{He}$ shares.

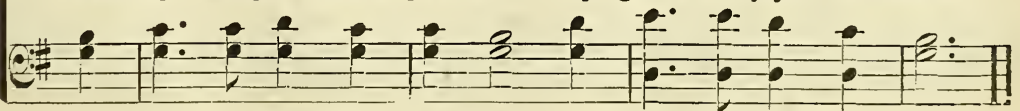

Copyright, 1908, by Evangelists Davis \& Mills. 
IDA L. REED.

Theo. E. Perins.

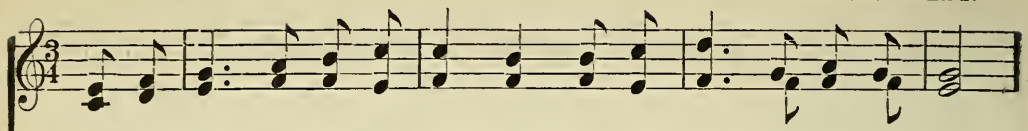

1. Let us bright - en all life's path - way, With the flow'rs of mer - cy sweet,

2. Let us leave be - hind us ev - er, All our earth - ly way a - long,

3. Let us ease for hearts a - wea - ry, As we jour - ney here, life's pain;
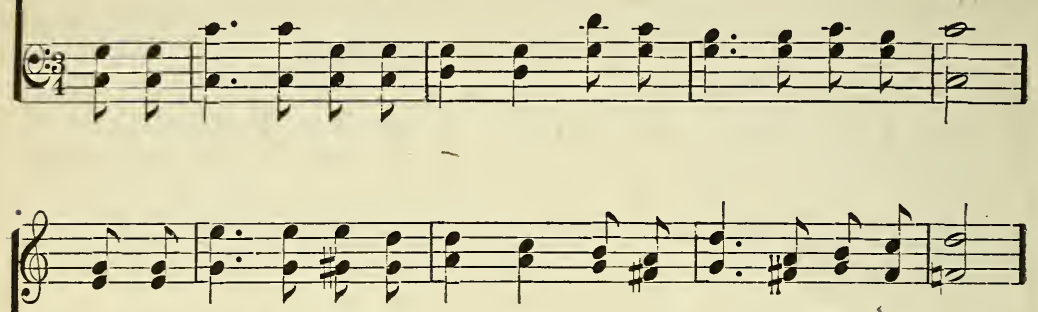

Scat - 'ring deeds of love and glad - ness, As we pass with hast'ning feet. Hope's clear light for oth - ers shin - ing,Till their faint-ing hearts grow strong. Strew - ing all the way with bless - ings, For we will not pass a - gain.

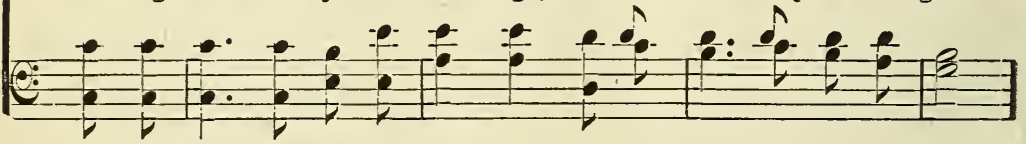

REFRAIN.

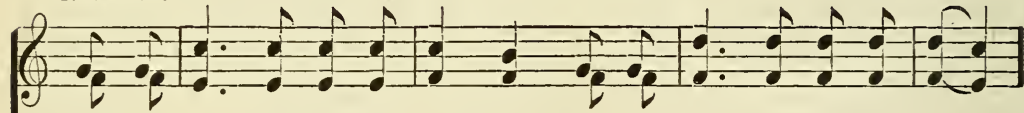

$\mathrm{Nev}$ - er-more we'll tread the path - way, That our feet may press to - day,
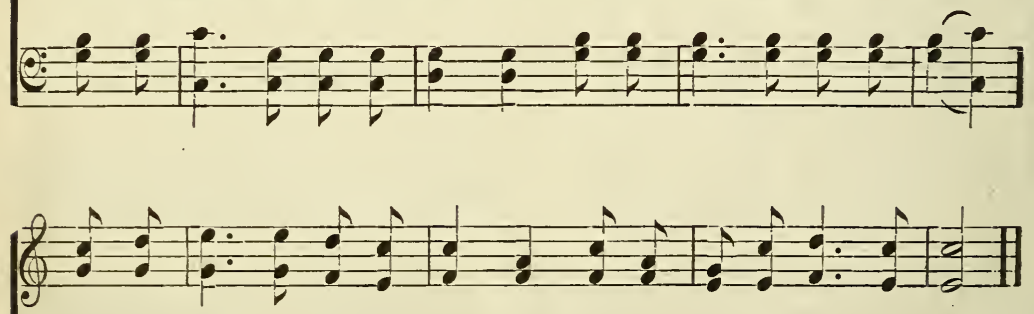

Then, 0 then with lov - ing kind - ness; Let us bright - en all the way.

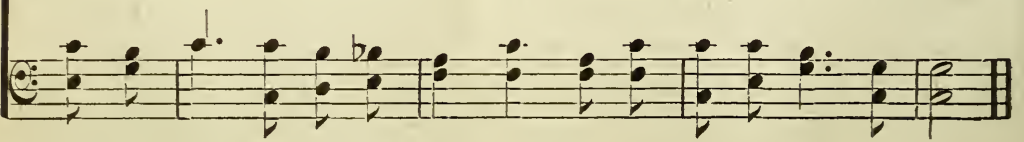

Copyright, 1910, by John R. Clements. 
T. $\mathbf{H}$.

THORO HARRIS.

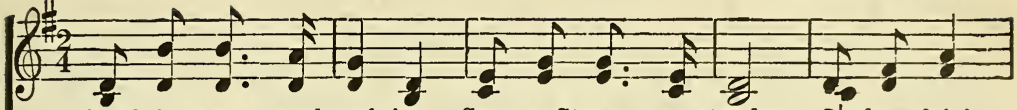

1. Knock-ing, ev - er knock-ing, See a Strang - er stands; ol how fair!

2. If thou let $\mathrm{Him}$ en-ter $\mathrm{He}$ will spread the feast; Thou shalt rest

3. Let Him in-'tis Je-sus! Show thy grat - i - tude To the one-

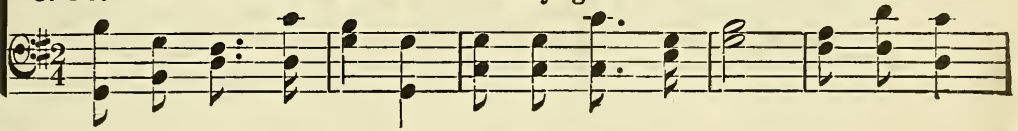

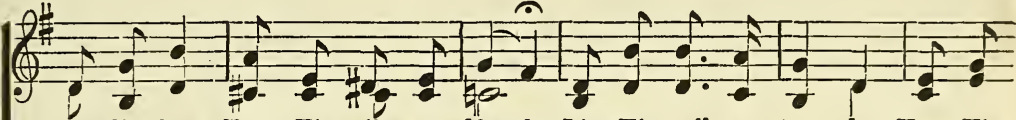

Waits He there, Shows His nail-scarred hands. List His call so ten - der, Hear His

On the breast Of Thy heav'n-ly Guest. KeepHim out no long-er By thy

God's dear Son-Who can do theo good. 0 -pen wide the por-tal of thy

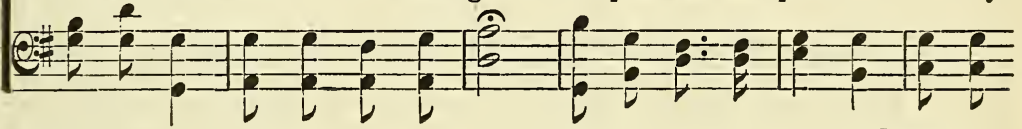

earn-est plea, "O my well-be-lov-ed, O-pen un - to me."
doubt and sin; An-swer, quickly an-swer, "Blessed Lord, come in." Some-bod-y's
heart to-day; Bid the Sav-iour en -ter To a - bide for aye.

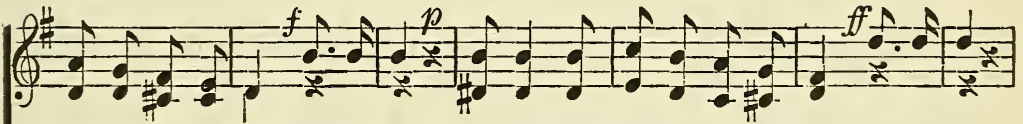

knocking at the door: let Him in! Some-bod-y's knocking at the door: let Him in!
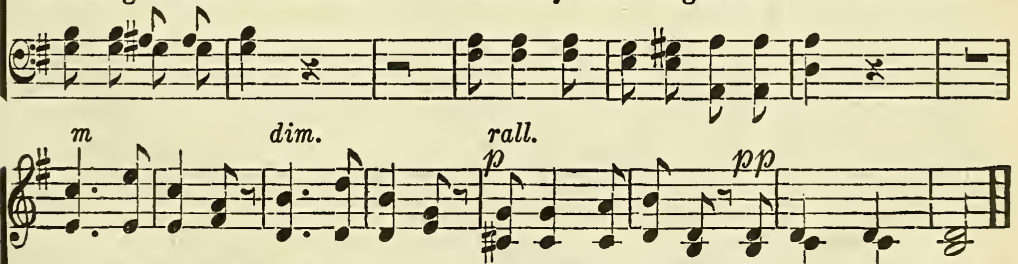

Sin-ner, an-swer; 'Tis your Sav-ior; Je-sus stands waiting: 0 let Him in!

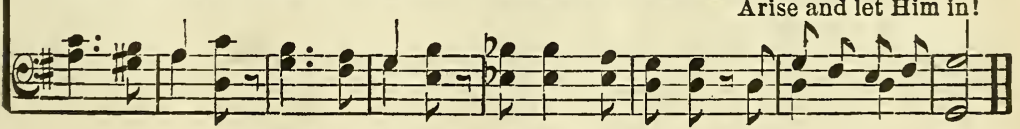

Copgright, 1906, by Thoro Harris. Henry Date, owner. 
G. H. C.

"A still small vorce."-1. Kings $19: 13$.

Not too fast.

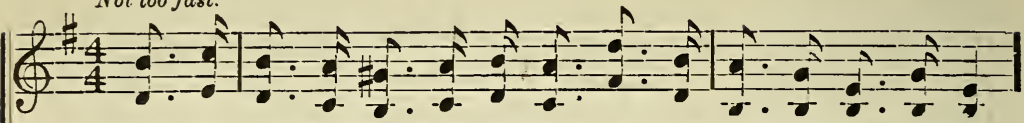

1. 'Mid the strife and cease-less struggle of the strong a-gainst the weak,

2. Oft per-plexed with ma - ny du - ties Call-ing here and eall - ing there,

3. When deep sor-rows o - ver-whelm you, And your soul is bowed with grief,

4. When your conscience sorely smites you With an aw - ful sense of sin,
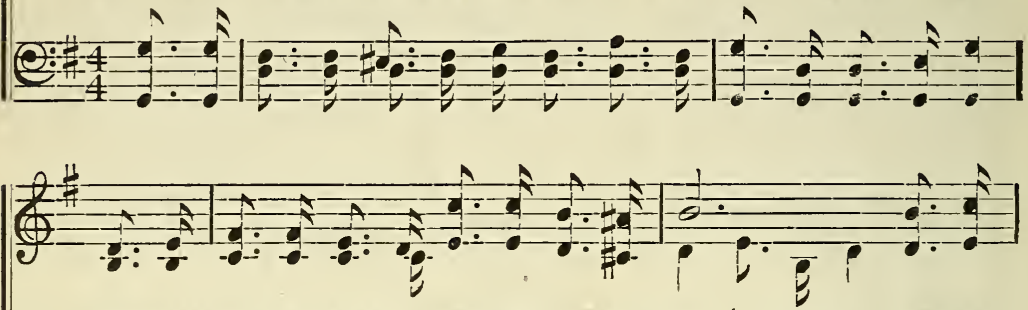

While the world goes mad-ly rush-ing to and fro; (to and fro;) There's a

What to do, the ques-tion comes to one and all; (one and all;) On - ly

Who can heal the ach-ing heart, you sad-ly cry; (sad-ly cry;) There is

Is there $\mathbf{a}$ - ny pow'r to help me, do you ask? (do you ask?) Yes, there's
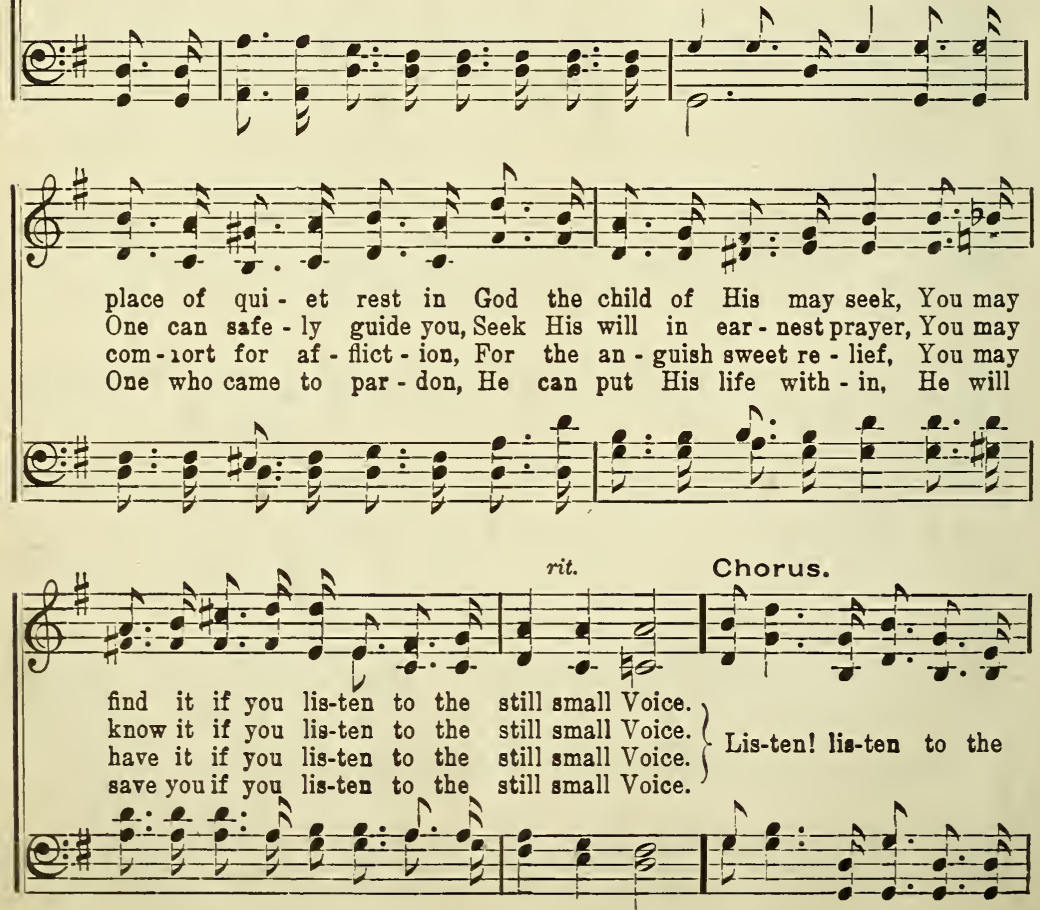

Copyright, 1908, by Evangelist John A. Davis 
Listen to tbe Itill Imall voice.

(2)

still small Voice Saying, "let me make your heart rejoice, Oh, hear what I would say and
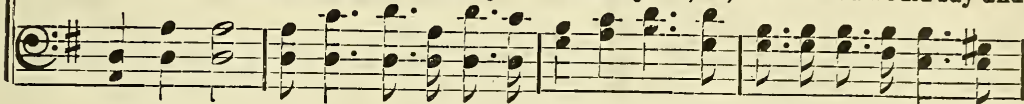

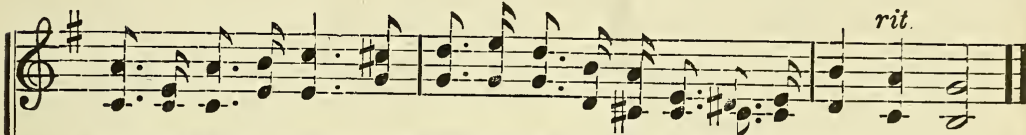

my command o - bey," Com-mun-ion is so precious with the still small voice.

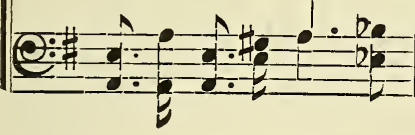

\section{7}

WiLhIaM Herbert HudNut.
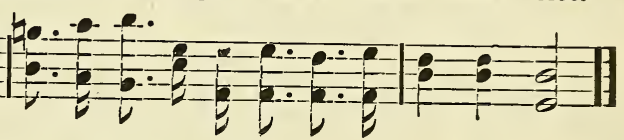

Be Strong.

Spirited.

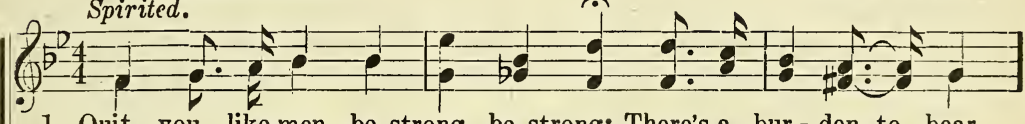

1. Quit you like men, be strong, be strong; There's a bur - den to bear,

2. Quit you like men, be strong, be strong; There's a bat - tle to fight,

3. Quit you like men, be strong, be strong; There's a work to do,

4. Quit you like men, be strong, be strong; There's a year of grace,

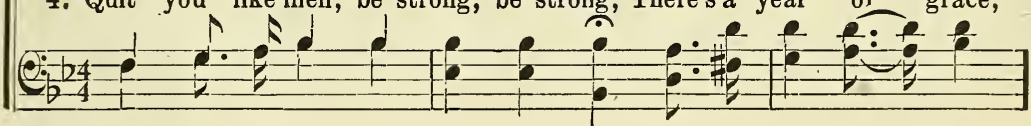

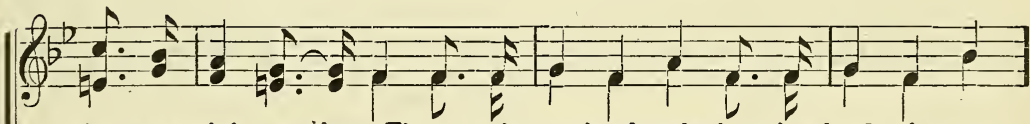

there's a grief to share, There's a heart that breaks 'neath a load of care,there's a wrong to right, There's a God who bless - es the good with mig t,there's a world to make new, There's a call for men who are brave and truethere's a God to fall, There's an-oth - er heat in the great world race-
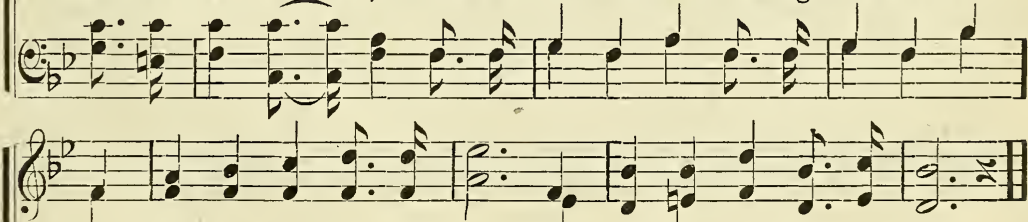

But fare ye forth with a song, but fare ye forth with a song.

So fare ye forth with a song, so fare ye forth with a song.

Speed on! speed on with a song, speed on! speed on with a song.

Speed on! speed on with a song, speed on! speed on with a song.

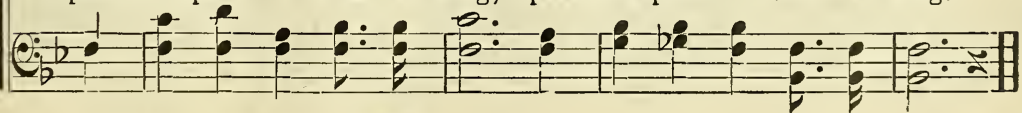

Copyright, 1910, by John R. Clements. 
Suggested by the sinking of the steamer. Rio at the Golden Gate, February, 1901.

John R. Clemments.

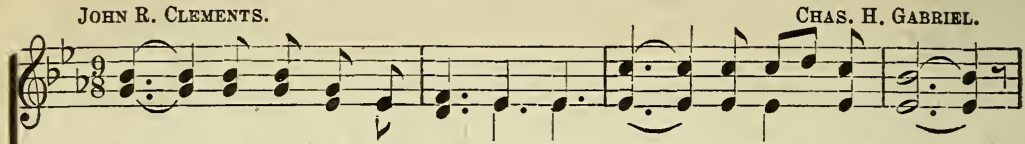

1. Lost in sight of the har-bor, Not on the track-less deep;

2. Lost in sight of the har-bor, The days of sail - ing past,

3. Lost in sight of the har-bor, The shore-bells ring - ing clear,

4. Lost in sight of the har-bor, Wreck'd by ' the fogs of sin,

5. Lost in sight of the har-bor, "Lost" What a word of woe:
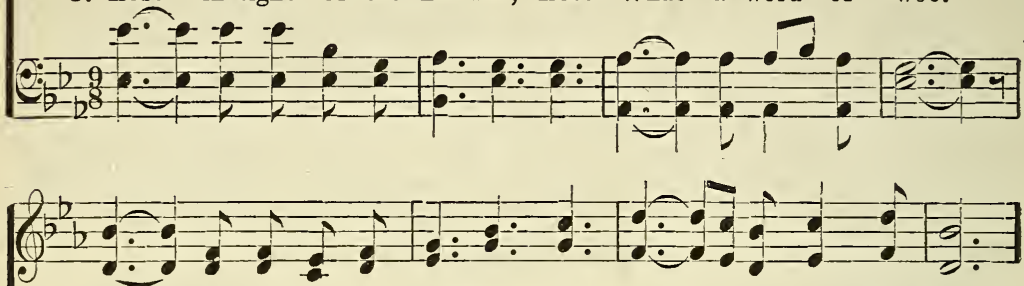

Not where o - cean is black - est, Nor

In a few more brief moments, The

Their sweet chimes the last music, That

Some poorsoul-ship that's sail-ing, Can

where the wild winds sweep.

shore lines might be cast.

Choose the on - ly Sure Pi - lot, Who

many a soul shall hear.

nev - er en - ter in.

"all the way" doth know.

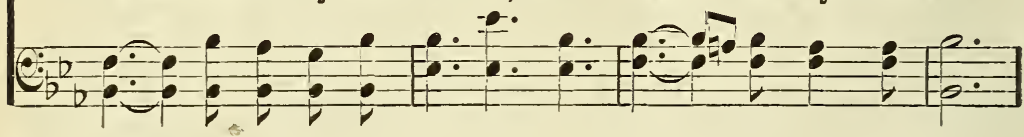

Chorus.

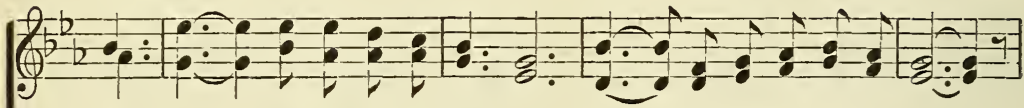

1-4. But lost in sight of the har-bor; Lost for the want of a Hand;

5. Then-safe you'll rest in the har - bor; Safe by the skill of a Hand,
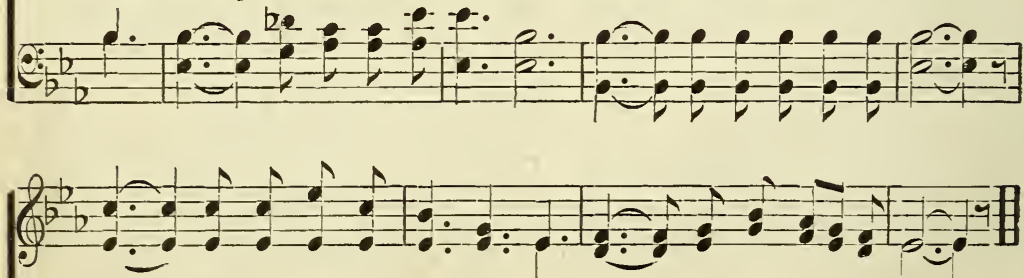

Strong and certain and steadfast, To pi - lot safe to the land,

Strong and certain and steadfast, The Pi - lot to "glo - ry land."

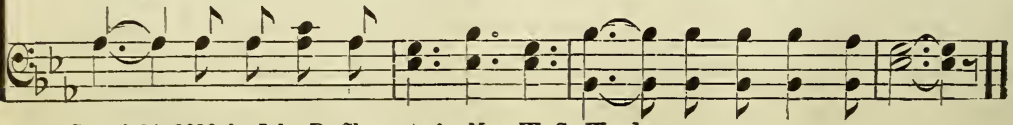

Coyyright, 1910, by John R. Clements for Mrs. W. S. Weeden. 
Alt. by JaMes M. Gray.

W. Owen. From the Welsh. Arr. by 0. F. Pugr.

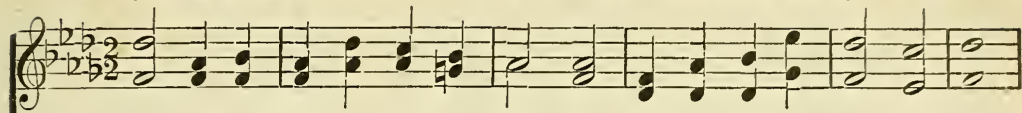

1. 0 list - en to our wondrous sto - ry: Counted once a - mong the lost,

2. No an - gel could our place have tak - en, High-est of the high tho' he,

3. And yet this tale wondrous pro-ceed-eth, Stirring heart and tongue a-flame!

4. Will you sur - ren-der to this Sav - ior? To His scep-tre hum-bly bow?
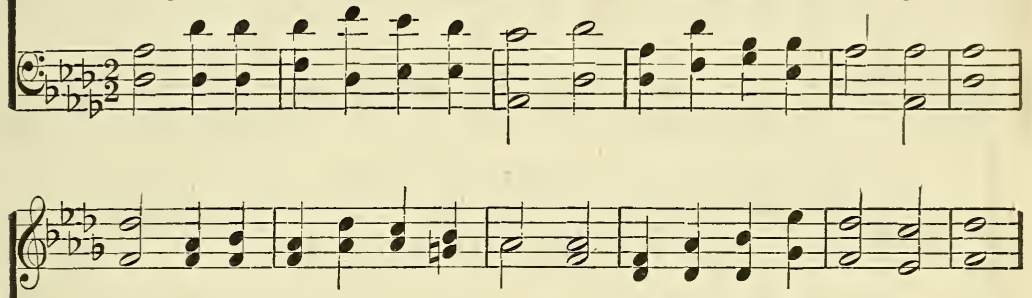

Yet, One came down from heaven's glo-ry, Sav-ing us at aw - ful cost! The loved One on the cross for - sak - en Was one of the God-head Three! As our High Priest in heav'n He plead-eth, And Christ Jesus is His name! You, too, shall come to know His fa - vor, He will save you, save you now!

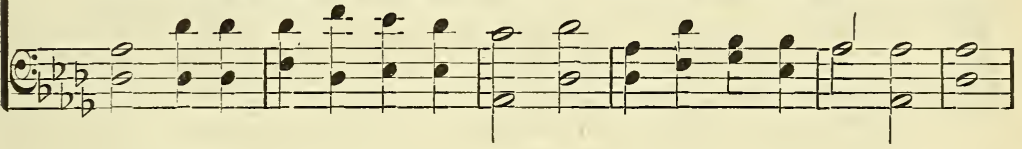

Chorus.
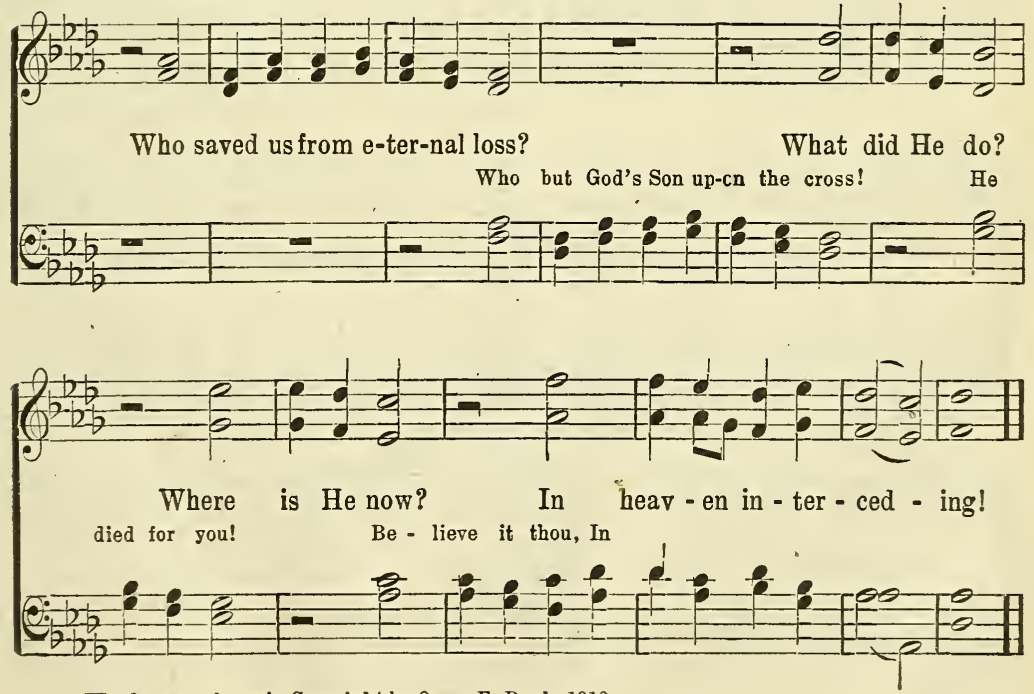

Words, arr. of music Copyright by Owen F. Pugh, 1910. 
Jorn R. Clements,

HARPER G. SMYTH.

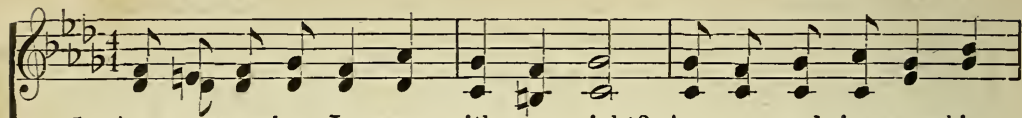

1. Are you serv-ing Je - sus with your might? Are you mak-ing sun-shine

2. Àre you preaching Je - sus by your life? Are you help-ing oth - ers

3. Are you do - ing ev - er Christ-like deeds? Are you scatt'ring glad-ness,

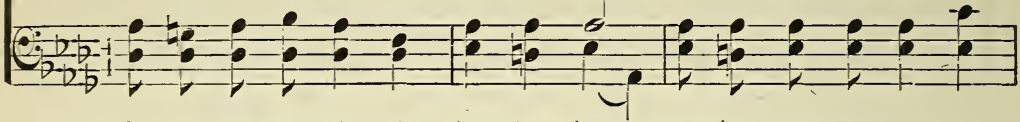

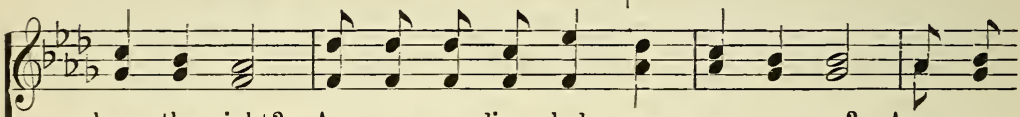

chase the night? Are you spreading glad - ness as you go? Are you in the strife? Are you glad - ly giv - ing all your days? Are you just like seeds, Soon to bud and blos - som, sweet and fair, And to

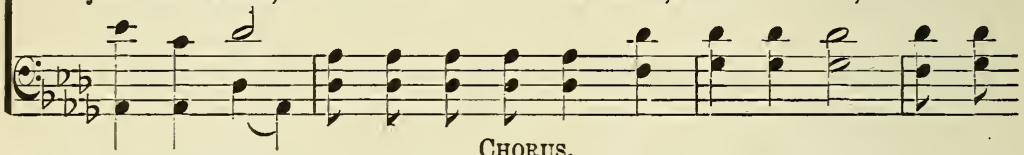

lead-ing oth-ers Christ to know?

teaching oth-ers Christ to praise? Serv-ing Je-sus all a - long the way, pour their fragrance ev'ry where? Serv -ing Je - sus all the way,

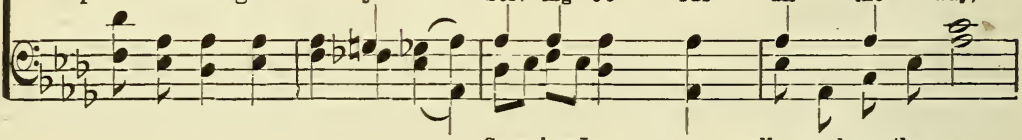

Serv-ing Je - sus all a-long the way,

(0)

Serv-ing Je-sus, faithful night and day; Serv-ing your Mas-ter as you

Serv - ing $\mathrm{Je} \mathrm{-} \mathrm{sus} \mathrm{night} \mathrm{and} \mathrm{day;}$

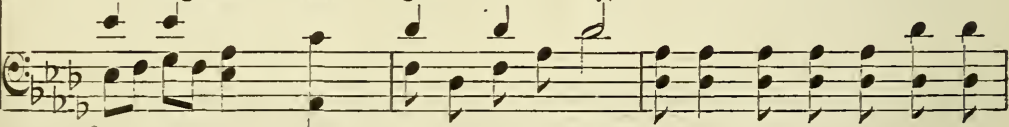

Serv - ing Je - sus faith - ful night and day:

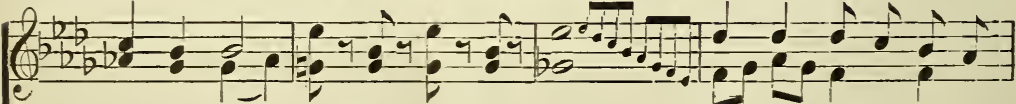
on-ward go, Lift this en - sign high. $\quad \mathrm{Ev}_{\mathrm{V}}$ er faithful let there

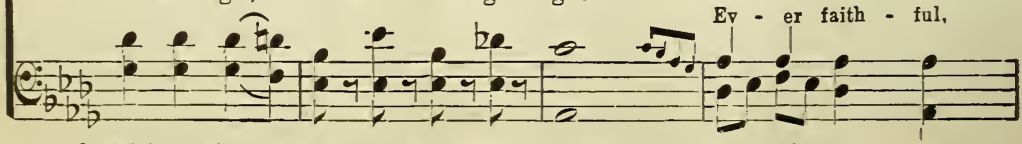

Copyright, 1908, by Harper G. Smith. J. Wilbur Chapman, owner. Used by per. 


\section{Serving Jesus.}

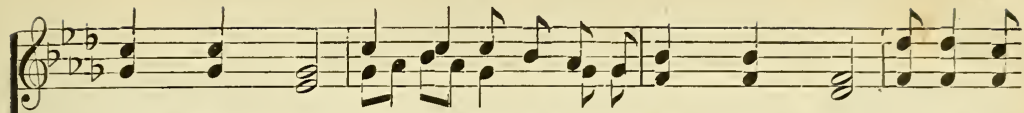

come what may; $\mathrm{Al}$ - ways ready an - y price to pay; Loving your come what may; Al - ways read - I the price to pay;

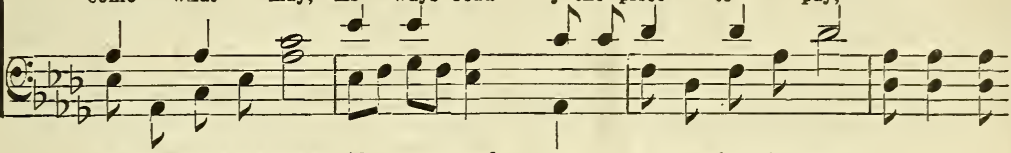

let there come what may; Al - ways read - y an - y price to pay;

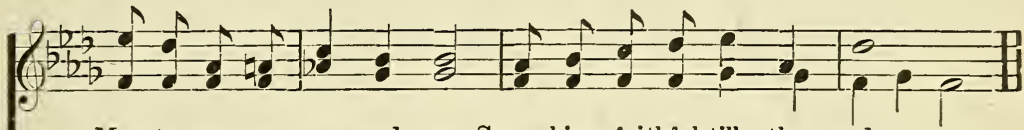

Mas-ter as you on - ward go, Serve him, faithful till the end.

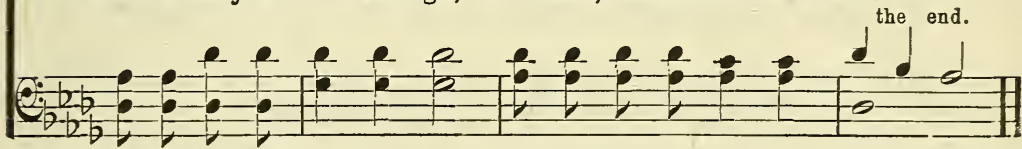

$31 \quad$ Look Away to Jesus.
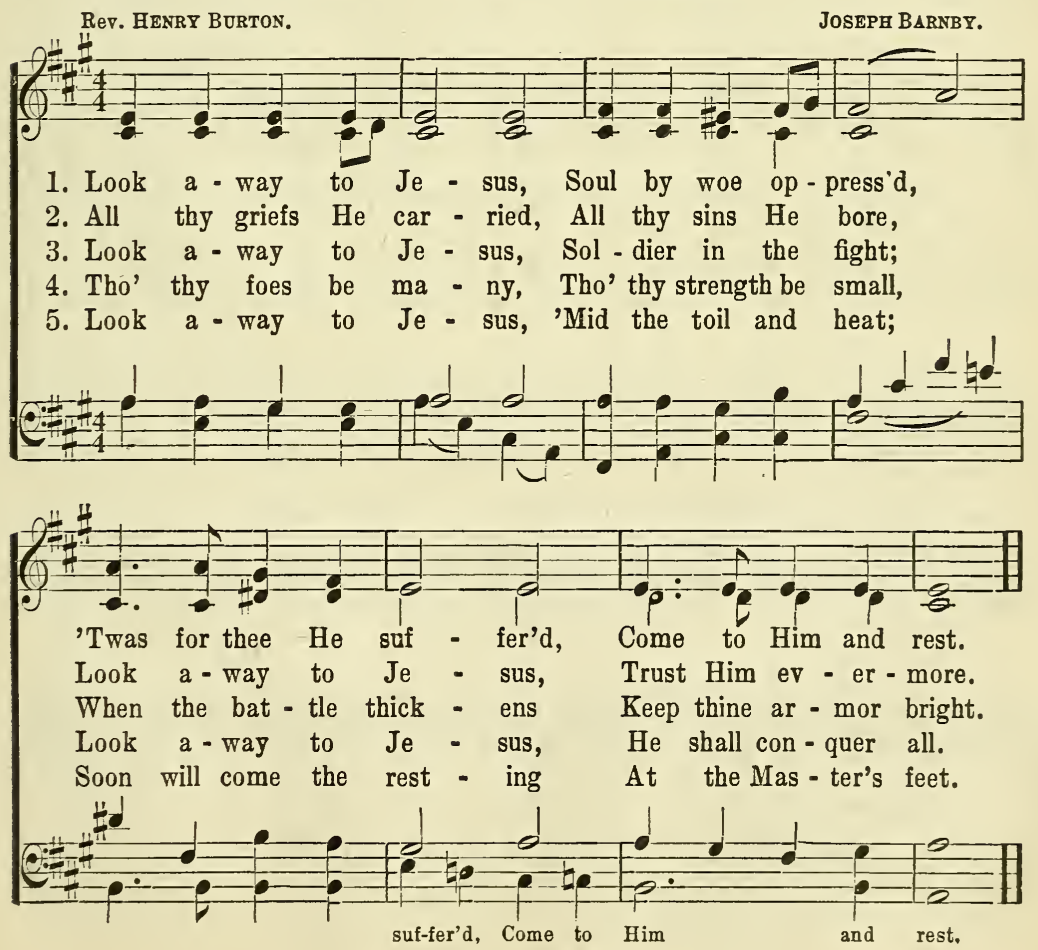
"For there is none other name under heaven given among men

G. H. C. whereby we must be saved." - 1 cTs $4: 12$.

GEORGE H. CARR.

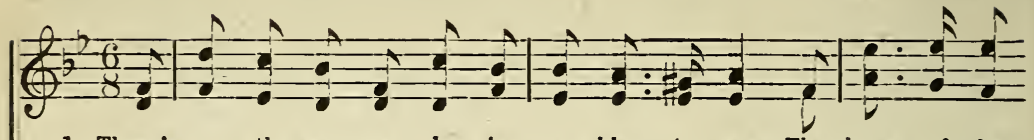

1. There's no oth - er one who is a - ble to save, The hope of the

2. There's no oth - er one who can cleanse us from sin, The hope of the

3. There's naught else on earth that can right ev - 'ry wrong, The hope of the

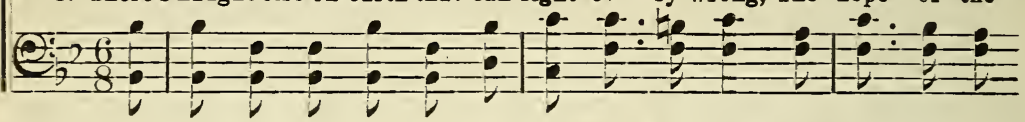

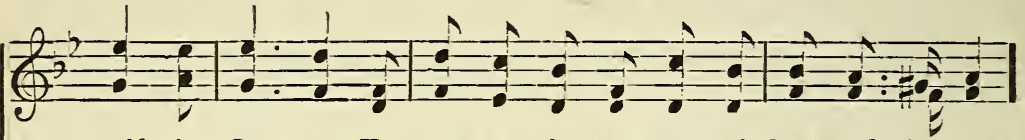

world is Je - sus; He conquers the ter-rors of death and the grave, world is Je - sus; None oth - er cantransform the na-ture with-in,

world is Je - sus; The bat - tle is not for the wise or the strong,

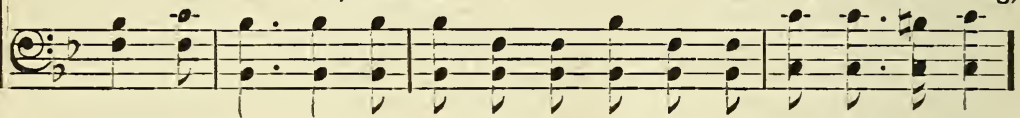

$\frac{1}{2}=1$

The hope of the world is Je - sus. The hope of the world is Je - sus,

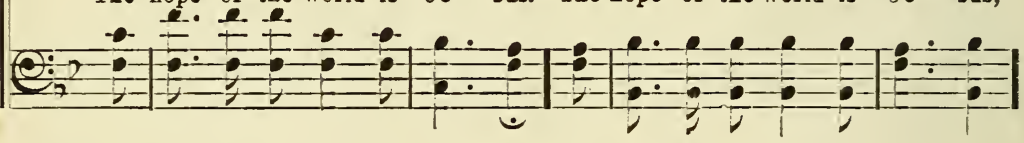
$\frac{f^{2}-2}{2}=\frac{1}{2}=\frac{1}{2}=$

The Christ who reigns a - bove; All pow - er is giv-en On

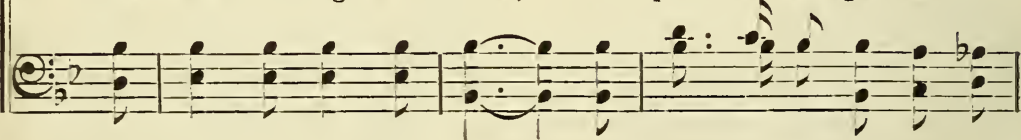
(4) earth and in heav-en, To Je - sus the gift of God's love.

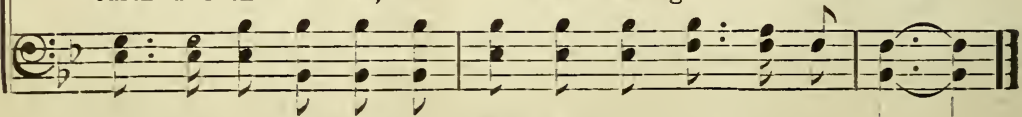
Copyright. rgo8, by Evangelist, John A. Davis. 
Written at the farewell meeting of Evangelists Davis, Mills and Carr, Chicago, April 9th, 1909.

E. E. B.

F. E. BELDRN.

Tenor may take alto part an octave higher, on 2 nd and 4 th stanzas. rit.

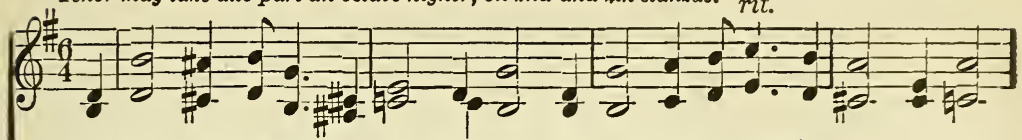

1. Shall one be missing When we meet there, Beyond our wishing,Beyond our care?

2. Is friendship giv-en For life's short way, And not for heaven's E-ter - nal day?

3. The brown leaf falleth, The flow'r is gone, The lone mate calleth, Yet answer none;

4. The word of greeting Is sweet to hear, The good-bye metting Hath many'a tear;

5. Be this our to-ken In part-ing hour, Of faith unbroken In Keeping Pow'r,
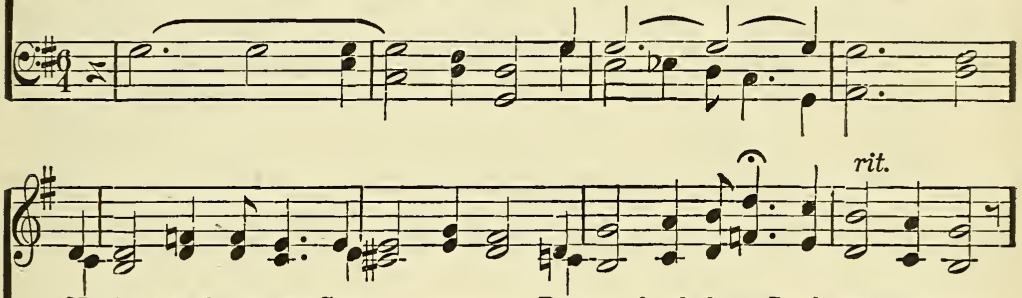

No fare-well sadness Can ev - er come, But on-ly gladness In that sweet home.

Can true love vanish Like summer hours, Or snow drifts banish Per-en-nial flow'rs?

But in God's E-den Of love and light, No thorn is hidden, There is no night.

But hope is beaming, Our guid-ing star, And haven gleaming Shines out a-far.

That none be missing Immortal love When warm hands pressing Shall clasp above.

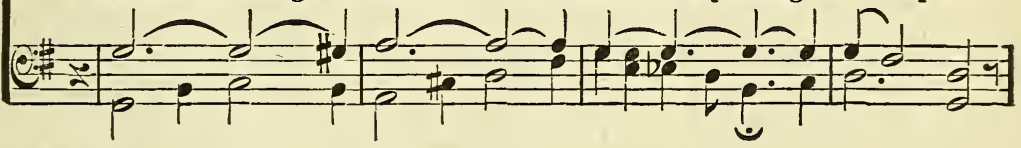

Chorus. (After 1st, 3rd, and 5th stanzas only.)

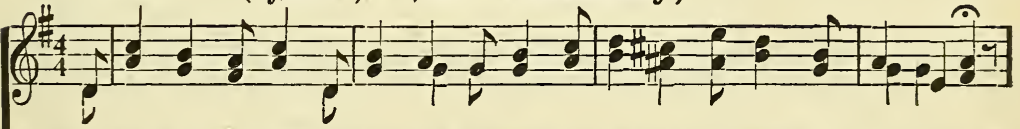

Shall one be missing, When warm hands pressing,And songs of blessing Our joy declare?
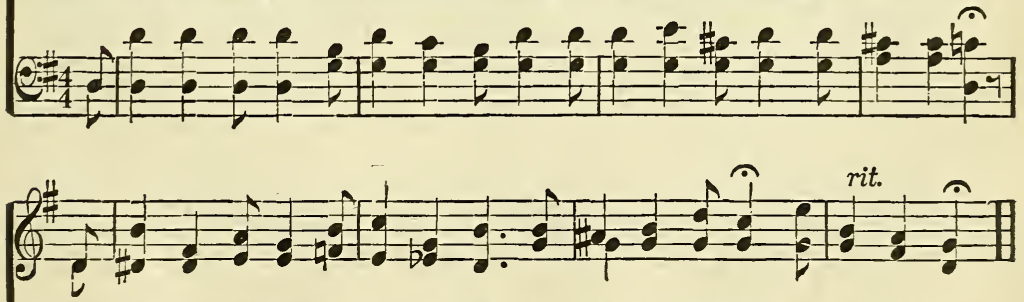

Sweet home eternal,Beyond earth care; Shall one be missing When we meet there?

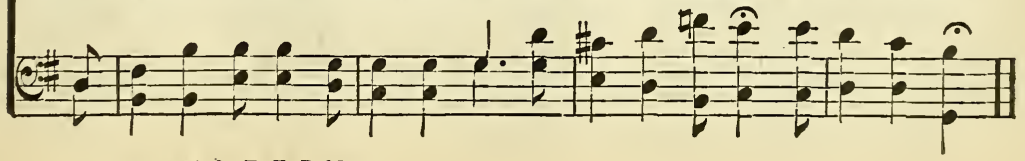

Copgright, 1909, by F. E. Belden. 
IBENE DURFEE

W. Sthliman Martin.

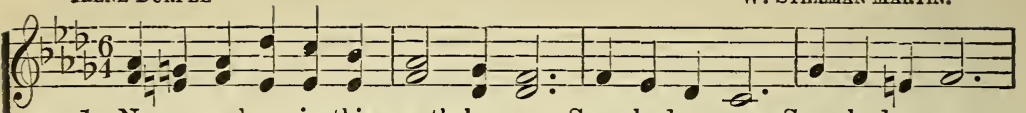

1. Nev-er a-lone in this earth-ly way, Somebody cares, Somebody cares;

2. When I am singing a hap-py song, Somebody cares, Somebody cares;

3. When I am weary and long for rest, Somebody cares, Somebody cares;

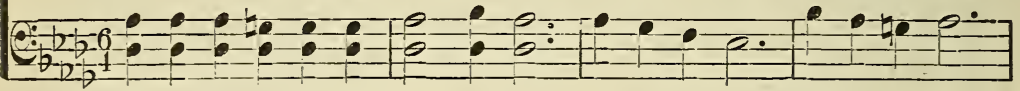

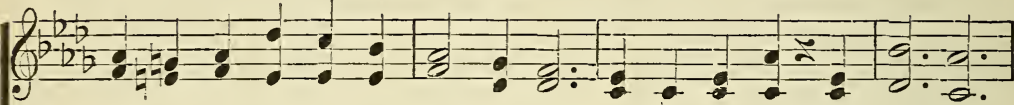

I have a help - er each bus - y day; Some-bod-y cares, tis Je - sus;

When I am fighting a-gainst the wrong, Some-bod-y cares, 'tis Je - sus;

When by the tempter I'm sore-ly press'd, Some-bod-y cares, 'tis Je - sus;

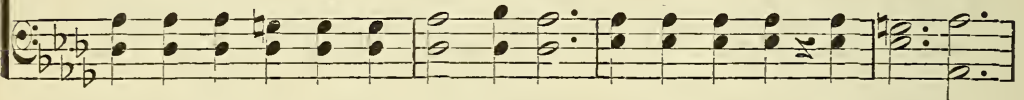

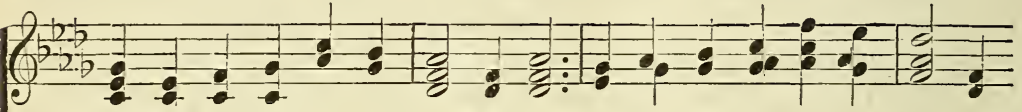

Some-bod - y cares when the clouds hang low, Cares when my heart is o'erwhelmed with Some-bod - y cares when I stand a - lone,Cares when the pleasures of earth are

Some-bod - y cares,and what-e'er be-tide, Walks ev-'ry hour by the Christian's

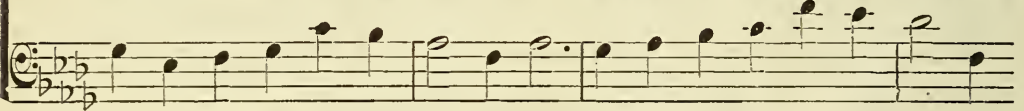

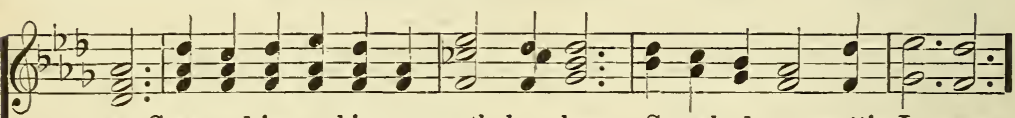
woe, Care and is marking my path be - low, Somebody cares, 'tis Je - sus. gone,Cares when my false hopes with wings have flown, Somebody cares, 'tis Je - sus. side, Love so a-maz-ing will e'er a - bide, Somebody cares, 'tis Je - sus.
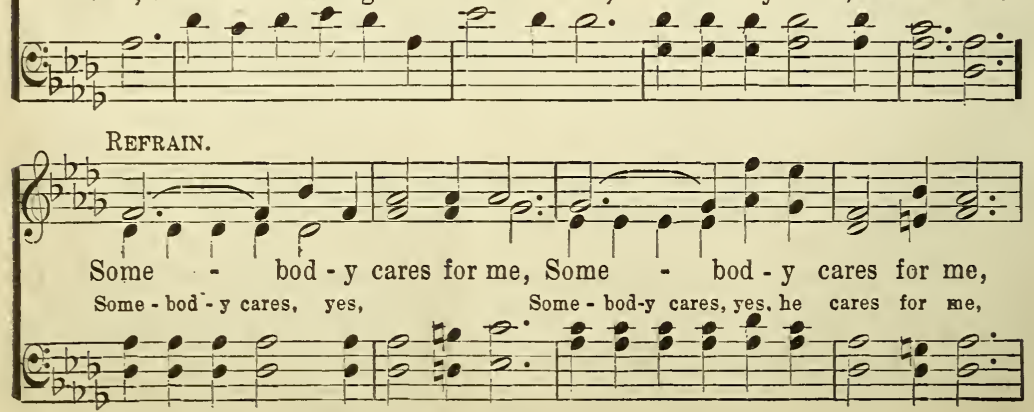

Copsright, 1908, by The Praise Pab. Co., Phila. Pa. 


\section{Somebody Cares.}

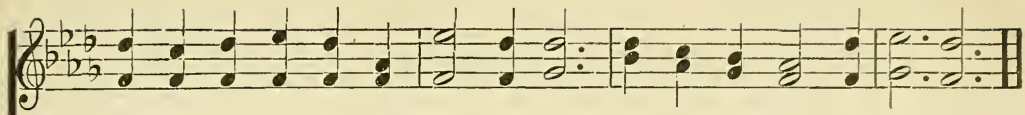

In all my life his kind hand I see, Some-bod-y cares,'tis Je - sus.

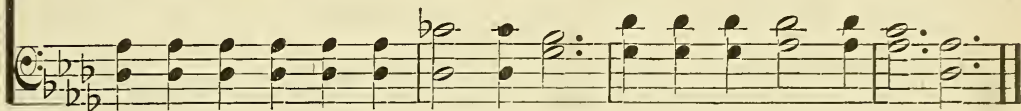

35

In the Waves.

Translated by Rev. ELVET LeWIS.

Composed in the Welsh by D. WilliaMs.

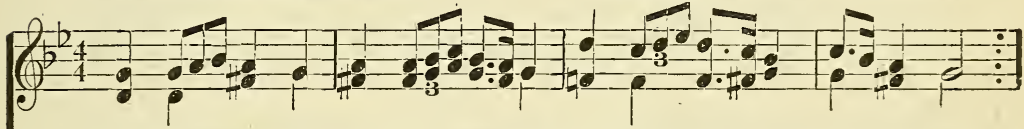

1. \{ In the waves and might - $\mathrm{g}$ wa-ters No one will sup - port my head ?

1. $\{$ But my Sav - ior, my Be - lov - ed, Who was strick - en in my stead; $\}$

2. $\{0$ the grace no will can conquer! The om - nip o - tence of love! $\}$

2. $\{$ Changeless is my $\mathrm{Fa}$ - ther's promise, It - will nev - er, nev - er move! $\}$
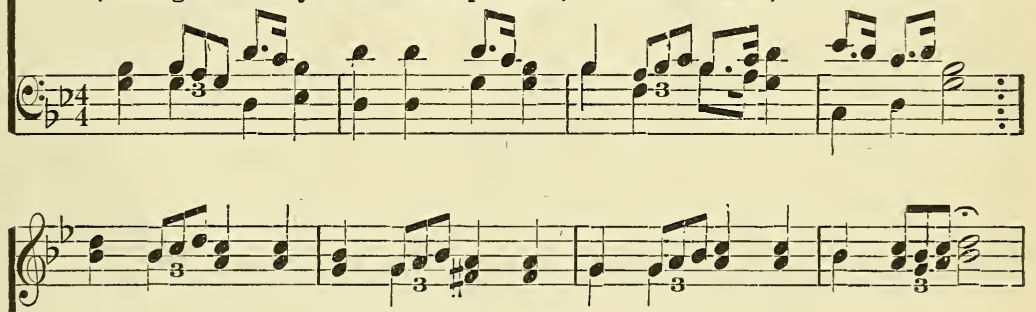

He's a Friend in death's dark riv - er, He will hold my head a - bove;

In the storm this is my an-chor-God will nev-er change His.mind;
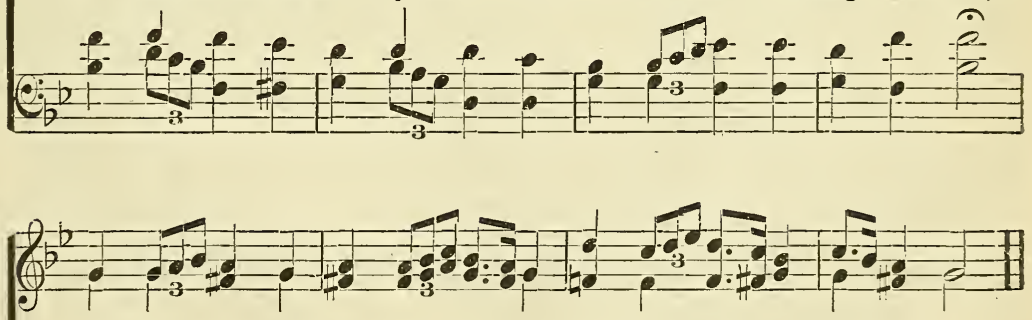

I shall thro' the waves go sing - ing, For one look of Him I love!

In the wounds of Christ $\mathrm{He}$ promised Life to me; and $\mathrm{He}$ is kind.

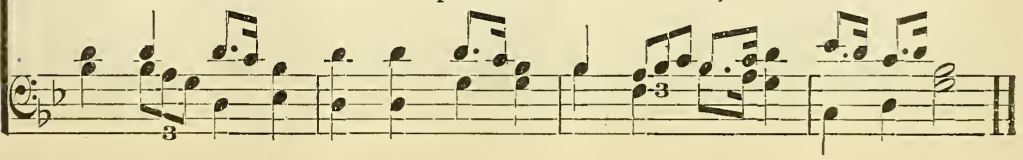


JOBR R. CLEMENTS.

P. P. BILHORN.

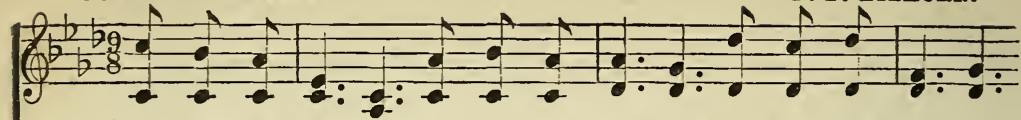

1. "Out of the mid-night in - to the morn-ing", Out of the old life

2. "Out of the mid-night in - to the morn-ing", Drawn by the Sav-iour

3. "Out of the mid-night in - to the mor-ning", Out of the tem-pest

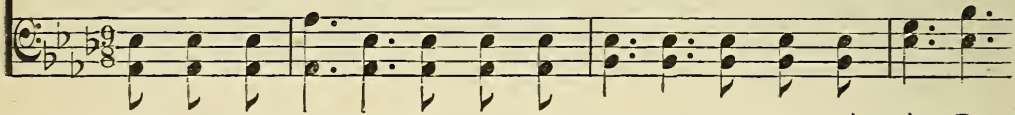

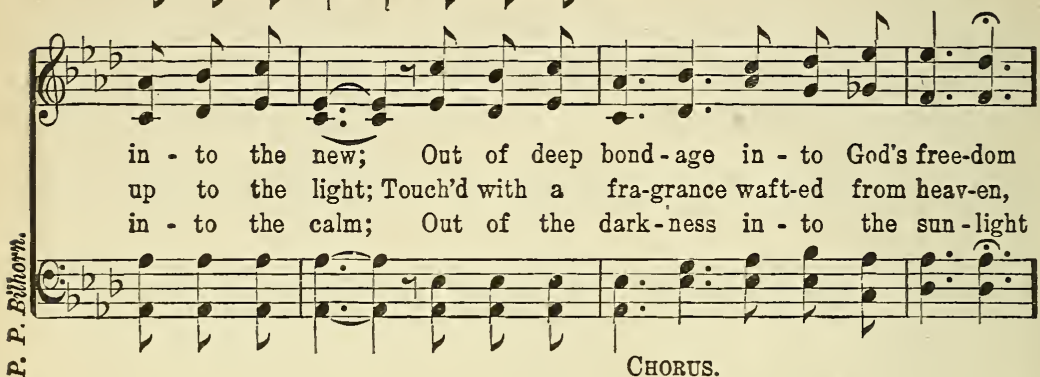

ฐั

Out of the sin life in - to the true.
Out

Lives that were e - vil turn to the right. "Out of the mid-night in-to the

Voic-es are chant-ing vic-to-ry's psalm.

(3,j,

เి

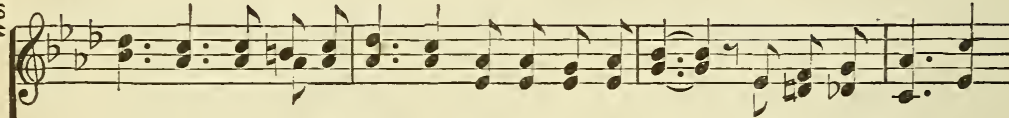

morn-ing," Je-sus with mighty arm ev-er will bring; Love beams of free-dom

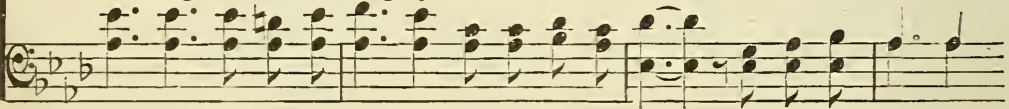

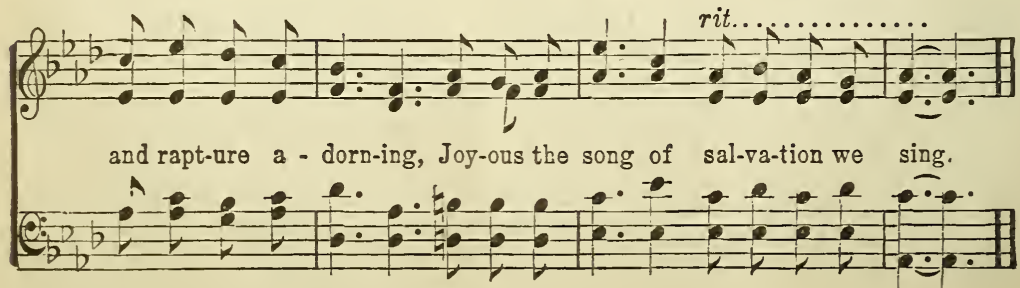




\section{Beneath the Cross of Jesus.}

Elizabeth C. Clephane.

Frederick C. Maker.

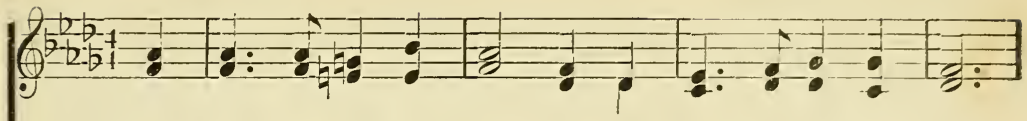

1. Be - neath the cross of Je - sus I fain would take my stand,

2. Up - on that cross of Je - sus Mine eye at times can see

3. I take, 0 cross, thy shad - ow For my a-bid - ing - place:
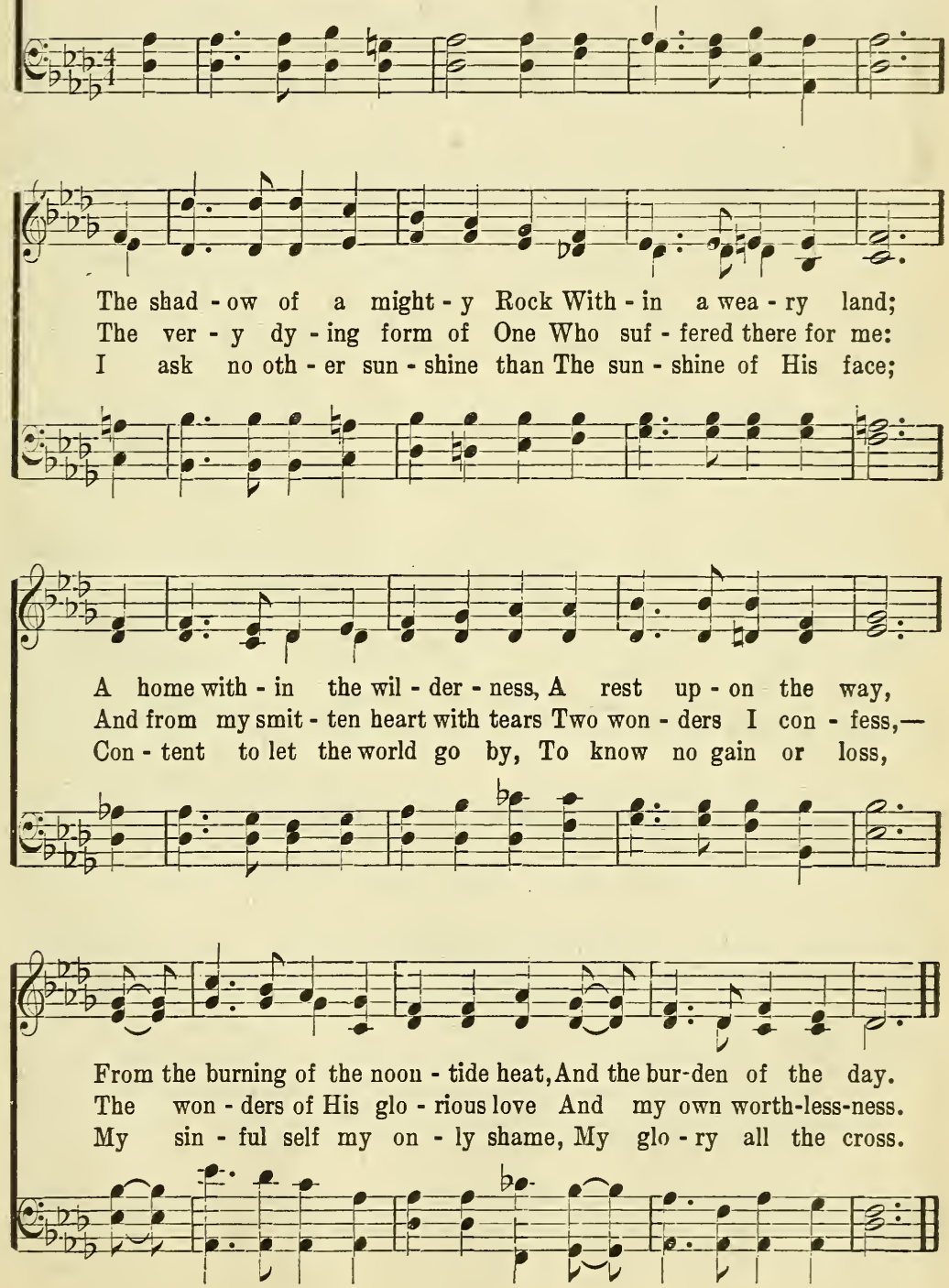
Mrs. C. D. MaRTLi.

Andante moderato.

(2)

1. Our Sav - ior will nev - er slum-ber, His eye will nev - er sleep, And the

2. He knows ev-'ry step be - fore us, He marks our pilgrim way, And the

3. More ten-der than love of moth-er, Is God's love for His own, Tho' $\mathrm{He}$

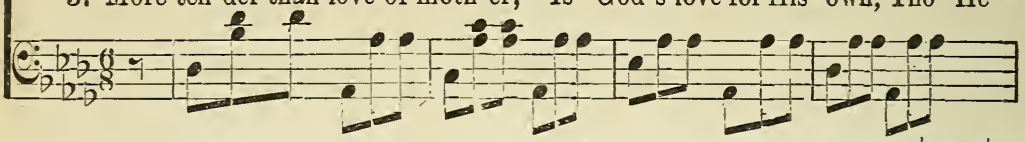

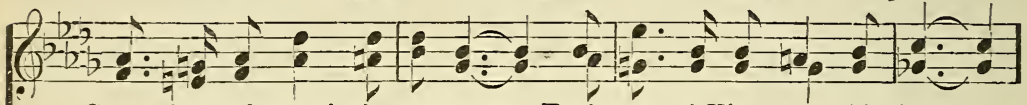

God who doth watch the spar-row, Each one of His own will keep; God who doth feed the spar-row, Will care for His own each day.

rules on His throne in heav - en, By Him ev - 'ry soul is known;

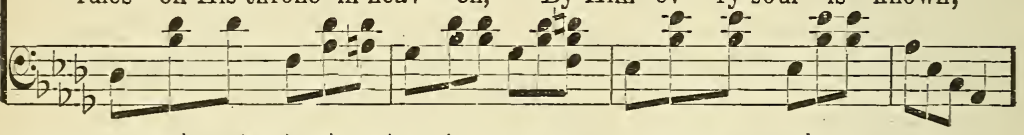

(0)

His love is a ho-ly gar-ment, His name is a might-y tow'r,

0 why should we ev-er mur - mur, 0 why should we rest-less be?

He sees ev - 'ry fall - ing spar - row, He hears ev-'ry earn - est cry,

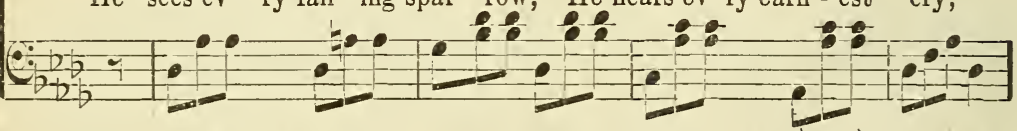

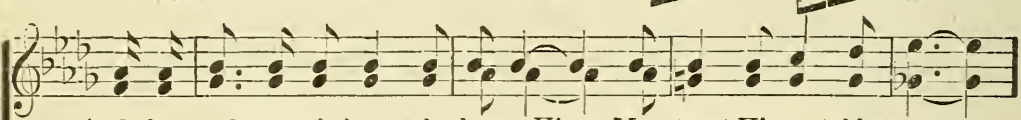

And the weak-est of those who love Him May trust His matchless pow'r;

When the weakest of those who trust Him, Erom care He will set free;

And the reak-est of those who know Him, May reign with Him on high;

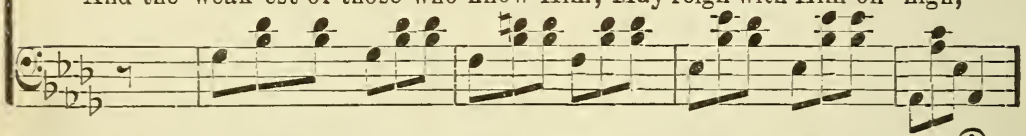

(2)

And the weak-est of those who love Him, May trust His matchless pow'r.

When the weakest of those who trust Him, From care He will set free.

And the weak-est of those who know Him, May reign with Him on high.

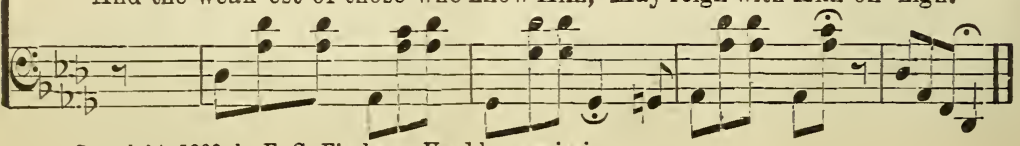

Copyright, 1909, by F. G. Fischer. Used by permission. 
B. B.

BaLLINGTON Booth.

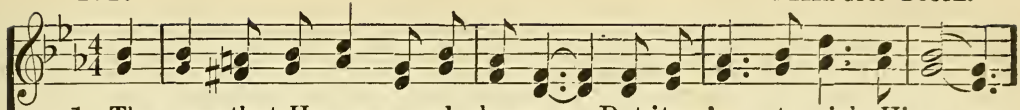

1. The cross that He gave may be heav - y, But it ne'er out-weighs His grace;

2. The thorns in my path are not sharp - er Than composed His crown for me;

3. The light of His love shin-eth bright - er, As it falls on paths of woe,

4. His will $I$ have joy in ful - fill-ing, As I'm walking in His sight,

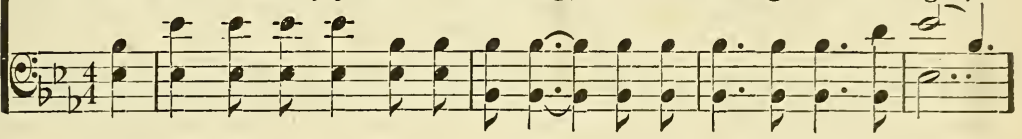

(0)

'The storm that I fear'd may surround me, But it ne'er ex-cludes His face.

The cup that I drink not more bit - ter Than Hedrank in Geth-sem-a-ne.

The toil of my work groweth light - er, As I stoop to raise the low.

My all to the blood I am bring - ing, It a - lone can keep me right.

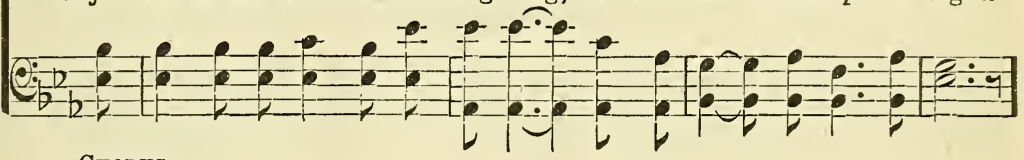

Chorus.

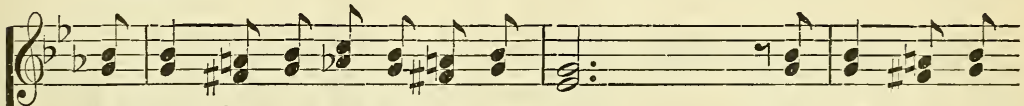

The cross is not greater than His grace,

The storm can - not
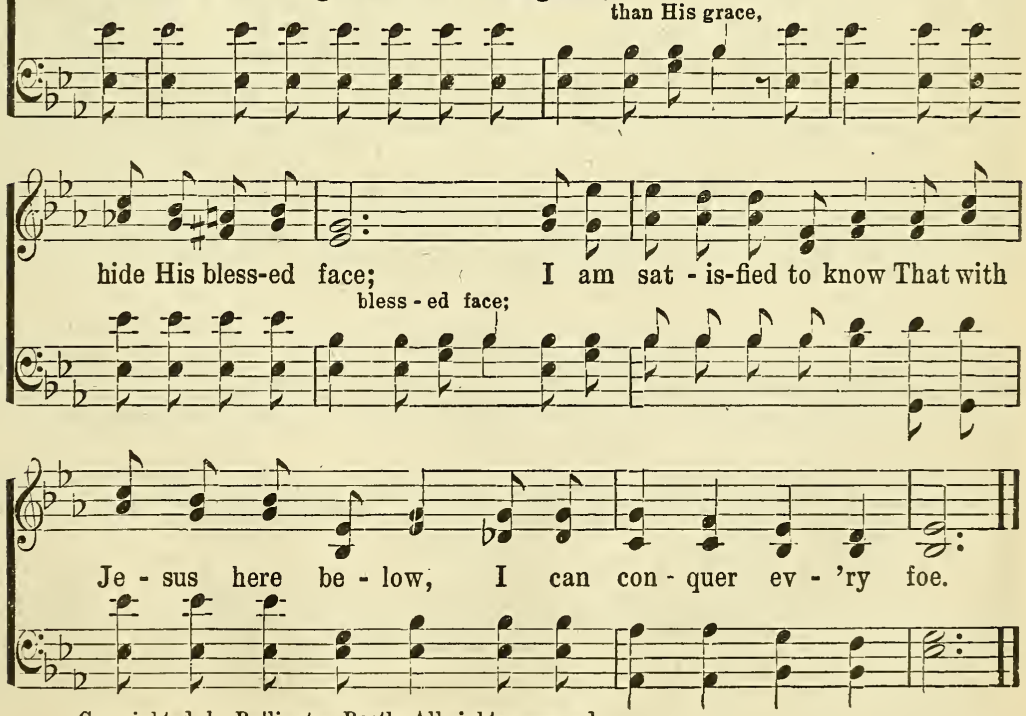

Copyrighted, by Ballington Booth. All rights reserved. 
Dr. Victor M. Staley.

Chas. H. GaBRIET.

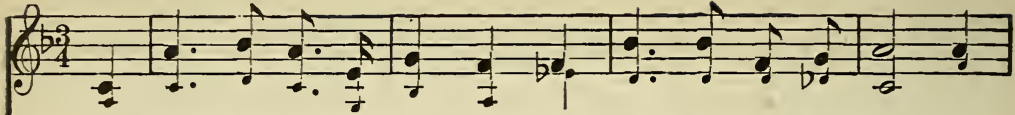

1. Some day 'twill all be 0 - ver-The toil and cares of life; Some

2. Some day I'll see the man-sions Of hear-en's cit- 8 fair; Some

3. Some day I'll see the Sav-ior, And know Him, face to face; Some
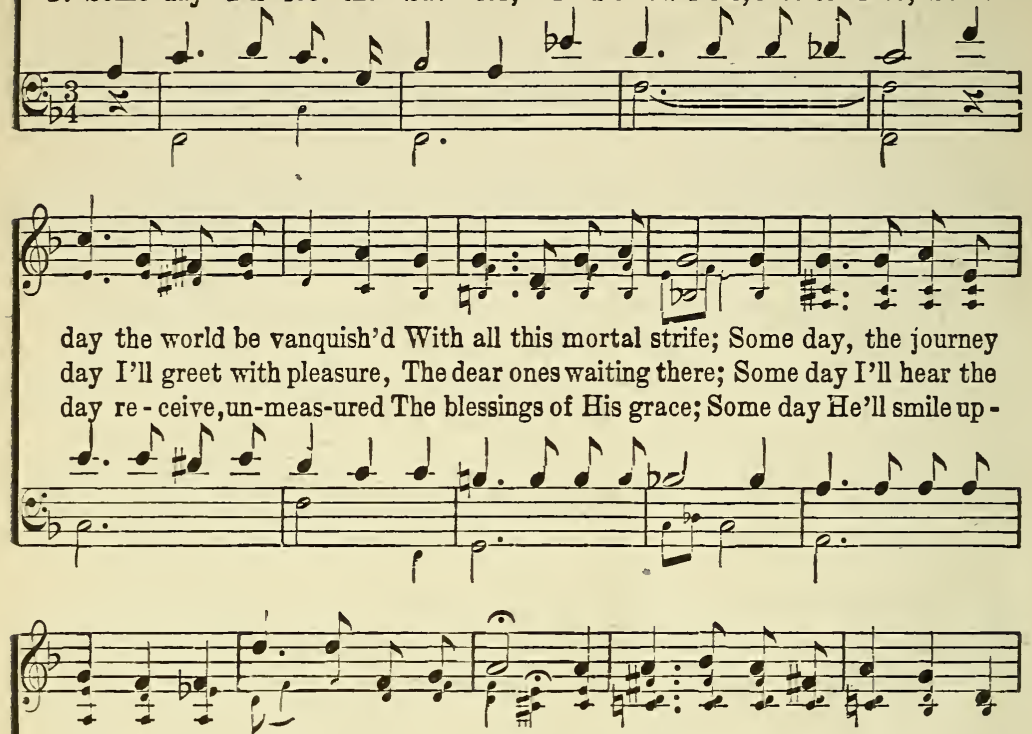

end - ed, I'll lay my bur - den down; Someday, in realms su - per - nal Re-

voic - es Of God's an-gel - ic throng; Some day I'll join the cho - rus In

on me from that white throne a - bove; Some day I'll know the full - ness Of

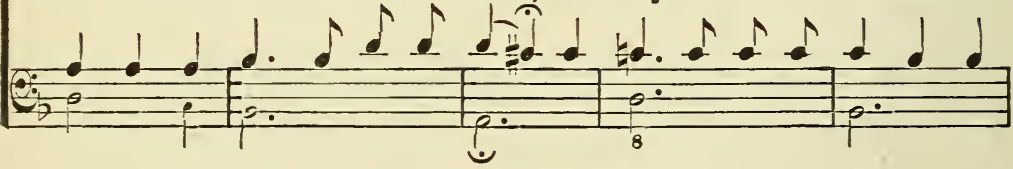

Chorus.

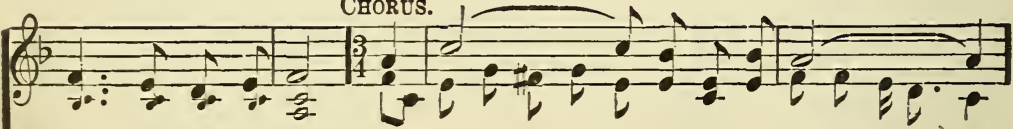

ceive, at last, my crown.

[some hap-pj day,

heav'n's im-mor-tal song. Some day, ..... some happy day, ......

His un - dy-ing love.

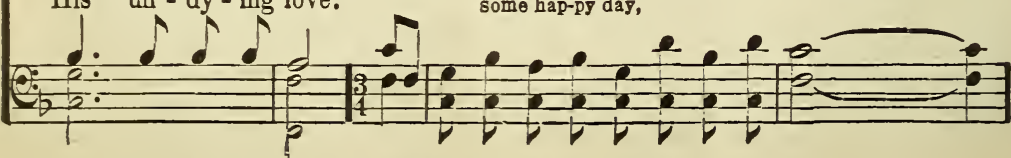

Copyright, 1903, by The Winona Publishing Co.. owned by R. A. Torrey. 


\section{Some Day.}

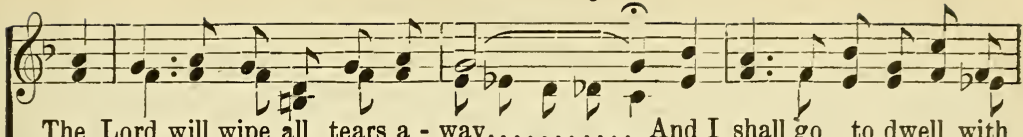

The Lord will wipe all tears $a-$ way,.......... And I shall go to dwell with
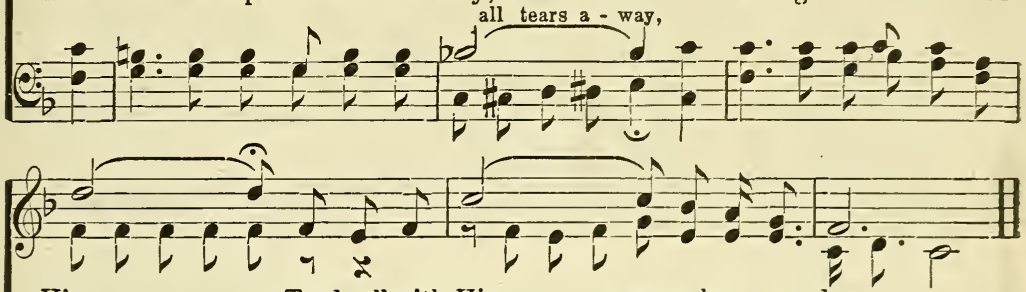

Him,....... To dwell with Him....... some hap - py day..... to dwell with Him, To dwell with Him, hap - py day.

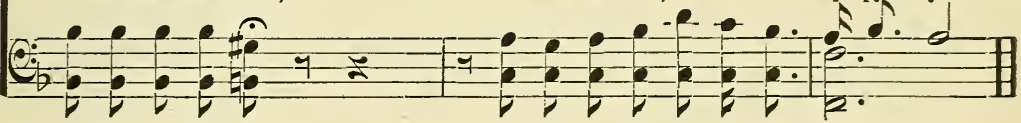

\section{Lead, Kindly Light.}

JoHN H. NEWMAN.

GEORGE H. CARR.

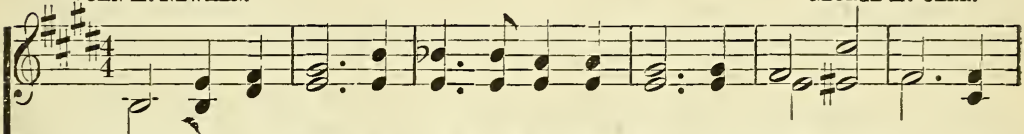

1. Lead, kind - ly Light, a - mid th'en-circling gloom,Lead Thou ine on; The

2. I was not ev - er thus, nor pray'd that Thou Shouldst lead me on; I

3. So long Thy pow'r hath blessed me, sure it still Will lead me on O'er
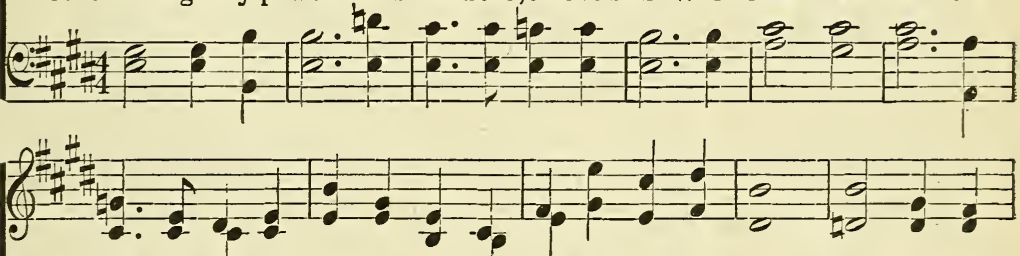

night is dark and I am far from home,Lead Thou me on. Keep Thou my lored to choose and see my path;but now Lead Thou me on. I loved the moor and fen, o'er crag and torrent, till The night is gone, And with the
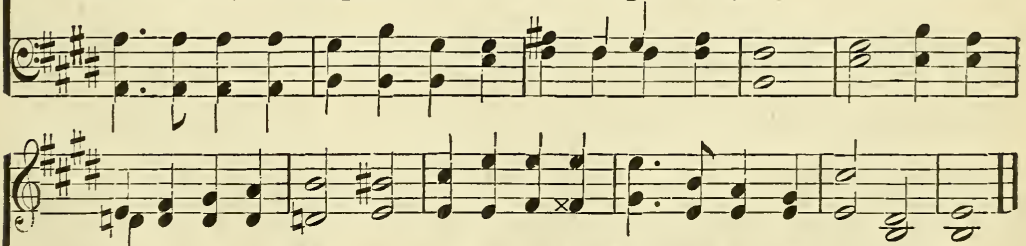

feet; I do not ask to see The distant scene;one step enough for me. ga-rish day,and, spite of fears, Pride ruled my will;remember not past years. morn those angels fac - es smile, Which I have loved long since, and lost a while.

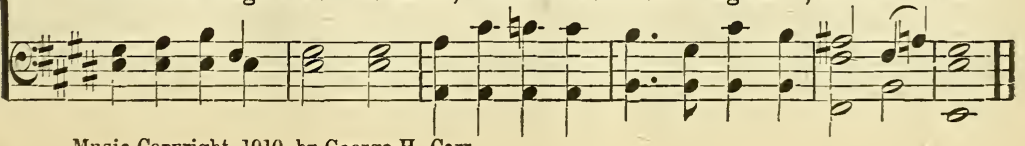


"He whith bigan a good work in you will perfect it until the day of Jesus Christ."-PHrL. 1: 6.

G. H. C.

George H, Carr.

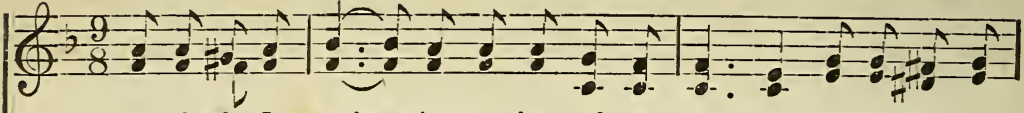

1. How oft do I grieve o'er my sins and my weak-ness, How oft am I

2. How oft do I long for the pres-ence of dear ones, In glo-ry to

3. How oft do I sigh for the life more a - bun - dant, When suff'ring and

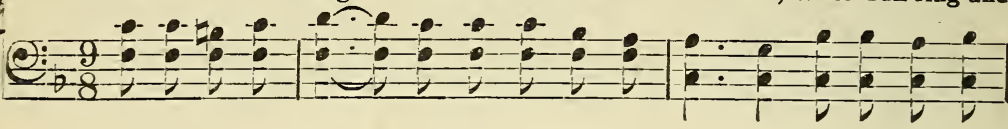
(f)lured from the nar - row way; Yet blest is the thought that each dwell in their midst al - way; Yet sure - ly I know that I'll tears shall have pass a - way; But Je - sus is com - ing to

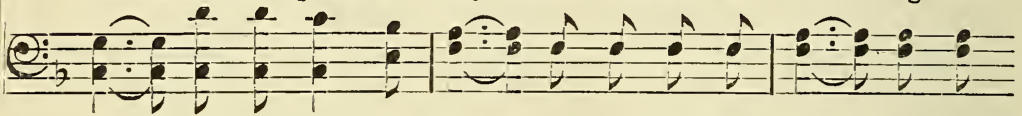

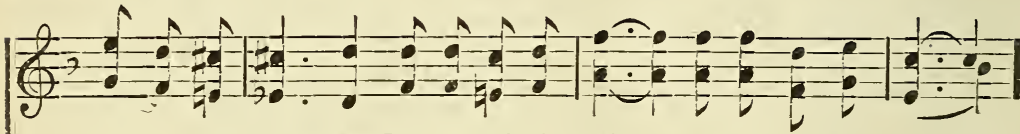
day I am strong-er To triumph o'er sin complete-ly some day. meet them in heav - en, How joy-ful will be the greeting some day. reign o'er His king-dom, Then all will be changed in-toglory some day.

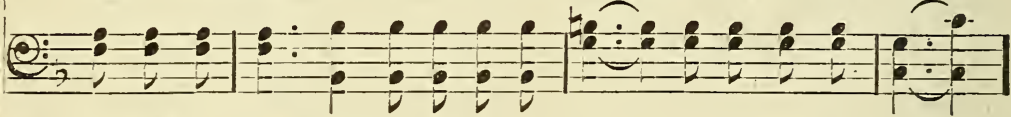

Chorus.

(5)

Some day I shall be... like Je-sus, my Sav-iour, transform'd by His

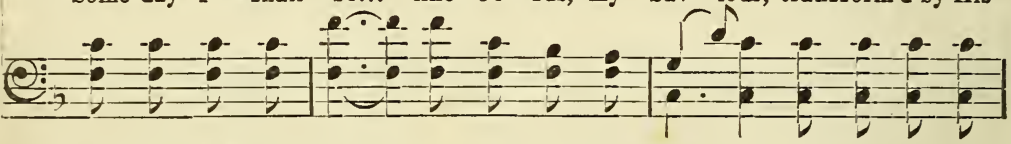

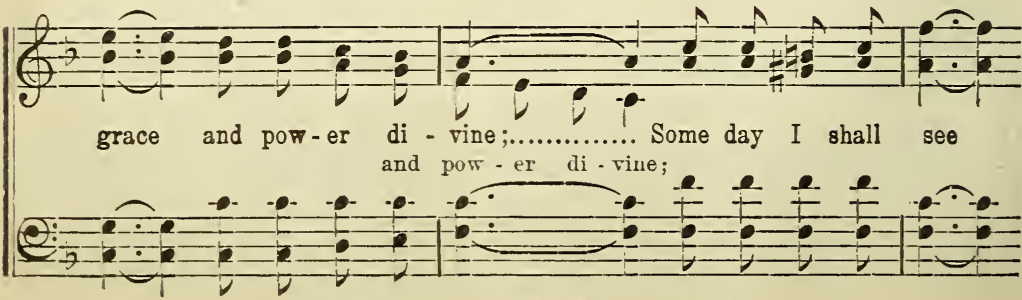
Copyright, 19o8, by Evangelist John A. Davis. 


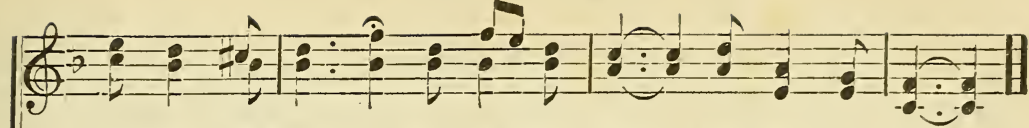

Him in His glo - ry, For I am His, and $\mathrm{He}$ is mine.

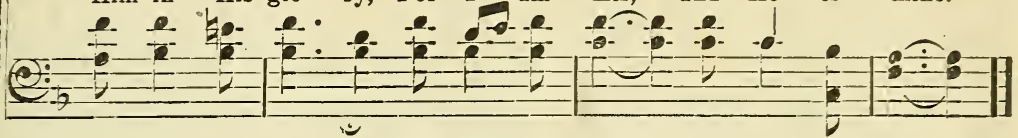

"It has beex very blessed, and God has done exceeding abundantly beyond my highest hopes ; but that is just like Him."-Rev. F. B. Mejer's report of "A merican Mission."

John R. Clements.

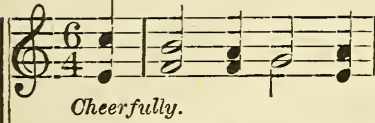

Rev. J. Mountain, D.D.

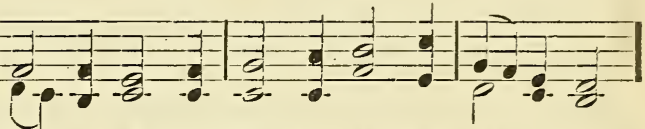

1. My God has giv - en rich sup-ply; With thankful tears my eyes are dim;

2. Each need hath shown His hand a - new, Aye, oft He's granted wish and whim;

3. $\mathrm{My}$ needs in Je - sus all are met, No more might ask the Ser - a - phim;

4. The life of yon-der health-y vine Is borne to ev-'ry twig and limb;

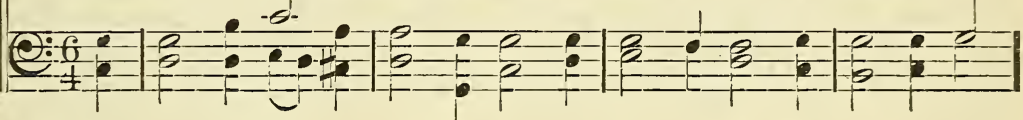

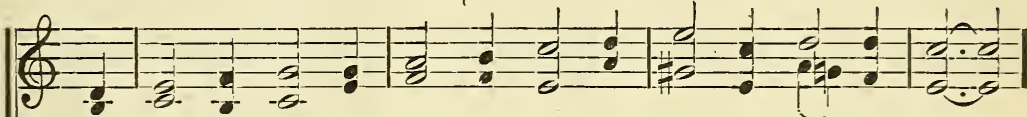

His gifts ex-ceed my larg - est cry,-But that is just like Him.

Per-chance to make my heart moretrue,-But that is just like Him.

The best God hath His chil-dren get,-But that is just like Him.

The wealth God hath $\mathrm{He}$ mak - eth mine,-But that is just like Him.

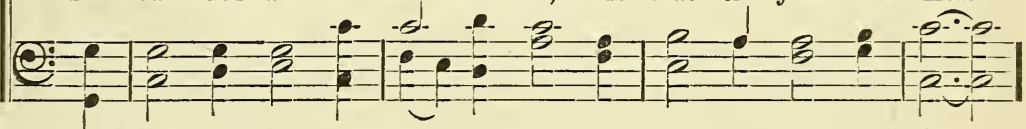

Chorus.

की

"But that is just like Him," We sing in joy - ful strain;

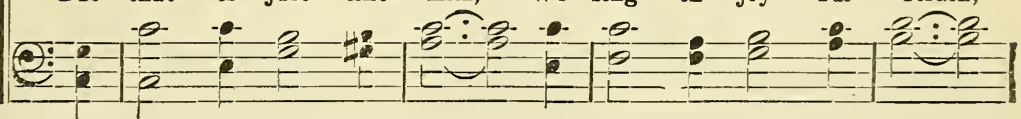

(4)

Earth's brightest hopes $\mathrm{He}$ far ex-ceeds,-But that is just like Him.

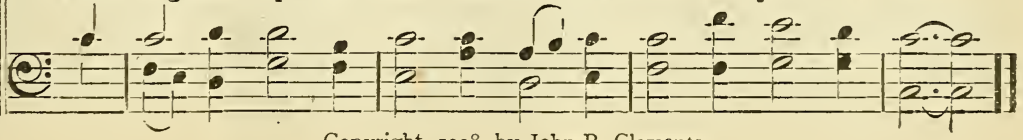

Copyright, Igo8, by John R. Clements. 


\section{Far Away He Saw Me.}

LizZie DEARMond.

With expression. Solo, or voices in unison.

W. A. Post.

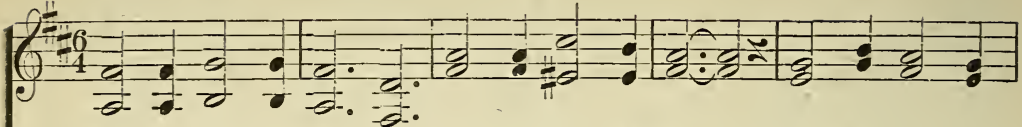

1. Far a-way he saw $m e$ in the paths of sin, By his lov-ing

2. Tho' at first I heed - ed not his gra - cious call- Would not make the

3. Now my soul is rest - ing on his faith-ful-ness, Look-ing to my
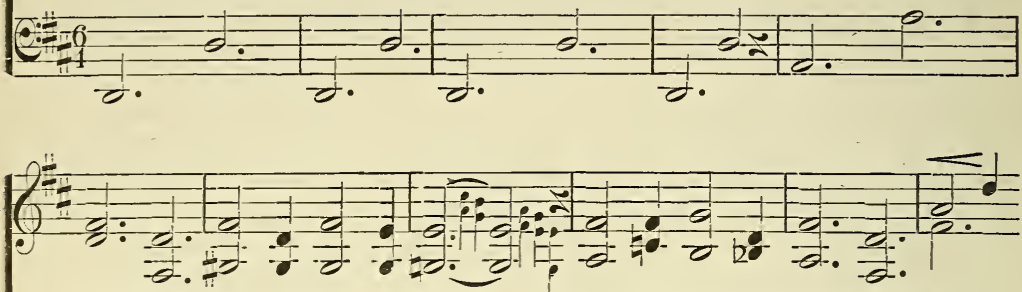

kindness sought my soul to win;

bless - ed Lord my all in all,

Sav - ior ev-er near to bless;

Broke the chains that bound me, set my Still with ten - der pa - tience, knowing Heir of his sal - va - tion thro' a -
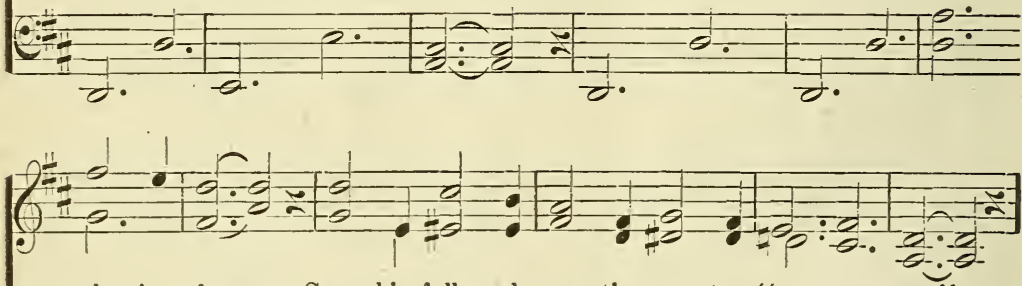

spir - it free, Gave his full sal - va-tion un - to "e - ven me." ev - 'ry need, Je - sus in his mer-cy proved a friend in - deed. bounding grace, Trust-ing in his goodness, I shall see his face.

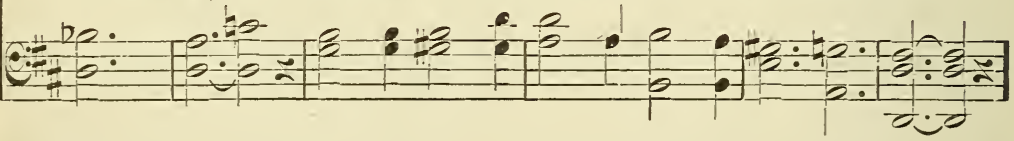

REFRAIN.

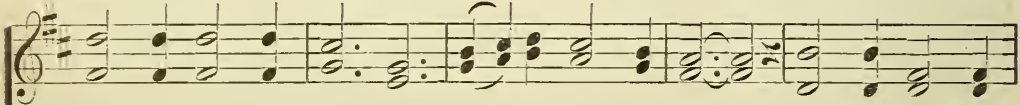

Far a - way he saw $m e$ in the paths of sins, By his love un-

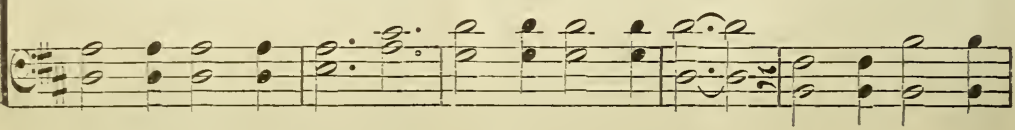

Copyright, 1904, by W. A. Post. The Praise Pub. Co., Phila. Pa. owners. 
cres.

Far Away He Saw Me.

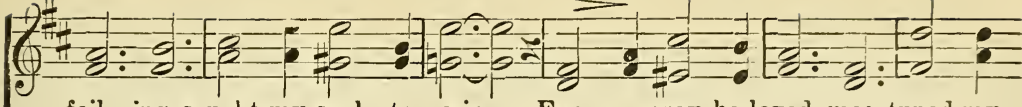

fail - ing sought my soul to win, Far a - way he loved me; tuned my

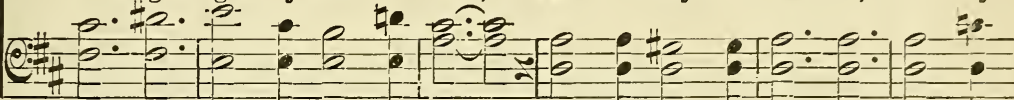

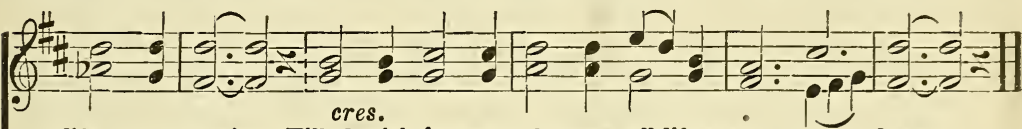

life to praise, Filled with joy and gladness all life's wea - ry days.

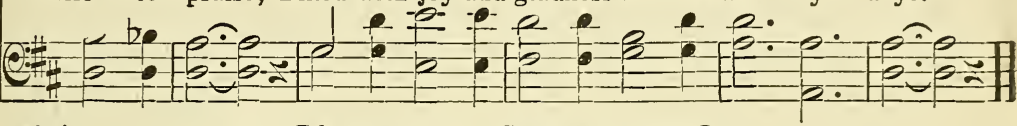
45

Christ or Barabbas?

"Whether of the twain will ye that I release unto you?"

F. E. B.

Solo or Quartet. Softly.

F. E. BELDEN.

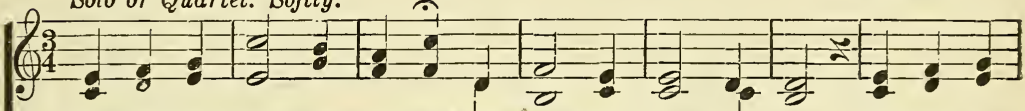

1. What will you do with Je-sus? He stands be - fore you now, Wear-ing the

2. Will you re - lease the rob-ber, The car - nal man of pride? Sin or a

3. Sol - emn and aw - ful question! How still the bal-ance stands! Mer - cy a

4. Self on the seat of judgment, Dare you the world de - ny? Loud-er and

5. Not to the sin - ner on - ly, The ques-tion comes with pow'r; Hear it, ye

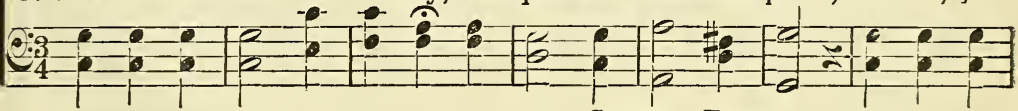
Chorus. Faster.

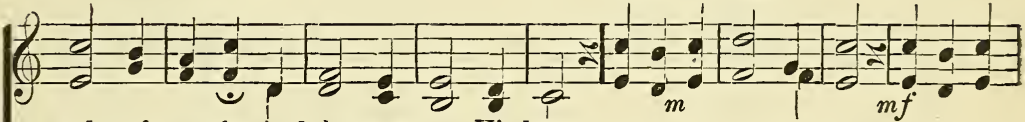
robe of pur-ple, And thorns up-on His brow.

sin-less Saviour?-0 which shall be de - nied? This is the question now; What shall the moment lingers, It trem-bles in her hands.

loud - er calling,"A-way!" and "Cru-ci - fy!"

halt-ing Christians, In ev - 'ry tri - al hour.
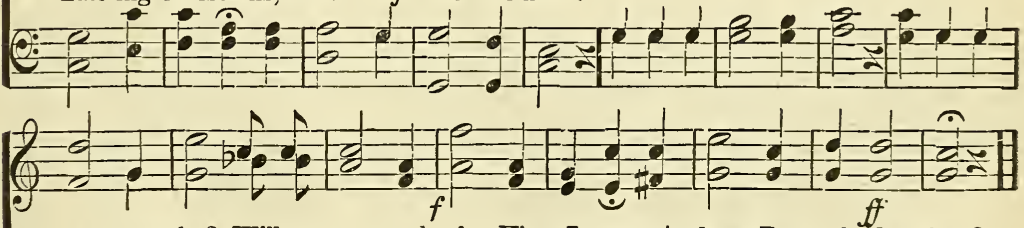

an-swer be? Will you cru - ci - fy King Je-sus, And set Bar - ab-bas free?

(Final) I will cru - ci - fy Bar-ab-bas, And set King Je - sus free.

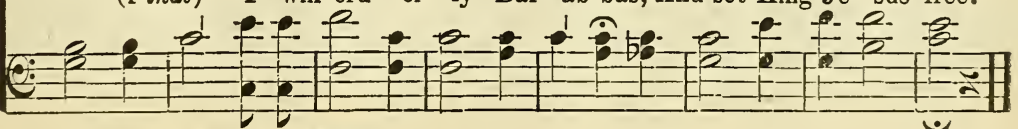

Copyright, 1909, by F, E. Belden. 
JoHn R. Clements.

W. S. WEEDEN.
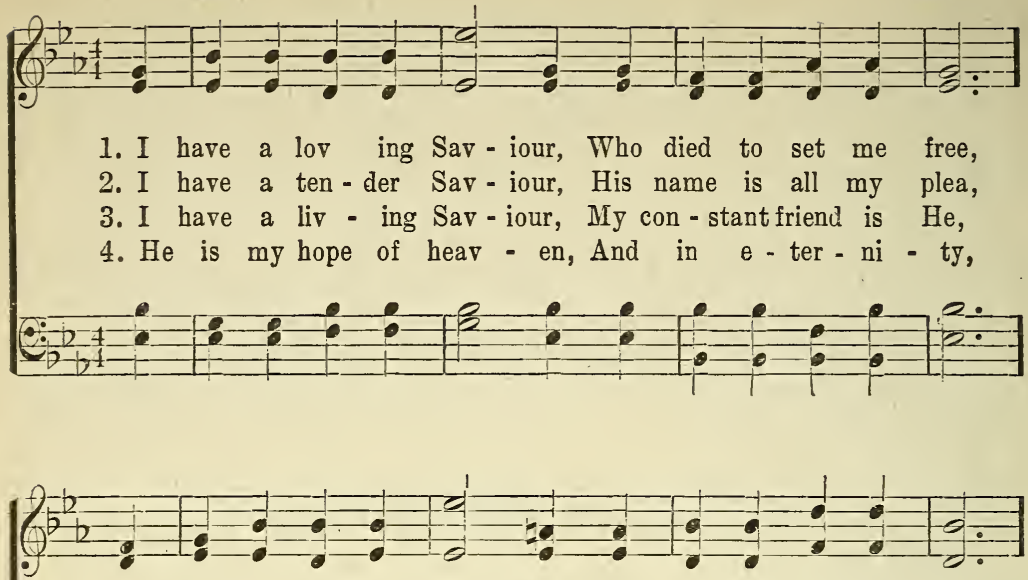

I can - not do with - out Him, He's ev-'ry-thing to me.

I dare not do with - out Him, He's ev-'ry-thing to me.

I will not do with - out Him, He's ev-'ry-thing to me.

I need not do with - out Him, He's ev-'ry-thing to me.

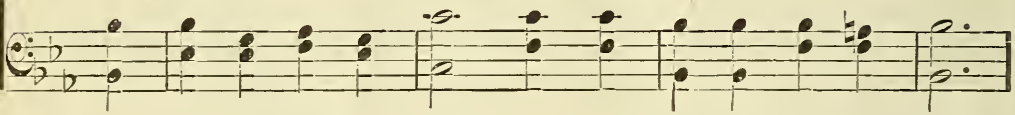

CHORUS.

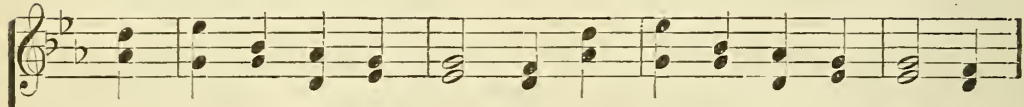

I can - not do with - out Him, I dare not do with - out Him,
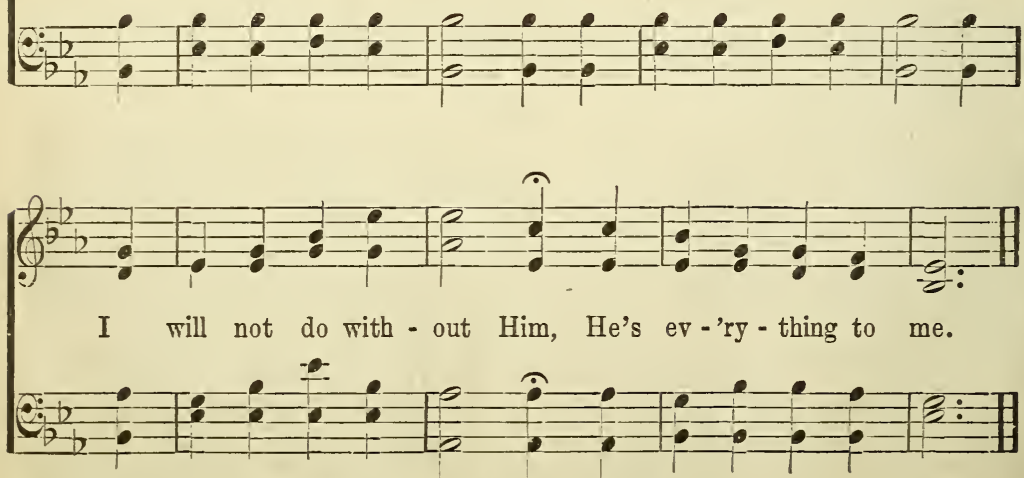

Copyright, 1910, by əohn R. Clements for Mrs. W. S. Weeden. 
ANNA L. WARING.

MENDELSSOHN-BARTHOLDY.

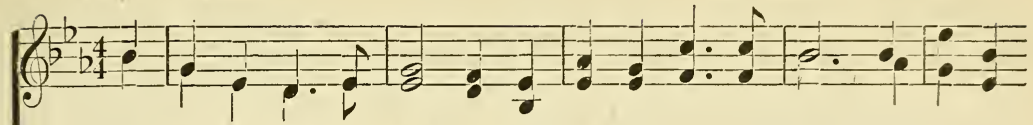

1. In heav'nly love a - bid - ing, No change my heart shall fear;And safe in

2. Wher-ev-er He may guide me,No want shall turn me back; My Shep-herd

3. Green pastures are be - fore me, Which yet I have not seen; Bright skies will

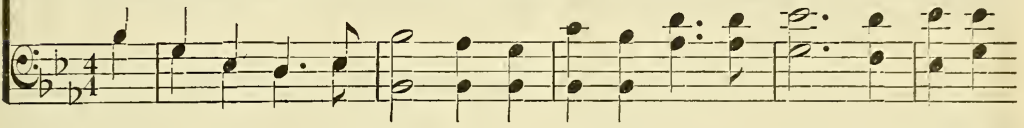

The storm may roar

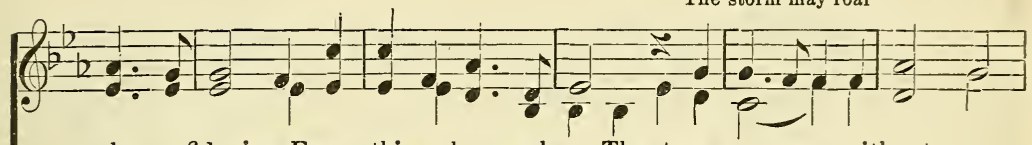

such con-fid - ing, For nothing changes here. The storm may roar without me, is be - side me,And nothing can I lack.His wisdomev - er wak - eth, soon be o'er me, Where darkest clouds have been. My hope I can-not meas - ure,

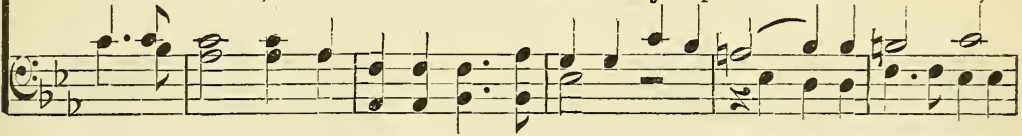

The storm may roar without me,

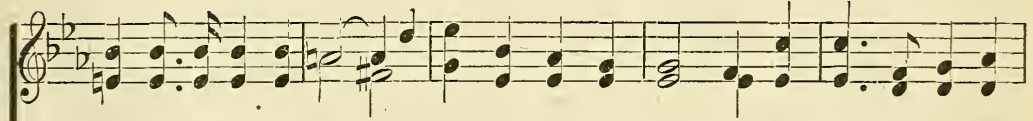

My heart may low be laid, But God is round a - bout me,And can I be disHis sight is nev-er dim, He knows the way He tak - eth,And I will walk with My path to life is free, My Savior has my treas-ure, And He will walk with
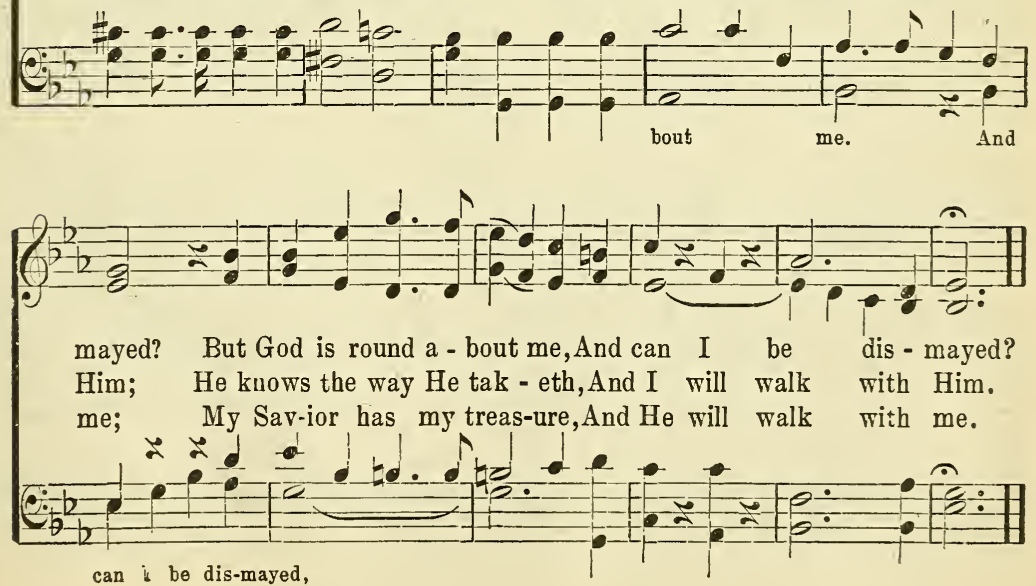
- G. H. C.

\author{
"And we came to Kadesh-barnea."-Deut 1 : 20.
}

George H. CARr.

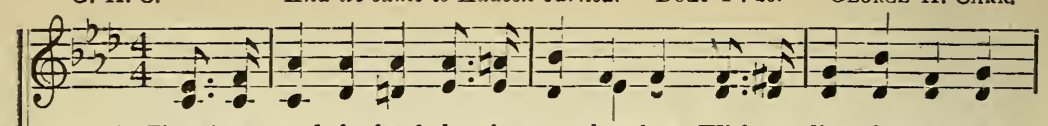

1. There's a good- ly land ly - ing on be-fore, With a life that sat - is -

2. Tho' the en - e - my long has held full sway, Fiercely ward-ing off at -

3. Fear ye not the foe, neith-er be dismayed, For the Lord will fight for

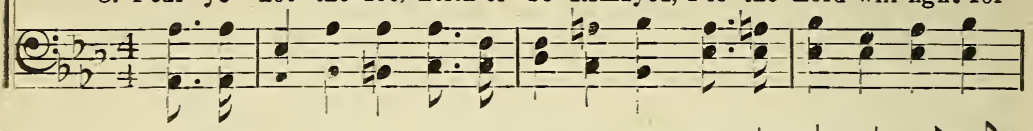

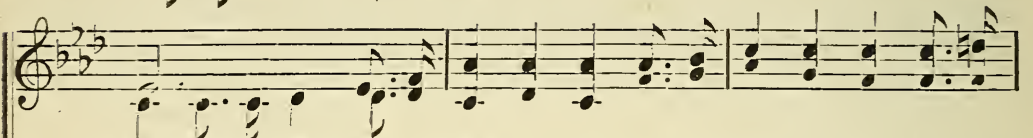
fies, (Sat- is-fies,) 'Tis a place of joy with a wealth un-told, Ev - er tack, (Off at-tack,) Yet the Lord will gain full pos-sess-ion now, For the you, (Fight for you,) Thro' His mighty pow'r you can con-quer all, If you

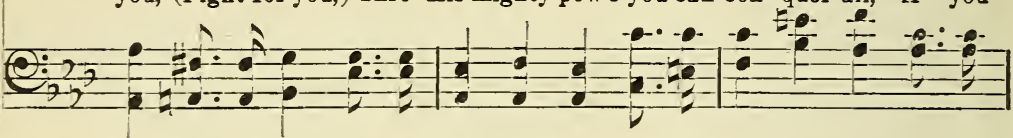

Chorus.

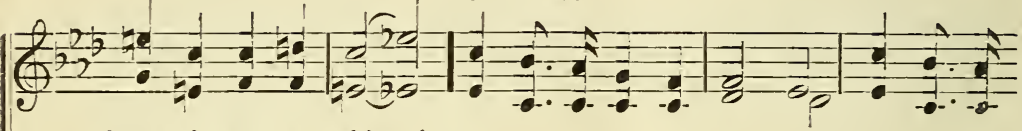
cheored by sun- ny skies. ) ones who ne'er turn back. $\{\mathrm{D}$, to the land of prom-ise! Out from the trust your Lead-er true.

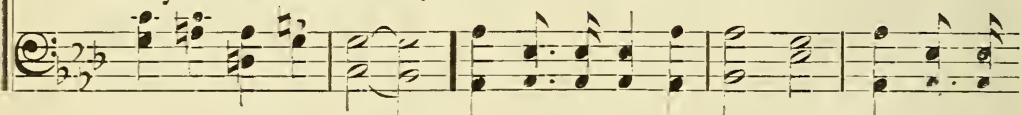

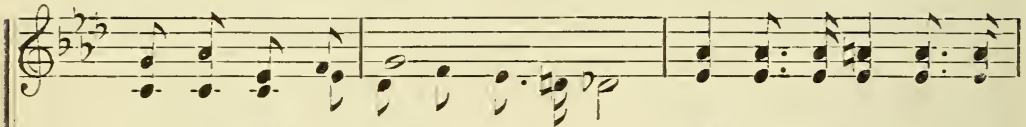

wil-der-ness of sin. Comes forth the call for de the wil - der-ness of $\sin$ !

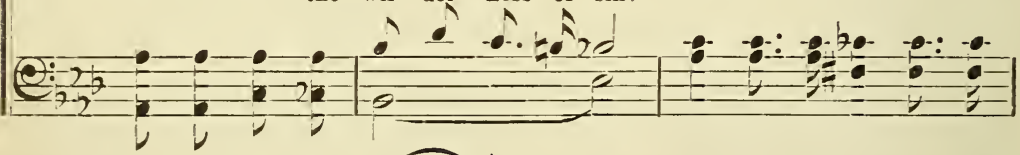

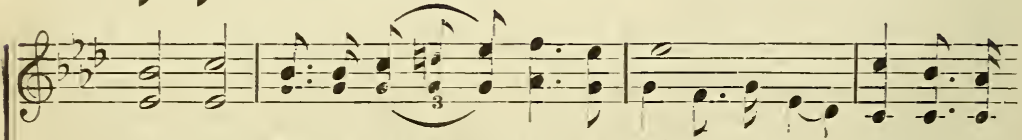

cis - ion, Who is read-y to en-ter in? en-ter in, Cast off the

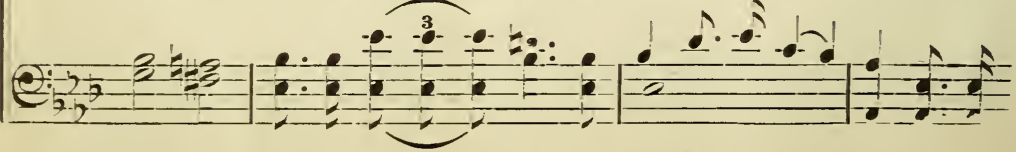

Copyright, 1908, by Evangelist Juhn A. Davis. 
On, to the $\mathbb{I} a n \sigma^{-}$of promise.

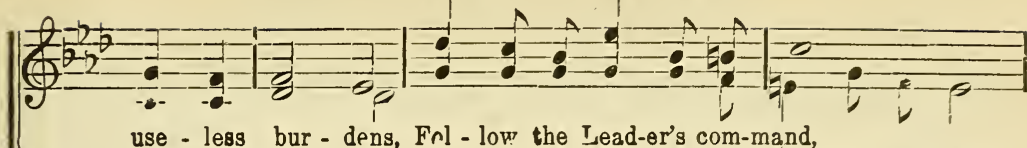

The Lead-er's com-mand.

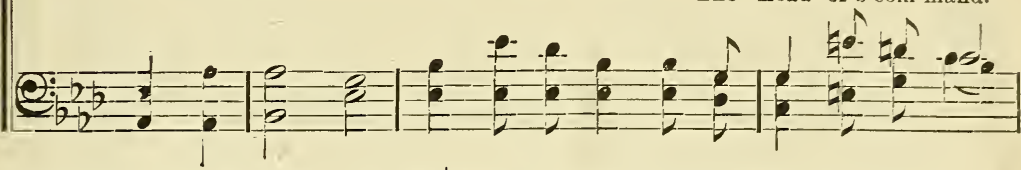

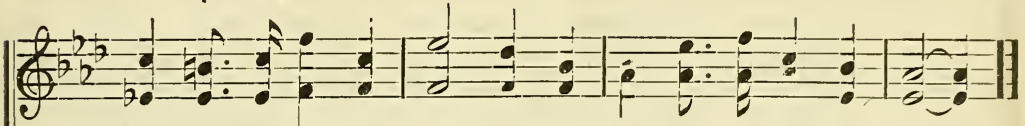

Go forth with full as - sur - ance, That you may pos-sess the land.

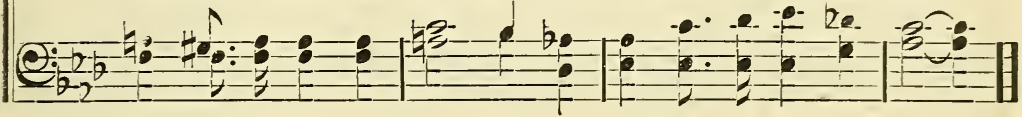

49

\section{Drifting.}

Maude Saunders.

"Tossed to and fro and carried about."-Eph. $4: 14$.

F. A. Mills.

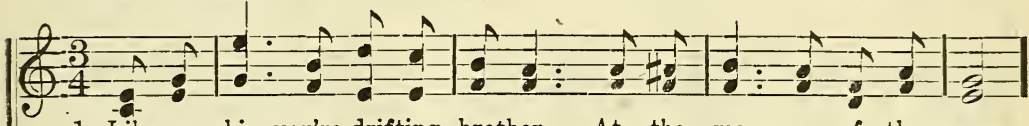

1. Like a ship you're drifting, brother, At the mer - cy of the waves,

2. Peace that pass-eth un-der-stand-ing, Joy the world can nev-er give,

3. He'll for-give! just seek His par-don, Ere His face is hid from sight,

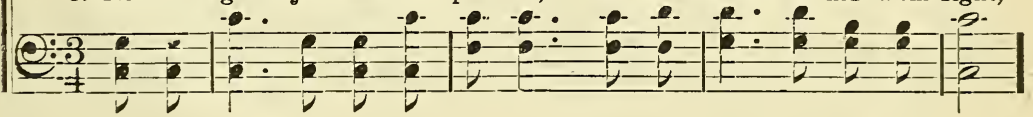

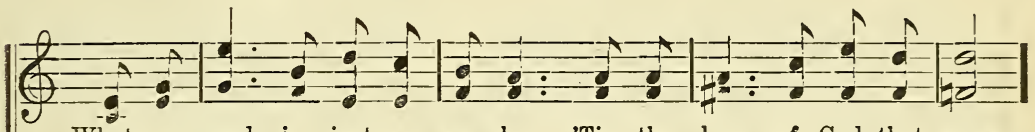

What you need is just an an-chor, 'Tis the love of God that saves.

Is the gift God has to of - fer. Let Him help you while you live.

And the shad-ows set-tle o'or you, Like the shades of dark-est night.

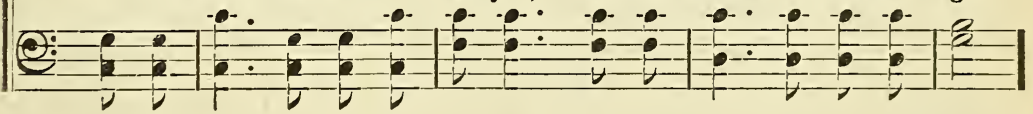

$4=0$

What you need is just an an-chor, 'Tis the love of God that saves.

This the gift God has to of - fer, Let Him help you while you live.

Ere the shad-ows set-tle o'er you, Like the shades of dark-est night.

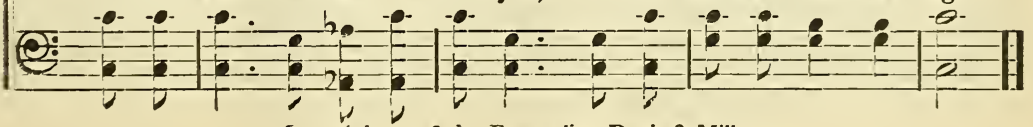

Copyright, 1908, by Evangelists Davis \& Mills. 
Dedicated to Edward Spencer, who rescued seventeen from the wreck of the "Lady Elgin" in Lake Michigan, Sept. 8, 1860, after battling with the elements for more than six hours. His daring heroism completely shattered his health. Partially recovering from the first collapse, his only fear was that he might have failed to perform his full duty; and he anxiously inquired, "Did I do my best?"

T. H.

THORO HARRIS.

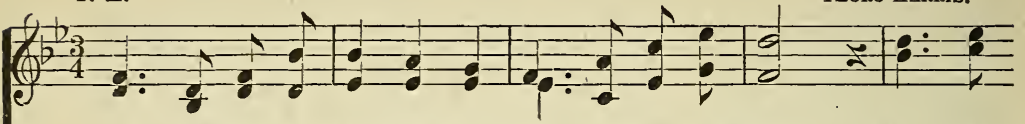

1. Dark the storm is ra - ging And loud the breakers roar; See, a

2. Ma - ny souls are shipwrecked Up.on life's storm-y main; Let us

3. Swift the day is dawn-ing, The night will soon be o'er, And a
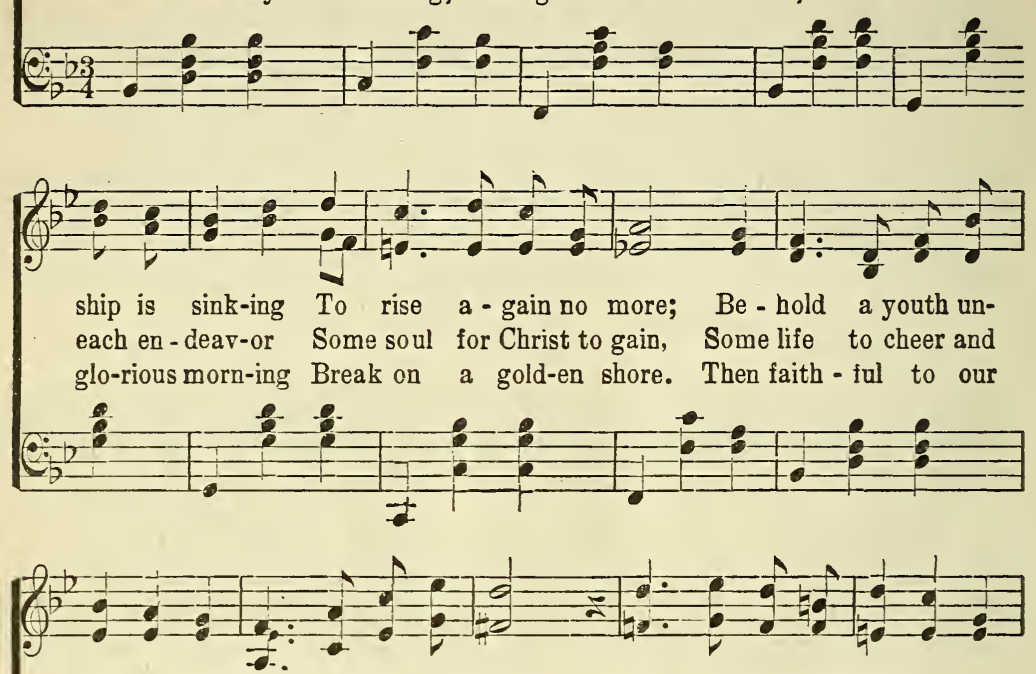

daunted, His faith and zeal at-test,

glad-den Now sin - sick and dis - trest;

This his on - Iy ques-tion: 0 ,

du - ty, O - bey - ing each be - hest,

While the lost are dy - ing Let May we hear his "Welcome, For

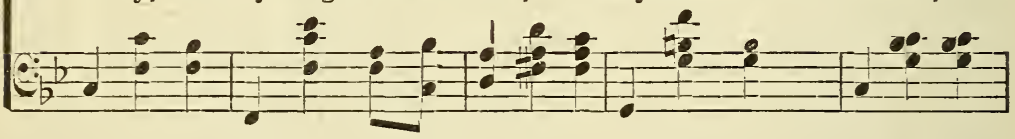

ChORUS.

(4)

have I done my best?

each one do his best. When the Mas-ter calls us Shall we stand the

je have done your best.",

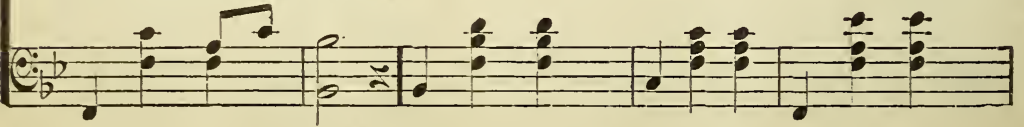

Copyright, 1909, by Thoro Harris. Henry Date, owner. 
Have I Done my Best?

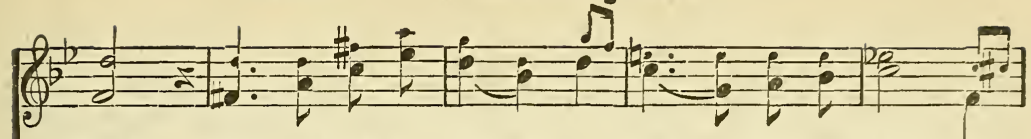

test? For the love of Je-sus, $\mathrm{O}$ have we done our best? To

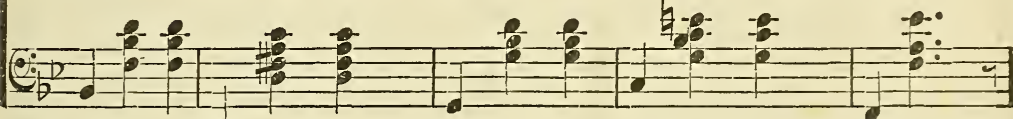

$\left(\frac{b}{2}-a\right)$

help some wea-ry trav'ler To en - ter in - to rest, Faithful bavewe

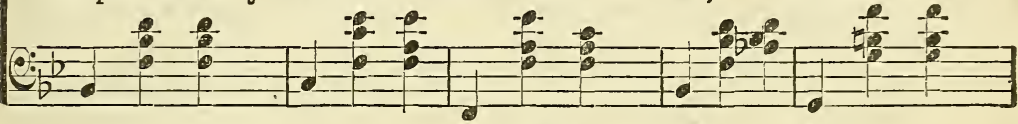

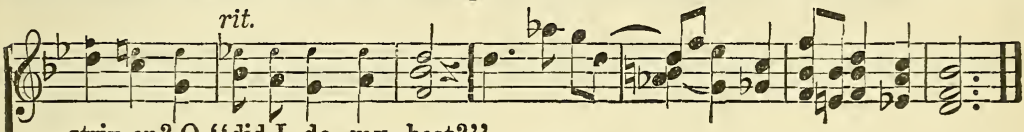
striv-en? 0 "did I do my best?"

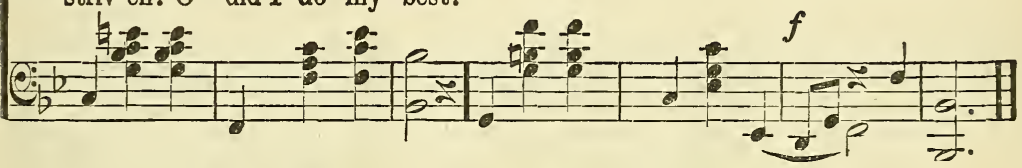

\section{$51 \quad$ May Jesus Chríst Be Praised.}

EdWaRd Caswall, tr.

JOSEPH BARNBY.

(4)

1. When morning gilds the skies My heart awaking cries, May Je-sus Christ be praised;

2. To Thee, 0 God a-bove, I cry with glowing love,May Je-sus Christ be praised;

3. Does sadness fill my mind, A solace here I find; May Je-sus Christ be praised;

4. Be this, while life is mine, My can-ti-cle di - vine: May Je-sus Christ be praised;

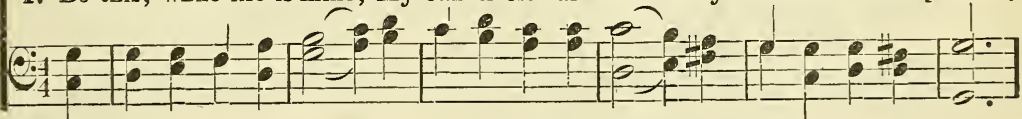

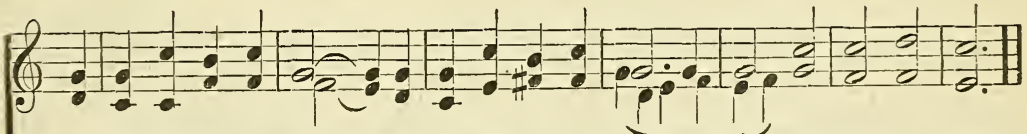

A - like at work and pray'r,To Je - sus I re-pair; May Je-sus Christ be praised. This song of scacred joy, It nev-er seems to cloy: May Je-sus Christ be praised. Or fades my earthly bliss, My comfort still is this: May Je-sus Christ be praised.

$\mathrm{Be}$ this th'eternal song, Thro' all the a-ges long: May Je-sus Christ be praised.

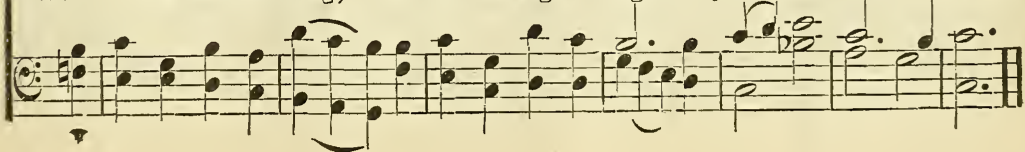


Rev. Hexky Hill

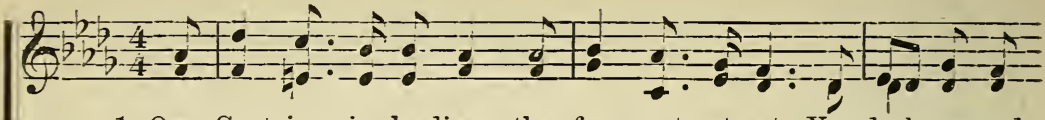

1. Our Captain is leading, the foe must retreat, Yes, darkness and

2. Our Captain is leading, take courage, be strong, Put on the whole

3. Our Captain is leading, the right must prevail, The conquest is

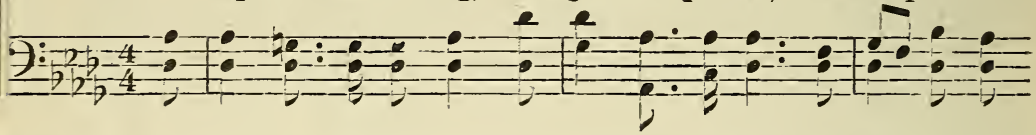

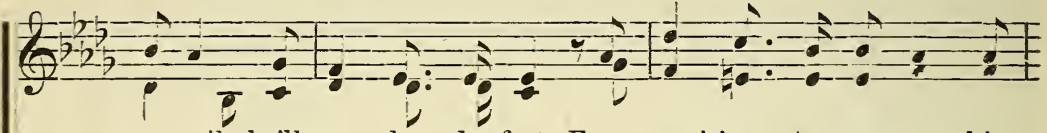

e - vil he'll sure-ly de-feat; From conq'ring to conquer his

armor and march 'gainst the wrong; From vic - t'ry to vic- t'ry, from

ours and our cause can-not fail; The for - ces of darkness and

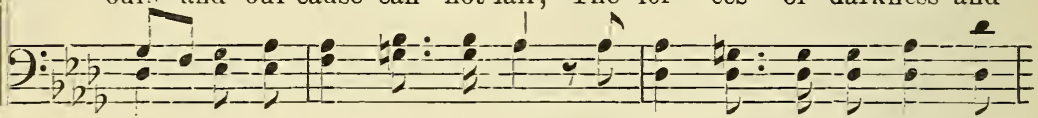

(5)

arm-ies he'll lead, Un - til o-ver all he is vic - tor indeed.

might un - to might, He'll lead if we fol-low from darkness to light.

e - vil shall fall, And he our great Captain shall reign o - ver all.

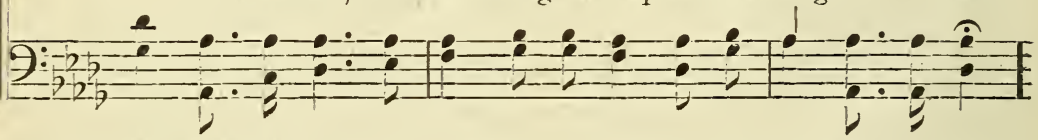

CHORUS.

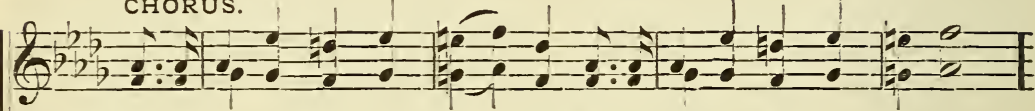

Then we'll follow where he lead - eth, We will do whate'er he biddeth;

Then we will follow where he lead - eth, We will do whate'er he biddeth :

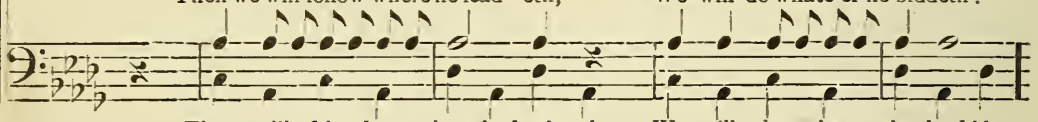

Then we'll fol - low where helead-eth, We will do what - e'er he bids;

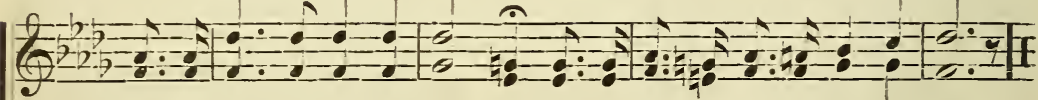

We will fight as he commandeth, And the banner of the cross uphold.

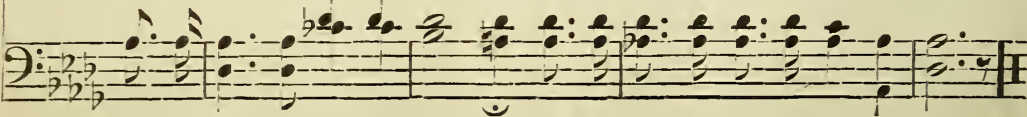

Copyright, 1907, by John A. Davis. 
LIZZIE DE ARMOND.

\author{
Dedicated to Mr. and Mrs. A. D. George.
}

1. Shall I stand all a-lone in the king-dom of God, Not a

2. Shall I look o'er the fields, with their har - vest so white Where

3. Shall I stand all a - lone when my Lord com - eth down To
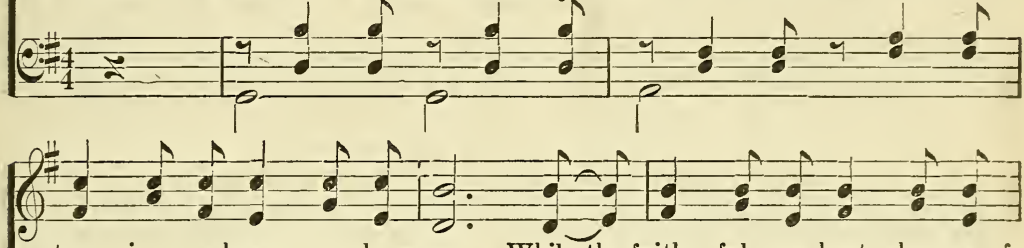

star in my heav - en - ly crown; While the faith - ful ones haste sheaves of oth - ers were faith - ful and true; And know that an-oth - er will bring his glad king - dom be-low; Will but $I$, of the millions who

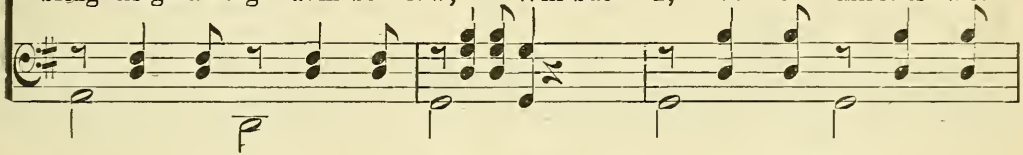

Chorus.

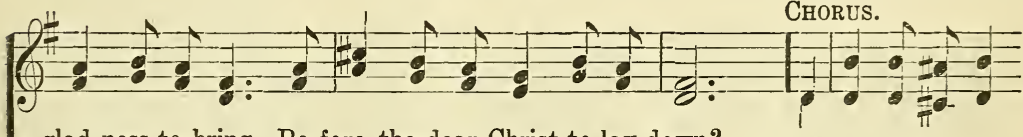
glad-ness to bring, Be-fore the dear Christ to lay down? reap the re-ward For toil that my handsfail'd to do?

A - lone, all a - lone, welcome his call, Have naught for my life-work to show?

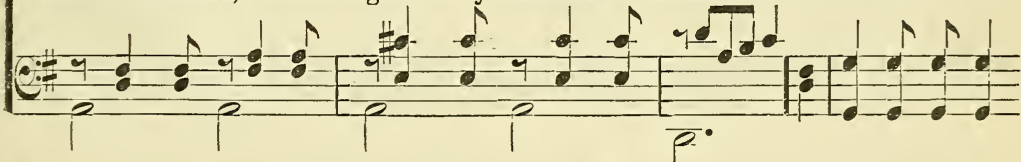

rit.

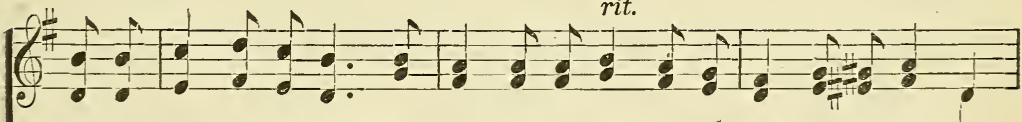

when I kneel at his feet, Who died for my sins long a - go, long a - go, 0

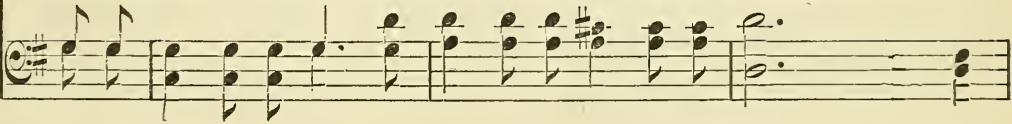

(0) help me to save just a soul in thy name, And show forth thylove here be-low.

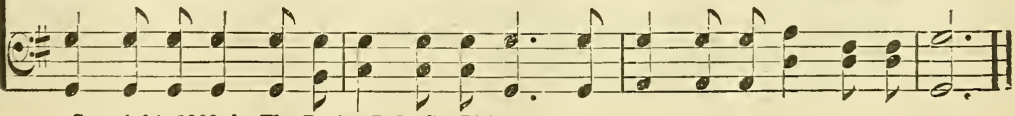

Copyright, 1909, by The Praiso Pub. Co. Phila., Pa. 
"He that followeth me shall not walk in the darkness." -John $8: 12$.

G. H. C.

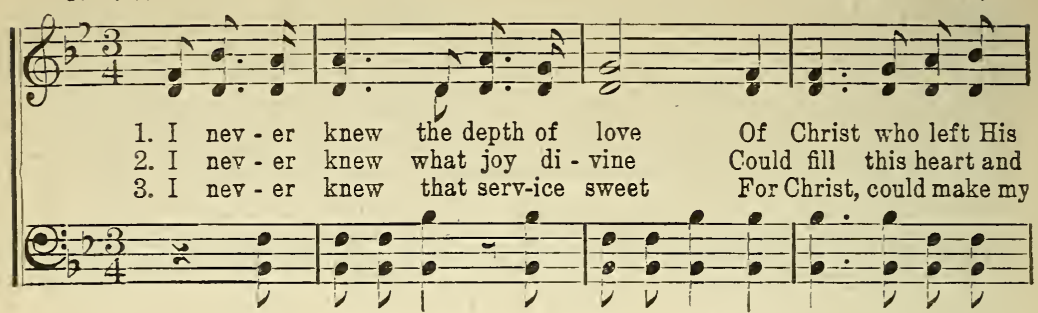

1. I nev.er knew the depth of love
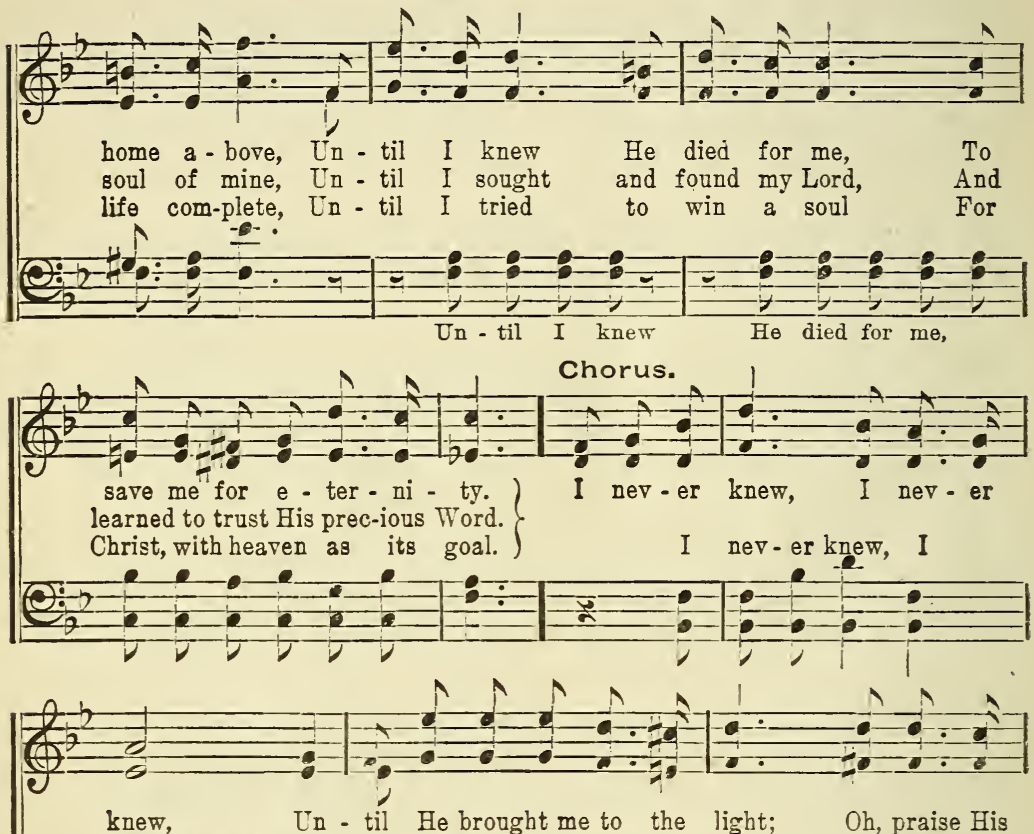

knew, Un - til He brought me to the light; Oh, praise His nev - er knew, Un - til He brought me to the light, Oh,

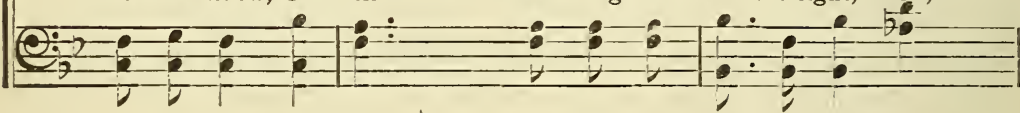

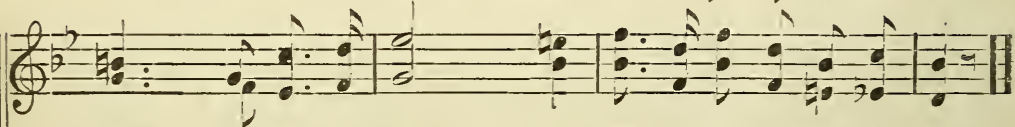

name for-ev-er more, For life in Him and clear-er sight.

praise His name for - ev-er-more,

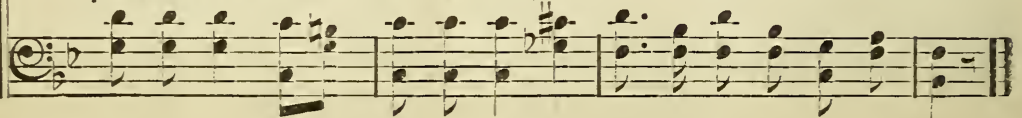

Copyright, Igo8, hy Evangelist John A. Davis. 
Mrs. C. D. MLARTIN

W. STILLMaN MARTiN.

Solo, or Unison.

(2)

1. The Sheperd sought his wand'ring sheep, Out

2. The Fa-ther sought his wand'ring child, Out

3. I was the sheep that went a - stray, I was the wand'ring child, I

in the drear - y way, $0^{\prime}$ er

in the sin - ful way, From

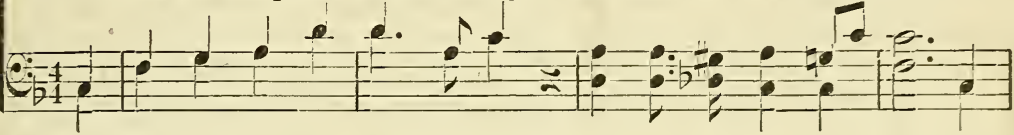

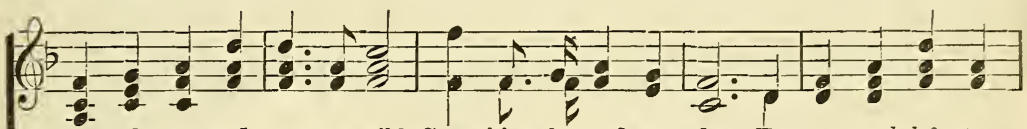

moor and crag and torrents wild, Searching from day to day; From wounded feet we love and home and friendship sweet, His child has gone astray; Out in the bus - $\mathrm{y}$ wan - dered on un-think-ing-ly, Out in the des-ert wild; He found me wounded,

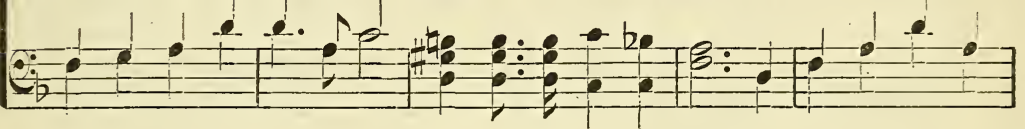

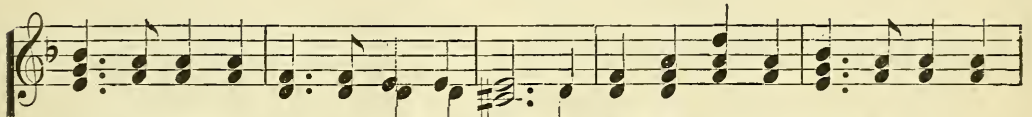
may behold His blood mark on the ground, He press-es on thro' heat and cold, Unhaunts of men, Where depths of sin abound, Un-ceas-ing - ly he seeks each day, Unsick, and sad, The march was hard and long, He sar'd me, fed me, and to-day My

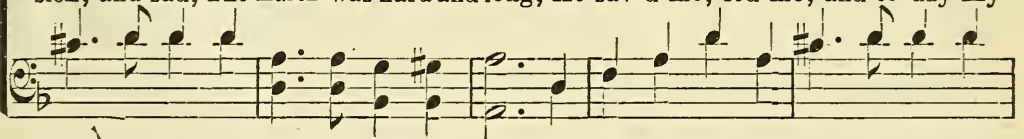

Chorus.

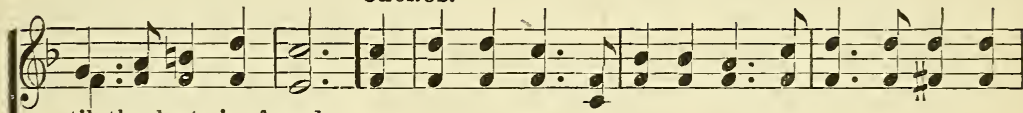

til the lost is found.

til the lost is found. The Lord brings back his own a-gain, 0 sing with heartand heart is fill'd with song.
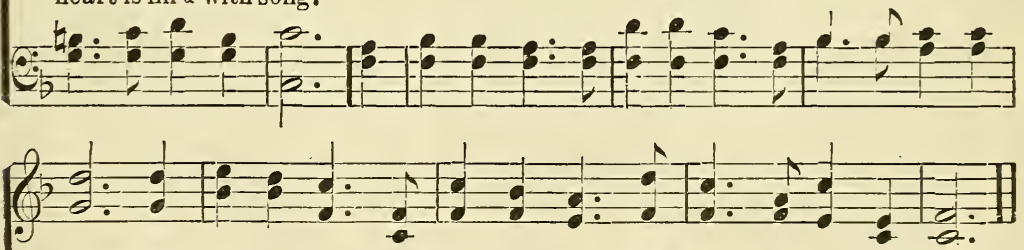

voice, The courts of heav'n with praises ring, The host a - bove re-joice.

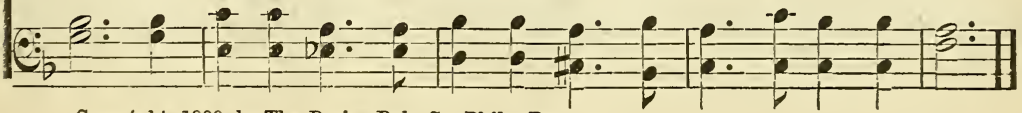

Copsright, 1909, by The Praise Pub. Co. Phila. Pa. 
Rev. W. A. KLECKNER.

W. S. WEEDEN.

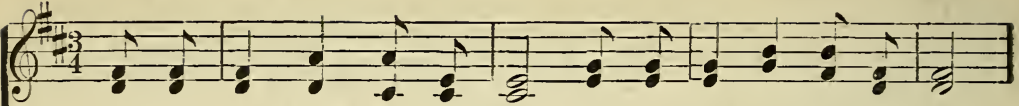

1. Sin - ner, Je - sus pleads with thee, Now he strives your heart to win;

2. He will give you sweet - est rest, Pow'r to con - quer ev - 'ry sin;

3. Sin - ner, Je - sus comes to bless, Comes to break your bonds of sin;

4. In the hour of pain and grief, Or when sore-ly pressed by sin;

5. Do not grieve the Spir - it now; Do not turn the Lord a - way,

6. Claim Him, own Him as your King,Crown Him,Lord of all with - in,
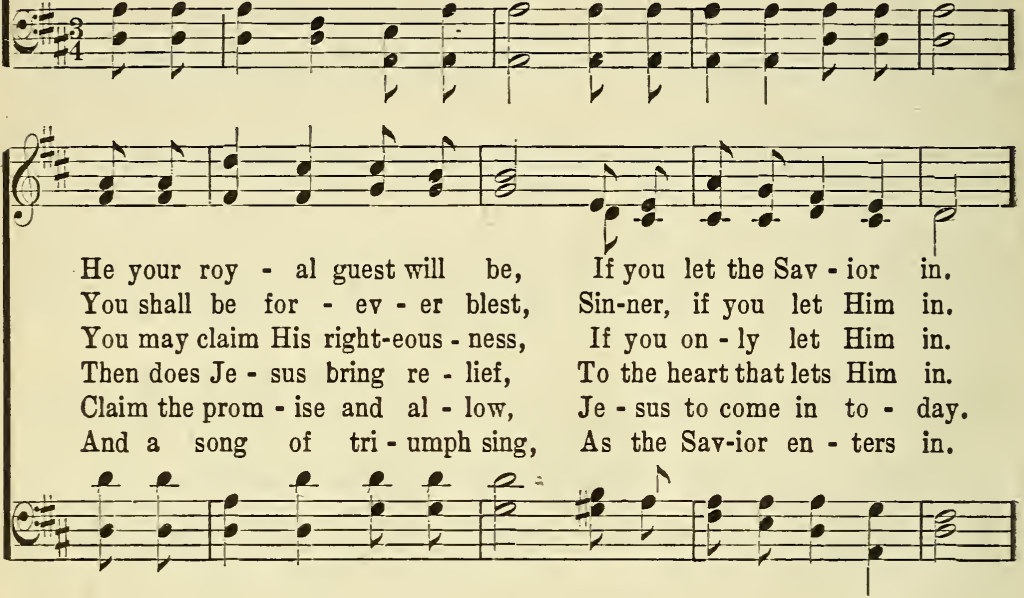

Chorus.

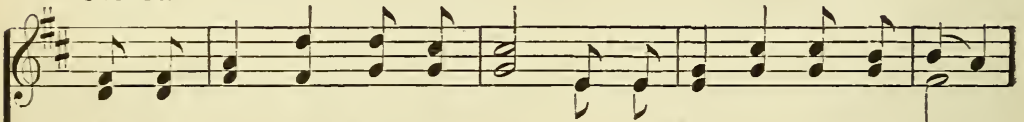

Let Him in, 0 let Him in! Do not bid your Lord de - part.
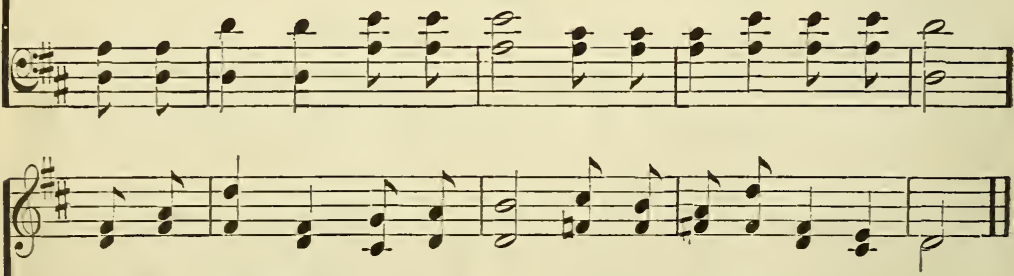

He will cleanse from er - 'ry sin; If you let Him in your heart.

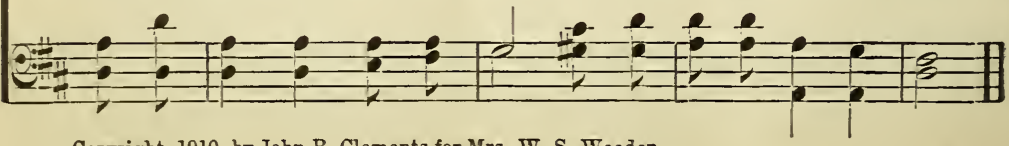

Copyright, 1910, by John R. Clements for Mrs. W. S. Weeden. 
Mrs. P. P. B.

Copyright, 1896, by P. P. Bilhom

P. P. BILFnR:

(4)

1. Oh, ye who have heard the gos - pel, Give ear to His word to - day,

2. Oh,ye who would meet your loved ones, And d well in the home on high;

3. Oh, ye who are lost in dark-ness, In Christ there is hope and cheer,

4. But bless-ed are we who trust Him,And un - to His word we cling,
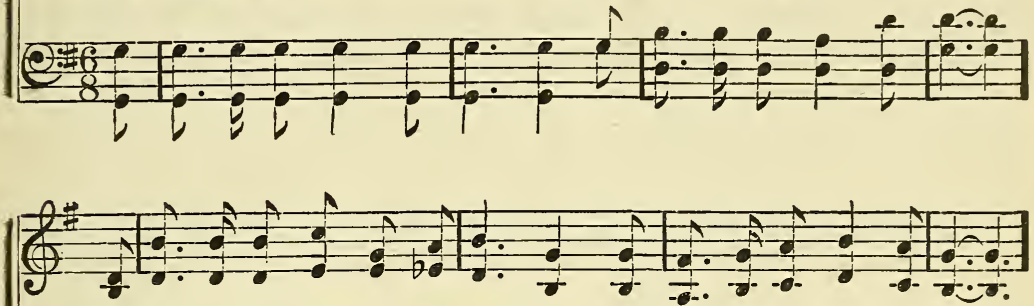

And o-pen your heart to receive Him, Lest grieved yeshould hear Him say.Make haste to be-lieve in the Sav - ior, For soon ye may hear this cry.-

But if ye neg. iest to re-ceive Him, For-ev-er these words you'll hear.-

His grace shall fo:-ev - er-more save us, And joy-ful this strain we'll sing.-

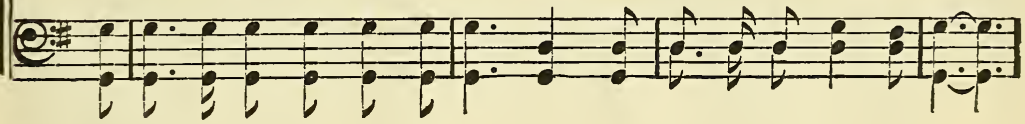

\section{CHORUS.}

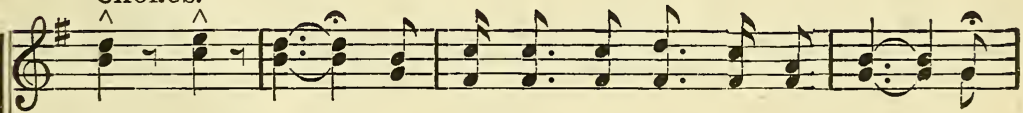

Lost! lost! lost! for - ev - er, e - ter - nal - ly lost! Ye 4th. Saved! saved! saved! for - ev - er, e - ter - nal - ly saved! We
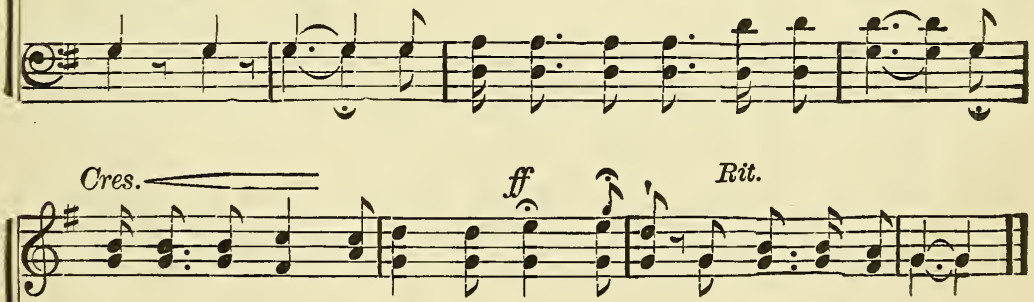

would not be-lieve, nor Christ re-ceive, And now e - ter - nal-ly lost!

trust-ed, be-lieved, and Christ received, And now e - ter - nal-ly saved!

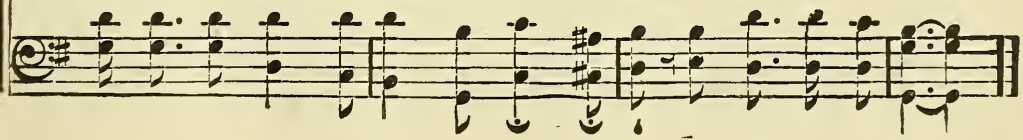


G. H. C.

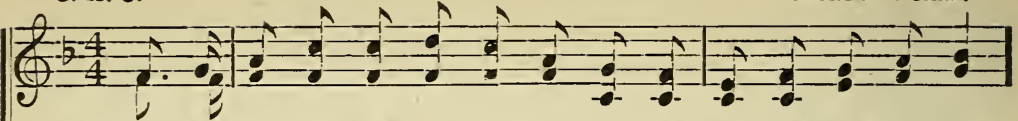

1. In the world of need $a$-bout us, I - dle ser-vants have no place,

2. Must the souls of man-y per - ish For the lack of help to save?

3 . When the books of heav'n are opened, And your works are counted o'er,

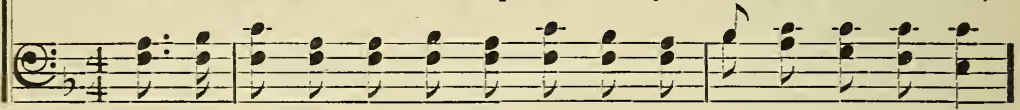

$\frac{1}{2}-1 \div+1=0=0$

There are souls to save from e - vil, In this age of love and grace;

Must some suf-fer need-less an-guish, While your sym-pa-thy they crave?

What shall be your heav'n-ly treas-ure, What re-ward shall be in store?

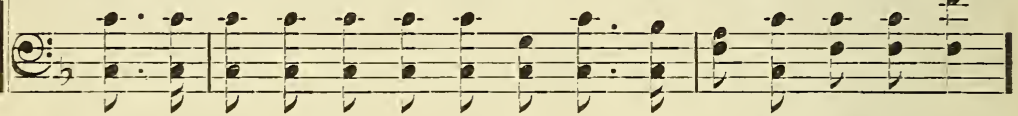

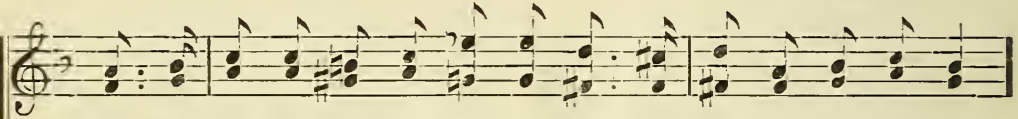

If each ser-vant of the-Mas-ter, Would but join the work-er's band.

There s a place for ev - 'ry tal - ent, Right - ly used in God's great plan.

Work for un-seen things e - ter - nal, Leave the stub-ble, wood and hay;

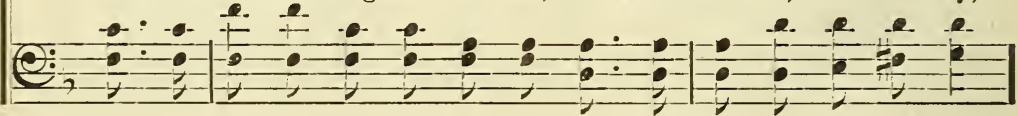

(4)

How the glo-ry of His kingdom, Soon would cov-er o'er the land.

Then a-rouse to act-ive ser-vice, Lend a hand wher-e'er you can.

Life is short, and time is fleeting, Work for Je - sus while you may!.

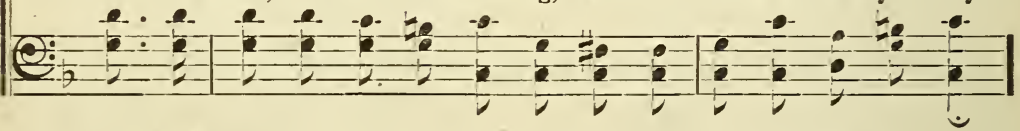

Chorus.

(5)

Be a work-er, not a shirk-er in the bus-iness of the King;

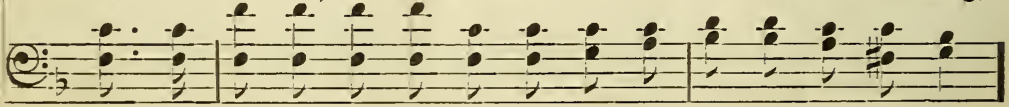

Copyright, Igo8, hy Evangelist John A. Davis. 
(6):

Put your heart in all your la-bor, Do your best in ev-'ry-thing;

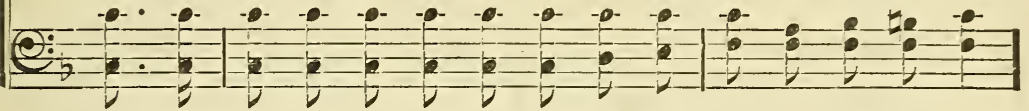

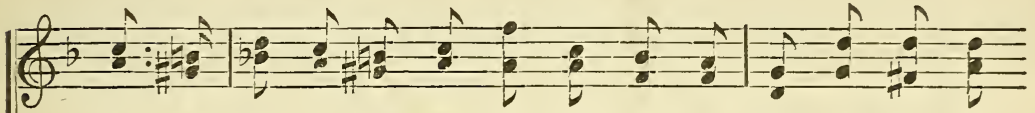

$\mathrm{Be} a$ - lert to use each mo-ment, Let no chan-ces slip a -

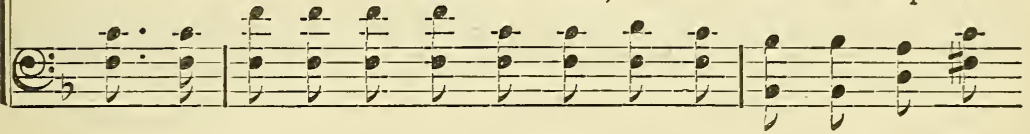

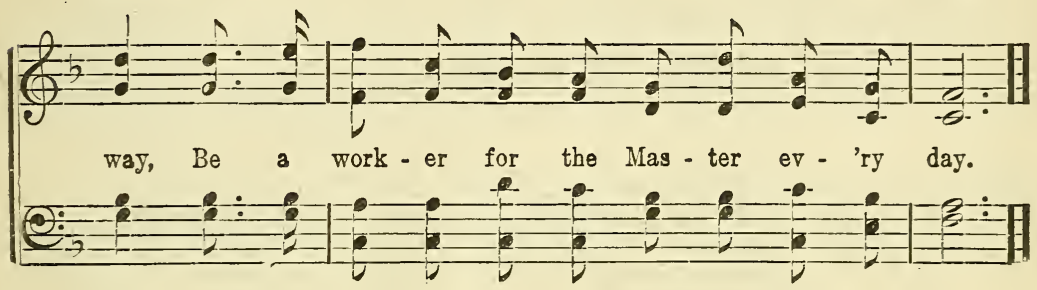

Rev. EDTARD MOTE.

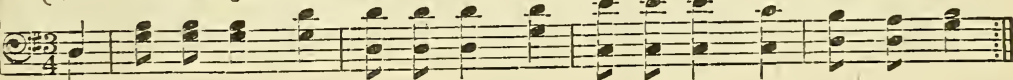

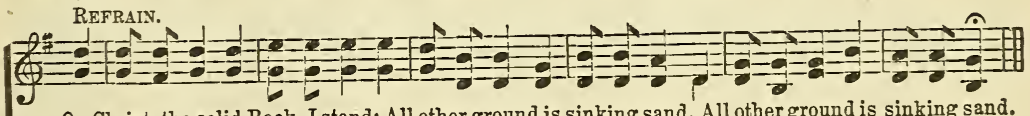

On Christ, the solid Rock, I stand; All other ground is sinking sand, All other ground is sinking sand.

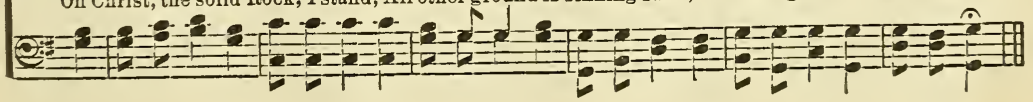


"In my itather's house are many mansions." - JоH 14: 2.

a $\pi$

George H. Carr.

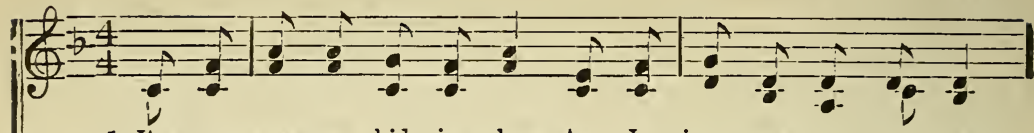

1. I've no sure a-bid - ing place As I jour-ney on my way,

2. 0 the time will not be long Ere I reach the pearl-y gates,

3. Wea-ry sin-ners with-out hope, Is there naught that you may claim?

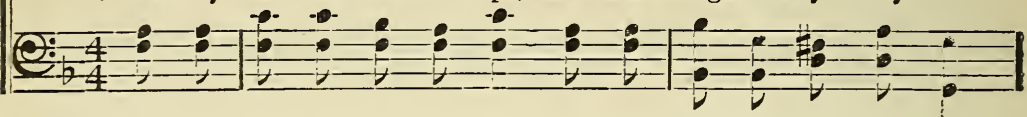

$\frac{\theta}{2}=-\frac{1}{2}=$

Scenes of earth soon lose their charm As I view them day by day;

There to greet the saints of God, And the + Sav-iour as he waits;

Yes, there's par-don full and free Thro'the pow'r of Je - sus' name;
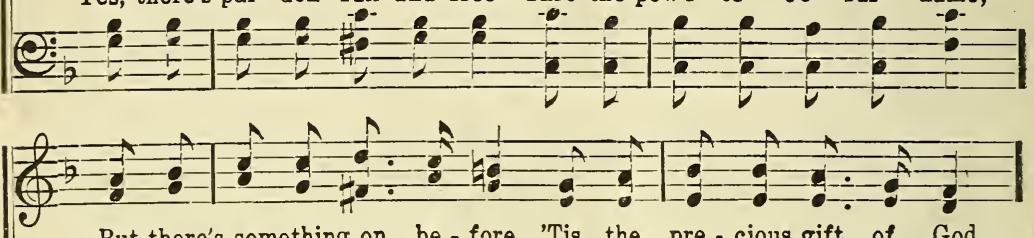

But there's something on be - fore, 'Tis the pre - cious gift of God,

May I la - bor earn - est-ly, Heed-ing all the Mas-ter's calls,

To the heav'n pre-pared a-bove The re-deemed ones $\mathrm{He}$ will bring,

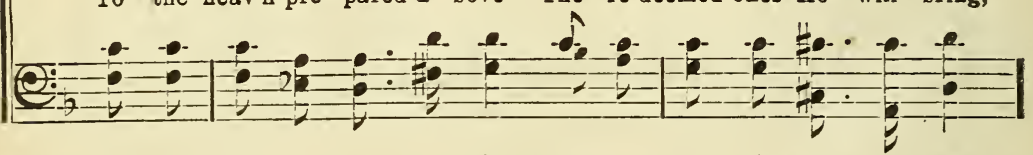

Q

Purchased on the cross of Christ, Sealed by His own pre - cious blood.

Stor-ing treas-ure up a-bove, Safe with-in the jas - per walls.

Trust-ing in His pow'r to save, With as - sur-ance you may sing.

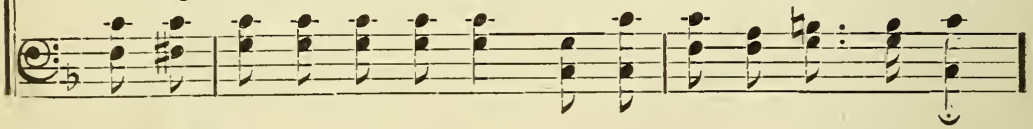

Chorus.

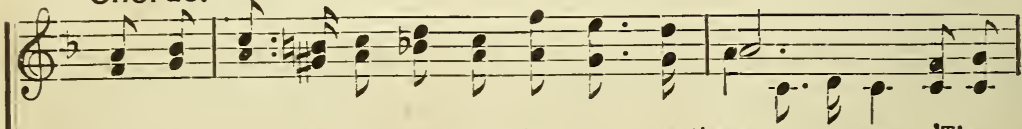

I've a ti - tle to a man-sion 0 - ver there (over there,) 'Tis a

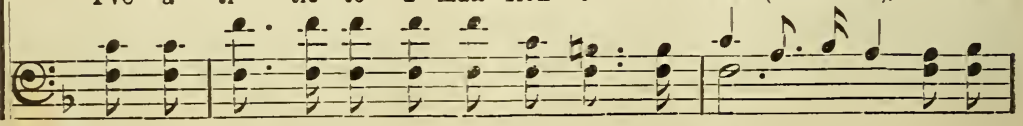

Copyright, rgu8, by Evangelist John A. Davis. 
Il've a Title to a Misansion.

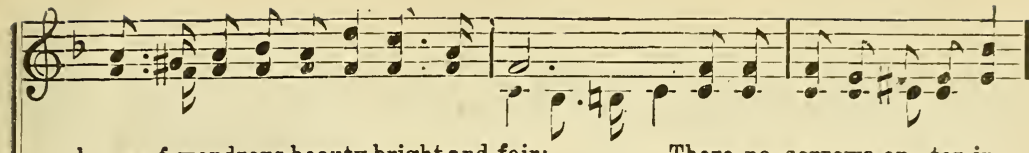

home of wondrous beauty bright and fair;

There no sorrows en - ter in, bright and fair;

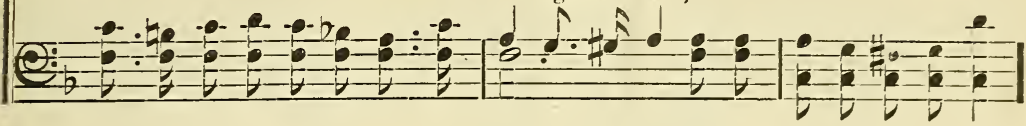

(9)

There's no sickness, death, or sin In the place prepared by Jesus o - ver there;

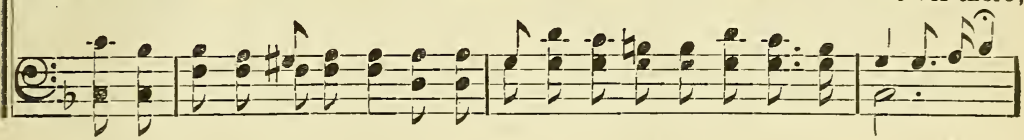

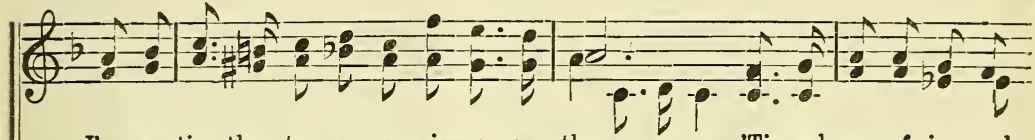

I've a ti - tle to a man-sion o-ver there, 0 -ver there,

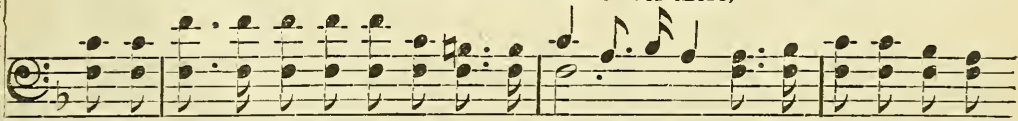

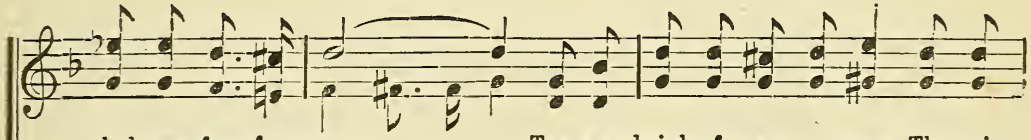

glad-ness free from care,............. Tears and sighs for-ev - er cease, There is free from care,

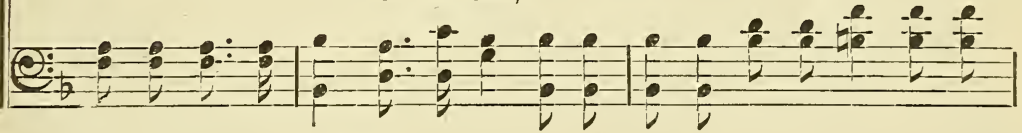

(马)

naught but per-fect peace, In my bless-ed heav'n-ly man-sion 0 - ver there.

$\therefore-0-0-0$ (2)

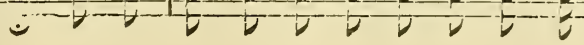




\section{All Hail the Power of Jesus' Name!}

E. PERRoNet.
(DIADEM.)
RICHARDS。

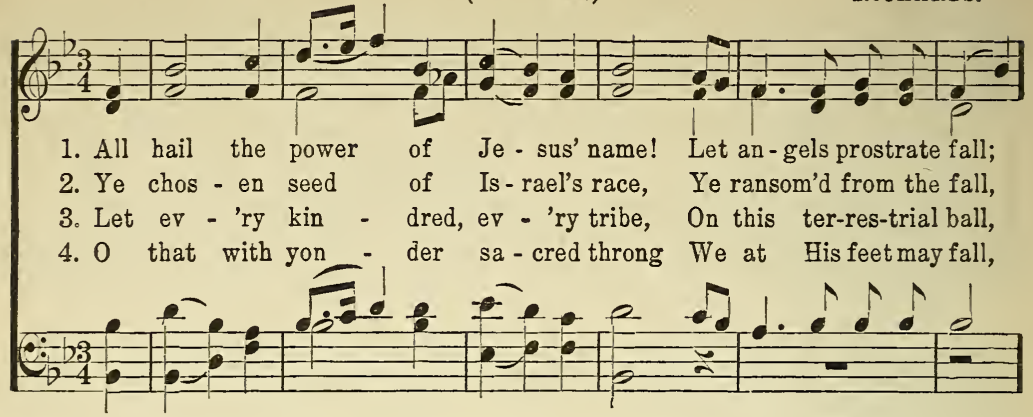

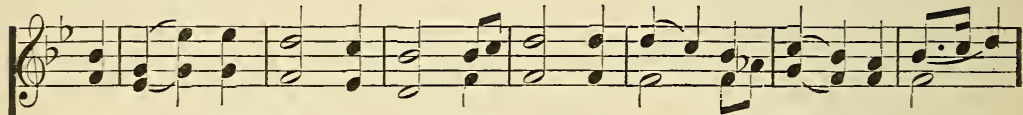

Let an - gels pros-trate fall, Bring forth the roy - al di - a - dem,

Ye ran-somed from the fall, Hail Him who saves you by His grace,

On this ter-res - trial ball, To Him all maj - es - ty as - cribe,

We at His feet may fall! We'll join the ev - er - last - ing song,

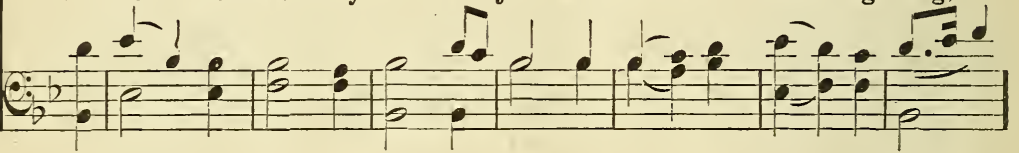

And crown......................... Him, crown Him

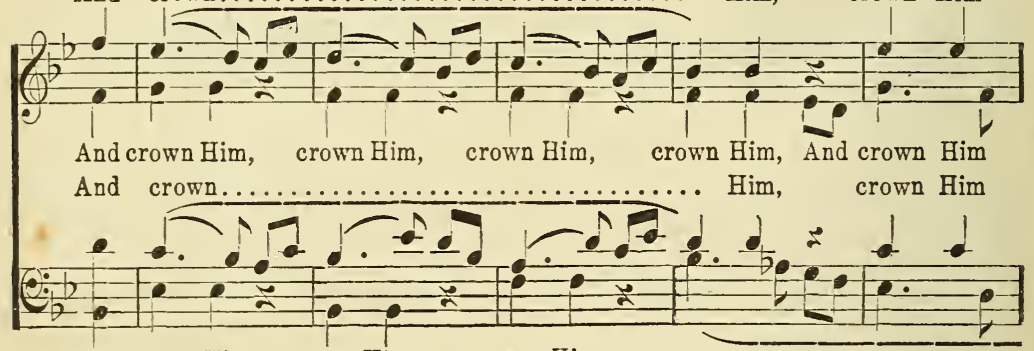

And crown Him, crown Him, crown Him,

crown...............

crown Him, crown Him,

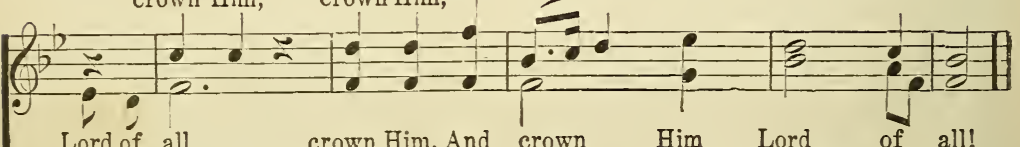

Lord of all,

crown Him, And

Him Lord

of all!

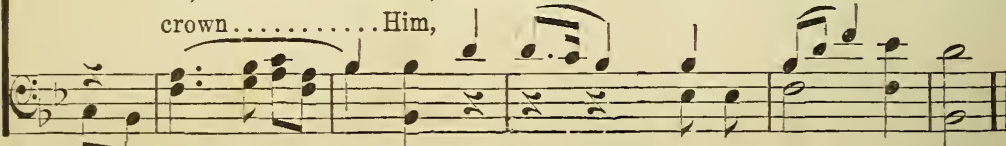

.............. Him,

crown Him Lord of all! 
John R. Clements.

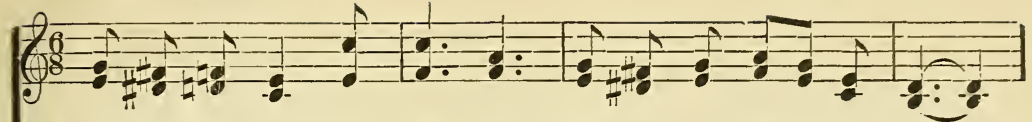

1. Aft - er the strain of bat - tle, Firm - ly and fierce - ly pressed,

2. Aft - er the fit - ful pas - sion, Born that it Imight an - noy,

3. Aft - er the walk of trust - ing, Faith-born and not by sight,

4. Aft - er the long-drawn ab - sence, Aft-er the pil - grims roam;

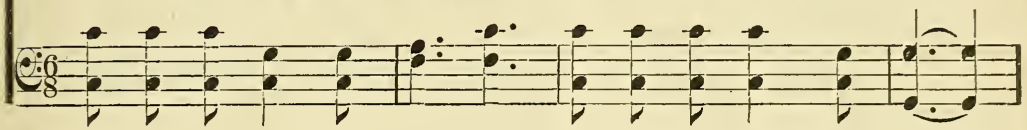

\section{Chorus.}

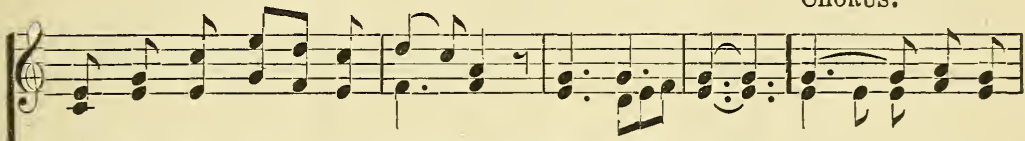

Aft - er the day of con-flict,-Rest, sweet rest.

Aft - er the hour of test - ing, Joy, sweet joy. Rest, in the

Aft - er the time of dark-ness, Light, sweet light. Rest,sweet rest,

Aft - er the day of du - ty,-Home, sweet home.
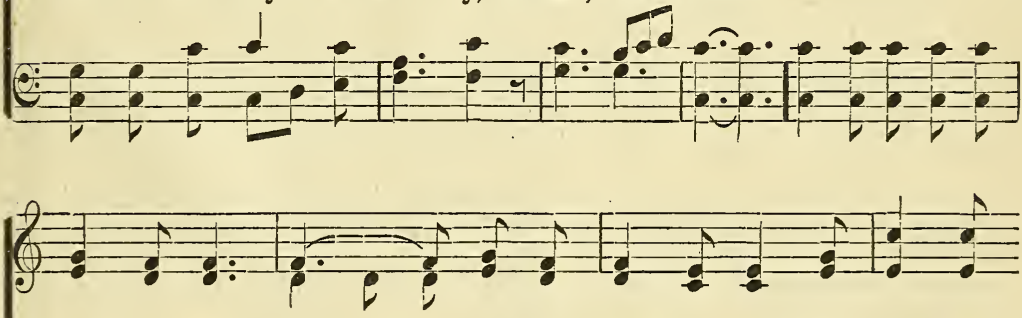

cru - ci-fied, Joy, in the Christ who died, A Light is Joy, sweet joy,
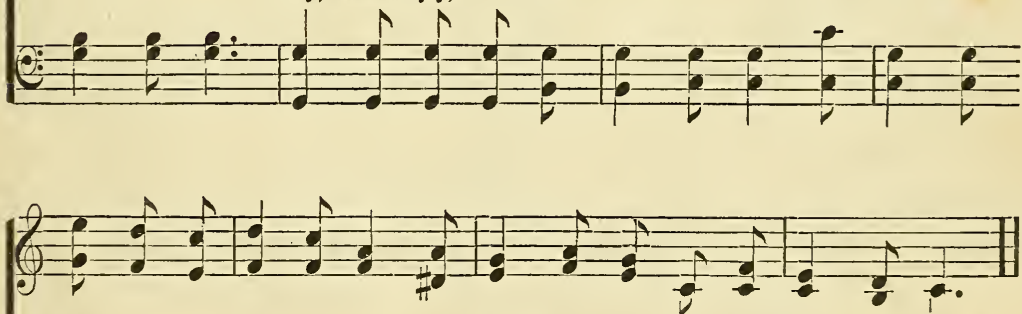

shin -ing a - long my way, To guide me home to an end - less day.

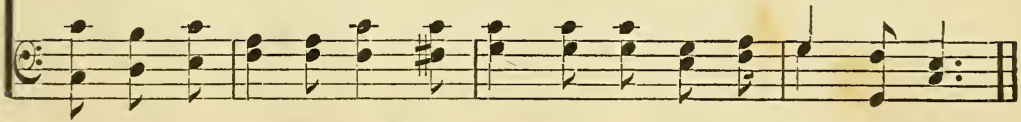

Copyright, 1910, by John R. Clements. 


\section{INDEX.}

All hail the power (Diadem) ...... 61 'Like a river glorious ......... 15

A wonderful gift is Jesus......... 17 Listen to the still smail voice ...... 26

Be a worker................. 58

Be strong.................. 27

Bear ye one another's burdens ...... 11

Beneath the cross of Jesus......... 37

Brighten all the way $\ldots \ldots \ldots \ldots \ldots .24$

Choose the best .............. 19

Christ or Barabbas ............. 45

Drifting $\ldots \ldots \ldots \ldots \ldots \ldots \ldots \ldots, 49$

Drifting down............... 10

Faith in the word of God......... 21

Faith of our Fathers ............ 3

Far away He saw me ........... 44

Fellowship with Christ............

Great is my need...$\ldots \ldots \ldots \ldots$.

Have I done my best?.............

He's every thing to me.............

His watchful eye...............

Home....................

I'm going al" ' $ə$ way $\pi$.ch Jesus.....

I never knew ...................

In heavenly love abiding............

In the waves ..................

Into the morning..............

I ought therefore I can ..............

I've a title to a mansion.............

Just like him ................

Keep confessing Jesus ...........,

Lead kindly light

Let Him In ..

Live fur others ............... 1

Look away to Jesus.............. 31

Lost................... 57

Lost in the sight of the harbor..... 28

May Jesus Christ be praised....... 51

Never give up ................. 14

Not a star in my crown.......... 53

0 love that will not let me go ...... 9

On to the land of promise ........ 48

Our Captain is leading ........... 52

0 what a change............... 4

23 Remember me.............. 5

13 Scatter the seeds of service ....... 6

Searching for jewels ........... 16

50 Serving Jesus ................... 30

46 Shall one be missing............ 33

38 Somebody cares................ 34

62 Somebody's knocking............. 25

Some day.................. 40

22 Some day I shall be ............. 42

54 Sweet and low ............... 20

35 The cross is not greater.......... 39

36 The fight is on ............... 8

18 The hope of the world is Jesus ...... 32

60 The Lord brings back His own ...... 55

43 The solid rock.............. 59

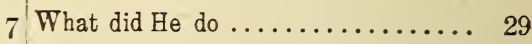

We're here to win $\ldots \ldots \ldots \ldots \ldots \ldots .12$

56 You can win the victory thro' Christ.. 2 



